\title{
Génesis y actualidad de la escena tecnológica de Buenos Aires (1996-2016) \\ Estudio de lo analógico a lo digital en la Danza Performance
}

Origin and current state of the technology scene

in Buenos Aires (1996-2016)

A study of analog to digital dance performance

Gênesis e atualidade da cena tecnológica de Buenos Aires (1996-2016)

Estudo do analógico ao digital em dança-a performance

Mag. Alejandra Ceriani

Director: Ing. Emiliano Causa

Codirector: Dra. Natalia Matewecki

Doctorado en Artes

Facultad de Bella Artes

Universidad Nacional de La Plata

La Plata

Octubre de 2017 


\section{Índice}

\section{Presentación}

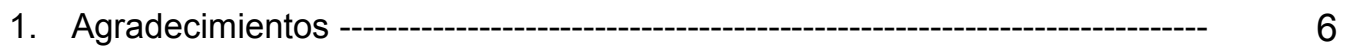

2. Motivaciones personales -

3. Resumen - Palabras clave - - 8

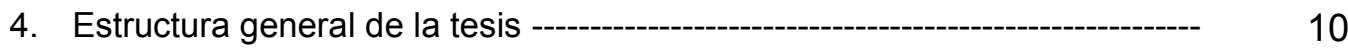

5. Definiciones y terminologías -------- 12

5.1. Aclaraciones de formato ---_-

\section{Capítulo 1. Diseño de la investigación}

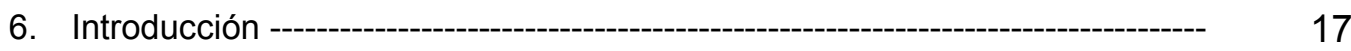

7. Estado del campo de producción y de estudios -- 17

8. Delimitación del problema de investigación --_- 21

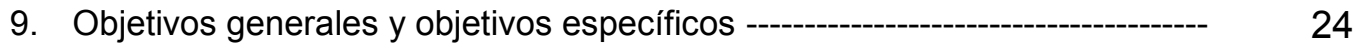

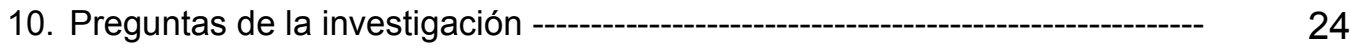

11. Argumento hipotético -------------------------------------- 25

12. Diseño metodológico para la sistematización de los datos ------------------- 27

13. Metodología para el estudio de prácticas artísticas híbridas ---------------- 32

14. Sistema de matrices de datos - 35

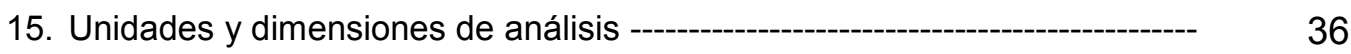

15.1. Unidad de análisis: cuerpo --_-_--- 37

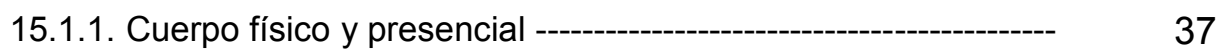

15.1.2. Cuerpo parametrizado y modelizado ----------------------------- 37

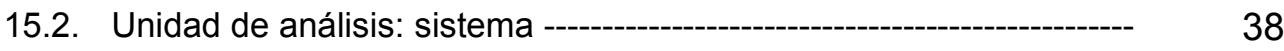

15.2.1. Dimensión hardware ------------- 38

15.2.2. Dimensión software ------------------------------------ 38

15.2.3. Dimensión humanware -- 39

15.3. Unidad de análisis: escena interactiva ----o--- 39

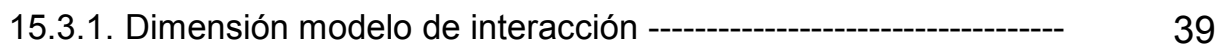

15.3.2. Dimensión modelo de inmersión --- 39

15.4. Indicadores y criterios de valoración -

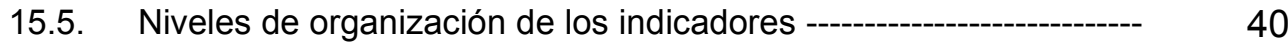

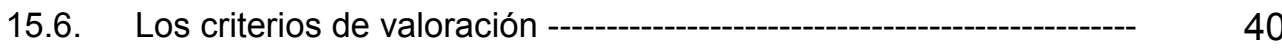

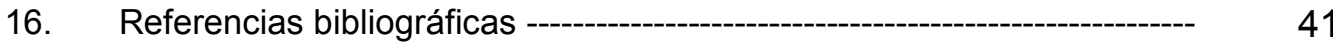




\section{Capítulo 2. Pasaje de lo analógico a lo digital}

Parte 1: Danza Multimedia. Origen de la danza con mediación tecnológica

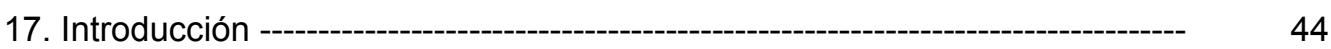

18. Algunas cuestiones sobre lo predigital, lo multimedia y lo audiovisual ------ $\quad 47$

19. La pantalla, el video y la escena ------------------------------------------------------ 53

20. Coreografías escénicas y coreografías videográficas en conjunción -------- 77

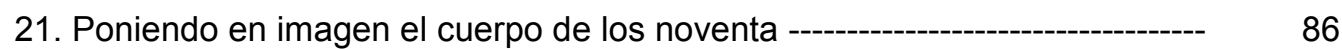

22. Festival Internacional de Videodanza Buenos Aires (FIVDBA): orígenes de la Danza Multimedia en la escena local ------------------------------------------ 98

23. Hacia una tecno-escena -------------------------------------------------------------- 104

24. De lo predigital a lo digital. Algunas conclusiones ----------------------------- 109

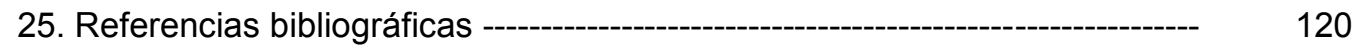

25.1. Referencias electrónicas ---------------------------------- 123

25.2. Entrevistas en video ----------------------------------------- 125

25.3. Otros materiales de consulta en línea ----------------- 126

\section{Parte 2: Danza Performance Interactiva}

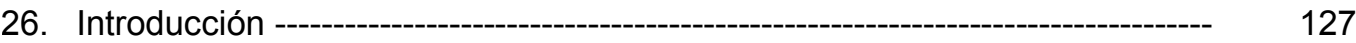

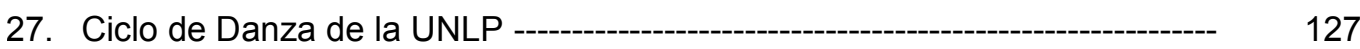

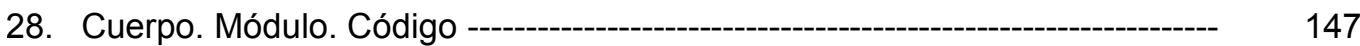

29. Cuerpo. Interfaz. Metáfora -------------------------------------------------------------- 150

30. La interfaz es el cuerpo del software ---------------------------------------------- 159

31. Concepciones del cuerpo en la programación ------------------------------------ 169

32. Concepciones del cuerpo en la mediación interactiva -------------------------- 175

33. Referencias bibliográficas --------------------------------------------------------- 190

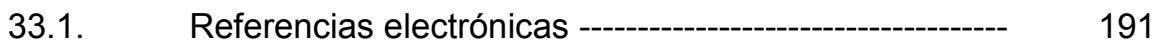

33.2. $\quad$ Entrevistas en video -------------------------------------- 194

33.3. Otros materiales de consulta en línea ---------------- 195

Parte 3: Danza Performance telemática y en red

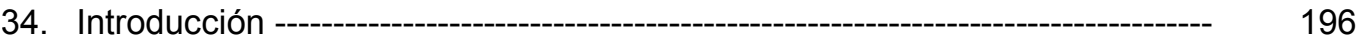

35. El cuerpo en conectividad ------------------------------------------------------------- 198

36. La red que se avecina ----------------------------------------------------------------- 205

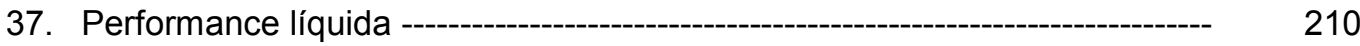

38. Conclusión tentativa para este caso analizado ---------------------------------- 212

39. Aproximaciones entre cuerpo, ciencia y arte ----------------------------------- 213 
40. Crear, copiar, imitar en la web ---on 221

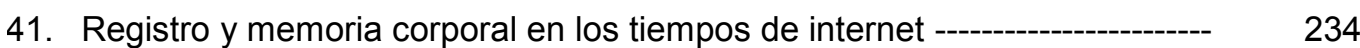

42. La emergencia de una dimensión cibernética de la corporalidad ------------ 247

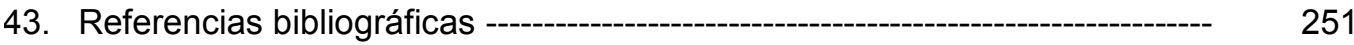

43.1. Referencias electrónicas --_- 254

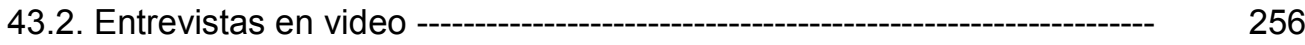

43.3. Otros materiales de consulta en línea -

\section{Capítulo 3. Diseño metodológico para el estudio de casos de Danza Performance Interactiva}

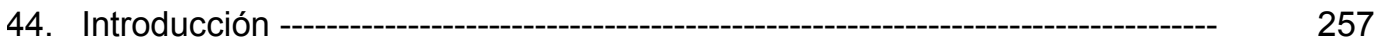

45. Análisis de un estudio de caso a partir del sistema de matrices de datos - 257

46. Parámetros de observación y de experimentación ------------------- 258

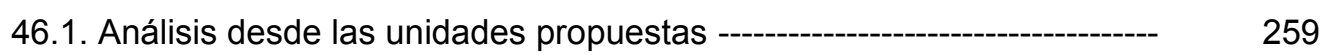

46.2. Sobre la unidad de análisis sistema: software de creación Cod05 ----- 260

46.3. Sobre la unidad de análisis cuerpo --- 268

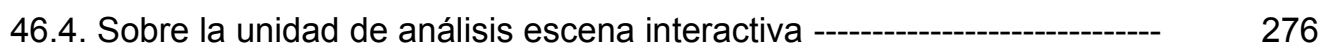

47. Dos estudios de casos: observación y análisis ----.--

47.1. Estudio de caso 1: observación y análisis por unidad ------------------- 284

47.1.1. Cuerpo físico y presencial -------- 284

47.1.2. Cuerpo parametrizado y modelizado -------------------------- 285

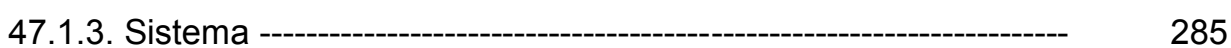

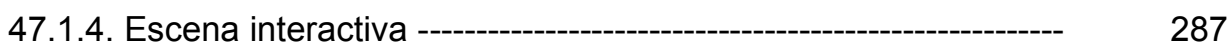

47.1.5. Representación gráfica de la información -------------------- 287

47.2. Estudio de caso 2: observación y análisis por unidad ---------------------- 288

47.2.1. Cuerpo físico y presencial --_- 289

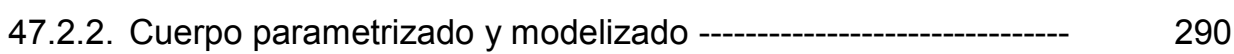

47.2.3. Sistema -- 291

47.2.4. Escena interactiva ---------------- 292

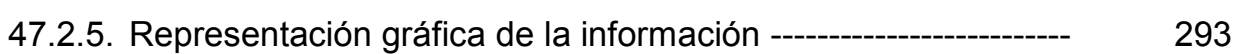

48. Conclusiones generales --------------------- 294

48.1. Estudio de caso 1: hacia una danza performática algorítmica -------- 296

48.2. Estudio de caso 2: hacia una danza performance de redes

hipermediadas ------------------------------------------------------------ 300

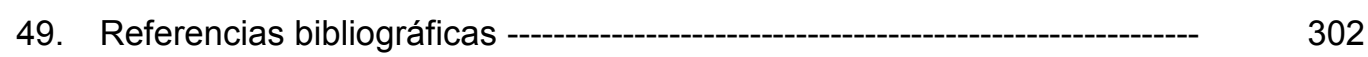

49.1. Referencias electrónicas -- 303

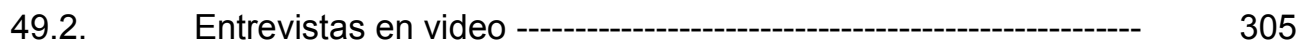

49.3. Otros materiales de consulta en línea - 305 


\section{Anexo}

50.1. Introducción -- 306

50.2. Transferencias en el campo artístico y educativo --------- 306

51. Cátedra libre de educación y mediación digital en danza y performance 308

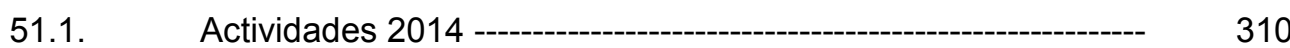

51.2. Actividades 2015 -------- 315

51.2.1. Actividades coorganizadas con la Bienal de Performances BP2015 ----o 316

51.2.2. Actividades de la Cátedra Libre --------------------- 317

51.3. Actividades 2016 - 322

52. Ciclo Danza "En2Tiempos" -- 325

53. Proyectos de investigación y desarrollo científico, tecnológico y artístico 327

53.1. Danza y nuevas tecnologías: nuevas estrategias en el campo de la formación y la producción -------------------------------------------------- 327

53.2. Introducción --- 328

53.3. Transferencia al campo educativo --_- 328

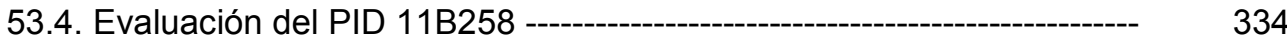

54. Proyecto de Investigación y Desarrollo PID, UNLP: Prácticas performáticas multimediales, redes telemáticas y educación --------------- 334

54.1. Introducción -- 335

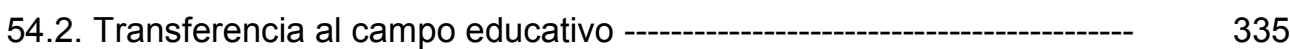

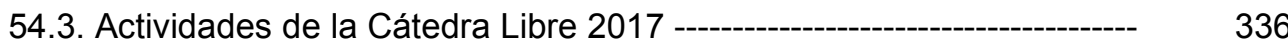

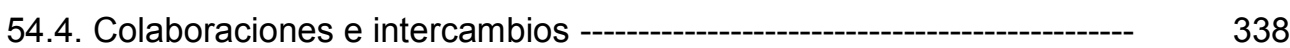

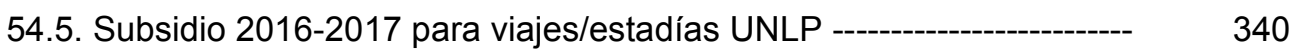

55. Referencias bibliográficas ----------- 341

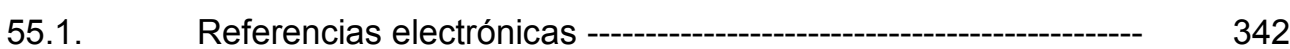

55.2. Otros materiales de consulta en línea -- 342 


\section{Agradecimientos}

A todos mis colegas, profesores y compañeros de trabajo, de cursadas, a artistas e intelectuales que, con su confianza, me han estimulado a escribir esta tesis doctoral y a aventurarme en proponer este estudio sobre la génesis y el desarrollo de la danza performática en la escena tecnológica de Buenos Aires.

Por este anhelo de contribuir al desarrollo del conocimiento que sobre la Danza Performance se tiene, procuré encontrar e indagar qué acontecía en los cuerpos de disciplinas en interacción, cuáles eran y cómo son hoy esos cuerpos que la empiria y la memoria van construyendo, incluidos en otros espacios donde las prácticas artísticas se virtualizan. Traté de pensar, experimentar, comprobar, dedicar tiempo a crear una serie de aproximaciones conceptuales y estéticas de la imagen, del sonido, de la complejidad de los lenguajes de código, signos y números.

Por eso quiero manifestar mi agradecimiento a quienes se sensibilizaron abordando, sosteniendo y participando en la construcción de nuevas definiciones y materiales teóricos. Al compromiso conjunto de artistas, docentes e instituciones de los distintos niveles educativos que desarrollamos nuevos contenidos y categorías de análisis para la investigación áulica; estimulando, de ese modo, la continuidad de los estudios interdisciplinares y transdisciplinares en la actualidad del arte.

\section{Motivaciones personales}

Quiero comenzar manifestando los motivos que sustentaron la realización de esta tesis doctoral y las razones personales que me han impulsado a la elección del campo de investigación y su objeto de estudio. En primer lugar, las motivaciones de carácter particular están vinculadas con mi formación en varias disciplinas, lo que impulsó a la conformación de una actividad profesional múltiple como artista escénica (danza, teatro y performance), de las artes visuales (pintura, cerámica e instalaciones) y audiovisuales (videodanza y documentales), y como académica y docente; y que me ha llevado a iniciar esta labor de retroalimentación entre el estudio, el análisis, la reflexión y la producción artística.

En ese sentido, se trata de poder cruzar estas actividades que, a lo largo de mi trayectoria, se han ido interrelacionando entrañablemente con la propia transformación del arte contemporáneo hacia la desmaterialización del cuerpo, que acercaron los procesos artísticos a la especulación teórica. 
Así, como artista creadora de cuerpos hibridados en la imagen analógica y digital, comienzo, en 1992, con la realización de piezas audiovisuales en videodanza; continúo en 1997 con la creación de obras escénicas de danza multimedia; y me oriento, desde 2005 hasta el presente, a la danza performance interactiva.

Por una parte, hoy estoy encaminando toda esa experticia hacia la conformación de comunidades artísticas, en las que los intercambios -tanto presenciales como virtuales- encarnen aportes prácticos y conceptuales. Por lo que soy consciente de los diversos procesos de proximidad que debemos promover -a través de la participación o ejecución de residencias, seminarios, talleres, conferencias, etc.- para la organización de estas comunidades especializadas en danza performance en interacción tecnológica.

Por otra, me dediqué al trazado de una cartografía de la danza y la performance contemporánea local y translocal, que abrió un espacio de encuentro, reflexión e intercambio de procesos de producción artística hacia la comunidad y con ella, con características propias del trabajo de campo en investigación cualitativa desde el ámbito universitario.

Desde este marco, se promueve la acción vital entre lo académico y la comunidad, para propiciar la construcción conjunta del conocimiento así como la indagación crítica de las dinámicas que son propias de la producción y de la formación en arte.

Finalmente, mencionaré mi trayectoria como investigadora categorizada por la Universidad Nacional de La Plata (UNLP) y como directora de proyectos de investigación y desarrollo científico, tecnológico y artístico vinculados directamente a la temática que nos concierne. En este sentido, me propuse, en una primera instancia, trazar ciertas reflexiones acerca de la relación entre el campo artístico y las nuevas tecnologías, más específicamente, entre la tecnología digital interactiva (en instalaciones con sensores de movimiento y captura en tiempo real), el espacio escénico y el cuerpo. $\mathrm{Y}$, en una segunda instancia -dado que en los últimos años dentro del currículo se han incorporado en forma generalizada y acelerada las tecnologías de la comunicación y la información en los procesos de enseñanza y aprendizaje-, he asumido un particular enfoque del arte y de la educación, que posibilita la selección de ciertos saberes propios del vínculo de la danza con otros lenguajes como las artes audiovisuales y multimediales.

La demanda que acusan estos vínculos en torno a los usos y las aplicaciones técnicas en conjunción con el desarrollo del cuerpo escolarizado requiere del estudio inaplazable de estas interacciones entre las disciplinas corporales en conexión con la ciencia y la tecnología. Entonces, expresar el porqué de las actividades de investigación como motivación personal responde a la intención de ampliar el 
conocimiento y su aplicación práctica en beneficio de la sociedad y de la comunidad especializada.

Por consiguiente, mi objeto de estudio se fue centrando en la elaboración de contenidos y saberes para la producción artística en danza performance interactiva y para la educación artística en la disciplina Danza, con base en la experimentación y el conocimiento, sin perder de vista que la gestión del conocimiento logrado todavía está poco instaurada en la investigación en arte. Esta gestión consiste, básicamente, en la dirección estratégica del conocimiento interdisciplinar y, por tanto, se estudia de forma integrada con los modos de interacción en condiciones reales, teniendo en cuenta la importancia de los procesos más que de los resultados de cada experiencia. Esto me permite realizar propuestas que se adecuan a las problemáticas que pueden surgir en el ámbito desde el cual se promueva y desde una perspectiva principalmente procesual y relacional.

En este sentido, siempre me he dedicado a trabajar en equipo y de modo colaborativo, en intercambio permanente, y entiendo que la búsqueda transdisciplinar que se inscribe dentro de este promisorio campo artístico puede continuar desarrollándose tanto en la conformación de grupos o equipos de trabajo como poniendo en práctica las propuestas que se encaminen a mi dedicación como artista investigadora.

\section{Resumen}

Las relaciones entre las prácticas escénicas y la tecnología emergen como uno de los temas de investigación más significativo para situar la migración del cuerpo performático al contexto mediatizado analógico y digital. Así, el objetivo de esta tesis es establecer como área de interés el estudio de la danza performance con sistemas informáticos en un espacio escénico localizado y en el espacio ubicuo de internet.

En la investigación, de carácter exploratorio, se analizan producciones enmarcadas en la concepción de danza performance multimedia, interactiva, telemática y en las redes sociales de internet. Metodológicamente, se incluirá el estudio de casos y la realización de entrevistas semiestructuradas con quienes consideramos son los principales responsables de las producciones teóricas, corporales y multimediales.

Palabras clave: cuerpo, arte, tecnología. 


\begin{abstract}
Abstrac
The relationship between theater space and technology appears as one of the most meaningful topics for research. The relationship marks a migration vector of the works performed into a context enhanced by both analog and digital media. The objective of this thesis is to establish dance performance involving computational technology in both local performance venues and global internet space.

Elemental to the focus and explorations of this research we analyze productions within the parameters of dance, performance, multimedia, as well as interactive, broadcast and social networks. Our methodology includes case studies and partially structured overviews of artists/performers we consider to be the leaders in theoretical, physical and multimedia productions.
\end{abstract}

Keywords: Body, Art, Technology.

(Traducción Prof. Dell Blair, Brigham Young University, USA).

\title{
Resumo
}

As relações entre as práticas cênicas e a tecnologia emergem como um dos temas de investigação mais significativo para situar a migração do corpo performático ao contexto mediatizado analógico e digital.

Assim, o objetivo desta tese é estabelecer, como área de interesse, o estudo da dança performance com sistemas informáticos em um espaço cênico físico e no espaço ubícuo da Internet.

$\mathrm{Na}$ investigação, de caráter exploratorio, analisam-se produções enquadradas na concepção de dança performance multimídia, interactiva, telemática e nas redes sociais de internet.

Metodologicamente, será incluído o estudo de casos e a realização de entrevistas semiestruturadas com aqueles que consideramos os principais responsáveis pelas produções teóricas, corporais e multimídias desse campo.

Palavras-chave: corpo, arte, tecnologia.

(Traducción: Prof. Ivani Lúcia Oliveira de Santana. Universidade Federal da Bahia, Salvador · Instituto de Humanidades Artes e Ciências, Brasil). 


\section{Estructura general de la tesis}

Esta tesis propone una presentación general, que comienza con la exposición de las motivaciones y el reconocimiento de quienes me alentaron a encarar su escritura. Seguidamente, se ofrece un Resumen de la temática -tanto en español como en portugués y en inglés-, los objetivos y la metodología utilizada. En la Estructura general, se explicita la ordenación de la totalidad del trabajo. Además, se ha preparado un glosario de Definiciones y terminologías con el fin de allanarles -a nuestros posibles interlocutores- el camino en la comprensión de las referencias pertenecientes a otros campos teóricos que, aun excediendo nuestra incumbencia, se aplican apropiadamente a esta tesis.

A continuación se configuran los tres capítulos que manifiestan el proceso metódico sobre el desarrollo del tema investigado.

Capítulo 1 aborda el diseño de la investigación, principalmente: el estado del campo de estudios, la delimitación de los problemas de investigación, los objetivos, las preguntas de la investigación, el argumento hipotético y el marco contextual con sus referentes teóricos. Estos, en su mayoría, han sido aportes de la cursada de la carrera del Doctorado en Artes FBA/UNLP. Otra contribución importante resulta de las derivaciones que estos mismos referentes extrapolaron en una profusa navegación hacia otros autores directamente conectados a la reflexión sobre su propia praxis. Es fundamental destacar el valioso aporte que constituye el crecimiento exponencial de la producción académica -a través de tesis de grado y artículos publicados- respecto del desarrollo artístico en articulación con el campo de la ciencia y de la tecnología. De ello nos hemos nutrido exponencialmente.

El Capítulo 2 se divide en tres partes en las que se profundiza el análisis teórico y reflexivo derivado de la observación y la actuación experimental a través de estudios de casos y entrevistas semiestructuradas. Consideraremos aquí las aportaciones de teóricos y productores que introducen aspectos reflexivos sobre los cambios de paradigmas fundamentales para reconocer el pasaje de lo analógico a lo digital en los recursos de creación escénicos y en el cuerpo disciplinar de bailarines, performers, videoartistas, músicos y programadores. Estas instancias proponen diversas prácticas 
e implican el cuerpo en nuevas formas culturales que, recíprocamente, reconocen e intervienen los contenidos que generan y circulan.

Atendiendo a la condición de estos cuerpos -tanto sea en su desdoblamiento en imagen y en sonido virtual e interactivo así como en esta convergencia tecnológica de consecuencias inauditas en la organización del tiempo y del espacio en las redes de internet-, nos dedicamos a observar, analizar y sistematizar:

- Las propuestas sobre el cuerpo y la escena física con proyecciones de video analógicas realizadas dentro del marco del Festival Internacional de Videodanza Buenos Aires (FIVDBA) entre los años 1996 y 2003.

- Las propuestas sobre el cuerpo interactivo que utilizan las versiones del software libre Moldeo Director, Moldeo beta 1.0 entre los años 2007 y 2015.

- Las propuestas sobre los procesos surgidos del ciclo de danza "En 2Tiempos", de la UNLP, entre los años 2012 y 2014.

- Las propuestas (network performance) desarrolladas en plataformas en línea entre los años 2013 y 2015.

- Las propuestas corporales en las redes sociales de internet año 2016.

El Capítulo 3 se sustenta en el compromiso de sistematicidad alcanzado. Aquí se explicita la organización que hemos pensado sobre las operaciones empíricas de los datos registrados a lo largo de esta investigación: la estructura, el tipo de estudio, las consideraciones metodológicas y la construcción de categorías analíticas aplicadas al vínculo cuerpo-sistema-escena interactiva. Se explicita también la instrumentalización de los procesos y las decisiones tomadas a través del lenguaje de datos o matriz de datos: las unidades de análisis, los sistemas de clasificación y las escalas de medición (las dimensiones, los indicadores y los criterios de valoración).

En el Anexo, se consignan las transferencias realizadas, ya que uno de los objetivos principales de los resultados obtenidos es producir contenidos digitales multimedia para la educación artística en la disciplina Danza Performance, y aportar al conocimiento metodológico de los contenidos que esta conjunción de la danza con la tecnología promueven tanto para los docentes y alumnos como para la nueva conformación en el espacio áulico a partir del ingreso de equipos de computación portátil en la educación pública.

Allí se exponen las actividades de extensión e investigación científica, tecnológica y artística a través del intercambio académico con numerosos equipos de artistasinvestigadores y del aporte teórico de los estudios e intercambios con laboratorios pertenecientes a universidades de nuestro país y de Latinoamérica. 
Observamos, para finalizar, el futuro de estas actividades de extensión que buscan contribuir al estudio de las interrelaciones entre arte, ciencia y tecnología, e impulsar las nuevas manifestaciones artísticas, las nuevas tendencias y las múltiples problemáticas que plantean el arte contemporáneo, las tecnologías de la comunicación y la información, y la co-construcción del conocimiento de modo colaborativo.

\section{Definiciones y terminologías}

En esta tesis doctoral no nos dedicaremos, de manera exhaustiva, a estudiar y a presentar todos los modelos, proposiciones o métodos teóricos que podrían sustentar nuestra perspectiva sobre el vínculo entre el cuerpo y el arte contemporáneo. Nuestro propósito es la revisión y la reflexión sobre las propias prácticas y la de otros pensando en producir y transferir conocimiento práctico y académico. Para ello, en primer lugar, daremos cuenta de los términos, definiciones y conceptos con los cuales trabajaremos con la idea de situar el campo teórico de la producción artística en danza performance con tecnología analógica y digital.

El orden de aparición no será estrictamente alfabético, sino que los términos y conceptos se agruparán por afinidad, al igual que los neologismos que funcionan como conceptos operativos propios, ya que ponen de manifiesto nociones surgidas del mismo proceso de estudio.

Lo analógico y lo digital: cuando nos referimos a estos dos términos, en materia de comunicación tecnológica, lo hacemos pensando en procesos en los que se compromete al cuerpo en interactuación con estas tecnologías. En este sentido, la generación de imágenes, a partir de la vinculación del cuerpo con interfaces y dispositivos analógicos o digitales, es clave para nuestra indagación.

Aplicamos los términos analógico y digital distinguiendo igualmente a objetos, mecanismos, sistemas, tecnologías, mediaciones y hasta al propio cuerpo. Nos interesa discriminar la transición técnico-estética-cultural de lo analógico hacia lo digital y hacia lo conectivo, las hibridaciones de las disciplinas que pueden producirse en el ámbito de la mediación tecnológica.

Hablamos de cuerpo analógico cuando nos referimos a aquel cuerpo del bailarín performer que experimenta con interfaces, dispositivos y sistemas analógicos y reactivos, básicamente, predigitales; por ejemplo, las prácticas artísticas de la videodanza y la danza multimedia. En cambio, hablamos de cuerpo digital cuando nos referimos a aquel cuerpo disciplinar del bailarín performer que interactúa con 
interfaces, dispositivos y sistemas interactivos electrónicos-digitales, por ejemplo, danza performance interactiva y danza telemática. En último lugar, hablamos de un cuerpo conectivo cuando la experiencia subjetiva de la percepción interactúa en las redes telemáticas -a través por ejemplo- de los teléfonos celulares. El alcance de los estudios sobre el espacio de internet y las plataformas colaborativas impulsadas por las redes sociales son un campo fértil y abierto de estudio para hoy y para el futuro. Más allá de los avances técnicos y de su impacto en las formas culturales de vida, es posible acercarse a esa manera particular de organización humana que se denomina prácticas artísticas en internet.

Danza Multimedia: consideramos aquí la conjunción de los términos danza y multimedia (es decir, el uso conjunto y compartido de diversos medios o soportes) como una propuesta escénica de sistemas analógicos donde se danza delante de una proyección de video formato VHS.

Danza Performance: consideramos aquí la conjunción de los términos danza y performance -y lo que sobrelleva desde el punto de vista disciplinar- como aquel cuerpo formado en la danza -básicamente contemporánea- que indaga en el campo performático. Para entender el sentido de esta hibridación, es necesario comprender el contexto evolutivo de la danza contemporánea y las derivaciones al suprimir esa distinción de criterios que insisten en establecer límites entre "géneros" artísticos y que requieren una reflexión sesgada de las cuestiones propuestas por los propios artistas.

Performance Interactiva: esta conjunción de términos deriva de la anterior y se vincula a la definición de metaformance, de Claudia Giannetti (1997), en la que se establece una conexión entre la idea de construcción del cuerpo, la metáfora técnica y la noción de proceso estético. Las performances interactivas componen una nueva categoría dentro de las artes escénicas y llegan a vincular varias ramas del arte interactivo y del arte escénico tradicional; dado que prescinden de la presencia física en el espacio de la acción y la simulan con la imagen electrónico-digital.

Sistema informático: a lo largo del texto aparecen también variaciones del vocablo sistema. Lo entendemos como un conjunto cuyos componentes se relacionan con al menos algún otro componente que puede ser material o virtual. Un sistema informático se basa, fundamentalmente, en la organización del empleo de la computación y del procesamiento de la información a través de un conjunto de funciones interrelacionadas (hardware, software y de recursos humanos). 
Sistema interactivo: es un sistema informático que se interrelaciona e incumbe a las acciones de un usuario para realizar una tarea, es decir, todo sistema en el que interactúan persona y máquina. Asimismo, cuando empleamos derivaciones de la terminología como sistema escénico interactivo o mediatizado, escena interactiva, tecnoescena, etcétera, aludimos a la sistematización del espacio escénico a través de los procesos de digitalización.

Reactividad/reactivo: es un sistema cuya interfaz se encarga de recibir los estímulos de entrada, e inmediatamente, generar las salidas. Ante la presencia y la acción del performer, responde con un off/on, sin implicar una retroalimentación.

Interactividad: hoy se utiliza con dos sentidos muy diferentes. Uno, como sinónimo de participación en relaciones comunicativas establecidas entre las personas: conversar, dialogar, colaborar, etcétera. $Y$ otro, en la relación que se establece entre las personas y las máquinas, esto es, el método por el cual un usuario se comunica con la computadora a través de sus periféricos (pantalla, cámara, teclado), sea local o remoto. Así pues, un sistema de intercambio de información mediado por la computadora tiene tres componentes: hardware, software y usuario/os. Según Claudia Giannetti (1999), "Si nos remontamos a la idea original de feedback, idea que estaba en la base del primer arte cibernético, entendemos de inmediato la posible diferencia entre sistemas que podemos definir como participativos y sistemas realmente interactivos". Esta dialéctica entre el determinismo y lo indeterminado hace pensar en la posibilidad de desarrollos emergentes, incontrolables e impredecibles.

Hoy las artes escénicas y el arte interactivo ${ }^{1}$ se vinculan cada vez más desde los diseños informáticos que facilitan el análisis y el sensado de espacios, de patrones de movimiento y gestualidad. Esta vinculación invita a la producción escénica y multimedia actual a convertirse en un campo de experimentación de las prácticas disciplinares y promueve nuevas poéticas tecnológicas.

Desde nuestro campo de investigación, hablaremos de interactividad como una categoría del arte interactivo que, además, refiere específicamente a la intervención del cuerpo motriz disciplinar con un lenguaje informático propuesto. A fin de acotar esta noción tanto sea en lo performático como en lo coreográfico con sus diferencias, proximidades y mixturas, aplicaremos el esquema del Ciclo Interactivo (Causa, 2014), pensado como un flujo de comunicación que va circulando por diferentes etapas entre

\footnotetext{
1 Para tratar el tema de lo interactivo, nos basaremos también en escritos y obras de David Rokeby. Con el fin de ampliar la información, véase: <http://www.davidrokeby.com/>.
} 
el interactor y el sistema. A este aporte se le incorporarán las contribuciones actualizadas surgidas de la propia experimentación, reflexiones y conceptualizaciones.

Tecnología: este término tan amplio hace referencia tanto a los procesos de reproducción mecánica como a los procesos electrónicos digitales propios de las nuevas tecnologías de la comunicación y de la información (TIC). En este contexto, estas tecnologías se convierten en dispositivos facilitadores y articuladores de muchas de las tareas que deben realizarse en el presente.

La convergencia de las prácticas artísticas y las tecnologías electrónicas digitales es extremadamente prolífica. No solo por el crecimiento de las posibilidades de producción de formas visuales y sonoras, sino también porque la llegada y la distribución social superan las de otros canales más tradicionales. Además, el encuentro entre la ciencia y el arte es cada vez más productivo, da lugar así a la recomposición de la grieta epistemológica que habitualmente disociaba la cultura científica de la humanística. Aclaramos que, en consonancia con el verbo tecnologizar (que posee una conjugación verbal irregular y no es pronominal), utilizamos tecnologización o tecnologizado/a.

\title{
5.1. Aclaraciones de formato
}

Uso de la cursiva en extranjerismos

La nueva ortografía de la Real Academia Española (RAE)

\begin{abstract}
... da cuenta de las normas que deben seguirse cuando se emplean en textos españoles palabras o expresiones pertenecientes a otras lenguas [...]. De acuerdo con estas normas, los extranjerismos y latinismos crudos o no adaptados -aquellos que se utilizan con su grafía y pronunciación originarias [...]- deben escribirse en los textos españoles con algún tipo de marca gráfica que indique su carácter foráneo, preferentemente en letra cursiva [...]. En cambio, los extranjerismos y latinismos adaptados -aquellos que no presentan problemas de adecuación a la ortografía española o que han modificado su grafía o su pronunciación originarias para adecuarse a las convenciones gráficofonológicas de nuestra lengua- se escriben sin ningún tipo de resalte y se someten a las reglas de acentuación gráfica del español.
\end{abstract}

Sin embargo, debido a la temática de esta tesis y el frecuente uso que en ella se hace de términos de origen extranjero muy difundidos -ballet, software, low-tech, 
performance, interface, etc.-, hemos decidido no utilizar ningún resalte tipográfico para señalarlos, pues al quedar gran parte del texto resaltado se dificultaría la lectura.

\section{Términos interface/interfase}

Cabe señalar que, según el Diccionario de la RAE, es correcto escribir interfase (con "s"), cuando se trata de un "período del ciclo celular en el que tiene lugar la síntesis de proteínas y la replicación del material genético' (Biol.) o de una 'superficie de separación entre dos fases' (Fís. y Quím.).

Sin embargo, cuando hacemos referencia a algún elemento relacionado con la Informática, lo correcto es utilizar interfaz - del inglés interface y que refiere a una 'conexión física y funcional entre dos aparatos o sistemas independientes'-, cuyo plural es interfaces.

En tal sentido, nosotros utilizaremos el término inglés interface (singular) e interfaces (plural), y como anticipamos en el ítem anterior, como extranjerismos, no llevarán resalte tipográfico. 


\section{CAPÍTULO 1. Diseño de la investigación}

\section{Introducción}

En este Capítulo 1 se abordarán las particularidades de la información que se precisa relevar, así como el análisis y la sistematización de los datos que requiere la investigación cualitativa. Dando significación al relato de las diversas experiencias de los sujetos y sus prácticas de producción o enseñanza en arte y tecnología, se pondrán en juego las relaciones sociales y formas de construcción del conocimiento. Pues al interpretar esas realidades atravesados por una multiplicidad de componentes que interactúan a partir de la digitalización, se concertará un campo de estudio propicio para el tratamiento e interpretación de los datos.

El trabajo de campo se realizará, principalmente, en los espacios físicos o virtuales donde las disciplinas del cuerpo y la tecnología den un nuevo sentido al alcance de la investigación. De ello nos hemos nutrido exponencialmente. Por tanto, "Desde este enfoque se propone brindar elementos de juicio mejor fundados para la toma de decisiones en una práctica que requiere ingenio y creatividad para la apertura de nuevos caminos" (Ynoub, 2015: 6).

\section{Estado del campo de producción y de estudios}

A lo largo de este proceso de escritura de la tesis doctoral, fuimos conjugando una serie de experiencias teórico-prácticas que conllevaron tanto lecturas y creaciones artísticas como la organización de jornadas y encuentros, la participación en eventos científicos, seminarios, entrevistas, encuentros y congresos nacionales e internacionales, jornadas de trabajo con colegas investigadores y artistas interdisciplinares; concertando, de ese modo, este escrito en el cual, como bien comenta Umberto Eco (1987: 252):

... solo se piensa en el momento de acabar: se sueña con las vacaciones subsiguientes. Pero si el trabajo ha sido bien hecho, el fenómeno normal es que, tras la tesis, surja un gran frenesí de trabajo. Se quiere profundizar en todos los puntos que habían sido dejados de lado, se quiere seguir las ideas acudidas a la mente, pero que tuvieron que ser apartadas, se quiere leer otros libros, escribir ensayos. $Y$ esto es señal de que la tesis ha activado el metabolismo intelectual, que ha sido una experiencia positiva. 
Uno de nuestros objetivos es analizar, comprender y fundamentar el proceso de virtualización del cuerpo en la Danza Performance. Para ello, estudiamos los pasajes desde un contexto y su sistema tecnológico hacia otro, considerando qué acontecía en los cuerpos de las disciplinas en interacción, cuáles eran y cómo son esos cuerpos que la empiria y la memoria constituyen, incluidos otros espacios donde las prácticas artísticas se translocalizan. Son inherentes a la evolución de los dispositivos e interfaces analógicas y digitales los cambios en la operatividad e instrumentalización de las relaciones sociales, objetuales mecánicas o electrónicas, así como en nuestra relación con la información.

Poniendo de relieve otros formatos y espacios desde donde se produce y estudia la interconexión cuerpo-tecnología, nos respaldamos básicamente en los laboratorios conformados y sustentados dentro del ámbito universitario. Esta concepción de laboratorio de creación-investigación permite explorar la potencialidad del ámbito de la práctica y la teoría por medio de colaboraciones entre interesados por la interrelación entre arte, ciencia y tecnología.

$Y$ aquí nos interesa nombrar al Grupo de Pesquisa Poéticas Tecnológicas (GP Poética) de la Universidad Federal de Bahía (UFBA), Brasil que tiene como objetivo promover la investigación, reflexión, y producción de performance en interacción y colaboración con las tecnologías transdisciplinares y en red. En este laboratorio, se viene desarrollando lo que se llama Danza Telemática o en red desde hace más de una década, en la que el proceso creativo distribuido se conecta entre tres o cuatro puntos del planeta e integra la danza, la música, el cine, el teatro y el arte interactivo. Allí, han diseñado una herramienta propia para la transmisión de video en tiempo real y red IP de alta velocidad denominada Arthron 1.0.

Dentro de esta misma casa de estudios, se encuentra el Laboratório de Pesquisa Avançadas do Corpo (LAPAC), vinculado a la Escuela de Danza en la UFBA y el Elétrico Grupo de Pesquisa em Ciberdança que tiene como objeto de indagación la danza contemporánea interrelacionada con el lenguaje de las nuevas tecnologías digitales, en especial, con software interactivos en tiempo real, como Live Forms e Isadora.

El laboratorio Kònic Thtr\&Lab aplica, en tiempo real, lo que denomina collage interactivo distribuido de danza, audiovisuales, música, performances, literatura, etcétera. Allí, han desarrollado un dispositivo electrónico inalámbrico que capta los datos físicos y reconoce las secuencias de movimiento iXKa.

Asimismo, en la plataforma interactiva Waterwheel, es posible mantener videoconferencias con múltiples usuarios mientras se está realizando una 
performance. Se trata de performances concebidas de forma colaborativa, en las que se comparten presentaciones y actuaciones a través de las diversas herramientas brindadas, previo registro de una cuenta personal. En general, participan de esta plataforma científicos, artistas, académicos, activistas de varias ciudades, que interactúan en línea con el público en los nodos situados en puntos remotos del planeta. A su vez, utilizan diversas plataformas de código abierto para ciberformance, que combinan imágenes, animaciones, audio, cámaras web, texto y dibujo en tiempo real para una audiencia en línea.

Bioscénica es una compañía interdisciplinaria y transdisciplinaria -radicada en México DF, que cuenta con el apoyo de instituciones académicas nacionales como la Universidad Nacional Autónoma de México y la Universidad Autónoma Metropolitanaque crea, desarrolla y produce propuestas que conjugan arte, ciencias y tecnología, aplicados en la escena y las artes performáticas en beneficio de públicos diversos. Uno de sus objetivos es crear una red de divulgación internacional, especialmente en Latinoamérica, con otros creadores que involucran la tecnología y la ciencia en propuestas escénicas.

En países limítrofes -como es el caso de la Universidad de la República, en Montevideo (Uruguay)-, otra serie de trabajos de investigación y publicaciones conjuntas abrió el escenario que posibilitó la instalación del tema en la agenda de la educación superior, con el grupo de Estudios e Investigación Cuerpo y Tecnología como actor destacado. Los encuentros, jornadas de intercambio y textos publicados en conjunto exponen una mirada crítica en torno al uso de los nuevos medios, el cuerpo, la danza, el sonido y el movimiento en la producción y en la educación.

En la Argentina, siguiendo esta misma lógica de vinculación con la universidad, y dentro del campo de la investigación a través del Programa de Incentivos a Docentes-Investigadores y sus publicaciones, compartimos experiencias y conocimientos con la Universidad Nacional de las Artes (UNA), en la Ciudad Autónoma de Buenos Aires, y el equipo de investigación INTAD con quienes mantenemos intercambios profundos y tenemos mutuos compromisos conformando, de esa manera, un equipo dentro del programa de Ciencia y Técnica de dicha institución.

Asimismo en el emmeLab -laboratorio de investigación y experimentación multimedial formado por docentes y alumnos de la carrera de Diseño Multimedial de la Facultad de Bellas Artes (FBA), de la UNLP-, entre los ejes de investigación que se proponen trabajar, tienen como objetivo "desarrollar espacios arquitectónicos o escenográficos que contengan una superposición de elementos físicos (hardware) y virtuales, los 
cuales funcionan como complemento o paratexto del espacio físico, ampliando la información visible y cargándolo de sentido".

Un factor determinante de la conformación de un circuito de producción ligado a lo académico o a los laboratorios, ámbitos que dificultan el intercambio mutuo de experiencias y conocimientos con el circuito de producción comercial o independiente, recae sobre lo extremamente onerosa e inaccesible que es la tecnología de punta, la high-tech ${ }^{2}$, para muchos artistas que se desarrollan en esta área. Estos altos costos favorecen la reproducción en tecnologías low-tech ${ }^{3}$, o de bajo rendimiento, por lo que se conciben, a la par, otras líneas exploratorias y conceptuales, junto a las que se diseñan con programas de licencia libre.

En esta investigación, el tema del cuerpo hará referencia a aquellos estudios corporales que indagan sobre la desestabilización simbólica que conllevan las nuevas configuraciones de la digitalización. El desafío es continuar coexistiendo simétricamente con nuestro "corpomídia" (Greiner, 2005), resultado de los cruzamientos de las informaciones que llegan con las que ya están. Este cuerpo medio se plantea no como vehículo de transmisión, sino como proceso evolutivo de selección de datos que van componiéndolo y producen nuevas tendencias y atribuciones. Mientras se va esfumando la metáfora del hombre-máquina y cede su lugar al modelo hombre-computadora y hombre-información, podría parecer que la materialidad de la sustancia que constituye a todos los seres vivos es bastante ambigua. Para la tecnología en clave biológica, el cuerpo humano es percibido cada vez más como una metáfora informática: "Al fin y al cabo, el ADN es un código: es pura información" (Sibilia, 2005). Esto habilita otro conjunto de estudios que proponen examinar los desarrollos teóricos sobre la mediatización que plantean nuevos puntos de partida.

Finalmente, sugestionados por la cuantificación del movimiento centrado en la funcionalidad y su potencial expresivo en el uso de tecnologías portátiles, pensamos en abordar el estudio del gesto, como una propuesta de estudio particularizado de la cinemática corporal. En consecuencia, problematizaremos los nodos aparentemente intrínsecos entre la gestualidad humana y la gestualidad tecnológica poniendo en cuestión tanto el valor efímero, intuitivo y presencial del gesto como su reproducción y estandarización. En este sentido, las posibilidades lúdicas y expresivas del cuerpo en

\footnotetext{
2 High-tech o low-tech es una distinción básica entre la brecha digital (que tiene que ver con el acceso a las tecnologías de las computadoras, especialmente en red y teléfonos móviles) y la brecha de participación (que tiene que ver con el acceso a los conocimientos y competencias necesarias para participar de manera significativa con la cultura en red). Si bien existe una clara relación entre ellos también hay también una clara disociación.

3 Según Rocío Agra (2008), en Jorge la Ferla (comp.), "La discusión entre high-tech y low-tech encarna en sí misma el problema del consumo de bienes tecnológicos y descubre la diferencia entre necesidades y voluntades. La velocidad de la obsolescencia no está regida por el agotamiento de las posibilidades de uso de la máquina, sino por la voluntad de renovación de programas cada vez más demandantes de capacidad de almacenamiento y velocidad de procesamiento".
} 
las artes performáticas digitales son materia de análisis. Nos interesa reconfigurar el gesto corporal a partir del uso tecnológico, y observar sus dinámicas y alteraciones.

\section{Delimitación del problema de investigación}

La propuesta de investigación cruza cuatro campos del conocimiento y de la praxis: arte, cuerpo, Danza Performance y tecnología. La presentación se organiza en tres niveles de análisis: macro, meso y micro.

El nivel macro fija los lineamientos del arte, sus prácticas e hibridaciones. Los otros dos niveles pertenecen a una dimensión operativa, y comprenden la diversificación del diseño corporal respecto del diseño técnico y viceversa.

El que llamamos nivel meso hace referencia al desarrollo de los campos disciplinares e interdisciplinares. En ellos, se da coherencia a la práctica disciplinar y se concretan las acciones de base en propuestas interdisciplinares de intervención teórico-práctica, según el contexto de cada producción hacia un nuevo acto paradigmático transdisciplinar.

Finalmente, en el nivel micro se observan, estudian y establecen los medios y secuencias de acciones, así como los instrumentos y recursos necesarios para detectar los procedimientos corporales en cada contexto tecnologizado.

A continuación, especificamos los tres:

a) Un nivel de macroanálisis, que considera la complejidad de la expansión del arte y toma como punto de inflexión la transformación entre técnica, materia y mediación en la producción artística contemporánea dentro de lo que podríamos denominar prácticas artísticas corporales mediadas, con el propósito de aportar a la conformación de una estética de la tecnología en arte.

b) Un nivel de mesoanálisis, que examina las actuaciones en un contexto o entorno físico o telemático determinado de donde se obtendrán dinámicas de diálogo, alcances, interacciones, transformaciones e inmersiones entre participantes de distintas disciplinas. Lo que aportaría un estudio de lo interdisciplinar y lo transdisciplinar.

c) Un nivel de microanálisis, que observa los patrones de diseño recurrentes en la propuesta de movimiento gestual y global del performer, así como los diseños 
de programación, dispositivos y aplicaciones del programador, en mutua proposición.

En síntesis, en esta tesis se analizarán el desenvolvimiento corporal, el diseño y la producción tecnológica en entornos estéticos y comunicacionales. La propuesta genealógica -dados los pasajes entre propuestas artísticas con tecnologías analógicas y digitales- será un intento de reunir, relacionar y organizar el estudio sobre danza performance informática, artistas, pensadores y formadores en determinadas condiciones técnicas, científicas, estéticas y culturales, los modos de experiencia y las dimensiones del pasado reciente y del presente continuo básicamente local en vínculo con lo translocal, con el fin de visualizar con ello tendencias.

Esto significa, por ejemplo, observar el proceso expansivo del cuerpo electrónico, interfásico, digital y conectivo; cómo se va afectando y mutando la gestualidad estetizada, y cómo se integra al espectador transformando su entorno y su percepción en una experiencia física y emocional. Esto implica, por una parte, plantear un nuevo concepto de estructura de la Danza Performance que se compatibilice con interfaces amplificadas, dado que, como todo sistema perteneciente a un contexto, siempre estará involucrada en una determinada cultura, la digital, y provocará en el sujeto que se la apropia mucho más que solo instrucciones motoras. Por otra parte, observar el proceso expansivo del cuerpo, cómo se va afectando y mutando la potencia referencial del cuerpo físico que, en la danza, es inherente.

Hoy cambió nuestro modo de concebir y experimentar lo real. Pensada desde la disciplina Danza Performance, ya no se trataría exclusivamente de una práctica realizada con los medios materiales tangibles como el peso, la firmeza, la fluidez, la resistencia, la vibración y la fragilidad, sino de permanencias sobre algún soporte que vehiculice ideas sobre esas materialidades. No es que esto deba ser dejado de lado. El arte, ahora, resulta de esa extensión de lo humano por las tecnologías y por los medios que suscitan otros problemas para nuestra existencia en torno a la mutabilidad, la conectividad, la no linealidad, la simulación, la red, estar en línea o fuera de ella, etcétera. Cuando cambia la materia y la técnica o cambia su discurso, o cambian los contextos, es inevitable el cambio de ciertas prácticas.

De este modo, será abordado, como problema de investigación, el cruce de aspectos que entendemos constitutivos, a saber: el hábito disciplinar, la práctica en la producción interdisciplinar y la conformación de una nueva experiencia estética transdisciplinar. En algún sentido, diríamos que el lenguaje es digital, fluido, inestable y en constante metamorfosis. Pero, justamente, Pierre Lévy señala que la rapidez con que se producen las innovaciones en las tecnologías, con sus aparatos y operaciones, 
"explica en parte la sensación de impacto, de exterioridad, de extrañeza que nos invade cuando intentamos aprehender el movimiento contemporáneo de las técnicas" (Lévy, 2007). Esta ambigüedad llevó a problematizar la percepción de desfasaje provocada, en gran medida, porque el medio impone su lógica y forma parte de la estrategia de producción. Nos encontramos así en un estado de innovación permanente que trasciende las nociones tradicionales de espacio, tiempo y modos de comunicación.

Hay dos cuestiones posibles para considerar, entre tantas, respecto a las poéticas corporales que pivotan entre lo material y lo inmaterial de sus producciones. Una es el operar desde la lógica del software y de las aplicaciones adecuando las performances a los requerimientos tecnológicos. Otra es poner en crisis los modos de composición y representación escénica derivados de la reproducción de formas previas, fundamentos y valores, muchos de ellos vigentes hasta hoy en la danza espectáculo occidental.

En este punto es importante destacar que si bien ponemos el foco en los procesos sociales y las prácticas que son las que propician los avances tecnológicos, para un artista/investigador es imprescindible colocar el acento en que trabaja mediado por herramientas físicas o simuladas para definir sentido y estética. $Y$ aquí entra a jugar el trabajo del ingeniero, del programador, artista o técnico que opera con dispositivos, aplicaciones o procesos tecnológicos en diálogo con el cuerpo del/de los performer/s que se circunscribe. Pero que también propone que los niveles de competencia tecnológica que deben operar para lograr modelizar el código fuente informático responden a las capacidades reales de los recursos humanos, de las máquinas y de los programas necesarios para dar forma a sus ideas estéticas en diálogo con la escena y los cuerpos.

Nuestra impresión es que hoy un número creciente de bailarines, coreógrafos y performers, así como programadores y artistas multimediales en conjunción, experimentan otros modos de operar con las asociaciones corporales, visuales y sonoras, y hacen surgir nuevos procedimientos, espacios y temporalidades. Esto articula con la necesidad de integrar a la investigación las preocupaciones empíricas acerca de las competencias tecnológicas y de las posibilidades existentes de complejizar el perfil de especialización dedicado al diseño de software y servicios informáticos para la escena.

Del mismo modo, habría que ir advirtiendo si la "institución danza", "el lenguaje de movimiento", "las técnicas corporales", "lo coreográfico", "los estilos de danza", "las metodologías que inscriben esos estilos", etcétera, resuelven renovar sus procedimientos para desarrollarse y persistir en estas nuevas condiciones. 
Tomamos nota de lo manifestado por Lévy (2007) cuando llama la atención sobre no evaluar los impactos sino descubrir las reversibilidades de una técnica: "Antes de que tomemos conciencia, la dinámica colectiva ha cavado sus surcos. Cuando atrae nuestra atención, ya es demasiado tarde... mientras nos seguimos interrogando, otras tecnologías emergen en la frontera nebulosa donde se inventan las ideas, las cosas y las prácticas".

Nos parece importante indicar que este trabajo deja las puertas abiertas para investigaciones posteriores sobre el tema, que amplíen y debatan lo que aquí se sostiene. Sabemos que el pensamiento, la investigación y el avance tecnológico no tienen interrupción. En poco tiempo, todo lo que aquí se ha planteado como sustento en el ámbito de la reflexión tendrá ineludiblemente que ser reconsiderado.

\section{Objetivos generales y objetivos específicos}

\section{Objetivos generales}

- Identificar los componentes que operan en la interacción de la danza performance con mediación o hipermediación tecnológica.

- Analizar los niveles de relación entre cuerpo-sistema-entorno informático y entorno en red.

- Caracterizar aquellos proyectos que se basan en la construcción de escenarios virtuales con sistemas informáticos o en el espacio de internet.

\section{Objetivos específicos}

- Diseñar un marco teórico sobre la danza performance con mediación e hipermediación tecnológica.

- Formular una genealogía de la danza performance con mediación o hipermediación tecnológica.

\section{Preguntas de la investigación}

En el presente proyecto podemos distinguir una pregunta principal y preguntas específicas agrupadas según los tres niveles de análisis anteriormente expuestos:

a) En el nivel macro: ¿Podemos reconocer una evolución de las tendencias digitales en el arte y su incidencia en los formatos tecnológicos en las prácticas 
artísticas escénicas? La colaboración y la cultura participativas han cambiado los hábitos del consumo cultural, consecuentemente, ¿las artes escénicas se han desarrollado en sintonía con estos cambios? ¿Cómo instalar la cultura escénica en vivo, en un contexto mediatizado e hipermediatizado? ¿Dependerá esta instalación de una inversión que contemple el rendimiento, el compromiso y el horizonte a futuro de políticas culturales locales? ¿O solo de la voluntad puntual de las compañías y de los equipos de investigación artística?

b) En el nivel meso (diálogos entre disciplinas o lenguajes artísticos/informáticos): ¿Las disciplinas artísticas y sus actores participan hoy desde una perspectiva diferente? ¿Hasta qué punto resulta necesario para la labor de creación teórica acuñar nuevos términos si los que se venían utilizando hasta ahora continúan teniendo eficacia? ¿Qué diferencias se encuentran entre este modo de producción y los tradicionales u otros conocidos? ¿Cómo se incluyen en la escena informática o se excluyen de ella? ¿Qué distingue a la danza performance interactiva digital de la multimedia predigital, telemática o en las redes sociales si el efecto visual contiene proyección de video en escena?

c) En el nivel micro (gesto ergonométrico/sensibilidad del sistema): ¿Qué concepciones del movimiento corporal se ponen en juego cuando se interactúa con interfaces y dispositivos predigitales o digitales? ¿Habría o no una constante? ¿Cómo se incluye o se excluye la dinámica, la energía de los cuerpos, los gestos, en el diseño del lenguaje de programación o software? ¿Por qué puntualizar en la gestualidad corporal expresiva con relación a una programación que codifique dicha expresividad? ¿Consta un lenguaje de movimiento particular para la Danza Performance según un contexto o entorno de programación simulado, interactivo, telemático, en red?

\section{Argumento hipotético}

Una de las hipótesis centrales de este trabajo es que el vínculo cuerpo-sistema -en mediación con tecnologías predigitales o digitales- condiciona la conformación de la gestualidad y motricidad ergonométrica-expresiva en la Danza Performance. En sentido recíproco, tanto la convergencia tecnológica como la comunicación bidireccional contribuyen, asimismo, a explicar las condiciones de operatividad con la tecnología y permiten representar las transformaciones de la mirada y de la 
corporalidad de quienes participan. Esta transformación estaría pensada conjuntamente como un proceso emergente de las prácticas sociales en un relativo dominio de la realidad contextual. Es decir, los medios digitales en relación con el cuerpo artístico y performático funcionarían en una dialéctica constante con los medios anteriores, exactamente igual a como cada medio lo ha hecho cuando se instaló.

Plantearse hoy, por ejemplo, que quien quiera puede bailar invita a un nuevo modo de concebir, ver y hacer danza, y nos obliga a reflexionar acerca del propio sistema de legitimaciones. La producción de sentido que se establece así implica competencias que involucran otras corporalidades, otras subjetividades artísticas que atraviesan y reconfiguran las categorías estéticas tradicionales. De esta manera, las nuevas tendencias en las artes del movimiento se construyen en sintonía con estas nuevas formas de representación contemporánea que implican esta interacción cuerpovisuales-sonido y la experimentación con la inmaterialidad del cuerpo, que pone en crisis el espacio de representación y el contenido de lo disciplinar. Entendiendo tanto las atribuciones que presentan las nuevas tecnologías, interfaces perceptivas y sensibles al gesto y al movimiento como la ubicuidad y la accesibilidad a los cuerpos en red de internet, construimos la siguiente hipótesis:

Las tecnologías digitales proponen nuevas trayectorias a los procesos de producción y formación en el campo de la Danza Performance. La programación libre, las interfaces y las aplicaciones así como las plataformas de código abierto para la presentación escénica en conectividad con redes de internet permitirán establecer otros principios de organización espacio-temporales tanto de la gestualidad expresiva como de la corporalidad distribuida, lo que proporcionará, a su vez, el acceso a herramientas conceptuales y experimentales inéditas.

En consecuencia, identificar, estudiar y sistematizar el conocimiento que bailarines, performers, coreógrafos y programadores desarrollan cuando están operando con tecnología y sus entornos nos habilitarán para construir una genealogía de los desplazamientos de la mirada y la corporalidad. 


\section{Diseño metodológico para la sistematización de los datos}

A continuación, presentaremos los contenidos correspondientes a la sistematización de los datos obtenidos a través de los distintos instrumentos de recolección -aplicados a nuestra investigación- del método de la investigación científica ${ }^{4}$. Es importante destacar -teniendo presente los debates y las configuraciones entre métodos cualitativos y cuantitativos, ciencias blandas y ciencias duras- que se "asume la existencia de 'un' método de la ciencia sin más" (Ynoub, 2015: 8). Esto da por sentado que "hay tantas técnicas como disciplinas o estrategias investigativas imaginables" (Ynoub, 2015: 8). De la misma forma, hay un recorrido que a los fines de nuestra tarea se hace necesario referenciar:

Los métodos de investigación responden a lógicas preestablecidas que integran un orden sistemático, esto es, una estructura dinámica o dispositivo organizado. Un sistema está constituido por un conjunto de elementos dispuestos para lograr cierta finalidad. El sistema obviamente es más abarcativo que el método (Díaz, 2007: 137).

Esther Díaz (2007) propone y delimita otras instancias para los mandatos de la ciencia entrelazados con las complejidades humanas y no humanas vinculadas al "deber ser científico" y al "ser tecnocientífico", haciendo referencia también a "la empresa científica actual":

Una de las tantas exigencias del conocimiento científico moderno fue que la investigación se desarrollara en el interior de los rígidos límites de cada disciplina. Pero a partir de la complejidad y la proliferación de nuevos saberes difícilmente una disciplina puede hoy "abastecerse a sí misma" [...]. No obstante, es dificultoso lograr "porosidad" entre los muros que delimitan las diferentes modalidades científicas. Tal porosidad facilitaría el intercambio de experiencias y la construcción conjunta del conocimiento. La resistencia a la apertura de los paradigmas no es ajena al temor a posibles pérdidas de poder cognoscitivo, normativo, controlador, tecnológico, económico o simbólico. Los saberes tienden a cerrarse en compartimentos estancos, aunque también existen intercambios (Díaz, 2007: 139).

\footnotetext{
${ }^{4}$ Nos acogemos a lo que Roxana Ynoub concibe como método de la investigación científica en una dirección que también podría definirse como metodología crítica.
} 
Podríamos señalar que en la actualidad existen modos de hacer investigación de corte "interdisciplinar o transdisciplinar, interactuante" (Díaz, 2007: 139). En este sentido, las palabras claves serían: diversidad, diferencia, articulación, confluencia, aporte, intercambio, entre otras; que amplían, de esa manera, la caja de herramientas metodológicas para ser plausible de modificaciones o adecuaciones. Igualmente, se hará una salvedad sustancial a lo expresado: "si bien puede existir transdisciplinareidad, no existe carácter transitivo de unas disciplinas a otras" (Díaz, 2007: 158). A esta afirmación la consideramos troncal para entender los límites de nuestras expectativas respecto a nuevas formas de articular la corporalidad con el procesamiento de datos, por ejemplo.

Acrecentamos lo expresado con un aforismo conceptual que se impone, en apariencia, a nuestro estudio de índole cualitativa y que se refiere a la supremacía de lo medible, a la necesidad imperiosa de medición, de cuantificación. ¿Por qué damos relevancia a esto? Sencillamente porque estamos investigando de manera interdisciplinaria entre campos de estudio del cuerpo, la Danza Performance, la tecnología y la Informática ${ }^{5}$. No olvidemos que la medición es uno de los fuertes de las ciencias duras, cuyo dominio y concepción heredada del positivismo postulan una reducción de su método hegemónico. Por ende, la pluralidad metodológica de las ciencias sociales -a la que pertenece la investigación en arte- disputa permanentemente una reivindicación ante la inversión del mercado político cultural hacia el desarrollo incesante de la máquina tecnocrática (Díaz, 2007: 159). En otras palabras, el contexto social produce y gestiona marcos representacionales y valoraciones asociadas a esas praxis dominantes que orientan la producción científica de sus protagonistas:

... Estas constricciones no serán impuestas ni ajenas al propio investigador, serán parte de su metabolismo representacional, confirmarán la concepción de la ciencia que nutrirán en concreto sus prácticas: se investiga, y cómo se investiga va asociado a dónde y para qué fines se investiga (Ynoub, 2015: 12).

De esta forma, adquirimos un saber basado en la experimentación y el intercambio dentro de las llamadas comunidades de investigadores, en las que los conflictos y las tensiones conforman una cultura y una práctica científica caracterizadas por protocolos que preservan sus tradiciones, entre ellos, la escritura. Hay que dominar el arte de la escritura científica, asevera Ynoub (2015: 15), pues afianza el conocimiento. Este integra lo conceptual-conjeturado con lo empírico, y viceversa; adscribe así a las

\footnotetext{
5 Perteneciente a la ciencia de la Computación que comenzó a establecerse como una disciplina académica en la década de 1950 y principios de 1960.
} 
regularidades fácticas o de hecho expresadas a través de una hipótesis. Esta debe estar abierta a una constatación práctica para producir evidencia. A la par, lo observable deberá tener carácter comunicable o público para poder explicitar los hechos y mediante qué instrumentos e indicadores se obtuvieron los resultados. $Y$ en este punto encontramos muy interesante advertir, en sintonía con Ynoub (2015: 29) y los autores con los cuales va conformando su teoría:

\begin{abstract}
De un modo general lo que puede reconocerse es que para que una acción devenga representación se requiere que las propias acciones estén a su vez estructuradas, que se constituyan en acciones repetibles, reproducibles. Esto es lo que Jean Piaget vio con especial profundidad ( $\sin$ duda "parado en los hombros de Kant"): la acción se torna potencial engendradora de intelección si está organizada como "esquema". Como lo ha reconocido Juan Samaja, la cuestión decisiva es advertir la diferencia entre un hecho material como lo es una secuencia de acciones, de un patrón o forma de secuencia de acciones. Este patrón es el que adquiere estatus de organizador de la experiencia y del pensamiento.
\end{abstract}

Experimentar con el propio cuerpo como parte del método para disponer, emancipar y procesar el conocimiento enactivo o corporal "se adquiere por el método de la tenacidad" (Samaja, 2003: 10), que "podemos describirlo de manera más precisa como el método simple y directo que consiste en el proceso por el cual adoptamos aquella creencia que surge cuando nos involucramos corporalmente", asevera Samaja (2003: 14).

El autor reconoce otros métodos como son el de la autoridad o de las tradiciones, y el de lo formalizado o de la reflexión. Estos métodos franquean la praxis humana porque se refieren a las diferentes formas de vida en que se produce conocimiento mediante: la vida biológica por el método de la tenacidad, la forma de vida comunal mediante el método de la autoridad, la forma de vida estatal mediante el método de la reflexión, y la forma de vida social mediante el método de la ciencia o de la eficacia. Esta última se constituye dentro del paradigma de la tenacidad a través de la percepción visual: "ver para creer", aunque esa visualidad esté totalmente mediatizada.

Es verdad que [lo] virtual implica ausencia de cuerpo. Pero la ilusión hace posible situaciones estimulantes poco factibles de producirse en la realidad concreta. [...] Las tecnologías generan un culto de sí mismas. Las cámaras fotográficas, las reproductoras de música o imágenes, los teléfonos y otros juguetes son portátiles 
y etéreamente livianos. Se han convertido en extensiones de nuestros cuerpos y de nuestras mentes. Existimos mediatizados (Díaz, 2007: 128).

En este punto, nos importa observar estas cuestiones sobre la tecnociencia que Esther Díaz examina de modo exhaustivo. Del párrafo citado destacamos "y otros juguetes" que Díaz alude al indicar a los dispositivos técnicos- sin desconocer los efectos superfluos del consumo tecnológico que se producen en una sociedad. Los aspectos que nos impresionan son los que pueden afectar nuestros intercambios entre disciplinas puestas a conjugarse con anhelo epistémico. ¿Por qué? Porque se trata de la disciplina de la danza y, de la tecnología; donde se requiere de especificidad técnico-cognitiva, "de personas bien entrenadas para instrumentar los medios establecidos por los investigadores, es decir, personal capacitado para la técnica" (Díaz, 2007: 133).

Por consiguiente, ¿ambos dominios de origen tan disímil podrán conjugarse? Para esta autora -como ya lo ha expresado-, sería dificultoso lograr tal "porosidad" entre diferentes modalidades científicas. Igualmente, las resistencias al detrimento del poder cognitivo disciplinar -en especial de las llamadas ciencias duras a las cuales la tecnología pertenece- tienden a cerrase "tomando caminos independientes, tanto en sus fundamentos epistemológicos, como en torno a las técnicas y estrategias empíricas que se fueron consolidando y -hay que reconocerlo- también 'convencionalizando' al interior de cada una" (Ynoub, 2015: 14). La interdisciplinariedad en la investigación científica en las áreas sociales, y más aún, en el territorio del arte, compone lo que se denomina "líneas de fuga" (Díaz, 2007: 91):

Cada disciplina delimita territorios. No obstante, existen pasajes de un territorio a otro que, a veces, se convierten en líneas de fuga. Producen desterritorializaciones: una poesía surgiendo de un libro teórico, una metáfora con valor estético irrumpiendo en un tratado científico, una fórmula matemática que sorprende en una novela.

Lo que nos anima a agregar a estas desterritorializaciones un algoritmo que opera a partir de las actuaciones intercondicionadas por los movimientos de un bailarín. ¿Será el cuerpo epistémico de la danza o será el cuerpo epistémico de la tecnología poroso? ¿Quién emigra o interviene desde su territorio a este movimiento expansivo? ¿Podrá ser un movimiento bilateral donde finalmente converjan? ¿Y esa convergencia podrá generar ese espacio en común? Por el momento, podemos responder citando un pasaje de Ynoub: 
El término "método" proviene etimológicamente de dos vocablos griegos: meta, que significa 'más allá' o 'fuera de'; y hodos, que significa 'camino'. De manera general, puede entenderse como 'plan de ruta' o 'plan de acción'. [...] Cuando la meta de esos caminos "es producir conocimiento científico", puede hablarse de método de la investigación científica (2015: 5).

¿Entonces estaríamos proyectando un camino metodológico que aúne estos territorios del cuerpo y de los dispositivos? Sin duda, es nuestro propósito.

Es la propia práctica científica la que gradualmente fue dando lugar a una nueva disciplina denominada metodología de la investigación científica. Y, valiéndonos de la potencia del método científico para la producción de nuevos conocimientos, promovemos ahora la prolongación de las fronteras del conocimiento disciplinario. La investigación en arte, en la actualidad, goza de una concepción que se ha ido consolidando en los últimos años para referirse no solo a la naturaleza del proceso artístico, sino también a la especulación teórica en un nuevo diseño y metodología de investigación académica.

Si observamos atentamente, al interés por la demarcación y la unidad de la ciencia le ha sucedido el énfasis en la diversidad, la fragmentación y la hibridación. Asimismo, las intersecciones existentes entre la ciencia y otras expresiones culturales como las artes plásticas, la danza, el cine, los massmedia, etcétera, también habilitan nuevos espacios que dan lugar a formatos híbridos de tipo diverso: objetos, organizaciones o agentes de naturaleza fronteriza que transitan entre formas de conocimiento y modos de acción, y ejemplifican la diversidad de manifestaciones que adoptan la innovación social y la cultura científica en el marco de la sociedad del conocimiento.

Por su parte, señalar la ubicuidad e incluso el valor de las fronteras es una característica representativa de los estudios sobre ciencia y tecnología contemporáneos. Sobre esta base, nos proponemos explorar algunos de los múltiples significados de la hibridación y el trabajo fronterizo. Pero estas interacciones no solo competen al arte, la ciencia, la tecnología; sino también a la sociedad y a la transformación de comunicadores y promotores de la cultura, y del público general interesado por el papel de estos territorios híbridos contemporáneos. $Y$ es a partir de aquí que nos adentraremos en el concepto de método y metodología para nuestra especificidad: la hibridación entre arte y ciencia. 


\title{
13. Metodología para el estudio de prácticas artísticas híbridas
}

Esta investigación se inscribe en un paradigma preliminar o exploratorio, por ende, suele decirse en estos casos "que la teoría emerge de los datos, que el fin de la investigación cualitativa es más construir teoría que comprobarla” (Ynoub, 2015: 214). Por tanto, la metodología de investigación utilizada es la exploratorio-descriptiva. Es exploratoria, dado que se ensaya un fenómeno contemporáneo dentro de su contexto real. $Y$ es descriptiva dado que busca especificar las propiedades importantes de los componentes humanos y los dispositivos técnicos. Es decir que se requiere, por una parte, categorizar el fenómeno explorado; y por otra, recopilar los datos concernientes. En esta tesis, es de suma importancia el diálogo con los protagonistas a través de actividades de campo compartidas; esto es, equipos de artistas investigadores en el marco de laboratorios académicos. Lo que nos permite, precisamente, poner en competencia los diversos enfoques o estrategias metodológicas. La llamada triangulación da cuenta de esas estrategias combinadas en el desarrollo de una investigación. Según Roxana Ynoub (2015: 14), actualmente, "existen distintas posiciones en el modo de comprender y aplicar este concepto. Desde esa perspectiva", se distinguen dos tipos de triangulación:

\begin{abstract}
a) "Triangulación de datos": consiste en cruzar o incluir información proveniente de diversas fuentes o informantes. Se pueden triangular personas o unidades, por ejemplo, se puede combinar el relevamiento de personas, díadas o colectivos, pero además la unidad puede ser también la interacción -si se asume que esta es algo más que el agregado de las personas-; se pueden triangular relevamientos en distintos tiempos, espacios o contextos.
\end{abstract}

b) "Triangulación de investigadores": la inclusión de distintos investigadores en el abordaje del mismo asunto contribuye a incrementar la confiabilidad de los resultados. Si se detectan sesgos habrá que evaluar si esas múltiples miradas incrementan la comprensión del fenómeno, o si se producen distorsiones por los investigadores/as y/o los procedimientos. Por lo demás, el trabajo con equipos interdisciplinarios o con investigadores/as con diversas experiencias y prácticas puede contribuir a un abordaje más rico del asunto investigado (Ynoub, 2015: 18).

Las técnicas dependen de su adecuación al objeto abordado, por consiguiente, no existirá una oposición entre ambos abordajes -cuantitativo y cualitativo-, sino una complementariedad, en tanto componen particularidades para producir conocimiento 
sobre distintos aspectos de un mismo contexto de prácticas. Los criterios para evaluar la validez, la confiabilidad y las posibilidades de generalización no deberían ser substancialmente diferentes, sino compartir ciertos esquemas básicos.

Nuestro propósito es comprender la interacción entre las diversas partes de un sistema interactivo informático local o en internet, sus características en relación con el gesto y el cuerpo en movimiento; de manera que este análisis pueda ser aplicado de modo general, en cuanto logra una comprensión de la estructura y los procesos más que un establecimiento de correlaciones o relaciones de causa y efecto, tanto desde la observación de fenómenos individuales como grupales. Además de la observación de estudios de casos, para la obtención de datos se utilizaron las entrevistas semiestructuradas -con y sin cuestionario-. Los instrumentos de aplicación que se emplearon fueron la selección, el análisis y la interpretación; y las acciones, las siguientes:

- Aplicación de categorías de observación que permitan distinguir los diferentes tipos de experiencias cuerpo-sistema-entorno mediatizadas y experiencias cuerposistema-entorno hipermediatizado en estudios de casos seleccionados.

- Diseño de entrevistas semiestructuradas con y $\sin$ cuestionario a bailarines performers, artistas investigadores y desarrolladores programadores.

Las entrevistas fueron flexibles y dinámicas -los entrevistados eligieron el lugar, la mayoría fueron realizadas por Skype-, además, fueron registradas en video y editadas con el fin de lograr el empleo más eficiente del tiempo de quienes visionaran luego estos materiales para sondear las citas.

\footnotetext{
Las informaciones fácticas proporcionadas por los sujetos resultan por lo menos igual de exactas y fiables que las recogidas mediante cuestionario estandarizado, pero más ricas que estas últimas, por contener información contextual que favorece una comprensión más cabal de sucesos y transiciones (Seid, 2016: 50).
}

Con las técnicas seleccionadas, se buscó indagar sobre el comportamiento focalizado y la apertura o inhibición de conocimientos psicofísicos en el momento de interactuar con los sistemas. Consultamos si existen y cuáles son esos patrones de diseño recurrentes en el movimiento y gestualidad del interactor. Consiguientemente, la selección de los estudios de casos, así como de los participantes para las pruebas abiertas y entrevistas, constituye el conjunto de unidades debidamente delimitadas en 
tiempo y espacio que poseen una o más características de interés. Esta delimitación debe ser coherente con el problema y alcances de la pesquisa, pues se convierte en el marco de referencia o universo al cual se vinculan los resultados y las conclusiones obtenidas en la investigación.

Esta selección pone en evidencia cada uno de los criterios estipulados, tanto teóricos como experimentales, y distingue las reacciones o interacciones, desvinculaciones, limitaciones, entendimientos, creaciones recíprocas, etcétera, entre cuerpos y sistemas. Teniendo en cuenta performances de artistas locales, translocales y experiencias personales, se conformó y se estudió un panorama de la Danza Performance con tecnología en el que nos proyectamos observar:

- La propuesta de diseño corporal del performer/bailarín/coreógrafo/compositor docente.

- La propuesta de diseño de la programación del programador/usuario de software.

- La retroalimentación o no de ambas proposiciones en un espacio-tiempo $\mathrm{real} /$ virtual/simulado/conectado.

Sabemos de antemano que lo que se da mayormente como experiencia del cuerpo con sistemas informáticos se realiza mediante la siguiente correspondencia: mientras el performer hace, el sistema capta; mientras el performer percibe y manifiesta las restricciones de la detección, modula sus movimientos y gestos para facilitarle el proceso al sistema.

Y aquí estamos frente a uno de los problemas esenciales de estas propuestas de producción creativa con mediación e hipermediación, a saber: el cálculo de la experiencia corporal en pos de la aprehensión por parte del sistema. A esto, Emiliano Causa (2014: 69), director de esta tesis, lo denomina "encorsetamiento" del cuerpo, porque "es como si el cuerpo fuera limitado en sus movimiento por un corsé virtual que el performer se autoimpone para amoldarse al sistema".

La consecuencia es clara: el performer debe moverse en función de hacer reaccionar al sistema. Se produce una serie de gestos, que si bien no dejan de proponer un "descentramiento de la formación antropocéntrica del bailarín"6, anulan -en principioel diálogo que se procura establecer como modo de operar con el sistema interactivo digital.

$6 \quad$ Alejandra $\quad$ Ceriani. Tesis de $\begin{gathered}\text { maestría. } \\ \text { <http:/// Puede }\end{gathered}$ 
Desde los límites materiales de los dispositivos, el margen de captura de un sensor óptico hace la diferencia; puesto que, al reducirse las posibilidades del sistema, impacta en su diseño poniendo en jaque la experticia del programador. En correspondencia lógica, se demanda una mayor adaptación al performer bailarín frente a las limitaciones aludidas. Entonces tanto la reformulación del diseño como el dominio del gesto -en toda su subjetividad y su singularidad corporal- procuran no caer en un ejercicio mecanicista.

En este marco, los procesos de innovación tecnológica pueden ser entendidos como procesos de innovación estética y de producción, y se constituyen en una instancia de creación de conocimiento transdisciplinar que permite que los saberes interdisciplinares se amplíen, en un proceso dinámico y continuo, que modifica y reelabora las competencias organizativas, entre otras.

Por tanto, los programadores informáticos, de igual forma, se implican no solo comprobando cuánto responden las interfaces y el hardware, sino diseñando procesos cuyos parámetros entrecrucen información en retroalimentación aleatoria con las expresiones sensibles de las propuestas corporales in situ.

Contando con un diseño de proceso en la programación y no solo con una forma preestablecida, se pueden operar los parámetros en tiempo real e integrar así los efectos dinámicos de la danza más allá de la metáfora bidimensional que generan las visuales en la pantalla o la proyección. $\mathrm{Y}$, en ese caso, habría que trabajar con la interpretación holística del movimiento que ejecuta el performer inmerso en una proyección tridimensional.

La simulación de los comportamientos gestuales humanos constituye, en la actualidad, un dominio que forma parte de la investigación científica y artística. Tener en cuenta esta complejidad hace que no abrevemos en el reduccionismo simplificador ligado a los valores dominantes de lo tecnológico, sino, por el contrario, despleguemos los múltiples recursos del arte y de la ciencia para un proceso mancomunado. Por lo que se deduce que, para interpretar el arte actual, es necesario dar las claves y acercar contenidos al campo de la práctica profesional y a sus potenciales participantes.

\section{Sistema de matrices de datos}

En un sistema de este tipo estudiamos y reconocemos los distintos momentos de un objeto en el tiempo, lo que se denomina "estado de cosas" (Ynoub, 2015: 229). El diseño de matrices de datos constituye entonces el primer paso para establecer "cuáles serán las unidades de análisis, qué aspectos y dimensiones o variables 
vinculadas a ellas son relevantes, qué dimensiones y a través de qué procedimientos se van a determinar dichos aspectos; de qué manera se van a distinguir los distintos estados (es decir, valores de las variables seleccionadas)" (Ynoub, 2015: 231).

El tratamiento de los datos que realizaremos -con la intención de sintetizar la información recabada- se basó en las unidades y dimensiones de análisis, dado que se trató de producir información sobre el perfil del estudio de caso seleccionado, para construir o identificar segmentos y tipologías que definen la base empírica de cualquier investigación:

\begin{abstract}
Por ejemplo, cuando tengamos que proponer cuáles serán las unidades de análisis, las variables, los valores y los indicadores respectivos. En tal ocasión deberemos tener criterios bien fundados para resolver cuáles son nuestros sujetos y sus predicados; cuáles son nuestras sustancias y sus accidentes; cuáles son sus inherencias y sus dependencias; cuáles son los textos, cuáles los contextos y cuáles los subtextos (para decirlo metafóricamente), etcétera (Samaja, 2003: 28).
\end{abstract}

Por consiguiente, todo dato posee una estructura básica dada por las unidades de análisis (UA), variables, valores e indicadores:

- Las unidades de análisis definen las "entidades/eventos/sujetos/objetos en que se focaliza la descripción o el análisis" (Ynoub, 2015: 231).

- Las dimensiones de análisis se constituyen por los "aspectos/características/propiedades que se han seleccionado para examinar o estudiar" (Ynoub, 2015: 231).

- Una variable es el estado particular que puede asumir valores o categorías, por ejemplo: alto, medio, bajo.

- Un indicador es la "manera en que van a evaluarse, observarse o medirse las variables": una vez definido qué evaluar, hay que definir el cómo se hará (Ynoub, 2015: 232).

\title{
15. Unidades y dimensiones de análisis
}

Las unidades de análisis sobre las que se trabaja son las siguientes: cuerpo, sistema y escena interactiva. 


\subsection{Unidad de análisis: cuerpo}

Se analizarán los procesos de mutación del cuerpo de carne y hueso al cuerpo interfaz modelizada hacia un cuerpo de "carne, hueso y sílice" detección y de modelización de los movimientos y los gestos, observando:

15.1.1. Cuerpo físico y presencial, que acciona un sistema también físico (hardware) y virtual (software). Se analizará el cuerpo propiamente dicho que interactúa con los sistemas analógicos, digitales, físicos y virtuales. Es el cuerpo que se mueve e induce al sistema, en su globalidad o por partes, particularizando gestos o micromovimientos (torso, brazos, manos, dedos). Por lo tanto, el cuerpo del performer/bailarín, como el del programador, es la derivación de tres factores:

- La detección del cuerpo físico en movimiento por parte de un sensor (óptico, de contacto reactivo o interactivo, micrófono).

- La lectura y la modelización que el diseño de la programación o aplicación generan a través del sensado.

- La incidencia del factor espacial y temporal sobre la fisicalidad y la virtualidad del movimiento proyectado.

15.1.2. Cuerpo parametrizado y modelizado, que se acciona con el sistema virtual/simulado y viceversa. Este cuerpo, tanto del performer interactivo como del programador, es la modelización de cuatro factores:

- Retroalimentación del sistema a través de los gestos y movimientos globales o particularizados en función de lo que se genera con la imagen, el sonido y la conectividad.

- Articulación de una forma particular de programación con la propuesta de movimiento en un determinado espacio escénico.

- Creación de una forma particular de movimientos, gestos y dinámicas corporales para esa programación.

\footnotetext{
${ }^{7}$ Para aportar al esclarecimiento de la metáfora utilizada por la Dra. Ivani Santana, brindamos la definición de este compuesto químico y su uso: "el sílice -elemento químico metaloide- es un semiconductor que se usa para la fabricación de microchips que se utilizan en las memorias y procesadores. El microprocesador (o simplemente procesador) es el circuito integrado central más complejo de un sistema informático; a modo de ilustración, se le suele llamar por analogía el 'cerebro' de un computador". Con el fin de ampliar la información, véase: <https://sapientia.pucsp.br/bitstream/handle/5194/1/lvani\%20Lucia\%20Oliveira\%20de\%20Santana.pdf>.
} 
- Comprensión locativa y ubicua (entre otras, observar la supresión de lo individual a favor de la realización intersubjetiva).

Por lo tanto, la unidad de análisis cuerpo tiene dos dimensiones:

- Dimensión cuerpo presencial. Se analiza el cuerpo disciplinar que interactúa en su globalidad o se particulariza en gestos o micromovimientos ante el sistema informático: hardware y dispositivos de captación o interfaces periféricas.

- Dimensión cuerpo modelizado. Se analiza el cuerpo capturado, modelizado y proyectado en la imagen o en el sonido que intercambia información codificada con la lógica de la programación del software.

\subsection{Unidad de análisis: sistema}

Los sistemas escénicos reactivos e interactivos, de alta o baja tecnología, de software comercial o de desarrollo, serán observados a través del estudio del diseño de interfaces o aplicaciones en intervínculo con el campo de la danza performance mediada, con la intención de que arrojen parámetros para su análisis tales como:

- La modelización en la programación de software, sensores y aplicaciones (ópticos y de contacto, reactivo e interactivo, digital o analógico).

- La disposición espacio-temporal con las pantallas y proyecciones (materiales, dimensiones, visuales).

- La gestión en la producción con protocolos de comunicación telemática y redes sociales.

Por lo tanto, la unidad de análisis sistema tiene tres dimensiones:

15.2.1. Dimensión hardware. Se analizan el rendimiento del computador y las interfaces periféricas de entrada y de salida.

15.2.2. Dimensión software. Se analizan las capacidades de interpretación, traducción y modelización del lenguaje de programación. 
15.2.3. Dimensión humanware ${ }^{8}$. Se analizan las habilidades de interpretación, traducción y modelización del programador o desarrollador hacia un usuario específico de software.

\subsection{Unidad de análisis: escena interactiva}

El estudio de los aspectos escénicos refiere al entramado de los procesos dinámicos entre el sonido, el movimiento, la gestualidad, las visuales, etcétera; articulados por el cuerpo y el sistema multimedia interactivo. Por consiguiente, la escena interactiva es la derivación de tres factores:

- La retroalimentación que hay entre el movimiento individual o grupal con las visuales, el video, el sonido y el entorno gráfico.

- La retroalimentación con la programación de visuales, video, sonido, por parte del programador o usuario de software (procesamientos de la información recibida y emitida).

- La puesta en escena como el conjunto de determinaciones entre unidades cuerpo y sistema.

Por lo tanto, la unidad de análisis escena interactiva tiene dos dimensiones:

15.3.1. Dimensión modelo de interacción9: niveles de intervención según la reciprocidad, reacción o modificación de un entorno.

15.3.2. Dimensión modelo de inmersión ${ }^{10}$ : niveles de ambientación según la actividad sensible de un entorno.

\footnotetext{
${ }^{8}$ Humanware es un término disciplinar que se utiliza para definir los recursos humanos de un sistema informático, o el hardware y el software que es diseñado pensando en el uso que le dará el usuario final. Con el fin de ampliar la información, véase: <https://es.wikipedia.org/wiki/Humanware>. Hemos decidido aplicar el término de humanware a la práctica de programadores y desarrolladores que en nuestro ámbito académico de investigación no solo son el recurso humano que diseña informáticamente, sino que lo hacen pensando en un usuario específico como sería aquel perteneciente al ámbito escénico. En consecuencia, implementar un software o un código de programación en desarrollo como es Cod05 teniendo en cuenta la democratización vigente del hardware en su contexto social, económico y cultural; y, que parta del lado humano para aplicar la tecnología escénica y experimental- requiere de una investigación previa, seria y profunda entre diferentes disciplinas de distintos campos de estudio y concepciones del saber. Sobre todo, asumiendo que las competencias digitales provocan un gran impacto -sea positivo o negativo- en la implementación de un proyecto artístico corporal.

9 Concordamos con el concepto de la tesis doctoral de Ludmila C. Martínez Pimentel (2010: 3): "La palabra 'interactividad', en un sentido más estrecho, [se usa] para performances colaborativas con sistemas de control (sistemas cibernéticos) en los cuales el movimiento del performer, el gesto y la acción son capturados por las cámaras, sensores y son usados como input para activar o controlar propiedades de otros componentes como videos, sonidos, MIDI, texto, gráficos, QuickTime movies, imágenes escaneadas, etcétera. Es decir, el 'sistema interactivo' permite al performer generar, sintetizar y procesar imágenes, sonidos, voces y texto, proponer y compartir un evento en tiempo real". Con el fin de ampliar la información, véase: <http://interaktionslabor.de/lab11/lachoreografia.pdf>.
} 


\subsection{Indicadores y criterios de valoración}

Los indicadores están organizados en dos niveles: nivel de conciencia y nivel de vinculación, que nos circunscribirán a estudios de casos, teniendo en cuenta un lugar, un tiempo, condiciones particulares y generales dentro de los períodos 1997-2003 y 2010-2016 (Como ya hemos expresado, el período 2005-2012 ha sido analizado y publicado en anteriores investigaciones). Individualizar estos dos niveles posibilita diferenciar tanto las condiciones del espacio, el tiempo y el cuerpo -físico y virtualcomo las condiciones del sistema en la modelización de los dispositivos.

\subsection{Niveles de organización de los indicadores}

- Nivel de vinculación (NV): cuando se da la interactividad o reactividad entre el cuerpo físico/material con el sistema físico/material (hardware y periféricos: la cámara y el espacio captado, el micrófono y el espacio sensado, la pantalla o plasma, etc.).

- Nivel de conciencia (NC): cuando se da la interactividad o reactividad entre el cuerpo virtual/simulado con el sistema simulado (software, programación, visuales, sonido, etc.).

\subsection{Los criterios de valoración}

Los criterios de valoración de los indicadores de vinculación y conciencia serán: altomedio-bajo (A-M-B).

- NV del cuerpo-como volumen en movimiento o como fragmento particularizado en gestos- accionando a nivel físico con lo físico del sistema (hardware y periféricos) y viceversa.

\footnotetext{
10 Concordamos también con Ludmila C. Martínez Pimentel (2010: 4) cuando sostiene que "La danza y las modificaciones en las nociones de un lugar específico en instalaciones interactivas precisan ser discutidas considerando la realidad virtual, los modelos de inmersión que integran fiscal y sintéticamente, los simuladores de 3-D, para que reconozcamos las conexiones entre designes basados en la representación espacial y designes generados por algoritmos. [...] Los performers pueden hacer experiencias físicas y táctiles relacionadas con la realidad virtual, en las cuales ellos pueden modificar y dar forma a ese espacio, moviéndose a través del mundo proyectivo generado por los ordenadores, eso significa decir que el performer se mueve a través de ondas, terrenos de colores y pulsaciones, navegando entre objetos virtuales, y su cuerpo potencialmente experimenta la ruptura, da forma cinética originada por nuestros sentidos visuales, expandiendo la superficie de nuestro cuerpo físico y obteniendo una extensión en su tacitilidad. Así también se disuelve la división clásica entre el performer y los espectadores, construyendo un espacio performático interactivo conjuntamente". Véase: <http://interaktionslabor.de/lab11/lachoreografia.pdf>.
} 
- NC del cuerpo parametrizado, accionando a nivel virtual con lo virtual del sistema (programación del software, proyecciones) y viceversa.

Podrá observarse en el Capítulo 3, el empleo de esta estructura de análisis de datos dispuesta en cuadros para poner en valor -a través del estudio de caso- las unidades de análisis, indicadores y criterios.

Nos proponemos previamente avanzar sobre el material teórico-reflexivo derivado del proceso de análisis de un corpus bibliográfico propuesto y de las entrevistas a los actores comprometidos, así como de la observación y la actuación experimental del pasaje de lo analógico a lo digital, tanto sea desde los recursos de creación escénicos como desde el cuerpo disciplinar de bailarines, performers, videoartistas, músicos y programadores.

\section{Referencias bibliográficas}

AA. VV. (1999), Quinto festival Internacional Videodanza, Buenos Aires, Universidad de Buenos Aires, Centro Cultural Ricardo Rojas.

Agamben, Giorgio (2006), La comunidad que viene, Madrid, Pre-Textos.

Brea, José Luis (2002), La era post media. Acción comunicativa, prácticas (post)artísticas y dispositivos neomediales, España, Editorial Centro de Arte de Salamanca.

Carlon, Mario (2016), "Conceptos y debates sobre la visualidad y dispositivo", en Visualidad y dispositivo(s). Arte y técnica desde una perspectiva cultural, Buenos Aires, Ediciones Universidad Nacional de General Sarmiento.

Ceriani, Alejandra (2011), "Espacio digital y cuerpo expresivo", en Con-figuraciones de la danza sonido y video del cuerpo, Montevideo, Comisión Sectorial de Educación Permanente, Universidad de la República.

Couchot, Edmond (1998), La tecnología en el arte. De la fotografía a la realidad virtual, París, Chambon.

Díaz, Esther (2007), Entre la tecnociencia y el deseo. La construcción de una epistemología ampliada, Buenos Aires, Biblos.

Eco, Umberto (1987), Como se hace una Tesis. Técnicas y procedimientos de estudio, investigación y escritura, México, Gedisa.

Flusser, Vilém (1994 [1991]), Los gestos: fenomenología y comunicación, Barcelona, Herder.

Greiner, Christine (2005), O Corpo em Crise: Novas Pistas e o Curto-Circuito das Representações, São Paulo, Brasil, Annablume. 
Kozak, Claudia (ed.) (2009), Tecnopoéticas Argentinas. Archivo blando de Arte y Tecnología, Buenos Aires, Caja Negra Editora.

La Ferla, Jorge (comp.) (2008), MEACVAD 08, Artes y medios audiovisuales: Un estado de situación II. Las prácticas mediáticas pre digitales y post analógicas, Buenos Aires, Aurelia Rivera, Nueva Librería.

Lévy, Pierre (1999), ¿Qué es lo virtual?, Barcelona-Buenos Aires-México, Paidós.

Lévy, Pierre (2007), Cibercultura. La cultura de la sociedad digital, Barcelona, Anthropos.

Prada, Juan M. (2012), Prácticas artísticas e internet en la época de las redes sociales, Madrid, Akal.

Santaella, Lucía (2003), Cultura e artes do pós-humano. Da cultura das mídias á Cibercultura, São Paulo, Paulus.

Santana, Ivani (2006), Dança na cultura digital, Salvador de Bahía, Edufba.

Scolari, Carlos A. (2008), Hipermediaciones: elementos para una teoría de la comunicación digital interactiva, Barcelona, Gedisa.

Sibilia, Paula (2005), El hombre post orgánico: cuerpo, subjetividad y tecnologías digitales, Buenos Aires, Fondo de Cultura Económica.

Ynoub, Roxana (2015), Cuestión de método. Aportes para una metodología crítica, México, Cengage Learnng Editores.

\subsection{Referencias electrónicas}

Alonso, Rodrigo (2002), "Elogio de la low-tech" [en línea]. Disponible en: $<$ http://www.roalonso.net/es/arte_y_tec/low_tech.php>.

Alonso, Rodrigo (2015), "Mitología y reflexión crítica. El arte tecnológico y su exhibición" [en línea]. Disponible en: <http://www.icm.arts.cornell.edu/conference_2011/Alonso_Reading.pdf>.

Causa, Emiliano (2014), "Cuerpo, movimiento y algoritmo" [en línea]. Disponible en: <http://fido.palermo.edu/servicios_dyc/publicacionesdc/archivos/523_libro.pdf>.

Causa, Emiliano y Andrea Sosa (2007), "La computación afectiva y el arte interactivo" [en línea]. Disponible en: $<$ http://www.biopus.com.ar/txt/textos/Computacion_Afectiva_Y_Arte_Interactivoemiliano_Causa-Andrea_Sosa.pdf>.

Ceriani, Alejandra (2012), "Investigación en la interacción entre un escenario laboratorio y un cuerpo extendido" [en línea]. Disponible en: <http://www.memoria.fahce.unlp.edu.ar/trab_eventos/ev.1787/ev.1787.pdf>. 
Ceriani, Alejandra (2013), "Entre lo material y lo inmaterial del cuerpo: la danza por satélite" [en línea]. Disponible en: <http://www.xanela-rede.net/wpcontent/uploads/2013/02/DANZA-TELEMATICA_-A.-Ceriani.pdf>.

Couchot, Edmond y Marie Hélène Tramus (2009), "Gesto y cálculo" [en línea]. Disponible en: <http://www.oocities.org/athens/8478/ardila.htm>.

Giannetti, Claudia (1997), "Estética De La Simulación" [en línea]. Disponible en: $<\mathrm{http}: / /$ www.artmetamedia.net/pdf/1Giannetti_EstSimulacion.pdf $>$.

Giannetti, Claudia (1997), “Metaformance. El sujeto-proyecto” [en línea]. Disponible en: $<$ http://www.artmetamedia.net/pdf/Giannetti_Metaformance.pdf>.

Giannetti, Claudia (1999), "Algunos Mitos del Final del Milenio. Contra la Trivialización de la Tecnocultura" [en línea]. Disponible en: <http://www.arteuna.com/talleres/lab/ediciones/libreria/Giannetti_AlgunosMitos.p $d f>$.

Machado, Arlindo (2000), "Repensando a Flusser y las imágenes técnicas" [en línea]. Disponible en: <http://www.arteuna.com/CRITICA/flusser2.htm>.

Martínez Pimentel, Ludmila C. (2008), El cuerpo híbrido en la danza: transformaciones en el lenguaje coreográfico e partir de las tecnologías digitales. Análisis teórico y propuestas experimentales, Tesis Doctoral, Universidad Politécnica de Valencia [en línea]. Disponible en: <http://www.youtube.com/user/ludmilapimentel>.

Martínez Pimentel, Ludmila C. (2010), “La coreografía digital interactiva”, Salvador de Bahía, Universidad Federal de Bahía, Laboratorio de Investigaciones Avanzadas del Cuerpo [en línea]. Disponible en: <https://www.academia.edu/2177314/La_Coreograf\%C3\%ADa_Digital_Interactiv a>.

Samaja, Juan (2003), Los caminos del conocimiento, Buenos Aires, Universidad de Buenos Aires [en línea]. Disponible en: <http://catedrafevre.com.ar/32rMl/Los_caminos_del_conocimiento\%20Samaja_r ed.pdf>.

Seid, Gonzalo (2016), "Más allá de subjetividades, discursos y sentidos: el método biográfico para reconstruir trayectorias de clase" [en línea]. Disponible en: $<$ http://www.conicet.gov.ar/new_scp/detalle.php?keywords=\&id=40580\&congres os=yes $>$. 


\section{CAPÍTULO 2. Pasaje de lo analógico a lo digital}

\section{PARTE 1. Danza Multimedia. Origen de la danza con mediación tecnológica}

\section{Introducción}

Como ya se ha planteado, el presente escrito establece como área de interés el estudio de las prácticas artísticas con sistemas informáticos localizados y en el espacio de internet. Nos proponemos brindar un marco teórico y proyectivo a los desarrollos dentro del campo de la Danza Performance con tecnología en tres períodos -que se corresponden con la organización de este Capítulo 2 en tres partesque marcan, respectivamente, el inicio, la evolución y el estado actual. Lo haremos a través del análisis de la selección de un corpus de obras producidas con la concepción de:

Parte 1: Danza performances multimedia: experiencias con el cuerpo en un espacio escénico físico, con proyección de video o imágenes y sonido, dispositivos e interfaces analógicas 0 analógico/predigitales. Observaremos el Festival Internacional de VideoDanza de Buenos Aires (FIVDBA), período 1996 al 2003, en el que se incluye la danza con pantalla y proyecciones en escena. Este Festival Internacional de Video Danza fue creado en 1995 y ha dado lugar a la reinstauración de propuestas de danza con uso de pantalla y proyección en escena.

Parte 2: Danza performances interactiva: experiencias con el cuerpo como mediador entre espacio escénico intervenido por dispositivos e interfaces informático/digitales con proyección de visuales y sonido. Clasificaremos sus componentes y los relacionaremos con el desarrollo de los procedimientos escénicos reactivos o interactivos. Observaremos el Ciclo de Danza Performance de la UNLP En 2Tiempos. Itinerarios de Danza, período 2012-2014. Iniciativa de la Prosecretaría de Arte y Cultura, espacio institucional dentro de la Secretaría de Extensión Universitaria de la UNLP, comenzó en el 2011 con presentaciones mensuales de producciones vinculadas a las artes del movimiento y sus cruces interdisciplinarios.

Parte 3: Danza performances telemática o en red: experiencias con el cuerpo desdoblado, en un espacio distribuido, que interactúa con dispositivos e interfaces informático/telemáticas en la red de internet. Observaremos performances 
realizadas dentro de la plataforma interactiva Waterwheel, período 2013-15, y las redes de videos en canales como Youtube, 2016. Waterwheel es una plataforma interactiva para realizar performances de manera colaborativa, compartir ideas y presentaciones a través de las herramientas allí brindadas.

En paralelo, realizaremos un cruce de la información obtenida en pos de hallar los elementos que validen la categorización entre las diferentes posibilidades de relacionar tecnología y cuerpo según los entornos en donde se ejecute. Suponemos que trabajar cuerpo a cuerpo mediados por un sistema informático pone en juego componentes prácticos y conceptuales esencialmente distintos para trabajar en conexión ubicua con otros cuerpos en la red conectiva de internet.

Por ello, proponemos indagar el período 1996-2004, pues consideramos que los inicios del uso de tecnología informática predigital en danza acontecieron puntualmente a partir de ese año y dentro de esa extensión temporal. Ya en el año 2005 es muy contundente el avance de la programación y el software de operación digital dentro de lo escénico y, en particular, ya hemos estudiado y divulgado el período que va del 2005 al $2011^{11}$. Asimismo, la denominación Danza Performance Interactiva ${ }^{12}$, pone en conjunción componentes tanto de una como de otra disciplina: la Danza y la Performance, a favor de la composición de movimiento con un sistema informático-interactivo.

Por lo tanto, nuestro interés por la Danza Performance con mediación tecnológica se concentra en observar qué sucede en los comportamientos individuales y colectivos. Con este propósito abordaremos el cuerpo y lo escénico desde su vinculación con tecnología predigital, digital y en red, en términos de reactividad, interactividad, conectividad, accesibilidad y ubicuidad. Son diversos y complejos los procesos de comunicación y telecomunicación que diferencian el tipo de mediación que desplaza el sentido tradicional de las propuestas escénicas hacia una comunidad tecno-escénica que incluye la interactividad de datos, mediante sensores remotos que colaboran con

11 El aporte teórico de los estudios realizados y sus resultados aparecen en dos instancias investigativas anteriores:

a. Beca de Formación Superior: investigación "Espacio digital y cuerpo expresivo" 2009-2011, FBA/UNLP. De esta se presentó un informe final. Véase en: <http://sedici.unlp.edu.ar/handle/10915/40944>.

b. Tesis de maestría "El descentramiento: cuerpo-danza-interactividad. Indagación en el territorio de la interactividad y el uso de las nuevas tecnologías aplicadas a las prácticas corporales, compositivas y escénicas" (Director Lic. Emiliano Causa, 2006-2010, FBA/UNLP). Presentación de las performances escénicas interactivas en tiempo real Proyecto Hoseo y Proyecto Speak. Se detallan los aspectos técnicoexpresivos, a la par que se describen las experiencias multimediáticas con el lenguaje del movimiento producido a partir de la interacción, a través de imágenes, esquemas y videos. Véase en: $<\mathrm{http} / / /$ www.alejandraceriani.com.ar/tesis_alejandra_ceriani.pdf $>$.

12 La conjunción de ambos términos indica que hay una formación disciplinar, la danza, que se conjuga con la actividad performática como práctica artística. 
la definición de telepresencia. En este sentido, hay que atender, tal como lo expone Pierre Lévy (1999: 20), que si bien la "proyección de la imagen del cuerpo está asociada generalmente a la noción de telepresencia, [esta] es mucho más que la simple proyección de la imagen".

A través de ella, los cuerpos se hacen visibles, audibles y sensibles desde el interior hacia el exterior; y así es que la virtualización del cuerpo intensifica todo tipo de intercambio hacia nuevas propuestas que generan profundas transformaciones no siempre incluidas o reconocidas por la teoría estética. La diversificación del uso de las tecnologías como herramientas aplicadas a la experiencia artística dio lugar a una profunda y progresiva división entre la crítica del arte, la estética y los contenidos propios de cada disciplina.

Esto nos llevará a examinar, en primera instancia, las nociones de lo disciplinar, lo interdisciplinar y lo transdisciplinar. Entendemos que el conocimiento transdisciplinar clarifica la investigación disciplinar de una manera original y propicia. En tal sentido, las investigaciones transdisciplinares y las disciplinares no son antagonistas sino complementarias, pues definen tendencias hacia la comprensión del objeto de estudio y su inclusión en el mundo actual. La interdisciplinariedad tiene una orientación diferente y refiere a la transferencia de métodos de una disciplina a otra, en tanto la interacción, interconexión y retroalimentación son características del propio proceso de producción entre disciplinas. En consecuencia, nos proponemos abordar desde un enfoque integrador -aun siendo conscientes de los problemas frecuentes de tales dependencias- las repercusiones e incidencias mutuas en un redescubrimiento continuo no jerárquico.

Ahora bien, la presunción que contiene este capítulo respalda la idea de que las performances digitales del presente -más allá de una nueva propuesta de cuerpo, espacio y temporalidad para la danza- son la derivación de las experiencias predigitales denominadas Danza Multimedia. Lo que nos interesa aquí es construir un marco teórico, examinar las propuestas escénicas con proyección de imagen y sonido analógico, analizar las entrevistas a los actores involucrados y revisar las publicaciones coetáneas que refieren a la temática.

Sin detenernos en la historia cronológica e ilustrada de las relaciones entre la danza y las diversas tecnologías, estamos enfocados en los eventos y artistas que podrían ser considerados precursores. Por lo tanto, la cuestión será interpretar qué aconteció con el movimiento danzado frente a lo multimedia analógico y predigital en proceso hacia 
lo digital como trayectoria intrínseca de lo que en la actualidad se designa performance interactiva $^{13}$.

Inferimos que la Danza Multimedia -que comienza a experimentarse en el marco del Festival Internacional de Videodanza de Buenos Aires, en el año 1996-comporta el origen local del uso de tecnología escénica predigital para la danza contemporánea. Vinculada a la proyección monocanal, inicia toda una serie de problemáticas que iremos tratando y que implican la relación entre el espacio escénico, el cuerpo y la proyección, los recursos formales y argumentales que dan sentido a estas interrelaciones así como a las condiciones técnicas.

La coyuntura que conlleva el montaje técnico colaborativo entre el videoartista y el bailarín plasmó un mundo de ficciones compartidas entre lo que acontecía en la pantalla y lo que acontecía en la escena. El reconocimiento de estas conexiones cobra sentido en las relaciones que las imágenes y la estructura coreográfica tienen con la propuesta multimedia integral.

El recorrido planteado, para esta Parte 1, se basa fundamentalmente en el estudio de los contenidos de las propuestas escénicas en torno al cuerpo disciplinar, del medio audiovisual predigital y de las problemáticas de producción que, en su conjunto, abarcan desde el año 1996 al 2004.

\section{Algunas cuestiones sobre lo predigital, lo multimedia y lo audiovisual}

Se podría establecer que los sistemas analógicos son la base para la conversión de los nuevos medios digitales, y un tema interesante es analizar cómo materiales y técnicas operadas con anterioridad vuelven a utilizarse con los mismos fines y procesamientos por medio de una computadora. Además, remarcamos que, desde sus inicios, el surgimiento de los nuevos medios y la informática conllevó posibilidades transformadoras de expresión generadas a partir de la fusión y la experimentación de diferentes tecnologías. Por lo tanto, las estrategias de una estética predigital pasaron a ser incluidas en los procedimientos y las metáforas de la interfaz.

Lev Manovich (2005: 8) destaca la diferencia fundamental entre medios analógicos y digitales, señala que estos últimos "se componen de código digital", es decir, sufren una conversión, una digitalización y "los medios se vuelven programables"; y avanza aún más enfatizando en que "los nuevos medios pueden parecer medios pero esa es solo la superficie. Los nuevos medios requieren de una nueva etapa en la teoría de los

\footnotetext{
${ }^{13}$ Las performances interactivas componen una nueva categoría dentro de las artes escénicas y llegan a vincular varias ramas del arte interactivo y del arte escénico tradicional.
} 
medios" (2005: 19). Estamos ante un cambio substancial, ante una fuente inagotable de estudios surgidos a partir de la expansión del medio digital en el campo del arte.

En consecuencia, nos proponemos desandar estos procesos de conversión vinculados al video, a la escena multimedia y al cuerpo interviniendo entre ellos. Una escena multimedia, de este modo, se podría indicar como la puesta configurada hacia las nuevas tecnologías.

Respecto de la palabra "multimedia", José Luis Brea (2002: 6) cuestiona su aplicación indiscriminada, y afirma que se la usa para nombrar lo que en realidad debería llamarse "multisoporte". Así como sucede con el término "multimedia", cuando se pretende aplicar el término "analógico" al estudio de lo escénico, aparecen varios equívocos. La expansión de los sistemas de representación y transmisión de información por dígitos con soporte o entorno digital se ha generalizado y ha ido reemplazando paulatinamente al soporte analógico tradicional, que representa y transfiere datos con soporte o entorno físicos y presenciales.

Lo que conlleva este pasaje de una estructura analógica a una digital es una comunicación más abierta y fluida entre sistema y cuerpo, dado que comprende actualizaciones continuas, versátiles, en una diversidad de itinerarios que interconecta recursos y multiplica así sus posibilidades interpretativas.

$Y$ es en el pasaje y la comparación entre los sistemas analógicos y digitales donde encontramos un mayor volumen de información que utilizaremos para nuestro marco teórico. En principio, tanto la tecnología como la técnica forman parte material y artificial de los fenómenos humanos sin ser independientes y actuar fuera de ello, no son determinantes pero sí altamente condicionantes y adaptables. "Una técnica no es buena ni mala" ni imparcial (Lévy, 2007: 12), "su presencia y su uso en tal lugar y en tal época cristalizan en unas relaciones de fuerza cada vez diferentes entre humanos", en un sentido no generalizado.

El cambio de tecnologías y técnicas sobrecarga nuestra endeble estabilidad, y aquello que denominamos "nuevas tecnologías" recubre, de hecho, la actividad multiforme de grupos humanos, un devenir colectivo que se cristaliza notablemente alrededor de objetos materiales, de programas informáticos y de dispositivos de comunicación. Por consiguiente, en nuestro trabajo, poder distinguir y analizar el modo y las características del proceso de apropiación que estaría a la par de poder afectarlo con las particularidades sistémicas de las herramientas para la puesta en escena.

Lucía Santaella (2003: 175) observa una diferencia -que es sustancial para caracterizar este pasaje de técnicas, tecnologías y relaciones humanas- cuando destaca "el salto cuántico que se da en el pasaje de las tecnologías electrónicas, pre- 
era digital, a las tecnologías teleinformáticas de la actual era digital"14, y señala que las tecnologías predigitales introyectaron conocimientos científicos en habilidades técnicas $\mathrm{y}$, las cibertecnologías introyectaron conocimientos científicos en habilidades mentales. En el ínterin de ese salto cuántico en la transformación material de los soportes, se previó que la virtualización de la información y la comunicación conmovería nuestras vidas en general, pero no que impactaría tan profundamente hasta dar un giro radical en la concepción productiva del desarrollo humano.

Por su parte, se denomina multimedia a la confluencia de sonido, imagen e información; pero el término -como se dijo- conlleva una profusa polisemia, y resulta fuente de no pocas indeterminaciones entre quienes lo utilizamos. Pierre Lévy (2007: 50) distingue "dos tendencias que sobresalen de los sistemas de comunicación contemporáneos: la multimodalidad y la integración digital"; es decir, no se trata solo de una variedad de soportes, sino su interconexión y composición, una infraestructura de comunicación para los sentidos.

Precisamente, en el ámbito de la comunicación, multimedia alude a dos escenarios: por un lado, a los lenguajes, y por otro, a los soportes. Esta distinción terminológica y conceptual tiene una considerable relevancia, ya que se genera en su combinación con otras expresiones y perspectivas muy variadas. Por tanto, vamos a evitar confundir el análisis de los soportes tecnológicos (hardware y software) con la puesta en escena multimedia (que, a su vez, puede pertenecer a coreografías preexistentes, a la combinación en un mismo espacio de lo escénico físico y lo proyectado virtual, etc.).

Básicamente observaremos la transformación de la tecnología predigital a la digital con un recorte espacio-temporal proporcionado por los estudios de casos y entrevistas a los actores comprometidos. Asimismo, estudiaremos los discursos teóricos circulantes en ese período en relación con los actuales. Todo ello en función de poder plantear, por una parte, que existe una estética y estándares de acción y de organización corporal audiovisual predigital; y, por otra, una estética y estándares de acción y de organización corporal audiovisual digital, ambas de plataforma low-tech ${ }^{15} \mathrm{o}$ bajo rendimiento, sin olvidar que la diferenciación entre lo audiovisual analógico y lo digital se dio no solo en la actualización y renovación técnica de los espacios, sino también en la apropiación que los artistas fueron realizando. En palabras de Marta

\footnotetext{
14 Traducción propia: "no salto quântico que se dá na passagem das tecnologias eletroeletrônicas, pre-era digital, para as tecnologias teleinformáticas da atual era digital".

15 Nos interesa distinguir la brecha digital entre lo high-tech y low-tech, puesto que, aunque coexiste una manifiesta relación entre alta y baja tecnología, también coexiste una clara disociación. Al problema del consumo y renovación de bienes tecnológicos se suma el acceso a los conocimientos y competencias necesarias, y las demandas de capacidad de almacenamiento y velocidad de procesamiento del hardware.
} 
Zátonyi (2011: 251): "Cuando cambia la materia y la técnica o cambia lo que quiere decir, o cambian las circunstancias, a largo plazo, es inevitable el cambio de lenguaje". Roy Ascott (2007: 49) presenta el término "multimedia" acompañado de dos siglas: CFD o SA. Las siglas CFD especifican "Conjuntos Finitos de Datos (Finite Data Sets): donde la acción se desarrolla dentro de unos límites prediseñados, presentados como una experiencia, ya sea unitaria o supuestamente 'interactiva' bajo el control del artista". A esto lo diferencia de los "Sistemas Abiertos (Open Ended System)": donde la acción se desarrolla como interacción dentro de unos sistemas de algoritmos evolutivos en red que dejan el control en manos del usuario o del entorno, proporcionando así los medios más efectivos para alcanzar un intercambio bidireccional entre la obra y su público.

He aquí dos elocuentes diferenciaciones que contribuirán a situar nuestras constataciones, y que van desde un sistema analógico predigital a otro digital, y atraviesan los siguientes procesos: desde la finitud de los datos a su evolución, desde los límites prediseñados a los límites en expansión, desde la experiencia controlada por el propio sistema a los procesos abiertos al entorno.

Miraremos ahora hacia las escenas multimediales entre lo analógico y lo predigital en las que el cuerpo -que aún no era considerado como una metáfora informática pero sí en un estado de digitalización- y los mecanismos de registro audiovisual merecen una revisión en correspondencia con esos contextos.

En definitiva, ¿qué es lo audiovisual? Según el Diccionario de la Real Academia Española, la palabra "audiovisual" 'se refiere conjuntamente al oído y a la vista, o los emplea a la vez'. En este sentido, hoy en día, se integra dentro de la fusión de formatos tales como el cine, la televisión, el video, las instalaciones multimedia, etcétera. Por tanto, el término "audiovisual" que nos interpela, se compone de la percepción auditiva y visual, tomando como medio el video (del latín videre, 'ver'). Eduardo Russo (1998: 269) señala que "puede significar varias cosas", pero, básicamente, es un sistema de grabación y reproducción de imágenes, que pueden estar acompañadas de sonidos, y que utiliza una cinta magnética. En la actualidad, el término hace referencia a los distintos formatos que pasaron de las cintas de video analógico a los formatos digitales. Digamos entonces que el video se extiende y se desarrolla a través de los formatos, y muta de forma permanente como concepción de producción y expresión, no tanto de valor sino preferentemente de sentido.

Michel Chion (1993: 175) define el binomio audio/visual como un contrato que "no entraña una fusión total de los elementos", sino que "los deja subsistir al mismo tiempo separadamente, cada uno por su lado. El contrato audiovisual sigue siendo en efecto una yuxtaposición además de una combinación". Si completamos esta dupla con el 
espacio escénico y los cuerpos danzando, solo "habrá que disponerse a la sorpresa del encuentro audiovisual" en el momento de delinear un procedimiento posible de análisis de esta práctica escénica que se denomina Danza Multimedia: "danza en vivo y en pantalla simultáneamente o danza en pantalla y en vivo"16. Los soportes empiezan a actuar decididamente a la hora de puntualizar una definición, no cuentan únicamente los lenguajes artísticos y sus combinatorias, sino también los aparatos y elementos que los median.

De esta manera, en la Danza Multimedia se mixtura el cuerpo en el espacio escénico con la pantalla o superficie de proyección de imágenes. Un espacio híbrido en el que se visualiza una compleja textura de discursos visuales y auditivos, en el que se articulan lo registrado, lo editado, lo topologizado, las proporciones y las conexiones entre lo físico y lo virtual. Douglas Rosenberg (1999:1), realizador y teórico estadounidense, denomina "screendance" a la conjunción danza, cámara y pantalla: "danza para la pantalla", puesto que lo considera un enunciado más inclusivo y multiplicador "de un tejido conectivo entre el cine danza, la videodanza y la danza digital".

Definir qué es la Danza Multimedia resulta complejo, dado que no es explícitamente video danza, tampoco es cine danza, ni danza digital -no por lo menos en el momento y contexto en que el FIVDBA lo acuñó-, es decir que puede ser un asunto aproximado, pero también una forma muy eficaz para reconocer los distintos contornos fluidos de una práctica artística que aún hoy sigue realizándose. En definitiva, hablamos de un cuerpo que danza en un espacio escénico con pantalla: "bailar con proyección detrás". El medio tecnológico, obviamente, especifica el trabajo realizado con video, o con celuloide, pantalla, monitores, etcétera, y lo restringe. En consecuencia, se puede afirmar que "cuando se utiliza al bailarín en términos fílmicos, en lugar de en términos de danza, el espacio y el tiempo son flexibles" ${ }^{17}$, y eso no sería un inconveniente hasta el punto en el que conviven la proyección y el vivo. Esas diferentes materialidades han resultado una gran contrariedad compositiva al procurar una integridad escénica.

La dependencia entre los dispositivos -el cuerpo en movimiento y la imagen proyectada- define una experiencia mediada, y un modo de pensar esta forma heterogénea de mediación es tomar la cámara como productora de espacios. Es allí donde ocurre la obra, en el ojo del camarógrafo en conjunción con el del coreógrafo o el performer. La composición de lo escénico se conforma, en primera instancia, por la

\footnotetext{
16 Programa de mano del Cuarto Festival Internacional de Video Danza, Centro Cultural Rector Ricardo Rojas, Universidad de Buenos Aires, 1998.

17 Traducción propia: "When the dancer is used in filmic terms, rather than dance terms, space, and time are flexible". Noël Carroll (2000), "Toward a Definition of Moving-Picture Dance", en Dance for the Camera, Symposium at the University of Wisconsin, p. 113.
} 
estrategia del encuadre para luego pasar por el proceso de edición. Aquí es donde dialogan el lenguaje audiovisual con los esquemas compuestos entre escena y pantalla. Este lenguaje nos ofrece una definición del espacio y del tiempo fluido, así como también un punto de vista variable en su microorganización.

Por su parte, la propia naturaleza de la cámara, con su capacidad de aproximarse o apartarse de un área en detalle, invita a la exploración de las mutaciones del cuerpo, al decir de Alejandra Ceriani (2010: 56):

\begin{abstract}
... el medio se vuelve cuerpo y el cuerpo es el medio que se hace carne, fuera de una tecnificación, de un control mecanizado, evidenciando, más que el movimiento de la cámara, la acción del cuerpo. La cámara es un punto de conexión que evidencia un gesto, respira, vacila, circula acopiando fragmentos. Esta relación inseparable del cuerpo-cámara propone una lectura nunca lineal, siempre inconclusa, trozos y partes que se producen tras la acción de ese cuerpo que es imposible reconstruir del todo. La cámara instaura el espacio del cuerpo y de la imagen; lo transforma, se establece así un diálogo espacial con un cuerpo que se mueve y que lo ocupa; no solo como un ojo que sitia sino como otra existencia que irrumpe de igual forma.
\end{abstract}

Y a la mediación de la cámara le sumamos la mediación de la pantalla en la escena, teniendo en cuenta no solo la duplicación, sino la triplicación entre los elementos que conviven para quien asiste esta particular ecología escénica. Partamos de la siguiente compatibilidad desarrollada por Paulina Ruiz (2015: 165):

\footnotetext{
Frente a la pantalla, la visión del espectador se transforma a través de la kinestesia visual producida por la imagen fímica y difiere de aquella que tendría frente a un espectáculo en vivo, ya que resiente el espacio de la danza identificándose por empatía kinésica con el propio camarógrafo.
}

Este doble espacio generado por el registro de los cuerpos reproducidos en la proyección añade un espacio más que es el de los cuerpos in situ sobre el escenario.

Si lo vemos desde el punto de vista del dispositivo, la pantalla comparte la instalación del "lugar o sitio virtual" con el "lugar o sitio físico" por excelencia que es el escenario (de hecho o espontáneo). Física y virtualmente, la proyección concierta entre el espacio de registro y el de la experiencia kinésica de expectación. Si lo vemos desde el punto de vista del cuerpo, el acento está puesto en el devenir del movimiento y en la amplificación del registro fílmico, en el detalle mínimo y en la dislocación espaciotemporal, que transpone y desdobla lo que hasta entonces había sido un conflicto: el carácter efímero y corpóreo de la danza.

Asimismo, la fragmentación del cuerpo en la pantalla sustrae de alguna manera su materialidad, y se resiste a las exigencias de linealidad espacio-temporal y 
secuencialidad terrestre. ¿Qué ocurre con este enlace de tiempos, espacios, tamaños, escalas y acciones diferidas? En primera instancia, hablamos de una proyección de imágenes registradas y editadas en sistema analógico o analógico-digital. Pero, en una segunda instancia, hablaremos de los modos de construcción de sentido de esas imágenes editadas y proyectadas puestas a interactuar en escena.

\section{La pantalla, el video, la escena}

Algunos lo llaman video-danza. Otros lo llaman danza filmada.

Yo prefiero llamar a mis trabajos "danzas multimedia".

Charles Atlas

A mediados de los setenta, se inicia una vacilante integración con el cine que, en los años ochenta, se convertirá en un vínculo que lindará con lo industrial, pero aun así: "El video no vivirá en el cine. La cuestión de las interrelaciones se desplazará a lo largo de los años ochenta hacia otros dominios"18. En los años ochenta y noventa, la experimentación evoluciona hasta consolidar las videoinstalaciones, que permiten el uso de varios componentes espaciales y la implicación directa del espectador, abriéndose paso en museos y galerías, básicamente, desde las artes visuales, para ocupar así una posición medular al finalizar el siglo XX.

Eduardo Russo (1998: 279) describe la trayectoria del soporte video hacia fines de los noventa:

... hasta hoy, la tecnología de videocasete sigue siendo la imperante, [...]. Pero las cosas están cambiando: las tecnologías digitales -con el oneroso disco láser como precursor, para un público que definitivamente será de elite, prometen para poco tiempo más formatos de grabación de video digital como el DVD (Digital Versatile Disk).

Asimismo, la modalidad del video-tape "es la que brinda mayores perspectivas, desarrolla una suerte de poesía que, bordeando -desde afuera o adentro- lo narrativo, propone algunos de los mayores desafíos a la mirada en los 90" (Russo, 1998).

La experimentación con el lenguaje audiovisual, la transgresión y la creación de nuevas narrativas instalan -a partir del videoarte- la innovación en el tratamiento de la

${ }^{18}$ Es interesante ampliar la lectura sobre este tránsito entre el cine y el video. Según Philippe Dubois (2001): "Después de Coppola, se terminan las experiencias de integración y transubstanciación de los soportes". 
plasticidad de la imagen electrónica, con la potencia visual del cine, pero consustanciando otras convenciones. Esto lo afirma Graciela Taquini (2008: 4):

Es a fines de la década del 90, cuando la actividad videográfica deja de ser un quehacer alternativo para embarcarse en un proceso de institucionalización sostenido, que lo relaciona con nuevos espacios expositivos y educativos, con el mercado del arte, con circuitos cada vez más amplios. Al video le ha costado mucho menos que a otros medios vincularse al sistema del arte.

Los inicios del video en la Argentina se vinculan fuertemente con la televisión como objeto que expone la mediatización en la que prima su presencia física antes que su contenido homogeneizado. A través del circuito cerrado de televisión, se privilegian los aspectos sensoriales de la imagen, el sonido, la emisión de luz y la profusa distribución en el espacio; esta es una de las principales estrategias artísticas a la que luego recurrirá el videoarte a fines de la década del sesenta. Otra línea precursora de la misma época, se generó con el movimiento del cine experimental con cámaras de $16 \mathrm{~mm}$ y super 8 , pero el revelado y la compra de película debió hacerse en el exterior, por lo que los costos se duplicaron; consecuentemente, estos formatos en nuestro país pasaron paulatinamente a disminuir su producción y exhibición. A partir de la década del setenta, presenciamos la entrada del video, teniendo en cuenta que "del 79 a la restauración de la democracia en 1983, hubo una gran efervescencia cultural fomentada por personas o grupos independientes. [...] La plata dulce hizo posible la llegada de equipos de video-home y profesionales" (Taquini, 2008). En los orígenes del videoarte en la Argentina, Rodrigo Alonso (2005: 5) describe el avance del video de la siguiente manera:

El video adquiere su mayoría de edad durante la década del noventa. La experimentación se consolida entre los artistas, las muestras se multiplican y el público responde entusiasta. A Buenos Aires Video se suman otras exhibiciones de importancia, como el Festival Franco Latinoamericano de Video Arte que organiza Jorge La Ferla en el Centro Cultural Rector Ricardo Rojas que luego se transforma en la Muestra Euroamericana de Video y Arte Digital-, el Festival Internacional de Video organizado por Carlos Trilnick, y el Festival Internacional de Video Danza, dirigido por Silvina Szperling, y especializado en un tipo de producción especial: la videodanza o danza para la cámara, piezas de video con coreografías realizadas especialmente para ser filmadas.

Justamente en este espacio de producción de videodanza o danza para la cámara nos centraremos. Margarita Bali (2014: 6), artista e investigadora de la danza, precursora de la videodanza y la Danza Multimedia local, en coincidencia con nuestra presunción, afirma que: 
La inclusión de lo tecnológico en la danza, en la Argentina, se inicia fundamentalmente a partir del video danza como disparador a comienzos del 90, con la perseverancia contra viento y marea del Festival de Videodanza que dirige Silvina Szperling y que siempre ha incluido aspectos relacionados a lo tecnológico o interactivo, en talleres e invitaciones de artistas y desarrolladores de tecnología extranjeros.

Al respecto, según Alejandro Ricagno (1996: 11), el FIVDBA tuvo y tiene el sentido claro de ser un espacio de "crecimiento y de retroalimentación, un lugar de encuentro y discusión antes que de competencia feroz". El propósito del festival apunta justamente a la formación porque, como predicaba Graciela Taquini (en Falcoff, 1996: 17), "Yo les decía a los organizadores del festival que habría que preparar algunas instancias previas al festival mismo, jornadas de reflexión. Porque todas las cosas tienen que hacerse también con una perspectiva didáctica".

Pensado desde esta retroalimentación que el FIVDBA instala, ¿cuál es diálogo que se establece entre las artes audiovisuales y las escénicas? Cuando las señales electrónico-analógicas se transfirieron al dominio de lo binario, de la digitalización de aparatos y procesos, se pasó de la presencia a la transparencia de procesamientos y articulaciones. Queda claro, asimismo, que sin la digitalización y sin la transparencia de la interfaz no gozaríamos de una interacción sujeto-sistema. Hoy presenciamos una nueva forma de cultura táctil, y dejamos la presión por el toque, por el deslizamiento sobre pequeñas superficies de una porción de los dedos de nuestra mano.

Entendemos que la descripción del pasaje de la Danza Multimedia a la interactiva y en red deberá distinguir -no solamente el nivel de transparencia que fue adquiriendo la interfaz, por ejemplo, sino- la concientización de los modos de producción y las formas lineales o jerárquicas del movimiento corporal. Ante la conversión condicionada de un cuerpo mecanizado que interactuaba con mecanismos, este cuerpo acoplado que interactúa identificándose con la estructura simbiótica de otro/s hace evidente que nuestro organismo convive con otras metáforas de organismos en una nueva conciencia ecológica de la comunicación. De todas maneras, el régimen de la estandarización del cuerpo, de los gestos eficaces con las lógicas del mercado tecnológico, está en función de la reproducción de las coreografías discretas, como expone Jaime del Val (2009: 129) en una visión de las coreografías que:

... realizamos cotidianamente con las interfaces físicas de la cultura digital (el ratón y el teclado, el joystick y el teléfono móvil...) que se distribuyen a través de las interfaces visuales y auditivas [...] (videos musicales, cine, pornografía, música comercial ubicua) y de las interfaces algorítmicas (software). En este dominio coreográfico de los afectos no hay diferencia ontológica alguna entre 
digital y analógico: ambos dominios son igual de reales en relación con la producción afectiva. Acaso el digital, lejos de ser menos real, se diferencie por ser el mecanismo por excelencia de lo hiperreal.

Este autor sostiene, además, que no hay diferencia entre lo analógico y lo digital con relación a la producción afectiva. El sistema informático solo puede explicar un aspecto de la tarea comunicativa e inmaterial que forma parte de la producción de prestaciones. La otra presencia del trabajo inmaterial la compone el compromiso afectivo que representa el contacto y la interacción humana. Esta producción afectiva, este intercambio y comunicación que refiere Del Val, está generalmente asociada con la presencia real de otro, en la que el contacto puede ser tanto físico como virtual. Este segundo aspecto inmaterial, su aspecto afectivo, está infaliblemente ligado a lo corporal y va más allá del sistema de inteligencia y comunicación que plantean las interfaces físicas de la cultura digital. Sin embargo, estos afectos que genera son inmateriales y no se definen porque esos dominios sean analógicos o digitales.

Por ende, a un usuario de las redes no le modifica su práctica afectiva que el medio sea analógico o digital, pero para la concepción de una práctica artística corporal sí. Básicamente porque "los nuevos medios son interactivos. A diferencia de los viejos medios, donde el orden de presentación viene fijado, ahora el usuario puede interactuar con el objeto mediático" (Manovich, 2005: 21). Y en ese proceso de interacción puede optar tornándose así coautor de la obra. Veremos, en el curso de este texto, que coexiste una nueva naturaleza del movimiento:

\footnotetext{
Se trata de un nuevo tipo de identificación, que resulta adecuado para la era de la información, con su trabajo cognitivo. Las tecnologías culturales de una sociedad industrial —el cine y la moda - nos pedían que nos identificáramos con la imagen corporal de otra persona. Los medios interactivos nos piden que nos identifiquemos con la estructura mental de otra persona. Si el espectador cinematográfico, hombre o mujer, codiciaba y trataba de emular el cuerpo de la estrella de cine, al usuario de ordenador se le pide que siga la trayectoria mental del diseñador de los nuevos medios (Manovich, 2005: 26).
}

En efecto, nuestros vínculos con la tecnología evolucionan cuando se consolida la imagen corporal y se domina la trayectoria mental, asimismo sobresalen otros rasgos en los que la virtualización de la afectividad es un acontecimiento que comprende al movimiento cualitativo antes que al movimiento como una sucesión de estados emocionales cuantificables. El movimiento corporal es continuo, es un flujo. Movernos discretamente nos asemejaría a un autómata. Nosotros somos un fluir, nuestra vida fluye y nuestro cuerpo lo hace con ella. Por tanto, podríamos pensar este no diferenciar ambos sistemas como una elucubración que se vincula con la sujeción a la 
norma social y cultural, a la vez que la gestualidad, los movimientos corporales y el sentido con que estos son empleados en la vida cotidiana como un proceso que implica a la producción y a la reproducción. Estos procedimientos conforman un dominio a través del cual se establecen puntos de contacto y puntos de fuga entre la corporeidad característica de un grupo social, un determinado sistema tecnológico, aparato o dispositivo, y lo propiamente subjetivo, momento en el que la indagación del bailarín, performer o actor tiene lugar.

Por ello, nuestra investigación hace foco en esos movimientos hibridados para su comprensión, puesto que no se identifican sin una observación y un análisis de esa particular interacción con los sistemas tecnológicos analógicos, digitales y en red.

Al visualizar estas transformaciones y actualizaciones que el espacio coreográfico viene atravesando en el diálogo con diferentes sistemas tecnológicos, podremos distinguir cuáles son las dinámicas entre el cuerpo y los ambientes predigitales o digitales. De ese modo, delimitaremos diferencias no lo suficientemente estudiadas y que esperamos puedan redimensionar conceptos de espacio, tiempo y cuerpo.

Si pensamos en el aprendizaje humano, en la reproducción del comportamiento ajeno, bien podría corresponderle una sugestión a lo contrario, una insubordinación o, por lo menos, una disociación de estas relaciones dadas entre cuerpo y sistema. ¿Pues acaso al bailarín o performer solo le cabe la nulidad de su dinámica frente a las restricciones de la captación para poder adecuarse al sistema y lograr "interactuar"? Aquí nos detendremos por un momento en esta otra idea, de contagio, para asociarla a las de contaminación y transferencia, que suelen vincularse con las tecnologías de la información y la comunicación. Por consiguiente, contagio hace referencia a un proceso de transmisión por contacto. Incluso, acudiendo a la etimología no se aclara la imprecisión de la idea de una transmisión alcanzada por contacto visual, sonoro o escrito -a través de dispositivos periféricos y aplicaciones que posibilitan la copresencialidad en las redes y aparatos de comunicación inalámbrica, etc.- para crear una red de cuerpos virtuales y reales. No obstante, esta codependencia como condición no establece una relación jerárquica, muy por el contrario, expone los problemas causados por la comprensión del cuerpo como procesador o vehículo de informaciones.

Cabe aclarar que la "investigación académica en torno al contagio comprende dos grandes áreas: los estudios acerca del contagio de emociones y los estudios acerca del contagio de conductas" (Pérez Cubas y Santagada, 2010: 8). Para el recorte que practicaremos en esta indagación solo nos aproximaremos a estos estudios con el fin de distinguir correspondencias y derivaciones que las tecnologías aportaron a las artes, y en particular, a las artes escénicas. 
Recogemos el argumento de Christine Greiner y Helena Katz (2005: 125), dos referentes de los estudios corporales, que plantean la coexistencia simétrica con nuestro cuerpo-medio: "corpomídia", no como vehículo de transmisión, sino como un proceso evolutivo de selección de informaciones que van constituyéndolo. Por tanto, la condición de la información es de aquella que "se transmite en un proceso de contaminación" en la experiencia de interacción con el medio, con otras personas dentro y fuera de nuestra cultura; ponderando siempre la reciprocidad en la que se asimilan y adaptan experiencias diversas en la construcción de un fenómeno colectivo. Planteárselo desde ciertas tendencias o modelos define el proceso de conformidad del sujeto a su entorno, y lo podríamos entender como contagio de conductas a través de la sincronización de actitudes corporales, gestualidades y movimientos.

Otra mirada al respecto, podría dirigirse hacia otro modo de manifestación de la memoria cultural que son las expresiones corporales que pueden ser entendidas solo por miembros de una comunidad. Paul Connerton (1989) localiza dos características básicas en las prácticas sociales que denomina prácticas de incorporación y prácticas de inscripción. En ambas, lo esencial es qué se aprende y cómo se incorpora a nuestras prácticas. De esta manera, parecería que la materialidad como componente principal de los cuerpos, susceptible a toda clase de contexto y experiencia, que se caracteriza por un conjunto de propiedades físicas o químicas, visibles a través de los sentidos, se ha extendido hasta novísimas derivaciones.

No obstante, a medida que se va esfumando la metáfora del hombre-máquina cede su lugar al modelo hombre-computadora, y este al de hombre-información. En este proceso, nos hemos fijado principalmente en aquella memoria basada en las experiencias que han quedado incorporadas como parte vital de la memoria corporal que se actualiza reinventándose cada vez. Esbozado desde la tecnología actual y en clave biológica, el cuerpo humano es percibido cada vez más como una metáfora informática, pues, como asevera Paula Sibilia (2005: 97), "al fin y al cabo, el ADN es un código: es pura información". Esta idea de cuerpo como pura información habilita otro conjunto de estudios que proponen examinar los desarrollos teóricos sobre la hipermediación como nuevos puntos de partida.

Pero antes de seguir avanzando sobre este presupuesto -que plantea la necesidad de mapear al cuerpo como un sistema y no como mediador o instrumento de mediación entre sistemas-, reconstruiremos algunas hipótesis.

Retomando nuestro propósito, hay que tener en cuenta que el cambio de paradigma tecnológico que circularía entre lo analógico o predigital a lo digital no implicó una ruptura radical, puesto que el conjunto de las estéticas y conceptos ya residían en las tendencias y movimientos anteriores al advenimiento de la computadora. El análisis de 
la relación de las tecnologías predigitales con el arte, y en especial con el campo de lo escénico y lo audiovisual, se enfoca desde el sistema de video $\mathrm{VHS}^{19}$ a la computadora. En ese pasaje, la producción escénica puede considerarse técnica, científica o artística. De tal modo, la indagación y la producción de lo escénico conquistaron otro lugar, salieron de su papel de objeto de la dramaturgia coreográfica y evolucionaron en un medio técnico, intrínsecamente conectado con algoritmos, dispositivos técnicos y medios electrónicos. Aunque es obvio que el arte digital y el arte con base analógica no se apoyan en las mismas tecnologías, coexisten tanto concordancias como discrepancias. Lo que es innegable es que la paulatina merma de cada medio conlleva variaciones en la determinación de la percepción y la creación. Incluso, provocan producciones artísticas o curatoriales que atraviesan críticamente dichos soportes, haciéndolos parte de su discurso estético. Al respecto, valen las palabras de la curadora de videoarte Graciela Taquini (2008: 1):

En 1999, se hizo en el Centro Cultural Recoleta una mega muestra llamada Siglo $X X$, Arte y Cultura en la que realicé un programa de video de autor en VHS, dividido en diferentes secciones temáticas. Este amplio resumen parecía una especie de canto del cisne tecnológico que rescataba toda una época que ya estaba mutando hacia la cultura digital, anunciando la muerte del video analógico, de la cinta, para entrar en la era de lo numeral, de lo binario, del puro píxel.

Participar de la muerte del video analógico, de todas maneras, nos insta a pensar -tal como lo especifica La Ferla (2009: 128)- en "evitar definitivamente esas fronteras ficticias [...]. Frente a la disolución de los soportes tradicionales analógicos y la imposición masiva de las nuevas tecnologías [...] implica revisitar los diferentes aspectos de la historia de la imbricación creativa entre ellos". Los cruces conceptuales y materiales entre los medios y sus transformaciones entretejieron y entretejen combinaciones atemporales que derivan en premoniciones estéticas y en búsquedas que superan las efemérides. Es decir, no hay una fecha de caducidad, sí estimaciones a las que limitamos nuestro análisis; pues mientras en el FIVDBA año 1996, estrenábamos la sección Danza Multimedia con proyección de materiales en formato VHS, el artista australiano Stelarc, por ejemplo, abordaba la obra interactiva Ping $B o d y^{20}$, una performance realizada y transmitida a través de internet en la que con un

\footnotetext{
19 VHS (Video Home System). Sistema de grabación y reproducción analógica de audio y video desarrollado en la década del setenta. Posee una cinta magnética ancha, y una caja o casete de plástico la contiene. La anatomía de un video-casete VHS comprende dos carretes internos y el recorrido de la cinta. La apertura por donde se accede a la cinta está protegida por una tapa que se abre automáticamente mediante un sencillo mecanismo cuando es introducida en un reproductor de VHS.

20 Ping Body fue realizada primero para Digital Aesthetics en Sidney, en 1995, y para el festival Dutch Electronic Art Festival (DEAF) en Rotterdam, en 1996. Véase en: <https://ejournalmecad.files.wordpress.com/2008/06/ejournal1.pdf>, p. 80.
} 
clic de los ciberusuarios accionaban el cuerpo del performer mediante un estímulo eléctrico.

De todos modos, la etapa comprendida entre mediados de los años sesenta y hasta avanzada la década del dos mil podría aludirse como lo predigital con relación a lo escénico, ya que los materiales expresivos en estos años fueron producto del sistema tradicional sumado a aparatos con captura analógica y procesos físicos, químicos y electrónicos. Además, la danza y el cine tienen una larga historia en común hasta la propagación del uso de la cámara de video portátil. Un análisis comprensivo de la aparatología escénica audiovisual en el campo de la Danza Multimedia prevé un recorrido por los medios audiovisuales monocanales para agenciarse su incorporación al espectro de lo analógico: las cintas VHS, el cine super 8, los casetes, la videocasetera, etcétera.

El cuerpo aquí sigue siendo un cuerpo físico en una escena física que concierta y reactiva estructuras de contenido y forma con la "gran" pantalla y la imagen proyectada. Desde su aparición en los años sesenta como medio de producción y reproducción de la imagen, el video albergó la hibridación de medios, formatos y lenguajes. Consecuentemente, esta hibridación fue comprometiendo soportes y procedimientos formales y expresivos. Ante estas conjunciones, hallamos válido el volver a estudiar y resituar la esencia de los medios audiovisuales y sus expansiones para considerar el proceso de las tecnologías predigitales al aparato digital por excelencia: la computadora. Con el propósito de presentar un marco histórico local desde el cual ubicar el antecedente de la práctica específica de la danza performance y el video, compartimos la siguiente interpelación de La Ferla (2009: 128):

\begin{abstract}
¿Dónde podemos buscar, en nuestro país, alguna marca significativa en sentido histórico que permita ubicar un lugar de anclaje y que posibilite, a su vez, reconocer el espacio de emergencia de un arte vinculado al trabajo con la imagen electrónica? El lugar de amarre es el CAV, Centro de Arte Visuales del Instituto Di Tella de Buenos Aires, creado en 1958, y dedicado por más de una década a estimular la experimentación en las artes visuales de nuestro país.
\end{abstract}

Asimismo, este centro aportó un ámbito favorable para la exploración y la producción de trabajos de investigación que imprimieron una nueva forma de expresión en el mundo de la danza. Otro dato significativo dentro del recorte de los años setenta aparece con el desfase entre la escena internacional y la nacional respecto al uso del video como medio y como soporte de mensajes artísticos. Esto implica, además, que hacia finales de los años ochenta, se mezclarán la práctica videográfica con otras prácticas artísticas. $\mathrm{Y}$ aquí destacamos el videoarte y las videoinstalaciones 
emparentadas con lo escenográfico como los formatos de mayor auge en nuestro medio.

También hay que tener en cuenta, para la contextualización de la temática, el desenvolvimiento de la danza multimedia local; y es que, a mediados de los noventa, aparecen los proyectores de tres tubos ${ }^{21}$ que impactan en la creación de espacios inmersivos y en la posibilidad de grandes proyecciones. Así, la variedad de formatos que se integra hacia fines de los noventa promueve el diálogo entre el video y los diferentes procesos de mediación, y abre diferentes canales que provocarán algunos corrimientos de lo digital hacia zonas más vinculadas con las tecnologías comunicacionales. El arte en internet iniciará su irrupción.

Asimismo, nuevas generaciones de videastas emergieron en la escena local, muchos de ellos procedentes de la danza contemporánea, cuyas perspectivas teóricas de las décadas del sesenta y del setenta -básicamente desarrolladas en EE. UU.- fueron responsables de originar algunas de las más importantes teorías del cuerpo en la contemporaneidad. Es interesante mencionar aquí una línea histórica denominada Danza Moderna (posmodern dance) en la que Marcelo Isse Moyano (2010: 44) destaca: "el conocimiento del medio material, el descubrimiento de las cualidades esenciales de la danza como arte, la separación de los elementos formales, la abstracción del diseño y la eliminación de las referencias externas como temática”. La Danza Moderna crea movimientos aplicando las emociones, estados de ánimo, visión artística o ideas; puede ser abstracta o narrativa, alegórica o metafórica, y, generalmente, está basada en la improvisación.

Así como la Danza Moderna surge como una reacción a las formas del ballet clásico, la Nueva Danza "surge como oposición a la figuras legibles y la estilización de la Danza Moderna"22. La técnica se basa en el estudio e interrelaciones cuerpo-mente, y el movimiento es el resultado de conceptos. Según Hugo E. Biagini y Arturo A. Roig (2008: 374), sus innovaciones contienen, entre otras modalidades, "la improvisación de danza en escena, la danza para la cámara, la danza y la tecnología, y la danza en espacios no convencionales [...]. La danza contemporánea argentina se

\footnotetext{
21 Proyectores CRT (Tubos de Rayos Catódicos): poseen tres tubos, uno por cada color primario -rojo, verde y azul- que, ayudados por una lente óptica, proyectan una imagen a color en una pantalla. Para su uso requieren de una oscuridad absoluta; recomendablemente, una sala pintada de negro. Son realmente voluminosos y pesados, lo que los hace no transportables, por lo que se reservan únicamente para instalaciones fijas.

22 En esencia, Merce Cunningham hace las siguientes propuestas: 1- todo movimiento puede ser material para una danza, 2- todo procedimiento puede ser un método de composición válido, 3- toda parte o partes del cuerpo pueden ser usadas (sujeto a limitaciones naturales), 4- música, vestuario, escenografía, iluminación y danza tienen lógicas e identidades propias por separado, 5- todo bailarín en la compañía podría ser solista, 6- todo espacio podría ser bailado (o todo espacio puede ser escenario de una danza, descentralización del uso del espacio) y 7 - cualquier tema es válido para la danza, pero esta es primera y fundamentalmente sobre el cuerpo humano y sus movimientos, comenzando con caminar.
} 
ve influenciada por la Nueva Danza a mediados de los años 80 "; pero no hay que perder de vista que, en nuestro país, durante la década del setenta y principios de los ochenta, imperó la falta de libertad expresiva e intelectual, debido a la sucesión de gobiernos dictatoriales.

Y no solo la falta de libertad de expresión podría ser motivo para admitir que casi no existía un acervo documentado de la danza argentina. Así se manifestaba Oscar Araiz (1999: 40): "Pero ¿dónde se había producido el corte, aquello que nos hacía sentir que debíamos comenzar siempre de cero, [...] que, a lo sumo, teníamos abuelos pero no padres?". La recuperación de una memoria colectiva de la danza se inició también de la mano del video, pues a fines de la década del ochenta, ya se había puesto de moda. El rasgo preponderante de mediados de esta década fue el éxodo de los artistas argentinos para buscar, en el exterior, nuevas tendencias corporales y pensamientos sobre la danza. Una novedosa conformación artística la equiparó con otras artes y le dio más interés al proceso por sobre el producto, a unir las cisuras entre las artes, el cotidiano y el diálogo artista y público.

Avanzada la década del noventa, se vive en el país una situación financiera propicia para la circulación y formación de compañías, la adquisición de subsidios y coproducciones para la creación y el perfeccionamiento de una danza a nivel profesional. Como expresa Silvina Szperling (2015: 1'25"): "todo lo que fuera posible de hacer se hacía... lo que hay se usa, lo que no hay se inventa o se imagina". Señala así la particularidad de la danza en conjunción con la tecnología electrónica que, si bien conllevaba las derivaciones de su campo, se sumaba inevitablemente a los costos favorables o no favorables de una producción con esas características. Se dependía de un aparato como el proyector o reproductor de imagen, sin él no había función.

\footnotetext{
En toda esa movida de expansión, que tiene un correlato de lenguaje artístico y de situación social, la danza estaba muy escindida... momento previo a decir dónde estamos, quiénes somos... el asunto de multimedia un poco por esta coincidencia "entre comillas" de la Cía. de Douglas Rosenberg y Li ChiaoPing's Dziga Vertov Performance Group (DVPG), obviamente, estos intereses, necesidades, ganas, deseos de la comunidad de la danza, de capital y alrededores (Szperling, 2015: 2'43").
}

La Danza Multimedia significó la reincorporación del video como herramienta principal de creación escénica. Al comienzo se presentaba como aproximaciones, como ensayos combinados, para ir paulatinamente tomando conciencia clara del medio en su doble rol cinético y poético. Se trataba de un uso escénico de las imágenes virtuales que participaban de lo coreográfico guiadas por una mirada mediada por la 
cámara, por las reversiones, aceleraciones o ralentizaciones del tiempo en la imagen y en los cuerpos, que componían la totalidad de la escena en profundidad con lo proyectado en pantalla.

Asumiendo que los códigos de la pantalla no son precisamente los mismos que funcionan en la dimensión escénico-teatral, hay un complejo -y no siempre logradotrabajo de hibridación entre lenguajes. Sumadas las magras posibilidades de desenvolvimiento tecnológico que ocupa la escena mediática en ese momento, se dificulta seriamente el continuo y sostenido avance en el conocimiento y la experimentalidad local. Así lo testimonia Silvina Szperling (2015: 2'43')' en el siguiente relato:

\begin{abstract}
Era todo low-tech, aparte, el director del Rojas había comprado un proyector de video, porque había calculado que alquilarlo era más costoso. Entonces era como decir: "lo que hay se usa, lo que no hay se inventa o se imagina". En esa movida como el festival siempre tuvo espíritu de hacer convocatoria abierta, multimedia, entró en esa misma mecánica. Los que se animaban básicamente entraban... eran muy pocas propuestas y entraban. El nombre multimedia se venía aplicando en EE. UU. a esa tecnología que se utilizaba y que todavía en la Argentina recién empezaba a existir internet y no tenía todo el mundo.
\end{abstract}

Con este rudimentario impulso de tendencias sobre el cuerpo, oriundos de áreas de lo más diversas, se privilegia la interacción con los diversos sistemas electrónicos emergentes -básicamente reactivos y analógicos- pero, en un marco restringido que desde 1995 se lleva a cabo en nuestro país promulgado por el Festival Internacional de Video Danza Buenos Aires, dirigido por Silvina Szperling. Al respecto, Rodrigo Alonso (2015: 72) enfatiza no solo el contexto de organización y producción, sino también algunos de sus artistas precursores:

\begin{abstract}
Mención aparte merece un género que se desarrolló con fuerza a partir de 1995, con la creación del Festival Internacional de Video Danza. Esta modalidad, en la que confluyen el video y la coreografía realizada especialmente para ser filmada, fue inaugurada en nuestro país a partir del Primer Taller de Video Danza para Coreógrafos, dictado por Jorge Coscia en 1993. De ese taller, surgieron las primeras producciones del género: Temblor (1993), de Silvina Szperling; Asalto al Patio (1994), de Margarita Bali; El Banquete (1994), de Paula de Luque. Margarita Bali es quien ha continuado con más constancia en esta vertiente. Sus videos se van depurando de la profusión de efectos que caracterizaron a los primeros, para llegar a una síntesis perfecta entre danza e imagen, en piezas como Agua (1997) y Arena (1998).
\end{abstract}

Hubo una iniciativa anterior -aunque poco tenga que ver con la envergadura que desplegó el FIVDBA desde sus comienzos a la actualidad- que data de 1992, en el 
1. ${ }^{\text {er }}$ Festival de Video Danza, organizado junto con el Fondo Nacional de las Artes y la Secretaría de Cultura de la Nación (1992). Pero es indudable que la generación y el sostenimiento de estas prácticas van de la mano del primer taller de videodanza (que concibió este "lenguaje híbrido" entre la danza y lo audiovisual) del FIVDBA, tanto para la exhibición de obra como para la generación de los espacios abiertos a la reflexión teórica y al crecimiento exponencial a nivel nacional e internacional.

Asimismo, el interés que promovió el establecimiento de la videodanza en la escena de creación local radica justamente en la importancia que va adquiriendo este concepto de hibridación en las artes y las derivaciones que hoy conocemos. Por lo que la danza y el video son copartícipes en la creación de una forma convenida en escena: la Danza Multimedia.

Si pudiéramos trazar un mapa del derrotero de los años noventa al dos mil, podríamos compartir el siguiente punteo propuesto por Silvina Szperling (2013: 2): "1. desde el escenario hacia la pantalla (videodanza "pura"), 2. de la pantalla al escenario (multimedia), 3. del escenario al espacio visual tridimensional (instalación) y al espacio público (intervenciones urbanas)". En la misma línea que estos argumentos de hibridación entre danza y video en escena, retomaremos a Rodrigo Alonso (2000: 1), quien convalida el inicio de estas prácticas desde el lugar de la experimentación escénica con la tecnología:

Los artistas del Di Tella agotaron las posibilidades de la representación
dancística. Los recursos técnicos del instituto les permitieron experimentar con
escenografías virtuales creadas a través de proyecciones de diapositivas o
films sobre el fondo del escenario. Con estos recursos, Oscar Araiz introdujo la
interacción de los bailarines con sus propias representaciones virtuales en
obras como Crash o Sinfonía (1969). Estos experimentos son los antecedentes
inmediatos de lo que hoy conocemos como danza multimedia (danza en vivo y
en pantalla simultáneamente).

Es interesante observar en el derrotero que describe Sperling y lo que relata Alonso cómo los vínculos entre el espacio escénico, lo audiovisual y el cuerpo se presentan en simultáneo. Ubicarnos cronológica y contextualmente en la escena local podrá orientar asuntos referidos a los dispositivos, a la escena inmersiva, a sus elementos estilísticos y temáticos, y los niveles de interacción o reacción para lograr construir sentido. La Danza Multimedia, de modo estricto, incluye un mismo espacio de sentido, al performer/bailarín y la proyección de imagen y sonido. Al respecto, Philippe Dubois (2001: 84) aclara:

Al principio se trató de una cuestión de soporte: la utilización de la película y de la banda magnética en una misma unidad de enunciación: el film de cine. Un 
asunto de soporte, es decir, de definición, de materialidad, de plasticidad. De "superficie" o aun de "corporeidad" de la imagen. Pero se trata siempre de una cuestión de relación, es decir, de montaje, de exclusión o de incorporación, de rivalidad o de armonía, de disparidad o de fusión. Se examinará pues lo que el cine y video tienen que ver, el uno con el otro, pero también el uno contra el otro, desde que pertenecen a un único cuerpo fílmico que se constituye a partir de su misma disparidad. [...] cuando el cuerpo fílmico nace de una fusión de soportes que pueden ir hasta la desaparición completa de todo signo distintivo, es decir, hasta una verdadera transubstanciación de los soportes en una nueva imagen.

Exacerbar o destacar las diferencias sería una vertiente de análisis posible para convalidar en nuestros estudios de casos, y habría que indagar ahí si es lo más sustancioso, lo que más aporte a la comprensión del campo de esta práctica artística. Pues, "la transposición escénica de esta idea implica el desafío de una relectura, una búsqueda de equivalencias con códigos que tienen que ver con la realidad de un ámbito teatral, una aproximación por elección, a una visión más conceptual, casi de laboratorio", explica Silvina Szperling (2013: 2). Uno de los tópicos problemáticos definido por estas relaciones formales se da entre la bidimensionalidad de la imagen proyectada y el volumen del conjunto en el que se contextualiza. Sobre ello, avanzaremos en el análisis de cada estudio de caso.

Una nueva observación sobre la época actual busca formas distintas de plantear la vinculación de danza y movilización, tratando de combatir el dominio sobre nuestros cuerpos que tiene su origen en el sentimiento general de agotamiento de nuestras formas políticas culturales y, más precisamente, prestar atención a las fuerzas que ponen a los cuerpos en movimiento en la etapa en que vivimos. Evidentemente, por sí sola la danza no puede generar ninguna transformación, pero sí puede desafiar los modos en que los cuerpos se reúnen y participan, ya que la danza tiene lugar cuando se torna encuentro, cuando se torna experiencia corporizada participativa, reemplazando, por medio del concepto de performance y de laboratorio, la tradicional división del trabajo.

Este es un momento propicio para la fusión con otras formas existentes, para resurgir de la posible marginalidad decorativa en pos de un discurso crítico que aporte una mirada analítica de las producciones, ya sea en obras coreográficas, trabajos de investigación sobre diseños de movimiento, performance con dispositivos interactivos, etcétera. Articular estas disciplinas -Danza y Video- requiere reunir el estudio crítico y teórico que el cine, el video y las artes visuales han provisto, por un lado; y, por otro, las formas de construcción de la corporalidad y la visualidad que dicha vinculación perfila. Se propone, por ejemplo, que esta articulación entre danza y video se defina en rededor de la necesaria organización colectiva de pensamientos para conseguir 
comunicar en la diversidad. No se puede operar desde trincheras disciplinares. Las ideas teóricas deben operar como puentes, caminos conceptuales por donde transitar hacia el encuentro con lo otro.

Por su parte, el pasaje de lo analógico a lo digital supuso desafíos difíciles de predecir en una secuenciación lineal, y acentuó la aparición de las categorías de lo viejo y de lo nuevo, puesto que pareciera ser que cada nueva tecnología crea un entorno que en sí mismo arrasa y transforma al que precede. Centraremos nuestro análisis en los cambios cualitativos que nos obligan a pensar ya no solo en términos científicos y técnicos, sino de propiedad y de accesibilidad; considerando, además, el espacio de lo tecnológico -con sus periodizaciones viejas y nuevas tecnologías-como algo más que un acontecer temporal lineal ineludible.

Las tecnologías no son solo recursos externos, sino que hay un plano virtual e inmaterial de ellas que se transcribe en la ampliación de capacidades e interacciones; en consecuencia, se constituyen en torno a una forma de maquinaria material y simbólica. Detengámonos en el párrafo de Arlindo Machado (2009: 180) en el que queda expuesto el vínculo entre el cuerpo, el contexto ideológico y los medios:

\begin{abstract}
En cada época y en el contexto de cada medio, nuestros órganos de los sentidos parecen estar "educados" para comportarse de una determinada manera con relación a los estímulos que se les ofrecen. No se trata de una educación formal, como la que recibimos en la escuela, pero tampoco se trata de un proceso de "aprendizaje" espontáneo y natural: por el contrario, este se produce intencionalmente, a través de todo un contexto ideológico favorable.
\end{abstract}

Estos nuevos desplazamientos en los sistemas de la percepción ya no son puramente audiovisuales. Se han introducido otros sentidos, y la motricidad del cuerpo ha retomado su preeminencia a través de gesto y el tacto, entre otros. Pero como este capítulo trata sobre el vínculo del cuerpo en escena con proyección audiovisual, la experiencia mediática se dirime con la pantalla, por lo cual, el ojo y el oído son aún hegemónicos.

Ahora bien, para continuar con el abordaje de lo multimedia en relación con lo escénico y lo audiovisual, enfocaremos la evolución de cierta problemática del lenguaje artístico híbrido y su vinculación con el contexto cultural que le es propio y adecuado. Igualmente reflexionaremos acerca de las condiciones de esa hibridación en cuanto a las trayectorias de cada disciplina dispuesta a congeniar; y, del mismo modo, realizaremos una observación de estudios de casos. Lo haremos no solo desde la perspectiva de la producción instrumental y metodológica, sino desde las consideraciones y las vivencias de los sujetos que han intervenido. 
Retomando el período que nos propusimos estudiar (1996-2003) en Buenos Aires y aledaños, articularemos el término "multimedia" con la disciplina llamada Danza Multimedia. Para ello, acudiremos a las palabras de Silvina Szperling (2015: 3'41"), quien, siendo directora del Festival Internacional de Video Danza de Buenos Aires, puso en circulación esta denominación y un espacio de presentación en la programación a partir del año 1996:

... multimedia se usaba no en el sentido que se usa ahora, incluso ya ni se usa; tenía que ver con lo online... lo digital. Multimedia o Mix-media, o Intermedia, venía como de mezclar medios y, los medios en ese caso tenían que ver con lo escénico -barra- imagen proyectada.

Mezclar medios escénicos con la imagen proyectada, incluidos los sujetos que actúan, resulta una simplificada pero eficaz definición para Danza Multimedia. Rodrigo Alonso (1998: 22), que ha colaborado profusamente con la teorización de la danza y lo multimedia, lo describe de la siguiente manera: "la representación electrónica ha ensanchado las fronteras de la acción coreográfica dentro y fuera del escenario, en la doble modalidad del video y la performance multimedia". Aquí se plantea un intenso diálogo con las artes de lo audiovisual, las artes de lo escénico, la performance y la danza, es decir, desde la materialidad de la puesta en escena del cuerpo a la diégesis audiovisual proyectada en la pantalla, y viceversa. Nos detendremos por un momento en el término "pantalla", tan utilizado para definir gran parte de la producción, sentido estético y problemáticas multimediales en danza.

Alberto Caballero (2011: 13) presenta la pantalla como aparato técnico y teórico, y como objeto -a través de un recorrido histórico de la mirada y su cosificación-, y argumenta al respecto: “... Así como quinientos años de historia de la perspectiva significaron quinientos años de narraciones, ahora se trata del vaciamiento de la narración, el resto, lo que queda como resto, es la pantalla misma". A su vez, el vaciamiento de la geometría de la pantalla conduce a evidenciar "la materialidad de la imagen, e introducir su inmaterialidad, o también podemos decir su materialidad lumínica".

Eduardo Russo (1998: 192) sostiene que “... Se trata de esa superficie de dimensiones variables por donde nos asomamos a una película. [...] Su proporción de alto y ancho, desde los orígenes del cine, ha variado llamativamente"; y agrega con relación a su funcionamiento: "No se trata tanto de dar a ver, sino de convocar a mirar". La pantalla propone ser definida como clave de la mirada y como objeto que recibe luz, pero que, también, es luz y es espejo y, de igual forma, convoca a un adentro y un afuera. Ambos espacios, indicará Gaston Bachelard (1997: 256), son 
"íntimos, están prontos a invertirse, a trocar su hostilidad. Si hay una superficie límite entre tal adentro y tal afuera, dicha superficie es dolorosa en ambos lados. [...] En este drama de la geometría íntima, ¿dónde hay que habitar?”.

Sobre esta idea de superficies y relaciones de tamaño, operan, en conjunción, un objeto y un espacio escénico, generalmente, un escenario a la italiana en cuyo fondo enfrentado al espectador se sitúa la pantalla. En referencia al juego con el espacio, se integran, en la propia diégesis audiovisual, las correspondencias con el movimiento del bailarín. Tanto para el espectador como para el bailarín, la mayoría de las veces, la pantalla ha trabajado de fondo. Otras, hubo voluntad de que la superficie de la imagen en movimiento atraviese los límites de la pantalla y se transforme en una atmósfera inmersiva; incluso, de que la variación de tamaños y recortes del espacio de la proyección genere las propias pantallas, alternando así entre la retroproyección y la proyección frontal.

La construcción de estructuras originales para la proyección en pantallas de diferentes formatos y medidas, como de paneles modulares que intentarán establecer un diálogo entre las imágenes en movimiento proyectadas y las de los propios bailarines en escena, fueron en principio bastante dificultosas de lograr; puesto que la instalación del proyector era fija dentro del espacio que observábamos. Volvamos entonces al escenario del Centro Cultural Rector Ricardo Rojas, en los años noventa, con su pantalla y su flamante proyector de tres tubos; y lo que, al respecto, Silvina Szperling (2015: 4'35") afirma: "Al principio, todo el mundo proyectaba en la misma pantalla, con el mismo formato, después se empezaron a buscar otras maneras"; lógicamente, dependía de conseguir otros proyectores, por ejemplo.

Se trata de un juego de variaciones dentro de la propia proyección que intenta romper el cuadrado del marco en busca de un diálogo de contrapuntos y asociaciones que hablan del cuerpo y la mirada del bailarín y del espectador a la vez. Una compleja propuesta de la representación del cuerpo en materiales diversos, en la que no siempre se obtienen los resultados deseados.

¿Será que el lenguaje audiovisual prima sobre lo coreográfico? ¿O viceversa? ¿Hubo mediación entre ambos en pos de una hibridación narrativa? ¿Es posible esta hibridación disciplinar? ¿Será que la danza escénica con proyección audiovisual en pantalla trata crudamente de trabajar el campo contra-campo entre el espacio de la escena y el espacio de la pantalla?

Es evidente que la mirada del espectador debe duplicarse, la omnivisión debe desdoblarse en el cotejo de las informaciones que cada espacio -virtual y realsolicita. De ahí, entonces, esa perspectiva variable, esa multiplicidad que constituye la complejidad de la Danza Multimedia, que no es sino el efecto de una modulación de 
miradas que la pantalla opera en el mismo espacio donde se instala. La posibilidad de alternancia del campo/contracampo entre pantalla y escena funciona requiriendo que la mirada se multiplique en una geometría aumentada correspondiente a la distribución topográfica de los cuerpos y situaciones que habitan en la escena y en las imágenes proyectadas.

Por lo tanto, la tarea que ocupa el espectador con la pantalla no se agota en el proceso de individualización con la cámara, sino todo lo contrario, lo escénico trabaja justamente en la diferencia que se establece entre esos puntos de vista físicos y los proyectados. Aquí es interesante observar esta idea de la individualización del sujeto expectante. Según Arlindo Machado (2009: 87): "Todo el material perceptivo termina por depositarse en el espectador, como si este fuese una segunda pantalla". En consecuencia, nos preguntamos ¿qué sucede con esa segunda pantalla donde cobra sentido y se constituye el campo de lo simbólico, teniendo en cuenta, además, que hay otro plano de percepción que es lo que está aconteciendo simultáneamente en la escena con los cuerpos reales? ¿Qué sucede con la sinergia que producen los movimientos del cuerpo del bailarín, del performer? ¿Habría una sobreidentificación fusionada o una sobreestimulación paralela?

O bien, como precisa Susana Tambutti (2007: 84), cuando plantea que las transformaciones en las maneras de entender la danza como hecho escénico "produjeron cambios en los modos de recepción e hicieron que ya no se intentara 'leer' una obra linealmente, sino que se pudiera 'entrar' a la obra a partir de cualquiera de sus partes". Esta ruptura de la linealidad es fundante, pues introduce lo heterodoxo, lo disidente, e intenta presentar posibilidades simultáneas para permitirnos concebir al mismo tiempo variadas alternativas, incluso, contradictorias. Un espectador de danza multimedia no solo ve comprometida su mirada escindida, sino que hay que sumarle su progresiva retirada de la "ensoñación de la butaca, de su pasividad motriz", tal como lo señala Jorge La Ferla (2009: 124); puesto que el video, generalmente, era exhibido como el cine desde la concepción técnica de sala, análoga a la teatral, lo que, como es natural, condiciona el desarrollo de una "narrativa" acorde a esta relación espacio temporal.

Para la danza, la sala, el espacio teatral, es el hábitat más frecuentado; en consecuencia, una ruptura con las formas del espectáculo uniformizadas significa replantear los supuestos estéticos, metodológicos y políticos que han heredado acerca del cuerpo y sus usos en la escena. De esta forma, la escena multimedia tendía a producir, esencialmente, a partir de la mixtura de disciplinas, teorías y aproximaciones estéticas que suponían un posicionamiento subjetivo y tecnológico. Lo que obligó a allanar el camino hacia la conformación de un artista que gestione su labor desde la 
investigación y desde la reflexión, y no solamente desde la recreación y el dominio de habilidades y destrezas.

Parafraseando a La Ferla (2009: 128), confluimos en la consideración de que "aquellos cruces ocurridos en un principio entre los medios analógicos generaron un importante espacio conceptual y material, un campo clave si lo queremos ver en toda su dimensión". En esa trayectoria de los cruces entre la danza, el espacio escénico y el video, la palabra "multimedia" fue mutando e involucrándose en otros regímenes con la escena local. Silvina Szperling (2015: 5'02") lo describe así en la entrevista realizada:

\footnotetext{
... la palabra multimedia empezó a sonar más en el mundo del software, y por otro lado hubo mucho estreno de danza que utilizaba video en escena, y que ni se anunciaba como multimedia, pero ya se había empezado a incorporar como algo "común".
}

¿Qué significa que un fenómeno se torne culturalmente "común"? En principio, podríamos decir que "lo multimedia no es exclusivamente de nadie", que pertenece o se amplía a varios contextos, criterios, y es adoptado así, como aceptado por todos o por la mayor parte. En el caso expresado, el devenir de lo multimedia en escena, lo común, fue entrar en un proceso de normalización en el que la proliferación de este tipo de incumbencias parece algo tan usual que no invita a una reflexión crítica sobre, por ejemplo, cómo se determina el cuerpo ante el mecanismo de producir el on-off; o, la desigualdad cinética entre lo proyectado y la versión en el escenario. Todas las comunidades de usuarios de proyecciones en escena empleaban básicamente las mismas técnicas para producir efectos, a pesar de lo radicalmente diferentes que pudiesen ser sus interpretaciones. En ese sentido, Szperling (2015: 5'30”) indica:

\footnotetext{
... nos empezamos a enterar de que había un montón de estrenos y además producir algo escénico era más complicado porque al proyector se le empezó a gastar la lámpara y la gente empezó a hacer cosas más arriesgadas, y no era tan fácil porque a veces fallaban, porque no teníamos la tecnología, ni teníamos el conocimiento de un montón de cosas, ni la plata.
}

Confirmando lo declarado respecto al destino de la Danza Multimedia, citaremos una nota de Alejandra Cosin (2005: 35), para quien la preocupación no es qué hacer con los avances de la tecnología, sino cuál es el lugar del cuerpo en las obras:

\footnotetext{
Me pregunto sobre la danza -como arte del movimiento- y su relación con la tecnología en el mismo momento en que Silvina Szperling lanza el siempre excelente Festival de Video Danza en noviembre de este año, nuevamente en el Rojas. Esta es la versión séptima, que reafirmará la independencia del arte del videodanza con respecto a la performance en vivo con utilización de
} 
multimedia, que estuvo presente en otros años. [...] en vez de dispersar energía en producciones que son de muy difícil concreción, tales como las obras multimediáticas, que hoy no se conforman con una pantalla y un cañón de video, como años atrás, sino que requieren una tecnología de punta costosa y complicada de instalar en el Centro Cultural Rojas, por ejemplo.

Tal como lo ha evidenciado Douglas Rosenberg (1999: 6) -teórico, realizador y consustanciado colaborador del FIVDBA-, con relación a este maridaje entre danza y tecnología:

Danza y tecnología es una construcción lingüística inapropiada. En realidad, se trata más generalmente de tecnología y danza. Seamos honestos nuevamente. Es la misma estructura genérica y jerárquica que se nombra a sí misma nombrando primero al otro o a quien no es. La intencionalidad del nombre perpetúa la ghettorización de un género de obras que está atrapada en su propia falta de contextualización histórica. Y nadie quiere "mover el bote".

Esta dependencia que acaba de ser denunciada es casi un sine qua non de estas propuestas artísticas, y la "padecieron" el FIVDBA y sus artistas. Eran épocas en las que solo algunas instituciones contaban con los aparatos indispensables para las realizaciones. Podemos ejemplificarlo con un fragmento de la publicación del propio FIVDBA (1999: 43):

En 1998, el Cuarto Festival Internacional de Video Danza de Buenos Aires presentó su Sección Multimedia en el marco del evento "la Fabriquera Audiovisual", organizado por la Facultad de Arquitectura, Diseño y Urbanismo, de la Universidad de Buenos Aires. En vista de una serie de dificultades técnicas que a último momento hicieron imposible que los grupos desarrollaran sus espectáculos, se decidió darles la oportunidad de hacerlo en 1999, fuera de la muestra competitiva.

Esta problemática de falta de equipamiento en las instituciones o salas que convocan a exhibir obras con uso de tecnología escénica se extendió al menos hasta muy avanzada la década del dos mil. El artista multimedial Gabriel Gendin (2016: 7'40") lo expresaba así, al comentar una performance realizada en el año 2003:

Todo lo que habíamos pensado con la imagen se usó un día sí y un día no; porque al otro día ese proyector se usaba en otra sala. Eso te demuestra la realidad con la que trabajábamos. Había en todo el Centro Cultural San Martín un solo proyector.

Hacer visible los límites de la presentación con soporte multimedia supone la exhibición de una realidad que escapa igualmente a la posibilidad de ser subsidiada -y y por tanto popularizarse- de manera sostenida. Se trata, entonces, de producciones 
que no pueden expresarse ni explicarse sin un grado de compromiso institucional, lo que va unido a la imposibilidad de una experiencia continua, de investigación y desarrollo en el área. Nuevamente citaremos a la investigadora en artes escénicas contemporáneas Alejandra Cosin (2005: 35), quien, desde su práctica como crítica de espectáculos locales, no pierde contacto con la sinergia del ambiente artístico, y advierte sobre la falta de políticas culturales actualizadas y de apoyo financiero para la Danza Multimedia: "aún sigue pensándose la performance multimediática como arte de elite, cuando esta es una experiencia escénica practicada hace ya varias décadas en todo el mundo".

Por lo tanto, "mover el bote", tal como arenga Rosenberg, dependerá del contexto en el que esté encallado. Asimismo, este reclamo puede ser interpretado como la probabilidad de "llamar la atención sobre un campo de reflexión en desarrollo que está contribuyendo decisivamente a la comprensión del mundo tecnológico en el cual estamos inmersos" (Mitcham, 1989: 13). Este autor aborda los problemas planteados por los diversos campos del conocimiento, y analiza y compara las principales tradiciones de la filosofía de la tecnología. Por ende, distinguirá si tales problemáticas tienden a involucrar a la técnica o a la tecnología, porque en sí poseen significados algo diferentes:

\footnotetext{
Técnica puede significar el 'conjunto de procedimientos puestos en práctica para obtener un resultado determinado. Existe la técnica de la caza, de la pesca, de la danza, de cocinar, de contar cuentos, etcétera'. La tecnología, o el quehacer de la ciencia moderna y la utilización de artefactos, presupone las técnicas como formas primordiales de la acción humana.
}

Existe, igualmente, la técnica de la danza, y esta presupone formas primordiales de la acción humana. Para los que estudian la danza como arte y como una educación del cuerpo, "la reflexión sobre los fundamentos de las técnicas y las concepciones de cuerpo que ellas ofrecen nos llevan a considerar la constitución del cuerpo como médium expresivo del arte de la danza y el movimiento como su objeto" (Escudero, 2013: 16). Y así, plantearnos una técnica de la danza y la tecnología que nos impulse a identificar de manera más precisa cuáles elementos de la danza pueden articularse con tales elementos de otros lenguajes como las artes audiovisuales y multimediales.

Cada vez que interactuamos conscientemente con un determinado sistema, sea este analógico o digital, tendremos estándares de movimientos basados en aspectos que no reduzcan el cuerpo solo a un medio, sino por el contrario, como producto emergente de la práctica con ( $y$ en) esas tecnologías. Entonces, por una parte, 
encontramos el tema de la danza y la definición de un ámbito de discusión, de evaluación, de análisis y de articulación con las nuevas formas de creación que proveen las tecnologías. Por otra, la conformación de una técnica de movimiento a través del vínculo cuerpo y tecnología y, más específicamente, el vínculo cuerpo y sistemas reactivos, interactivos, o con sistemas interactivos multimodales. Douglas Rosenberg (1999: 6), hacia fines de la década del noventa, apunta:

Es tiempo de una recorporeización de la danza y la tecnología, tiempo para inscribir al cuerpo en el corpus de la tecnología [...] ¿Cuáles son los puntos de resistencia a esta revolución? Es una revolución demasiado civil, demasiado pasiva.

Una evaluación crítica constante es, fue y será parte de nuestra práctica con tecnología, y así es que el "artista debe aprender a lidiar con ella si no quiere transformarse en el cómplice involuntario", alega Rodrigo Alonso (2015: 188); puesto que los discursos persuasivos tienen una naturaleza doctrinaria por su eficacia formal e interactiva. Sin desviarnos demasiado del tema de este capítulo, aludiremos a la tecnocracia ${ }^{23}$ como un punto clave para no perder de vista. Desde una perspectiva materialista, se ha cuestionado el mito de la máquina restituyéndola al universo de lo instrumental sin desmerecer por ello su poderosa capacidad transformadora. Instalar y ejercer una mirada reflexiva análoga en el terreno de las artes electrónicas y digitales establecerá una de las aportaciones más pujantes para la comprensión de los procesos artísticos en la actualidad; sobre todo, partiendo de un posicionamiento crítico que no sea subsumido por la exacerbación del impacto de lo espectacular o anteponiéndole la problemática ya citada de los recursos disponibles y la actualización en las operaciones del hardware o del software. Ocultándose tras las innovaciones que prometen la panacea del Hazlo tú mismo (DIY: Do It Yourself) que ilustra Douglas Rosenberg (1999:5), parecen ser constitutivos del trabajo con tecnología los discursos formalistas e instrumentalistas. Recreémoslo en este relato:

\begin{abstract}
Un miembro del departamento de danza quiere comprar una videocámara digital. Pregunta: "¿qué videocámara digital debería comprar?". Respondo: "¿para qué necesitas una videocámara digital en lugar de una cámara analógica?, ¿para qué necesitas una videocámara?, ¿entiendes perfectamente, en este momento, cómo utilizar una cámara, incluyendo cuestiones estéticas con relación al encuadre, composición e iluminación, y otras pragmáticas como
\end{abstract}

\footnotetext{
${ }^{23}$ El término "tecnocracia" se impone a partir de los primeros años de la década del treinta para indicar la progresiva expansión -alentada por algunos, temida por otros- del poder de los técnicos de producción: químicos, físicos, ingenieros, y programadores -añadiríamos hoy-; basado en el supuesto de que quien está capacitado para gobernar el proceso industrial empresarial y científico está capacitado para gobernar no solamente a los sectores productivos, sino también a la sociedad en su conjunto. Volveremos luego sobre el tema del poder de los programadores en la práctica artística contemporánea.
} 
profundidad de campo, control del iris, configuración de f-stop?, ¿en qué formato te gustaría la salida, VHS, S-VHS o betacam?, ¿entendes o entienden tus alumnos la edición analógica, lineal, o están saltando hacia la edición digital sin ningún contexto? Y, aún más importante, ¿dónde colocarás las cuestiones de contenido y cómo afectarán estas tu elección del hardware?, ¿conoces la historia de la danza para la cámara?, ¿te interesa? [...]. Estamos aquí sentados en un ghetto que privilegia la forma por sobre el contenido, las herramientas por sobre la práctica [...] estamos atrapados por la atracción de la tecnología.

La exigencia que nos interpela respecto a la generación de contenidos para proyectar un pensamiento sobre la danza con tecnología como prácticas híbridas será, claramente, considerar no solo la categoría de cuerpo, sino, del mismo modo, las prácticas como acciones situadas para el acontecimiento de nuevos procesos.

Volviendo a la escena de fines de los noventa y la trayectoria de lo que se denominó Danza Multimedia, es interesante conocer, en palabras de sus protagonistas, cómo fue transmutándose y originando nuevos caminos para tomar. Atendamos a esta otra y discutible localización a través de la entrevista a Silvina Szperling (2015: 6'17'), quien manifestaba lo siguiente: "pasó a otro registro, no al registro de lo excepcional, de investigar tanto en el formato sino en el registro de es una herramienta más para la escena" (la cursiva es nuestra).

Nos referiremos ahora a una experiencia realizada con el fin de ahondar en esta expresión una herramienta más para la escena: tras un censado de artistas e investigadores académicos que estuvieran interesados en las diversas vertientes del campo de la danza y de la performance con mediación tecnológica, se llevó a cabo un relevamiento -en principio, vía correo electrónico- con la intención de recopilar información sobre esos grupos.

A partir de un correo electrónico publicado por Alejandra Ceriani (2011: 155), enviado por una colega en función de esta indagación, se nos abrieron profundos márgenes reflexivos -particularmente, en la ciudad de Buenos Aires- sobre los desarrollos de un artista o grupo que se implique con la tecnología:

... Bueno, la verdad es que ya en danza y en teatro la tecnología se ha vuelto herramienta, no fin en sí misma... Nadie está trabajando con tecnología como novedad, se usa para fines dramáticos o estéticos... pero como algo más que aporta -a veces no, pero ese es el objetivo de los artistas, que aporte- a la escena, al total... Así que te diría... que las tecnologías en las artes escénicas pasaron de moda... o se incorporaron a la paleta de herramientas posibles. No hay como en los 90 y 2000 gente que esté "investigando", porque no solo ya se ha visto todo lo posible, sino que lo imposible no está a mano, es muy caro y engorroso para los espacios de la ciudad que no cuentan con los elementos necesarios o las condiciones para que alguien ponga en escena las últimas tecnologías a rodar [correo electrónico del 03/04/11]. 
Para dar una respuesta crítica a esta idea del uso específico de la tecnología como medio para un fin o solo como herramienta escénica y dramatúrgica -sugerencia que se hace en el citado correo y en la lectura sobre el único cambio de registro de lo multimedia-, reflexionaremos partiendo de la observación de las representaciones que el concepto de "espectáculo" puede ejercer frente a las propuestas emergentes de formato laboratorio.

Creemos que elaborar una respuesta de este tipo nos lleva:

$\checkmark$ A entender que una parte de nuestros colegas (bailarines, coreógrafos, críticos, programadores, etc.) en danza contemporánea o performance en danza se suman a propuestas de "actualidad" a modo de experiencias coyunturales.

$\checkmark$ A cuestionar aquellas consideraciones prioritarias sobre los costos y condiciones para la realización de "espectáculos escénicos" de mayor envergadura, en detrimento de concebir otros espacios, medios y modos de organizar trabajos.

Lo escénico-espectacular funciona como corporación en una estructura jerárquica con una división especializada del trabajo (actores y bailarines principales, de reparto, equipo técnico, programadores, etc., cada uno con su tarea específica); y hay, también, otras distribuciones que tienden a ser más horizontales, descentralizadas y siempre debatibles. Frente a estas políticas del espectáculo, industrias culturales, tendencias y preceptos, se contraponen otras formas escénicas que hallaron su lugar de manifestación en espacios periféricos o alternos, organizando los recursos en un sentido procesual, y en los que lo efímero suscita nuevas estrategias escénicas.

Uno de los inconvenientes fundamentales de la producción y el consumo artístico así como de la formación disciplinar con base en la aplicación de tecnologías no solo pasa por no evolucionar en consonancia con los avances tecnológicos, sino, y más precisamente, que esa disparidad dé cuenta del carácter silencioso y oculto de los mecanismos de reproducción y de asimilación. Mecanismos que preexisten a la decantación social y cultural, tan necesaria para madurar y cuestionar cada mediación. Es indudable, por lo pronto, que el automatismo en directo de las nuevas tecnologías de la imagen y la comunicación transfieren, como consecuencia, la generación de discursos multimediáticos no afianzados previamente por la palabra y emancipados del cuerpo. Patrice Pavis (2000: 2), advirtiendo sobre el destino de las escrituras dramáticas contemporáneas y las nuevas tecnologías, lo manifestaba de la siguiente manera: 
A pesar de la aparente victoria de los especialistas informáticos sobre los directores de teatro y artistas, a pesar del dominio de la función mecánica sobre el objeto estético, hay un momento en que lo reprimido del cuerpo y de la presencia humana, de la voz y del texto vuelve a hacer aparición, como el diablo encerrado en su caja de sorpresa. Lo que surge es el cuerpo del actor sometido por un momento a la regularidad de la máquina, el cuerpo de los tramoyistas, el cuerpo deseoso del espectador. El actor es siempre la causa del desplazamiento de la imagen escénica, el cuerpo extraño e irreductible que se impone a pesar del dispositivo aséptico de las máquinas escénicas, de los videos o de las computadoras, que vuelve a encontrar algunas de sus antiguas facultades: presencia, voz, ritmo biológico, rendimiento físico, derecho a equivocarse.

Teniendo en cuenta que esto fue escrito y pronunciado en el año 2000, y hoy podríamos contemporizar ciertas apreciaciones totalmente discutibles, destacaremos, sobre todo, esta idea de que el cuerpo puede equivocarse, un derecho que parece excluir el dispositivo aséptico. Este entretejido textual del ayer y del hoy que hemos propuesto para nuestra tesis, aseveramos que el derecho a equivocarse también lo es para las tecnologías, las máquinas escénicas, de los videos o de las computadoras.

El error de los aparatos o sistemas se denomina glitch o error informático y es el resultado de variaciones inesperadas o intencionales que acontecen durante el envío o la recepción de la información que alteran la información original. Estas fallas se incorporan en la representación audiovisual para experimentar nuevas estéticas.

Por ello, desde esta enajenación -con la que se propone analizar experiencias multimediáticas, oponiendo el cuerpo a los procedimientos escénicos y audiovisuales-, solo se consigue exacerbar la omnipotencia creadora de un lenguaje por sobre el otro y disipar su intrínseca sensorialidad.

Pero si hasta ahora hemos prestado atención a los procesos que demuestran el diálogo, la confluencia y la hibridación de diferentes medios, lenguajes o disciplinas, qué sucedería si focalizáramos nuestra atención en los movimientos particulares que las disciplinas intervinientes componen, ¿hablariamos de procesos divergentes más que de procesos convergentes? O, tal como expresa Mariela Yeregui (2008: 21), que toma como punto de partida la idea de reciprocidad entre disciplinas que: "a luz del pasado siglo pudieron ser vistas desde un vínculo disfuncional -casi un divorcio de hecho y de derecho- debiera visualizarse hoy desde miradas que se corren de los enfoques tradicionales".

Probablemente, desde esta perspectiva, adquieren una mayor relevancia las transformaciones en la periferia, el desgaste de los bordes afilados de procedimientos, dogmatismos y materialidades de cada uno, para ir ganando espacios insospechados. 
Si hacemos una lectura de las producciones de académicos y artistas de los noventa, encontraremos ideas sobre la centralidad del lenguaje audiovisual, sobre cómo se había convertido el video en un elemento fundamental para comprender el arte y la cultura contemporánea. Componiendo un transcurso cronológico a grandes rasgos, y a sabiendas de su coexistencia transversal, podemos decir que el video comenzó a mediados de la década del sesenta, básicamente, en un formato experimental. Los artistas exploraron el video como un material electrónico, procesando la energía y el tiempo en formas de onda, frecuencia, luminancia, etcétera, a través de máquinas diseñadas para producir una imagen sin usar una cámara o procesando la imagen de la cámara o alterando la imagen de la televisión.

\section{Coreografías escénicas y coreografías videográficas en conjunción}

El cambio que proponen las nuevas coreografías predigitales o coreografías videográficas para la escena es, a grandes rasgos, el de la presencia e interactuación con las imágenes proyectadas en el mismo espacio escénico que la danza. Pensemos en la mirada que actúa sobre estas imágenes, no es la misma que "danza" frente a un espejo, por ejemplo. A la par, estas visuales contienen tiempo performático y superan el rol de video proyectado para convertirse en una narración latente en busca de danzar simultáneamente con los cuerpos, espacios, sonidos y tiempos tanto físicos como proyectados.

Para accionar las interfaces analógicas propuestas (pedales, micrófonos, conexión alámbrica, etc.), se requería un modo concentrado que reunía, a su vez, sinestésicamente, una audiovisión interna o externa, es decir, audible y visible físicamente. Allí, una audiovisión interactiva pugnaba ante la disponibilidad reactiva del momento.

Uno de los grandes problemas del desarrollo de la Danza Multimedia como tal, es decir, dentro del contexto técnico brindado, fue no poder contar con el montaje de la técnica obligada para el ensayo y error que permitiera un ida y vuelta en la experimentación. Se probaba montando sobre otras condiciones, por ejemplo, con un televisor detrás del bailarín, cuyo tamaño nada tenía que ver con la pantalla y el escenario donde se realizaría la presentación. A diferencia de hoy que podemos tener en nuestros hogares un estudio muy completo, o simplemente una computadora, un software y un proyector para ensayar e ir experimentando.

Si la videodanza había comenzado a poner en juego la fragmentación y la ubicuidad del cuerpo danzante, la Danza Multimedia instalaba, en un mismo espacio físico, el 
desdoblamiento del cuerpo en las imágenes del audiovisual y en la ejecución coreográfica en escena. Lo grabado se emparejaba con lo presencial en uno de sus puntos críticos: la dialéctica del sentido argumental -tanto figurativo como abstractode lo que sucedía en la escena y de lo que sucedía en las imágenes proyectadas. Al respecto, podemos indicar esta compaginación con una predominancia tanto formal como temática y, en el mejor de los casos, con la hibridación de ambas. Es decir que la vinculación es más o menos explícita con relación a los patrones puramente formales entre la imagen proyectada y lo que se propone en la escena o en lo que relata entre la escena y la proyección.

En este sentido, podemos citar a Santiago González (2015: 1') en una entrevista grabada para esta tesis, en la que remembró las concepciones de lo audiovisual, de la escena y de la danza. En principio, consideró la correspondencia formal -buscada entre el cuerpo físico y la proyección- como disociada pero, asociada y coordinada escénicamente. Asimismo, hoy cree que en las performances lo que sucede es que "el algoritmo está garantizado, porque hay sensores, porque está toda la maquinaria coordinada, y esto, en todo caso, no es una coordinación, es una extensión, es prótesis". Continuando con esta línea comparativa sobre el proceso de hibridación dentro del contexto local, González (2015: 5'20') reflexiona sobre el cuerpo que danza en el espacio escénico delante de una pantalla:

\footnotetext{
Parecería que hay un lastre de lo que significa la conexión mecánica entre el bailarín y la pantalla, lo que está pasando ahora, lo que fundamentalmente pasa ahora es un cierto mecanicismo. De la misma manera, nos podemos remontar y se puede hablar de la evolución de un estadio antes de lo que nosotros estuvimos haciendo, buscando montajes paralelos o costuras entre lo que se ve en pantalla y lo que uno puede pensar... cosas que se hicieron mucho antes proyectando super 8 en una tela y bailando, y eso en todo caso no tenía ninguna relación... jugando una cosa muy primitiva, pero que también podría estar dentro del esquema de estudio. Este super 8 o este cine proyectado no era más que otro elemento considerado un tipo particular de escenografía.
}

Varias cuestiones para tratar se desprenden de este párrafo. Una de ellas son los fundamentos teóricos y metodológicos de la Danza Multimedia y, en ese sentido, vincular las experiencias del pasado con las del presente permite la elaboración crítica sobre lo acontecido y restituye la capacidad de confrontación, discusión y enunciación no solo de lo transitado sino también de los futuros posibles. En consecuencia, el énfasis está puesto no en el relato histórico sino en el sujeto recordante. Al respecto, consideramos que recordar no es estrictamente historiar sino experimentar, ponderando el proceso, el ejercicio, la acción del propio cuerpo en la evocación. 
Por tanto, la presencia e intercambio directo con los protagonistas y no solo con el soporte teórico requerido, conformará una trama conceptual altamente performática. De ahí que examinaremos -en este puente constituido entre la escena predigital y reactiva a esta escena actual, digital e interactiva- lo que subyace como conexión mecánica entre el bailarín y la pantalla. Asumimos que esta conexión puede derivar del conjunto de hábitos que sobrevienen a la situación de un cuerpo al estar danzando frente al objeto pantalla (como aquella superficie delimitada que recibe una proyección).

La presunción inicial daría a entender que aquellos movimientos o estados de presencia corporal ante la pantalla (tengamos en cuenta que en el período y eventos observados se trataba mayormente de proyecciones por detrás de la posición de los cuerpos en el espacio escénico) responderían a paradigmas cuasi instalados, funcionales que, según Oscar Traversa (2008: 3), son "el resultado de una operatoria cualquiera de pantalla mediada por una 'lógica' con límites y cursos estereotipados".

Por su parte, Juan L. Moraza (2003: 97) detecta más bien un conflicto, pues muchas veces se "juega con esta rivalidad entre la pantalla, el cuerpo en la pantalla, y el cuerpo de los bailarines en la escena. Entre los dos se da una verdadera relación conflictiva, como si para el cuerpo real se tratara siempre de ganar al cuerpo en imagen que para el espectador, debido al formato, es siempre más fascinante". Recordemos que aún la imagen bidimensional y el cuerpo tridimensional conviven en un mismo espacio virtual y real sin mediaciones, ni captaciones, ni software; no estamos todavía ante la producción de un cuerpo de su propia imagen.

También estamos ante coreografías previas que se coordinan con las imágenes proyectadas, no ante lo que Moraza (2003: 97) llamaría "la imagen del cuerpo performativo". No hay cuerpos productores de imagen y sonido que exigen mudar la mirada del espectador de videos o de danza hacia un espectador testigo de una acción performática. Lo que coexiste es una coreografía montada en función del video, o viceversa -cada cual por su canal de recursos- que se cruzan, se provocan, se reclaman, pero sin posibilidades técnicas que abran el juego performático en escena. Sin perder esa representación mental de un cuerpo frente a una pantalla, especulamos sobre si este cierto mecanicismo o lógica operatoria podría ser el resultado de los propios movimientos diseñados -ya sea que partieran de una secuencia coreográfica o de una improvisación- sin considerar la no correspondencia de escala, es decir, de tamaños entre el cuerpo físico y la imagen, o no pudiendo resolver esta predisposición a nivel técnico, o de todo ello a la vez. Pero, pensado desde lo audiovisual, ¿cuáles podrían ser los diseños convenientes para la exhibición de contenidos comunicacionales, estéticos y en coordinación con estas circunstancias mencionadas? 
¿Estarían igualmente posibilitados de dar respuestas mediante la producción de sentido en la pantalla y en el escenario?

Noël Burch (1999: 193) destaca la manera de codificación llamada Modo de representación institucional, una forma dominante de construir el relato cinematográfico, televisivo y videográfico contemporáneo. Regido por el concepto productivo -análogo a lo teatral-, se trata de una fuerza para desarrollar una instalación afín a esta correspondencia espacio temporal de los formatos de exhibición: uno o más individuos sentados o de pie frente a una proyección fija.

Por lo tanto: ¿podemos afirmar que la Danza Multimedia, en sus orígenes locales, estaba supeditada a las características intrínsecas del dispositivo y su disposición espacial? Innegablemente que sí. Recordemos las palabras de la directora del FIVDBA, Silvina Szperling (2015: 2'): “Era todo low-tech, aparte, el director del Rojas [Darío Lopérfido] había comprado un proyector de video, porque había calculado que alquilarlo era más costoso". Incluso, las compañías extranjeras debían adaptarse a estas posibilidades que brindaba la sala. $Y$ en este punto se nos insta a considerar la relación entre arte y tecnología, entre el campo de los artistas y sus prácticas con tecnología, pues emergen -constantemente- los debates divididos que, en líneas generales, auspician los discursos que adhieren o se resisten a esta relación.

Transitando por los términos medios de estos extremos, somos conscientes de que el estudio de este enlace no se limita a las obras, a las tendencias o a los artistas, sino que se van entramando con la incidencia de lo tecnológico en los procesos de producción y comunicación. Un cambio de tecnología condiciona estos procesos, pero no por ello los cercena, muy por el contrario, creemos que los dinamiza. Sin embargo, el desfasamiento en estos procesos coexiste, tal como lo interpreta Nicolas Bourriaud (2013: 79), en "Relaciones pantalla-estética relacional", respecto a los lazos entre arte y tecnología:

La teoría modernista del arte postulaba que el arte y los medios técnicos eran contemporáneos. Creía que existirían lazos inseparables entre el orden social y el orden estético. Hoy podemos ser más cautos, más circunspectos en cuanto a la naturaleza de esos lazos: la tecnología y las prácticas artísticas no siempre van juntas, sin que ese desfase sea perjudicial para alguna de las dos.

El mismo autor (2013: 80) asevera que "la nuestra es verdaderamente la época de las pantallas" y continúa brindando contenidos sobre este dispositivo:

Es sorprendente, además, que la misma palabra se use para una superficie que retiene luz, en el cine, y para una interfaz sobre la que se inscribe información. Sus distintos significados dan prueba de cambios epistemológicos (nuevas estructuras de la percepción), que son el resultado de la aparición de 
tecnologías tan diferentes como el cine, la informática y el video, reunidos alrededor de una forma (la pantalla, la terminal) que sintetiza propiedades y potencialidades. Si no reflexionamos sobre esta coincidencia, que se da en el interior de la herramienta mental y desemboca en nuevas maneras de ver, nos condenamos a un análisis desde la mecánica de la historia del arte naciente.

Desembocar en nuevas formas de ver nos tiene que conducir en un movimiento de ida y vuelta, que sitúe a la tecnología en su contexto productivo y que analice sus relaciones coetáneas. Volvemos entonces al testimonio de Silvina Szperling (2015: 0'26') sobre ese momento en el que queda expuesto el trayecto hacia la conformación del espacio que acogería y daría la posibilidad de desarrollarse a la Danza Multimedia:

... y el cine era como más de la industria; de los superochistas, etcétera. Yo me acerqué como a todo ese mundo que para mí era totalmente nuevo. $Y$ entonces se empezaron a plantear todas estas alianzas o fusiones artísticas que al mismo tiempo conllevaban la idea del equipo. [...] Y como en el Rojas había una movida de danza muy fuerte, que era "la movida de danza", no existía Prodanza. Eran los 90 y no existía dinero para nada.

Reforzamos esta idea de conformar un contexto que sirviera como "una cosa medio de nido" con la cual Silvina Szperling (2015: 6'04") metaforiza la cabida de la Danza Multimedia dentro del FIVDBA, para luego ir dejándola paulatinamente fuera de la grilla de programación por cuestiones de costos y complejidades técnicas exigidas por el propio devenir de esta práctica híbrida y básicamente tecnológica. Ese "nido" -como una metáfora para referirse al lugar que el festival incluyó dentro de su programación y que posibilitó dar inicio a la danza escénica con video proyectado- hoy lo observamos y describimos como un objeto de estudio. Gaston Bachelard (1997: 135) le da al nidocasa un sentido de amparo y pertenencia, y sostiene que es "el interior del nido lo que impone su forma. [...] El nido es un fruto que se hincha, que presiona sobre sus propios límites". La Danza Multimedia dentro del festival creció en expectativas, en experimentación, sumada a la digitalización de los medios, y, en consecuencia, ese espacio cedió y la Danza Multimedia, según Silvina Szperling (2015: 6’56”), “quedó de vuelta como algo excepcional en el festival, pero cada tanto ingresa y vuelve a salir".

Si retomamos los vínculos con el tema de lo audiovisual y esta lógica operatoria vemos que, si bien el cine experimental y el videoarte son medios que proponen la ruptura con las narrativas del cinematógrafo, es evidente que los modos de producción institucionales proscribieron estas liberaciones. Asimismo, la participación de los bailarines, el coreógrafo y los espectadores quedaba delimitada por las dimensiones espaciales de la sala y la ubicación del proyector o, en el mejor de los casos, quienes 
accedían a tener proyectores independientes trascendían esta relación tradicional de frontalidad.

Lo ideal sería que, en una proyección, la distancia entre el espectador, los bailarines y la imagen se modifique en función de las posiciones "móviles" de esta terna, dentro de la obra en un contexto arquitectónico en el cual la imagen se exhibiera sin estar enmarcada por una pantalla o un proyector único y fijo, y donde se pudiera circular sin distancias establecidas, reconstituyendo así un equilibrio fluctuante entre un espacio disponible y ocupado. Las fronteras entre la arquitectura del escenario, el tamaño del cuerpo y de la imagen proyectada no lograron disolverse del todo. Sin embargo, como entiende Oscar Traversa (2008: 4), el artefacto pantalla tiene otros alcances, presenta enumerando propiedades comunes que permiten establecer conexiones entre las distintas variantes o, por lo menos, son diferentes:

\footnotetext{
... esa participación pantalla en la producción de sentido, experienciada de un modo singular, puede dar lugar a ecos, generar relaciones diferenciadas, o eventuales vínculos heterogéneos entre aquellos que, de alguna manera, la emplean (quiero decir que el lugar asignado en los desempeños sociales no es idéntico, ni goza de ninguna jerarquía a priori, es un hueco para siempre llenar).
}

Por tanto, hallamos significativo "desnaturalizar" la mecánica de la mediación entre un cuerpo en escena y el objeto pantalla, como un aporte necesario para los procesos cognoscentes de interactuación. Pero la inquietud del término lastre persiste, pues, creemos que no es lo mismo interactuar escénicamente con una imagen analógica, reactiva y audiovisual que hacerlo con una imagen digital, informática e interactiva. ¿Cuál sería la estereotipia vincular entre cuerpo y pantalla que persiste en este pasaje de la tecnología predigital a digital?, dado que, tal como acota Nicolas Bourriaud (2013: 87), "la influencia de la tecnología sobre el arte que le es contemporáneo se ejerce dentro de los límites que ella misma establece entre lo real y lo imaginario". La pantalla y la cámara no son los mismos dispositivos dentro de la escena multimedia que dentro de una escena interactiva en la que la pantalla puede estar adosada al cuerpo del bailarín y la cámara ser el sensor de ese cuerpo. Cada escena está delimitada por sus recursos de producción, es decir, por las tecnologías del momento.

En la escena multimedia siempre hubo una relación intrínseca con la imagen, sobre todo con la imagen del video. La capacidad de manipular la imagen del cuerpo a través del propio cuerpo -que posibilitan los sistemas interactivos- desplaza el problema de la pantomima de la escena analógica que exige un proceso ordenado de montaje o de una puesta en escena previsible. Ese pasaje entre la acción y la 
capacidad de reproducir o producir del cuerpo evidencia un problema: ¿acabaremos cautivos de nuestros propios artificios?

Hannah Arendt (2009: 16) realiza una inquietante exhortación: la ciencia y la técnica nos convierten en "irreflexivas criaturas a merced de cualquier artefacto técnicamente posible" de construir. El problema coexistirá al adaptar de forma mimética los gestos homogeneizados al propio desarrollo científico-técnico. Si la adaptación a aquello que artificialmente construimos es la cultura que debe conducir nuestras vidas o a la inversa, entonces hay que tornar una cultura no adaptativa hacia una crítica.

En consecuencia, adquiere vigor el interrogante enunciado por Nicolas Bourriaud (2013: 5):

\begin{abstract}
¿De dónde provienen los malentendidos que rodean el arte de los años noventa sino de una ausencia de discurso teórico? La mayor parte de los críticos y filósofos se niega a pensar las prácticas contemporáneas en su totalidad, que permanecen entonces ilegibles, ya que no puede percibir su originalidad y su pertinencia si se las analiza a partir de problemas ya planteados o resueltos por generaciones precedentes. [...] Muchas veces solo se trata de hacer el inventario de las preocupaciones de ayer para lamentarse luego de no haber podido encontrar alguna solución. Y, sin embargo, el primer interrogante, en lo que concierne a estos nuevos enfoques, se refiere evidentemente a la forma material de la obra.
\end{abstract}

Transformar en fetiche los objetos materiales y, por ende, las correlaciones formales con él acarrea una generalización de las relaciones en todos los niveles de producción. Es a través del diálogo crítico entre conceptos de distintas prácticas y situaciones que las nuevas creaciones artísticas se aventuran, en ocasiones animando prejuicios con respecto a los instrumentos y lógicas de transición y coexistencia.

Retornamos a la materia y esquema de acción en este pasaje de lo predigital a lo digital dentro del FIVDBA para ejemplificar lo que estamos exponiendo; para ello, citamos a Silvina Szperling (2015: 7'):

\footnotetext{
El espectador no se enteraba de la interactividad que había, porque no había diferencia que lo hubiera programado en equis minuto en el VHS del año 97, que primero venía esta imagen y después esta otra; que el hecho de que los bailarines con sus movimientos disparaban tal o cual imagen, encima, era recomplicado de conseguir que suceda porque había muchos fallos.
}

¿Cuáles son esos gestos, ese esquema de acción, esos movimientos disparadores que no se diferencian unos de otros, dado que las propias imágenes son producto de un cálculo programático y no ya del prediseño gestual?

José Luis García Nava (2015:1) argumenta que "la inmensa mayoría de las obras artísticas basadas en el uso de sistemas interactivos audiovisuales presenta un 
comportamiento igual de literal". Reflexionamos, en principio, sobre este recorte de lo expresado por sobre el comportamiento igual de literal, incluidos el cuerpo, el performer, el bailarín, y vinculados transversalmente a las tecnologías de la imagen. Conforme esto, haremos referencia al concepto de fuerza innovadora de Philippe Dubois (2001: 10), quien, al integrarlo a la dimensión "maquinística" de los dispositivos, vivifica la problemática de la retórica de lo nuevo:

La técnica y la estética conformaban entonces en ellas [la fotografía, la cinematografía, el video y la imagen informática] un nudo plagado de ambigüedades y de confusión sabiamente mantenida [...]. Al fin de cuentas, en buena medida, esas últimas tecnologías de imagen no han hecho otra cosa que poner al día antiguas cuestiones de representación, reactualizando (en un sentido no siempre novedoso) viejas apuestas de figuración.

El desafío que los sistemas plantean al cuerpo va mucho más allá de la cuestión del comportamiento o de su sentido discursivo. Creemos que las tecnologías redefinen y ponen en crisis la impostergable realidad del cuerpo: su intrínseca materialidad.

Podríamos preguntarnos cómo se inscribe esa materialidad del cuerpo en un planteamiento escénico cada vez que nuevas propuestas lo convocan, lo recontextualizan, lo enmarcan, etcétera, y las respuestas eventuales a ese planteo no siempre son "novedosas". Es más, parecieran ser manifestaciones ingenuas, inexpertas, aun a veces a su pesar, con una disposición interpretativa y demostrativa asumida como voluntariosa. Philippe Dubois (2001: 11) se cuestiona al respecto:

\begin{abstract}
¿En qué reposa ese discurso de la innovación? Esencialmente en una retórica y en una ideología. La retórica de lo nuevo, presente y autoproclamada, está en todas partes [...], siempre la misma en casi dos siglos, produce un doble efecto reiterado: un efecto de enganche [...] y el efecto de profecía [...]. Esta retórica de lo nuevo es el vehículo de una doble ideología bien determinada: la ideología de la ruptura [...]. Y la ideología del progreso continuo. [...] Amnésico, el discurso de la novedad oculta completamente todo lo que pueda ser regresivo en términos de representación (ocultamiento de la estética en beneficio de lo tecnológico puro), o rechaza el carácter eminentemente tradicional de algunas preguntas, planteadas desde siempre...
\end{abstract}

Limitarnos a reflexionar sobre esa idea de innovación nos llevaría a pensar -sea cual sea por otra parte la disciplina artística- en términos de oposición, de ruptura. Si lo hacemos desde la danza, esto supone la existencia de una vieja danza -porque habría una nueva- y promueve el planteo de una cuestión generacional. Aceptar esta terminología implica tener que hablar, entonces, de una generación que ha transitado por la Danza Multimedia y otra que transita actualmente por una danza interactiva, 
generativa y en red. La misma suerte corre para los videastas con relación a lo que es hoy un programador de lenguaje informático.

Un bailarín o performer pasó de una reproducción cuasi reductiva del cuerpo -que inducía activando sistemas responsivos- a dialogar con sistemas interactivos. Pero la innovación en la danza o la performance no es necesariamente sincrónica con los avances informáticos en el mercado. La intención es clara, más que inventar, innovar, lo que interesa en estas mediaciones es experimentar, indagar, conocer. De hecho, no hay "técnicas de danza digital", para denominarlo de algún modo.

En consecuencia, el lugar desencantado al que se acude enunciando lo "interactivo", en verdad, administra lo responsivo como estrategia básica. Por lo cual retomamos el comentario de José Luis García Nava (2015: 3):

\begin{abstract}
... hasta hace muy poco tiempo, la experiencia típica con una obra audiovisual interactiva basada en movimiento se reducía a una modulación lineal de imágenes y sonidos que alguna vez, con aguda ironía, uno de los maestros en el equipo de trabajo de este diplomado describió como "me muevo y suena, me muevo más rápido y suena más alto".
\end{abstract}

Cabe destacar que para artistas como Rejane Cantoni y Leo Crescenti (2009: 8'45"), comprometidos con el desarrollo de estrategias para la experimentación y la implementación de instalaciones interactivas abiertas al público, existe una preocupación que prima ante cualquier propuesta de esta índole y radica en indagar "cómo elaborar dispositivos audio-táctil-visuales que posibiliten transformar aspectos del mundo físico, sígnico o mundos híbridos en información sensorial que cualquiera pueda entender"24.

$Y$ aquí surge otra concepción de la interactividad humano-sistema, y es la de la información sensorial que cualquiera pueda entender, para que cualquiera pueda participar, no solamente en el nivel lúdico-corporal, sino a través de una acción que logre ser entendida, de igual modo, como pensamiento y como herramienta de comunicación y afección.

Por tanto, más allá de exponer los discursos coyunturales que acompañan la novedad de cada sistema y sus medios, dejaremos expuesta la problemática del cuerpo, del estado de experiencia consciente, de su accionar lúdico, estético, exploratorio, hacia un acceso recíproco y sensorial de (y con) las tecnologías. Un acceso que llegará cada vez más lejos y, como vaticina Roy Ascott (2007: 49), "nos dará herramientas para rematerializar el arte".

\footnotetext{
24 Traducción propia: "Como elaborar dispositivos áudio-tátil-visuais que possibilitam transformar aspectos do mundo físico, signico e ou mundos híbridos en informação sensória que qualquer um possa entender".
} 


\section{Poniendo en imagen el cuerpo de los noventa}

Detengámonos en las imágenes del cuerpo en la década del noventa por un momento. Planteado el cuerpo desde la videodanza, podemos hacer extensivas algunas observaciones que, sobre el trabajo con la imagen electrónica, se han realizado, y de ahí, desplegar la complejidad de lo escénico que conlleva la Danza Multimedia. De esta forma, consideremos lo que José Ramón Pérez Ornia (1991: 106) sostiene sobre la imagen en el video experimental:

\footnotetext{
Cuando la imagen electrónica crea su propio campo visual se produce el tránsito de los cuerpos y de la coreografía desde el espacio físico del escenario al espacio imaginario de la imagen, ese espacio que solo existe en la cámara y en la edición o montaje. [...] El montaje crea el espacio y el tiempo de la imagen. El realizador se convierte en coreógrafo. Se encuentran y se funden dos artes visuales: la danza y la imagen electrónica. Ya no se trata de representar la danza, de reproducir la representación, sino de crear una coreografía electrónica, inexistente en el escenario pero que se basa en la fusión de danza e imagen.
}

Esta idea de crear una coreografía electrónica reaparece en el concepto de coreoeditar que se originó, en gran medida, a partir de la acción técnico-expresiva de editar y coreografiar a la vez. El procedimiento de editar en video aparece asociado al de coreografiar como un tipo de acción bisagra entre ambas dimensiones espaciotemporales, que, a pesar de ser diferentes, se vinculan al componer con el movimiento de un cuerpo que danza en la imagen digitalizada. Por lo tanto, se ralentiza o se acelera el movimiento del cuerpo grabado, y se trabaja en la edición sobre esa rítmica de la imagen.

Ambos territorios, el del cuerpo y el de la imagen, convergen como-procesos de gestación e incorporación uno en el otro. Pero es una danza que solo existe en virtud de la imagen electrónica. ¿Qué sucede cuando esa danza se extiende y comparte a la par la materialidad electrónica con la de carne y hueso?

Susana Tambutti (2008: 14) traza un itinerario progresivo de los modos en los que la danza artística se ha ido perfilando como campo autónomo; parte, justamente, de las formas de producción y recepción que se ejercieron sobre el arte de la danza y sitúa con este designio histórico- "la búsqueda de respuesta a la pregunta que podría traducirse como ¿cuáles son las posibilidades y límites representacionales de la danza?". La respuesta distingue tres momentos que convivieron, y que, incluso, conviven, en el amplio panorama de la actualidad: un primer momento se relacionaba 
con la teoría de la imitación y la representación de la belleza ideal; un segundo, con la teoría de la expresión; y, el tercero reconocía la forma como único contenido de la obra coreográfica.

Asimismo, Tambutti (2008: 16) sitúa el devenir en el marco del interrogante paradigmático de “¿es 'esto' danza?”, respecto de aquellas producciones a las que no se podía aplicar las nociones tradicionales que la historia sucesiva había acuñado, dada la contaminación con movimientos del cotidiano o el no movimiento, que causaron la desaparición del dato perceptivo más inmediato consistente en las destrezas corporales de los bailarines.

De esta manera, se torna insoslayable afirmar que toda esta trama de mutaciones producidas en la década del sesenta haya determinado un punto sin retorno para los modos de representación, el entrenamiento físico, los modos compositivos, los contenidos de las obras, su posicionamiento ideológico frente a lo institucional, la inserción en el mercado cultural -por ende, en el consumo de sus "productos"-, los géneros legitimados, las herramientas coreográficas, etcétera. Sumada la revolución tecnológica, y la mediatización, como afirma Susana Tambutti (2007: 87), "resulta evidente el impacto de estos factores en los imaginarios simbólicos del coreógrafo y en la transformación sustancial en los modos de representación".

A continuación, compartimos un párrafo en el que Vicky Olivares (Olivares-Isse Moyano, 2011:57) da cuenta de su investigación en el campo de la danza contemporánea argentina y la plasma en una interesante observación:

\footnotetext{
Del análisis de todas las características, observadas en muchos ejemplos de espectáculos presentados como danza, se ha observado que se busca "presentar" más que "representar". [...] En la escena contemporánea, aquellas escenas de las neovanguardias de los setenta, sin distinción entre mostración y representación que corrompían la historia de siglos, en la estética occidental, han vuelto a la vida. [...] En algunos de los ejemplos analizados, el descentramiento del cuerpo ha avanzado frente a la imagen virtual, hasta hacer de él algo casi imperceptible.
}

Esa metamorfosis del cuerpo en la plasticidad de la imagen lo separa de la función representadora de lo real. Al respecto, José Ramón Pérez Ornia (1991: 106) destaca que "cuando las imágenes se difuminan y se desprenden de la materia corpórea, entonces solo queda la coreografía del video".

Pero ¿qué sucede cuando las imágenes no logran desprenderse del cuerpo y este continúa allí tan presente en la escena? Si el peso, la gravedad, la presencia de un cuerpo no se extinguen en la fluidez ingrávida de lo proyectado, lo que queda es 
emplear la magia, los trucos, la alquimia, la fantasía. Cotejemos esta respuesta con los testimonios de lo empírico.

En una entrevista, Margarita Bali (1999: 24) comenta sobre su próxima producción en la que llevará al escenario una obra realizada en formato video: "Con la gente en vivo, más las que están en la pantalla, va a haber trucos visuales donde no sabes bien si estás viendo el real o el proyectado". Otra crónica de época realizada por María Rosa Petruccelli (2000: 49) la lleva a detallar un espectáculo en el que se trabajó, a través del uso de tecnología, el "fluctuante límite entre fantasía y realidad". Según el testimonio de la coreógrafa e intérprete:

\begin{abstract}
Quisiera lograr -dice Susana como conclusión- una alquimia, cuando pongo todas las escenas en una narración que va creando una lógica particular y abre un mundo personal. Y espero que el espectador también pueda abrir su propio mundo. Digo alquimia porque mi deseo es que los distintos lenguajes de la puesta en escena -movimiento, video, música- se fusionen y den una obra única, con un mensaje.
\end{abstract}

¿Real-imaginario: competir con diferentes niveles de verdad? ¿Ocultando el mecanismo o haciendo que la magia esté a la vista? La imagen electrónica suponía, para algunos, crear esa ilusión: "Pero la ilusión escénica, ¿no es algún tipo de verdad? Yo creo que sí", afirma Daniel Veronese (en Duran, 2005: 16).

Desde otra perspectiva de análisis, vamos a tomar como punto de partida la videoinstalación o videoambiente -básicamente monocanal y con proyección- sin olvidar que fue el prototipo videográfico -no en tanto contenido, sino como proyecto de acción- lo que permitió el desarrollo del formato de exhibición de la Danza Multimedia en los años noventa.

Apoyándonos en ciertos componentes y procesos de la videoinstalación -que se presentan como adecuados-, podremos interpretar cómo el bailarín entra en relación reactiva, on-off, con las instalaciones operativas (pantalla, proyector, escenario, luces, etc.) y con la tecnología del video analógico, no solo como "máquina de visión, sino también como andamiaje protésico del cuerpo". Tal como lo describe Ana Claudia García (2012: 240) cuando se refiere a los dos elementos básicos con los cuales trabaja una videoinstalación:

Uno de ellos es la imagen electrónica, sea esta de naturaleza analógica, digital o mixta. Trabajar con video significa trabajar con materia electrónica, aunque asumiendo, por sobre todas las cosas, que se trata de algo de consistencia casi inmaterial y que además se desarrolla antes en el tiempo que en el espacio. El otro elemento significante de las videoinstalaciones es el espacio real, es decir, el espacio tridimensional actual donde la obra se concreta. La 
videoinstalación se nos presenta, generalmente, como la puesta en relación de esa clase particular de imagen (la electrónica temporalizada) con un dispositivo de enunciación objetual -tridimensional-que excede a la imagen.

Este excederse -con un objeto tridimensional- a la imagen será para nosotros la posibilidad de resignificarlo a través de un cuerpo que entra en relación con un espacio virtual, centrífugo, y otro físico, centrípeto, que lleva al límite los niveles de inmersión con los cuales la danza resuelve dicha articulación. $Y$ esto es clave para la Danza Multimedia, siempre se actúa en mayor o menor medida en un ambiente inmersivo.

Considerando la distribución y el desplazamiento del cuerpo en ambos espacios, indicaremos que o bien podría ser una elección de la experiencia en la materiaespacio-tiempo centrífuga o centrípeta, o bien sería la interpretación de algo que se presume está representando. Por consiguiente, hay que articular el cuerpo con el significante de ambos espacios más otros significantes que se ponen en juego en la cadena asociativa tanto por la coreografía o la improvisación, como por lo visual abstracto o figurativo de lo proyectado. Presentamos un fragmento de la entrevista a Santiago González (2015: 17'30”), en el que explica su forma de trabajo con lo audiovisual en escena:

Yo todo el tiempo estoy pensando en las formas que hay ahí dentro de la pantalla y lo que no hay adentro si tiene una forma, si no es informe... porque también está el tema del fuera de campo [...] lo que está fuera del encuadre, que sigue existiendo a pesar de que está en un escenario, pero sigue existiendo ese fuera de campo que existe en la cinematografía. Digamos que es un estado híbrido, en el cual está lo centrífugo del cine con su fuera de campo y lo centrípeto de lo escénico con el teatro, esas dos cosas pueden construir dialécticas interesantes a la hora de pensar la estructura del trabajo.

No debemos olvidar que hay un aquí y un ahora en el proceso de expectación que involucra dos temporalidades sincrónicas pero de distinta naturaleza: una percepción del tiempo y espacio físico de la danza y otra del video. El fuera de campo de la imagen puede o no diegetizar ${ }^{25}$ o interferir en el campo escénico, tanto sea a través de la imagen o del sonido. Tenemos la imagen del cuerpo y la imagen proyectada simultáneamente en la escena y en el dispositivo video y un momento de colaboración, un acto de voluntad que supera los límites del registro coreográfico y de la narratividad cinematográfica que una y otro conllevan como legado histórico. Tal legado como enclave en la danza de las categorías de la belleza, de lo trascendental, de un lenguaje expresivo y emocional de una interioridad que nos hacía únicos.

\footnotetext{
25 Diegético y diégesis pertenecen a la ficción en cine, pero creemos oportuno incluirlo aquí puesto que "lo diegético no solo comprende lo representado en la pantalla, sino el universo sugerido del cual lo mostrado es solo parte".
} 
De este modo, los distintos posicionamientos respecto al quehacer coreográfico van modificándose. Según Susana Tambutti (2005):

En la danza de los 90, se corre el riesgo de volver a la antigua dicotomía mente-cuerpo, pero esta vez el cuerpo danzante podría transformarse en una imagen que puede alterarse a voluntad, reduciéndose a simple materia prima apta para la modificación óptico-iconográfica digital. La transformación del cuerpo danzante en una confluencia entre máquina corporal entrenada y ordenamiento óptico digital tiene su repercusión en algunos exponentes de la danza internacional post-2000.

Esta mutación del cuerpo fisiológico al tecnologizado, del predigital al digital, va modelando el cuerpo de los noventa que "no está menos mediatizado que la realidad que nos rodea. [...] El cuerpo es hoy día el lugar de 'creación' de la propia imagen, no más nuestros objetos", se sostendrá desde el programa de mano del propio FIVDBA (1996: 21). Este devenir matérico llevó a postular que la imagen no puede seguir estando "restringida al nivel de la apariencia de la superficie, sino que se debe extender hasta abarcar íntegramente el proceso a través del cual la información puede ser percibida por medio de la experiencia corporizada". La mirada puesta sobre la experiencia corporizada -respecto al trabajo corporal propioceptivo- fue permitiendo nuevas formas de experimentar el arte mediático y, con ello, también experimentar con las imágenes y el sonido.

Pero, evidentemente, la apariencia de la superficie es el efecto que rige el uso de la imagen en el espacio escénico $y$, cualquiera sea el sistema utilizado, normaliza toda puesta que no tome en cuenta estas problemáticas: "Las imágenes en la pantalla son, en este caso, como un decorado móvil aunque lo ubiquemos delante de la coreografía, vemos a los bailarines moverse detrás". Ampliando estas consideraciones que produce la pantalla como punto de conexión con la imagen, el cuerpo y el lugar de convivencia, prestemos atención a la siguiente acotación sobre un trabajo de Danza Multimedia, concerniente a la división de métodos y abordajes, tanto sea en la construcción de sentido al interior de las imágenes, de lo coreográfico así como de su puesta en escena. Santiago González (2015: 3') sostiene:

En el comienzo del trabajo con Danza Seca, ustedes [estaban] muy preocupadas en lo que implicaba el diseño de lo coreográfico y la cuestión que estaba muy presente y más que presente en ese momento porque estamos hablando de los inicios; y lo que nos tocaba a nosotros, en el tema de lo que estaba en la pantalla, era tratar de ir viendo ciertos ensayos, teníamos un ida y vuelta, casi casi una especie de ciclo, en el que se iba formando un proto-guión de imagen que iba a ser proyectada, [...] era obligación que tuviera una fuerte coordinación y relación formal que justificara su bi-representación: lo que estaba adelante y lo que estaba atrás. 
Innegablemente, las estructuras coreográficas tradicionales se vieron exigidas a agitar una nueva concepción escénica y metodológica, en la que la noción de indeterminación (con la improvisación como condición compositiva) comenzó a plantear cambios, incluso mayores. Esta obligación a una fuerte coordinación y relación formal entre los movimientos del bailarín y lo que sucedía en la pantalla hacía que cada elemento asumiera su parte figurativa y narrativa complementándose, contradiciéndose o replicándose.

Aquí es oportuno citar a Michel Chion (1993: 153) cuando individualiza las características del video que se alían con la danza:

\begin{abstract}
Se encuentran, sin embargo, en el arte del video, preocupaciones generales, corrientes. Por ejemplo, su frecuente unión con la danza. ¿Por qué razón? Porque si la danza juega con la velocidad del movimiento hasta poder detenerlo en una postura, el video permite también jugar con las velocidades de desplazamiento y, en el límite, fijar la imagen, sin que esta imagen, por ello, cambie de naturaleza.
\end{abstract}

Reconociendo como natural esta asociación de las cualidades compartidas del "movimiento" en la práctica artística de numerosos videastas que filman la danza, se establece su entidad encarnada en la materia del dispositivo. La especificidad del videoarte "oscila así de un extremo al otro, entre una imagen totalmente fijada de antemano y otra que resulta de sucesos en tiempo real, entre la unicidad o la multiplicidad de pantallas", señala Michel Chion (1993: 152). Asimismo, la volubilidad y ligereza del video le son propias, y -reuniéndolo con la palabra hablada como gestoel texto oído y la imagen podían ir a la misma velocidad, pero esa rapidez de la palabra dicha y escuchada hace perder la calidad de la imagen ponderando sus cambios de ritmos, los cortes, la edición.

Se trata de pensar el movimiento desde la imagen y el dispositivo. En esta disquisición se aduce que si esto fuese acaso la razón por la cual, en video, no se sabe muchas veces qué hacer con el sonido, pues "las vibraciones, la fluidez, la movilidad perpetuaya estarían en la imagen. [...] La imagen es, de todas maneras, el punto de partida. [...] A vuestras pantallas, pues, pero no olvidéis los altavoces", replicará Michel Chion (1993: 154). La imagen de video, es decir, su materialidad, ya tiene cualidades propias de movimiento; por consiguiente, según Philippe Dubois (2001: 66), será "necesario interrogarse sobre lo que explica esta diferencia histórica de tratamiento entre las dos dimensiones del audio/visual".

Entre el conjunto de figuras que componen la categoría del tratamiento de imagen entre cine y video, de acuerdo con Dubois (2001: 68), vamos a destacar aquellas que 
a la par compondrían las figuras entre la danza y el video en escena, a saber: los movimientos aéreos de aparatos y los efectos del espacio flotante, donde se expone que en el "cine no solamente se muestra el movimiento, sino que es el movimiento mismo. Esa será su identidad".

Ahora bien, ¿de qué tipo es ese movimiento "propiamente" cinematográfico?". Si repasamos los movimientos técnicos listaríamos básicamente el travelling, la panorámica, el zoom, y sus variaciones; pero si lo pensamos desde la mirada, la corporeidad del punto de vista sigue siendo esencial, y es ahí donde la subjetividad encarnada en la cámara crea marca registrada o se desvanece en las destrezas del dispositivo técnico. Un dispositivo como la cámara es vehículo para la movilidad absoluta de la percepción, mediadora, prótesis del cuerpo que la vehiculiza. Pero qué decir de la identidad compartida del cine, del video con la danza, dado que es, exactamente, el propio movimiento lo que las integra.

Alejandro Ricagno (1996: 10), crítico especializado en lenguajes audiovisuales, a propósito de los materiales presentados en el II FIVDBA, aclara:

\begin{abstract}
La imagen video es la imagen danzante por excelencia, la que nunca está quieta, la que no se completa jamás. Su encuentro con la forma de la danza ya se incluye en su propio origen, es su esencia. Como sucede con la definición misma de la video-creación o del video-arte, la video-danza ya encuentra en este territorio las dificultades para establecer sus límites. Por eso, dentro mismo de este II Festival Internacional de Videodanza encontramos propuestas heterogéneas. ¿Pertenecen a la misma categoría estética una obra hecha en video para video que otra realizada en fílmico? La respuesta estaría no tanto en el material sino en la forma creativa con que el material es trabajado.
\end{abstract}

La danza es movimiento, y su contrapartida es el no movimiento, esto la define también como su principio identitario. Ahora, la cuestión es pensar consecuentemente cómo ambos campos de desarrollo artístico, partiendo de un mismo postulado, acarrean distintos inconvenientes técnicos, estéticos, formales, de sentido, entre otros, a la hora de colaborar en un mismo espacio.

Citaremos como ejemplo un comentario que revela cómo se apreciaba la incipiente producción local en videodanza, en este caso, por parte de la curadora de videoarte y jurado del II FIVDBA Graciela Taquini: "mover una gasa frente a una cámara y moverse a la vez no era hacer videodanza. Esto es algo que encontré muchísimo: cámaras estáticas, conceptos teatrales en el sentido que la pantalla sería la cuarta pared, cosas horribles, antiguas" (en Falcoff, 1996: 16). Desde la perspectiva de lo audiovisual, siempre resultó difícil definir la videodanza, pero lo que sí está claro es 
que se asocia directamente con el video y no con el cine. $Y$ esto no es menor por varias razones, algunas de las cuales vienen siendo expuestas.

Volviendo a Taquini (en Falcoff, 1996: 16), transcribamos otra afirmación suya: "Yo creo que lo que existe es el video, el video como arte que fusiona otras artes. Es bárbaro que exista el encuentro entre danza y video; pero en realidad el producto final es un video". ¿Qué sucede, por lo tanto, con la Danza Multimedia si seguimos este razonamiento? Porque, dentro del marco de análisis propuesto, se trabajaba mayormente con proyección de un video, pero, del mismo modo, con los procedimientos del espacio escénico de la danza.

Retornemos a las figuras propuestas por Philippe Dubois (2001: 73). Entonces vemos que la relación de autonomía entre cuerpos y decorados analiza ciertas formas de vinculación desplegadas por el cine y el video entre el cuerpo del actor y el decorado donde este actúa. Se hace presente el concepto de incrustación ${ }^{26}$, puesto que:

... cuerpos y decorados pueden provenir de dos fuentes diferentes que solo han sido combinadas en la imagen final. Una y otra funcionan entonces como dos realidades independientes armonizadas en el mismo cuadro. $\mathrm{Y}$ este principio de autonomía de los cuerpos en relación con los decorados autoriza toda suerte de puestas en imagen inéditas.

Evidentemente, esta técnica alteró el espacio escénico con la posibilidad de introducir decorados ficticios, simultáneos, múltiples y electrónicos. Esa separación entre el cuerpo y el decorado, por causa del chroma, rompe con la frontalidad de la representación y del punto de vista. Esa imagen final -ese producto final- en la Danza Multimedia la totalizaría, en primera instancia, el propio bailarín con la pantalla, y, en una segunda instancia, el espectador, encastrando así pantalla y escena.

Al igual que la idea de desfase del cuerpo con relación al decorado trabajado por la estética del burlesco en los años veinte, en la que la aparente hostilidad que desplegaba la imagen al cuerpo invasor era parte de la odisea para poder ser integrado a ella, según Dubois (2001: 76), "el decorado es la imagen. El cuerpo es lo extranjero. Uno se desliza sobre el otro hasta la incorporación".

Un último ejemplo son las películas coetáneas realizadas en estudio con una escenografía que es una imagen proyectada y el lugar por donde los actores deambulan: "personajes y escenarios ya no se pertenecen, el secreto de la ósmosis se ha perdido, el divorcio entre el cuerpo del actor y la materia de la imagen está casi anunciado: es un sálvese quien pueda", sostiene Dubois (2001: 76). Evidentemente,

${ }^{26}$ Se refiere específicamente al procedimiento técnico "Chroma Key". Se trata de una de las técnicas más utilizadas en la actualidad en cine, video, televisión y fotografía que consiste en grabar un personaje u objetos sobre un fondo verde o azul, para que en posproducción se reemplace el área de color por otro fondo fijo o en movimiento. 
no siempre funciona, ni aun siendo producido desde la industria del cine. Esta correlación que estamos exponiendo puede facilitarnos pistas teóricas por las que deslizarnos entre cuerpos e imágenes en pantalla.

En principio, lo interesante que encontramos en esta figura específica es la posibilidad de revertir la idea de que la pantalla circunscribe lo que se puede realizar dentro y fuera de ella, por este principio de autonomía de los cuerpos con relación al escenario. Continuando con las figuras propuestas por Philippe Dubois (2001: 77), observamos la toma multicámara, es decir, filmar una escena a partir de varias cámaras simultáneas (algo propio de la televisión), que establece finalmente "una posición de centralización. Un efecto de control del dispositivo. [...] Verlo todo, preverlo todo, saberlo todo". Ideal de la videodanza respecto a poder registrar y mostrar todas las facetas de un cuerpo en movimiento, aquellos lugares inaccesibles a la mirada, un panóptico móvil del cuerpo que danza.

Por esa misma senda citamos la sucesiva figura: el ralentí y cambios que permiten "una nueva dramaturgia del cuerpo humano. [...] El video hace, de esa manera, funcionar la disminución de velocidad de las imágenes, como acelerador del pensamiento", igualmente, el mismo juego de la multiplicidad de puntos de vista puede facilitarse desde la escena a la pantalla, como precisará Dubois (2001: 82).

Otra figura sumamente movilizante en esta suerte de sustitución conceptual propuesta desde el análisis que Dubois realiza sobre los formatos audiovisuales es el trabajo de puesta en escena del lenguaje desde la técnica televisiva. Se definen allí las múltiples formas del directo, cuya lógica escenográfica de la superficie propone una "frontalidad sostenida, en la cual la mirada (y la escucha) del espectador recae sobre la imagen, se golpea en ella y vuelve", sostendrá Philippe Dubois (2001: 83).

Esto nos hace agudizar la revisión de nuestras primeras experiencias en Danza Multimedia local, ya que fueron signadas por la frontalidad de la sala, de la pantalla y del cuerpo, lejos de favorecer una transición fluida entre los pasajes fílmicos y los genuinamente escénicos.

Cada una de estas figuras del cine y del video que hemos intentado llevar a nuestro campo de estudio moviliza correspondencias teóricas entre la imagen, el cuerpo y el sonido. Por supuesto, no olvidaremos el sonido, tal como lo reclamaba Michel Chion (pero no olvidéis los altavoces); y citaremos también a Margarita Bali, una de las principales promotoras de la Danza Multimedia "en la que bailarines en vivo interactúan con imágenes pregrabadas, una tendencia en la que también se destaca Susana Szperling”. En este sentido, Margarita Bali (1999: 25) va a resaltar los recursos que despliegan las tecnologías analógicas en uso con relación a lo sonoro en la danza: 
La sonorización es también un nuevo campo para explorar al permitir al coreógrafo nutrirse de códigos distintos que provienen del video y del cine, que pueden aportar una nueva manera de percibir y resolver el aspecto sonoro musical de una obra coreográfica. Estos códigos llevan a cuestionar los parámetros comúnmente aceptados del uso de la "pieza musical" para la coreografía escénica e introducen el concepto del sonido realista, o sea, la impresión de realidad del sonido que da credibilidad a la imagen, el valor del silencio, la sugestión generada por la elipsis de sonido o de imagen, el sonido fuera de imagen, la palabra, etcétera.

Asimismo, la tecnología no es un instrumento, sino que amplía las posibilidades de las realizaciones creativas que generan cambios en la apariencia espacio temporal del cuerpo, el espacio y el sonido en movimiento. Esto, a su vez, produce permutaciones estructurales en las conductas perceptivas tanto del bailarín como del espectador y constituye nuevas matrices de vinculación entre cuerpo, entorno y dispositivo. Susana Tambutti (2005: 3) lo describe del siguiente modo:

... para los coreógrafos de los 80 , todavía no existía internet, la relación entre danza y tecnología era impensable en la forma en que hoy la conocemos. La sola aparición del video, con la posibilidad del registro, de ver imágenes repetidamente, controlarlas, pensar el movimiento desde la imagen, la inclusión del video en el hecho escénico de la danza, el uso de los programas computarizados para componer secuencias de movimiento, supuso una pequeña revolución que naturalmente debemos incorporar a la hora de pensar la coreografía.

El nacimiento local de la Danza Multimedia fue analógico, electrónico y objetual. Se utilizaba casete VHS, proyector de tres tubos y videocasetera para su reproducción. Sobre el uso de esta tecnología, Rodrigo Alonso (2016: 0'23") enfatizaba: "hubo toda una tecnología que al contrario, digamos, llevó las cosas para atrás" y, en consecuencia, "hubo que reinventar todo de nuevo". Plantearse las continuidades existentes entre los nuevos medios y los viejos medios es hacerlo desde las interacciones constantes entre lo que se considera "repetición" y lo que se considera "innovación".

Lev Manovich (2005: 51), quien utiliza la palabra "lenguaje" llanamente para referirse a técnicas, estrategias o convenciones, se pregunta: “¿De qué manera se valen de los viejos lenguajes y formas culturales? ¿Hasta qué punto rompen con ellos?”. Desde el testimonio de Alonso (2016: 6'12"), iremos dando respuesta a este interrogante, pero pensándolo desde la Danza Multimedia: 
En las obras más viejas el bailarín y el cuerpo del bailarín seguían a la propuesta audiovisual y hoy en día hay una tendencia a que la propuesta audiovisual sea generada por el bailarín. [...] Había que coordinar todos los movimientos del bailarín con lo que pasaba en la pantalla, y la pantalla dictaminaba lo que el bailarín podía o no podía hacer, o lo que debía o no debía hacer en la escena. Hoy en día hay una tendencia fuerte a que esa escena no exista si el bailarín no la provoca.

En los años ochenta -y en los noventa de un modo más extensivo en nuestro país-, se impulsó una nueva generación de artistas especializados en video y nuevos medios, en la cual, el artista ya no obraba detrás de la cámara o como intérprete, sino como productor o editor. La emancipación del video analógico en el abismo digital ha expandido otros recursos y procedimientos. Pero el suceso introducido por el video en las artes escénicas va más allá de la innovación del dispositivo escenográfico, e involucra, el desdoblamiento de las escenas en tiempo real con la multiplicación en el espacio y con la participación del espectador de manera más activa. Hay una multiplicación de la mirada y de la audición en una coordinación simultánea que invocan cada vez a una sintaxis de la conciencia entre todos los interesados y los comprometidos.

Nos resulta importante el aporte de Douglas Rosenberg (2010: 63), cuando destaca un punto muy sensible para la discusión como es posicionarse frente a la crítica según el campo artístico del que se proviene:

La forma en que la danza en un film o en una pantalla tiende a ser discutida y criticada depende del origen de quien lo hace. Si la danza y su diáspora son privilegiadas por el que habla/ve, el lenguaje de la danza será el valor por el que se criticará el trabajo. Si el público privilegia la película o el video es probable que el lenguaje de la imagen en movimiento lleve al discurso lejos de los problemas de la kinestesia u observaciones coreográficas ${ }^{27}$.

Ahora bien, toda investigación que parte de los actores de un campo, a través, por ejemplo, de entrevistas, pretende, como cualquier otro método, la comprensión del pasado y del presente a partir de la utilización de testimonios y evocaciones, considerando que son aspectos parciales y subjetivos de lo que se narra y se recuerda de lo experimentado, sin perder de vista las publicaciones de época, como críticas o gacetillas de espectáculos. Ambos proporcionan un buen material para analizar e interpretar, pero falta conceptualizar sobre Danza Multimedia.

\footnotetext{
27 Traducción de Victoria Conte: "The way in which dance on film or screendance tends to be discussed and critiqued thus depends on the point of origin of the speaker. If dance and its diaspora are privileged by the speaker/viewer, the language of dance will be the currency by which the work is critiqued. If the speaker/viewer privileges film or video (and its diaspora), it is likely that the language of the moving image will lead the discourse away from issues of kinesthetic and/or choreographic observations".
} 
Asimismo, los autores y las teorías -que aportan a la conformación de este campo híbrido del arte de la danza y el video, directa o indirectamente- corresponden ser revisados. Puesto que la inercia voluntarista de entender y comunicar puede llevarnos a aprobar -incautamente- un discurso cristalizado, separado de los orígenes históricos, de la red de problemáticas, de las necesidades y de los usos en lo que halla su sentido, en la esfera del saber sabio ${ }^{28}$, para convertirse en un saber descontextualizado, despersonalizado.

O bien, como sostiene Eduardo Grüner (2002: 1): "Una de las funciones del arte, por suerte no la única, ni la determinante, ha sido la construcción de la memoria histórica y un espejo de reconocimiento para los sujetos, miembros de las sociedades en las cuales esa producción artística se inscribe". En consecuencia, transcribimos un fragmento de Pierre Lévy (2007: 7) para quien se hace imposible separar lo humano del entorno material y artificial que promueve:

Se toma a los rodeos intelectuales como si fueran actores porque hay grupos muy reales que se organizan alrededor de estos recortes verbales (ministerios, disciplinas científicas, departamentos de universidad, laboratorios de investigación) o porque ciertas fuerzas tienen interés en hacer creer que tal problema es "puramente técnico", o "puramente cultural" o más aún "puramente económico". Las relaciones verdaderas no se dan pues entre "la" tecnología (que sería del orden de la causa) y "la" cultura (del orden de los efectos), sino entre una multitud de actores humanos que inventan, producen, utilizan e interpretan diversamente unas técnicas.

Es importante profundizar ahora en ese origen disciplinar desde el cual se observa esta práctica híbrida llamada Danza Multimedia. Solo como ejercicio comparativo, presentaremos tres comentarios provenientes de una bailarina, videasta y cineasta; una teórica y pionera de las artes electrónicas; y, un estudioso del teatro.

28 Se toma de forma sintetizada el concepto de transposición didáctica planteado por el matemático francés Yves Chevallard, quien sostiene que un determinado elemento del saber sabio debe sufrir adaptaciones y transformaciones para convertirse en objeto para enseñar. Estos procesos de adaptación y transformación deben ser sometidos a una estricta vigilancia, denominada "vigilancia epistemológica". 


\section{Festival Internacional de Videodanza Buenos Aires (FIVDBA): orígenes de la Danza Multimedia en la escena local}

Hay un punto de inicio consensuado para el cruce entre la danza y el video en nuestro país: el Primer Taller de Videodanza para Coreógrafos, organizado por la Secretaría de Cultura de la Nación y dictado por Jorge Coscia en la sede de la Biblioteca Nacional, en 1993; taller que dio origen, a su vez, al FIVDBA. En aquel entonces participó la Coordinadora del Área Danza de la Secretaría de Cultura Nación, Mariela Queraltó, y figuras destacadas como Silvina Szperling, Margarita Bali, Melanie Alfie y Paula de Luque.

Alejandro Ricagno (1996: 10), en una nota sobre el 2. ${ }^{\circ}$ FIVDBA, hacía referencia al propósito del Festival de Buenos Aires: "confrontar tendencias para enriquecer mutuamente las búsquedas de un lenguaje que está en formación". Y hablamos de la videodanza, ya que el proceso de la Danza Multimedia corre un destino paralelo, pero no por ello equivalente.

Estamos en los comienzos de la Danza Multimedia y en la Argentina. Tanto en el teatro como en la danza, estas prácticas que conjugan proyecciones y escenas no fueron tan difundidas como lo fue la videodanza, o, en el mejor de los casos, "la videodanza incluye diversas manifestaciones tales como los espectáculos de Danza Multimedia -danza en escena junto con proyecciones audiovisuales-", según lo señala Mariel Leibovich (2012: 252) en el texto Tecnopoéticas argentinas. Archivo blando de arte y tecnología.

Paula de Luque (2014: 4'26") siempre estuvo asociada a la videodanza, como parte del Ballet Contemporáneo del Teatro General San Martín (con la dirección de Oscar Araiz) y en Danza Multimedia con la dirección de Margarita Bali. De hecho, su primer largo cinematográfico está estrechamente vinculado con esa práctica. Su trayectoria puede resumirse del siguiente modo:

\footnotetext{
El grupo de danza del film El exilio de Gardel era Nucleodanza. Yo que venía con el rodete, las puntas y la pierna en la oreja dije: -Ah, ¡no! ¡Eso es lo que yo quiero hacer! Finalmente, entré a Nucelodanza que era una compañía a la que era muy difícil entrar. $Y$ me pasé diez años viajando y bailando muchísimo. Pero en esos viajes descubro un género llamado videodanza que yo no sabía que existía. De pronto fue como un sueño revelador porque mezclaba mis dos pasiones: la situación dramática del movimiento de los cuerpos enmarcada en un espacio audiovisual. Cuando vuelvo a la Argentina, de esa gira por Europa, descubro que hay un antecedente filmado en super 8 donde una bellísima y jovencísima Ana Kamien bailaba descompuesta casi cuadro a cuadro ${ }^{29}$.
}

${ }^{29}$ El grupo Nucleodanza fue creado y dirigido por Margarita Bali y Susana Tambutti, entre los años 1975 y 2000. "Ana Kamien realizó, junto al cineasta Marcelo Epstein, la primera obra que puede considerarse, en 
Dicha presentación encuadra, sobre todo, el descubrimiento de la videodanza y la incidencia que este hecho tuvo en el desarrollo de su actividad como directora de cine. Reparemos en su comentario:

Muchos años después cuando yo me empiezo a dedicar al cine, me doy cuenta de todo lo que me sirve aquel primer curso y lo agradecida que estaba por eso, también cómo incorporé el tema de la danza en mi carrera como cineasta, porque la verdad es que hay algo del tema del espacio y de la relación del cuerpo con el espacio y el cuerpo en el cuadro que no es lo mismo si has pasado por la danza que si no has pasado [por ella].

Graciela Taquini, la "tía del videoarte en la Argentina" ${ }^{30}$, madrina ${ }^{31}$ del FIVDBA, fue jurado en varias ocasiones, y manifiesta al respecto:

Confieso que aun viniendo del campo de la historia del arte, del cine y el video en estos años he tenido un duro aprendizaje para tratar de entender este fenómeno acotado del videodanza tan difícil de definir ante la falta de modelos y las limitadas posibilidades de frecuentación. Este año, el material en competencia ha sido un tanto desilusionante. Lo cierto es que si lo bueno brilla, relucieron muy pocas cosas, incluso las piezas venidas del exterior y garantizadas por becas de nombres rimbombantes ${ }^{32}$.

Graciela Taquini (en Falcoff, 1996: 17), desde su formación, reconoce: "A mí lo que me interesa es el video, y entonces, cuando el video se junta con la danza y se expresa [...] de una manera interesante, los efectos propios del video, de la edición... eso me gusta".

$Y$ aquí podríamos mencionar -sin extendernos, pero con la intención de brindar diferentes entradas a esta hibridación entre danza y video- el tema de la programación y la curaduría. La metodología de selección y circulación de materiales en los festivales de videodanza se ejerce mayormente a través de la programación. Es decir, los videos ingresan por convocatoria abierta o por selección, para luego ser

\footnotetext{
todo su sentido, 'danza para la cámara'. Efectivamente, Ana Kamien (1970) reemplaza el escenario teatral por un espacio físico neutro creado por los movimientos de la cámara y del cuerpo de la bailarina, donde cada movimiento cobra sentido en función de su posición respecto del objetivo cinematográfico, y el montaje crea su propia coreografía a partir del material visual" [en línea]. Dirección URL: <https://vimeo.com/122801024>. Véase detalle del film mencionado en: <https://youtu.be/1u2wYoLEVu0>, 5'05".

30 Rodrigo Alonso coloca como dedicatoria en su libro Elogio de la low-tech, Historia y Estética de las artes electrónicas en América Latina: "A Graciela Taquini, la tía del video arte en Argentina".

31 "Por eso fue invitada Graciela Taquini, que es madrina del festival [Festival Internacional de VideodanzaBA].

32 Artículo de Graciela Taquini para el Festival Internacional de Videodanza de Buenos Aires. HEROICA video de Gabriela Golder y Silvina Cafici 10'. Primer premio Festival Internacional de Video Danza de Buenos Aires 1999 [en línea]. Dirección URL: <http://www.gabrielagolder.com/heroica2.htm>.
} 
organizados por temáticas o rubros propuestos para su exhibición. Diferente es la curaduría pues crea un sentido de identidad, formatos de visión y parámetros discursivos, abriendo así la posibilidad a un diálogo crítico, activo, una retroalimentación con el público. En videodanza, lo usual es la programación, no la curaduría.

Douglas Rosenberg (2010: 142) considera, acerca del tema, las siguientes preguntas: “¿Qué responsabilidad tienen programadores y directores de festivales de danza para la pantalla respecto de la definición del campo?". Diferenciarse no constituye un género, y "quizá el proyecto de la curaduría es, a la larga, inventar finalmente la danza para la pantalla" (Rosenberg, 2010: 147).

Entendemos en este punto, dado lo dicho hasta aquí, que la Danza Multimedia no ha sido favorecida ni por los espacios en los festivales o fuera de ellos, ni por la crítica, ni por la curaduría. Recordemos lo que Silvina Szperling (2014: 3'39") revelaba acerca de la participación de la Danza Multimedia en el FIVDBA: "Los que se animaban, básicamente, entraban, eran muy pocas propuestas y entraban". En consecuencia, la continuidad y conformación del campo local se forjó y se forja a través de la constitución de equipos interdisciplinarios de investigación artística emergente o perteneciente a las universidades, de unos pocos artistas que lo sustentaron y le fueron dando filiación. Pero, aún hoy, no se reconoce ampliamente lo significativo que fue ese pasaje de lo producido entre lo predigital y lo digital para la conformación de un campo de conocimiento y práctica de la danza y la tecnología escénica.

Continuando con la observación de este entrecruzamiento del lenguaje escénico con elementos provenientes de otros soportes como la plástica, el cine y los recursos multimedia, vemos que esta mixtura no siempre se integra de manera armónica, muy por el contrario, por momentos, se torna conflictiva.

Existe una tradición de la danza en el cine, películas de danza o de historias relatadas a través de la danza, pero el video, con todas sus condiciones, propone la experimentación y la ruptura en esta conjunción de materialidades. Jean-Claude Gallotta (en Pérez Ornia, 1991: 104), que viene de la danza nouvelle francesa, ve con gran interés que el "video ha[ya] transformado las imágenes y la coreografía", y hace extensiva su declaración cuando involucra al teatro: "Entiendo que la gente de teatro haya tenido miedo de esos efectos del video, pero al coreógrafo le da un poder inimaginable".

Dentro de las artes dramáticas, si bien no ha sido asiduo el vínculo con la tecnología, es claro que, durante el pasado y el presente, siempre hubo una fluctuante predisposición a experimentar. A partir de la inclusión de proyecciones en la puesta en escena fueron muchas las obras que articularon teatro con imagen audiovisual. 
Retornemos a argumentos de época, pues recrear la cosmovisión y los fundamentos conducentes a la conformación de las artes escénicas con tecnología ubica el desarrollo de los elementos técnicos con relación a las necesidades de la representación que le son coetáneas; incluso, no solo a las "necesidades" sino, igualmente, a las "imposiciones" que, a la par, parecen implantarse. Releamos las consideraciones de Patrice Pavis (2000: 1) sobre el avasallamiento de la puesta en escena:

\begin{abstract}
Para los medios de comunicación, la puesta en escena desaparece "en provecho" de un funcionalismo tecnológico en el que la máquina y las computadoras son celosos servidores. [...] La tecnología y el pensamiento tecnicista cuestionan sin cesar la noción de autor y de autoridad de la puesta en escena. En el espectáculo, no todo tiene la misma función estética: en ocasiones lo único que cuenta es el funcionamiento técnico, pero la mayor parte del tiempo, la puesta en escena y su condición estética deciden cuál va a ser el sentido. Principios estéticos diferenciados atraviesan la línea divisoria entre el hombre y la máquina, lo animado y lo inanimado, la voz y el micrófono, el actor y la marioneta. Pero esta línea divisoria cambia y se impugnan las viejas dicotomías; virtudes de ficción diferentes se aplican a la imagen o al actor vivo, a la presencia o a la repetición; densidades diferentes caracterizan todos los elementos de la puesta en escena.
\end{abstract}

Tal como lo cuestiona Pierre Lévy (2007: 5): “¿Vienen las técnicas de otro planeta, el mundo de las máquinas, frías, sin emoción, extraño a todo significado y a todo valor humano, como una cierta tradición de pensamiento tiende a sugerirlo?". No, al parecer. Y si bien el propio Patrice Pavis (2000: 1) justifica sus reacciones de rechazo como "un poco excesivas que se pueden calificar de nostálgicas, tradicionalistas, conservadoras, incluso reaccionarias, y que, en efecto, quizás habría que matizar", como teórico y veedor de obras escénicas -así como otros teóricos y veedores locales- ha cristalizado criterios, concepciones y prejuicios respecto a ideas y representaciones materiales y artificiales de lo escénico y lo multimedial. Además, la tecnología siempre ha sido indispensable en la danza y en el teatro. La tarea del director de escena consiste, esencialmente, en asociar diferentes funciones técnicas para montar un espectáculo; en ese sentido, si bien no tiene motivo para profesar de técnico, debe disponer de algunas nociones. Además, las artes escénicas han desplegado -desde hace muchos años, hasta siglos- la faena tecnológica para movilizar estructuras, así como también, para la creación de espectáculos audiovisuales.

Habiendo transitado cierto derrotero analítico volvemos a preguntarnos: ¿en qué radica lo que diferencia a un lenguaje, disciplina, práctica artística de otra si no es tanto el tipo de experiencia emergente que construye? 
Las dificultades en el cruce de lo escénico con los lenguajes audiovisuales deben considerarse a partir de las diferencias entre los modos de presentación. Si lo planteamos desde la escena en Danza Multimedia regresamos a la puesta en escena y a la pantalla. Entender cómo pueden mancomunarse -dada la pluralidad de códigos en juego- es lo que permitirá experimentar hasta dónde puede fusionarse lo específico; y aquí, habría que examinar las fórmulas, los clichés (el lastre) que se adoptan para ello. Es decir, aquellos resultados, obras, espectáculos aprobados por la crítica especializada, la prensa, etcétera, lo que "funciona" en la apropiación de las dinámicas corporales como detonadoras de las formas visuales y sonoras, son los modelos para reproducir. Esta argumentación subraya el hecho de que una importante cantidad de obras artísticas basadas en el uso de sistemas de proyección escénica audiovisual presentan -tal como lo afirma José Luis García Nava (2015: 3)-: "un comportamiento igual de literal".

Si como se viene argumentando, el meollo de la cuestión podría reposar en los modos de presentación escénicos, cae de maduro que se refiere a qué sistema se utiliza. Ese sistema, como ya se ha deliberado, predica determinados comportamientos, maneras de posibilitar el diálogo en escena. No olvidemos que nos estamos refiriendo al video de sistema analógico ${ }^{33}$ operado coordinadamente con videoartistas ${ }^{34}$ no con programadores ${ }^{35}$.

$\mathrm{Si}$, por ejemplo, se trabajaba con aparatos en escena, había una serie de complicaciones que había que resolver a medida que iban surgiendo, lo cual generaba grandes trastornos a la manera de producir de ese momento. Rodrigo Alonso (2016: 8'20") testimonia los modos de producción y presentación de la Danza Multimedia en el FIVDBA: "si pausabas un video se apagaba solo si no recibía señal [...]. Había que inventar alguna cosa escénica para ir a prenderlo de nuevo", y eso evidenciaba el incidente técnico en la continuidad dramatúrgica.

Para que las proyecciones videográficas pudieran convertirse en un componente escénico más, hubo que transformar valores significativos y expresivos concretos dentro del proyecto coreográfico. Susana Tambutti (2005) analiza estas

\footnotetext{
${ }^{33}$ Las imágenes que grabamos con una cámara de video analógica se transforman en una señal eléctrica, la base de este sistema de grabación de video analógico es la acción que esta señal eléctrica opera sobre un campo magnético (la cinta de video) y de forma reversible, la base del sistema de reproducción del video es que todo campo magnético genera, a su vez, una señal eléctrica.

34 El videoartista utiliza la narrativa audiovisual del video para producir. Generalmente, se dedica y es responsable de toda la cadena de producción de un video, la realización de las funciones de productor, camarógrafo, fotógrafo, editor de video, etcétera. Su trabajo es multidisciplinario.

35 Se refiere al programador ingeniero de software, al científico de la computación, al desarrollador de software y al analista. Estas personas tienen o pueden compartir diferentes habilidades y propósitos. En líneas generales, un programador diseña, a través de un código fuente, diferentes herramientas informáticas, tales como programas, sistemas o páginas web.
} 
transformaciones desde el cuerpo como un "modelo físico para la conversión ópticoiconográfica" y lo expone de la siguiente manera:

\begin{abstract}
El intérprete "tradicional" que reivindicaba la esencia de la identidad física en el proceso de creación, pretendía establecer una relación de complicidad con el público: el cuerpo-acción del artista buscaba un acercamiento directo al cuerpomente del observador a través de la unión espaciotemporal. Su cuerpo era un cuerpo-puente entre obra y receptor. Los recursos tecnológicos empleados en estas obras transforman el cuerpo en una superficie lisa y operativa.
\end{abstract}

Esta afectación del concepto mismo de "danza" hubo de ser transitada, puesto que, siendo coreógrafo o bailarín/coreógrafo, había que ocuparse no solo del diseño y distribución espacial de los movimientos, sino también de codirigir o guionizar con el videoartista la inclusión de las proyecciones junto con las demandas técnicas. En este punto, es interesante ejemplificar la complicidad con el público, este acercamiento que establecía la tradición coreográfica y que los recursos tecnológicos fueron transformando.

En la entrevista realizada, Gabriel Gendin (2016: 8'03") describe lo que se planteaba con el público ya atravesado por la puesta tecnológica predigital: "Era un poco jugar en el falso tiempo real que, me parece, tiene un doble logro, porque estábamos como entre burlándonos y problematizando ese tiempo real. [...] Ana lo filmaba, rebobinaba y tiraba el play". Así es que el público era registrado en reserva, en equis momento, y más adelante se proyectaba en la pantalla creando una situación ambigua de no saber si se estaba siendo grabado en ese instante, tratando de identificarse pasaba del otro lado de la butaca e ingresaba al universo virtual, audiovisual, y a ser recíprocamente observado. Por lo tanto, los recursos tecnológicos empleados, que eran predigitales, y el low-tech transforman el cuerpo del espectador en una superficie lisa y operativa dentro de un falso tiempo real ${ }^{36}$.

\footnotetext{
36 Un Sistema en Tiempo Real (STR) es aquel sistema digital que interactúa activamente con un entorno con dinámica conocida en relación con sus entradas, salidas y restricciones temporales. Un STR interactúa con el mundo físico y emite respuestas correctas responsivas. El concepto de STR no queda restringido a los sistemas digitales o de cómputo; pero si lo aplicamos a un sistema de registro y posterior proyección, no estaríamos dentro de esa previsibilidad temporal, por ello, la denominación de falso hace como si lo fuera.
} 


\section{Hacia una tecnoescena}

María F. Pinta (2012: 200) describe el evento Tecnoescena ${ }^{37}$ como "la relación de las artes escénicas (teatro, danza, performance, entre otras) con la tecnología” y agrega que "debe ser considerado a la luz de la multiplicidad de lenguajes y tecnologías sonoras, visuales y audiovisuales que conviven en toda representación escénica", que encarna las evoluciones desde las tensiones y vinculaciones entre arte y tecnología en su época.

Por consiguiente, ¿de qué forma se relacionan la coreografía y el video en las prácticas escénicas? Es sugestivo proponer el análisis de diversas condiciones y procesos para el trabajo y la producción de la Danza Multimedia, que pondrán a circular distintas implicaciones sobre el cuerpo, el movimiento, los soportes, la tecnología, las metodologías compositivas, etcétera; razones que comenzaron a vislumbrarse del 96 al 2000, y, a partir de allí, ir vislumbrando respuestas a esta pregunta inicial.

La experimentación en danza ha pasado por diferentes niveles reflexivos, se han cuestionado las distintas categorizaciones y márgenes disciplinares, espaciales, conceptuales, corporales y kinéticos. Merce Cunningham (en Pérez Ornia, 1991: 102), impulsor de esta actuación conjunta del cuerpo y los dispositivos, explica cómo la presencia de la cámara afecta al espacio, al cuerpo y al tiempo: "Uno imagina la danza en un escenario, pero cuando hay una cámara, se está delante de ella y es muy diferente".

Merce Cunningham y el compositor John Cage han colaborado profusamente en la creación de ambientes, de climas, puesto que "la danza es movimiento, y el movimiento no necesita excusas" 38 . Ambos han ejecutado performances en diversos ámbitos que exceden la frontalidad de las salas teatrales y encuentran su lugar en los espacios públicos. Es una concepción de escenario abierto donde bailarines, músicos y videastas colaboran con los dispositivos audiovisuales de manera creativa, es decir, tomando en cuenta la presencia y el funcionamiento de los aparatos emplazados. Un formato de laboratorio que propone reconfigurar un espacio o una institución o la reciprocidad de un grupo de individuos y sus aparatos. Habría que indicar también que estas propuestas de escena-laboratorio han coexistido y han sido veladas por la

\footnotetext{
${ }^{37}$ En nuestro país, encontramos antecedentes del neologismo de la mano de Javier Acuña, creador y director de los proyectos Alternativa Teatral (espacio autónomo e independiente que aporta las herramientas disponibles en nuestra realidad actual) [en línea]. Dirección URL: $<$ www.alternativateatral.com>) y Tecnoescena (encuentro Tecnoescena 2005 Centro Cultural Borges y 2008 Centro Cultural. Recoleta. Se trata de un proyecto de sensibilización que se propone como espacio para explorar alternativas escénicas en el actual contexto multimediático).

38 Entrevista a John Cage [en línea]. Dirección URL:

<http://elpais.com/diario/1985/07/25/cultura/491090405_850215.html>.
} 
magnificencia del espectáculo, por sus organizaciones políticas y culturales fuertemente consolidadas.

Esto explicaría, en parte, la dificultad que ha tenido la experimentación escénica compartida con el público (limitándolo a la danza, porque si pensamos en la performance, el laboratorio abierto al público ha sido, básicamente, su espacio vital) para desarrollarse y consolidarse, desde aquellas propuestas de los setenta pasando por los noventa y, por qué no plantearlo, hasta nuestros días. De este modo, en la Danza Multimedia local los procesos se realizan, sustancialmente, desde un enfoque más narrativo, desviándose en cierta manera de la neta experimentación con la tecnología y sus dispositivos.

Se trata de concebir un laboratorio abierto al público no solo para la producción de contenidos, sino para la conformación de comunidades artísticas, en las que los intercambios impliquen aportes prácticos y conceptuales. En tal sentido, recurrimos nuevamente a Eduardo Grüner (2002: 4), quien enfatiza sobre las consecuencias de la "separación entre sujeto y objeto. La transformación del arte en espectáculo, y del sujeto en espectador de ese espectáculo", como un invento característico de la modernidad, el estar el público encerrado entre cuatro paredes de un edificio para contemplar o escuchar. "Este es el símbolo más evidente de la separación entre el arte y la vida cotidiana", concluirá el autor al respecto.

Regresando a Buenos Aires, proponemos revisar algunas ideas que los coreógrafos tienen sobre el amplio universo significativo y expresivo que se deriva de la práctica entre el imaginario escénico y el audiovisual.

En una entrevista realizada a Margarita Bali (1999: 21), le preguntan: “¿Cuál es la diferencia entre crear una coreografía para ser mostrada en un escenario y otra para video? Es otro lenguaje, son otros objetivos". Evidentemente, la mixtura entre el uso de las estrategias audiovisuales y las artes escénicas reinventa la organización de los formatos de producción, puesta en escena y representación. Continuando con la entrevista, cuando se le consulta a Bali sobre si había una motivación para narrar una historia, responde: "Parte de dos ideas que van en paralelo y se juntan. Una que tiene que ver con el uso del espacio y otra con la fisicalidad que te aporta el espacio".

Si hay algo que la tecnología aportó a la danza es la posibilidad de encarnar y darle un nuevo sentido a la noción del espacio y del tiempo, haciendo visible una multiplicidad de lugares que no son visibles, un estallido fractal, brindando una amplia autonomía para la construcción de estructuras coreográficas impensables. Asimismo, lo esbozará Gabriela Prado (2007: 45), quien fue convocada a reflexionar sobre su trabajo como coreógrafa, y escogió una experiencia en la que cruzó danza y cine. Así relata el vínculo con el espacio CeTC (Centro de Experimentación del Teatro Colón): 
Desde la composición coreográfica, las escenas se armaron a modo de tablero de doble entrada donde los bailarines eran piezas de un juego de ocultamiento; el video completaba las visiones que el ojo del espectador no alcanzaba. Aumentando el espacio con proyecciones del CeTC dentro del CeTC, como el reflejo de los espejos entre sí, multiplicando infinitamente el propio espacio. Alternancia y simultaneidad de sucesos coreográficos, más escenas de video.

Por qué, como coreógrafa, estoy atrapada por la videodanza como género de creación, se pregunta Margarita Bali (1999: 25). Para quien implicaba un reto el hecho de que el desplazamiento de los cuerpos pueda replicarse con las posibilidades que brinda el movimiento de la cámara, el movimiento generado por los cortes, los cambios en la duración y velocidad a través de la edición. "Es agregarle dos opciones más al movimiento convencionalmente manejado en el espacio teatral", yuxtaponiéndole la no linealidad espacio-temporal no solo al movimiento sino, de igual forma, a una "nueva manera de relatar lo coreográfico". Considerar lo audiovisual y lo coreográfico como pensamiento a partir del cual se percibe y distingue el movimiento como substancia del tiempo.

Al respecto de su trabajo, Douglas Rosenberg (en Ricagno, 1996: 12) sostendrá: "es un interés por las cualidades temporales, por los cambios que experimenta una obra y su espectador en el tiempo. Mi obra en videodanza no es sino otra cosa que el arte de mirar".

Para Rodrigo Alonso (2016: 1'), la pantalla crea otro espacio, "construye una nueva idea del espacio", y el cuerpo se vincula con la pantalla, por ende, con esa "espacialidad que se abre dentro de ese plano". Igualmente la coreografía -apuntará"tiene que ver con el cuerpo, pero tiene que ver también con el espacio, con una construcción del espacio". Sobre este tema de la danza relacionada con una pantalla concluye que "esta problemática con relación a la pantalla y al cuerpo involucra el espacio. Un espacio que no responde a una lógica espacial", que conlleva a pensar el espacio desde el exterior y el interior, el adentro y el afuera.

El filósofo Gaston Bachelard (1997: 256) repara en lo que es la dialéctica "de lo fuera y de lo dentro", planteándolos como contextos opuestos. Sin embargo, debemos comprender que existe un momento o punto de relación entre ambos lugares (dentro y fuera). Por lo tanto, para nosotros será representado por medio de la "superficie límite" de la pantalla, ya que esta permite una conexión sensorial e intelectual, con el inmenso universo que genera interna y externamente. ¿Será esa la faena de los cuerpos en la Danza Multimedia: deambular entre esos espacios dando cuenta de su imposibilidad fantasmal que solo propicia confusiones vastas? Adentro el espacio y la forma se reducen, afuera forma y espacio son diferentes, siempre el espacio supera a 
la forma. Para Bachelard (1997: 269), ese circuito entre el adentro y el afuera se prolonga: "Pero iqué largo es el circuito! Para vivirlo en la realidad de las imágenes parece preciso ser sin cesar contemporáneo de una ósmosis entre el espacio íntimo y el espacio indeterminado".

Proponemos un ejemplo para aplicar los conceptos filosóficos citados a través del comentario de Santiago González (2015: 18'):

\begin{abstract}
De qué manera la pantalla en su profundización, en su encuadre, pero al mismo tiempo lo que está fuera del encuadre, sigue existiendo a pesar de que está en un escenario, porque sigue existiendo ese fuera de campo que existe en la cinematografía. Digamos que es un estado híbrido, en el cual está lo centrífugo del cine con su fuera de campo y lo centrípeto de lo escénico con el teatro, esas dos cosas pueden construir dialécticas interesantes a la hora de pensar la estructura del trabajo.
\end{abstract}

Por una parte, y grosso modo, hay quienes han tratado de reproducir los efectos y representaciones propios de los espacios creados en el video, encaminando lo escénico hacia una irremediable comparación y, de cuya diferencia, solo le aporta derivaciones un tanto superficiales. Alejandro Ricagno (1996: 14) escribirá respecto de las obras realizadas por estas tierras: "No digo que las obras fueran un mero registro coreográfico, pero con contadas excepciones, no encontraban el punto de inflexión entre la danza y su reelaboración a través de la imagen electrónica". Por otra, se podría enfatizar en cómo ciertos artistas, conscientes de no intentar imitar la impresión de virtuosismo que el video facilita, han articulado sus dispositivos con el tiempo y el espacio propios de los cuerpos en la escena, y han fundado así una estética acorde a sus recursos.

Esta paulatina transición que se reinicia en el año 1996, en la que los artistas se vuelcan hacia la producción enlazada entre la danza y las artes audiovisuales, genera un nuevo pensamiento sobre el quehacer coreográfico. Detengámonos en el 2004, en el Centro de Experimentación del Teatro Colón (CeTC), y atendamos a la reflexión de Gabriela Prado (2007: 42):

Si tuviera que reconstruir el camino empírico diría: me proponen un ámbito: cine/danza. Aparece una idea: primeras experiencias fílmicas, 1880. Se desprenden conceptos sobre el uso del tiempo. Desprendo la idea directriz para orientar a la videasta. Desprendo la idea directriz para mi investigación kinética. Idea de insomnio: nociones de acumulación, distintos pulsos en distintas partes del cuerpo. Idea de los movimientos que habitan dentro de dos gestos. [...] los videos creados por la artista plástica traen rasgos que remiten a ese tiempo del insomnio. [...] Así el espacio escénico se convirtió en ícono de un espacio psíquico, onírico. 
Las imágenes de video en la escena actúan no solo como ambientaciones con sus implicaciones psíquicas sino, además, como ambientaciones arquitectónicas y narrativas, que pueden recombinarse. Silvina Szperling (2013: 3) dirá sobre la obra multimedia de Margarita Bali del año 1998: "Sin el recurso de la imagen proyectada, el espectador nunca podría tener la sensación de estar en medio de Plaza de Mayo, al menos en forma tan inmediata".

Lo que habitualmente se entiende por Danza Multimedia es, en un plano, una sucesión de eventos coreográficos encarnados por cuerpos que danzan y, en otro plano, una sucesión de imágenes y sonidos aportados por lo audiovisual. Estos últimos tienden a situar el plano de la escena en otra parte distinta a la que están. Los niveles de coincidencia o de enmascaramiento de ambas partes son considerados como atributos expresivos. En ese sentido, los coreógrafos también hablan de "transposición escénica" de "relectura" de "equivalencias" de "diálogo poético" y de "recursos" cuando se refieren a congeniar material audiovisual con el espacio físico del escenario. Por lo general, trabajan en equipo con el realizador de video.

Al respecto, resulta una contribución citar nuevamente a Santiago González (2015: 9'08') y observar con qué criterios un video creador aporta a la puesta en conjunto, pues para él: "había que ir juntando los sentidos". Al mismo tiempo, comenzaremos a introducir el tema del pasaje de lo predigital a lo digital, que desarrollaremos a continuación:

La diferencia que nosotros planteamos era la de asumir una narrativa paralela que debíamos interconectar, con lo que sucedía dentro del escenario; hoy por hoy queda en un segundo plano; o por lo menos, la puedo dejar en un segundo plano. Porque la conexión directa de la interface que se le da al bailarín para que experimente ese espacio, para que tenga nuevas reglas, está mediada.

Nos preguntamos entonces, ¿el video en escena no nos mediaba? Sí, de forma reactiva, era la única posibilidad dentro del contexto que ya ha sido descripto. Para deslindar qué es lo reactivo citaremos al artista electrónico Rafael Lozano-Hemmer (1994: 1):

El arte reactivo, en su definición más amplia, es aquel que cambia con la presencia y actividad del público. En el arte reactivo, el espectador no espera a que la obra se desdoble ante sus ojos, sino al contrario, es la obra la que aguarda a que el espectador haga algo, para entonces reaccionar de una forma u otra. Los ordenadores facilitan esta vocación de vigilancia: las obras ven, escuchan y sienten al público, y se comportan según el mensaje o sensación que cada artista desee programar. 
El bailarín, la coreografía o la improvisación se ajustaban a la linealidad del video para producir lo que Santiago González señalaba como una narrativa paralela que debíamos interconectar. ¿Cómo hacer reaccionar al video en la escena? Si nos remitimos a los comienzos -como explicamos- había que coreografiar siguiendo las imágenes y su temporalidad, o esas imágenes eran un fondo escenográfico que participaba o complementaba, o -en el mejor de los casos- un operador disparaba desde una casetera el momento combinado -tal vez cierto gesto o instante de disminución lumínica, etcétera-, en definitiva, lo que marcará el pie de entrada del proceso audiovisual.

Rodrigo Alonso (2016: 7'53') relata cómo se organizaba el trabajo en la Danza Multimedia: "Agarrabas un papel, te imaginabas cómo iba a ser [...] era todo como en papel". Gabriela Prado (2007: 37) refuerza lo dicho: "No tenemos un guión que nos ampare [...]. La cabeza de danza resuelve". Estamos lejos aún de que los dispositivos escuchen y sientan el accionar o la simple presencia del cuerpo.

\section{De lo predigital a lo digital. Algunas conclusiones}

El querer presentar un desenlace fehaciente sobre los fenómenos culturales contemporáneos resulta, sin lugar a dudas, todo un desafío; e intentar tratarlos en su máxima expresión ya excede el tema de nuestra tesis. Por ende, nos centraremos en destacar determinados puntos de vista en los que se da relevancia a los procesos artísticos como parte constituyente e inseparable del relato social. Aparece, entonces, la necesidad de repensar la diversidad de los intercambios, lo que trae aparejado y que, indiscutiblemente, nos sitúa en una revisión de la autonomía de los campos disciplinares, que es clave para la neutralización o la frustración del propósito de proseguir las interrelaciones respetando su autonomía. $Y$ este desenlace para las prácticas artísticas híbridas es medular. Las tensiones en el momento de "crear" un proceso artístico conjunto son parte inevitable de los procedimientos y formatos de acción de las prácticas transdisciplinarias.

De acuerdo con la hipótesis que postula el filósofo Vilém Flusser (1994: 189), en la que expone que el "desciframiento" del gesto es lo que nos permite ver el modo en que nos hallamos en el mundo, abordaremos el gesto corporal, en el período predigital al digital, como potencial informador. A su vez, Jaime Del Val (2009: 133) se manifiesta sobre la estandarización de lo gestual: "Las interfaces producen formas de pensamiento del cuerpo", y afirma a continuación que lo que consta es normalizar formas de relación en el "pensamiento mismo, entendido como el pensamiento 
encarnado de una conciencia corporal". En ese sentido pero no por ello concordando, pongamos en cuestión lo que este filósofo plantea en las conclusiones y consecuencias de su hipótesis:

\begin{abstract}
Una de las conclusiones de esta hipótesis es que las modificaciones, que pueden observarse en nuestros gestos, hacen "legibles" unos cambios existenciales que vivimos al tiempo presente. Otra consecuencia es que afloran de continuo gestos antes no observados, que proporcionan una clave para el desciframiento de una forma nueva de existencia. El gesto por el que se maneja el video representa ya en parte el cambio de un gesto tradicional.
\end{abstract}

Seguimos paralelamente lo que expresa Del Val (2009: 134) -quien se autodefine como "disidente de los disidentes"- cuando propone indagar acerca del cuerpo como "cartografía e instrumento del poder y su relación con tecnologías de la representación, como la cámara" que, al colocarla dirigida al cuerpo, enfocando partes minúsculas de la piel, consigue disolver en la proyección la "centralidad cámarapantalla-escenario y la mirada-escucha". Lo expresado en la cita se acentúa, justamente, por la problemática que acarrea el gesto respecto al hábito o ¿al habitus?

En busca de alternativas conceptuales favorables, la noción de habitus nos permitiría ampliar la analogía cuerpo-objeto al tener en cuenta el entorno que las personas comparten, en nuestro caso, el campo artístico. Tal como lo describía en una entrevista Pierre Bourdieu (en Ssociólogos, 2013: 7) -para quien el habitus se aprende mediante el cuerpo, se in-corpora mediante un proceso de familiarización práctica-, el campo es el lugar de relaciones y de disputas proclives a transformarlo y, por lo tanto, es "el lugar de un cambio permanente; y no de una suerte de autodesarrollo inmanente de la estructura".

Interpretándolo diríamos que las tensiones en el interior del campo del arte y de la tecnología, por ende, de un campo híbrido, están siempre subdeterminadas y tienden a funcionar en una doble lógica. Tienen implicaciones estratégicas en virtud de la paridad de las producciones que se establecen entre tal y tal configuración de comunicación, y tal y tal modalidad de producción e interacción dentro del espacio constituido tomado en su conjunto.

En ese sentido, la práctica es resultado de un habitus que es, a su vez, consecuencia de la incorporación de tendencias, una retroalimentación inscripta en el presente, en estado de "potencialidad objetiva" para la transición. El habitus temporaliza pasado y futuro en el propio acto del presente. Bourdieu (en Ssociólogos, 2013: 11) expone esas combinatorias de tiempo y espacio de la siguiente manera: 
La relación entre el habitus y el campo es, en primer lugar, una relación de condicionamiento: el campo estructura el habitus, que es el producto de la incorporación de la necesidad inmanente de ese campo o de un conjunto de campos más o menos concordantes - pudiendo estar las discordancias al principio expresadas bajo la forma de habitus divididos, hasta destrozados-. Pero es también una relación de conocimiento o de construcción cognitiva: el habitus contribuye a constituir el campo como mundo significativo, dotado de sentido y de valor, en el cual vale la pena invertir su energía.

Por consiguiente, hay que intervenir, hacer detonar lo acostumbrado, el lastre. Grosso modo, diríamos que todo se dirime desde una forma de estar en permanente devenir, de ensayo en ensayo en los cruces de la danza y la tecnología. Retomando a Flusser, a sabiendas de que la observación del gesto transformador no se efectuaría sobre un objeto, aparato o dispositivo puntual, sino que dicha observación se determinaría dentro de un campo que constituye un espacio potencialmente abierto al juego de disputas y subversiones, cuyos límites son dinámicos, observaremos cuál sería ese gesto de la electrónica en el sonido y en video para la Danza Multimedia. En principio, es un gesto combinado, transdiciplinar, dado que para Vilém Flusser (1994: 194): "Se tratará de gestos, que ya no perseguirán el producir una obra, cuyo sujeto sería el ejecutante, sino de gestos que intentan alcanzar un acontecimiento" compartido agregamos-.

Sin embargo, es relevante tensarlo a hoy día para registrar qué queda en el medio, es decir, en palabras de Nicolas Bourriaud (2013: 57), "ya no existe la primacía del proceso de trabajo sobre los modos de materialización de ese trabajo [...]. Al contrario, los objetos son parte integrante del lenguaje" y asevera a continuación: "Esta distinción arbitraria entre el gesto y las formas producidas es puesta en tela de juicio", dado que lo que prevalece son las "relaciones sociales que regulan los encuentros humanos", en el espacio y el tiempo, conformando en un punto, “¿la relación hacia otra relación?”. Hasta aquí, queda al descubierto la cuestión entre la autonomía o la imposición solapada de regularidades que coaccionan las disciplinas artísticas, y en medio, recorriendo estos extremos, aparecen todas las exploraciones y realizaciones interdisciplinares. Lo que se extracta nos deja una caja negra conceptual. Se trata de la metáfora de la caja negra (como concepción del aparato "cámara" y su contenido mayormente indescifrable) de Flusser (1990: 28): "La cámara hace lo que el fotógrafo quiere que haga, aunque el fotógrafo no sabe lo que sucede en el interior de la caja negra".

Cuando la pretensión es identificar con relativa precisión los procesos específicos que vinculan causalmente las propiedades objetivas del entorno, los comportamientos y las prácticas que atienden a los gestos, nos faltaría identificar el procedimiento causal 
subyacente. Y, en nuestro caso, ¿cuáles serían las razones para identificarlo?: Saber si la danza, o lo que hasta hoy reconocemos como "danza", ha creado gestos propios en el diálogo como "artistas" con la caja negra (tanto sea con la cámara, el sampler o con la computadora).

Por ende, estaríamos en condiciones de aseverar que hemos producido un gesto transgresivo ${ }^{39}$, un saber sobre los aparatos como tales, pero no en primera instancia, sobre los conocimientos que orientarán la construcción que le da forma a esos aparatos. Hemos generado un lenguaje particular con las máquinas desde la dinámica del propio movimiento, aunque no así la decodificación de su mutación abstracta, de los conceptos de la formalización científica que posibilita el funcionamiento de las máquinas de imagen: tales como la fotografía, el cinematógrafo, la televisión, el video y la imagen informática: "Cada una de estas 'máquinas de imagen' encarnan una tecnología y se presentan como una intervención de cierto modo radical en relación con las precedentes" ${ }^{40}$, según Philippe Dubois (2004: 33). Entonces, por el momento, nos quedaría saber: ¿cuál sería ese gesto transgresor que en el universo audiovisual interviene y genera una dislocación transdisciplinar? Intentemos dar respuesta a través de dos ejemplos.

Jean-Luc Godard (1980: 138), que experimenta con la técnica desde el cine al video y del video al digital, manifestaba su pensamiento a través de videoensayos sobre el cuerpo de la palabra, la imagen/sonido y sobre el tiempo corporeizado, a saber:

Lo interesante es, por ejemplo, el momento en que Nanuk levanta el arpón y espera... es la espera. En efecto, la mirada, hay una mirada de Nanuk sobre la espera, que está muy ligada a la espera. Pero ni siquiera me he dado cuenta de que [lo que] yo buscaba era precisamente esta mirada sobre el gesto, y el gesto mismo, el hecho de la espera, y entonces se va a atrapar algo, en lugar de atrapar un pez, se va atrapar una mano, y esa mano -siguiendo lo que haga- va a satisfacer también nuestra hambre.

Procuraremos hilvanar el sentido de "permanecer en un sitio hasta que [alguien o algo] llegue o hasta que [algo] suceda". La espera es una temporalidad inminentemente humana. La mirada a través del encuadre atrapa el gesto corporal suspendido de la espera. En tal sentido, Robert Bresson (1977: 67) sostiene: "Tu película no está del todo hecha. La hace paulatinamente la mirada. Imágenes y sonidos en situación de espera y de reserva". Aquí hay cierta idea de acecho, de algo que permanece

\footnotetext{
${ }^{39}$ Esta idea de gesto transgresivo fue tomada del texto de Fortanet Fernández (2010), Foucault y Rorty: presente, resistencia y deserción: "El gesto transgresivo no es un gatillo nihilista; es un gesto genealógico que remonta las aguas de la racionalidad para situarse en el lugar no del origen, sino de la invención. Y allí, justamente, se nos aparece la decisión ontológica por medio de la cual se ha constituido un valor, un concepto, un saber".

40 Traducción propia de: “Cada uma destas 'máquinas de imagem' encarna uma tecnologia e se apresenta como uma intervenção de certo modo radical em relação às precedentes”.
} 
agazapado y que condice con la cita de Godard. La cámara es el instrumento de la movilidad real, el ojo instrumental que liberará un tiempo y un espacio de lo fílmico y de lo existente.

Ahora, de acuerdo con Philippe Dubois (2001: 69), "el movimiento representado (de un cuerpo, de un objeto), tal como lo vemos en la pantalla, no existe efectivamente en ninguna imagen real". La imagen de video es un proceso, no existe en el espacio, sino que tiene existencia temporal. Y aún más, el desarrollo de la técnica transformó los aparatos haciéndolos cada vez más independientes del cuerpo físico de la persona que lo operaba.

Tal como explica Dubois (2001: 73), el proceso de las experiencias gestuales del video:

\begin{abstract}
El ojo ya no es el órgano operatorio del movimiento; ahora es el dedo, el que aprieta las teclas, el que hace que la imagen sea digital. Para hacer una imagen electrónica, no tanto hace falta saber ver, ejercer una competencia visual, cuanto saber escribir a máquina. El teclado se impone a la cámara. Estamos en la era del telecomando. Y es la mano la que "ve" antes, capta, hace nacer la imagen. El ojo, por su parte, eventualmente controla. Por otra parte, filmar no es observar, medir distancias, buscar los mejores acercamientos. Es tocar, palpar, andar a tientas, infiltrar, tomar, acariciar, rechazar. [...] ese "ojo" en la punta de los dedos.
\end{abstract}

Para ampliar esta síntesis de cómo el cuerpo de las imágenes y los sonidos mutaron, citaremos a Jorge La Ferla (2009: 63), quien traza un mapa analítico sobre las prácticas de realización entre el cine y la computadora con sus diferentes recorridos, incluidas las instalaciones y espacios inmersivos. Este autor hace hincapié en que "no hay que perder de vista que, históricamente, las computadoras no fueron creadas ni pensadas como máquinas audiovisuales" y mucho menos -completamos- como partenaires. Pero mediante la digitalización de los medios, el cuerpo tornó en interfaz física, la visión tornó en háptica, y la audición tornó en performance sensoriales.

Veamos, con este segundo ejemplo, cuál es el recorrido del gesto de la mano ahora en la digitalización, según Santiago González (2015: 7’40”):

La imagen que yo traía de la mano y el polvo atmosférico. Yo creo que lo que está pasando ahora es que esa ley de choques de partículas, ese fluido dinámico, esa cuestión óptica del rayo de luz que da sobre los granos y todo lo demás, en todo caso es lo que está haciendo la máquina. $Y$ eso es lo que da y añade al movimiento de tu mano. Al rayo ese podes agregarle láseres y se transforma de otra manera. Lo que es más bien en un sentido se transforma en multilineal. Uno puede pensar y jugar, y básicamente no es distinto, porque hay ciertas leyes que fijan el movimiento de esas partículas. Yo me embelesaba cuando veía que, en realidad, adivinaba los vórtices. 
Existe una relación de estos relatos sobre los gestos de las manos como microportadores de significado, que son interpretaciones aledañas de la información transmitida por los gestos vinculados a algún sistema tecnológico. Esos gestos nos hablan de fenómenos que involucran el tiempo y la física de los elementos. A un tiempo como dimensión física con la que medimos la duración o separación de acontecimientos; un período que transcurre entre un estado $X$ y el instante en el que $X$ registra una variación perceptible para un observador: Nanuk esperando cazar el pez con el gesto del arpón suspendido, Godard esperando atrapar esa mano con el encuadre, "y esa mano va a satisfacer también nuestra hambre" de observar el mundo y sumergirnos en él como en un océano de imágenes -añadimos-.

Parafraseamos a La Ferla (2008: 13) cuando enuncia que "el objetivo de pensar el audiovisual, en las artes escénicas y puntualmente en la danza local", "en momentos de la desaparición de los soportes tradicionales analógicos, llevó a revisar la historia de los dispositivos tecnológicos en las diversas prácticas mediáticas”.

La revisión también se hace extensiva al audio y a sus prácticas mediáticas, puesto que es innegable que ha recibido con mayor intensidad la conversión de las innovaciones tecnológicas. Consideramos que el pasaje de lo predigital a lo digital fue más fluido desde el procesamiento del sonido, el desarrollo en la producción multimedia y el trabajo colaborativo entre músicos, bailarines y coreógrafos. Obviamente, hacer música involucra algún equipo o tecnología especialmente diseñada, es decir, la música invariablemente se ha elaborado y transmitido mediante diferentes tecnologías según el contexto. Para nuestro análisis, nos focalizaremos en el pasaje de la música electrónica a la digital en interacción con el pasaje entre la danza escénica a la danza performática.

La música electrónica desde finales de los años noventa, al igual que el video, se popularizó a partir de la disponibilidad y accesibilidad del consumo tecnológico. El semiólogo y escritor Umberto Eco (1968: 287) promulgó su interés por la "música de máquina" y por una nueva figura de músico, quien debe poseer conocimientos de matemáticas, de física, y dominar los aparatos electrónicos. Se trata de un músicoingeniero predispuesto a lograr una graduación de sonidos hasta sus ínfimos matices y timbres.

Este autor (1968: 288) refiere, igualmente, a la cultura musical reciente a pesar de no ser un experto en el tema, y sienta las bases de un paradigma que identifica, hoy en día, toda la dinámica musical contemporánea. Aquí lo extractamos: "La llegada de una 'música de máquina' no plantea tanto nuevos problemas filosóficos y estéticos, cuanto 
una serie de problemas sociológicos, psicológicos y críticos, diferentes para la 'música reproducida' y la 'música producida por medio de máquinas'”.

Por una parte, citamos a Umberto Eco, pues, nos consta hacia dónde dirige su razonamiento -atravesado por su experiencia de vida respecto al fenómeno artístico $^{41}$ - por el que alega que, prácticamente todas las formas de hacer música (arte) dependen de algún equipo o tecnología diseñados a partir de una necesidad. Así, establece argumentos para quienes sostienen que la electrónica priva a la música de humanidad, y pasa a estar dominada por la máquina; presenta un enfoque inverso, puesto que la aparición de la electrónica en la música organiza nuevas condiciones sin por ello desplazar las anteriores, sino por el contrario, sumándose.

Por otra, Eco (1968: 296) contribuye, de este modo, a consolidar las facultades consecuentes de lo que hoy se denomina performer interactivo, y su impronta con sistemas de captación en tiempo real, al argumentar que "en el plano más específicamente artístico, la música electrónica elimina el dualismo entre ejecutante e intérprete". Es decir, desde de la consumación de los medios electroacústicos, ese lugar categórico de la instancia interpretativa dejó de ser imprescindible y tanto el radio de acción como las posibilidades de abordaje se han expandido. En tiempos preliminares, las limitantes tecnológicas condicionaron la probabilidad de operar el sonido en tiempo real. Ahora, esas limitaciones -a favor del desarrollo de los medios electroacústicos y mucho más de los medios digitales- se han esfumado, y es una opción del artista combinar sistemas analógicos o digitales.

Retomando el argumento comparativo -de este dualismo eliminado entre ejecutante e intérpretes en la música- lo hacemos extensivo a la danza identificando el dualismo bailarín intérprete y performer interactivo. Un performer interactivo (conjunción de los términos performance e interactividad) establece la conexión entre la disposición del cuerpo y la herramienta digital a través de una metáfora de programación ${ }^{42}$ (conceptualizaciones que retomaremos en el próximo capítulo de esta tesis). No obstante, estos cambios se corresponden con la digitalización masiva, aspecto innegable en cuanto observamos que lo que se produce actualmente pasa por la computadora y se afianza en los componentes de la informática.

\footnotetext{
${ }^{41}$ A finales de los cincuenta, Umberto Eco trabajaba en la RAI de Milán, como coordinador de programas culturales. Dos pisos más arriba de su despacho estaba el estudio de fonología musical (phonos: sonido, logo: estudio) dirigido por Luciano Berio “... Era un continuo silbar de ondas cuadradas y sonidos blancos...". Pasaban por allí Maderma, Boulez, Poussier, Stockhausen, y realizaban experimentos musicales que despertaban su curiosidad al punto de realizar en colaboración un experimento sonoro, una transmisión radiofónica de cuarenta minutos sobre la lectura del Ulises, de Joyce.

42 Tengamos en cuenta que el lenguaje de programación demanda el uso de una sintaxis muy inflexible. El ambiente de trabajo colaborativo entre arte y tecnología debe favorecer el proceso creativo y no imposibilitarlo. Es esencial modificar entonces el modo de pensar acerca de los programas y, en consecuencia, de las performances híbridas, utilizando una metáfora que tome elementos del mundo real para construir simulaciones algorítmicas.
} 
El video, la imagen audiovisual, el sonido electroacústico, el cuerpo, etcétera, todos han pasado al dominio de lo digital. Por esta razón, estudiaremos cómo se dio ese trayecto. A partir del análisis propuesto indagaremos en los aspectos que refieren al intercambio entre músico y bailarín en el cruce metamórfico entre lo analógico predigital a lo digital. Por ello, dentro de la selección de casos, transcribiremos tres entrevistas abiertas en línea a músicos involucrados en los inicios de la Danza Multimedia.

Comenzaremos con el compositor, pedagogo musical, violinista y performer electrónico Sami Abadi $(2016)^{43}$, quien codirigió $U c s o n^{44}$, una performance que tuvo dos etapas. Una primera en la que se escribe el encuentro entre un lenguaje de movimiento (tanto de la bailarina como del músico con relación a su instrumento) surgido de la propia investigación sobre la trayectoria y el corte, su calidad y niveles de potencia, y una forma de operar con la composición musical partiendo de la ejecución del violín y el procesamiento electrónico de su sonido. Una segunda etapa en la que el despliegue sonoro de los movimientos da material a la impronta de la composición musical, sumándose así -al procesamiento electrónico del sonido del violín- los sonidos emanados del cuerpo danzante que son capturados y vueltos música.

\footnotetext{
El planteo inicial desde la composición musical fue disparado desde la búsqueda de gestos o trazos que pudieran tener correspondencias con el movimiento danzado, también era interesante la posibilidad anempática ${ }^{45}$. El cuerpo de herramientas para la realización de la música en vivo estaba formado esencialmente por mi violín, los procesadores -incluyendo la looperay un pequeño sampler de frases. Todo pasado por una consola.
}

$Y$ aquí es interesante puntualizar el surgimiento de lo gestual como posibilidad de interactuación con el sistema; en este caso, a través de la toma directa de sonido para procesarlo y generar un loop ${ }^{46}$ de voz. De manera precaria, apareció allí el gesto de la boca, resoplidos, vocales guturales frente al micrófono. Vilém Flusser (1990: 41) se interroga si el gesto de hablar será mover la lengua, el paladar, los labios "de tal modo que el aire que los rodea vibra de una forma que ha sido codificada en unos sistemas denominados ‘lenguajes”'. Sami Abadi (2016) describirá así el proceso:

\footnotetext{
${ }^{43}$ Entrevista realizada vía correo electrónico el 3 de febrero de 2016.

${ }^{44}$ Obra Ucson. Dirección, coreografía e interpretación: A. Ceriani. Música en vivo: violín y sintetizadores a cargo de Sami Abadi. 2001 [en línea]. Dirección URL: <https://youtu.be/yMlacLwAVrY>.

45 La empatía y la anempatía (versión negativa de la empatía, es decir, lo que no afirma el sentido dramático) actúan como principios generales de la funcionalidad de la música y del sonido respecto de la imagen en lo audiovisual (Chion, 1993).

46 Un loop es un archivo de audio que se repite dentro de una composición. Como recurso surge de una grabación previa, es decir, de samples, pedazos de música.
} 
Privilegiando la metodología de tomar el sonido y loopearlo en tiempo real $-\mathrm{y}$ luego procesarlo con una reverb de parámetros móviles- se dio como algo casi natural la experimentación con la voz de la bailarina -que aparecía sin amplificar en algunos tramos de su propia performance-; lo que hicimos fue acercar un micrófono aéreo en una de las secciones del trabajo, para incorporar la voz de la bailarina, sincronizada orgánicamente a sus movimientos, e introducirla en el loop (en un ciclo de unos 10' de duración). El loop de voz rápidamente pasaba a ser procesado -modulación en anillo- y se incrementaba el largo de la reverb antes de cerrar la sección súbitamente.

Sin duda, para el bailarín/performer estar en un escenario transforma todo mínimo movimiento en un gesto, mayormente estilizado. Cabe decir, no obstante, que además de ingresar el gesto vocal para provocar al sistema, trae consigo que esa gestualidad se desfase de lo coreográfico. ¿Por qué desfasarse? Ya hemos discurrido sobre cómo se van afectando los procedimientos coreográficos ante las alianzas con el video, incluso más cuando el cuerpo comenzó a interactuar físicamente en un espacio en común con el músico y sus aparatos analógicos y digitales.

Siguiendo con la toma de sonido, es decir, la voz de la bailarina que era originada por el gesto de la boca, introduciremos otra observación realizada por Gabriel Gendin (2016: 8'50”), quien explica cómo, por una parte, se organizó la posible reactividadinteractividad entre instrumentos analógicos y digitales, y, por otra, el cuerpo se apropió de ese cruce: "Es el momento en que, con los tornillos empezás a repetir y a repetir y, te lo metes en la boca. Es un momento interesante que se ve tu cuerpo que hace un clic: ¿para dónde me lo llevo, para dónde lo estoy manipulando?, ahí está toda esa exploración, esa búsqueda" entre la tecnología existente, la puesta en escena y el cuerpo buscando cómo allanar el camino hacia la virtualización en germen.

Arlindo Machado (2009: 132) hace referencia a un gesto similar ocurrido en los primeros tiempos del video musical, una producción que tenía como protagonista a Laurie Anderson ${ }^{47}$ en un diálogo minimalista entre la cámara y sus gestos: "El momento fuerte sucede cuando Anderson pone una fuente de luz dentro de su boca: en la penumbra, por sus movimientos, es como si emitiera chispas y rayos entre los dientes".

A continuación, Gabriel Gendin (2016: 6'12”) describe cómo conectó ese sistema entre aparatos analógicos y digitales aprovechando los recursos existentes:

47 "O Superman" (EE. UU., 1981), de Josh White y Laurie Anderson, álbum Big Science [en línea]. Dirección URL: <https://youtu.be/QH2x5pARGdE>, en 1'52". 
Yo me las ingenié para ver cómo -eso que era el lenguaje $\mathrm{MIDI}^{48}$ - se lo podía transferir a un sensor, porque en realidad era partir de un teclado común. Lo que yo hacía era burlar la ingeniería del teclado con dos tornillos; y los pedales lo que hacían era juntar los dos cables. Entonces el programa Reaktor ${ }^{49}$, que era el único que me corría en la PC, era el que usaba para programarme toda una plataforma para poder usar eso, para que reciba también los micrófonos. En realidad eran tres sensores: los dos tornillos más tres pedales y un teclado para poder trabajar en vivo, a partir de lo que se iba generando.

Uno de los temas primordiales -en estas primeras performances- era ver de qué manera se habilitaba al cuerpo infiltrándolo para controlar y mediar en la emisión de sonido, tornándolo una interfaz escénica y siendo evidente que las condiciones físicas, tangibles, volumétricas, se imponían.

Reparemos en cómo Sami Abadi (2016) proponía esa conexión de diferentes materialidades en escena:

Si ubicamos el foco en la cuestión de lo analógico y lo digital debemos decir que en Ucson solo era analógica la toma de sonido (la toma del violín a través del micrófono de contacto, y la toma de la voz a través del mic aéreo), y también la mezcla en tiempo real en consola. Pero todos los procesadores eran digitales (la loopera JamMan, el sampler Boss, los procesadores MPX100 y 1404 ya mencionados). Obsérvese que no utilizamos computadoras. No eran mi elección en ese momento, y nunca lo han sido -tampoco hoy-, las razones son estrictamente de desinterés en la interface, y poco estímulo en el flujo de trabajo que en mí se pone en marcha. Hoy sigo trabajando con procesadores y sintetizadores de hardware. (Por supuesto, no estoy descalificando los magníficos trabajos que pueden hacerse con esas herramientas, sino que describo una situación particular que se da en mí como músico y performer en su relación con los instrumentos, relación que tiene mucho que ver con la participación activa de mis manos, mis sentidos y mi cuerpo todo). Desde mi punto de vista, esta cuestión de lo analógico versus lo digital en Ucson ha estado más bien marcada por un condicionamiento del mercado: la tecnología disponible al momento -0 al menos accesible para mis circunstancias, incluyendo fragilidad, portabilidad y estabilidad de los equipos- era digital.

A partir de lo expuesto hasta aquí, podemos presumir que el video predigital y la proyección en pantalla no facilitaron el acceso a una mediación del cuerpo interfásico en escena. En cambio, el proceso de digitalización, con su poder de hibridación,

\footnotetext{
${ }^{48} \mathrm{MIDI}$ es una sigla que significa interface digital de instrumentos musicales, y su nombre procede de la expresión en lengua inglesa Musician Instruments Digital Interface. El MIDI es un sistema o protocolo de comunicación que reconoce la intercomunicación de dos o más equipos electrónicos (análogos o digitales) entre sí para la grabación y reproducción de órdenes. Como sistema de intercomunicación digital, implica que por él no circula audio (sonido), sino órdenes de ejecución de un instrumento preciso. Ofrece la posibilidad de trabajar con una entrada llamada MIDI IN, una salida llamada MIDI OUT y una salida alternativa para la intercomunicación con un tercer equipo llamada MIDI TRHU (generalmente, se trata de un teclado externo).

${ }_{49}$ Reaktor es un programa que permite a los músicos e ingenieros diseñar y construir sus propios instrumentos, samplers, efectos y herramientas de diseño sonoro. Uno de las características interesantes es que todos los instrumentos pueden ser inspeccionados y modificados libremente.
} 
encontró en los dispositivos musicales una mayor disposición para que a nuestra implicación en el sistema de interacción se le vaya atribuyendo una eficacia subjetiva. A la par, mientras procesábamos y experimentábamos el trayecto predigital, se iban concretizando los acontecimientos virtuales, es decir, en tanto el sujeto-bailarín iba ejerciendo e identificándose en la virtualización, equivalentemente, se transitaba hacia una operatoria y un constructo de la simulación, en lugar de la representación o la presentación. Consecuentemente, emerge la hibridación cuando cuerpo, imagen y sonido se interpenetran, sin contornos ni subordinaciones. En la lógica de la simulación, se reproduce artificialmente un fenómeno o las relaciones entrada-salida de un sistema y en donde imágenes, cuerpo y sonidos se intercambian de roles hasta la indistinción de unos y otros.

El bailarín ya no permanece más en el umbral de la pantalla, sino que se sumerge. En el sistema predigital de la representación nos hallamos con que el artista y el espectador se localizan a través de la imagen/sonido y de sus soportes físicos, con las tecnologías digitales se trata más bien de una simulación consumida absolutamente en la virtualidad.

Para cerrar este capítulo, apelaremos a la descripción de un instante dentro una secuencia performática de la performance Toulouse (Ceriani-Gendin, 2003) ${ }^{50}$, en la que la bailarina ejecuta un gesto revelador que nos conduce hacia la conclusión de lo expuesto en este capítulo. El gesto es el siguiente: en los dedos pulgar e índice de la mano derecha la bailarina tenía unidos dos tornillos. Cada uno de ellos está acoplado a un cable bipolar, largo, con entrada MIDI final en el teclado y actúan como conectores on-off. Al ejecutar el movimiento de introducir dentro de la boca los dos tornillos se compone un gesto que manifiesta -en una plena visión poética- el pasaje del cuerpo orgánico al interfásico.

A continuación, damos introducción a la Parte 2 de este Capítulo 2 que versa sobre la danza performance interactiva, el performer interactivo, los programadores y la digitalización de todos los recursos escénicos -básicamente- haciendo referencia al software de creación, software libre u open source.

\footnotetext{
50 Véase 0:17 a 0'25" [en línea]. Dirección URL: <https://youtu.be/Witxr6ZMwEk>.
} 


\section{Referencias bibliográficas}

Alonso, Rodrigo (1998), “Actualidad de la Video Danza”, en Quinto festival Internacional Video danza 99, Buenos Aires, Secretaría de Extensión Universitaria, Universidad de Buenos Aires, Centro Cultural Ricardo Rojas, p. 22.

Alonso, Rodrigo (2015), Elogio de la low-tech, historia y estética de las artes electrónicas en América Latina, mecenazgo cultural, Buenos Aires, Luna editores.

Araiz, Oscar (1999), "Escrito en el aire", en Quinto festival Internacional Video danza 99, Buenos Aires, Secretaría de Extensión Universitaria, Universidad de Buenos Aires, Centro Cultural Rector Ricardo Rojas.

Arendt, Hannah (2009), La condición humana, Buenos Aires, Paidós.

Ascott, Roy (2007), "El web chamántico. Arte y conciencia emergente", en Jorge La Ferla (comp.), Artes y medios audiovisuales: Un estado de situación II. Las prácticas mediáticas pre digitales y post analógicas, Buenos Aires, Nueva Librería.

Bachelard, Gaston (1997), La poética del espacio, España, Fondo de Cultura Económica.

Bali, Margarita (1999), "Por qué como coreógrafa estoy atrapada por el video danza como género de creación", en Quinto Festival Internacional Video Danza 99, Buenos Aires, Secretaría de Extensión Universitaria, Universidad de Buenos Aires, Centro Cultural Ricardo Rojas.

Biagini, Hugo E. y Arturo A. Roig (2008), Diccionario del pensamiento alternativo, Buenos Aires, Editorial Biblos.

Bourdieu, Pierre y Loïc Wacquant (2005), "El propósito de la sociología reflexiva”, en Una invitación a la sociología reflexiva, Buenos Aires, Siglo XXI Editores.

Bourriaud, Nicolas (2013), Estética relacional, Buenos Aires, Adriana Hidalgo.

Bresson, Robert (1977), Notas sobre el cinematógrafo, Madrid, Biblioteca Era.

Burch, Noël (1999), El tragaluz infinito, Madrid, Cátedra.

Caballero, Alberto (2011), "De la inversión de la pantalla Peter Greenaway, de la imagen al cálculo", en Gabriel Sasiambarrena (ed.), La mirada en la performance, Buenos Aires, Edición independiente.

Ceriani, Alejandra (2010), "Proyecto Webcamdanza", en Terpsícore en ceros y unos, Buenos Aires, Guadalquivir.

Ceriani, Alejandra (2011), "Un recorte del mapa situacional de la danza/ performance con mediación tecnológica", en Seminario Internacional sobre Dança, Teatro e Performance: poética tecnologías: Anais do III Seminário Internacional sobre 
Dança, Teatro e Performance: poética tecnológicas, Salvador, Brasil, Universidade Federal da Bahia, Programa de Pós-Graduação em Artes Cênicas.

Chion, Michel (1993), "La boca y el video”, en La audiovisión Introducción a un análisis conjunto de la imagen y el sonido, Buenos Aires, Paidós.

Cosin, Alejandra (2005), "Cuestión de Piel", Revista Funámbulos. Cultura desde el teatro, año $8, \mathrm{~N}^{\circ} 23$ junio/agosto, Buenos Aires, Secretaría de Cultura de la Ciudad Autónoma de Buenos Aires.

Costa, Flavia (2012), "Tecnoescena", en Claudia Kozak (ed.), Tecnopoéticas argentinas archivo blando de arte y tecnología, Buenos Aires, Caja Negra Editora.

Dubois, Philippe (2001), Video, Cine, Godard, Buenos Aires, Libros del Rojas.

Dubois, Philippe (2004), "Máquinas de imagens: uma questão de linha geral", Cosac \& Naify, San Pablo, Brasil.

Duran, Ana (2005), "Entrevista a Daniel Veronese", Revista Funámbulos. Cultura desde el teatro, año $8 \mathrm{~N} .{ }^{\circ}$ 23, julio agosto, Buenos Aires, Secretaría de Cultura de la Ciudad Autónoma de Buenos Aires.

Eco, Umberto (1968), Apocalípticos e integrados, Barcelona, Tusquets.

Falcoff, Laura (1996), "Entrevista a la jurado Graciela Taquini”, Revista Tiempo de Danza, año 2, N. ${ }^{\circ} 7$ octubre /noviembre, Buenos Aires, El Bosque editora.

Flusser, Vilém (1990), Hacia una filosofía de la fotografía, México, Sigma.

Flusser, Vilém (1994), Los gestos: fenomenología y comunicación, Barcelona, Herder.

Fortanet Fernández, Joaquín (2010), Foucault y Rorty: presente, resistencia y deserción, España, Prensas Universitarias de Zaragoza, p. 50

García, Ana Claudia (2012), “Instalaciones. El espacio resemantizado”, en Jorge La Ferla y Sofía Reynal (comps.), Territorios Audiovisuales: cine, video, televisión, instalación, documental, nuevas tecnologías, paisajes mediáticos, Buenos Aires, Libraria.

Godard, Jean-Luc (1980), Introducción a una verdadera historia del cine, Madrid, Alphaville.

Greiner, Christine y Helena Katz (2005), "Por uma teoría do Corpomidia”, en O corpo, pistas para estudos indisciplinares, San Pablo, Annablume.

Isse Moyano, Marcelo (2010), La danza contemporánea argentina cuenta su historia, Buenos Aires, Editorial IUNA.

La Ferla, Jorge (comp.) (2008), Artes y medios audiovisuales: un estado de situación, Buenos Aires, Nueva Librería.

La Ferla, Jorge (2009), Cine (y) Digital: Aproximaciones a posibles convergencias entre el cinematógrafo y la computadora, Buenos Aires, Manantial. 
Leibovich, Mariel (2012), “Videodanza”, en Claudia Kozak (ed.), Tecnopoéticas argentinas. Archivo blando de arte y tecnología, Buenos Aires, Caja Negra Editora.

Lévy, Pierre (1999), ¿Qué es lo virtual?, Barcelona, Buenos Aires, México, Paidós.

Lévy, Pierre (2007), Cibercultura. La cultura de la sociedad digital, Barcelona, Anthropos.

LLumá Diego (1999), "Entrevista a Margarita Bali”, Revista Balletin Dance, año 5 N. ${ }^{\circ} 59$, febrero, Buenos Aires, Secretaría de Cultura de la Ciudad Autónoma de Buenos Aires.

Lozano-Hemmer, Rafael (1994), Arte Virtual y Reactivo, Programa muestra Metro Opera, Madrid.

Machado, Arlindo (2009), El sujeto en la pantalla La aventura del espectador, del deseo a la acción, Buenos Aires, Gedisa.

Manovich, Lev (2005), El lenguaje de los nuevos medios de comunicación. La imagen en la era digital, Barcelona, Paidós.

Mitcham, Carl (1989), ¿Qué es la filosofía de la tecnología?, Barcelona, Anthropos.

Moraza, Juan L. (2003), "Cuerpo e imagen en la nueva danza”, en José Antonio Sánchez (ed.), Cuerpos sobre blanco, España, Ediciones de la Universidad de Castilla-la Mancha.

Olivares, Vicky y Marcelo Isse Moyano (2011), Danza. Investigación en Argentina, Buenos Aires, Ediciones Balletin Dance.

Pérez Ornia, José Ramón (1991), El arte del video: Introducción a la historia del video experimental, Madrid, Ediciones del Serbal.

Petruccelli, María Rosa (2000), "Inflamable", Revista Funámbulos. Cultura desde el teatro, año 3 N. ${ }^{\circ}$ 12, septiembre octubre, Buenos Aires, Secretaría de Cultura de la Ciudad Autónoma de Buenos Aires.

Pinta, María Fernanda (2012), “Tecnoescena”, en Claudia Kozak (ed.), Tecnopoéticas Argentinas. Archivo blando de arte y tecnología, Buenos Aires, Caja Negra Editora.

Prado, Gabriela (2007), "Pero definitivamente 'al espacio lo construyen quienes lo habitan”', en Creación coreográfica, Buenos Aires, Libros del Rojas.

Ricagno, Alejandro (1996), “Il Festival de Video-danza. Invitación a la video-danza, Revista Tiempo de Danza, año 2, N. ${ }^{\circ} 7$ octubre /noviembre, Buenos Aires, El Bosque editora.

Rosenberg, Douglas (1999), "Apreciaciones sobre la danza para la cámara y manifiesto", en Quinto Festival Internacional Video Danza 99, Buenos Aires, 
Secretaría de Extensión Universitaria, Universidad de Buenos Aires, Centro Cultural Ricardo Rojas.

Ruiz, Paulina (2015), “Del precine a la pixelación: poéticas fragmentadas, reconstrucciones y emergencias estéticas", en Memoria histórica de la videodanza, México, Editorial de la Universidad de las Américas Puebla.

Russo, Eduardo (1998), Diccionario de cine, Buenos Aires, Paidós.

Sánchez, José Antonio (ed.) (2003), Cuerpos sobre blanco, España, Ediciones de la Universidad de Castilla-la Mancha.

Sibilia, Paula (2005), El hombre post-orgánico, Buenos Aires, Fondo de Cultura Económica, p. 97.

Tambutti, Susana (2005), “Cuerpos en fuga. Danza y tecnología”, conferencia en $1 .^{\circ}$ Congreso de Artes del Movimiento, Buenos Aires, Universidad Nacional de las Artes.

Tambutti, Susana (2007), “Herramientas de la creación. ¿Una escalera sin peldaños?”, en Creación coreográfica, Buenos Aires, Libros del Rojas.

Traversa, Oscar (2008), "Regreso a pantallas", en Dossier de Estudios Semióticos. La Trama de la Comunicación Volumen 12, Anuario del Departamento de Ciencias de la Comunicación, Rosario, UNR Editora [en línea]. Dirección URL: <http://www.sema.org.ar/downloads/SemPrim_02_Gruner.pdf>.

Yeregui, Mariela (2008), "Prefijando el medio (o cómo las categorías se desplazan hacia los bordes)", en Jorge La Ferla (comp.), Artes y medios audiovisuales: un estado de situación II. Las prácticas mediáticas predigitales y postanalógicas, Buenos Aires, Aurelia Rivera, Nueva Librería.

Zátonyi, Marta (2011), Juglares y trovadores. Derivas estéticas, Buenos Aires, Capital Intelectual.

\subsection{Referencias electrónicas}

Alonso, Rodrigo (2000), Del tango a la videodanza. Danza para la Cámara en Argentina [en línea]. Dirección URL: <http://www.roalonso.net/es/videoarte/tango.php>.

Alonso, Rodrigo (2005), Hazañas y peripecias del video arte en Argentina [en línea]. Dirección URL: <http://www.roalonso.net/es/videoarte/incaa.php>.

Bali, Margarita (2014), "La danza proyectada", Revista Digital Revol, octubre 14 [en línea]. Dirección URL: <http://revistarevol.com/tag/margarita-bali/>. 
Brea, José Luis (2002), La era postmedia. Acción comunicativa, prácticas (post)artísticas y dispositivos neomediales, Salamanca, CASA [en línea]. Dirección URL: <http://fba.unlp.edu.ar/lenguajemm/?wpfb_dl=8>.

Cantoni, Rejane y Leo Crescenti (2009), Cartografias - ZI Vórtice [en línea]. Dirección URL: <https://youtu.be/MtLJ16HzZno>.

Connerton, Paul (1989), "Memoria social. Paul Connerton”, How Societies Remember. Cambridge, Cambridge University Press [en línea]. Dirección URL: $<$ https://estudioscultura.wordpress.com/2012/03/01/memoria-social-paulconnerton/>.

Cosin, Alejandra y Alejandra Ceriani (2005), La danza performance: Una perspectiva alternativa [en línea]. Dirección URL: $<$ http://performancelogia.blogspot.com.ar/2008/07/la-danza-performance-unaperspectiva.html>.

Del Val, Jaime (2009), "Cuerpo común y guerra de los afectos. Coreografías globales y cuerpos en serie del afecto capital", Cuadernos de Información y Comunicación 14 [en línea]. Dirección URL: <http://revistas.ucm.es/index.php/CIYC/article/viewFile/CIYC0909110121A/7222 $>$.

Escudero, María Carolina (2013). Cuerpo y danza: Una articulación desde la educación corporal [en línea]. Trabajo final de posgrado. La Pata. Facultad de Humanidades y Ciencias de la Educación. Universidad Nacional de La Plata [en línea]. Dirección URL: <http://docplayer.es/17057777-Cuerpo-y-danza-unaarticulacion-desde-la-educacion-corporal.html>.

García Nava, José Luis (2015), Arte transversal: Fórmulas equívocas. Experiencia y reflexión en la pedagogía de la transdisciplina, México, Dirección General de Publicaciones / Centro Nacional de las Artes del Consejo Nacional para la Cultura y las Artes [en línea]. Dirección URL:<http://www.joseluisgarcianava.com/transdisciplina/dinamicas-corporalesen-el-audiovisual-digital/>.

Grüner, Eduardo (2002), "El sitio de la mirada", Conferencia dictada en Sociedad de Estudios Morfológicos de la Argentina [en línea]. Dirección URL: <http://www.sema.org.ar/downloads/SemPrim_02_Gruner.pdf>.

Pavis, Patrice (2000), "Escrituras dramáticas contemporáneas y nuevas tecnologías" [en línea]. Dirección URL: <http://www.casa.cult.cu/publicaciones/revistaconjunto/123/pavis.htm>.

Pérez Cubas, Gabriela y Miguel Á Santagada (2010), "La corporeidad del actor: ¿simulacro, contagio o creación?”, en Memoria Académica de las VI Jornadas de 
Sociología de la UNLP, 9 y 10 de diciembre, La Plata [en línea]. Disponible en: <http://www.memoria.fahce.unlp.edu.ar/trab_eventos/ev.5674/ev.5674.pdf>.

Rosenberg, Douglas (2010), Excavating Genres [en línea]. Dirección URL: <http://journals.library.wisc.edu/index.php/screendance/article/viewFile/321/315>.

Santaella, Lúcia (2003), Cultura e artes do pós-humano. Da cultura das mídias á cibercultura, São Paulo, Paulus Editora [en línea]. Dirección URL: $<$ https://identidadesculturas.files.wordpress.com/2011/05/santaella-culturas-eartes-do-pc3b3s-humano.pdf>.

Ssociólogos (2013), "Entrevista a Pierre Bourdieu. La lógica de los campos: habitus y capital" [en línea]. Dirección URL: <http://ssociologos.com/2013/06/23/entrevistaa-pierre-bourdieu-la-logica-de-los-campos-habitus-y-capital/>.

Szperling, Silvina (2013), "Nuevos recursos tecnológicos en la danza - Sobre la obra de Margarita Bali" [en línea]. Dirección URL: <http://www.margaritabali.com/Szperling_nuevos-recursos-danza.pdf>, <http://www.untref.edu.ar/cibertronic/tecnologias/nota13/nota13.html>.

Tambutti, Susana (2005), Danza o el imperio sobre el cuerpo [en línea]. Dirección URL: $\quad$ <http://es.scribd.com/doc/182922255/Danza-o-El-Imperio-Sobre-ElCuerpo-Susana-Tambutti\#scribd>.

Tambutti, Susana (2008), "Itinerarios teóricos de la danza", Revista AISTHESIS N. ${ }^{\circ} 43$, Chile, Instituto de Estética, Pontificia Universidad Católica de Chile [en línea]. Dirección URL: <http://www.redalyc.org/pdf/1632/163219835001.pdf>.

Taquini, Graciela (2008), “Una crónica del videoarte en la Argentina. De la transición a la era digital" [en línea]. Dirección URL: <http://videoarde.net/pdf/taquini.pdf>.

Taquini, Graciela (2008), "Video en Latinoamérica. Una historia crítica”, en Laura Baigorri (ed.), Brumaria 10, Madrid, Agencia Española de Cooperación Internacional para el Desarrollo [en línea]. Dirección URL: $<$ http://www.brumaria.net/>.

\subsection{Entrevistas en video}

Ceriani, Alejandra (2015). Entrevista a Santiago González [en línea]. Dirección URL: $<$ https://youtu.be/Djlmna83o90>.

Ceriani, Alejandra (2015). Entrevista a Silvina Szperling [en línea]. Dirección URL: $<$ https://youtu.be/gafVeV-wQXU>.

Ceriani, Alejandra (2016). Entrevista a Gabriel Gendin [en línea]. Dirección URL: <https://youtu.be/rxEbXQQniv8>. 
Ceriani, Alejandra (2016). Entrevista a Rodrigo Alonso [en línea]. Dirección URL: <https://youtu.be/aZNf_3lcfz4>.

\subsection{Otros materiales de consulta en línea}

Danzainteractiva (2009), Toulouse Primera Parte [en línea]. Dirección URL: $<$ https://youtu.be/IAVbvN7SKLw>.

De Luque, Paula (2014), VIDEODANZA ARGENTINO [en línea]. Dirección URL: $<$ https://youtu.be/tiQ82AopEqw>.

Szperling, Silvina (2014), VIDEODANZA ARGENTINO [en línea]. Dirección URL: $<$ https://youtu.be/tiQ82AopEqw>.

TOULOUSE 2003 / CERIANI-GENDIN [en línea]. Dirección URL: $<$ https://youtu.be/Witxr6ZMwEk>.

Ucson (2001) [en línea]. Dirección URL: <https://youtu.be/yMlacLwAVrY>. 


\section{CAPÍTULO 2. Pasaje de lo analógico a lo digital}

\section{PARTE 2. Danza Performance Interactiva}

\section{Introducción}

Como ya se ha dicho, esta tesis establece como área de interés el estudio de las prácticas artísticas con sistemas informáticos localizados y en el espacio de internet. Asimismo, nos proponemos presentar un marco teórico y proyectivo para los desarrollos dentro del campo de la Danza Performance con tecnología en tres períodos desde el inicio hasta los estados actuales. Hemos expuesto, en la Parte 1, el período analógico, predigital; y ahora nos introduciremos en el análisis de la selección de un corpus de obras producidas con la concepción de Danza Performance Interactiva.

Puntalmente, esta Parte 2 versará sobre las experiencias con el cuerpo y sistemas informáticos, con proyección de visuales y sonidos. En tal sentido, clasificaremos sus componentes y los relacionaremos con el desarrollo de los procedimientos escénicos interactivos. Observaremos que, dentro del Ciclo de Danza de la Universidad Nacional de La Plata (UNLP), denominado "En 2Tiempos, Itinerarios de Danza", período 2011 2012, y el llamado "En 2Tiempos. Itinerarios de Danza con Mediación Tecnológica", 2013-2014, el cambio en la denominación se debe a que el proceso de entendimiento y de localización de las prácticas realizadas se vinculó con una creciente concientización del uso de la tecnología y con la claridad de las pautas no solo de producción sino de conceptualización de la experiencia. Al respecto, se fomentó tanto el intercambio disciplinar entre artistas como la incorporación del público dentro del proceso de producción de sentido.

A continuación, caracterizaremos el espacio institucional que dio lugar al ciclo de danza en el edificio del Rectorado de la UNLP, a sus actores y sus metodologías.

\section{Ciclo de Danza de la UNLP}

El proceso creativo mediado por las tecnologías digitales promueve un amplio campo de investigación sobre las prácticas y los procedimientos de interacción entre lenguajes artísticos e informáticos, performers, bailarines, programadores, artistas visuales, músicos, entre otros. Del mismo modo, se abre un campo de indagación con el público, pues si bien no hablamos de que existe un público sino públicos, fue 
interesante detectar - a medida que este asistía a las presentaciones del ciclo y se disponía al diálogo abierto al finalizar cada performance- la capacidad de interpretación y de conciencia del fenómeno transdisciplinar que se estaba generando, y que solo puede observarse y expresarse con nuevas percepciones y valoraciones.

Esta manera de organización de los conocimientos y sus prácticas trasciende lo disciplinar hacia una mirada integral que no reduce su especificidad y distingue sus diferencias. Por eso, establecer el diálogo entre los implicados desde una concepción interactiva de la comunicación conlleva a la reflexión, al conocimiento relacional y la revisión permanente del mundo circundante. Nos interesa ver de qué forma la tecnología podría expandir nuestro contexto de interacción y cómo eso podría cambiar la experiencia sensible de los copartícipes.

Por tanto, los propios artistas convocados, así como los espectadores participantes, han compartido una experimentación perceptiva, sensorial, de conexión con el sistema informático y no en el uso espectacular del dispositivo per se. Se trata de una propuesta de ser partícipes de los procesos de cognición en este intercambio de lo interdisciplinar hacia lo transdisciplinar.

Así es que, partiendo del objetivo de sistematizar la escena mediatizada local para la práctica de la Danza Performance Interactiva, nos propusimos plantear -de forma participativa y con una mirada actualizada- lo que está aconteciendo en el vínculo entre los desarrollos del lenguaje de programación, el universo digital y las prácticas mixturadas del lenguaje del movimiento, por ende, de los desarrollos entre la producción tecnológica y la corporal. Sabemos que no podemos percibir esto solos, al menos no todavía, porque no venimos naturalmente-provistos con los sensores apropiados. Por ende, aprender con otros provenientes de distintos campos como la informática y la ciencia transdisciplinar es capital.

Nos parece oportuno entonces comenzar ampliando el significado de la conjunción de Danza Performance; para ello, a esta conjunción le agregamos "interactiva". En primer lugar, estamos haciendo referencia a la danza académica -tanto clásica como contemporánea limitándonos a esta última-, es decir, estamos partiendo de una formación sistematizada en diferentes técnicas del movimiento y la composición.

En segundo lugar, referirnos al lenguaje de movimiento desde la danza no es equivalente a decir desde la performance. No solo tiene que ver con la sistematización del movimiento corporal en posiciones y estilos, sino con cuestiones que atañen a lo disciplinar y sus componentes básicos: espacio y tiempo.

En una performance, el espacio y el tiempo están manifiestos de manera substancial: son la performance, soslayando la exhibición de lo ficcional, de lo representativo. Julia E. Sagaceta (2013: 141), a partir de la nominación de performances teatrales, 
reflexiona: “¿Es válida esta denominación? Cuando hablo de 'performances teatrales' me refiero a aquellas performances que ponen más énfasis en lo escénico". Ella parte de la performance pensada como una interrelación de artes y del cuerpo como espacio, como acción.

Así volvemos sobre otra pregunta: ¿La misma suerte del teatro correría para la danza al conectarla con la performance? Aquí proponemos una salvedad. Si se plantea desde un cuerpo formado académicamente en la danza contemporánea, diremos que la mayoría de las veces le es dificultoso (no imposible) salir de la codificación formal de las técnicas y de la composición coreográfica. Pero si partimos de la concientización del problema de la identidad en la danza y focalizamos en las experiencias procesuales del movimiento, la consecuencia es bien otra:

Lo que ha cambiado en los escenarios de danza es estrictamente el pensamiento acerca de la identidad que, a diferencia de su histórico destino de imitación, copia o mímica en la representación corporal de modelos, actualmente ha de pensarse más bien como performance, como ejecución procesual. Si la danza con Merce Cunningham se revela como arte del movimiento más allá de las artes figurativas, la literatura y el teatro, es porque abandona el principio de la imitación. En el preciso instante en el que la danza se vuelve idéntica a sí misma, se aliena de su propia historia. Con ella, los bailarines se distancian de su propio cuerpo y de su memoria del movimiento (Siegmund, 2003: 56).

Por lo que sería lógico pensar estas prácticas performáticas como prácticas corporales especializadas, como "arte del movimiento" en un sentido amplio -no solo derivadas del teatro o de la danza- donde existe conciencia del cuerpo en movimiento y de la gestualidad expresiva.

Entre las visiones que componen esta confluencia (danza y performance) se destacan "las prácticas coreográficas contemporáneas que se basan en una concepción de la danza que no se limita al cuerpo en movimiento", sino que toman al "fenómeno de la inmovilidad -que se considera el grado cero de la danza-" como "un umbral perceptible que reconfigura la relación entre la dimensión corporal y la subjetividad" (Fuentes y Taylor, 2011: 523).

Encontramos en esta indagación un planteo intrínseco desde la danza -dado que el devenir continuo de espacio y tiempo hace a su definición estructural- hacia la performance. En ese sentido, Marcela Fuentes (en Fuentes y Taylor, 2011: 524) explicita que la inmovilidad "coloca a la danza dentro de una 'ontología de la performance' en la que la presencia importa más que el movimiento en sí". 
Este abordaje que abre una perspectiva distinta a la danza acercándola a una experiencia perceptual pone en evidencia una problemática que hay que afrontar con un sistema de captación "del movimiento". Se puede pensar que el cuerpo de un bailarín performer debe moverse, gesticular o accionar para producir una respuesta del sistema. No obstante, eso dependerá, por una parte, del tipo de técnica de captura de movimiento; y, por otra, de la complejidad en la traducción que el programa efectúe.

\begin{abstract}
La captura óptica (motion capture), por ejemplo, se realiza por comparación de imágenes: consiste en comparar cada uno de los fotogramas con los anteriores, es decir, se usa un retardo (delay) que demora la imagen para luego realizar la substracción, una resta entre la imagen demorada y la actual. Digamos que la diferencia entre lo actual y el pasado es el cambio. Por lo cual, el cambio en la imagen es igual a movimiento. Entonces, no lee el movimiento sino el cambio. Cuando los píxeles de una y otra imagen coinciden dentro de la función del delay, la substracción entre valores idénticos resulta cero, lo que, traducido a color, es igual a negro (cero luz, o falta total de luz). Esto tiene como desventaja el hacer esta técnica muy sensible a los cambios de luz o al ruido visual de cámara o la iluminación, generando inconvenientes a la par que insta al uso de la luz como propuesta para interactuar. Esto incide directamente en el tipo de gestualidad y movimientos con los que se interactúa; ya que, si el performer se queda quieto, el método no lo detectará. Se capta la cantidad de movimiento, en consecuencia, la quietud entra a dialogar a nivel compositivo como silencio visual o sonoro (Ceriani, 2011: 89).
\end{abstract}

Por ende, de una u otra manera, la Danza Performance Interactiva, al entrar en interacción con la interfaz de captura, resuelve desde el cuerpo especializado, desde los movimientos en sintonía con esta gramática generativa o responsiva dispuesta.

Esta aclaración es válida, por una parte, para los aspectos generales de este tipo de producción, pero en sus aspectos particulares -dentro de este trayecto que estudiaremos-, abarcará a aquellos bailarines que iniciaron una experiencia dentro de lo que se denomina performance interactiva, es decir, las performances que componen una nueva categoría dentro de las artes escénicas y que se conectan al arte interactivo -activando a partir del movimiento y el gesto corporal- sonidos, dibujos, diseños visuales y audiovisuales. Pero, por otra parte, quedan en evidencia las limitaciones de búsqueda que un performer puede encontrar en una instalación de captación del movimiento. 
La descripción del cuerpo del dispositivo es muy básica; por ejemplo, representa la posición de la mano con un punto, es decir que no tiene conciencia de la ubicación de la palma, los dedos, etcétera. Por lo tanto, si el performer hace un gesto sutil con su mano, lo más probable es que no sea captado. Todas estas restricciones recién comentadas, hacen que el supuesto propósito de "captar el movimiento del performer" se transforme en una intersección entre lo que el performer hace y lo que el sistema puede captar, que es, por supuesto, un importante recorte del fenómeno en sí (Causa, 2014: 69).

La sutileza y la inmovilidad, evidentemente, no pueden hoy ser parte del trabajo corporal mediatizado. Así es que el ciclo de danza en la universidad se posiciona como un laboratorio de eventos interdisciplinares donde el diseño de una asociación arte y ciencia tiene una plataforma temporaria en común. La pregunta “¿Cómo vivir juntos?"51, en una situación "escénica" creada in situ, implica resolver alguna problemática emergente por el bien común.

Entonces agregaremos otro interrogante: ¿Cómo pueden crear juntos un bailarín y un programador? (en una comunidad artística estructurada sobre un delicado juego de códigos y autonomías, comunicación y discreción, efectos y moderaciones, presididos por la consigna del diálogo). La migración del cuerpo es múltiple y simultánea: va del código a la intersubjetividad y de la lógica del sentido programado a la improvisación gestual, pero también va del deber al gozo. De la comunión regulada de pensar cómo hacer que el sistema funcione a pensar cómo sería el espacio que les gustaría danzar. Junto con el público asistente y la reflexión espontánea de los actores, se presentaba cada vez un estado de la cuestión.

Cada equipo conformado desde una propuesta individual puso a prueba los supuestos teóricos y prácticos aplicándolos en un proceso que tuvo un programa de implementación y seguimiento. En esa instancia, el público participante podía distinguir entre los datos objetivos ofrecidos como parte de la exploración técnica y la interpretación que de ellos hacía en las devoluciones, comentarios y opiniones que se realizaban al final de cada presentación.

En este sentido, nos pareció un método apropiado para investigar a pequeña escala en un marco limitado de tiempo, de espacio y de recursos. El ciclo "En2Tiempos. Itinerarios de danza" se realizó en salas del rectorado de la UNLP; consecuentemente, no estamos hablando de un escenario tradicional, sino de espacios que no son habituales y que no fueron pensados, arquitectónicamente, ni para la performance ni para la danza espectacular.

\footnotetext{
51 Título que Roland Barthes elige para bautizar un seminario en el Collège de France, 1976-1977.
} 
El espacio en la danza aspira a ser el "adecuado", con esto nos referimos a cierta amplitud y a pisos parejos, nivelados, básicamente. Para la performance, el espacio es significante, manifestará tanto como el cuerpo y estará determinado por el montaje conceptual, más allá de su calidad y su adecuación. Apropiarse de los espacios del Rectorado -a través de la danza performance mediada por sistemas tecnológicos- fue la clave del ciclo para problematizar y formalizar en una investigación artística que pasó de ser de recopilación y actualización de los actores locales a constituirse en un ensayo para los procesos empíricos planteados.

La consigna de la convocatoria del ciclo 2013 se basó en la migración del cuerpo analógico al contexto digital a través de las características del dispositivo, la interfaz, las aplicaciones; se observó en conjunto cómo se afectaban y transformaban:

- La adecuación gestual estetizada, ergonométrica e interactiva de los bailarines performers.

- La comprensión de los niveles sensibles del movimiento corporal por parte de los programadores.

- El comportamiento espectatorial y analítico en el espectador/participante.

Además, teniendo en cuenta los procesos de adecuación al interior de las disciplinas en convergencia, nos propusimos atender a:

- La dinámica disciplinar: hábitos y problemáticas.

- La adecuación interdisciplinar: encuentros y divergencias.

- La conexión transdisciplinar: acuerdos y derivaciones.

A partir de este corpus propuesto para la creación artística dentro de una investigación procesual, pudimos constatar un claro desplazamiento del sentido tradicional de las puestas en danza y en performance hacia un devenir escénico informatizado. Consideramos este desplazamiento como el punto determinante del proceso de transformación hacia una interacción cuerpo/sistema más eficaz en su coyuntura. Estos intercambios nos permitieron cotejar, por ejemplo, que la producción de una "obra de danza" ha dejado de ser la que delibera sobre la representación o interpretación dramática de la corporalidad en el espacio-tiempo gravitacional, para pasar a ser la producción de un proceso de creación en Danza Performance con interactividad como un sistema que cuestiona nuestra fisicalidad, nuestros entornos materiales, nuestros modos de comunicación gestual. Un sistema que proporciona nuevas visiones del cuerpo y de su existencia ubicua, fundamentándose en el método 
procesual y en el modelo de sistema interconectado que adquiere un sentido renovado para la escena performática contemporánea.

Adentrándonos en el ciclo "En2tiempos. Itinerarios de danza", diremos que comenzó en el año 2011 y se desarrolló hasta el 2014. Tuvo como marco una iniciativa de la Prosecretaría de Arte y Cultura, espacio institucional dentro de la Secretaría de Extensión Universitaria de la UNLP. Se organizó a partir de presentaciones mensuales de producciones locales vinculadas a las artes del movimiento y sus cruces interdisciplinarios con tecnología digital de bajo rendimiento (low-tech).

Dentro de este marco, se promovió el trazado de una cartografía de la danza local, de sus prácticas ${ }^{52}$ y sus producciones, y se brindó un espacio de encuentro e intercambio de los procesos artísticos con el público. Reflexionamos conjuntamente sobre las posibilidades de reciprocidades entre un sistema informático, bailarines performers y espectadores participantes, y señalamos los límites, las dificultades y los desencuentros en una invitación al diálogo y al conocimiento.

El ciclo se inicia proponiendo dos escenarios: uno con obras en formato escénico y otro con obras en formato video (video danza o danza filmada). Esta primera instancia tuvo un carácter de relevamiento para determinar la situación real de los artistas platenses vinculados al uso de tecnología, por una parte; y, por otra, un carácter exploratorio al iniciar este proceso de aplicación en espacios no convencionales. Al finalizar, concluimos que era posible proponer un cruce de ambas experiencias: la física y la virtual.

Así fue que, en ciclo del año 2012, decidimos acentuar el énfasis en aquellas intervenciones que tuvieran en cuenta el espacio como parte de la propuesta de presentación. Dicho espacio, el edificio de la Presidencia de la UNLP -con una marcada densidad histórica en nuestra ciudad de La Plata-, proporcionó la oportunidad a diferentes grupos de danza de apropiárselo, poniendo en diálogo la producción disciplinar en un trabajo en equipo.

Nos orientamos entonces hacia los diálogos entre la danza, la fotografía y las artes audiovisuales. En este sentido, quien filmaba o fotografiaba se integró con la cámara y con su cuerpo en el espacio escénico escogido, formando parte así de un proyecto en común.

Para ello, fueron convocados realizadores de la Carrera de Comunicación Audiovisual, de la Facultad de Bellas Artes (UNLP), y bailarines o compañías locales de danza.

52 Cuando hablamos de práctica hacemos referencia a la práctica artística, instalando a la par una diferenciación con la producción artística y con la creación artística, dado que no es lo mismo por las implicaciones que supone identificarlas. Una de las particularidades de la práctica artística contemporánea es la disolución conceptual de las prácticas tradicionales. La tecnología informática inauguró nuevos espacios $y$ formatos $y$, no solo sugiere las técnicas o los medios, sino, fundamentalmente, la inherencia conceptual en la producción. 
Otra de las proposiciones para el año 2012 fue organizar encuentros con especialistas en fotografía y videodanza, quienes, con sus relatos, brindaron una perspectiva desde la propia experiencia sobre qué es filmar o fotografiar danza.

Se trata de preguntarnos y respondernos: ¿Qué acontece en el cuerpo y en la mirada de quien es mediado por una cámara ante aquellos otros cuerpos que danzan en un mismo espacio? En esa escena compartida, la mirada se desconcierta y se disuelve en el proceso de búsqueda de unidad en la presencia y en los fragmentos encuadrados. Evaluamos no tanto el valor funcional y de calidad técnica del sistema propuesto, sino el sentido que configura a la mediación, su proceso creciente de complejización y el lugar de las interconexiones que se establecen con la acción del cuerpo y de la mirada. Eduardo Russo (2004: 91) lo describe como "la ya conocida problemática de la mirada con el peso de un cuerpo".

Al finalizar estas performances establecimos una fecha de exhibición para las producciones audiovisuales que fueron producto del registro de lo que aconteció en la escena compartida entre la danza, la fotografía y las artes audiovisuales. En este sentido, las variables de análisis derivaron en la particularización, por ejemplo, del nivel de participación del camarógrafo en el espacio de la performance. Algunos formaron parte del diseño general del movimiento en el espacio, otros irrumpieron tanto en el espacio como en las trayectorias prefijadas, otros ocuparon sitios estratégicos para registrar e invitaban a transcurrir por él, otros incluso traspasaban la cámara a los bailarines performers.

Habiendo dos modalidades documentales y videodanza, las condiciones de participación implementadas para los camarógrafos de fotografía y video fueron las siguientes:

- Establecer contacto con el grupo.

- Integrar el proceso del trabajo desde el inicio para la generación de una propuesta en conjunto.

- Asistir a todos o algunos de los ensayos previos o el mismo día de la presentación.

- Poseer cámara digital de video o de fotografía.

- Tener hardware y software para edición.

- Entregar a término la pieza digitalizada en formato video DVD para fecha convenida de exhibición.

Entre los términos de producción, se les solicitó: 
- Combinar el material registrado con otros de su autoría, dado que el video debe incluir un $50 \%$ del material obtenido en las presentaciones.

- Presentar un registro de fotografías en formato final video, editado o animado.

- Producir una pieza audiovisual en género documental (incluidas entrevistas) o videodanza.

- Estipular una duración mínima de 1' y máxima de 15'.

El material producido se exhibió en presentaciones exclusivas en las que los referentes de la fotografía y del video en danza hicieron una devolución sobre el video en diálogo con los autores y con el público. Dados los resultados de esta propuesta interdisciplinar, para el año 2013. Nos propusimos poner en diálogo al cuerpo, los dispositivos y las interfaces interactivas, enmarcándonos dentro de proyectos abiertos al arte y a la informática. Para ello, fueron convocados alumnos avanzados y profesores de la Carrera de Multimedia de la Facultad de Bellas Artes (FBA), bailarines y compañías locales que se comprometieran a trabajar conjuntamente.

Nos interesó compartir, dialogar e interrogarnos colectivamente sobre los procesos de exploración del movimiento y la gestualidad estetizada que interactúa a través de la operación de un software, aplicaciones y la programación algorítmica; posicionando, de este modo, a los artistas y al público en la situación de percibir una relación viva y fluida, real y virtual, con el lema: cuerpo a cuerpo.

Promovimos la idea de transitar la producción artística como un trabajo de campo, indagación y estudio de los procesos de creación en los que el cuerpo fuese el protagonista -y no solo el cuerpo del performer bailarín (que sería obvio), sino también del programador-. Lógicamente no de la manera en que se llevó adelante en el ciclo antecesor en el que fue parte activa de la escena, sino haciendo consciente lo que David Le Breton (2002: 9) denomina el "borramiento del cuerpo que se traduce en múltiples situaciones rituales de la vida cotidiana". En el ámbito de nuestra incumbencia, ese borramiento se daría en la situación de estar programando. Asimismo, haciendo consciente la disociación que se efectúa entre el cuerpo y la persona "a través del modelo privilegiado de la máquina" (Le Breton, 2002: 27).

Continuando con el caso del ciclo 2013, se conformaron equipos de trabajo en los que el bailarín performer y el programador fueron acompañados por alumnos avanzados o docentes del Departamento de Estudios Históricos y Sociales, de la Facultad de Bellas Artes, o investigadores en formación, tesistas, becarios o cursantes de posgrado de universidades afines, para realizar producciones escritas sobre el proceso de cada uno 
de los equipos interdisciplinarios en formato de reseñas ${ }^{53}$. El objetivo fue doble: por una parte, constituir una sistematización de las prácticas como un proceso de producción de conocimiento -que empodere a los sujetos que realizan la sistematización- surgido de los propios actores del proceso (bailarines y programadores de sistemas interactivos digitales); y por otra, aportar a la reflexión teórica -y en general a la construcción de teoría- de estas nuevas prácticas artísticas en el terreno del estudio y la divulgación crítica.

Asimismo, un videasta o un fotógrafo registraban el proceso de cada equipo y realizaba un video con las mismas pautas y características del año precedente. Aquí la idea de documentación audiovisual del proceso, con ensayos, conversaciones y entrevistas a los actores comprometidos, daba como resultado una pieza audiovisual de puntos de partida diferentes. El producto podía ir desde unas imágenes autónomas que aportaran información nueva -con énfasis en la objetividad y la lógica argumentativa- a imágenes que compartieran los desarrollos tecnológicos desde un acercamiento más autoconsciente y autocrítico, a ofrecer una visión poética del proceso documentado.

Las condiciones de participación de los reseñistas fueron las siguientes:

- Disponer de horarios para realizar el seguimiento de acuerdo con la organización que se diera el equipo en cuestión.

- Realizar un trabajo de campo: observación y recolección de datos.

- Proponer un eje temático rector con incumbencia en la danza y las mediaciones tecnológicas.

- Escribir una reseña (con una extensión de una carilla A4 o entre 3.000 y 4.000 caracteres con espacios) para ser publicada en el Anuario de Arte y Cultura 2013.

- Contar con dispositivos técnicos propios: grabador, cámara, etcétera.

- Presentar de informes de avances de la escritura del proceso en las fechas pautadas por el ciclo.

Los reseñistas escogieron la modalidad de conferencia performática ${ }^{54}$ para la presentación de informes. Según Julia E. Sagaceta (2004: 1), este tipo de conferencia:

\footnotetext{
${ }^{53}$ La reseña es un escrito argumentativo breve que intenta dar una visión panorámica y, a la vez, crítica, sobre un análisis de una obra (en este caso de un proceso) y su relevancia en la investigación de un tema.

54 Puede verse en línea. Dirección URL:

<https://www.facebook.com/alejandra.ceriani/videos/10152075554516118/> y

<https://www.facebook.com/alejandra.ceriani/videos/10152090138086118/>.
} 
... toma las características de un hecho académico o, $[\ldots]$ de alta cultura y lo lleva a una acción artística. Puede aplicar todas las manifestaciones escénicas que el performer elija: estar sentado leyendo un texto que lo involucra y hacerlo seriamente o con humor, usar tecnología, música, actitudes actorales, objetos que lo ayudan en la lectura. También puede eludir esta y hablar narrando su conferencia. Lo que tienen en común todas estas formas performáticas es que se realizan con el tono y las actitudes de un conferenciante serio.

Esta conferencia tenía otra característica para destacar, y es que se vinculaba con un sistema interactivo de obtención de la información registrada a través de ciertas claves que abrían el juego al público asistente, quien finalmente, organizaba de modo aleatorio las presentaciones discursivas y visuales de las reseñas y sus reseñistas.

Al respecto, brindamos una breve descripción: se había dispuesto en la sala una computadora portátil conectada a un proyector y a un teclado intervenido en el que, apretando las teclas $\mathrm{F} 3$ + un número del 1 al 9, aparecían en pantalla palabras clave de los textos de las reseñas, por ejemplo, "módulo", "cuerpo expandido", "descentramiento", etcétera. Apretando F1 y F2 + un número del 1 al 9, aparecían las visuales, imágenes y fragmentos de los videos de las performances realizadas durante el ciclo.

El software Resolume -programado por dos de las videastas del ciclo- permitió que el propio público asistente convocara a las reseñistas performers, quienes interactuaron con sus palabras clave, imágenes y sonidos a través de esta videoinstalación compartida y editada en tiempo real. A partir de esta organización, se desplegó un abanico de estímulos para que los equipos interdisciplinarios produjeran materiales articulados en un discurso simbólico estético y narrativo con las nuevas tecnologías. Del mismo modo, continuaron los encuentros con especialistas en el tema, quienes presentaron una especie de trazado desde su propia experiencia, desde su visión, desde sus trayectorias para poder compartir, dialogar e interrogarnos junto con el fin de posicionarnos tanto a los artistas como al público.

El ciclo del año 2014 estuvo signado por el resultado de esta experiencia interdisciplinar, por la continuidad de las conferencias performáticas ${ }^{55}$ y por la posibilidad de que a la organización se sumen la Cátedra Libre de Educación y

\footnotetext{
55 Por orden de participación contamos con la conferencia performática de Maida Withers, directora de la Dance Construction Company y profesora de la Dance and Theatre, George Washington University in Washington DC. Traductor simultáneo: Adrián Salinas, miembro del colectivo artístico A.mo.ver, UNA. Reseña de Profesor Maximiliano Wille, UNA. Valeria Pagola y Federico Joselevich Puiggrós, "Inevitable / Inagotable" FBA, UNLP. Con Reseña de María Mercedes Viola, FBA, UNLP. Véase en línea: $<$ http://www.alejandraceriani.com.ar/pdf/Resena_Danza.pdf>.
} 
Mediación Digital en Danza ${ }^{56}$, otras universidades del país y del exterior, para promover espacios de formación ${ }^{57}$ y diálogo en la articulación entre danza performance y tecnología producida dentro de los laboratorios de las instituciones educativas.

Las conferencias performáticas se presentaron en clave audiovisual y corporal, ya que todos los invitados realizaron sus presentaciones en torno al cuerpo, a la proyección de videos y a la intervención del espacio con visuales, animaciones y textos proyectados.

En las jornadas interinstitucionales, se compartió uno de los ejes rectores del ciclo que observaba las posibilidades y las dificultades de la interrelación entre el cuerpo en movimiento y la tecnología, procurando generar, en el diálogo, una reflexión de carácter colectivo.

Uno de los interrogantes que surgió con respecto a esta temática situó la relación entre la limitación o la autonomía tanto del performer como de los propios programadores al trabajar desde sus posicionamientos disciplinares. Es decir, hasta qué punto el performer está realmente dialogando con el sistema y cuánto de esto el programador advierte y puede traducir y modelizar como operador de software o como desarrollador de lenguaje algorítmico.

Nos detenemos por un momento para precisar el alcance de estos dos términos: traducir y modelizar. Traducir, para Vilém Flusser (1985: 6), es "cambiar de un código a otro, por lo tanto, saltar de un universo a otro" ${ }^{58}$. Los procesos de trascodificación que conllevan a sucesivas abstracciones dan ingreso a la traducción como un posible regulador entre lo que se inmaterializa y lo que se rematerializa, lo que implica la mutabilidad de un sistema nominal hacia otro sistema modular. Claudia Giannetti (2002: 174) apunta al respecto:

En el concepto de "traducción" se encuentra el problema, puesto que, además de conectar distintos canales de entrada y salida, tiene que regular y transmitir diferentes procesos de codificación. Asimismo, se trata de una interfaz humano-

56 Con el fin de ampliar la información, véase: <http://www.alejandraceriani.com.ar/catedra_libre.html; http://tecnologiaydanza.blogspot.com.ar>.

57 Por orden cronológico, se organizaron los siguientes encuentros y jornadas: I Encuentro sobre Educación, Danza y Mediación Digital y III Jornada de Intercambio en Tecnología Aplicada a la Danza, Universidad Federal de Bahía Salvador, UFBA, Brasil e InTAD, UNA, Departamento de Artes del Movimiento, CABA. Reseñas de la Prof. Diana Montequín y la Lic. Mariana Sáez. I Jornadas Nacionales de Danza y Performances En Clave Audiovisual, Universidad Nacional del Nordeste, Universidad Nacional de Villa María, Universidad Nacional de las Artes. Reseñas de la Dra. Natalia Matewecki. Jornadas sobre Espacios y Cuerpos de Código Abierto, Facultad de Periodismo y Comunicación Social, UNLP, UISEK, Santiago de Chile, Escuela de Danzas Clásicas LP. Reseña de la Lic. Javiera Sáez Mansilla [en línea]. Dirección URL: <http://www.unlp.edu.ar/uploads/docs/anuario_arte_y_cultura_2014.pdf>.

58 Traducción propia: "Traduzir: mudar de um código para outro, portanto, saltar de um universo a outro". 
máquina, o los canales de entrada y de salida pueden ser adaptados entre ellos, ya que la persona, como un sistema autopoiético, no los posee; o no se puede hablar de una traducción de procesos de códigos, ya que las formas de representación simbólicas del sistema nervioso humano (aún) no han sido descifradas.

Giannetti se refiere a un lenguaje del cuerpo en el que lo proyectado se torna visible, pero cuya complejidad no puede ser simplemente descifrada. Un cuerpo como material y matriz de otro lenguaje de código inmaterial, de otra naturaleza. En este sentido, podemos vincular un entorno de programación para el desarrollo de algoritmos, el análisis de datos, la visualización y el cálculo numérico con la capacidad que tiene el programador de "interpretar los datos del sensado" -registrados previamente por un dispositivo de captación (ej. cámara kinect)- sea de un gesto o del movimiento global del cuerpo.

A su vez, el ingreso de datos y su recodificación comporta un ciclo con una serie de fases o etapas a las que Emiliano Causa (2014: 66) describe como ciclo interactivo y que se comporta de la siguiente manera:

... el ciclo de la interacción transita por siete pasos que van desde el interactor (humano) al sistema (el dispositivo, la o las computadoras, etc.) y vuelve hacia el interactor nuevamente. El ciclo se piensa como un flujo de comunicación que va transitando entre el interactor y el sistema, y en cada una de estas "partes" transita por diferentes etapas. Cada etapa representa una problemática en la que intervienen diferentes elementos y variables, y en las que se producen diferentes fenómenos y tipos de información. En el humano (el interactor), las etapas son tres: Percepción, Interpretación y Acción. En el sistema, pasa por cuatro: Captación, Análisis, Simulación y Representación.

Comprender la interacción entre las distintas partes de un sistema y sus características más importantes vinculadas con el cuerpo en movimiento -de manera que pueda ser aplicado de modo general- aporta a una comprensión de la estructura y los procesos, más que a un establecimiento de correlaciones o relaciones de causa y efecto. El pasaje del músculo al píxel y de la carne al número es metáfora de disolución de la materia física y orgánica del interactor hacia la constitución de otra materialidad a través del sistema, pues, si la materia tiene masa y ocupa un lugar en el espacio, indica que es cuantificable, es decir, que se puede medir. En tal sentido, es 
determinante la posibilidad técnica de la interfaz o dispositivo ${ }^{59}$, pues da mayor o menor rendimiento al procesamiento y transformación de los fenómenos físicos en datos numéricos.

Con referencia a esto, Emiliano Causa (2014: 68) advertirá sobre ciertas confusiones que esta tarea del sistema genera para quienes lidiamos "solamente con el canal productivo, pero no con el proceso codificador interno" (Machado, 2000: 20):

\begin{abstract}
Uno de los errores más comunes que se establecen es que el artista (tanto el performer, como el artista programador, ambos roles pueden ser realizados por la misma persona) confunde la captación del fenómeno con el fenómeno en sí, olvidando que la captación es un proceso de modelización de la realidad y, por ende, conlleva una pérdida, determinada por los límites del dispositivo.
\end{abstract}

A partir de la pregunta “¿Una intervención artística verdaderamente fundante es impracticable si no hay una movilización hacia el interior de la caja negra?" (Machado, 2000: 22), nos situamos en la problemática sobre el nivel de competencia tecnológica que debe tener un artista como usuario de la computadora. En programación, se pone el énfasis en el qué se hace más que en el cómo se hace. El denominador común en el avance de los lenguajes de programación ${ }^{60}$ ha sido el nivel de abstracción que utilizan para parametrizar el qué se hace, o, lo que equivale a decir que se asignen valores a los parámetros ostensibles para modificar o influir en su comportamiento.

Igualmente, la abstracción consiste en aislar y simplificar, minimizando así la cantidad de características que definen a un objeto. Esto conlleva varios problemas intrínsecos que, pensados desde la interactuación entre un cuerpo en movimiento y la captación del sistema, podrían exponerse como aquellas problemáticas que se originan a partir de priorizar lo contingente o lo eficaz. Es decir, si se propone desde la improvisación pautada a través de los componentes abstractos del movimiento o se priorizan aspectos efectivos de estímulo-respuesta a través de la gestualidad a niveles "expresivos" del movimiento.

Actualmente, y "gracias a las tecnologías vinculadas con el análisis de movimiento es posible capturar las dinámicas particulares que acontecen en una frase motriz para expresarlas en formas audiovisuales", asegura José L. García Nava (2012: 2). En esa

\footnotetext{
${ }^{59}$ En informática, la interfaz o dispositivo es una conexión que se da a nivel físico (hardware) y a nivel lógico (software) con la computadora.

60 Un lenguaje de programación es un conjunto limitado de palabras y de símbolos que representan procedimientos, cálculos, decisiones y otras operaciones, que tiene la capacidad de ejecutar una computadora. Existen lenguajes declarativos, imperativos y de programación orientada a objetos.
} 
misma línea de desarrollo de métodos computacionales, la Computación Afectiva (Affective Computing) tiene como objetivo que computadoras, cámaras y programas asociados puedan interpretar los comportamientos y gestos de los seres humanos para generar emociones sintéticas. Estos son los estudios sobre la codificación de las emociones en equipos informáticos más empáticos en la interacción humanocomputadora.

Así es que citaremos a la bailarina performer Soledad Belén (2013: 1'45") -en una de las entrevistas realizada durante el seguimiento del proceso de esta propuesta de investigación artística- cuando declara: "Me sentí traducida", pero agrega "lo que siempre se cruza, es lo más difícil de lograr, que se traduzca porque es lo más difícil de captar: es la energía; y es la energía de la danza".

Pareciera ser que habría que conocer cómo opera la caja negra, y aquí entramos en un debate iniciado por Arlindo Machado respecto de la argumentación que Vilém Flusser (1985: 11) expone desde este vínculo productivo con los aparatos: "Quien ve input y output ve un canal y no un proceso codificador que pasa en el interior de la caja negra. Somos, por lo tanto, analfabetos en cuanto a las relaciones de las imágenes técnicas. No sabemos cómo descifrarlas" ${ }^{21}$. Siguiendo este concepto de Flusser, Machado (2000: 40) destaca que "registrar automáticamente impresiones del mundo físico transcodifica determinadas teorías científicas en imágenes", o para usar las palabras propias de Flusser, "transforma conceptos en escenas".

Jean-Luc Godard (1980: 83) sostiene que quienes realizan el acto de registrar automáticamente impresiones del mundo físico como aficionados "hacen la fortuna de la Kodak; ruedan muchos planos, pero siempre ruedan un solo plano [...] no ruedan nunca otro plano detrás de ese plano". En cambio, al usuario que trabaja con dispositivos y obtiene de ellos las imágenes técnicas, Flusser -citado por Machado (2000: 21)- lo denomina funcionario:

El funcionario domina solo el input y el output de las cajas negras. Él sabe cómo
alimentar las máquinas y cómo apretar los botones adecuados, para que el
dispositivo pueda escupir las imágenes deseadas. De esa manera, el funcionario
elige, entre las categorías disponibles en el sistema, aquellas que le parecen más
adecuadas y con ellas construye su escena. Visto que puede elegir, el
funcionario piensa que está creando y ejerciendo una cierta libertad, pero su
elección será siempre programada, porque está limitada por el número de

61 Traducción propia: "Quem vê input e output vê o canal e não o processo codificador que se passa no interior da caixa preta [...] somos por enquanto analfabetos em relação às imagens, não sabemos como decifrá-las". 
categorías inscritas en el aparato. Para producir nuevas categorías, todavía no previstas en la concepción del aparato sería necesario reescribir su programa, o sea, penetrar en el interior de la caja negra y rehacerla.

Pensamos entonces que esta movilización de la que habla Arlindo Machado -en la sapiencia del bailarín performer- no sería hacia nociones que desentrañen el lenguaje de la caja negra, sino hacia una movilización de asociaciones conceptuales que permitan el desarrollo de prácticas artísticas interdisciplinares; y derriben preconceptos tácitos que existen entre tecnólogos y artistas de la danza performance. Lo esperado sería congeniar hacia una conciencia transdisciplinar.

Otra cuestión clave es el concepto de modelización utilizado en informática para la propia experimentación del cuerpo en vinculación con un sistema interactivo basado en el movimiento. Modelar, en este campo específico del trabajo con lo escénico y sus implicancias, es construir un modelo de un fenómeno físico en términos matemáticos por parte del programador. El modelo que se construya dependerá, por lo tanto, de los objetivos del programador, de las restricciones y de las simulaciones que se hagan sobre el fenómeno corporal, en nuestro caso.

Tener en cuenta la dimensión sensible de las tecnologías nos permitiría iniciar una observación concreta de los procesos cinestésicos en el cuerpo y en la percepción tanto en performers bailarines como desarrolladores $u$ operadores de sistemas interactivos escénicos. En ese sentido, preguntarse si es posible una danza, un lenguaje del movimiento plenamente interactivo, conforma otro de los ejes que ha atravesado las reflexiones a partir de la experimentación del 2013 y los eventos del 2014.

En una entrevista realizada a Ludmila Hlebovich (2013: 70), otra de las reseñistas, que llevó a cabo el seguimiento de CuerpoMóduloCódigo ${ }^{62}$-equipo conformado por la bailarina performer Soledad Belén y los programadores del Laboratorio Multimedial emmeLab ${ }^{63}-$, señala:

Es una ilusión la de pensar que la danza brindará sencillamente el aporte de su campo a las nuevas tecnologías o viceversa. Este encuentro tiene características y consecuencias que reclaman un trabajo atento, que reclaman investigación. Para la performer, el encuentro con una cantidad de información novedosa implicó cierta complejidad, además del desafío de esta experiencia particular de

62 Reseña CuerpoMóduloCódigo, p. 74. Con el fin de ampliar la información, véase: $<$ http://www.unlp.edu.ar/uploads/docs/anuario_2013_de_arte_y_cultura.pdf>.

63 Se trata de un laboratorio de investigación y experimentación multimedial, formado por docentes y estudiantes de la carrera de Diseño Multimedial, de la Facultad de Bellas Artes, UNLP. 
ser intérprete y creadora al mismo tiempo. [...] existe una nueva complejidad y readaptación de la bailarina respecto de las nuevas tecnologías.

La lucidez de la observación citada pone de manifiesto que la problemática que nos atraviesa no es solo del orden de lo reflexivo, de voluntades por trascender los límites disciplinares, etcétera, sino que son problemas sistémicos y funcionales a las propias tecnologías. Al respecto, Ludmila Hlebovich (2013: 9'44") declara: "lo que yo vengo observando hasta ahora son los límites entre los distintos lenguajes y hasta dónde se pueden realmente comunicar". Emiliano Causa (2014: 68) revela esta limitación ya en la captura:

... la Kinect puede parecer un dispositivo maravilloso que nos brinda la información del fenómeno que queremos captar, es decir, podemos confundirnos y creer que "la Kinect captura el movimiento del performer". Pero si ahondamos en cómo funciona este dispositivo, comprenderemos sus límites. Cabe aclarar que no estoy criticando al dispositivo en sí, realmente la Kinect es una gran herramienta, sino que quiero llamar la atención sobre cómo nos posicionamos como artistas frente a estos dispositivos y nos dejamos obnubilar por sus capacidades y perdemos de vista sus limitaciones, que son las que influenciarán y determinarán parte del derrotero del ciclo interactivo.

Asimismo, cabe destacar que uno de los mayores problemas que presenta la interfaz de Kinect es que, al presente, no permite personalizar los gestos para que el software los reconozca. Este inconveniente hace que, cada vez que se desarrolla una aplicación que utilice como entrada los datos ya recabados por el sensor Kinect, tengan que estudiarse primero los movimientos que tendrá que reconocer el software, para, posteriormente y a través de la escritura en código, asignarle los componentes precisos para que los reconozca durante la ejecución.

En ese sentido, sería óptimo para el bailarín performer realizar un sistema de captura y reconocimiento de gestos que le posibilite definir sus propias posturas, sus propios gestos, personalizando así la interfaz y no que sea siempre del modo inverso. Conocer de antemano estas limitaciones es fundamental, pues en general la obsecuencia hacia la tecnología discurre y se naturaliza nuestra imposibilidad o, por el contrario, vamos pensando y creyendo que los dispositivos, la interfaz y el software pueden capturar el movimiento del performer tal cual, per se.

En ambos casos, la tecnofantasía se fundamenta en la confluencia entre tecnología y deseo, tanto en el sentido corporal como en el social; y planteárselo deja expuesto nuestro modo de "poner el cuerpo" ante los artefactos. Uno de los integrantes del 
grupo de investigación y experimentación multimedia emmeLab lo ejemplifica cuando expone el inicio de la experiencia de interacción con la bailarina: "Nosotros creíamos que esto iba a ser tan sencillo como asignarle algún elemento al espacio o al cuerpo y que convivan espacio y cuerpo, y terminábamos ahí" (Rivero, 2013: 0'50").

No debemos dejar de mencionar otra idea que ponderamos en la interacción, y es la de diálogo. Esta acción comunicativa está profundamente arraigada en el ideario de nuestras acciones con instalaciones interactivas, por ejemplo, y en donde se proyecta esa cuasi otredad incorpórea que entra a responder en ese ida y vuelta sensorial a través de imágenes o sonidos.

Rosa Nolly (2013: 8'01"), compositora invitada por el laboratorio emmeLab, entrevistada en un ensayo, decía al respecto:

Nolly: Por un lado, está el directo que es el cuerpo y las extremidades moviéndose, y eso generando un dato puntual; y por otro lado, está cómo eso va a generar algo visual, cómo eso se expande a nivel visual y a nivel sonoro.

Entrevistador: Entonces el cuerpo está mediado, no es que el cuerpo está produciendo, sino que tira una data que se transforma en otro sistema y ahí vuelve, ¿o no vuelve ya?

Nolly: No ya no, es solamente como un reflejo.

En ese sentido, podemos especular con que la interacción solo es efectiva si existe retorno de información, un feedback. Si quien está interactuando carece de respuestas, no puede saber si está actuando correctamente; y es ahí donde prevalece la capacidad de un software o programación para interpretar y dar retorno en condiciones y contextos específicos. $Y$ aquí aparece nuevamente el concepto de ciclo interactivo: si no hay feedback se dificulta la etapa de interpretación del humano. Entonces diríamos que la simulación física de las coordenadas del gesto/postura puede considerarse como ese "reflejo" de la experiencia corporal en un sistema interactivo. Una de las facetas posibles de la improvisación con sistemas de captación óptica es la relación que se organiza entre la presencia del cuerpo y la ausencia física de la interfaz. Esa indeterminación del gesto en la ejecución interactiva, las adaptaciones y los cambios que se convierten en el evento son también parte de un método aleatorio de control del sistema de captación que se genera en la propia improvisación.

Por ello, el bailarín performer que nos interesa estudiar aquí es el que está predispuesto no solamente a comprender los mecanismos del ciclo interactivo, a traducir al lenguaje corporal los conceptos y las estructuras generales de la puesta 
multimedia, sino también a familiarizarse con el modo de construir abstracciones complejas que hagan uso del sistema en ejecución. Por ende, son fundamentales el intercambio y la comunicación entre el equipo o el artista programador y el performer interactivo para lograr un entendimiento mutuo. Al respecto, Jean-Luc Godard (1980: 85) señala:

\begin{abstract}
A veces intento hacer una investigación, a mi manera. Es decir... he trabajado... ella ha trabajado... pero vivimos en un mundo en el que hasta en esta actividad en la que me parece más fácil, no se consigue trabajar conjuntamente. $Y$ no creo que sea muy fácil trabajar con alguien.
\end{abstract}

Más adelante nos detendremos a revisar cuestiones que atañen a un desarrollador de software, pues este necesita comprender las proposiciones corporales, sensitivas y dinámicas del bailarín, para compartir y resolver las dificultades que se van generando en las diferentes fases en la que transcurre un proceso interdisciplinar de estas características. También es muy importante conocer las bases teóricas y comprender de forma integrada distintas disciplinas que tienden a verse como cajas estancas y sin relación. De este modo, habría que diferenciar al bailarín intérprete de un espectáculo con sistema tecnológico escénico de un performer que interactúa dentro de un laboratorio abierto al público.

Soledad Belén (2013: 2'43") deja en claro la conciencia interdisciplinar que está advirtiendo en su proceso de trabajo con los programadores del emmeLab: "Todo lo que hago cobra sentido porque se traduce inmediatamente. Estoy todo el tiempo armando a partir de eso. Ni estoy sola ni tampoco me muevo como quiero... y lo que pasa es lo que pasa; en ese sentido, sería para mí efectista". Además, manifiesta la sensación de crisis a medida que comprende qué niveles de competencia tecnológica debe operar un bailarín, un performer, un coreógrafo: "te da como una cosita de crisis porque decís: ¡acá no me veo, no me luzco, no se me ven los músculos...!" (Belén, 2013: 4'45").

Entonces, qué tipo de movimientos, qué carácter del gesto corporal se debe desplegar para interactuar a través de reconocer la díada diálogo o control. Las transformaciones que provoca en nuestros cuerpos y nuestra percepción la tecnología interactiva en tiempo real involucra, asimismo, otras destrezas y comprensiones en el orden kinestésico y compositivo dentro del lenguaje de movimiento para la danza performance: 
La idea de un desplazamiento del centro, de un descentramiento, la hallaremos como figura aprehensible junto con la idea de la materialidad-inmaterialidad del cuerpo en interacción con dispositivos, software y programaciones. Esto motivará otra brecha para la observación que puntualizaremos como "la imagen del cuerpo digitalizado". Esta entra en relación con el movimiento y el discurso, los problemas de representación y los mecanismos de interpretación. Esto conlleva efectos a nivel compositivo para el lenguaje corporal que dialoga con el sistema interactivo: no se logra reproducir movimientos, ni coreografiarlos desde el enfoque habitual con el que se produce en danza. Consideramos que se hace necesario reflexionar sobre los cambios significativos en el lenguaje de movimiento, sus formas y modelos compositivos. Es ahora cuando el cuerpo vive innovadoras e intensas experiencias (Ceriani, 2010: 5).

$Y$ es justamente esta posibilidad de controlar, o no, la que queda en jaque y produce nuevas coyunturas al interior del diseño de movimientos en la danza performance así como en el diseño de interacción. En consecuencia, ampliaremos el campo de investigación, pues ya no solo nos ocupará el performer bailarín, sino el programador u operador de sistemas informáticos interactivos. Ello conlleva a pensar lo que plantearon las reseñistas Diana Montequín y Mariana Sáez (2014:26) sobre la factibilidad de:

\begin{abstract}
... pensar la tecnología como un performer más, lo que implicaría correrla del lugar de mera reacción pasiva ante estímulos producidos por un cuerpo humano- activo y darle el lugar de colaborador o, incluso, de autor (o coautor) del hecho artístico. Otro de los ejes de debate se centró en la posibilidad de reconocer este campo de interjuego entre danza y tecnología como un nuevo lenguaje estético, que se distinguiría de los lenguajes de la danza y del arte digital.
\end{abstract}

Una revisión de los paradigmas en los cuales estamos pensando y actuando es lo que dará sustento material al desarrollo de lo que sigue a continuación. Por tanto, ya se auguraba, desde estas reflexiones conjuntas, que se vuelve necesaria una concepción -de la tecnología, de la propia danza y del cuerpo del performer bailarín- que Diana Montequín y Mariana Sáez (2014: 26) expresan del siguiente modo:

... dejar a un lado el mecanicismo, el positivismo y el instrumentalismo. [...] Quizás, dejar en suspenso las preguntas por definiciones en términos de lenguajes, disciplinas y técnicas nos permita correr las limitaciones conceptuales, corporales y estéticas que todavía nos anclan a esos viejos paradigmas. 
Por una parte, indagar cuáles son las transformaciones del cuerpo disciplinar en articulación con los sistemas interactivos es pensar crítica y sensorialmente fuera del gesto reduccionista de ser solo una pieza activante del sistema. Por otra, indagar es identificar cuáles son las limitaciones de los programadores u operadores informáticos que solo articulan con un cuerpo basado en coordenadas, cuyo reconocimiento se aplica mediante un modelo que debe funcionar para cualquier cuerpo que realice "ese" gesto ergonométrico. Por el contrario, se aspira a congeniar la performance interactiva en un proceso algorítmico en el que el cuerpo active -con un cierto grado de autonomía- un sistema que se retroalimente no desde un reflejo, sino del propio cuerpo actuante y consciente de estos niveles de abstracción con el que será traducido y modelizado.

Por consiguiente, a continuación, iniciaremos una revisión de los trabajos generados dentro de la investigación artística del ciclo 2013 a partir de la consigna "un programador y un bailarín trabajando cuerpo a cuerpo". Dentro de este marco, vamos a analizar la performance interactiva CuerpoMóduloCódigo, que estuvo a cargo de Soledad Belén. Asimismo, la programación fue del laboratorio emmeLab (Francisco Álvarez Lojo, Ezequiel Rivero, Ariel Uzal, Rosa Nolly y Emiliano Causa), la reseñista fue Ludmila Hlbovich, y la producción audiovisual, de Cirila Luz Ferrón.

\section{Cuerpo. Módulo. Código.}

CuerpoMóduloCódigo es una performance interactiva creada para "poner cuerpo a cuerpo" a un programador y un bailarín, una convocatoria que propone hacer consciente la presencialidad del cuerpo para ambos. En esta ocasión, se conjugaron la coreógrafa, bailarina y performer Soledad Belén con el grupo de programadores pertenecientes al emmeLab. Centralmente, exploraron la relación entre el cuerpo, el movimiento, su modelización y transformación en imagen y música. Se observó cómo el cuerpo iba incorporando la lógica de las máquinas sonoras virtuales que lo captaban, incluían y condicionaban, desplegándose así una trama musical que intentó aprehender la gramática del movimiento.

Tanto los programadores como la performer destacaron que hubo un fenómeno en la transmutación de estos sistemas de distinta naturaleza y al cual denominaron módulo o ente, producto de informaciones previamente inexistentes. En ese sentido, Ezequiel Rivero (2013: 0'18') declara: 
La fusión de estos dos universos: danza o el universo corporal y nuevas tecnologías, en realidad, proponían no una unión sin la modificación de ninguno de ellos sino como una negociación. Nosotros descubrimos que apareció un nuevo ente que nos forzaba y tomaba decisiones por sí solo. Es decir, nosotros [los programadores] teníamos unos planes originales sin tener en cuenta esa mixtura que iba a suceder. Finalmente, nos dimos cuenta de que nuestros planes eran ideales y que no estábamos considerando un montón de elementos que fueron apareciendo.

El término módulo que forma parte del título de la performance refiere a una operación que Ezequiel Rivero (2013:1'20") explica de la siguiente manera: "De hecho el proyecto se llama CuerpoMóduloCódigo, porque citamos una palabra, justamente: módulo, que es el resto entre un cociente de dos términos, no el resultado, sino el resto, lo que queda". Dicho fenómeno se instaló como un elemento extraño, es decir, como una información nueva creada por la acción recíproca de los artistas: programador y bailarina mediados por hardware, software y dispositivos, van montando una modificación del código, a fin de hacerlo más rico, permitiendo, de ese modo, que envíe datos de un nuevo patrón.

Estos elementos extraños, estos ruidos, operaron como intermediarios que no solo comunicaban o posibilitaban la fluidez entre ambos sistemas -el de programación y el de movimiento-, sino que crearon un tercer componente híbrido que ingresó como un posible regulador entre lo que se inmaterializaba y lo que se materializaba, implicando, de esta manera, el tamiz entre un sistema unívoco y otro articular. Es decir, se trata de un sistema de experiencias de interacción con estratos de información, no en términos unívocos sino relacionales, no como descripciones sino como manifestaciones en las que tuvo lugar una intercomunicación original, inaudita, una por cada exploración.

Ezequiel Rivero (2013:1'50") ilustra lo expuesto: "Nosotros empezamos el proyecto tratando de conseguir un resultado de la fusión de estas dos cosas [danza y tecnología]. Finalmente lo que obtuvimos no fue el resultado sino el resto". Así describirá este acontecimiento Ludmila Hlebovich (2013: 71):

Este nuevo ente, a fuerza de resistencias, rompió con los planes originales de los programadores hasta que todo el grupo decidió trabajar con esa novedad. Incluso, el nombre de la performance incluye la palabra "módulo", tomada en su acepción de resto de la división de dos números naturales, buscando dar cuenta de que la performance tenía por foco y protagonista al resto -y no al resultadode este encuentro entre danza y tecnología. 
Por su parte, el concepto de mediación es esencial, pues es lo que permite establecer una relación, real, simbólica o, incluso, híbrida, entre estos componentes, que retiene algo de su sustancia anterior y, al mismo tiempo, le confiere una nueva.

Por lo menos existen tres posibilidades de abordaje para la creación, producción y difusión de los trabajos artísticos basados en sistemas informáticos. Estos consisten en un conjunto de partes: hardware, software, sus dispositivos periféricos y las personas que lo aplican; en este punto, Emiliano Causa (2014:71) describirá la experiencia performática:

... Si se desea trabajar con el movimiento del cuerpo, como información de entrada en el sistema, es necesario que los procesos de captación y análisis tengan la mejor resolución posible. En el caso de la captación, la cuestión se encuentra determinada por los límites de los dispositivos y el margen de maniobra se reduce a la calibración de dicho componente.

Yendo más lejos, aludiremos al cuerpo que danza para engendrar una actualización en los planos de composición donde materia-energía se propaga en materiainformación, y hace surgir una nueva condición antropomórfica que no solo atañe al cuerpo físico, sino a la sensibilidad y a la conciencia humana. Aquí es importante dejar claro que los dispositivos tecnológicos solo trabajan en la superficie aparente, siempre reconocible, padronizable.

Por este motivo, Emiliano Causa (2014: 69) continúa afirmando:

... En tanto el performer sea consciente de estas restricciones en la captación, puede suceder que este empiece a modular sus movimientos y acciones para facilitar la captación, pero en vez de lograr que el sistema capte el fenómeno, lo modifica desde la misma producción del fenómeno, es decir, se degrada la experiencia para que sea aprehensible por el sistema. A esto he decidido llamarlo "encorsetamiento" del cuerpo, porque es como si el cuerpo fuera limitado en sus movimientos por un corsé virtual, que el performer se autoimpone para amoldarse al sistema.

Desde nuestra experimentación -que lleva un largo recorrido-, diremos que en estas prácticas artísticas el cuerpo no interviene ni es intervenido, sino que interactúa transmutando su materia de carne a número. En primer término, dialogando en retroalimentación con el sistema de interacción inmersivo propuesto: con los dispositivos de captación, el espacio medido y las respuestas en tiempo real de las interfaces; y, en segundo término, activando la conciencia de la amplificación del 
cuerpo real en la imagen virtual. Esta amplificación deriva en la constitución de un cuerpo digitalizado cuya otredad, cuya materialidad, depende de la propuesta de movimiento global que la performer efectúe.

Para este trazado desde las perspectivas de la programación y la interacción con dicho sistema, citaremos otro pasaje del texto de Emiliano Causa (2014: 72) en el cual expresa:

\begin{abstract}
... Creo que es importante ser consciente del funcionamiento del ciclo de interacción, porque al conocer las restricciones implicadas en cada etapa, su tratamiento pasa a ser una decisión de diseño y no un accidente que genera ruido en el discurso. [...] Por esto, es una decisión del artista, ver cómo establecer este juego de relaciones, y qué lugar toman las restricciones en este complejo proceso de representación.
\end{abstract}

En consecuencia, plantearemos que la creación dentro de estas prácticas artísticas se refiere a programar -a través del conocimiento de los códigos propios del lenguaje informático o a través del conocimiento del software y sus objetos preconfigurados, o de la mixtura de ambos procesos con dispositivos e interfaces escénicas- con la propuesta de movimiento corporal y, básicamente, con la conciencia de los planos existentes y simulados de los artistas intervinientes.

Y aquí queda manifiesta la distinción: no hay un artista y su obra, sino una propuesta participativa en una práctica artística integrada a un proceso de investigación y desarrollo que coloca, en un plano híbrido, al programador y al performer en procura de una renovación conceptual y sensorial sobre la mirada del arte y de una estética que se enlaza con procesos científicos y con tareas de laboratorio.

\title{
29. Cuerpo. Interfaz. Metáfora
}

Podríamos emprender un nuevo análisis suponiendo que toda producción de arte electrónico-digital es resultado de colaboraciones entre artistas de dominios heterogéneos. Nos centramos en dos cuestiones esenciales: por un lado, los interrogantes teóricos que se plantean en el campo de la danza a partir de la dominancia en la mediatización contemporánea alcanzada por los sistemas informáticos y por las interfaces específicas que se articulan; $y$, por otro, la mediatización como una perspectiva de estudio que posibilita la identificación de una cantidad de particularidades de los actores intervinientes, en la que se puede distinguir 
al programador o desarrollador de sistemas a partir de situarse como operador, como técnico o como un metaperformer que se integra al trabajo creativo. Por tanto, este apartado está constituido también por los relatos de los investigadores y artistas sobre la mediatización y su dimensión disciplinar.

Centrarnos en las diversas exploraciones llevadas a cabo por los participantes del ciclo de danza en la Universidad, así como por colegas con los cuales hemos trabajado y continuamos intercambiando hace algunos años, hace de este texto un abordaje enriquecido desde diferentes perspectivas y enfoques, algunos más teóricos y otros mayormente vinculados a las prácticas y a los usos propios de la etapa actual de la mediatización.

Cabe señalar que hoy la investigación interdisciplinar se abre hacia un futuro en el que el arte y la informática, el cuerpo y la digitalización, estarán aún más compenetrados de lo que se entiende en el presente, y la transdisciplinariedad avanzará sobre formas de investigación integradas.

Consiguientemente, nos formulamos la pregunta: “¿dominio o disciplina?" que ya realizara Umberto Eco (2000: 23) a propósito de su campo de estudio. Entonces, interpretaremos esta pregunta en función del devenir reflexivo sobre el arte digital o arte interactivo, la danza, la performance, etcétera, prácticas híbridas puestas a colaborar para crear no solo un producto, sino una metodología transdisciplinar.

Así, los sistemas complejos conformados por unidades heterogéneas en intercambio permanente con un contexto activo nos permiten concebir cada campo disciplinar en juego como un sistema dinámico que enfatiza los procesos y las transformaciones que operan en resultados momentáneos; por tanto, el diseño mismo de la reciprocidad comprende lo inesperado, lo contingente, lo fluctuante. De este modo, nuevas experiencias transdisciplinares -que cada artista proveniente de la escena, la informática o la ciencia comparte- promueven dominios diferenciados $\mathrm{y}$, a la par, dispuestos a integrarse. Con esta hibridación urge empezar a formalizar una construcción metodológica sobre el entrecruzamiento que se da entre los discursos artísticos, los distintos medios y los conocimientos tecnológicos, a la hora de poner en práctica una creación colaborativa en tiempo real.

Sin embargo, aun pudiéndose hacer una diferenciación objetiva entre ambos, nos preguntarnos si la informática aplicada al arte, y en particular al arte escénico, es una disciplina artística con su objeto y método propio o es un "dominio de estudio, un repertorio de intereses todavía no unificados y quizás no del todo unificable" (Eco, 2000: 23). Hacer esta distinción nos guiará hacia argumentos que reúnan conceptos y metáforas de nuestra incumbencia. 
Entonces, comenzaremos interrogándonos acerca de la creación y la producción. Para ello, citaremos a Marta Zátonyi (2002: 9) cuando plantea: “¿La informática genera arte?, ¿existe arte que no esté solo transmitido, sino también producido por los medios y por la tecnología de la informática?". Uno y otro interrogante ya han abierto el debate

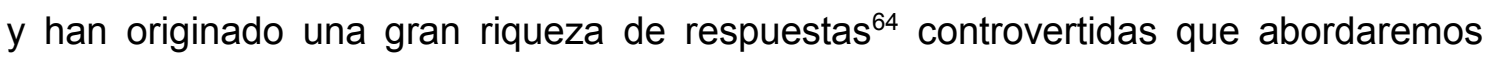
examinando, por una parte, la idea de la disolución de una materialidad a otra: de la danza a las matemáticas, del cuerpo físico al cuerpo digitalizado; y, por otra parte, incursionando sobre qué piensa un programador cuando está generando el mismo tipo de información para una persona (bailarín performer) o para una máquina (ciclo interactivo).

Esto nos lleva a considerar que dicha materialidad requiere un tratamiento específico para la obtención de algún resultado, por lo tanto, se podría afirmar que se ponen en interacción ciertas técnicas -en el sentido de reglas para la obtención de algún resultado- que se aplicarían sobre dichas materialidades: cuerpo y algoritmo.

Un particular entendimiento entre el entorno digital y el cuerpo real reactualiza el concepto de lugar que se aparta claramente de su acepción tradicional y hace necesario que el cuerpo -nuestro soporte material- y el lugar físico de la realidad se disuelvan para que se pueda realizar la conectividad cambiando, de esto modo, nuestra aprehensión sensoriomotriz y nuestra interacción espaciotemporal. Los vínculos entre territorio y lenguaje corporal se enriquecen, y todo ello es traducido por lo digital que vivifica cualquier forma de interacción. En consecuencia, el trabajo con los espacios obrados por dispositivos técnicos actuales, es decir por medio de una interfaz física y virtual, busca en las artes en general nuevas redefiniciones.

Para comenzar, diremos que hablar de interfaz es hablar de un espacio que media entre el cuerpo, la herramienta y el objetivo de una acción con alguna finalidad:

La conexión entre estos tres campos se produce a través de una interfase. Se debe tener en cuenta que la interfase no es un objeto, sino un espacio en el que se articula la interacción entre el cuerpo humano, la herramienta (artefacto, entendido como objeto o como artefacto comunicativo) y objeto de la acción. La interfase vuelve accesible el carácter instrumental de los objetos y el contenido comunicativo de la información. Transforma los objetos en productos, transforma la simple existencia física (Vorhandenheit) en el sentido de Heidegger, en disponibilidad (Zuhandenheit) [SIC] ${ }^{65}$ (Bonsiepe, 1999: 17).

64 Al respecto, véase en línea: <http://www.xanela-rede.net/wp-content/uploads/2013/02/DANZATELEMATICA_-A.-Ceriani.pdf>.

65 Uso de interfase/interface aclarado en el Capítulo 1 de esta tesis. 
Por su parte, el carácter inmaterial de la informática ha favorecido para clarificar y propagar el concepto de interfaz a otras categorías del diseño industrial del cual parte este autor. Lo que habría sido hasta entonces solo un instrumento descriptivo de una realidad interna o externa es entendido ahora como un dominio generativo capaz de crear nuevas realidades por medio de actos proyectuales donde la materialidad se transforma en un recurso ligado a un rendimiento.

\begin{abstract}
En 1972 no teníamos el término "interfase", tal vez ni existía en el campo de la informática. Pero visto desde hoy podemos decir que diseñábamos una interfase para poder intervenir en algunas variables neurálgicas de la economía, sus centros de producción y de distribución. Hoy tenemos otro concepto para el trabajo hecho hace treinta años: visualización de datos complejos para hacerlos comprensibles. Ahí tocamos una de las áreas más estimulantes del diseñador actual: usar el poder del espacio retínico (retinal space) para fines cognoscitivos y operativos [SIC] (Bonsiepe en Palmarola, 2001).
\end{abstract}

Este argumento nos permite ver la interfaz como una "necesidad de la construcción (un soporte necesario para la existencia y la mediatización) y la metáfora como la manifestación del fenómeno multimedia" (Causa y Joselevich Puiggrós, 2013: 45). La interfaz no lineal, como parte integral de su intención estética y comunicacional, genera diversas formas discursivas en nuevos contextos inmersivos de intercambio. Los lenguajes de programación por código o por entornos gráficos de objetos idearán un sistema que "no solo reaccione a un estímulo empleando una respuesta almacenada previamente entre muchas, sino que debe ser capaz de participar de manera tal que su conducta esté en el mismo nivel jerárquico que la del intérprete o la del público" (Zorrilla, 2011: 6).

La tendencia emergente de las redes virtuales hace que las interfaces que se integran, sean más participativas con los sistemas; más aún, con independencia, interdependencia y autorregulación, aprovechando así los niveles de interactividad en los que tanto el intérprete como el sistema participarían de la configuración del discurso artístico por igual.

Se podría definir el arte de la programación informática como aquel trabajo que hacen los artistas programadores cuyo material estético es el código y cuya producción expresiva es la programación. Por tanto, el software no tiene una función meramente instrumental, y el algorítmico escrito por los propios artistas (programas autónomos o aplicaciones basadas en secuencias de órdenes) es una creación artística por sí misma. En ese sentido, el código informático es material artístico genuino como lo son 
las imágenes en soporte digital o matérico. Una posible definición de código que sustenta la arquitectura del software es un conjunto abstracto de patrones que, según Hernando Barragán (2008: 140), sería:

Código: es el lenguaje preestablecido entre el programador y la máquina, mediante el cual ponemos en términos inteligibles por esta nuestras manifestaciones de creatividad; es pertinente aclarar que los lenguajes de programación y el código escrito en estos lenguajes (instrucciones codificadas) no son para comunicarse, sino para dar instrucciones a la máquina. La diferencia está en que no se pretende enviar un mensaje a la máquina, sino darle unas órdenes, y en que la máquina no puede usar este lenguaje para respondernos. La posterior interpretación y ejecución del código por parte de la computadora, materializa la posibilidad de una experiencia para el espectador (usuario) siguiendo un algoritmo, que paso a paso, nos permite estar más cerca de alcanzar nuestro objetivo en particular.

El entorno de la programación ${ }^{66}$, en nuestro dominio, es un espacio o escenario aplicado a lo informático en el que se emplean desarrollos de visuales, sonidos, proyectos multimedia y propuestas interactivas que comprometen al cuerpo. Son entornos inmersivos digitales en los que, en tiempo real, conviven datos con la mutabilidad permanente al ser tratados dentro de un contexto artístico, lo que promueve una actitud diferente del programador que configura un proyecto con otros artistas de otros campos.

Podemos ilustrar esta idea de entorno citando una entrevista que fue realizada al equipo $\ln T A D^{67}$ en la que, al preguntarles sobre un entorno gráfico aplicado a la danza, responden:

¿Isadora ${ }^{68}$ es un software? ¿Cómo trabaja?

Maximiliano: Isadora es un lenguaje o entorno de programación gráfico de alto nivel, desarrollado por Mark Coniglio para su compañía Troka Ranch, que dirige junto con Dawn Stoppiello desde 1994 hasta la actualidad. Tiene una interfaz

\footnotetext{
${ }^{66}$ En informática, un entorno puede ser uno de múltiples lugares en donde se siguen una serie de reglas o se suceden acciones similares de acuerdo con parámetros predeterminados. Entre los entornos más utilizados se pueden contar las aplicaciones y software de programación, que disponen de elementos y variables compartidas de manera que el desarrollador opere en consecuencia. También se suele hablar de entornos web en la medida en que responden a criterios o estándares a nivel internacional de funcionamiento. Con el fin de ampliar la información, véase: $<$ http://www.definicionabc.com/tecnologia/entorno.php>.

67 Equipo de Investigación en Tecnología Aplicada a la Danza (InTAD), Departamento de Artes del Movimiento, Universidad Nacional de las Artes.

68 Isadora, un software con licencia restringida, orientado al procesamiento de imagen en tiempo real, utiliza procesos automatizados o datos tomados del entorno a través de cámaras, micrófonos o sensores como cámaras infrarrojas o la Kinect. Con el fin de ampliar la información, véase: <troikatronix.com/>.
} 
gráfica de usuario extremadamente accesible que permite comenzar a programar casi inmediatamente que el usuario conoce el software e invita a la exploración y a la creación artística (Wille en Giovo, 2016: 1).

A continuación precisaremos qué es un programa, un programador y una programación. La programación es una redacción en lenguaje especializado para procesadores informáticos y "trata acerca de la construcción de algoritmos (conjunto de instrucciones que la computadora deberá seguir). Durante el desarrollo de dichos algoritmos es necesario establecer algunos datos. Los datos sirven generalmente como parámetros que establecen el grado y la forma con los que se ejecutan ciertas instrucciones" 69 . El lenguaje de programación está conformado por una serie de parámetros y códigos que el programador utiliza para desarrollar un software o una aplicación.

Existen distintos tipos de lenguajes, como el C, BASIC o Ruby ${ }^{70}$, especializados en ciertas tareas, que ocupan una posición intermedia entre los lenguajes nativos humanos y los lenguajes de la máquina. Pueden utilizarse para establecer programas que controlen el comportamiento físico y lógico de una máquina, para expresar algoritmos con exactitud o como modo de comunicación humana, etcétera. Por tanto, la programación -este conjunto de símbolos y reglas sintácticas y semánticas- define una estructura que escribe, ensaya, depura, compila y mantiene el código fuente de un programa informático.

Un programa es una lista bien organizada de instrucciones codificadas que pretenden hacer cumplir una tarea particular a uno o varios procesadores. A través de los circuitos que controlan, los programas interpretan datos, actúan sobre las informaciones, transforman otros programas, hacen funcionar ordenadores y redes, accionan máquinas físicas, viajan, se reproducen, etcétera (Lévy, 2007: 27).

La programación es una herramienta fundamental, pero es frecuente confundirla con la ingeniería de sistemas. Esta última se centra en los métodos, herramientas y procedimientos para establecer una observación en su desarrollo, lo que permite prever los resultados garantizando, de ese modo, la calidad de los sistemas. Ello no solo involucra la parte tecnológica, sino también su entorno; es decir, su viabilidad,

\footnotetext{
69 Con el fin de ampliar la información, véase: $<$ http://www.biopus.com.ar/emiliano/tutorial_programacion/tipos_de_datos/>.

70 Por ejemplo, Ruby es un lenguaje de programación interpretado, reflexivo y orientado a objetos; creado por el programador japonés Yukihiro Matsumoto, quien lo presentó públicamente en 1995. Software libre diseñado para desarrolladores que enfatiza las necesidades humanas más que las de la máquina.
} 
factibilidad, implantación y evolución de la solución integral. Una característica relevante de los lenguajes de programación es precisamente que más de un programador pueda usar un conjunto común de instrucciones que sean comprendidas entre ellos para realizar la construcción del programa de forma colaborativa.

En consecuencia, de estos avances en el ámbito del aprendizaje de la programación y en su proyección hacia el futuro, el software libre ha adquirido en la actualidad una gran trascendencia. Por tanto, dentro de los puntos principales para tratar respecto del software libre, podemos señalar que su uso permite la fomentación de valores tales como la ética y la no discriminación. $Y$ esto es lo que sucede comúnmente en la creación de comunidades de software libre y open source. Ambos términos, si bien están relacionados, se suelen usar indistintamente, aunque no signifiquen exactamente lo mismo, ya que existen algunas diferencias puntuales que consideraremos a continuación.

Entonces, el ingeniero de sistemas diseña, implementa, mantiene e innova el software. En cambio, un programador escribe, depura y mantiene el código fuente de un programa informático a partir de un algoritmo o instrucción, regularmente no se dedican a crear software. Los programadores de aplicaciones ${ }^{71}$, a diferencia de los ingenieros de sistemas y programadores, no necesitan conocer a fondo el modo de funcionamiento interno del programa. Por su parte, los programas de aplicaciones habilitan a las computadoras para suministrar determinados servicios a sus usuarios.

Tener en claro estas diferencias nos permite referirnos a las posibilidades de abordaje para la creación, producción y difusión de los trabajos artísticos basados en sistemas informáticos. Esto implica involucrarse interdisciplinariamente con quienes:

a) programan creando desde el lenguaje informático en beneficio de una determinada propuesta artística;

b) operan con programas de aplicación, aprovechando su accesibilidad;

c) trabajan en equipos colaborativos tanto con a como con $b$.

Esbozadas estas especificidades del trabajo con desarrolladores u operadores de software libre, open source o privativo, surge el siguiente interrogante: ¿qué tipo de software compartimos? ¿Por qué a algunos artistas nos interesa saberlo? El software "no es una herramienta más: se trata de una herramienta compleja cuyos componentes, su funcionamiento y su creación se nos presentan como una caja

\footnotetext{
${ }^{71}$ El software de aplicación (también conocido como aplicaciones o apps) es un software diseñado para asistir en tareas específicas. Dependiendo de la tarea para la que fue diseñada, una aplicación puede manipular texto, números, gráficos o una combinación de estos.
} 
negra, en términos de la teoría de Flusser" (Pagola, 2007: 1); y con respecto al artista: "seguramente le interesara conocer su herramienta de producción, para entender su lógica de funcionamiento".

Que sea libre, open source o privativo plantea, en primera instancia, una aptitud diferente ante el compromiso que asume el equipo de trabajo, puesto que, lo convierte en un modo alternativo de producción y circulación cultural. Nos disponemos o no a una conciencia participativa y adaptable que habla de nuestra condición e idiosincrasia. Las diferencias circulan entre una permanente evolución y manifestación del conocimiento emancipado o uniforme. A partir de este hacerse permanente de una propuesta artística con tecnología abierta o privativa, el tipo de software amplía las condiciones de experimentación en las que los artistas -yendo por ese camino rizomático- revelan usos casuales e, incluso, suscitan derivaciones inusitadas que contribuyen al trabajo de los desarrolladores o programadores.

Mudando la perspectiva de análisis pero en relación con la materia propia de cualquier tipo de software, Martin Heidegger (2010) llama "informe" a aquella materia que aún no ha sido formada y que constituye a la obra, y da como ejemplo un bloque de granito. En este plano de indagación, ¿qué diríamos de la materia "código"? El código es un signo, no está dado en la naturaleza como el granito, hay que generarlo. Una vez generado estaría en un primer estado que no es directamente ejecutable por la computadora, sino que debe ser traducido a otro lenguaje o código binario. Para esta traducción se usan los llamados compiladores, ensambladores, intérpretes y otros sistemas de traducción. Una vez traducida sería, entonces, una cosa: "La cosa es una materia formada" (Heidegger, 2010), pero a diferencia de los objetos materiales que se fabrican, los programas se escriben.

Para Emiliano Causa, estas herramientas de escritura que permiten crear programas en diversos lenguajes tienen cosas en común:

\begin{abstract}
En todos los casos se pudieron reconocer ciertos elementos generales que aparecían de manera constante, aun cuando los paradigmas de programación de cada lenguaje fueran diferentes. Estos elementos los definimos con los nombres de Materialidad, Representación, Primitivas, Parámetros, Estructuras y Espacios $^{72}$. Materialidad refiere a la salida que el programa puede producir (Causa y otros, 2015: 130).
\end{abstract}

La materialidad del código está conformada por una notación matemática entrelazada con una gramática rudimentaria, y está, a su vez, dentro de una computadora. Y la

\footnotetext{
72 Con el fin de ampliar la información, véase: <http://www.invasiongenerativa.com.ar/>.
} 
computadora, ¿qué sería?, siguiendo esta lógica de pensamiento, sería un útil. La esencia del útil reside en lo que Martin Heidegger (2010) denomina "ser de confianza". Este ser de confianza queda oculto, permanentemente encubierto en el útil a fuerza de la repetición cotidiana que produce el contacto con la cosa, con la computadora, por ejemplo.

Pero una computadora, para crear obra, precisa de las intervenciones intelectuales de lo humano, entonces ¿dónde ubicamos el lenguaje de programación? Si consideramos arte al código software, ¿deberíamos considerar a la notación matemática como su materia base? Y al fragmento de código, ¿cómo la materia formada?

\footnotetext{
Hablar del contexto "artístico" del código suena algo extraño, pero debemos comprometernos en la búsqueda y en la experimentación de buenos trabajos que reflejen el pensamiento creativo contemporáneo. Para ello, debemos poder usar todas las formas de la expresión de la cultura actual, y si nos preguntamos cuál es la forma más pura del pensamiento contemporáneo, pienso que el código software es arte (Barragán, 2008: 139).
}

Todo artista, en cierta manera, utiliza, para crear, los nuevos medios o lenguajes que le son contemporáneos. Por lo tanto, la subversión y la experimentalidad de los “juglares digitales" (Zátonyi, 2002: 41), que desde las artes irán manifestando nuevos saberes, pondrán en crisis y alterarán toda condición específica de una tecnología, tornándola vital.

Para seguir avanzando en el análisis sobre estas disquisiciones de una estética de la tecnología, citaremos nuevamente a Martin Heidegger (2010) cuando se interroga:

Pero ¿en qué se distingue la producción como creación de la producción [como] confección? Así como es fácil distinguir la creación de la obra y la confección del útil, así es difícil perseguir ambas clases de producción, cada una con sus rasgos esenciales. A primera vista, encontramos la misma conducta en la actividad del alfarero y el escultor, del carpintero y el pintor. La creación de la obra requiere la acción manual.

Y esta acción manual del artista -que se menciona en el párrafo citado-, con la materia y su técnica, habla de una especie de saber y no de una forma de ejecución práctica. Esta idea disiparía la convicción de que cuando la máquina se inmiscuye en la producción de la obra, esta escapa al control del artista, la máquina se opone a la mano. 
Pues hasta aquí hemos vinculado a la máquina con un saber, un saber especializado. Retomando la noción de la "caja negra", pensada desde el hardware, nos repreguntamos: ¿es una confección del útil? Y pensada desde los objetos preconfigurados de un software, ¿lo es del mismo modo?

Consecuentemente, escribir un código de programación, ¿es creación o producción? ¿Hay solo acción manual o un saber entre los dispositivos de una escena informática?

\footnotetext{
En nuestra práctica nadie puede utilizar solo una herramienta (informática), lo más común es utilizar varios lenguajes (de programación) a la vez y conectarlos entre sí. [...] La forma de escapar de esta suerte de estética "determinada" por el lenguaje es mezclar [los diferentes lenguajes] y tener una suerte de "paleta" de estéticas y posibilidades (Causa en Pagola, 2010).
}

Por consiguiente, deducimos que la creación en esta práctica artística es programar a través del conocimiento de los códigos propios del lenguaje informático o a través del conocimiento del software y sus objetos preconfigurados, o de la mixtura de ambos procesos. Sin olvidar la intervención de los dispositivos e interfaces escénicas, la propuesta de movimiento corporal y, básicamente, la conciencia de estar trabajando entre el plano físico del cuerpo, tiempo y espacio; y en el plano del algoritmo, su utilización y operación técnica en esta "intersección entre lo que el performer hace y lo que el sistema puede captar, que es, por supuesto, un importante recorte del fenómeno en sí" (Causa y otros, 2015: 95).

$\mathrm{Y}$ aquí queda manifiesta la distinción: no hay un artista y su obra, sino una propuesta participativa en una práctica artística integrada a un proceso de investigación y desarrollo que coloca, en un plano híbrido, a "juglares y trovadores digitales" en procura de "una renovación conceptual sobre la mirada del arte" (Zátonyi, 2002: 42) y de una estética que se enlaza con procesos científicos y con tareas de laboratorio. La investigación interdisciplinar se presenta como crucial en los modos de producción entre ciencia y arte.

\section{La interfaz es el cuerpo del software}

Teniendo en cuenta la trayectoria de un arte que se formula a partir de la transformación creativa como forma colectiva de producir multidisciplinariamente y proponiendo prácticas de arte colectivo en tiempo real en las que unos alimentan el trabajo del otro, se pone de relieve un proceso que coloca a la figura del programador 
informático como parte de ese colectivo y no como técnico facilitador de las condiciones informáticas. Por lo tanto, hacer más accesible la limitación del uso y ergonométrica de la interfaz que se establece entre el cuerpo y el sistema interactivo escénico superaría, en gran parte, el problema del intercambio entre ambos métodos creativos.

Ubicados dentro de esta zona de interfaz, nos preguntamos: ¿podrían influir los nuevos conceptos de desarrolladores en la resolución del problema de comprensión de la traducción y la modelización? Consideramos que este problema podría ser solucionado desde una posición híbrida, que contenga a ambos paradigmas de las disciplinas actuantes.

Sobre esta tendencia se manifiesta Fabricio Costa Alisedo, desarrollador del software de código abierto Moldeo.org ${ }^{73}$ : "las interfaces tienen que ser más fáciles de usar. La limitación más grande que tenemos todavía son las interfaces" (2013: 10"). Se trata de crear un sistema en un programa, ejecutarlo y obtener de vuelta unos nuevos parámetros.

El artista programador o ingeniero puede descartar esa programación y volver a empezar o cambiar alguna de las reglas. Es un proceso interactivo que se inicia y termina en una idea a partir del diálogo entre el artista y el sistema. Los desarrolladores despliegan un vocabulario característico, patrones de puntuación e indudablemente un estilo narrativo, pero aunque las pautas varíen de un lenguaje de programación a otro, el principio subyacente es el mismo: escriben código para que otros desarrolladores puedan leer.

Ahora, la manera de abordar un discurso artístico implica su actividad performativa, lo que este hecho pueda suscitar como pensamiento y como experiencia. De ese modo, lo que importa es cómo acceder a las líneas de intensidad que componen la vinculación entre el cuerpo humano, la herramienta y el objeto de la acción, dirá Bonsiepe, y nosotros agregaremos: entre las interfaces, la materialidad dual del cuerpo $^{74}$ y la programación comprendida por una metáfora que estimule la acción. Entre los principios de diseño de interacción que propone Bruce Tognazzini (2006), se

\footnotetext{
${ }^{73}$ Moldeo es un software interactivo de visuales en tiempo real, de licencia libre y en idioma español. Es una plataforma creada por un equipo de programadores liderado por Fabricio Costa Alisedo y con la substancial colaboración -en los últimos años- de Dante Sáez Mansilla, quienes, a partir de la experimentación con nuevas tecnologías en computación gráfica, posibilitan la realización de entornos interactivos con elementos de video y animación -en dos y tres dimensiones- y con efectos digitales en tiempo real así como con nuevos conceptos artísticos, comunicacionales y científicos.

${ }^{74}$ Don Ihde describe los diversos significados del cuerpo en relación con nuestras experiencias de estar corporeizados. Al modo de ser a través del cuerpo lo llamó Cuerpo Uno. También somos nuestro cuerpo en tanto lo experimentamos en un sentido social y cultural. A ese espacio de significación cultural del cuerpo lo llamó Cuerpo Dos. La conexión entre el Cuerpo Uno y el Cuerpo Dos es una tercera dimensión: la dimensión de lo tecnológico. Pág. 13. Véase en línea. Dirección URL: <http://www.uoc.edu/dt/esp/ihde0704/ihde0704.pdf>.
} 
encuentra el uso de metáforas: "Escoge aquellas metáforas que permitan al usuario comprender los detalles del modelo conceptual. Las buenas metáforas son historias que crean imágenes mentales" 75 .

Por su parte, el concepto de mediación es esencial, pues permite establecer una relación -real, simbólica o, incluso, híbrida- entre el cuerpo físico y el cuerpo virtual. Y, en este punto, la percepción se torna múltiple, omnipresente bajo el efecto de encadenamientos de diversos fragmentos de espacios y de tiempos que componen la potencia mudable de la realidad.

Lo significativo es acceder a esa constitución alternativa de intensidades, porque es a través de ellas que un nuevo lenguaje -tanto corporal como algorítmico- será percibido como un medio constitutivo y no solo como un medio operativo. Para Costa Alisedo, su "trabajo tiene que ver con conceptos abstractos llevados a la forma, al movimiento" (2013: 1'02"). ¿Qué es el movimiento?, se pregunta. Una respuesta posible sería poder sintetizar el movimiento del cuerpo en el espacio y en el tiempo, y aplicarle conceptos matemáticos. Indagar qué significa cada factor dentro de estas funciones, recordando que ya se estudió por medio de la Biomecánica ${ }^{76}$-cuya propuesta es analizar al cuerpo humano incluido el entorno donde se desenvuelve-.

En ese sentido, es interesante pues toma las matemáticas en movimiento figurado para interactuar con el cuerpo digitalizado, dado que las capacidades de abstracción deben ser consideradas como una de las actividades esenciales de un programador. El conocimiento de algunos modelos matemáticos con los cuales comprender el cambio, la variación y el cálculo de las variables introducidas desde el análisis de una secuencia o gestualidad secuencial de bailarín performer conforma la relación entre las gráficas de velocidad y de posición del movimiento con respecto al tiempo e interpreta lo que está sucediendo con el movimiento en cuestión.

\begin{abstract}
Con las herramientas matemáticas vos tenes la capacidad de de-construir y encontrar el esqueleto, la estructura del universo. No es simplemente el cuerpo, el objeto, el hardware... No. Con el nivel de matemática que tiene un programador, un científico, un físico, tenes acceso a poder proponer modelos
\end{abstract}

\footnotetext{
${ }^{75}$ Nos interesa citar aquí a Bruce Tognazzini -presente en el programa de formación universitaria de la carrera de Diseño Multimedial, de la Facultad de Bellas Artes (UNLP)- dado que nos permite reparar en las premisas con las que se forma un diseñador multimedial, cuyo perfil crítico atiende a vincular "la técnica, el lenguaje, la comunicación y la estética con los problemas del mundo contemporáneo". Con el fin de ampliar la información, véase: <http://www.galinus.com/es/articulos/principios-diseno-deinteraccion.html\#objetos-humanos>.

76 Área de conocimiento interdisciplinaria que estudia los fenómenos cinemáticos y mecánicos que presentan los seres vivos considerados sistemas complejos formados por tejidos, sólidos y cuerpos mecánicos. Es una ciencia, por lo tanto se basa en el conocimiento científico, es decir que se fundamenta en la investigación. Para traducirla en cifras, hay que aplicar ecuaciones físico-matemáticas. Por eso no es sinónimo de anatomía funcional. Incluye elementos para ver el consumo energético de cada movimiento en particular y de los movimientos globales.
} 
abstractos que describan lo que experimentas. Entonces, al programar Moldeo, estoy continuamente pensando y creando desde esa abstracción, pero ahora con la comunidad, justamente con gente que es de diferentes disciplinas estamos construyendo "el cuerpo" para hacer de vuelta esta estructura, o sea que hay una metáfora, una alegoría continua de cómo te relacionas vos con "la realidad" (Costa Alisedo, 2013: 0'50").

Si bien las matemáticas y sus estructuras de entes abstractos resultaron siempre un abordaje complejo para quienes no comulgamos con esta formación -en el campo de la danza y en diferentes momentos-, coreógrafos y bailarines han investigado dentro de esta comunidad.

Según el filósofo matemático Gottfied Leibnitz, contemporáneo de Isaac Newton e inventor de la primera calculadora, el universo es todo sentido, y este es el mejor universo que se podría crear. En controversia con Newton sobre la invención del cálculo infinitesimal, no se puede negar que Leibnitz aportó a la matemática la notación hoy popularmente usada para describir uno de los procesos clave del cálculo: la integral. La integral resolvía el cálculo de áreas compuestas por curvas (cuadraturas). La integración definida como la antiderivación es quizás lo que ha dado tanto optimismo en cuanto a la potencial capacidad predictiva de las ciencias mecanicistas.

$\mathrm{Si}$ entendemos y podemos describir un proceso (con funciones conocidas), derivando estas funciones podremos descubrir el comportamiento intrínseco de su movimiento, y en este proceso de deducción profundizaríamos en el origen de ese comportamiento. Mientras que integrando estas funciones, podríamos estudiar su evolución y predecir algunas características de su comportamiento. Esta capacidad positivista inherente al método del cálculo se diluye con la aparición de la incertidumbre cuántica, y finalmente muere con el descubrimiento de los sistemas complejos, la sensibilidad a las condiciones iniciales y el universo fractal. El concepto de continuidad deja de tener tanta relevancia. La sociedad [se halla] nuevamente perdida al ver que la verdad del universo se aleja nuevamente a la velocidad de la luz, en un tejido cuántico impredecible para nuestros ojos (Costa Alisedo, 2014: 12).

La obra Quantum, de Gilles Jobin, es creada a partir de una indagación efectuada tras haber sido seleccionado para una residencia artística en el laboratorio de física CERN (Centro Europeo para la Investigación Nuclear o Laboratorio Europeo de Física de Partículas Elementales), de Ginebra, en el año 2012. 
Conceptos de la física y de las partículas como las fuerzas fundamentales (fuerzas de no contacto), generadores de movimiento, interacciones y simetrías se utilizan como herramientas para concebir un sistema de secuencias coreográficas complejas. El CERN potencia la conexión entre arte y ciencia recreando en sus laboratorios la colisión mente e imaginación de artistas y científicos para que nuevas formas de pensar se hagan realidad. Pero si enfocamos lo disciplinar, el campo de la ciencia, lo que ocurre en la noosfera de las matemáticas, nos encontramos con otras posturas más radicales respecto al conocimiento específico de las matemáticas, la informática y el "usuario":

\begin{abstract}
Las matemáticas son el pináculo de la enemistad con el usuario. Si usted lee los catálogos de las editoriales de libros de texto, notará que la recomendación más trascendente que le dan a un libro es que sea a-matemático, que no requiera conocimientos matemáticos, etcétera. Así que, la amistad con el usuario es, entre otras cosas, la causa de un error frenético por ocultar el hecho de que las computadoras son máquinas matemáticas de por sí (Dijkstra en Van Vlissingen, 1985: 4).
\end{abstract}

Existen diversos lenguajes y paradigmas de programación. La programación tradicional no orientada a objetos, como C o BASIC, basa su funcionamiento en el concepto de procedimiento o función, es decir, un conjunto de instrucciones que operan sobre unos argumentos y producen un resultado. Con esta lógica, un programa no es más que una sucesión de funciones, ya sean estas del sistema operativo, proporcionadas por el propio lenguaje, o desarrolladas por una aplicación.

En el caso de los lenguajes orientados a objetos, como es el caso de C++ y Java, el elemento básico no es la función, sino una unidad denominada exactamente objeto.

Un objeto no es más que un conjunto de variables (o datos) y métodos (o funciones) relacionados entre sí. Los objetos en programación se usan para modelar objetos o sujetos del mundo real. Un objeto es, por tanto, la representación en un programa de un concepto, y contiene toda la información necesaria para abstraerlo: datos que detallan sus propiedades y procedimientos.

El cambio en los lenguajes de programación como enunciados formales de la semántica de los lenguajes de programación permitió nuevas conexiones entre este, el cuerpo y la experiencia.

El arte software implica una actividad artística que, gracias a su medio -o, más bien, a su material-, hace posible una reflexión crítica sobre el propio software (y sobre su impacto cultural). Así, el software puede destacar los subtextos 
estéticos y políticos de cuestiones técnicas aparentemente neutrales. [...] Para el arte software, resulta mucho más interesante la noción de "performatividad" del código que su naturaleza "generativa". Proponemos la noción de la performatividad del código como una de las razones del creciente interés de los artistas contemporáneos por usar el software como material artístico (Arns, 2005: 1).

Un ejemplo claro es la inclusión del arte generativo a través del algoritmo como herramienta para la creación en la música electrónica, en la composición algorítmica, en el diseño gráfico por animación, en la escena de danza interactiva, en la cultura VJ, etcétera. En este sentido, se destaca el empleo de los procesos generativos; para Inke Arns (2005: 2), es básicamente la "negación de la intencionalidad" que genera hechos impredecibles. $Y$ es en este punto donde no se puede usar la noción de arte generativo como sinónimo de arte software, pues:

El arte software no se refiere al software meramente como una herramienta pragmática e invisible que genera ciertos resultados visibles, sino que, por el contrario, se centra en el propio código del programa, incluso, cuando este código no se deja explícitamente abierto o puesto en primer plano.

A diferencia del arte software que se centra en el resultado, el arte generativo es aquel en el que la obra es producto de la ejecución de un programa y se centraliza en el proceso generativo. En este ámbito, el software es visto y usado como herramienta para provocar consecuencias a través de procedimientos que activan -con un cierto grado de autonomía y aleatoriedad- "la creación de una obra de arte completa".

Según la música y matemática Lali Barrière (2010: 112), "este proceso generativo se define como un proceso con parámetros con los que el artista debe experimentar hasta que los resultados finales sean estéticamente satisfactorios y, en la medida de lo posible, sorprendentes". Estas en general son las condiciones en las que se manifiesta el software cuando es el material artístico principal, explorando así narrativas dependientes de contextos programables, comunes en prácticas de software-art ${ }^{77}$, net-art o performance visuales y sonoras.

Encontramos aquí dos líneas de trabajo: de un lado, el trabajo con el código en sí mismo; del otro, el trabajo crítico en torno de la vertiente cultural de los programas"

77 Transmediale es un festival anual sobre arte y cultura digital, que se celebra en Berlín. En sus comienzos fue un festival de video y películas de arte contemporáneo que se inició en 1988. Desde el año 2001, ha sido dirigido por Andreas Broeckmann, quien introdujo un gran interés en el arte software y convirtió el festival en un contribuyente importante para la escena del arte europeo. Con el fin de ampliar la información, véase: <https://transmediale.de/content/history-transmediale>. 
(Barrière, 2010: 116). Se aprecia ya el hecho de que el algoritmo o el programa pueden ser parte de la obra o evento y no solamente un método o un procedimiento de creación que pueda generar muchas variaciones sobre el mismo sistema, sobre el mismo conjunto de algoritmos.

Algo ha pasado con el diseño de lenguajes de programación. Los lenguajes de programación deben ser, por supuesto, amistosos con el usuario, a los programadores deben gustarles. Durante mucho tiempo, las características de los lenguajes de programación se incluían en los lenguajes de acuerdo con su supuesta popularidad -el criterio principal era si a la gente le iba a gustar o no-, partiendo otra vez de una triste percepción del usuario. El gran cambio en los lenguajes de programación vino cuando empezamos a dar definiciones formales a la semántica de los conceptos de los lenguajes de programación. Algo que hace falta si se quieren probar cosas sobre los programas escritos en él. Y aun si no se espera conseguirlo de una manera formal, es un ejercicio extremadamente saludable para los diseñadores de lenguajes de programación. La formalización actuó como un sistema de alerta temprana: si la definición formal de una característica se vuelve confusa y complicada, entonces no se debe ignorar esa advertencia (Dijkstra en Van Vlissingen, 1985: 6).

¿Qué es la semántica en programación? En informática, es considerada una aplicación de la matemática lógica, y manifiesta el significado de programas o funciones. Por ende, los programas pueden separarse en su parte sintáctica (la estructura gramatical) y su parte semántica (el significado), tornando el uso de estas herramientas en "sistemas sensibles"; es decir, gracias a su cualidad de procesadores de información, generan datos al sistema a partir de la lectura de los cambios o variaciones de un ambiente dado, por ejemplo, las variaciones en el pulso cardiaco de un bailarín conectándolo a sensores analógicos o digitales al sistema.

La creación artística a través de sistemas participa de un cambio cultural profundo, que suple estructuras jerárquicas por sistemas complejos, sistemas de control por autoorganización, unidad por multiplicidad, etcétera. Se vincula con la propensión a estudiar los "sistemas" como entidades más que como compuestos de partes articulados; en otras palabras, se trata de estudiar las interacciones para explorarlas en su amplitud. Esto produce experiencias con esquemas alternativos, coexistentes, en las que "el individuo no tiene el monopolio de la subjetividad, de modo que poco importa el modelo del Autor" (Bourriaud, 2013: 117).

Esto hace ineludible volver a preguntarse dónde quedaría la autoría, ya que no solamente numerosos códigos de estos sistemas se comparten gratuitamente por la 
web, sino que se hace colaborativo el proceso de creación con un algoritmo que puede generarse a sí mismo. En principio, los autores de programas informáticos comerciales o privados preservan el código fuente para modificar y distribuir el programa, lo cual significa que tiene autor y que este prohíbe e impide la cooperación entre usuarios. La aparición de la licencia pública general (GPL) produjo un espacio de cooperación para programadores informáticos libres a través del método denominado copyleft ${ }^{78}$, así como incitó a la reflexión y a permanentes interrogaciones sobre el derecho de autor compartido y abierto.

Esto nos lleva nuevamente a la idea de la transdisciplinariedad que va más allá de todo lo que habitualmente se está haciendo desde lo interdisciplinar, puesto que supera la unidad del conocimiento pensada como un medio y avanza hacia la autotransformación en una sinergia interpretativa y combinada no solo entre humanos sino entre los sistemas informáticos, con la estructura sensible del software. Evidentemente, las consecuencias de esta sinergia tendrán también propiedades emergentes diferentes en las que los componentes preliminares no podrán ser perceptibles así como tampoco podrán ser predecibles en esta red de relaciones. En ese sentido, las propuestas desenlazan verdaderos híbridos o invenciones estéticas en una suerte de mixtura entre lo humano y una tecnología colectiva. Esto radica también en la importancia del movimiento del software libre y el dominio de:

... los movimientos de software libre con su exigencia de licencias abiertas a modificaciones, expansiones, reutilizaciones y derivaciones, etcétera. Como ya comentamos, son muchos los que reclaman la aplicabilidad de los principios que fundamentan las traducciones o las prácticas de código abierto a todo tipo de producción cultural, proponiendo como ideal una autoridad siempre colectiva volcada en el desarrollo de propuestas artísticas abiertas a ulteriores alteraciones derivativas, expansiones o adaptaciones (Prada, 2012: 177).

Lanzados al ciberespacio, el debate gira en torno a cómo circulan esos contenidos que mayormente proliferan en estado procesual. Volviendo a software libre o código abierto, vemos que están intrínsecamente relacionados, pero hay algunas diferencias puntuales. El software libre o free software acata muchas libertades de los usuarios que lo adquirieron pues puede ser usado, copiado, estudiado, modificado y

\footnotetext{
${ }^{78} \mathrm{El}$ copyleft usa la ley de copyright, pero la da vuelta para servir a lo opuesto de su propósito usual: en lugar de ser un medio de privatizar el software, se transforma en un medio de mantener libre el software. La idea central del copyleft es que le damos a cualquiera el permiso para correr el programa, copiarlo, modificarlo y redistribuir versiones modificadas - pero no le damos permiso para agregar restricciones propias-. De esta manera, las libertades cruciales que definen al "software libre" quedan garantizadas para cualquiera que tenga una copia, se transforman en derechos inalienables. Con el fin de ampliar la información, véase: <http://www.wipo.int/sme/es/documents/opensource_software_primer.htm\#element>.
} 
redistribuido libremente, pero no necesariamente abre su código; mientras el código abierto deja ver su código y, por ende, permite ser modificado.

En este sentido, vamos a aludir al software Moldeo.org ${ }^{79}$, cuyo objetivo principal reside en el desarrollo de una herramienta de código fuente abierto para la producción en tiempo real de animaciones y procesamiento de imágenes, videos y datos tridimensionales. Este software crea un entorno de programación gráfica que proporciona control interactivo sobre medios digitales, con énfasis especial en la captura en tiempo real de video digital, creando así complejas relaciones interactivas que se pueden controlar ya sea con dispositivos externos o el movimiento macro o micro del cuerpo, el gesto, el rostro. Puede aplicarse a diferentes fuentes de entrada como el video en vivo o datos a través de una red en la que los elementos de salida son visualizados en una pantalla de computadora o bien proyectados en grandes superficies o redirigidos a través de la red.

La utilidad central de Moldeo es crear experiencias audiovisuales en distintos espacios escénicos: teatro, instalaciones, performances, eventos de comunicación. Los conceptos de interpretación y improvisación están implicados dentro de Moldeo de forma central, ya que este permite al usuario/intérprete/artista literalmente "tocar" (así como quien toca un instrumento) las imágenes y todos los parámetros que las afectan ${ }^{80}$.

Desde el sitio Moldeo.org se nos interpela: "Crea, clona, comparte" y se nos confieren "las referencias a las fuentes necesarias para empezar a ser un usuario o incluso un desarrollador"81. Esta plataforma, propagada por un equipo de programadores liderados por Fabricio Costa Alisedo, lleva unos doce años desde su estado embrionario como programa para VJ y llega a ser hoy un proyecto de código abierto que viabiliza la contribución de una comunidad colaborativa como clave en su constante desarrollo.

En general, los métodos existentes en el arte basado en la interactividad vienen cerrándose en herramientas y conceptos que van necesitando abrirse a nuevas coordenadas emergentes y dinámicas. Esto implica que traen consigo los problemas

\footnotetext{
79 Actualmente Moldeo presenta tres versiones consumadas y en investigación: Moldeo Director (se desarrolla el Proyecto Speak) / Moldeo 1.0 Beta (para las netbooks) / Moldeo Escena (interfaz en desarrollo). Estas versiones buscan dar un mayor acceso a los usuarios tanto expertos como inexpertos y presentan una interfaz amigable y una instalación que es independiente de la capacidad gráfica que las computadoras posean. La última versión 1.0 Beta ha recibido una mención a la innovación en el concurso organizado por el Centro de Producción Digital de la Provincia de Buenos Aires CPD 2014. Véase: $<$ http://www.alejandraceriani.com.ar/moldeo.html>.

${ }^{80}$ Con el fin de ampliar la información, véanse los tutoriales que pueden descargarse en Dirección URL: $<$ http://moldeo.org/>.

81 Véase en: <http://moldeo.org/documentacion>.
} 
que presenta la regulación de estos sistemas para que puedan autoconservarse y autorreproducirse dentro de los procesos denominados narrativas interactivas.

La dimensión narrativa está presente en todos los procesos de interacción y en la acción performática de un bailarín "deviene una subobra de la narrativa interactiva aportada por estos [...] siendo fomentada por la propuesta del guión escénico interactivo que refuerza además la característica inmersiva de la instalación" (Costa Alisedo, 2014: 24).

Así, en el campo de la informática, un ecosistema no hace referencia a las interacciones de seres vivos, pero sí a emular el comportamiento de las diferentes partes de una cadena que, en este caso, irían desde los servidores, la base de datos, hasta los sistemas operativos, las aplicaciones, etcétera, cohabitando y conformando una plataforma en común. Los programas informáticos de código abierto conforman en sí un ecosistema que brinda a los programadores y usuarios de programas informáticos una opción para desarrollarlos y distribuirlos.

Al mismo tiempo, el software Moldeo y sus desarrolladores aspiran a que las mismas reglas que definen a los sistemas orgánicos sean sublimadas a través de la reproducción de su código fuente o en el esquema estructural de la instalación. La composición tiende hacia la construcción del concepto de ecosistema, de ecoinstalación: algo que intentará mantenerse dinámicamente y sobrevivir. Entonces el interrogante que surge para Costa Alisedo reconfigura el preconcepto de que la abstracción guía a las matemáticas:

FCA: Todas las composiciones que estamos empezando a crear van hacia este concepto definitivamente más "moderno" entre comillas, más actual, que tiene que ver con el ecosistema, la ecoinstalación. ¿Desde qué reglas matemáticas, sistémicas vos creas una instalación? O sea una instalación donde hay todo tipo de elementos. Desde las mismas bases que regulan los ecosistemas, digo: me encantaría que crezca un árbol de la mano de la persona.

$\mathrm{P}$ : ¡Ah! ¿Tan figurativo es?

FCA: Sí, puede ser completamente figurativo. Figurativo para mí es la capacidad que tengo de poder imaginarme. Figurativo puede ser la forma que uno conoce, pero puede no ser una forma que conozcas. Justamente qué hago yo, hago el camino inverso, digo: ¿Cómo creo el árbol? En realidad son células... son... Haces ese trabajo matemático que hace un físico. Un físico mira las estrellas y no se imagina una estrella de cinco puntas... Sabe que esas puntas son una ilusión óptica. Él está pensando de qué está compuesta la estrella. Bueno, con el cuerpo, con el movimiento pasa lo mismo (Costa Alisedo, 2012: 3'20"). 
Un sistema abierto es definido como aquel sistema que intercambia materia con el medio circundante, que presenta reciprocidades, desplazamientos, complexión y degradación de sus componentes y mecanismos materiales. Incluso esa materialidad, en el sentido de representación en la pantalla de la computadora, es lo que vuelve a las interfaces tangibles.

Los desarrolladores del software Moldeo.org consideran que su entorno gráfico representa "el cuerpo del software" (Costa Alisedo, 2013: 0'27'); y su propósito es resolver problemas de comunicación de manera efectiva tanto funcional como estéticamente, pues, muchas funcionalidades de Moldeo están todavía en su ciclo de desarrollo, teniendo en cuenta su ciclo como en espiral cuya principal característica es la gestión de prueba de forma periódica en el desarrollo, realizada además por la interacción de los propios usuarios pertenecientes a la comunidad Moldeo ${ }^{82}$.

\section{Concepciones del cuerpo en la programación}

Proponer la temática del cuerpo pensado desde los propios programadores nos ampliará la perspectiva sobre las partes intervinientes en una propuesta escénica interactiva, su modo de percibirlo y las concepciones que giran en torno al fenómeno interdisciplinar. Partimos del planteo de que estas nuevas corporalidades que van tomando forma dentro de acontecimientos híbridos del arte contemporáneo vinculado a las tecnologías instalan la evidencia de una transformación profunda que compromete cada vez más una actuación transdisciplinaria de las artes y de las ciencias.

Planteamos un cruce de ideas para continuar reflexionando sobre el aporte que la vinculación del cuerpo performático y la tecnología movilizan en diversas experiencias tanto corpóreas como incorpóreas. En ese sentido, un lenguaje de programación para el cuerpo nos remite a la experiencia performática del equipo emmeLab que se describe como: "Un intento de generar un entorno que permita una suerte de live-coding ${ }^{83}$ combinando programación en vivo con Danza Contemporánea o Expresión Corporal".

Esta propuesta performática que se genera a partir de "transformar el acto de programar en un acto performático" (emmeLab, 2013: 127) es testimonio del borramiento de los límites disciplinares para dar lugar a otros sentidos y prácticas en el terreno de lo

82 Espacio creado por uno de sus miembros Dante Sáez Mansilla para promocionar las nuevas características del software Moldeo 1.0, unir a su comunidad y compartir experiencias en torno a su uso. Véase: <https://www.facebook.com/comunidadmoldeo> y <http://www.moldeo.org/community\#head>.

83 "El live-coding es una disciplina que consiste en transformar el acto de programar en un acto performático. El programador-performer se presenta ante el público y escribe con su herramienta predilecta un programa que genera visualizaciones o musicalizaciones en tiempo real. 
estético y lo artístico, a través de las prácticas de programación performática de imagen, música, sonido y "cuerpo". Así es como se detalla la relevancia que se le da hoy a la intervención del cuerpo del bailarín performer:

Aunque el proyecto surge en parte basado en el live-coding, no consideramos que se pueda clasificar puramente dentro de esa disciplina, pues se busca generar una expansión de la danza hacia la tecnología y la programación, y no desde el live-coding hacia la danza. Los lineamientos del desarrollo se encuentran condicionados por la intención de no restringir al bailarín/performer, lo cual no da lugar a aumentar las limitaciones en un proyecto tan experimental.

$\mathrm{Y}$, si bien la utilización del lenguaje de programación dentro de la creación visual/sonora en términos de evento artístico no es nueva en el arte, sino que data de las primeras incursiones a través de la música experimental, el live-coding pertenece a las particularidades del arte generativo, una práctica definida del arte digital que ha desarrollado sus propios conceptos y técnicas transdisciplinarias, así como sus herramientas y estilos, con un fuerte anclaje en el proceso creativo y empírico de sus hacedores.

El desafío aún hoy es que el programador performer ponga el cuerpo en escena además de estar activando visuales, sonido, etcétera. En la actualidad, ha de pensarse la performance como toda aquella ejecución procesual, toda experiencia corporal caracterizada por una conciencia de lo tecnológico que diseña nuestra manera de concebir y presentar una práctica artística.

Se desplaza a la persona antropocéntrica que se encontraba escindida del proceso creativo integral, es decir, de la posición habitual de un programador sentado frente a la pantalla de su computadora a la situación de encontrarlo entremezclado con otros cuerpos, soportes y otros efectos sinestésicos provocados por la multisensorialidad de estar presente en un escena.

Fabián Kesler (2016), músico, programador y performer del laboratorio multimedia interactivo Speakinteractive ${ }^{84}$, concibe la programación desde:

Dos variables: 1) La cuestión anatómica, es decir, la funcionalidad posible de la parte del cuerpo que yo sensaré. Por ejemplo: si son los pies, tengo que pensar en fuerza, velocidad, cantidad de personas que lo puedan usar simultáneamente,

\footnotetext{
${ }^{84}$ Speakinteractive es un laboratorio artístico que propone la presentación de performances interactivas en tiempo real donde el cuerpo de los programadores -tanto de visuales como de sonido- incursiona en la escena participándola con una bailarina performer. Con el fin de ampliar la información, véase: <http://www.speakinteractive.blogspot.com.ar/> y <http://www.alejandraceriani.com.ar/speak.html>.
} 
posibilidades de una persona no bailarina y una persona profesional y condiciones del escenario. 2) Respecto de los aspectos escénico-estéticos: a qué tipo de obra se puede aplicar, qué tipo de imaginario puede sentir inspiración con mi programación. ¿Un/una director/a más conservador/a o más experimental? Siendo este mundo aún de muy corta edad históricamente, no es tarea sencilla incentivar su uso en obras que nunca antes lo habían hecho ¿Se puede integrar a otra disciplina sin colisionarse, sino por el contrario enriqueciendo la propuesta? Para ello, el programador tiene que conocer la obra, realmente interesarse y evaluar si realmente su labor puede realizar aportes significativos (Kesler, Mensaje 23/04/16,19:42).

Cabe señalar que, en este mismo sentido, se considera el cuerpo a partir de sus partes ergonométrico-gestuales con el fin de localizar posibles parámetros que sirvan a ambas disciplinas en su despliegue motriz y expresivo.

Atendamos al siguiente párrafo, resultado de una indagación efectuada por el equipo emmeLab (2013: 125) a una bailarina formada en danza contemporánea:

Tras una breve investigación en danza se advirtió que existen ciertos parámetros "técnicos" en la disciplina que son utilizados para describir un paso o movimiento, se intentó explotar estos parámetros y, al mismo tiempo, que los gestos propios del lenguaje no comprometieran la posibilidad de una interpretación estética o natural por parte del performer.

Esa breve investigación en danza lleva a los integrantes del emmeLab a suponer que para abordar el movimiento corporal es indistinto trabajar desde la danza contemporánea o desde la expresión corporal. Este preconcepto, establecido sobre la indistinción entre los campos de formación y producción en danza, es propio de pensar a grandes rasgos el cuerpo en movimiento. Tener solamente en cuenta las finalidades que podrían establecerse -por ejemplo, en función de cooperar con la captura óptica, o de contacto, con la gestualidad ergonométrica para su modelización, entre otras- hace obviar las diferencias en la evolución de una misma disciplina artística, sus vertientes y convergencias, como es el caso de la Danza.

Creemos conveniente subrayar esta no diferenciación que en general tiende a aparecer cuando se alude a "las danzas", pues las diferencias no solo son de corte técnico sino también filosófico. No hay que perder de vista que estas devienen de la ruptura con sus fundamentos de origen. Examinemos entonces el estudio de campo realizado por Ana Sabrina Mora (2008: 2) en la Escuela de Danzas Clásicas de la ciudad de La Plata 
(provincia de Buenos Aires, Argentina), institución perteneciente al Estado, cuya oferta educativa forma en danza clásica, danza contemporánea y danza-expresión corporal:

La Danza Contemporánea suele caracterizarse a sí misma como una danza de ruptura con relación al ballet clásico, en el que paradójicamente se apoya y al que reconoce como su base. El distanciamiento de la estructura del clásico incluye romper con algunos de sus principios básicos (como el en dehors o las posiciones rotadas hacia fuera, la rigidez del tronco, el mantenimiento constante del eje), sus posiciones (prevalece el trabajo en sexta posición, con ambos pies paralelos), su vocabulario de pasos (desplegando o modificando algunos de los existentes, creando otros nuevos) y el modo de construcción de las producciones. Esta danza es heredera de la danza moderna que fue creada por bailarinascoreógrafas y bailarines-coreógrafos de Europa y Norteamérica, desde fines del siglo XIX y, sobre todo, en las décadas del 30, 40 y 50 del siglo XX. [...] La Expresión Corporal-Danza es una forma de danza creativa, cuya denominación fue acuñada por la argentina Patricia Stokoe en la década de 1950, reconociendo como antecedente a la danza libre alemana. Este lenguaje artístico ha sido concebido como una forma de arte del movimiento, basada en la exploración y el conocimiento del propio cuerpo, cuya modalidad de trabajo esencial es la improvisación. Plantea, en primer lugar, que todas las personas pueden danzar, y que cada uno puede encontrar "su propia danza". El objetivo central no es el aprendizaje de pasos establecidos ni la creación de una coreografía repetible, sino fundamentalmente la exploración y la toma de conciencia del propio cuerpo y sus posibilidades de movimiento, y la construcción de un lenguaje corporal propio, para con él poder expresar estados, vivencias, experiencias. Lo que se espera de sus producciones es que tengan riqueza expresiva.

Sin embargo, la mezcla y la apropiación entre disciplinas que hacen posible este fenómeno interdisciplinar implican, por su complejidad, arribar finalmente al desconocimiento de los componentes que conforman a cada una en sus particularidades. Por ello, es significativo revisar algunas concepciones desde donde se proyectan experiencias interdisciplinares o transdisciplinares performáticas, puesto que los códigos y procesamientos audiovisuales parecieran ser los responsables de articular con mayor o menor intensidad la construcción de situaciones y espacios dramáticos de la escena contemporánea. $\mathrm{Y}$ el cuerpo de un bailarín o performer interactivo -formado en danza clásica, danza contemporánea o expresión corporal- es solo, a grandes rasgos, subsidiario de la información precisada para la captura de movimiento en tiempo real. 
La interdisciplinariedad parece ser la única vía practicable en los próximos decenios. Sin embargo, carecemos todavía de elaboraciones epistemológicas adecuadas frente a la magnitud del problema que enfrenta la práctica artístico-científica, lo que determina perplejidades, reclamaciones y parcelaciones que llegan a ser contrarias a un discurso integrativo y pluralista.

Así es que la performance -como práctica artística que desde su predisposición a la diversidad matérica, a mediaciones, a discursos abiertos y a clandestinidades- debería transformarse en una de las propuestas híbridas más significativas para el abordaje transdisciplinar. Esto no quiere decir que no haya que cuestionarse los cambios en los hábitos corpóreos producidos por los procesos de hibridación con los sistemas tecnológicos, por la relatividad entre lo cercano y lejano, presente y ausente, real y ficcional, consecuencia de la incorporación y el contacto constante con dispositivos y redes digitales que amplían, fragmentan y trasladan nuestra identidad corporal a otras dimensiones.

El movimiento, el espacio y el tiempo no son solo sugerencias, sino la base material de la danza y de estos nuevos formatos artísticos que además conciertan lo real con lo virtual. En algunos casos, la propia tecnología se convierte, incluso, en el objetivo mismo para ciertos artistas, los cuales tienden a analizar cómo se manifiestan estas relaciones entre arte y tecnología, desarrollando modos y códigos preocupados por ser comprendidos.

Y hay un último punto más práctico que es el costo, el tiempo de armado que me lleva a mí, y lo fácil-difícil que pueda ser implementarlo en escena para una persona que no es especialista. Todo eso es clave contemplarlo. El programador necesita ponerse en el lugar de los no programadores si quiere que sus trabajos tengan utilidad y aceptación en situaciones escénicas reales (Kesler, mensaje 23/04/16, 19:42).

En un tiempo futuro, la inteligencia artificial desarrollará computadoras y programas capaces de simular los procesos del pensamiento y de las acciones del hombre, pero hasta el momento cada disciplina sigue produciendo desde diferentes técnicas compositivas, esto se hace evidente tanto en lo expresado por Kesler como lo que manifiesta Alain Baumann ${ }^{85}$ :

\footnotetext{
85 Alain Baumann, músico y artista multimedia, lidera, junto a Rosa Sánchez, una de las agrupaciones pioneras en la utilización e incorporación de tecnología interactiva en proyectos de creación. Se trata de Kònic thtr, plataforma artística con sede en Barcelona, con más de veinte años de trayectoria, en la que la danza y la tecnología conviven como el resultado de una profunda tarea de investigación sobre nuevos lenguajes basada en el eclecticismo disciplinario. Desde 1990, coordinan y dirigen las actividades de esta plataforma de creación en la que también se impulsa, a través de sus proyectos, el encuentro y la
} 
El punto de partida es intentar entender hacia dónde se va. Mi trabajo ahí es aportar, pero cuando empiezo a programar es todo lo que tiene que ver con la informática. Unos pequeños caminos que nos obcecan como señales de sonido, etcétera, que no tiene ya que ver con el cuerpo. La dinámica de la programación es algo lenta y pesada, un poco autista. Una idea surge, se hace una primera aproximación, se pone en ensayo con el cuerpo, se ve lo que puede funcionar o no y se vuelve a seguir trabajando. Es una dinámica de trabajo muy típica de este tipo de unión. Son ciclos, los ensayos no se dan continuamente como en una compañía más convencional, sino que son etapas, se tiene que dar espacio a los desarrollos porque todavía es más lento desarrollar que crear con el cuerpo, no es tan inmediato (Baumann, 2016: 3'24').

La performance del cuerpo y la programación evolucionan sobre vertientes heterogéneas, a veces algunas de ellas se adelantan a otras conformando tramos que proliferan antes de que se logre investigar en profundidad. Este es el caso del código pensado específicamente para ser controlado mediante captura de movimiento que se utiliza cada vez con más frecuencia en diferentes escenarios, y del cual solo estimamos los resultados estéticos sin tener verdaderamente conciencia de las reglas de programación que generalmente contienen las motivaciones conceptuales de su uso y cómo esto impacta en el cuerpo de quien interactuará.

Hacía un mapping sobre el cuerpo de dos bailarinas; yo tiraba sobre los cuerpos la misma imagen de ellas, armaba una imagen y necesitaba que el cuerpo se adaptase, y no al revés, no era tanto la informática al servicio del cuerpo, sino el cuerpo readaptándose a esa informática. Yo precisaba que ellas tuerzan el cuerpo de alguna manera para que les dé bien. Me acuerdo de que estaban así media hora mientras yo estaba probando eso, y me gritaban: "¡Somos bailarinas!", como diciendo: "nuestro cuerpo está para bailar" (Gendin, 2016: 9':19").

Este cuerpo interfaz que aún puede considerarse como adaptativo al sistema, hoy se plantea no como vehículo de mediación, sino como proceso evolutivo de selección de informaciones, que, a la par de ir constituyéndose, produce nuevas tendencias y atribuciones. Así es que, a medida que se va esfumando la metáfora del hombremáquina, hombre-interfaz y hombre-información, cede su lugar al hombre-emisión

colaboración con otros artistas invitados a compartir propuestas creativas o de investigación. Con el fin de ampliar la información, véase:: <http://koniclab.info/es/>. 
cuya relevancia comienza a no estar puesta en la mediación sino en el acceso y en la emisión de información.

Acorde con esto, Rosa Sánchez (2016: 6'15") -perteneciente a la plataforma artística Kònic thtr-, en una entrevista efectuada con relación al lugar que ocupa el cuerpo en las configuraciones performáticas con las que se interactúa, señala:

\footnotetext{
El programador está programando con datos de captura, al mismo tiempo, ve esos datos al otro lado, en el cuerpo que está siendo capturado, ve el proceso que está haciendo el bailarín/na, sabe que está emitiendo en código para que el otro lo reconozca. Entonces, para mí, para que esta comunicación se establezca entre el programador y la bailarina, ha de haber siempre esta conciencia de traducción continua.
}

Situados en esta conciencia de emisión de códigos por parte del cuerpo a la luz de las nuevas globalidades, expresiones y dispositivos, habrá que renovarse siguiendo una lógica ineludible hacia la experimentación del fenómeno de la temporalidad y la especialidad con subjetividades que se desdoblan, se ficcionalizan en este influjo de la traducción y modelización autorregulable. El interés reside en entender otros criterios más complejos entre los componentes y la dimensión de los diferentes niveles de participación. No solo porque seguirán afectando lo conocido, sino porque se postularán como un nuevo desafío para las categorías de realidad que se plantearán en un futuro no tan distante.

\section{Concepciones del cuerpo en la mediación interactiva}

El propósito del presente apartado es reflexionar sobre el lugar que la interdisciplinariedad desarrolla entre el cuerpo y los sistemas interactivos, distinguiendo inicialmente la interdisciplinariedad experimentada de la interdisciplinariedad idealizada como opción metodológica en el acontecer actual de las prácticas artísticas.

Tanto las disciplinas como sus actores debieron primero afirmar sus compatibilidades en la consolidación de sus intercambios para inminentemente -dadas las exigencias actuales de las coyunturas en la producción artística- concertar desde los ámbitos originarios e integrarse inter- y transdisciplinarmente.

Se trata de observar qué es y qué no es la interdisciplinariedad, al mismo tiempo que se plantean implicaciones subjetivas en esta revisión, puesto que la fundamentaremos 
a partir del entramado de los testimonios de los propios actores. Por una parte, protagonistas del Ciclo de Danza Performance de la UNLP "En 2Tiempos. Itinerarios de Danza", período 2012-2013; y por otra, los colegas artistas investigadores que producen y estudian el binomio cuerpo-tecnología en los laboratorios conformados y sustentados también desde el ámbito universitario. Este formato de laboratorio de creación-investigación plantea explorar la potencialidad del ámbito de la práctica y la teoría por medio de colaboraciones entre científicos y creadores de las artes escénicas dentro del espacio académico. Nos interesa citar, de igual modo, al LaPAC (Laboratório de Pesquisa Avançadas do Corpo, UFBA), InTAD (Equipo de Investigación en Tecnología Aplicada a la Danza) y a Kònic Thtr\&Lab ${ }^{86}$.

La idea es transcurrir por las diferentes narraciones en torno a discrepancias, consensos, intentos, ensayos, errores y posibles acuerdos entre la danza performance y la tecnología digital interactiva, así como entre los sujetos artistas bailarines, coreógrafos e informáticos, entre otros.

Teniendo en cuenta que nuestros problemas de investigación actuales indagan en la interlocución colectiva, no se puede sino observar las problemáticas que surgen desde los dominios disciplinares para poder responder a: ¿Cuándo una disciplina o dominio comienza a transformarse a partir de los procesos de interdisciplinariedad?

Algunas experiencias irrumpen y desplazan sus estructuras, otras exigen una reformulación. Fue lo que ocurrió, por ejemplo, con los modos de organización de las artes escénicas así como con los modos de operar de la informática. $Y$ si bien se ha vuelto cada vez más difícil clasificar las manifestaciones artísticas a partir de rótulos tradicionales, las nociones de cuerpo y movimiento están estrechamente relacionadas con los dominios que ejercen tanto el bailarín como el programador. En general, han ido definiéndose a partir de la tensión generada entre la realidad material del cuerpo anatomo-fisiológico y la inmaterial del cuerpo anatomo-digital.

Don Idhe (2002: 27) describe esta tensión como una "experiencia total o multidimensional" conformada desde dos perspectivas posibles del cuerpo: una

\footnotetext{
${ }^{86}$ Entre estos laboratorios citamos al LAPAC (<http://www.danca.ufba.br/estrutura.html>), que está en relación con la Escuela de Danza en la UFBA, y el Elétrico Grupo de Pesquisa em Ciberdança, que tiene como objeto de indagación a la danza contemporánea interrelacionada con el lenguaje de las nuevas tecnologías digitales, en especial con software interactivos en tiempo real, en particular el Live Forms e Isidora. El equipo InTAD (<https://intad1.wordpress.com/>) se conformó en el intercambio con el LaPac y pertenece al Posgrado en Lenguajes Artísticos Combinados, del Departamento de Artes Visuales, UNA. El laboratorio Kònic Thtr\&Lab (<http://koniclab.info/es/>) es una plataforma artística con base en Barcelona dedicada a la creación contemporánea en la confluencia de arte y nuevas tecnologías, conforman grupos interinstitucionales como el GTMDA formado por el Grupo de Pesquisa Poéticas Tecnológicas, Corpo e Imagem/Universidad Federal de Bahía (Brasil), Kònic Thtr/Kòniclab (Barcelona), Fundación i2Cat, Lavid/UFPB Laboratorio de Aplicaciones de Vídeo Digital/Universidad Federal de Paraiba (Brasil), Laboratorio Natalnet Departamento de Computación y Automatización de la Universidad Federal de Río Grande do Norte (Brasil).
} 
encarnada desde adentro y otra de "objetivación visual que se asemeja más a presenciar un espectáculo externo":

Ambas perspectivas son posibles -y pronto intentaré mostrar cómo las dos están profundamente arraigadas en nuestras acciones culturales-, e incluso podemos ver una dialéctica en la cual la imaginación de un "cuerpo actual" en el que se proyecta determinada experiencia adquiere cierta primacía sobre esa cuasiotredad incorpórea que también resulta imaginable y que cuenta con sus propias ventajas. Tal dialéctica, no obstante, se evalúa desde la riqueza sensorial que se concede a la primera perspectiva, que asociaremos al cuerpo de la vida real. Y la postura desencarnada o la perspectiva del cuerpo como cuasi-otro es, en sí misma, un cuerpo virtual en una proyección no tecnológica. Este modo de virtualidad es un cuerpo-imagen (Idhe, 2002: 27).

Ludmila C. Martínez Pimentel (2010: 2) valida a Loie Fuller ${ }^{87}$ como una de las primeras en considerar la "Danza en interfaz con las nuevas tecnologías, además de ser innovadora en su proposición del cuerpo que baila como un cuerpo-imagen, y no más reforzando el cuerpo como mero reproductor de movimientos". La imagen, por tanto, se convierte en un espacio en donde se articulan y convergen los conceptos que intervienen, componen y determinan la cultura del cuerpo y la performatividad en la actualidad, estableciéndose así un territorio para la lectura y las propuestas sobre lo que es el cuerpo: los límites difusos y a la vez definidos que lo conforman, su implicancia ideológica y estética. Una posibilidad de replantear las relaciones humanas, adentrándonos en el análisis de los aspectos que son de vital importancia para revisar la relación del cuerpo y la imagen.

En la danza, para mí, se tiene un gran equívoco, y es no pensar la danza como un arte de la imagen y del movimiento; la imagen del cuerpo; un cuerpo imagen, un cuerpo imagen y movimiento. ¿Por qué? Porque tradicionalmente está establecido que la danza es lenguaje del movimiento; se prioriza eso: hacer movimientos (Martínez Pimentel, 2014: 8').

\footnotetext{
87 Loie Fuller y su famosa danza serpentina (1892) presentaba una innovadora visión del cuerpo, desarrollaba con sus experimentos infinidad de ilusiones ópticas. Sus juegos lumínicos y de vestuario, que tan solo con dos varillas como extensión de sus brazos, moviendo en círculos gigantes de telas que abrían y cerraban su figura y funcionaban como pantallas, lograban crear imágenes de impactantes niveles de abstracción.
} 
El cuerpo imagen puede ser visto a través de una proyección generada por la captura directa de una cámara, por el uso de un software, o incluso una sombra; es estimado un elemento poético para la danza digital contemporánea. Por lo tanto, nuestro interés por la danza con mediación tecnológica se ha centrado siempre en la experiencia perceptiva, sensorial, de reciprocidad y no en el uso del dispositivo per se, analizando sus implicaciones y conformaciones conceptuales y estéticas en otros espacios y temporalidades.

Haciendo hincapié en esta migración del cuerpo al contexto digital a través de las características de los dispositivos y las interfaces observamos, en principio, cómo se van afectando y mutando la corporalidad y la percepción de quienes intervienen. Basándonos en la coexistencia material del cuerpo, la clave fue aplicar el concepto de traducción -utilizado en informática- para la propia experimentación del cuerpo en vinculación con un sistema interactivo basado en el movimiento, la imagen y el sonido. Teniendo en cuenta que, en informática, mediante un traductor, se hace posible la comunicación entre el programador y la computadora, entre el lenguaje-fuente y el lenguaje-objeto, se realizaron observaciones de su diseño en relación con los mecanismos formales de la comunicación, y en particular de la semántica.

En consecuencia, se planteó que el movimiento no es el único imperativo que define a la danza. Un universo virtual y digital irrumpe con sus resignificaciones en el devenir del espacio y tiempo físico y proyectado. Hay otro espacio y tiempo en la escena y en lo proyectado. Otra presencia del cuerpo traducido en imagen y sonido, por consiguiente, otra gramática del lenguaje de la danza, percibida en lo que denominamos danza performática interactiva o performance interactiva.

Entonces se considera el cuerpo un conjunto integrado de partes más o menos traducibles y modelizables para el sistema. A este panorama, se unen las concepciones socio-culturales del cuerpo y sus significados. La traducción forma parte de las nuevas maneras de pensar los lenguajes integrados y de crear opciones para un formato de comunicación informático que puede entenderse también como una corporeización de concepciones inmateriales que permanece fuera del campo de la mirada.

Por lo tanto, lo que podría denominarse cuerpo extendido es aquella dimensión corporal integral que comprende lo material y lo inmaterial, en la que el arte contemporáneo se sitúa como un escenario-laboratorio, para -en nuestro casoexperimentar en la relación con los sistemas de comunicación digital. Este cuerpo extendido mediante procesos de informatización modifica nuestra concepción individual de cuerpo, exteriorizándolo en computadoras y redes. Todo está conectado 
con todo a través de enlaces que se procesan en una totalidad inseparable y, a la par, ramificados.

Se activa una manera de abordar la realidad física y de dejarse interpelar por ella, una manera de producir discurso con el transcurrir de la experiencia y no con sus representaciones. Ponemos al cuerpo en correspondencia con el espacio, el lugar, el acontecimiento, sea este físico real, o virtual o aumentado, pero siempre siendo el cuerpo sentido y no solo experimentado en la percepción externa.

Instalados en este paradigma que logra conjugar elementos virtuales con la realidad física que nos rodea, introducimos la mayor parte de las experiencias de multimedia escénica, como las instalaciones, las performances y las intervenciones interactivas en las cuales realidad y simulación se funden. En este sentido, el cuerpo extendido es un cuerpo cuyos contornos son prolongables a la imagen y al sonido digitalizado, proyectados a través de las interfaces, los lenguajes de programación y el control gestual interactivo. La facultad de administrar nuestros gestos y conductas expresivas a la hora de proceder con el ciclo interactivo ${ }^{88}$ de un sistema -de hacer circular a las partes del cuerpo por un pasaje determinado de la contingencia propuesta por ese sistema de captación, traducción y modelización- es de una fuerza en esencia productiva, ya que puede conseguir la transformación de las marcas de formación disciplinar.

Con la intención de aportar desde el testimonio de los coreógrafos y bailarines performer frecuentadores de este tipo de experiencias, avanzaremos por los modos de concebir al cuerpo y al movimiento en interactividad con el espacio escénico mediatizado.

Pierre Lévy (2007: 65) indicará que la interactividad designa la participación activa de una transacción de información, y que "de hecho, sería fácil demostrar que un receptor de información, salvo que esté muerto, nunca es pasivo". Procede luego sobre aparatos analógicos y digitales que viabilizan la comunicación según el entorno: "La comunicación a través del mundo virtual es pues, en un sentido, más interactiva que la comunicación telefónica porque implica en el mensaje la imagen de la persona y la de la situación, que son casi siempre metas de la comunicación".

Lévy deja planteada la problemática de la dimensión corporal puesta en juego en la interactividad, en el grado de interactividad de un dispositivo y, sobre todo, reclama la urgencia de la constitución de una cartografía de los modos de comunicación; pues el cuerpo está cada vez más supeditado a las "configuraciones" de la comunicación. "La

\footnotetext{
${ }^{88}$ Nuevamente citamos el esquema del ciclo de la interacción de Causa y Joselevich (2014: 66) dado que, al recorrer "siete pasos que van desde el interactor (humano) al sistema (el dispositivo, la o las computadoras, etc.) y vuelve hacia el interactor nuevamente", nos pautan tramos ahora descriptos desde la perspectiva de los programadores.
} 
interactividad designa más un problema, la necesidad de un nuevo trabajo de observación, de concepción y de evaluación de los modos de comunicación, que un carácter simple y unívoco atribuible a un sistema o a otro" (2007: 68).

Con esta condición de las configuraciones de la comunicación ${ }^{89}$ física y virtual dadas al cuerpo, citaremos testimonios de coreógrafos, bailarines y performers para trazar algunas reflexiones acerca del lenguaje de movimiento producido a partir de estas interacciones con sistemas informáticos. Además, contamos con algunas conclusiones desarrolladas en investigaciones anteriores y que contribuyen al presente.

Entre ellas, consideramos aquellas conclusiones que derivaron del estudio de las performances interactivas (Hoseo y Speak ${ }^{90}$ ), dando comienzo a un encadenamiento de reflexiones acerca de la danza contemporánea, la performance y la danza performática vinculadas estas a las prácticas con las nuevas poéticas tecnológicas. Por ende, se problematizaron los medios y los modos de creación, representación y producción. Por eso podemos manifestar que:

\begin{abstract}
En principio, las nuevas tecnologías no están revolucionando la danza, sino expandiéndola o, en el mejor de los casos, la danza como disciplina artística está apropiándose de las nuevas tecnologías como si se tratase de nuevos recursos escénicos (Ceriani, 2010: 62).
\end{abstract}

Los diferentes elementos y procedimientos vinculados a lo escénico, al adecuar o aplicarse a los nuevos recursos tecnológicos, dejan entrever que no todos sus componentes y experiencias dan respuesta o están disponibles en otras formas de interacción. La discusión hace foco en la incumbencia de lo disciplinar: la danza o performance vinculada al arte interactivo. En este punto, nos hemos encontrado frente a un sinnúmero de discusiones e interrogantes que condujeron nuestra indagación hasta concebir las siguientes enunciaciones: El desplazamiento antropocéntrico del performer, correrse de su centralidad, se originó a partir de "la imagen del cuerpo virtual y digitalizado". Esta imagen y sus cualidades están dadas por el tipo de interfaz y sensado escogido. A cada opción de interfaz, software, programación y capacidad de sensado, le corresponderá un tipo de movimientos con los cuales se interactuará y pondrá en diálogo el cuerpo con el sistema.

\footnotetext{
89 Definimos la comunicación como el intercambio de información, un proceso o paso de un estado a otro que indica una serie de actos concatenados, y no un efecto o consecuencia de una acción. Es un proceso de comunicación entre el cuerpo y el sistema anclado en un marco espacio-temporal y cultural caracterizado por códigos y lenguajes disciplinares en conjunción.

90 Con el fin de ampliar la información, véase: $<\mathrm{http}$ ://www.alejandraceriani.com.ar/anexo_alejandra_ceriani.pdf>.
} 
En suma, la imagen del cuerpo digitalizado es lo que determina, directa o indirectamente, la conciencia del estado interno y externo del cuerpo físico interactuando con dispositivos e interfaces en el entorno, y es en esa determinación donde cobra sentido. Actúa tanto sincrónica como diacrónicamente. Por ende, entendemos que: en el estado de discernimiento de ambas imágenes, la imagen proyectada digital y virtual y la imagen mental de nuestras sensaciones, se origina el lenguaje corporal propio, aquel que surge de la interacción con el cuerpo físico real y el conjunto de los sistemas interactivos en tiempo real.

En todo este estudio se ahondó en el comportamiento disciplinar de la danza en cuanto a qué sucedía con el cuerpo al ser captado por un sistema óptico; observando la descomposición de un tipo de materialidad física hacia otro tipo de materialidad virtual.

Internamente el discernimiento de lo que sucede con el cuerpo en movimiento, concierne a la distribución entre el cuerpo y los algoritmos de la programación, entre el movimiento y el procesamiento de datos. Surge de este modo un nivel de conciencia de la interacción entre la percepción a través de los sentidos (sinestesia), la digitalización de la imagen y del sonido y los dispositivos analógicos y digitales. Por lo tanto, se puede estar siendo consciente o no consciente de lo que está aconteciendo en esos niveles perceptivos. $\mathrm{Y}$, en consecuencia, enriquecerse o no de un lenguaje corporal propio surgido de la interacción entre el cuerpo físico y la mediación tecnológica propuesta.

\begin{abstract}
Cada una de las tecnologías que posibilitan trabajar con la tecnología digital en danza precisa de algunos años para llegar a la construcción de un lenguaje y para llegar a la construcción de una poética. Entonces yo permanecí mucho tiempo requerida por la videodanza, las instalaciones interactivas, las performances interactivas en tiempo real y la coreografía interactiva (Martínez Pimentel, 2014: 4').
\end{abstract}

Para Ludmila C. Martínez Pimentel, así como para Rosa Sánchez, la danza es imagen, no solo cuerpo y movimiento; hay que aprender a bailar con la imagen de uno mismo y de los otros. Asimismo, esto conlleva un tiempo de vinculación, un proceso de trabajo con la tecnología primero, hay una información que, como interactor con el sistema, se debe conocer para estar al tanto de cómo y con qué códigos resolver el movimiento, pues es, desde esos códigos, que será posible emitir en relación con ese sistema. 
Cada bailarina, bailarín, tiene una memoria, una configuración, una historia corporal distinta, técnicas de danzas, de aprendizajes. Nosotros hacemos un proceso de varios años con la misma bailarina o bailarín. Necesitan de un proceso de comprender los medios con los que están trabajando; pero también cómo ese cuerpo se tiene que articular, desde dónde tiene que emitir, una experiencia performativa -más que de danza- una experiencia que incorpore estos nuevos lenguajes, medios, espacios que se definen en el momento en que se trabaja con un sistema de captura, un sistema sensible (Sánchez, 2016: 7'20").

Ahora bien, una manera de ejercicio del producto artístico inmediato, que también coexiste junto a estos otros procesos de investigación sostenida a través de los años que refiere Sánchez y al que nosotros adherimos-, conforma experiencias que, por lo general, tienen por objeto los cuerpos disponibles y por objetivo su normalización. En este tipo de propuestas los movimientos son -en el peor de los casos- una reproducción ajena al sistema o -en el mejor de los casos- justificaciones matemáticas. La disciplina en danza en estos casos tiende a la homogeneidad desde donde inscribe al cuerpo como objeto y blanco de aplicación. Podrían encontrarse en estas prácticas interdisciplinares signos de esta dedicación al cuerpo, al cuerpo sobre el que se opera, al que se lo desdobla en imagen y sonido, al que se lo instrumentaliza, que responde o que se torna más activo a medida que el proceso responsivo del sistema lo empodera.

En general, se observa que las prácticas artísticas contemporáneas, justamente al "estar siendo", suelen ofrecer una superficie libre de fisuras al primer vigilo; pero en busca de señales que revelen el camino de tendencias mucho más amplias y profundas, aparecen otras superficies menos conscientes de sí mismas para llegar al meollo del estado de las cosas.

En ese sentido, nos interesa retomar la reflexión que Siegfried Kracauer (2008) hizo sobre la danza que, al desprenderse de su sentido ritual, se fue centralizando en configuraciones plásticas cuyo significado, en cierta medida, proveyó de un tipo de concepción del mundo en el que la estandarización y el interés estético de una comunidad tecnologizada se estaba consolidando. Según este autor, la eficacia que conduce a la autorregulación del cuerpo o a su adaptación ergonométrica a artefactos de su época recibe asimismo su contenido, su forma y su contexto, y origina nuevas dinámicas que suscitan mutaciones en el movimiento corporal:

El ornamento que se desprende de sus portadores hay que concebirlo racionalmente. Consiste en estructuras lineales y círculos tal como los que se 
encuentran en los libros de geometría euclidiana; también se incluyen configuraciones elementales de la física, ondas y espirales. Quedan excluidas las proliferaciones de formas orgánicas y las irradiaciones de la vida anímica (Kracauer, 2008: 53).

Para Kracauer, el término estandarización se encuentra intrínsecamente relacionado con homogenización y este, a su vez, con control. El ornamento es la disposición que se despliega en la cultura para compartir búsquedas y consumaciones análogas con un mismo efecto visual. Vistas sucintamente estas ideas sobre cuerpo, danza, diseño coreográfico, podemos ir dando cuenta de cómo se va desarrollando la evolución mutua entre persona-sujeto respecto a la técnica y a la tecnología en contexto.

Para conectar en este punto el pasado reciente, revisamos posturas ideológicas vigentes -que no son incompatibles con las formulaciones que describe Kracauer, pero sí guardan la debida distancia respecto al contexto en el que hoy se desarrollany que están atravesadas por una red de relaciones, que no siempre se anteponen a los pre-conceptos de deslindar práctica y teoría. Queremos remarcar que la investigación en arte suprime esa perspectiva dependiente-aplicacionista, cuyos argumentos se construyen para decir que práctica y teoría solo guardan una correspondencia de observancia.

Entonces, tenemos, por un lado, las formas de disciplinar el cuerpo individual, de volverlo un cuerpo disponible para su captura y procesamiento; $y$, por otro, nuevas formas de expandir y proponer la producción escénica con sistemas tecnológicos físicos y virtuales.

El equipo del emmelab subraya en el prólogo de una nueva edición sobre investigación en el ámbito del arte generativo que "Fiel a nuestro estilo, categorizamos estos textos en dos secciones, tituladas 'Pensar' y 'Hacer', buscando propiciar la reflexión teórica, pero también valorando la experimentación y su difusión" (Causa y otros, 2015: 4); guarda así un delicado equilibrio entre el lugar concebido a la teoría y el lugar concebido a la reflexión práctica.

Juan M. Prada afirma que se está dando un cambio en la interacción ser humanomáquina que, incluso, describe como crisis de la interactividad: "Poetizando sobre el ideal de la interactividad, que no olvidemos solo podríamos concebir adecuadamente como un darse lingüístico al otro, como un intercambiar lo que no se tiene, es decir, lo que uno es" (Prada, 2015: 11'47"). Esto agita las relaciones "tolerablemente" conformadas entre bailarines performers y programadores, pues no son infrecuentes las críticas que ven el fenómeno del arte interactivo como un cambio de la representación a la manipulación, considerando al arte interactivo como el desarrollo y 
la sofisticación de una tendencia para muchos generalizada en el arte contemporáneo hacia la administración del cuerpo.

Con esta lógica, el cuerpo se manifiesta para ser tomado como un claro objeto de onoff presente en la frecuentación de las instalaciones interactivas. Esto estaría en correspondencia con una nueva forma de instrucción del cuerpo sugerida, enseñada y reproducida por distintos discursos y medios. Es decir, el término imagen corporal, que pertenece al dominio de lo abstracto, es una construcción simbólica que se ha tornado substancial e instrumental, esto a través de los cambios en la construcción del cuerpo como hecho subjetivo.

En algunos discursos de artistas investigadores, se ve reflejado que estos cambios propios de la interacción y del intercambio a conciencia promueven una apropiación por parte del cuerpo tanto de los performers como de los programadores, lo que conlleva un largo proceso hasta llegar a una vinculación productiva y de entendimiento mutuo, aunque este siempre sea fluctuante:

\footnotetext{
Conocer a los bailarines, conocer que memoria tienen, de dónde vienen y cómo responden, para poder entender desde qué lugar puedo proponerles el trabajo. Porque para mí no pasa por describir didácticamente cómo tienen que relacionarse para poder trabajar con los sistemas desde otro lugar más interno, sin tanta preocupación por hacerlo de determinada manera. Desde sus claves cómo pueden configurar su cuerpo en un espacio de captura. Si lo hago al revés quedaría algo rígido, didáctico, demostrativo (Sánchez, 2016: 8’46”).
}

En este proceso, el bailarín performer adquiere no una autonomía individualista, sino una autonomía compartida, todos se someten a un conjunto de reglas cuyo límite es la autonomía del otro. Esta modalidad es congeniada para guiar y crear con (y hacia) los cuerpos, para movilizar lo más interno e interrelacionarse con los sistemas y con quienes crean esos sistemas. Aun así, las mínimas o invisibilizadas disputas de los campos disciplinares ejercen resistencia.

Observemos el siguiente diálogo ocurrido en la entrevista realizada a un programador y una coreógrafa bailarina, en el ya citado equipo Kònic Thtr que lideran juntos desde hace más de veinte años. Incluso con esta trayectoria común, esas tensiones de legitimación disciplinar ocurren en el ejercicio compartido, ya que una disciplina se estructura como un conjunto de saberes organizados que dan sustento a una práctica, a una serie de representaciones, a la construcción de un objeto de estudio, a un campo científico específico de conocimiento. 
A: No trabajamos el cuerpo sin que haya mínimo un tipo de interfaz.

R: Una cosa es el proceso que se hace con el bailarín y otra cosa es el proceso que se hace con el bailarín y el sistema, es otro proceso, es un segundo paso.

A: Es impensable sin que haya en el trabajo algún tipo de dispositivo presente. El dispositivo es parte de lo que hace el cuerpo. El cuerpo trabaja con esta migración.

R: Trabaja con una globalidad de lenguajes. La danza es importante, pero es parte de un todo. Es el todo pero también es parte de un todo. $Y$ esto es una diferencia con respecto a la danza sin esta inmersión

[Entrevista a Rosa Sánchez. Parte 1, 2016: 10'45"].

La frecuentación a menudo prescinde de la reflexión crítica sobre el hacer y desdibuja el sustrato de supuestos tácitos que la emplazan. Este cuerpo de intuiciones y formalidades aplicadas en las prácticas artísticas interdisciplinares cristaliza en una mirada naturalizadora de sus fundamentos, lo que imposibilita el reconocimiento del predominio que determinadas creencias, presunciones y proposiciones asignan a nuestras percepciones e interpretaciones de los fenómenos sobre los que procedemos.

Esta red de interacciones gana cuerpo a la par que no pierde su invisibilidad en distintas dimensiones del quehacer profesional. Heredera del pensamiento cartesiano, de la distinción entre lo objetivo y lo subjetivo, propugna la utopía de un trabajo equitativo e imparcial. Esta red algo híbrida pero articulada de supuestos admitidos sin discusión -o si hay discusión, esta posee en sí un alto porcentaje de negociación a favor de un producto- es un piso sobre el que se sostienen los discursos disciplinares que coordinan casi todas las experiencias en el campo de la investigación y la producción artística de bailarines, coreógrafos e informáticos.

Las formas de vinculación -en general los modelos hegemónicos de práctica profesional instalados en cruce del arte y de la ciencia- siguen siendo desiguales en cuanto se le confiere una mayor legitimación social y cultural a lo "científico", fortificando así el prestigio académico y prescindiendo de una revisión crítica.

La práctica misma logra encontrar en el análisis y en la profundidad del debate que vaya proponiendo la emergencia de nuevos escenarios donde repensar las intervenciones y sumar a los procesos transformadores que conllevan las propuestas transdisciplinares en el actual contexto.

En consecuencia, nosotros sí estamos proponiendo otras perspectivas de análisis que incluyen las visiones de los sujetos formados en diferentes disciplinas, puesto que los recursos metodológicos en ellas operan implícitamente para la generación de competencias y discursos, que a menudo son centralizados y autosuficientes. 
Los modelos explicativos y los procesos de comprobación empírica excluyen, por lo general, los procesos inciertos, azarosos, desmadrados, aplicando una clasificación de los fenómenos revisables capaces de adecuarse como objetos de estudio a sus instrumentos analíticos. Por ende, aquellas experiencias que no se apropian de sus procedimientos quedan adosadas a su modelo metodológico como islas que componen un potencial territorio de suministro.

En este sentido, pensado desde la performance como una acción individual del cuerpo que encarna la articulación con el sistema, se hace palpable el gesto interactivo del performer para con el sistema, pero no lo suficientemente visible para el espectador.

\begin{abstract}
Nosotros entendemos como una de los cuestiones difíciles de entender cuáles son los gestos que se traducen en visuales y sonidos, qué fragmentos de cuerpo vemos; cómo se mueve la mano, el pie, la pierna. Las variables semánticas no las capta la computadora. Es extremadamente difícil modelizar la manera en que una persona entiende el movimiento de la bailarina. A medida que avance la técnica se saldrá de la situación de dato hacia una situación semántica de interpretación del cuerpo, siempre con un límite. La computadora no sabe leer una novela, sabe leer comandos básicos. Con el cuerpo pasa lo mismo. El dispositivo está vinculado al dato y son complejas de por sí las relaciones que el público pueda interpretar (Causa, 2013: 0'10").
\end{abstract}

La lógica particular de ciertos desarrollos disciplinares implica una independencia respecto de otros dominios del saber determinando así algún grado de incomunicabilidad entre ellos. La disposición endogámica interdisciplinar produce no pocas veces una ignorancia absoluta de lo que transcurre extramuros $y$, lo que es peor aún, el desconocimiento de dicha ignorancia.

En tal sentido, el uso de las tecnologías se ha generalizado en los entornos artísticos y ha producido actitudes de rechazo hacia las tecnologías con argumentos como la carencia de información sobre cuál es el uso apropiado, la aparente complejidad, la falta de tiempo para reconocer un nuevo participante y la falta de recursos de los espacios de ensayo y exposición, una cierta actitud de reserva hacia el cambio, el temor a romper con la concepción habitual de proceso, hallazgo y diseño coreográfico.

Es algo generacional de llegar tarde a las tecnologías y tenerle hasta un poquito de miedo al principio. Fui siempre bastante austera en la puesta. Ingresar en este mundo de la tecnología, el cable, la cámara, me generó miedo de perder el 
control de la totalidad. Las bailarinas se quejaban todo el tiempo: “¿Pero esto qué es? ¿Qué somos, el último orejón del tarro? ¡Esto no funciona!” Decirles: "Son un elemento más. Realmente son un elemento más" (Olivieri, 2013: 5'34").

Otro componente inquietante es el propio público de danza. La relación de la danza con las nuevas tecnologías es un tema que se presta con facilidad a enfoques apocalípticos en torno a su futuro y su siempre cuestionada dominación por parte de la tecnología.

El público también tiene que aceptar que se está haciendo una evolución. EI público de la danza es al que más le cuesta aceptar este tipo de vínculo. Se detiene solo a ver la danza y no ve la totalidad. La gente que no viene del ámbito de la danza es capaz de verlo todo, es como que tiene menos prejuicios (Olivieri, 2013: 8'15").

Analizando lo expresado por la coreógrafa, queda evidenciada la referencia a la regulación, al control sobre el sistema que parece necesario al estar interactuando. Para Emiliano Causa (2013: 4'26”) y los integrantes del equipo emmeLab, está incluido en el proceso de creación del sistema:

Nuestra estrategia de visibilizar los procesos tiene que ver con poder, de alguna forma, desaherrojar el cuerpo de la bailarina; de poder desbloquearlo y darle fluidez nuevamente a partir de que ella sienta que puede tener el control de lo que está haciendo; a partir de lo que está sucediendo, de una real comprensión.

Soledad Belén (2013: 2'23") -bailarina performer que investigó con el equipo emmeLab en esa experiencia conjunta- apunta: "No me pareció para nada restrictivo, pero sí tuve que buscar formas de moverme para poder dialogar con ese sistema". Evidentemente, el proceso creativo mediado por las tecnologías digitales suscita un vasto campo de investigación de las percepciones entre los performers bailarines, programadores y artistas involucrados, así como con el público que se convierte en un participante más en estos términos de creación sistémicos y dinámicos.

En este sentido, un proceso es un conjunto de actividades mutuamente relacionadas - de modo simultáneo o sucesivo- con los elementos de entrada que los convierten en productos o resultados. Consecuentemente, al interactuar juntos la programación, el proceso y el cuerpo, nuestro interés por la danza con mediación tecnológica se ha centrado siempre en la experiencia perceptiva y sensorial $-\mathrm{y}$ no en el uso del dispositivo per se-. 
Si se insiste en el propio cuerpo podría hablarse a partir de lo interno, lo externo orgánico, propioceptivo o cenestésico. Entonces otro tipo de precisiones reclaman e interrogan: ¿Ese cuerpo en interacción con un sistema informático construye gestualidad precisa o movimientos indeterminados? ¿Ese cuerpo-sujeto es consciente de que produce datos cuando danza? ¿O danza inconscientemente con imágenes y sonidos como escenografías móviles de fondo?

Haciendo hincapié en el propio sistema informático, podría hablarse a partir de una concepción interactiva afecto-expresiva, interactiva funcional o viceversa. Cualquiera de estas perspectivas en sus especificidades construye datos mensurables, experimentables, datos que se traducen y modelizan para retroalimentar un sistema interactivo o reactivo compuesto de visuales, sonido y diseños gestuales. En consecuencia: ¿los programadores programan sistemas que deben ser accionados o sistemas que deben ser afectados, interrumpidos y retroalimentados? ¿Se programa para un cuerpo que danza, para el lenguaje de movimiento en su abstracción atemporal y dinámica, o en su fisicalidad espacio-temporal concreta?

Según los integrantes del InTAD, "el desafío es construir la performance desde el punto de cruce entre el mundo digital y el cuerpo, explorar la forma en que el cuerpo, que puede ser el del performer o el del espectador, o ambos, habitar el tiempo y el espacio virtual del mundo digital" (Zorrilla en Giovo, 2016: 2). Estas realidades -la física y la digital-, si bien son de naturaleza desemejante, pueden compatibilizarse en la evolución de la tecnología del presente. Maximiliano Wille (en Giovo, 2016: 1) agrega, a propósito de una residencia en tecnologías multimediales interactivas efectuada:

\footnotetext{
Uno de los trabajos de la primera residencia se titulaba "El cuerpo no puede reducirse a un secuencia de números", y expresaba esta idea de irreductibilidad: para habitar el mundo virtual el cuerpo se debe hibridar y prolongar por medio de extensiones que se adapten a él. Uno de los procedimientos que exploramos en nuestro trabajo es la forma en que el cuerpo funciona como la fuente de los datos que el sistema tecnológico utilice.
}

Analizando esta idea de que el cuerpo debe hibridarse y prolongarse, citaremos nuevamente a Soledad Belén, pues ella, como otras bailarinas del ciclo de danza de la universidad, han realizado una evolución que consistió, entre otras cuestiones, en la apropiación y comprensión de términos y formas de componer y adecuar el cuerpo, articulaciones, gestos y movimientos ergonométricos en vinculación no solo con el 
sistema propuesto sino con los modos. Esta es la parte más fructífera de una exploración conjunta entre desarrolladores y bailarines:

El mayor desplazamiento puedo hacerlo en el eje $X$, lo más bidimensional posible. ¿Por qué? Porque pasa que todavía no está tan discriminado el sistema de lectura de la cámara Kinect, se confunde el cuerpo que está leyendo y aparecen entrelazadas las que serían las articulaciones con las extremidades (Belén, 2013: 3'10").

En definitiva, dar cuenta desde lo corporal de la presencia operativa de los dispositivos y del entorno de mediatización crea un escenario propicio para un resultado que dialogue con estas diversas apropiaciones, derivadas, sin lugar a dudas, de los sistemas técnicos y tecnológicos. De igual modo, estas lógicas renovadas de creación, en conjunción con lo experimentado, disponen todo a la aparición de otros procedimientos accionados desde otras reglas. Las lógicas de la mediación que se establecen entre los procedimientos hibridados atraviesan los dominios englobantes del arte y de la ciencia. Asimismo, para aprender de las lógicas de los sistemas interactivos se debe advertir (y transitar por) lo que ocurre en interacción, y comprender las particularidades de su evolución.

Si repasamos un período de tan solo diez años atrás, las artes escénicas, en general, y la danza, en particular, aparecían a la defensiva, desbordadas por las novedades culturales mediatizadas. La intransigencia de los artistas bailarines y coreógrafos se situó en posturas que iban desde la desconfianza a la negación, pasando por la subestimación: "se trata de una moda".

El paradigma de la digitalización, cuya magnitud y celebridad tendían y tienden a adelantarse a los fenómenos de asimilación socio-cultural, fue para la danza y para la performance un proceso complicado y altamente resistido. La preocupación por denominar y llamar a conceptualizar nos distancia tanto de las experiencias que solo sirve para transmutar el pensamiento artístico en una elaboración para el observador. La instancia de lo no categorizado parece siempre marcada por lo inconsistente. Cuando emergen conexiones que no están manifiestas en el cuerpo, pero que se constituyen en tránsito con el entorno en un proceso ambivalente de organización y desorganización, desafían nóminas estéticas, curatoriales, académicas, etcétera, y por eso, generalmente, son desestimadas.

Hoy, la principal característica es que conviven los resultados directos de nuestra experiencia y de nuestras búsquedas en las redes de internet. Ese espacio producido por sus propios contenidos torna evidente la coexistencia de todas las prácticas 
artísticas, incluidas las del cuerpo. Tal vez, la propia vida de la danza y de la performance mude casi definitivamente debido a la intervención de las nuevas mediatizaciones en la red.

Estas nuevas vinculaciones entre "¿disciplinas?" -que habitualmente se han estimado como de naturalezas paralelas como podríamos suponer que son la informática y la danza performance, por un lado; y lo escénico físico, lo escénico simulado y el ciberespacio como un híbrido entre ambos, por el otro- han transcurrido por la interdisciplinariedad hacia una transdisciplinareidad con una altísima conciencia del trabajo demandado.

Si bien la producción corpórea-digital está cambiando gradualmente, vemos que la vida profesional de los artistas y sus relaciones con los espacios de presentación y tipos de público también lo están haciendo, y esto hay que observarlo y no será prejuiciosamente de un modo negativo. Entendemos que es significativo comprender $y$ fructificar los cambios con los que estamos coexistiendo; $y$, teniendo en cuenta este escenario, nos seguiremos abocando a las relaciones entre la danza performance, las mediaciones y los espacios en la red.

A continuación, nos introducimos en la Parte 3 de este Capítulo 2 que versa sobre la danza performance telemática o en red: experiencias con el cuerpo desdoblado, en un espacio distribuido, que interactúa con dispositivos e interfaces informático/telemáticas en la red de internet.

\section{Referencias bibliográficas}

Barragán, Hernando (2008), “¿Software arte?”, en Jorge La Ferla (comp.), Las prácticas mediáticas predigitales y postanalógicas. Artes y medios audiovisuales: un estado de situación II, Buenos Aires, Nueva Librería.

Barthes, Roland (2003), "Cómo vivir juntos: Simulaciones novelescas de algunos espacios cotidianos", en Notas de cursos y seminarios en el Collège de France 1976-1977, Buenos Aires, Siglo XXI Editores.

Bonsiepe, Gui (1999), Del objeto a la interfaz: mutaciones del diseño, Buenos Aires, Ediciones Infinito.

Bourriaud, Nicolas (2013), Estética relacional, Buenos Aires, Adriana Hidalgo.

Causa, Emiliano y otros (2015), "Un lenguaje de programación para el cuerpo. Abordaje retórico sobre la programación y su articulación con las artes performáticas", en Invasión generativa II, La Plata, Año 2 - N. ${ }^{\circ} 2$.

Eco, Umberto (2000), Tratado de Semiótica General, Barcelona, Lumen. 
Flusser, Vilém (1985), Filosofia da caixa preta. Ensaios para uma futura filosofia da fotografia, São Paulo, Editora Hucitec.

Fuentes, Marcela y Diana Taylor (eds.) (2011), Estudios avanzados de performance, México, Fondo de Cultura Económica.

Godard, Jean-Luc (1980), Introducción a una verdadera historia del cine, Tomo I, Madrid, Alphaville.

Heidegger, Martín (2010), "El origen de la obra de arte", en Arte y poesía, México, Fondo de Cultura Económica.

Ihde, Don (2002), Los cuerpos en la tecnología. Nuevas tecnologías: nuevas ideas acerca de nuestro cuerpo, Minneapolis, Universiry of Minnesora Press.

Kracauer, Siegfried (2008), La fotografía y otros ensayos. El ornamento de la masa, Barcelona, Gedisa.

Le Breton, David (2002), Antropología del cuerpo y modernidad, Buenos Aires, Nueva Visión.

Lévy, Pierre (2007), Cibercultura: La cultura de la sociedad digital, México, Anthropos.

Machado, Arlindo (2000), El paisaje mediático. Sobre el desafío de las poéticas tecnológicas, Buenos Aires, Universidad de Buenos Aires, Libros del Rojas.

Prada, Juan Martín (2012), "Remix: las estéticas digitales de la remezcla”, en Prácticas artísticas e internet en la época de las redes sociales, Madrid, Akal.

Prada, Juan Martín (2015), “Interactividad electrónica e interacción social”, en Prácticas artísticas e Internet en la época de las redes sociales, Madrid, Akal.

Russo, Eduardo A. (2004), “El ojo electrónico: mirada, cuerpo, y virtualización”, en Marta Zátonyi (comp.), ¿Realidad Virtual?, Buenos Aires, Nobuko.

Siegmund, Gerald (2003), "El problema de la identidad en la danza contemporánea: del arte de la imitación al arte de la acción”, en Cuerpos Sobre Blanco, España, Ediciones de la Universidad de Castilla-la Mancha.

Tambutti, Susana (2008), "Itinerarios teóricos de la danza", AISTHESIS N 43, Instituto de Estética Pontificia Universidad Católica de Chile, Chile, pp. 11-26.

Zátonyi, Marta (2002), ¿Realidad virtual?, Buenos Aires, Nobuko.

\subsection{Referencias electrónicas}

Arns, Inke (2005), "El código como acto de habla performativo" [en línea]. Dirección URL: <http://www.uoc.edu/artnodes/espai/esp/art/arns0505.pdf>.

Barrière, Lallie (2010), "Arte y algoritmos" [en línea]. Dirección URL: $<$ https://madamconbarba.wordpress.com/tag/lali-barriere/>. 
Causa, Emiliano (2014), “Cuerpo, movimiento y algoritmo”, en Cuadernos del Centro de Estudios en Diseño y Comunicación [Ensayos], Buenos Aires, Facultad de Diseño y Comunicación de la Universidad de Palermo [en línea]. Dirección URL:<http://fido.palermo.edu/servicios_dyc/publicacionesdc/archivos/523_libro.p $d f>$.

Causa, Emiliano y Federico Joselevich Puiggrós (2013), "Interfaces y diseño de interacciones para la práctica artística", Buenos Aires, Universidad Virtual de Quilmes [en línea]. Dirección URL: $<$ https://es.scribd.com/doc/234778885/Emiliano-Causa-Federico-JoselevichInterfaces-y-Diseno>.

Causa, Emiliano y Silva Christian (2008), "Interfaces y metáfora en los entornos virtuales", RIM. Revista de Investigación Multimedia, IUNA, Año 1, número 1, Buenos Aires, pp. 43-50 [en línea]. Dirección URL: $<w w w . i u n a . e d u . a r / i n s t i t u c i o n a l / p u b l i c a c i o n e s / p d f / r i m . p d f>$.

Causa, Emiliano y Andrea Sosa (2007), "La computación afectiva y el arte interactivo", Buenos Aires, Estudio Biopus [en línea]. Dirección URL:<http://www.biopus.com.ar/txt/textos/Computacion_Afectiva_Y_Arte_Interac tivo-Emiliano_Causa-Andrea_Sosa.pdf $>$.

Ceriani, Alejandra (2010), "El descentramiento: cuerpo-danza-interactividad". Indagación en el territorio de la interactividad y el uso de las nuevas tecnologías aplicadas a las prácticas corporales, compositivas y escénicas". Tesis de magíster, Facultad de Bellas Artes, Universidad Nacional de La Plata [en línea]. Dirección URL:<http://www.alejandraceriani.com.ar/tesis_alejandra_ceriani.pdf>.

Ceriani, Alejandra (2011), "Espacio digital y cuerpo expresivo", en Diego Carrera (comp.), Con-figuraciones de la danza sonido y video del cuerpo, Montevideo, Comisión Sectorial de Educación Permanente [en línea]. Disponible en: <http://www.alejandraceriani.com.ar/pdf/libro-con-figuraciones-de-la-danza.pdf>.

Costa Alisedo, Fabricio (2014), "De la ambientación interactiva a la instalación ecosistémica. Proyecto de investigación 'La Narrativa Interactiva. El relato hipermediático y las mutaciones del tiempo y el espacio escénico'”, Director Martín Groisman, UNA Artes Multimediales [en línea]. Dirección URL: $<$ https://artesmultimediales 1 .files.wordpress.com/2015/02/fabricio-costaalisedo_2014,pdf $>$.

García Nava, José Luis (2012), "Dinámicas corporales en el audiovisual digital”, en Arte transversal: fórmulas equívocas. Experiencia y reflexión en la pedagogía de la transdisciplina, México, Dirección General de Publicaciones, Centro Nacional de las Artes del Consejo Nacional para la Cultura y las Artes [en línea]. Dirección 
URL: <http://www.joseluisgarcianava.com/transdisciplina/dinamicas-corporalesen-el-audiovisual-digital/>.

Giannetti, Claudia (2002), "Arte interactivo", en Estética Digital. Sintopía del arte, la ciencia y la tecnología, Barcelona, ACC L’Angelot [en línea]. Dirección URL: <http://www.artmetamedia.net/pdf/4Giannetti_EsteticaDigitalES.pdf>.

Giovo, María José (2016), "Entrevista a Maximiliano Wille y a Aníbal Zorrilla (equipo de Investigación en Tecnología Aplicada a la Danza, InTAD)", Departamento de Artes del Movimiento, Universidad Nacional de las Artes [en línea]. Dirección URL: < https://intad1.wordpress.com/page/4/>.

Hlebovich, Ludmila (2013), "El resto como resultado. Algunas consideraciones sobre la obra performática CuerpoMóduloCódigo" [en línea]. Dirección URL: <http://www.unlp.edu.ar/uploads/docs/anuario_2013_de_arte_y_cultura.pdf >

Montequín, Diana y Mariana Sáez (2014), Reseña del I Encuentro sobre Educación, Danza y Mediación Digital y III Jornadas de Intercambio en Tecnología Aplicada a la Danza, La Plata, Publicación de la Secretaría de Arte y Cultura, Universidad Nacional de La Plata [en línea]. Dirección URL: <http://www.unlp.edu.ar/uploads/docs/anuario_arte_y_cultura_2014.pdf>.

Martínez Pimentel, Ludmila C. (2010), "La coreografía digital interactiva”, Salvador de Bahía, Universidad Federal de Bahía, Laboratorio de Investigaciones Avanzadas del Cuerpo [en línea]. Disponible en: <https://www.academia.edu/2177314/La_Coreograf\%C3\%ADa_Digital_Interactiv a>.

Mora, Ana Sabrina (2008), "Lógicas y modalidades del aprendizaje de la danza", Ponencia presentada en el IX Congreso Argentino de Antropología Social, Misiones, 5 al 8 de agosto [en línea]. Dirección URL: <http://www.grupodeestudiosobrecuerpo.blogspot.com.ar/2010/06/logicas-ymodalidades-del-aprendizaje.html>.

Pagola, Lila (2007) “¿Por qué a algunos artistas nos interesa el software libre?”, Revista Escaner [en línea]. Dirección URL: <http://revista.escaner.cl/node/382>.

Pagola, Lila (2010), "Entrevista a Emiliano Causa (proyecto Biopus)" [en línea]. Dirección URL: <http://www.nomade.org.ar/sitio/>.

Palmarola, Hugo (2001), "Entrevista a Gui Bonsiepe”, ARQ. Número 049, Pontifica Universidad Católica de Chile, Santiago de Chile, pp. 54-56 [en línea]. Disponible en: <http://www.sistemasdg.com.ar/apuntes/entrevista\%20bonsiepe.pdf>.

Sagaceta, Julia Elena (2013), " $\{$ P e r f o r m a t i v i d a d e s: experimentaciones en la escena de Buenos Aires\}, Performance y Teatro" [en línea]. Dirección URL: < https://www. publionline.iar.unicamp.br/index.php/pit500/article/viewFile/146/149>. 
Sagaseta, Julia Elena (2004), “Conferencias performáticas” [en línea]. Dirección URL: <http://territorioteatral.org.ar/html.2/articulos/pdf/n12_04.pdf>.

Tognazzini, Bruce (2006), "Principios de diseño de interacción" traducción del artículo 'First Principles of Interaction Design'" [en línea]. Dirección URL: $<$ http://galinus.com/es/articulos/principios-diseno-de-interaccion.html>.

Van Vlissingen, Rogier F. (1985), "Entrevista a Dr. Edsger W. Dijkstra" [en línea]. Dirección

URL:

<https://www.cs.utexas.edu/users/EWD/misc/vanVlissingenEntrevista.html>.

Zorrilla, Aníbal (2011), "La interacción en el marco de la tecnología digital”, I Jornadas Nacionales de Investigadores Teatrales Pensar y hacer en las artes escénicas, Departamento de Artes del Movimiento, UNA [en línea]. Dirección URL: $<$ http://anibalzorrilla.blogspot.com.ar/2011/11/i-jornadas-nacionales-deinvestigadores.html>.

\subsection{Entrevistas en video}

Ceriani, Alejandra (2013). Entrevista a Fabrico Costa Alisedo, Desarrollador de Código Abierto. Dirección URL: <https://youtu.be/LXxvLSLQnsU>.

Ceriani, Alejandra (2013). Entrevista a Soledad Belén. Dirección URL: <https://youtu.be/pTbbRUXFUSs>.

Ceriani, Alejandra (2013). Entrevistas a Florencia Olivieri, "En2Tiempos", UNLP. Dirección URL: <https://youtu.be/b49tK14NQrs>.

Ceriani, Alejandra (2014). Entrevista a Ludmila C. Martínez Pimentel, Parte 2. Dirección URL: <https://youtu.be/gGQQKyXq1tQ>.

Ceriani, Alejandra (2014). Entrevista a Ludmila C. Martínez Pimentel, Parte 3. Dirección URL: <https://youtu.be/ohuLv0mc-1w>.

Ceriani, Alejandra (2016). Entrevista a Alain Baumann, Kônic Thtr, Parte 1. Dirección URL: <https://youtu.be/dDFC4Z1LXLQ>.

Ceriani, Alejandra (2016). Entrevista a Gabriel Gendin. Dirección URL: $<$ https://youtu.be/rxEbXQQniv8>.

Ceriani, Alejandra (2016). Entrevista a Kònic Trth, Parte 2. Dirección URL: $<$ https://youtu.be/pwl4xPNt51k>.

Ceriani, Alejandra (2016). Entrevista a Rosa Sánchez, Kônic Thtr, Parte 1. Dirección URL: <https://youtu.be/dDFC4Z1LXLQ>. 


\subsection{Otros materiales de consulta en línea}

Belén, Soledad, CUERPOMODULOCÓDIGO, 2013. Dirección URL: <https://youtu.be/8rmfOoUNBIE>.

Causa, Emiliano, En qué pienso cuando ideo software para el arte, 2012. Dirección URL: <https://youtu.be/dNio_fDJa5Y>.

Causa, Emiliano, Generatividad, código y cuerpo: intersección entre la danza las nuevas tecnologías, 2013. Dirección URL: <https://youtu.be//EzJPqXS2VA>.

Ciclo de danza UNLP y emmelab, Generatividad, código y cuerpo: intersección entre la danza y las nuevas tecnologías, 2013. Dirección URL: $<$ https://youtu.be/IEzJPqXS2VA>.

Code.org, Todo el mundo debería saber programar, 2013. Dirección URL: $<$ https://youtu.be/DcSyPhLbrbw>.

Costa Alisedo, Fabricio, Estudiar Computación, 2012. Dirección URL: $<$ https://youtu.be/r3pj1YVQzOw>.

Emmelab, Cuerpo Módulo Código, 2013. Dirección URL: $<$ https://vimeo.com/92772100>.

Nolly, Rosa, CUERPOMODULOCÓDIGO, 2013. Dirección URL: $<$ https://youtu.be/8rmfOoUNBIE>.

Prada, Juan M., Comunidades de expresión, 2015. Dirección URL: <https://youtu.be/xKPuDtijaYs>.

Rivero, Ezequiel, Presentación de Cuerpo.Modulo.Código, 2013. Dirección URL: $<$ https://youtu.be/AqXULE067uY>. 


\section{CAPÍTULO 2. Pasaje de lo analógico a lo digital \\ PARTE 3. Danza performance telemática y en red}

\section{Introducción}

Hoy danzamos a conciencia entre la corporalidad expuesta de nuestros límites fisiológicos y la expansión del cuerpo transmitida a través de los sistemas informáticos y de las redes de telecomunicación. Se trata de la integración de este considerado desde las lógicas participativas como flujos de actividad que han abierto tres instancias para el estudio del fenómeno de la comunicación interactiva del cuerpo como interfaz, del cuerpo en diálogo con el comportamiento de los sistemas, y del cuerpo en conectividad con las redes de internet.

Para nuestro estudio, estas instancias han ido atravesando y definiendo diferentes niveles de análisis -en este mismo capítulo pero en las partes anteriores-, por tanto, nos dedicaremos en esta tercera parte, a la indagación de nuevas alternativas de creación mancomunada en la red de internet, más conscientes y críticas basadas en los entornos escénicos y audiovisuales en línea (2013-16) y, justamente, en la conectividad.

Ahora bien, el desarrollo de las interfaces en la interacción cuerpo-sistema digital ha permitido, y permite, nuevas conexiones entre el cuerpo y una experiencia más instintiva; se accede así a otras dimensiones del movimiento y su gestualidad. E diseño de interfaces siempre ha estado presente en el diseño de la interacción gestual, lo que encarna la evolución de la experiencia del propio usuario.

Una preocupación central en el marco emergente de las redes de internet es el contexto que nos circunda cargado de expectativas de socialización. A su vez, se podría afirmar que -a lo largo de la última década- ha problematizado intensamente la mixtura entre la frontera del en línea/fuera de línea.

En la actualidad, por el contrario, este entorno de la red ha dejado de sustentar esa diferenciación entre los espacios dentro y fuera, pues se basan en nuevas formas de producción signadas por una misma lógica de comunicación interna y recíproca. Esto genera -de alguna manera- una dificultad para distinguir entre necesidad de comunicación y mero consumo, y promueve estrategias de circulación del goce afectivo hacia lo que Juan M. Prada (2013: 2) señala como nuevas industrias de la subjetividad. 
Otra mirada sobre este estado de emergencia la proporciona Roy Ascott (2007: 51) cuando define el contexto que crea la conectividad como un universo telemático postbiológico:

A medida que interactúo con la red, me reconfiguro a mí mismo; mi extensión-red me define exactamente como mi cuerpo material me definía en la vieja cultura biológica; no tengo ni peso ni dimensión en cualquier sentido exacto, solo me mido en función de mi conectividad.

Para construir la estructura de lo que es un contexto cibernético, nos introduciremos en el concepto de cibercepción, de Roy Ascott, que comprende la relación del sujeto con las ciencias, el arte y las tecnologías de red ante el surgimiento de una nueva facultad. Pero ¿qué comprende esta nueva facultad? En palabras del autor, "estamos desarrollando un cuerpo nuevo, una conciencia nueva y un nuevo sentido de cómo podríamos convivir en el interespacio entre lo virtual y lo real".

La cibercepción contiene la tecnología transpersonal, de la comunicación, de la participación y de la colaboración; trasciende así las condiciones materiales del cuerpo. La cuestión es observar y estudiar estas nuevas estructuras que están emergiendo en las redes, otro tipo de prácticas y de producción artísticas, de aprendizaje, de investigación, de interactuación de las personas entre sí, y de estas con el entorno.

Por ello, hay que considerar un conjunto de hipótesis precedentes sobre el vínculo del cuerpo, de la corporalidad con las tecnologías de la información y la comunicación. En este sentido, el filósofo Javier Echeverría (1999) denominó a ese espacio telemático, electrónico y digital nuevo espacio social: el tercer entorno ${ }^{91}$; y es en este nuevo espacio tecnológico donde se desarrolla la sociedad de la información.

Ya que los grandes cambios que suscita este tercer entorno se vinculan con la distancia de interrelación y de ejecución, hay que tener en cuenta la estructura matemática de este espacio diferente a los espacios físicos y matéricos que aún habitamos y que coexisten con la simulación interdependiente con el segundo y primer entorno. Es condición previa apropiárselo para poder interactuar en él; puesto que lo que habita y opera en las redes telemáticas son los bits, los flujos electrónicos.

\footnotetext{
91 Evidentemente, se plantea el tercer entorno en contraposición a la existencia clara de otros dos. El primer entorno sería aquel que gira alrededor del ambiente natural del ser humano. El segundo sería el urbano, social y cultural. El tercer entorno es un nuevo espacio social básicamente artificial cuyas tecnologías modifican las relaciones sociales y culturales que se daban, y dan, en los entornos primero y segundo. Echeverría analiza las estructuras y características del tercero de ellos con la intención de establecer diferencias entre este y los entornos primero y segundo.
} 
En consecuencia, no es preciso moverse corporalmente, sino informáticamente, pues lo que se transporta es información. No vamos a desarrollar las características que este autor ha determinado, porque, para nuestro trabajo, nos interesa solo señalar las instancias reflexivas que sobre el espacio y el cuerpo se han ido planteando. Al mismo tiempo, para analizar el presente de nuestro cuerpo performático, precisamos dar cuenta de los cambios culturales que se han generado en el corto y mediano plazo, poniendo de manifiesto así que en el futuro cercano podrían existir diferentes modelos de sociedad en las redes de internet (al igual que existen hoy diferentes funcionamientos de lo que se conoce como sociedad industrial).

En esta línea, encontramos los trabajos de Don Ihde (2002), quien desarrolla la categorización de los cuerpos I, II y III. El cuerpo I recupera el elemento vivencial de la experiencia; el II es aquel cuerpo trazado culturalmente. Esta distinción soslayaría según Ihde- confundir el uno con el otro, y además, daría lugar a argumentar que esta operación permite analizar cómo se trata el cuerpo en la experiencia virtual encarnada y desencarnada, y establecer distintos roles para el cuerpo III en la tecnología.

\section{El cuerpo en conectividad}

Dentro de la organización del campo de observación y estudio, nos planteamos transitar entre propuestas que construyen su poética participando -conscientes o node la lógica de la conectividad, consideradas a través de casos locales y globales de la danza/performance en internet. Adoptar una postura más pragmática favorecerá entender nuestras propias formas de comunicación para luego darles significado. Personas diferentes, con visiones y perspectivas distintas, con sus propias culturas, están cada vez más próximas, y establecen así un mayor contacto. Esa hibridación cultural que se da en las conexiones de los espacios de internet demanda entender las diferencias para saber cómo se afecta el intercambio y cómo se hace más efectivo un posible entendimiento.

Siempre existirá una tensión entre dos personas de culturas diferentes. Entonces, generar un espacio en común que sea dinámico aportaría al desenvolvimiento de estrategias situacionales en experiencias cuyo contexto es global pero que, por ejemplo, difieren en recursos. Esto nos lleva a referirnos a la distribución desigual de lo tecnológico así como reconocer por qué las diferencias nacionales persisten y nos conducen inexorablemente al mito tecnocéntrico en la producción artística. Al respecto, Rodrigo Alonso (2011: 191) manifiesta: 
... El circuito del arte, en su alianza cada vez más íntima con los productos tecnológicos, con el poder institucional y el mercado, parece haber perdido la capacidad para formular un posicionamiento crítico propio que no sea subsumido por la exaltación de su impacto espectacular y su capacidad para el asombro, pero no para la reflexión. Esto se nota, con más fuerza aún, en los grandes proyectos de arte tecnológico que no logran enraizar en su entorno geopolítico y cultural.

La producción del arte en las redes mediáticas propaga las controversias culturales más profundas con las que artistas e instituciones artísticas están interactuando. Pero quizá se relaciona más con reinventar el papel del arte, con involucrarnos para traducir lo extraño y, asimismo, traducir las mutaciones y mixturas de la heterogeneidad del cuerpo hibridado con las tecnologías de manera cada vez más encarnada, en lugar de descarnadamente.

La creación actual, basándose en el método procesual y en el modelo informático, adquiere un sentido renovado en el contexto de producción y estudio hacia un sistema que proporciona nuevas visiones de la coexistencia material del cuerpo; de modo que este análisis pueda ser aplicado de forma general, en tanto logra una comprensión de la estructura y los procesos, la afectación y la mutación del cuerpo, de la gestualidad estetizada y del movimiento de quienes se compatibilizan, más que el establecimiento de causas y de efectos entre sistemas y cuerpos interactuando.

Otras formas de interactividad humana han sobrevenido como la base instrumental prioritaria de producción artística; en consecuencia, la danza performance -como un sistema perteneciente a un contexto determinado- estará siempre en simultaneidad con otros cuerpos, espacios y tiempos ubicuos internalizando, de ese modo, mutaciones en los hábitos afectivos, operativos y cognitivos. Nuestra impresión es que hoy un número creciente de bailarines, coreógrafos y performers, así como programadores y artistas multimediales, en conjunción, experimentan otras maneras de concebir las asociaciones corporales, visuales, sonoras, narrativas, y hacen surgir otros criterios de producción de experiencias subjetivas.

Para el presente texto consideraremos, por una parte, el caso de la plataforma en línea interactiva y colaborativa Waterwheel, prototipo de acción artística, de tendencias y poéticas performáticas practicadas en lo que Juan Martín Prada (2012) ha llamado el "sistema-red". Por otra, haremos una observación de casos puntuales del cuerpo en conectividad, en los que se revelan nuevos enlaces entre la individualidad y la colectividad. 
Ambas cuestiones nos plantean problemáticas actuales "sobre las formas de conducta" en la red (Ascott, 2007: 47), y establecen, asimismo, una filiación entre afectividad e interactividad. Esto resulta interesante pensado desde una perspectiva que analiza los aspectos "ficcionales" de la globalización y otra que propone la idea de un borramiento entre la vida en línea/fuera de línea a modo de sujetos contaminados, compartidos.

Consecuentemente, nos preguntamos: ¿una perspectiva se antepone a la otra? o ¿será que tras la anunciada disolución de la ficción global estamos frente a una hibridación como sujetos compartidos, como sujetos que habitamos sin rupturas el espacio de internet y el espacio de la vida real cotidiana? Para Prada (2011: 1), las lógicas de las corporaciones de internet se establecerán en situaciones de cooperación entre comunidades comunicativas, "intensificando cada vez más el carácter afectivo de la comunicación":

\begin{abstract}
... no podemos olvidar que hay toda una estrecha dependencia entre afectividad e interactividad, en lo que supone el "estar en contacto". El estudio de las interacciones afectivas apuntaría siempre a la virtualidad del mundo, a su potencial de ser para el sujeto, al indicarle que no es una parte completa de la realidad. Hablar del concepto de afectividad nos exige ante todo hacerlo desde un permanente exceso o exteriorización del individuo, de su auto-rebasamiento, evidenciado en el conjunto de sus inclinaciones por los otros o por las cosas del mundo, es decir, en la propensión del sujeto a querer. Desde luego, la sintonía afectiva, el afecto conjunto, es la base elemental para una verdadera experiencia de interacción comunicativa. Podríamos afirmar, por tanto, que la afectividad es el motor de arranque en la generación de toda socialidad, al actuar como punto de enlace primordial entre el afuera y el adentro, entre la individualidad y la colectividad.
\end{abstract}

Una estrategia necesaria, en este caso, es desnaturalizar los temas familiares alrededor de internet y hacer que se vuelvan extraños, para recapacitar acerca de cómo la práctica cotidiana moldea ciertos aspectos y margina los restantes. El desafío es continuar coexistiendo simétricamente sobre estas dos nociones pues, en definitiva, ambas son construcciones.

Nuestros hábitos perceptivos y nuestra manera de comunicación siguen transformándose; la regla es la prontitud, la patronización generalizada, la repetición de estructuras contaminantes a nivel global entre las comunidades virtuales, a través como ya se ha expresado- de nuestro "corpomídia" resultado del cruce de las informaciones preexistentes y las nuevas que llegan. 
Este "cuerpo medio" se plantea no como vehículo de transmisión, sino como proceso evolutivo de selección de datos que van constituyéndolo. Por tanto, la condición de la información es de aquella que "se transmite en un proceso de contaminación" (Greiner, 2010: 132), en la experiencia de interacción con el medio, con otras personas dentro y fuera de nuestra cultura, donde el acto de danzar produce nuevas tendencias corporales y conceptualizaciones.

$\mathrm{O}$, asimismo, y desde otras perspectivas, nos referimos -más que a un cuerpo medioa una memoria. Es una memoria en la que participamos todos los seres humanos, ya que tenemos capacidad para simbolizar y experimentar la consistencia de las diferentes impresiones, y de diseñar procesos para situar las experiencias en el espacio y tiempo concreto. Es una memoria que se ejercita de distintas maneras: individual o grupal, pero mediatizadas por distintas tecnologías. Se trata de una memoria no discursiva que está vinculada a una experiencia corporal pasada e interiorizada que incluye el proceso emocional en la recursividad técnica.

El antropólogo Néstor García Canclini (2011), por su parte, piensa que deberíamos encontrar una reformulación al proyecto que toma en cuenta la vida social y cultural:

\footnotetext{
Se globaliza el conjunto de insumos con que un artista llega a producir obra, y luego la circulación. Tengo la impresión de que está pasando la época en que se creía en una cultura o un arte globales. Fue una ficción: sigue habiendo una tensión constante entre las tradiciones, creencias, iconografías locales y la circulación y las demandas o expectativas que se suponen en audiencias de otros lugares.
}

Veámoslo desde otra óptica, puesto que lo que importa "no es la realidad virtual, sino la realidad de lo virtual. En sí misma la realidad virtual es una idea bastante miserable: la de imitar la realidad, la de reproducir su experiencia en un medio artificial" (Zizek, 2006: 19), con sus consecuencias y secuelas reales. $Y$, en este punto, podríamos denominar esta contaminación entre la vida en línea/fuera de línea como la vida cotidiana de lo virtual, que reproduce las experiencias de un contexto artificial en uno real, resignificándose uno en otro de manera fluida, indistinta, en un mundo no de diferencias, sino de compatibilidades.

Precursora de esta idea del borramiento en línea/fuera de línea es la "segunda vida" (o second life), un mundo virtual 3D distribuido en una amplia red de servidores y que puede ser jugado a través de internet por los usuarios o "residentes" que participan en su economía virtual y operan como en un mercado real. 
¿Cuál es el horizonte de posibilidad de estas mutaciones? ¿Qué es lo que lo hace factible en el presente y en el futuro cercano? Por una parte, pensarnos compartidos en permanente estado procesual, adaptativo, transitorio, pero sin perder de vista cierta perspectiva apocalíptica de una humanidad acoplada y reducida a la uniformidad.

En este punto, sostenemos que el arte constituye una práctica reflexiva, cognoscitiva así como también de índole político-cultural y emocional. Las propias referencias emocionales de los individuos pueden conmover o distorsionar las emociones que perciben en los demás. La empatía -habilidad que se desarrolla gradualmente a lo largo de la vida y que prospera cuanto mayor es el contacto- puede ser observada hoy en el comportamiento individual y grupal de las redes sociales.

Por otra, lo singular tiene que ver con la historicidad: el estar apegados al pasado nos hace seres duales, y la dualidad no se asocia con el borramiento entre la vida en línea/fuera de línea. Por tanto, haber mancomunado lo personal con lo colectivo abolió lo oculto y lo exclusivo en las prácticas sociales del arte, y trajo aparejado los contenidos implícitos en los cambios de los consumos culturales.

Desde una perspectiva vinculada al anhelo de vivir experiencias en alianzas no adversas con la ficción, Néstor García Canclini (2011: 10) señala que “... las artes dramatizan la agonía de las utopías emancipadoras, renuevan experiencias sensibles comunes en un mundo tan interconectado como dividido". Así, cuanto más se ficcionaliza y estetiza la vida cotidiana con recursos mediáticos, más ávidamente se busca jugar con la incertidumbre en un entorno no estanco, pues los acontecimientos van más rápido que las representaciones.

Retomando lo escénico, este ha sido un lugar para la representación de ficciones que se reflejan a partir de la voz y el movimiento de los intérpretes, el sonido, la iluminación, etcétera; y que descansan, en mayor o menor grado, en el empleo de recursos teatrales para crear espacios ilusorios. Luego, otras formas escénicas formularon posibilidades de creación experimentales y encontraron su lugar de expresión en espacios periféricos o alternativos. Surgen así otros conceptos y recursos asociados a estas transformaciones de la producción y la circulación que atañen a lo procesual y a lo efímero.

La performance, por ejemplo, sumada a la multiplicación de opciones presenciales de las nuevas tecnologías, ha dado lugar a esta escena vuelta imagen y sonido a distancia con un concepto ampliado de artes escénicas ${ }^{92}$, entendidas como artes de la

\footnotetext{
92 Se podría citar como ejemplo la obra de teatro telemático Distancia, de Matías Umpierrez, una pieza virtual que desafía los límites de la escena con intérpretes en vivo (vía streaming) desde Hamburgo, París, New York y Buenos Aires, 2013. Es oportuno comentar, además, los inicios de estas experiencias en CABA con el Festival Tecnoescena 05, dirigido por Javier Acuña, que contó con la obra Código BA,
} 
comunicación directa entre un actor y un espectador en cualquier contexto social o mediático.

Asimismo, no se trata solo de saltar hacia un estado de destrezas en conexión, en programación, en estrategias de ubicuidad, sino de transitar hacia un estado permanente de actitud crítica frente a la retórica de los efectos especiales, frente al relato tecno-espaciotemporal, hacia una lógica no lineal, híbrida, fractal. Pero lo escénico-espectacular, como corporación, incluso en la web, sigue autorrepresentándose y estableciéndose de acuerdo con una diferenciación por géneros, que excluye lo que no se adecua a la codificación definida por el hábito.

El hábito de lo espectacular está conformado por una sistémica implícita en la diagramación de la mirada, en la alegoría del espacio y del tiempo, en la configuración a través de acciones y sucesos, y en una estructura jerárquica. Hay una división especializada del trabajo: actores y bailarines principales, de reparto, equipo técnico, etcétera, cada uno de los cuales se ocupa de su tarea específica. Al respecto, en el prólogo de la segunda edición de La sociedad del espectáculo, Christian Ferrer (2008: 10) expresa:

\footnotetext{
Prescribiendo lo permitido y lo conveniente así como desestimando en lo posible la experimentación vital no controlada, la sociedad espectacular regula la circulación social del cuerpo y de las ideas. El espectáculo, si se buscan sus raíces, nace con la modernidad urbana, con la necesidad de brindar unidad e identidad a las poblaciones a través de la imposición de modelos funcionales a escala total.
}

"La dimensión política de la sociedad espectacular es el síntoma de nuestra época", continúa diciendo Ferrer (2008: 13). El poder implícito se articula a priori a través de la reproducción de cualidades que se naturalizan y se vuelven globales, hegemónicas, definiendo así el marco de lo sistematizado.

En la actualidad, uno de los problemas que creemos fundamentales es que esa disparidad evidencie el carácter silencioso y oculto de los mecanismos de reproducción y asimilación naturalizados. Mecanismos que preexisten a la decantación social y cultural necesarias para madurar y cuestionar cada mediación hacia el entendimiento de estas configuraciones complejas en las que intervienen muchos actores y lógicas. Como señala Nicolás Bourriaud (2013: 102): "Si hay que rechazar

una improvisación experimental entre dos grupos de teatro conectados entre sí a través de internet: uno de los equipos transmitió desde Barcelona y el otro desde Buenos Aires, 2005. 
todo tipo de agrupamiento comunitario impuesto, es justamente para sustituirlo por la creación de redes relacionales".

La cultura ya no se define como una herramienta de almacenamiento y depósito patrimonial o de archivo, sino más bien en términos de dinámica, proceso y arquitectura relacional, herramienta de interacción y principio de la acción comunicativa. Del mismo modo, se está dando un nuevo estado del saber, una nueva forma cultural en la que cambian los regímenes de subjetivación, que ya no solamente son individuales, sino también colectivos.

Situados desde esta idea de anticipar la escena del futuro, se vislumbra, además, la posibilidad de que se pueda convertir en un régimen alienante. Proponemos por tanto una revisión crítica de las prácticas artísticas, de la producción tecnológica y de la corporalidad a la luz de estos nuevos laberintos franqueados por la tecnofantasía.

Es indudable, igualmente, que el uso en directo de las nuevas tecnologías de la imagen, la comunicación y la automatización conmueve la escena contemporánea. El proceso de disolución es cada vez más radical, y va a expandirse siguiendo una lógica inevitable hacia la experimentación del fenómeno de la temporalidad y la especialidad con cuerpos que se desdoblen en la habitabilidad de la imagen. Por lo tanto, sostenemos que "lo que es experimentable no puede ser representado" (Debord, 2008: 13).

Partimos de esta idea para justificar nuestro posicionamiento al plantear que las performances en tiempo real, en las que se destaca una labor de investigaciónproducción, nos proponen otro camino completamente diferente, y es el de reflexionar acerca de cómo el uso de las tecnologías -que son asimismo de conocimientogeneran otra forma de pensar y habitar el espacio global a partir de nuevos modos estéticos y políticos sobre las prácticas artísticas que producen. Pues si continuamos en el paradigma de lo espectacular como formato dominante de producción artística, incluso en internet, se contribuirá a instalar que los “... flamantes espacios de la Web 2.0 son interesantes, aunque más no sea porque se presentan como escenarios muy adecuados para montar un espectáculo cada vez más estridente: el show del yo" (Sibilia, 2008).

Esta tendencia hacia la construcción de una subjetividad contemporánea occidental, global y favorecida, ¿podría ser sospechada -retrógradamente- puesto que el "deseo de ser singular es el gusano en la fruta del colectivismo?" (Marker, 1983) ${ }^{93}$. En este sentido, habría que esclarecer cuál es el lugar que nos toca vivir en un mundo repoblado por los valores y representaciones de la tecnología, por sus requerimientos,

\footnotetext{
93 Comentario en off del film Sans Soleil, de Chris Marker (1983).
} 
ficciones y formas de exclusión, y si “ ¿... es posible una transposición tecnológica de realidades tan diferentes? ¿Para qué sirven las transposiciones, entonces, que parecen imposibles, pero que las hay, las hay?" (Alonso, 2011: 184).

Hoy se habita en una sociedad enmarañada de relatos que se tornan conflictivos a la hora de intentar organizarlos. Paradójicamente, esta maraña de relatos se convierte en su ausencia. "La idea de que falta una narrativa organizadora surge con la globalización"; y, como sostiene el propio García Canclini (2011: 2), "así como no tenemos una teoría de la globalización económica y financiera satisfactoria, sino aproximaciones, tampoco hay una visión consistente que organice los muchos modos de imaginar lo que la globalización es", y hace al arte, a sus prácticas, sus hacedores, por ende, a sus relatos.

\section{La red que se avecina}

Waterwheel es una plataforma en línea interactiva creada para realizar performances de forma colaborativa, compartir ideas y presentaciones; en la que se puede subir todo tipo de archivos al TAP o grifo ${ }^{94} \mathrm{y}$, a través de él, conocer gente y audiencias de todo el mundo. Todas sus funciones son designadas con metáforas relacionadas con el agua, por ejemplo, Newsfeed o el suministro de noticias son arroyos de actualizaciones regulares, de la información y de los aportes de un mar de fuentes; Media Centre es el centro de la rueda hidráulica, la prensa, donde se almacena todo el contenido etiquetado de videos, imágenes, grabaciones, etcétera. De este modo, también se da una idea a la audiencia de cómo usar el sitio y tener una interpretación del contenido que se sube.

EI TAP es el resultado de muchos años de pesquisa y puede compararse con una plataforma de comunicación intuitiva y colectiva para reuniones de grupo (6 webcams) en un escenario en tiempo real y, a la par, un chat de texto. Es el lugar virtual donde se realizan presentaciones y actuaciones a través de las herramientas que se ofrecen para interactuar, previo registro de una cuenta personal dentro de la plataforma. Allí se puede dibujar en una pizarra virtual en tiempo real, cargar elementos multimedia e íconos que se pueden mover, rotar, cambiar de tamaño, desvanecerlos y superponerlos. Todos estos movimientos e intervenciones se pueden ver de forma instantánea.

94 EI TAP (o Rueda) está conformado por anillos concéntricos que representan las últimas cuarenta subidas. Cualquier persona puede acceder al sistema, cargar datos y hacer comentarios con otros usuarios. 
Los usuarios pueden invitar a su propia crew (tripulación) para presentarse públicamente o en privado en una performance que dura como máximo media hora, luego se desconectan. Se puede participar "como artista, inventor, intérprete, ejecutante o curador; con una obra de arte, dibujo, video clip, poema, canción, animación, etcétera. Una presentación en vivo o un espectáculo como una propuesta por escrito o video (de hasta veinte minutos), un proyecto curatorial"95. En general, participan científicos, artistas, académicos, activistas de varias ciudades, que interactúan con el público en línea en los nodos situados en Alemania, la Argentina, Australia, Colombia, EE. UU., Francia, Grecia, Israel, Marruecos, Nueva Zelanda, Polonia, Taiwán y Túnez.

En 2014, la plataforma tradujo todos sus tutoriales al español y algunos de ellos al portugués, porque una de las grandes dificultades de su uso es el idioma. Otro problema aún más crítico -y que únicamente se contempla como un entorpecimiento en el momento de la acción performática- es el de la velocidad de conexión que trae aparejada la desigualdad en las posibilidades de conectividad y participación.

$Y$ aquí retomaremos algunas perspectivas para reflexionar sobre cierta afición de las prácticas artísticas, que puede traer consigo cierta vorágine de actuación acrítica en el seno de la comunidad artística en línea, y en la que podemos, asimismo, detectar fricciones entre lo local, lo regional y lo global.

Extrañamente, el sistema-red se escuda con una apariencia ajena a signos de dominación, pero limitados "por la pantalla del espectáculo, tras la cual ha sido deportada su propia vida, conoce solamente a los interlocutores ficticios [...]. Aquí se pone en escena el camino de salida falso para un automatismo generalizado" (Debord, 2008: 154). Por tanto, “¿seríamos ciegos a aquello sobre lo que inevitablemente seríamos ignorantes?" (Brea, 2005), pero que, incluso así, nos abocamos con cierta presteza o alegría virginal a ser parte de la novedad.

Habiendo participado en dos de las ediciones de Waterwheel, nos debemos esta especulación crítica de la experiencia. $\mathrm{Y}$, en este sentido, es sugestiva la idea de interlocutores ficticios que cotejaremos con quienes asistan participativamente a, por ejemplo, los TAP o grifos. Examinemos entonces si en ese streaming asoma una nueva especie de interlocutor, pues este asiste a la performance y, a la par, escribe en el chat del evento del que está participando y, en simultáneo con otros, intercambia opiniones. Esto acontece durante la performance, y, una vez finalizada, se abre el diálogo con el público asistente.

\footnotetext{
95 Véase en línea (3WDS14 PROGRAMA - versión española): <http://blog.waterwheel.net/2014/02/3wds14-programa-espanol.html>.
} 
Esta perspectiva interaccionista del espectador es, precisamente, la que nos hace ver el chat como un medio para el establecimiento de experiencias interpersonales y transacciones estético-culturales entre los individuos ubicuos. Justamente, uno de los atributos que caracteriza el chat es que no existe restricción en cuanto a la ubicación geográfica de los participantes y ofrece un sinfín de oportunidades para el intercambio de significados con audiencias empíricas, no ficticias.

No obstante, hay algunos aspectos contradictorios, como lo es el sentimiento de frustración que se puede experimentar al no compartir la lengua, ya que se pierde parte de la conversación mientras se intenta descifrar lo que escriben otros. Además, la rapidez con que se mueve la pantalla al recibir los mensajes puede hacer difícil su seguimiento. En la comunicación con personas de otros países, el manejo del idioma entre otros factibles- puede acarrear problemas de incomunicación, enajenación o agotamiento.

El artista catalán Antoni Muntadas ${ }^{96}$ aborda este tópico tomando como punto de partida un juego infantil de teléfono descompuesto en el que un enunciado es transmitido a través de una cadena de personas con las consecuentes mutaciones de sentido. El enunciado Los sistemas de comunicación proveen la posibilidad de desarrollar un mejor entendimiento entre la gente: ¿pero en qué idioma? fue traducido por una sucesión de veintitrés traductores de diferentes lenguas. Hay que observar que no solo involucraba una traducción de lenguas humanas (francés, inglés, alemán, ruso, coreano, japonés, español, etc.), sino que la propia labor de los traductores se afectaba por las trascodificaciones tecnológicas: sistemas operativos heterogéneos, distintos caracteres, teclados, etcétera.

En conclusión, lo que advertimos es que, de manera equivalente, a la pérdida de sentido surge una renovación de este por parte de cada traducción, que hace que el sentido original lineal varíe en una comunicación o una intercomunicación resignificada, amplificada, aleatoria y productiva. Efectivamente, la traducción entre medios tecnológicos y entre culturas se traspone dando como resultado una heterogeneidad de sentido cuyo creciente interés se ha tornado indispensable para la comprensión e interpretación de experiencias interdisciplinares que estimulan el estudio de las complejas y polifacéticas realidades contemporáneas.

Por tanto, lo ficticio podría estar comprendido dentro del resultado de esta maratón comunicativa -e incluso con el recurso de los moderadores en sesión-, cuando

\footnotetext{
${ }^{96}$ Antoni Muntadas propone procesos creativos como un acto que, empezando por una idea, se mueve entre territorios geográficos y virtuales, entre disciplinas humanísticas y científicas, entre individuos e instituciones culturales para materializarse en un evento visual específico que requiere ser traducido. La obra On Translation: The Internet Project comenzó en 1995. Este proyecto, realizado en la web, fue una coproducción con la Documenta X y el Goethe Institute.
} 
tendemos a quedarnos solo con lo materializado en el intercambio por chat con aquellos que son competentes y no contemplar que muchos otros no lograron soslayar estas dificultades permaneciendo fuera (out).

$\mathrm{Y}$ aquí es valioso tener en cuenta la idea de que tampoco existe una traducción acabada, pero sí la indagación de una equivalencia. Así lo explica García Canclini (2008: 12):

... Al reconocer lo que es intraducible comprendemos que la diferencia entre lenguas y entre culturas es insuperable, vivimos la distancia entre lo propio y lo extraño. Intentar la traducción es hacer la experiencia de la heterogeneidad radical y, por tanto, de la imposibilidad de lograr una equivalencia perfecta entre una lengua y otra. Sin embargo, existen personas multilingües, intérpretes y traductores. [...] Aun quienes son perfectamente bilingües saben que no pueden decir [algo] de modo idéntico en distintos idiomas, pero encuentran valor en decirlo de otro modo.

Sin embargo, pensado desde la lógica informática cabría una solución técnica que facilitaría la actualización y la migración comunicativas a través de los denominados protocolos de comunicación, y proporcionaría, por ejemplo, servicios de traducción simultánea. Los protocolos son conceptos análogos al de los idiomas de las personas, ya que si dos personas hablan el mismo idioma, es posible que se comuniquen y transmitan ideas.

Retomando las indagaciones sobre las fricciones concretas entre lo local, lo regional y lo global, citaremos un sugestivo aporte de Gustavo Zalamea (2006: 14), al observar las prácticas artísticas en la web que:

... proponen nuevas vías operativas y procuran una recuperación de la comunicabilidad. Sus planteamientos son problemáticos pero seductores $\mathrm{y}$, cosa fundamental, el humor las ha permeado y penetrado profundamente [...]. ¿Habrá que oponer a las utopías de transparencia y liberación una ética y una estética del juego, de la seducción, de la impureza? Las palabras contaminación, reapropiación, redistribución, simulacro, reciclaje, están a la orden del día.

Nuestro cuerpo mediado por redes en la web y las estructuras de producción que consideramos devenidas en prácticas artísticas tecnologizadas, dirá Christine Greiner (2010: 93), son cuerpos y estructuras que están contaminados, colonizados: 
Una información que está dentro de una producción industrial de distribución masiva tiene mucha más probabilidad de "contaminarnos", porque estamos más [expuestos de modo más] directo $\mathrm{y}$, si somos "cuerpomedios", todo aquello con lo que entramos repetidamente en contacto tiene más oportunidad de contaminarnos, de colonizarnos.

Ampliamos este concepto de contaminación con lo que sugiere José Luis Brea (2009: 157): "Todo conocimiento puesto en la red hace rizoma, se despliega y se disemina imparablemente, se desborda en su conexión incontrolada con otros lugares, con otros saberes". Considerando que lo que conocemos y vemos depende de nuestra pertenencia y participación cultural -tanto en el ámbito local, regional como globalapelamos a "... ver con una lógica de visibilización de lo no visible, con un cierto traer a la luz aquello que permanecía oculto" (Brea, 2009: 149).

Con este deseo de situarse en la experiencia de la plataforma Waterwheel, nos preguntamos, en primera instancia, si cabe la posibilidad de participar desde un posicionamiento local que no responda, desde un automatismo generalizado, a las expectativas de los circuitos globales. En este punto, más que friccionar la piedra para producir chispas, habría que plantearse, acaso, otro paisaje.

Brea (2009) habla de que el efecto de globalidad de la red nunca podría consumarse dentro una figura de universalidad, de macro-red sin presentar diferencias. Por el contrario, una red de redes generaría pertenencia y establecería formas flotantes de comunidad; no circuitos sino fluctuaciones en conjunción momentánea, no reglamentadas por identidad, cultura, origen, sino que activen lo micro, lo intermedio en un prototipo global ininterrumpido.

Por tanto, en este paisaje suspendido, lo oculto no tendría lugar alguno, pues la red hace el mundo transparente, penetrable. A la sazón, cabría la posibilidad de comulgar en microrredes desde una microcomunidad dando lugar a la interrupción de la lógica de la propiedad y del proyecto de comunidad como obra, pues, hay una conexión tangible entre la negativa de la condición dogmática del automatismo generalizado y, el punto de fuga que puede sobrevenir.

La plataforma arenga sobre hacer y compartir acerca del agua: "There are no borders or boundaries (No hay fronteras o límites)". Waterwheel o la Rueda del agua fluye a lo largo de su curso natural, y establece -parafrasearíamos- formas flotantes de comunidad artística; en las cuales -retomando a Suzon Fuks ${ }^{97}$ - se pueden descifrar los patrones de la fluidez, las rayas y los ritmos que relacionen la gráfica, lo

97 Suzon Fuks es la fundadora de la plataforma. Véase entrevista en Youtube (2012: 1'): $<$ http://youtu.be/J5I_A7wLSgs>. 
coreográfico, lo musical y las formas cinematográficas, para encontrar, en ese diseño del fluir, un entendimiento entre las distintas disciplinas.

\section{Performance líquida}

Estamos de acuerdo con los posicionamientos críticos respecto a la fascinación con la tecnología, a sus atributos y sus efectos en la producción artística, a la celeridad con que caducan, a la carrera contrarreloj que la novedad aplica, entre otros desvelos. En definitiva, se trata de poder plantearse una reformulación sin desprenderse de la historia y del contexto artístico local, y congeniar con el estudio de lo que está sucediendo en el contexto global para comprender la idoneidad, la naturaleza y el sentido de lo compartido.

Plataformas como Waterwheel esperan crear conciencia sobre los problemas del agua, generar nuevos caminos, nuevos trabajos y nuevas formas de presentar herramientas para fomentar el intercambio y la creatividad, el diálogo intercultural, la reciprocidad intergeneracional y el debate de proyectos polémicos, para visibilizar el tema haciéndolo más público, y facilitar la toma de decisiones y la acción práctica.

Asimismo, con esta conciencia sobre la vinculación y la relevancia de lo que está sucediendo en el mundo con relación a los aspectos tanto negativos como transformadores, abiertos y flexibles del agua, esta plataforma tecnológica requiere de cantidades igualmente considerables de recursos humanos, materiales y conocimientos para lograr su funcionamiento.

La expansión sectorizada de la informática y la globalización cultural o estilo intercultural pone en contraste estos eventos, dado que, por un lado, se busca atraer e implicar a los usuarios en la participación performática estética y lúdica, pero, por otro, se mitiga su exclusión en el conjunto de insumos con que un artista o grupo llega a producir obra. Sigue habiendo una tensión constante entre la adquisición y circulación de tecnología local y las demandas o expectativas que se presumen en audiencias de otros lugares.

Tomando como ejemplo la performance SPEAK 4.0 LIQUID ${ }^{98}$-producida para el evento Waterwheel 2014- el uso de dispositivos tecnológicos se vio argumentado por los procesos investigativos que se desarrollaron en torno a crear ambientes y

\footnotetext{
98 Performance multimedial para streaming mundial preparada especialmente para el evento con sede en Sidney, Australia. Idea, performance, animaciones, diseño sonoro y visual, música: SPEAK (Alejandra Ceriani, Dante Sáez, Fabricio Costa, Fabián Kesler). Para consultar acerca de los materiales técnicos propuestos, véase en línea: <http://r.water-wheel.net/3wds14-chap8.pdf>. Water Views: Caring and Daring - 3WDS14 - Waterwheel World Water Day, pp. 464-469.
} 
atmósferas que permitieran la exploración de nuevos modelos comunicativos en los que se conjugasen la expresión del cuerpo y su procesamiento en tiempo real en diálogo con lo visual y lo sonoro.

A través de la interfaz que propuso Waterwheel, la performance se transmitió en vivo y estuvo abierta al público asistente en red para ser intervenida con dispositivos touch (celulares, tablet), afectando así la imagen y el sonido. Debemos considerar que toda esta logística fue parte del trabajo de investigación de los programadores de Speak con dispositivos y aplicaciones low-tech.

Con relación a las poéticas corporales que oscilan entre lo material y lo inmaterial de sus producciones, hay -entre tantas- dos cuestiones posibles para analizar. Una es la operar desde la lógica del software y de las aplicaciones iniciando o adecuando la performance a los requerimientos tecnológicos. Al respecto, existe cierto prejuicio con los proyectos encarnados desde una estructura compatible con el sistema, sea porque se considera su condicionalidad o su finalidad vinculada al entretenimiento o la exhibición; pero lo que parece ineludible es involucrarse con las capacidades, captaciones y limitaciones de las máquinas físicas y virtuales, sus lecturas y sus traducciones.

La primera intervención en la plataforma Waterwheel fue realizada adaptando la performance interactiva en tiempo real Proyecto $H_{0 s e o^{99}}$ a la temática y a las condiciones operativas. Esta adaptación implicó una incrustación de acciones para dar cuenta de la metáfora ejecutora. $Y$ esto suscitó, justamente, uno de los conflictos básicos: primar el contenido de la representación sin conjugarlo con los aspectos limitantes de la técnica utilizada. El dispositivo de captación era una cámara web que permaneció fija en un encuadre de entorno general, lo que impidió -al mismo tiempo por su restricción técnica- registrar detalles esenciales como el escurrir del agua por el cuerpo, por las regueras originadas en los pliegues del nylon que lo ceñía.

La otra cuestión fundamental del trabajo con procedimientos informáticos consideramos que es el fenómeno de lo imprevisible, del "todo puede fallar", que genera desorganización, incertidumbre y demandas estresantes. Por ende, aprehender este rasgo constitutivo en todos los niveles de la producción y la difusión, haciéndolo parte sine qua non, hablaría de una amplitud sistémica en los mecanismos culturales, de gestión y de exhibición, de públicos, artistas y curadores, de nuevas

99 Waterhole, performance interactiva, realizada en vivo para Waterwheel Symposium, el 22 de marzo 2013: “¿Cómo contribuir a la tierra? ¿Qué cosa que 'drena' del ser humano ayudaría al ambiente? ¿Cómo contribuir nosotros los humanos drenantes? El cuerpo de la performer está cubierto de ampollas de agua, envuelto en un film plástico y recubierto de barro. La performer aguija y deja escapar el líquido recolectado en las ampollas, este se desliza lentamente por el cuerpo embarrado. Lo que se escabulle lo recibe y absorbe la tierra base. Así se cierra un ciclo circular". Véase completo en línea: <http://waterwheel.net/m/90/90/25/19202590901.pdf>, <http://youtu.be/dLn582BmghY>. 
comunidades de usuarios utópicos y antiutópicos, que suministraría una bocanada de aire nuevo a la implementación de los imaginarios alternativos en contextos equitativamente distribuidos y de por sí fluctuantes del dominio inmaterial.

\title{
38. Conclusión tentativa para este caso analizado
}

Al avanzar en el escrito, surge otra pregunta: ¿cuál es nuestra relación con la tecnología? En este camino de aproximaciones y divergencias podríamos presentar al menos algunas respuestas contingentes. Pero, en primera instancia, creemos que el vínculo con las tecnologías hay que construirlo.

Carl Mitcham (1989: 119) explica cómo podría situarse esa construcción:

\begin{abstract}
Es importante destacar que la tecnología en sí misma parece favorecer ciertos tipos de sistemas éticos. [...] la tecnología también tiende a socavar la significación de aquellos tipos de acciones humanas individuales. [...] A nivel individual o personal, la "ética del no poder" no es tanto una opción moral como una realidad impuesta. En una sociedad tecnológica avanzada, el empuje de la tecnología no depende tanto de los individuos como de las decisiones de grupo.
\end{abstract}

Otro aspecto crítico para señalar en estas configuraciones complejas en las que intervienen muchos actores y lógicas son las condiciones actuales de la producción corporativa y su expansión mercadotécnica, los excesos en la comercialización y la ilusión de "cambiar el mundo" ${ }^{100}$ que guían la especulación y el funcionamiento en la investigación y en los negocios de la industria tecnológica. La ambivalencia reina entre los sectores hegemónicos y populares, y generan así nuevas desigualdades y diferencias. Por una parte, se propician formas inéditas de colaboracionismo productivo, comunicacional y de contribución altruista en varias regiones y aun en varios continentes; $y$, por otra, en mayor o en menor medida, hay una expropiación del patrimonio cultural inmaterial a la par que se brindan oportunidades para difundir la producción local en los mercados internacionales.

Por lo mismo, pensamos con García Canclini "que es preciso abarcar en los análisis tanto los procesos de liberación de las fronteras, de ubicuidad de los productos, de los mensajes y los consumos como los movimientos de afirmación territorial, de

\footnotetext{
100 Fragmento del capítulo "TechCrunch Disrupt Parod", de la serie Silicon Valley, 2014. Véase en línea: <http://youtu.be/J-GVd_HLIps>. "En el MIT buscamos sin cesar el dispositivo que cambie el mundo" (<http://toyoutome.es/blog/\%E2\%80\%9Cen-el-mit-buscamos-sin-cesar-el-dispositivo-que-cambie-elmundo\%E2\%80\%9D/19125>).
} 
señalamiento de las diferencias" (García Canclini en De la Haba y Santamaría, 2001: 10). En consecuencia, focalizando en el caso de la plataforma observada, propondríamos analizar y reformular, por ejemplo, las estructuras organizativas, los modos de interpelación, la avidez de ubicuidad y las maratones de intercambio comunicacional y artístico en pos de audiencias más moderadas e interconectadas que puedan generar una retroalimentación con impronta reflexiva. La idea de obtener no solo información técnica y sinóptica de la performance por realizarse, sino también información sobre su contexto físico, condiciones de producción y costos reales de su participación en los simposios.

Tal vez esto arrojaría un aporte de datos fehacientes acerca de la particularidad de los posicionamientos artísticos frente a las incertidumbres y los conflictos simbólicos surgidos de este piélago de nodos, las decisiones estilísticas como motores de nuevos sentidos culturales, políticos, humanísticos, pertinentes; y principalmente, manifestaría otras propuestas emergentes de concebir y compartir formas de ciudadanía en la cultura digital. Del mismo modo, se percibiría cómo las prácticas artísticas pueden responder creativamente a los desafíos de la movilidad y, en particular, se posibilitaría observar, analizar y descubrir lo que los artistas (bailarines, performers, coreógrafos) exudan y piensan qué están haciendo cuando se está utilizando la tecnología y su entorno en internet.

\section{Aproximaciones entre cuerpo, ciencia y arte}

Reconocer la dificultad que el discurso teórico tiene a la hora de reflexionar y determinar el papel de la danza en el arte del presente forma parte del cuestionamiento general que ha promovido -desde sus fundamentos más naturalizados- otras perspectivas de sus elementos medulares: el movimiento, el cuerpo, la coreografía o el intérprete.

Nuestro propósito es enunciar algunas de las problemáticas con las que este discurso se ha precipitado a la hora de abordar estos elementos en conjunción con sistemas informáticos escénicos físicos, virtuales o en hibridación, acotando así nuestro objeto de estudio a la danza y a la performance contemporánea occidental. Diversas formas de experimentar la danza con la incorporación sistemática de estas nuevas mediaciones tecnológicas consiguen nuevos cuestionamientos.

Este apartado se sustenta en distintas fuentes de la teoría de la danza junto a las aportaciones de los entrevistados provenientes del ámbito de la filosofía, la estética y la curaduría. 
Retomando la distinción que se antepone entre teoría y práctica planteada desde la danza, Susana Tambutti (2008: 11) afirma al respecto: "No se puede concebir una reflexión teórica sobre el arte de la danza sin una confrontación con el análisis empírico". Consideramos fundamental esta enunciación, pues nos define e identifica tras la paulatina incorporación de la danza y la performance en los contextos académicos; y de cuyas coyunturas político-culturales ya hemos departido, pero que, de igual modo, se renuevan con cada contextualización en la que se comprende la articulación entre arte, cuerpo y conocimiento:

\begin{abstract}
Cuando es aplicado a la danza el término "teoría" se utiliza, muchas veces, de manera imprecisa confiándose en una comprensión intuitiva de su uso. Aunque con validez actual, el problema de la relación entre "teoría" y "práctica", es una discusión antigua, cuyas graves consecuencias se deben a que fueron entendidas como compartimientos estancos. Paradójicamente, a pesar de que durante casi cuatro siglos los textos existentes fueron desterrando cualquier idea que pudiera relacionar la producción de obras coreográficas con conceptos como ingenuidad, espontaneidad e irracionalidad, por lo general, aún así son admitidos e incluso elogiados como si fueran parte de la riqueza de este arte. [...] Los primeros intentos de teorización eran básicamente textos informativos, manuales de coreografía que desarrollaban rudimentarias teorías artísticas sobre las reglas coreográficas a seguir en el proceso creativo e interpretativo de una danza (Tambutti, 2008).
\end{abstract}

Los cuestionamientos de los modelos hegemónicos de arte, ciencia y conocimiento, que comienzan a plantearse a partir de mediados del siglo XX erosionan las demarcaciones de sus cotos de influencia e inician interacciones entre sus diferentes sapiencias, así como emergen espacios para debatir sobre la rigurosidad entre ciencias duras y ciencias blandas.

La investigación burguesa es una técnica, "es un discurso cuya meta utópica es el conocimiento cada vez más objetivo" que se diferencia de las metodologías y fines del presente dado que "la investigación se convierte en un diálogo, cuya meta utópica es el conocimiento cada vez más intersubjetivo de nuestras circunstancias vitales", como explica Vilém Flusser (1994: 207).

Es así que en este contexto:

Se legitima la multiplicidad de perspectivas y la pluralidad de voces, adquieren gran importancia las narraciones, en las que el conocimiento se encuentra entrelazado con las vidas concretas y las experiencias personales, que 
comienzan a ser consideradas fuente de conocimiento. El relato en primera persona es reivindicado hasta el punto en que el conocimiento en sí no deja de ser una narración más que participa en el mundo de las narraciones sobre la vida. Esto conduce a una valoración positiva de la subjetividad y las emociones del investigador, que dejarán de ser una mancha, algo que contamina para convertirse en un material que aporta a la investigación y la enriquece, llegando a ser algo necesario y deseable. En el campo del arte, distintos sucesos históricos provocan modificaciones en las concepciones, valoraciones y prácticas artísticas (Del Mármol y Sáez, 2013: 198).

Sobre este cuestionamiento de lo hegemónico, y al focalizarlo en el campo de la danza local, es necesario destacar el origen de la susceptibilidad que generan ciertos términos según la lupa con la que se los examine. Cuando Susana Tambutti aborda los conceptos y las teorías sobre los que se cimentó el espacio artístico de la danza escénica en nuestro medio, lo describe taxativamente con el mote de una "evolución imitativa":

Los distintos programas artísticos, el discurso crítico y el pensamiento teórico en su conjunto estuvieron subordinados a las narrativas culturales dominantes y fueron determinados por una "evolución imitativa", aparentemente irremediable, respecto de los discursos estéticos hegemónicos (Tambutti, 2013: 183).

Ahora bien, no estamos instalando problemáticas de acción, sino de conocimiento, es decir, recapitulaciones y procesos conectados a las necesidades propias de nuestro campo de estudio: la danza, la performance, los sistemas tecnológicos digitales físicos y virtuales; y a la construcción de sus saberes específicos. En tal caso, no hay una respuesta definitiva a nuestra interpelación sobre cuál es el problema del cuerpo hoy, pues la magnitud alcanza tanto a lo que intenta abarcar como a lo que se nos resiste. Las problemáticas por analizar implican la urgencia de hallar respuestas a una cuestión que viene siendo indagada; lo cual nos lleva, irremediablemente, a establecer más preguntas, pero ¿cuáles son las preguntas que les corresponderían hacerse a las disciplinas del cuerpo?

En este proceso creativo del pensamiento, su enunciación más aproximada nos posibilitará abrir planos hacia una legítima arquitectura conceptual. En tanto, las circunstancias que rodean la nueva situación sociocultural colocan al cuerpo en un lugar central. Sumados los cambios de paradigmas científicos en concatenación con los avances tecnológicos cada vez más a la mano de la comunidad, activaron la producción artística tanto como la teórica. 
De este modo, se desmantela la comprometida distinción entre ciencia, técnica y política. "El investigador deja de ser un 'puro' sujeto, para convertirse en un ser humano. Eso significa, al mismo tiempo, un ser vivo, comprometido epistemológica, ética y estéticamente" (Flusser, 1994: 206).

Haciendo un simple racconto, vemos que fue a través de figuras y prácticas influyentes de la década del sesenta que la danza y sus fundamentos más arraigados renovaron no solo la necesidad o idoneidad del movimiento, sino también del cuerpo e, incluso, de la autonomía del discurso teórico o crítico. Desde lo local, durante los años setenta, el uso de la tecnología en el arte pasó de ser un poder transformador de la vida cotidiana a ser un instrumento del pensamiento:

\footnotetext{
El artista es ahora un escrutador de la realidad, un analista de sistemas, medios y procesos que la constituyen, un exégeta de construcciones discursivas e ideológicas. Este nuevo rol traza el punto final del arco en el que arte y tecnología se confrontan en los treinta años que median entre las producciones de los cuarenta y de los setenta (Alonso, 2011: 58).
}

Dentro de este panorama, tanto en el campo del arte como en el de la tecnología, las prácticas corporales que empatizan con mayor avidez con estos acontecimientos descritos por Alonso se asocian más a la performance -que produjo una sucesión de roturas, a la vez que potenció el encuentro y el diálogo entre disciplinas- que a la danza. En otras palabras, la performance, en el transcurso de la primera etapa de los años setenta hizo ostensible -por medio de una diversidad de prácticas- "una misma función: la de provocación, de toma de posición contra la tradición, de enfrentamiento al orden artístico y estético prevaleciente" (Sagaceta, 2013: 35).

Ya, junto a Alejandra Cosin, vislumbramos esta sujeción de la Danza Performance atravesada por una imprescindible conexión: el cuerpo.

La danza como forma de arte nace tomando pautas de la composición literaria y figurativa, utilizando el cuerpo para inscribir la imagen, señalar la lectura. Es EN el cuerpo entonces donde sucede la acción. Luego, ya en la modernidad, los autores de danzas no ven elementos suficientes en estas formas compositivas para expresar los mundos vitales contemporáneos, y usarán el cuerpo como acción, se compondrá CON el cuerpo. Pero seguirá siendo la representación, y por lo tanto la lectura de signos, la organizadora de una composición donde el cuerpo habla (Ceriani y Cosin, 2005: 1). 
La acción urgente consiste en intervenir allí donde la danza y la performance se articulan, pues no se puede disociar aquí el acto de comprender el nuevo entorno en el que se desarrollan. Es necesario buscar los estratos en función de los cuales se desenvuelve nuestra realidad cultural, e identificar y delimitar cuáles son sus problemas actuales que arrastran problemáticas pasadas que continúan adyacentes. Por tanto, la marca literaria y figurativa de la danza obstaculiza su desarrollo hacia la experimentación, el riesgo, la provocación; por lo menos la gran mayoría de sus producciones están alineadas en el encantamiento de lo puramente visual.

\begin{abstract}
Será Cunningham quien proponga desmaterializar el cuerpo, y valorará el movimiento por sí mismo, para desprenderse de la representación de emociones. Se buscará, hasta el llamado posmodernismo inclusive, la desmemoria del cuerpo cotidiano, para negarlo y repensarlo, fiel a sí mismo, prácticamente ahistórico (Ceriani y Cosin, 2005: 1).
\end{abstract}

Habrá que aguardar hasta la mitad del siglo XX para advertir como Merce Cunningham $^{101}$ se apartará de la narrativa dramática tradicional del ballet y de su dependencia de la música como proveedora de una estructura métrica del movimiento. También reparar en cómo se apropió -desde procedimientos precursores- a una danza de la era electrónica, ligando todos sus componentes a la creación escénica del movimiento, el espacio y el tiempo; así como su aporte a la problemática de la notación coreográfica, a través de un sistema virtual tridimensional con el primer software que proveía de estas características (Life Forms -utilizado por muchos bailarines y performers en la actualidad, caso Ludmila C. Martínez Pimentel citada en el apartado anterior de esta tesis-).

Entonces cabría preguntarse: ¿qué elementos de la danza son realmente necesarios para que esta sea una danza mediada o la performance una performance mediada? ¿Qué ocurre cuando el movimiento estetizado queda condicionado al procesamiento de una captura óptica o a la depreciación de un software? $Y$ más aún: ¿qué acontecerá cuando también el movimiento sea innecesario y solo el cuerpo sea considerado la única condición necesaria de la danza?

Siguiendo el trayecto de estos interrogantes nos asalta -nuevamente en este contexto de lo escrito- la misma e inquietante pregunta: ¿con la presencia del cuerpo inmóvil, hay danza? Sí, pues invariablemente hay algún movimiento, por ejemplo, el pestañeo, la respiración, la elasticidad o la tensión de los músculos al sostener un gesto, una

101 Solista de la compañía de Marta Graham. Otro rasgo particular de la disciplina de la danza: ser hijo prodigio de una compañía o de un coreógrafo prominente. 
postura, etcétera. La estructura de nuestro cuerpo está dispuesta para poder movernos, no por una técnica determinada o por un estilo.

Por ello, el análisis que buscamos hacer se explica por el fenómeno del movimiento en sí, en cada interacción dependiente del contexto. Es evidente que una producción social es la condición de una producción cultural, implica dependencia y relaciones de fuerza inherentes: la primera se encierra en el círculo de la segunda. Si estas mismas preguntas y esta misma interpretación se aplican a la performance, ¿qué respuestas obtendríamos?

Antes de intentar contestar, recapitulamos otra etapa atravesada por la performance, y que se produce en la década de los noventa. Concierne al devenir del género artístico y a su institucionalización, a través de otras acciones como la ritualización y la discursividad sobre el mundo y sobre el yo. Pero sucede algo aún más radical:

El cuerpo se desplaza a la imagen y se convierte en un elemento entre otros. Ahora importa el producto más que el proceso y vuelve a considerarse la noción de representación. Como se ve, parece difícil establecer una clara y concluyente definición del término. Es precisamente esta circunstancia, el hecho de que la performance resiste toda clasificación lo que la hace un campo tan interesante en las artes. [...] La idea de performance se aplica a las artes visuales tanto como al teatro y la danza. En el campo académico, la Filosofía, la Sociología, la Lingüística y la Antropología visitan la performance como una forma de examinar instancias de las ciencias sociales (Sagaceta, 2013: 36).

En consecuencia, respondemos lo siguiente: la performance es transversal, transdisciplinar, y el cuerpo que en ella se activa es modular, emergente, excede a la subjetividad y se expande en el espacio físico y virtual trascendiendo, de ese modo, al ser cartesiano.

El problema es cuando se pretende que la imagen audiovisual no interpele, sino que guste. ¿Cómo huir de su sino despótico? Tal vez alternar con la versión "desenchufada", volver a la comunicación pretecnológica in situ como lo hicieran los performers de las acciones de arte de los sesenta a los ochenta. Reversionar las formas artísticas que hicieron del arte performático un elemento de ruptura con el sistema... Es otra opción (Ceriani y Cosin, 2005: 3). 
Por su parte, la danza, primordialmente, es disciplinar; e interdisciplinar en interacción. La mediación de nuestro cuerpo en su intencionalidad motriz o en el premovimiento ${ }^{102}$ instituye sentido, y esta intencionalidad se nos revela en el espacio entre el movimiento y la representación de ese movimiento en nuestro pensamiento.

Lo que denominamos técnica, en danza, se manifiesta en el cuerpo hasta dar con un vocabulario disciplinar propio, de tendencias gestuales y dinámicas. El descentramiento -de la formación antropocéntrica en la danza occidental- puede forjarse y vislumbrarse entre ambas imágenes -la proyectada y la imagen mental de nuestras sensaciones-, ahí es donde se concibe el lenguaje corporal genuino, surgido de la propia interacción con el cuerpo físico real, el contexto y la mediación sea de un objeto, sistema u otros cuerpos.

La imagen del cuerpo significante es la característica corporal que determina, directa o indirectamente, y es en esa determinación donde cobra sentido. Incluso, siendo el doble de la particularidad física, diferencia al cuerpo en movimiento de la imagen mental de nuestras sensaciones físicas como performer. Actúa tanto simultáneamente como no. Uno puede estar siendo consciente, como no, de lo que está aconteciendo a esos niveles perceptivos. Entre la imagen física de nuestra cenestesia y la imagen visual digitalizada y proyectada hay un margen aleatorio que permite instalar esta presunción del descentramiento de las aptitudes del performer. Este descentramiento podría configurarse como un primer aporte al trabajo interactivo del cuerpo con los dispositivos tecnológicos escénicos. Es en esa brecha dominada por el espacio creado por la interface, que media entre el cuerpo, la computadora y su sistema de sensado y, el objetivo de una acción, en la que la imagen digitalizada o proyectada juega lo suyo (Ceriani, 2012: 123).

La comunicación en la danza, habitualmente, aúna a la coreografía y al movimiento en la creación de una pieza de danza. Este proceso creativo no se distanciaría demasiado de quien programa visuales o sonidos para ser interpelado por un instrumento virtual o, incluso, quien interactúa con los dispositivos e interfaces de la computadora.

Pero si bien ya lo hemos analizado -en los apartados anteriores- esta manera de interactuar del cuerpo con un sistema escénico o en el ciberespacio, es de nuestro interés focalizar en experiencias del cuerpo disciplinar que conlleven el uso de

102 Según Hubert Godard, se llama "premovimiento" a esta actitud hacia el peso, la gravedad, que ya existe antes de que nos movamos, en el simple hecho de estar de pie, y que producirá la carga expresiva del movimiento que ejecutaremos. Para ampliar sobre la temática, véase en línea: <http://www.raco.cat/index.php/EstudisEscenics/article/viewFile/253945/340731>. 
recursos audiovisuales en internet. Las nuevas tecnologías insertadas en las redes sociales y los dispositivos móviles hacen posible que cada vez sea más accesible este formato de visionado.

Podríamos indicar a Youtube como una de las redes más considerables en cuanto a cantidad de videos reproducidos, al igual que por su preponderante posicionamiento en materia de motores de búsqueda. A pesar de que estos no pueden observar el contenido del video, este está relacionado con palabras que lo describen (keywords o palabras clave, tags y etiquetas).

El tráfico y la repercusión de los videos en internet y en las redes sociales eran desconocidos hasta hace poco tiempo, pero su crecimiento radica en que permite la integración de elementos como imágenes, sonido, video y texto, y posibilita el máximo de conectividad e interactividad.

Respecto de las definiciones actuales de multimedia, todas ellas presentan algo en común: se considera "multimedia" la disposición de dos o más medios, que implica o asume interactividad a través de la computadora, en ella es clave la integración de medios.

Los materiales digitales multimediales en los que incluimos el video, y más específicamente los videos de danza o performances, tienen como propósito, entre otros, potencializar la representación de la información a través de medios de comunicación como audio, video e hipertexto, de tal forma que se logre fusionar las posibilidades de estas nuevas tecnologías con las etapas de un proceso de observación, formación o consumo dirigido a un fin propuesto en el curso de la navegación. Teniendo en cuenta los aspectos de usabilidad de acuerdo al contexto y a los objetivos del visionado o interacción, el video puede suponer la observación y el análisis de ciertos criterios como la factibilidad de acceso a la información, los aspectos técnicos, la conectividad, los resultados de aprendizaje, entre otros no menos importantes.

Encontrar diversas ventajas sobre estos materiales multimedia los convierte, a su vez, en nuevos elementos de estudio, y se transforma en una herramienta que conlleva aprender y, lo más importante, autoevaluar la formación adquirida a través de este. Los materiales digitales multimediales están tomando mucha fuerza en el cambio paulatino del proceso de formación en la danza, lo que conduce a la caída de los paradigmas centrados en el sistema de enseñanza-aprendizaje. Por ejemplo, abren la posibilidad de un valor agregado en la usabilidad y reutilización de recursos diversos que impulsan la consideración de otras formas de concebir la relación de lo físico y de lo virtual. 
Centrándonos más en los aspectos disciplinares, veremos cómo en la danza, en la performance y en el propio cuerpo se ponen en crisis estrategias aplicadas en los espacios de formación, que proporciona -en la virtualidad de la web- nuevos entornos para recrear procesos de producción, observación y análisis de la visibilidad de los materiales propios. Entre ellos consideraremos el estado en cuestión de conceptos de creación, copia, imitación, repetición, entre otros.

\section{Crear, copiar, imitar en la web}

A mediados de la década de los noventa, muchos artistas comenzaron a hacer de internet un nuevo medio o espacio en el que intervenir, experimentar y reflexionar creativa y críticamente. Esta tendencia artística no se ha dedicado exclusivamente a indagar las posibilidades estéticas de las tecnologías. Así, se han evidenciado los usos dominantes de producción estética, cultural, ética y se han contrarrestado las lógicas de las instituciones gestoras tradicionales del arte.

Este espacio virtual es considerado un auténtico espacio alternativo, independiente, emancipado; con una extraordinaria capacidad para promover lo procesual, lo colaborativo, más vinculado a la producción de situaciones y procesos comunicativos particulares que a la generación concreta de obras.

El carácter inmaterial de las creaciones en línea y su intransigencia a una fácil comercialización solo era una de las tantas fisonomías que caracterizaban a estos inicios; así como el carácter participativo, la priorización de la comunicación sobre la representación, su inmediatez y la disolución de las fronteras entre lo público y lo privado.

Aquí lo interesante es observar cómo -en este intento por conseguir una apropiación social del medio- se redefinen las prácticas artísticas, costumbres, formatos, etcétera. Los viejos términos y convenciones implícitas intentan adecuarse y en medio de esa conversión van mutando, o, por el contrario, desaparecen dando lugar a recomposiciones inéditas o a nuevas estrategias. El sentido original lineal de muchas rutinas en danza se transforma, resignificándolas y actualizándolas de forma impredecible.

En consecuencia, los términos y las teorías sobre la imitación y la reproducción -que han llevado a la danza a una alta codificación, a un control disciplinario sobre el movimiento y a un dominio orgánico sobre el propio cuerpo- han ido evolucionando. Puesto que el interés por la virtualidad del cuerpo en un contexto digital va disipando el 
interés por un cuerpo real utilizado ya no como avatar o sustituto, sino como una concreta representación de una persona que quiere interactuar con otras.

Ante este panorama, replantearse los hábitos disciplinares como lo es el entrenamiento disciplinario cotidiano, por ejemplo, aún hoy transcurre ante la barra y el espejo. Susana Tambutti lo explicita del siguiente modo:

Aunque la pedagogía de danza muestre hoy algunos aspectos del viejo orden disciplinario y convencional existen otras técnicas que proponen una mayor necesidad de flexibilidad. La información, la estimulación de las necesidades, la revolución sexual, el culto a lo natural, crearon nuevas orientaciones que dejaron de lado la tiranía de los detalles y que reducen al mínimo las coacciones. Las metodologías de aprendizaje muestran una doble tendencia: por un lado, la humanización, la diversificación y la programación opcional de la formación del bailarín es pensada casi como un menú a la carta; por otro lado, el incremento de un virtuosismo en el que el bailarín sigue intentando superar sus propias marcas (Tambutti, s/f).

Que la danza y el cuerpo buscan repararse de las verdades establecidas es un hecho indiscutible; pero si enmarcamos ese cuerpo disciplinar en el uso interactivo en red, las cuestiones que atañen a los modos de producción, creación y entrenamiento físico nos exigen tener un cuidado mayor. Según Juan M. Prada, "el fuerte determinismo tecnológico naturalizado que la sociedad hoy sufre o disfruta está permanentemente modificando hábitos, alcanzando un potencial de transformación de la subjetividad humana imprevisible a largo plazo".

Por tanto, nos proponemos revisar ciertos términos que han sido parte de una tradición y una identidad mecanicista de la disciplina Danza. Podemos referirnos así a la imitación, la reproducción o la copia, y precisarla relatividad de sus alcances según el contexto de observación y estudio.

De acuerdo con lo que describe Wladyslaw Tatarkiewicz (1987:301), el término imitación "ha existido desde la antigüedad; sin embargo, el concepto ha cambiado. Hoy día, imitación significa más o menos lo mismo que copiar". Si observamos la trayectoria de la mimesis en el arte occidental, podemos exponer su comportamiento expresándolo en una línea histórica que va encauzada por los avances técnicos y tecnológicos:

He observado previamente que la mimesis ha sido el centro del arte occidental desde los griegos; e históricamente, ha avanzado mediante la utilización de las tecnologías y técnicas más avanzadas disponibles. La abstracción del 
modernismo es una aberración en el flujo histórico. Ciertamente, la historia de los medios populares siguió el camino de la mimética. A partir de los autómatas del siglo XVII -como por ejemplo el famoso pato de Vaucanson, un autómata mecánico que podría batir sus alas, comer y excretar los desechos sin olor-, la mimesis ha sido el principio rector. Esta trayectoria continúa a través de la fotografía, las novedades visuales como estereogramas Wheatstones y Diorama de Daguerre, el cine, la televisión, animación por ordenador y las atracciones de los parques temáticos (Penny, 1993) ${ }^{103}$.

Por ende, prosiguiendo este recorrido podríamos corroborar que, en general, se advierten diferencias entre crear y copiar; se conciben como dos procesos distintos. Aun así, esta distinción es problemática dado que es muy improbable crear de la nada. Es justo asumir, por tanto, que toda creación presupone la utilización de algo conocido, lo que determina cierto tipo de continuidad entre lo antiguo y lo nuevo. Sin embargo, la divergencia entre crear y copiar puede y corresponde ser fundada.

Por su parte, entender que la creatividad es una manera de utilizar provechosamente lo que está disponible para recrear un conjunto de recursos vistos, oídos, leídos, etcétera, pero proyectados en una nueva dimensión. Eliminada esta condición restrictiva de crear a partir de los elementos existentes, revisamos la asociación de los términos creador y creatividad con el lenguaje del arte, pues casi se han convertido en su propiedad exclusiva.

Ante la posibilidad de justificar que la copia es un acto legítimo de la especie humana, se considera que "nuestra cultura se compone por la información almacenada en nuestra memoria y absorbida habitualmente por imitación (mímesis), por enseñanza o por asimilación" (Tobar Abarca, 2013: 216). Por lo tanto, esta se ha convertido en una herramienta. La copia deja de ser un término estigmatizado para pasar a componer un acto de desarrollo, de manutención, de adaptabilidad dentro del cuerpo de internet.

Desde nuestro análisis, nos interesa observar cuáles serían esas prácticas, qué perfil de interacción generan; los órdenes se han invertido en favor de la emancipación de una sociedad que apuesta por un medio de comunicación eficaz, que reduce distancias y aligera el tiempo. La accesibilidad, la virtualidad, la ubicuidad y la interactividad -entre otras viabilidades que identifican la red- han hecho de ella un

103 "I've previously observed that mimesis has been the focus of western art since the Greeks, and historically, has advanced by utilising the most advanced technologies and techniques available. The abstraction of modernism is an aberration in that historical flow. Certainly the history of popular media followed the mimetic path. From automata of the seventeenth century, such as Vaucanson's famous Duck, a mechanical automaton which could flap its wings, eat and excrete foul smelling waste matter, mimesis has been the guiding principle. This trajectory continues through photography, C19th visual novelties such as Wheatstones stereograms and Daguerre's Diorama, to cinema, TV, computer animation and theme park attractions". 
espacio sugestivo para diferentes prácticas artísticas, así como la concepción de otras prácticas en hibridación constante, consecuentemente, para la danza, la performances, etcétera.

Partiendo de esta perspectiva del acto de copiar, no puede definirse la imitación como mera reproducción de un movimiento vacío. Tomarlo y situarlo en otro contexto, aplicarlo de otra manera, proyectarlo de un modo parcialmente inédito, hace de la imitación y de la creatividad conceptos que se entrecruzan de manera no menos compleja. El desarrollo de formas alternativas de experiencia reflexiva impacta movilizando hábitos y formas predominantes de intercambio a través de la colaboración y participación colectiva que se da en las redes directa o anónimamente. Por un lado, analizar las relaciones entre los conceptos de representación y de mimesis es analizar también cómo el cuerpo aprende y cómo se conecta con otros cuerpos y sistemas. Esas relaciones son muy discutidas en los ámbitos artísticos instando a considerar posturas contrarias y a cuestionar discursos que suponen un paralelismo entre representación, arte y realidad. Estas nociones han estado vinculadas al concepto de semejanza presente en los debates acerca de las relaciones entre discurso científico y realidad, y entre expresión artística y realidad.

Por otro, la dificultad de transitar por estas nociones fuertemente vinculadas a las artes plásticas genera, en la danza, un problema de terminología, ya que no siempre estos dos mundos comparten términos con igual acepción. La danza contemporánea, al estar particularmente ligada al discurso teórico, intenta explicar su significación y su capacidad de abrir interrogantes ante la densa conceptualidad con la que operan los discursos científico, filosófico, sociológico, entre otros. Se trata de responder a la necesidad de establecer conceptualmente un enfoque metódico entre las condiciones de abordaje de los diferentes discursos, el cuerpo y la disciplina de la danza; expresar, asimismo, las coyunturas y configuraciones que se adopten:

Una rápida clasificación nos permite identificar al menos los siguientes tópicos: 1) la forma de entrenamiento específico que siguen los diversos estilos de danza, 2) las morfologías corporales resultantes de los diversos estilos de danza, 3) la necesaria presencia del cuerpo en la realización de la obra (carácter performático), 4) la búsqueda de significados subyacentes del cuerpo que rigen la construcción de un lenguaje de movimiento, 5) la aparición del cuerpo como problema poético en la historia compositiva de la danza, 6) la búsqueda de un discurso del cuerpo en la composición de una obra, 7) la aparición del cuerpo como problema teórico en la comprensión/crítica de una obra (Escudero, 2008: 1). 
Esta clasificación nos organiza al describir cómo surge la necesidad de una conceptualización teórico-práctica y dónde se inscriben las referencias conceptuales de los términos que estamos estudiando. En el nivel de la especulación que circula en torno a la creación a partir de la copia, la mimesis, la representación, se patentiza, por una parte, la necesidad de esclarecer la especificidad de los recursos y contextos de producción; y, por otra, la necesidad de situar los tópicos arriba enunciados en dichos recursos y contextos. Nos estamos refiriendo específicamente a situarlos entre el espacio de formación tradicional y el espacio de internet.

\footnotetext{
Hay un proceso que todo bailarín asume: te enseñan copiando. Yo creo que en realidad es una forma de des-empoderarte de un ejercicio. Tenés la capacidad de entender incluso hasta de tus propias limitaciones, que es lo primero que aprendes en la danza. $Y$, tenemos la capacidad de poder desandar los procesos (Masnatta, 2016: 1').
}

Con lo expresado anteriormente, queda claro que la idea de aprendizaje no pasa por el sentido habitual de acumulación, de sobreponer como consecuencia de jerarquizar, sino de tratar de no permanecer en el mismo lugar, de acrecentar los elementos del colectivo que nos constituye. Se trata de inventar, crear nuevas relaciones desequilibrando posturas, gestos.

En el marco de una situación de interiorización o imitación de un esquema gestual a través de materiales audiovisuales de internet, se reconoce la importancia de la repetición como método de organización del conocimiento en las reestructuraciones que se producen debido a la interacción entre las estructuras ya existentes en el sujeto y la nueva información. Es vital considerar que para que esta reestructuración se produzca se requiere de un saber formalmente establecido, que presente, de modo organizado y preciso, la información que debe desequilibrar las estructuras previas.

Para Frederick Matthias Alexander (2011: 202), "el proceso de imitación no comienza a funcionar a menos que haya algo llamativo a imitar, y el principal estímulo para la imitación proviene de nuestra percepción consciente o inconsciente". Puesto que este proceso no es una simple asimilación pasiva de información literal, el sujeto la transforma y la estructura.

En este sentido, Ana C. Lima Monteiro (2010: 60), refiriéndose concretamente al cuerpo, explica:

La diferencia entre la repetición del cuerpo y la repetición ejercida solo como método de memorización no parte del mismo principio. Repetir en el cuerpo 
requiere un camino largo de entrenamiento, desplazamientos, insistencia y, en última instancia, de producción de una nueva relación con el mundo. En cada repetición, se adquieren nuevas cualificaciones, y nuevas significaciones son construidas activamente por el sujeto que está adquiriendo un nuevo hábito. En contrapartida, las simples repeticiones de una frase no exigen del sujeto que él se re-coloque, que, literalmente, él cree nuevas posiciones. El éxito de la memorización no está en el propio acto de repetir lo que se pide, pero sí de construir nuevos sentidos para lo que está siendo memorizado [...]. Cada repetición es una adquisición, una nueva forma de posicionarse ${ }^{104}$.

En el mismo orden de ideas, estamos en condiciones de afirmar que solamente podemos aprender o aprehender algo nuevo cuando existe algún conocimiento previo sobre el cual anclar la novedad. Por ende, la dimensión representacional hace referencia al tipo de procesos mediante los que se codifica, transforma y retiene la información, que iría de lo meramente memorístico o repetitivo a lo plenamente significativo.

Retomamos lo expresado por Ana C. Lima Monteiro sobre que "la repetición del cuerpo y la repetición ejercida solo como método de memorización no parten del mismo principio", que para el cuerpo implica un nuevo orden de sentido desde donde posicionarse. El valor conceptual que ejerce esta diferenciación en el presente, respecto a la forma de adquisición del conocimiento corporal, encuentra reparo al proponerse un recorrido histórico por las representaciones propias de lo disciplinar, puesto que han ejercido tal matriz que aún hoy no pierde vigencia.

Retomamos también la pregunta de Susana Tambutti (2008: 12) sobre cuáles son las posibilidades y límites representacionales de la danza, y lo que propone como respuesta: un itinerario con tres momentos que no son excluyentes y conviven en la actualidad. Entonces hubo un primer momento, en el que "la preocupación principal estaba relacionada con la teoría de la imitación y la representación de la belleza ideal". Un segundo que instaló "la teoría de la expresión como verdadera, lo cual ponía en conflicto la tradición anterior". Y, un tercer momento, se excluyó de la "teoría que la definía como arte que expresaba las emociones del artista".

\footnotetext{
104 Traducción propia: "A diferença entre a repetição do corpo e a repetição exercida apenas como método de memorização não partem do mesmo princípio. Repetir no corpo requer um caminho longo de treinamento, deslocamentos, insistência e, em última instancia, de produção de uma nova relação com o mundo. A cada repetição, adquirem-se novas competências, novas significações são construídas ativamente pelo sujeito que está adquirindo um novo hábito. Em contrapartida, a simples repetições de uma frase não exige do sujeito que ele se reposicione, que, literalmente, ele crie novas posições. $O$ sucesso da memorização não está no próprio ato de repetir o que se pede, mas de construir novos sentidos para o que esta sendo memorizado. [...] Cada repetição é uma aquisição, uma nova forma de se posicionar".
} 
En consecuencia, pensar hoy la danza implica recurrir a múltiples teorías que nos aporten un cierto arsenal de conceptos que permitan identificarla como tal, justamente porque la danza hoy no se deja encerrar bajo ningún concepto definitivo. Nunca tendremos "la" teoría correcta para todas las formas de danza (Tambutti, 2008: 26).

Así que la cuestión central no está en la mera aparición de diferentes momentos y métodos disponibles que cada uno instala, sino en la suficiencia para diferenciar los alcances y límites del método de acuerdo a la situación de la cual se parte, para no confundir el sentido primordial que cada método creativo abarca. La atribución sin mediar una conciencia apropiadora mecaniza los procesos de exploración y reduce los componentes solo a sus aspectos externos.

La apropiación consiste en tomar una obra de arte para producirla nuevamente manteniendo tanto sus motivos como la técnica empleada. El resultado de esta acción es una obra exactamente igual (visualmente) a la primera, pero realizada por otro artista. El cambio de rótulo "plagio" por "apropiación" forma parte del argumento propuesto por los artistas apropiacionistas, quienes aludían a que sus obras no eran una mera copia sino un nuevo original recontextualizado y resignificado (Matewecki, 2006: 1).

¿Será que la apropiación -en el universo inorgánico, en esa gran variedad de estructuras cohabitantes de la web- no es otra cosa que la propia disolución de lo orgánico en imágenes y conexiones multidireccionadas?

Siguiendo esta línea de cuestionamientos y tal como lo expresa Susana Tambutti (2005):
¿Podría esperarse que en el próximo siglo el cuerpo danzante haya perdido definitivamente toda relación con su origen? El sentimiento insuperable de decepción que le produce su materialidad, ¿buscará remedio en la fragmentación en una multiplicidad de imágenes o en su transmutación en holograma? ${ }^{105}$.

Y en este punto, podemos proponer dos miradas analíticas para el origen de la danza local: una que descubra los rasgos de una identidad cultural y social propia frente a la imposición de lo "universal", y otra que explique las influencias que hemos asimilado y naturalizado sin cuestionamientos. Es decir, iniciar una reflexión sobre nuestra

\footnotetext{
105 Véase Susana Tambutti en "Danza o el imperio sobre el cuerpo". Conferencia presentada en el $\checkmark$ Festival Internacional de Buenos Aires, 2005 [en línea]. Dirección URL: <http://movimientolaredsd.ning.com/profiles/blogs/2358986:BlogPost:3762> [Consulta: 19/05/16].
} 
corporalidad disciplinar a partir de "la subordinación estética respecto de los centros de poder que la transformó en un epígono menor" (Tambutti, 2013: 189).

Lo que nos conduce a pensar en esa apropiación de los estratos conservadores físicos y materiales del mundo orgánico hacia un mundo inorgánico. Observar cómo esa fisicalidad institucionalizada se traspasó al espacio virtual e inorgánico no solo a partir de la Web 2.0 sino prontamente a la Web 3.0, y centrarse en un futuro en el que domine la inteligencia artificial y la retroalimentación tecnológica. Se trata entonces de reparar en esas transformaciones para poder analizar estas nuevas tendencias en el contexto de la cultura y la sociedad, pero sin olvidar, a la vez, una perspectiva histórica que la sustente.

De igual modo, sigue siendo el cuerpo el lugar donde se concentra simultáneamente lo que es efímero y lo que es intenso, sigue siendo nuestro modo de vida presente estar en el mundo con un cuerpo casi inorgánico. Extraído del espacio de lo privado, se lo incorpora en una infinidad de lugares del espacio público virtual, y muy por el contrario de lo que se cree: cuanto más virtualización más corporeidad.

En particular, el mundo inorgánico que nos interesa señalar es aquel cuya realidad virtual puede ser relevo de la realidad física a niveles conceptuales, con nuevos códigos de intercambio, modelos de conocimiento y de representación. Theodor Adorno y Max Horkheimer (1944:35) expresan: "Sin duda la facultad de representación es solo un instrumento. Mediante el pensamiento, los hombres se distancian de la naturaleza para tenerla frente a sí en la posición desde la cual dominarla".

Esto nos lleva a pensar que esa representación de cuerpos que danzan en la virtualidad es el dominio de la materia-cuerpo. Aun siendo posible este fenómeno de transmutabilidad, ¿no será sustancialmente ilusorio? Pues, a pesar del impacto de las tecnologías relacionadas con la transmisión de la información, no debe entenderse que esto conduce inevitablemente a una desmaterialización de los soportes físicos, tangibles. Sin duda, la generalización de internet ha transformado el panorama y, por lo tanto, no resulta fácil evaluar las derivaciones en nuestro modo de entender el arte.

Actualmente, habría que planteárselo desde los términos en que la tecnología mundializa la cultura, haciéndola parte de una escenario que obliga a pensar las competencias intelectuales con nuevas categorías, superando, sobre todo, la visión exclusiva de códigos binarios que ha dominado desde los tiempos de una modernidad crítica. Alcanzar una visión heterogénea que desmitifique viejas discusiones ortodoxas vendría a favorecer y renovar la circulación de los bienes culturales que han sido reconfigurados por las Tecnologías de la Información y la Comunicación (TIC) con un gran impacto en las esferas del arte. 
Asimismo, se hace imprescindible observar que la especialización de todas las áreas del conocimiento humano ha sido determinante -siguiendo lo expresado por Rodrigo Alonso (2010: 7)- sobre:

... la disgregación de ese núcleo productivo. En su lugar, los saberes científicos, artísticos y tecnológicos fueron dotados de finalidades diversas, incongruentes, e incluso antagónicas. En virtud de una cuestionable ideología de la pureza, se desecharon las "contaminaciones" que suponían establecer puentes y diálogos entre aquellos que, cada uno a su manera, erigían visiones de la realidad y del mundo a su alrededor.

Evidentemente, esto implica movilizar - desde las fronteras del campo de las artessignificaciones elementales de las prácticas cognoscitivas de este. $Y$, haciéndolo más extensivo, al lugar del arte y la tecnología integrando lo institucional a este sistema propositivo, abierto y alternativo de la web. Por ende, lo que se propone hoy en estos cruzamientos, estas confluencias, estas articulaciones del arte, la ciencia y la tecnología, son prácticas propiamente contemporáneas que tiendan a borrar las fronteras de los discursos institucionalizados, intercambiar estrategias y experimentar saberes, etcétera, desde la generación de metáforas pensantes y poéticas.

El interés de estos nuevos proyectos, según la propia Ivani Santana (2011: 86), "no está solo en utilizar internet como medio de transmisión, sino en verificar cómo la viabilización del encuentro con individuos distantes puede derivar en una danza remota, distribuida"106, en la que un bailarín no actúa con un otro cuerpo presencial, pero sí con imágenes, sonidos y datos de su colega. Y entonces Santana (2011: 86) se pregunta:

¿Cómo es posible bailar con un cuerpo no más de carne y hueso? Para eso, el aparato sensorio-motor del bailarín es requerido de forma muy diferente de los contextos presenciales, ya que parece estar fuera del espacio y del tiempo pero abierto a sus efectos. Así ponemos al contenido de la imagen en vinculación con el cuerpo en movimiento y las interfaces propuestas, puesto que "el bailarín observa su propia imagen moverse, para tener como referencia su relación con el compañero y, así poder bailar. Él hace bailar su imagen para bailar con el otro.

\footnotetext{
106 Traducción propia: "O interesse desses projetos nao está apenas em utilizar a Internet como meio de transmissao, mas verificar como a viabilizaçao do encontro em indivíduos distantes pode acarretar em uma dança remota, distribuída".
} 
Consideramos la danza o performance telemática ${ }^{107}$-o danza en red como se denomina actualmente, lo que equivale a decir bailar a larga distancia-, una de las propuestas híbridas más significativas entre lo material y lo inmaterial del cuerpo, generadas a partir de la interconexión por internet. Aquí los performers danzan, en mayor o menor medida, con la imagen del cuerpo en movimiento de otros performers. Según John Berger (2012: 21), los cuerpos de los bailarines:

\begin{abstract}
Con su tipo particular de dedicación, son duales. Y esto se ve, hagan lo que hagan. Están determinados por una suerte de principio de la incertidumbre; en lugar de ser alternativamente partícula y onda, sus cuerpos son alternativamente donante y don [...]. La dualidad de cada cuerpo es lo que les permite, cuando actúan, fusionarse en una única entidad.
\end{abstract}

Esa única entidad, ¿serán los otros cuerpos y los espacios reales-virtuales entre pantallas? Claudia Giannetti (1998: 5) señala que, para la acción de una performance telemática, "hay que pensar cómo alcanzar una cohesión interactiva entre las distintas partes del mundo, cómo solucionar los problemas de diferencias de horario, cómo jugar con la improvisación respecto al determinismo, los ecos, los acoplamientos y los espacios vacíos".

En una de las varias performances telemáticas realizadas entre el Grupo de Pesquisa Poéticas Tecnológicas de la Universidad Federal de Bahía, Brasil (Ivani Santana) y el grupo catalán Kònic Lab (Rosa Sánchez y Alain Bauman), se pueden destacar tres elementos de esta comunicación distribuida:

- La simultaneidad de elementos en tiempo real.

- La posibilidad para el público de interactuar con la obra.

- La difusión multicanal de la pieza.

En una entrevista que realizamos a Jacson Espírito Santo, coordinador de MAPAD2 ${ }^{108}$, en el marco de una acción telemática, responde a la pregunta sobre qué tipo de diálogos establecían entre el cuerpo y los dispositivos, y los define como acciones y motivaciones que se establecen con los dispositivos. $Y$ agrega:

No hay coreografías previas. Obvio que hay una acción de repetición por causa de esos dispositivos, del encuadre de la cámara, con la relación en el propio

\footnotetext{
107 El término "telemática" fue acuñado en Francia, en 1976.La Telemática es una disciplina científica y tecnológica que asocia las telecomunicaciones con la informática. La Telemática incluye el estudio, diseño y administración de las redes y los servicios de comunicación de datos.

108 El Mapa y Programa de Artes en Danza (y Performance) Digital es una plataforma virtual para la difusión y el apoyo educacional, tecnológico y mercado lógico del ámbito de la danza y de la performance con mediación tecnológica, en países de lengua portuguesa y española. Véase en línea: $<$ http://www.portalseer.ufba.br./>.
} 
ambiente, con un escenario que está siendo construido... va a generar en nosotros, performers, un camino, mas en ese camino, para esa acción se va a lidiar con las incertezas del momento (Espirito Santo, 2011: 7'20" a 8'34").

Además, cabe indicar que al finalizar la performance se realiza una videoconferencia con el fin de discutir sobre la producción artística en red. Esta particularidad del ejercicio del diálogo con el público conforma el contexto de la cultura digital en proyectos de danza con mediaciones tecnológicas a niveles de investigación académica. Ya no es solo mostrar un espectáculo con múltiples medios, sino hacerse responsables por las reconfiguraciones en el sistema conceptual y del inconsciente cognitivo de esos artistas implicados y, en otro nivel, de los interactores-espectadores que son impulsados también a otras demandas cinestésicas.

En palabras de Ivani Santana (2006: 79): "La danza es un conocimiento que desestabiliza los mapas neuronales y las imágenes mentales ya organizadas, promoviendo nuevas posibilidades de ese cuerpo de relacionarse con el mundo"109. Esa relación en la danza desarrollada en la web -tanto el registro de cámara como la emisión directa de los cuerpos, o partes de ellos- juega con distintas opciones narrativas en el movimiento y propone diversidad de tamaños en capas diferentes de la imagen, lo que multiplica las posibilidades narrativas entre los cuerpos ubicuos. En ellas se pueden apreciar las variadas capas de efectos simultáneos en el nivel de la imagen y en el nivel compositivo, a modo de un rompecabezas que va acomodando sus partes y penetrando en otras.

Nos detendremos aquí para establecer, en términos técnicos, lo que permite una gestión de flujo de la imagen. Esta se efectúa a través de un streaming ${ }^{110}$ o transmisión en tiempo real.

El software libre Arthron ${ }^{111}$-un buffer de datos de descarga continua- es utilizado por el grupo de la universidad brasilera que creó una herramienta para performances artístico-mediáticas distribuidas que recibe y selecciona de cada punto emisor la imagen que ingresa desde las cámaras que filman a los performers en vivo. El programador de Arthron también es parte de la performance, es un actor/improvisador de la escena puesto que está tomando decisiones sobre qué se ve y cómo se ve.

\footnotetext{
109 Traducción propia: "A dança é um conhecimento que desestabiliza os mapas neuronais e as imagens mentais já organizadas, promovendo novas possibilidades desse corpo se relacionar com o mundo".

${ }^{110} \mathrm{El}$ streaming es la distribución de multimedia (video y audio) a través de una red de computadoras, de manera tal que el usuario consume el producto al mismo tiempo que se descarga. Esto se contrapone al mecanismo de descarga de archivos, que requiere que el usuario descargue los archivos por completo para poder acceder a ellos. Se popularizó a fines de la década de dos mil, cuando el ancho de banda se hizo lo suficientemente barato para gran parte de los usuarios.

111 Arthron: Uma Ferramenta para Performances Artístico-Midiáticas Distribuídas [en línea]. Véase: $<$ http://www.lavid.ufpb.br/gtmda/Manual_Athron_Final.pdf>.
} 
"Las audacias del camarógrafo pueden, de hecho, compararse con las del cirujano. En un catálogo de destrezas cuya técnica es específicamente de orden gestual" (Benjamin, 2007: 170). Así es probable que otra configuración de coreógrafo se esté amalgamando, basada en una concepción de la danza que no se limita al cuerpo en movimiento y que, incluso, no provenga directamente del campo de la danza, sino que conlleve parte de su actuación y pensamiento sobre componer con los cuerpos, el espacio y el tiempo, pero coreo-editando (AA. VV., 2010) en un ambiente fluido y dinámico, ejecutando una kinestedición (Field, 2010: 98-100) con imágenes de cuerpos que hiperdanzan por el ciberespacio.

Sumado a esto, el usuario-espectador también puede intervenir en los procesos hipercoreográficos como parte de una experiencia dirigida hacia un modo perceptual nuevo. Por ende, a través de un sistema satelital interactivo más vinculado con la percepción que con la producción de movimiento, la danza muestra esta perspectiva particular de estudio y de exploración en la que la presencia material e inmaterial importa más que el movimiento en sí.

Rosa Sánchez -en un intercambio de investigación, vía correo electrónico, sobre la imagen que se proyecta en las performances telemáticas- respondió algo que condensa las ideas que sobre el trabajo del cuerpo y la imagen veníamos planteando:

Te contestaré desde el punto de vista y la experiencia de Kònic, ya que creo que cada autor tiene su manera de trabajar con la imagen en los proyectos telemáticos. Es probable, de hecho, que la manera de trabajar nuestra sea bastante peculiar, ya que los otros proyectos que conocemos usan la imagen entre los dos lugares conectados para hacer una performance conjunta en telepresencia, tratando de reproducir al máximo lo que sería un escenario convencional, pero distribuido entre dos o más lugares distantes.

En nuestro caso, queremos entender que el medio tiene sus peculiaridades, y una de ellas es que lo que se distribuye entre los diferentes espacios no son los cuerpos de los bailarines, sino su representación videográfica, su mediatización. Por ello, nos parece igual de importante tratar con la imagen que con los cuerpos. Lo que hacemos, en general, es tratar la imagen en tiempo real (Max+Jitter) para hacer una realización en directo entre las imágenes de los espacios conectados. Podemos pensar en una especie de videodanza en directo y distribuida. Muchas veces, el resultado final, la composición resultante, se verá por streaming en internet, además de una composición específica para cada espacio físico con bailarín [Comunicación personal por correo electrónico entre Alejandra Ceriani y Rosa Sánchez, 25 de enero de 2013]. 
La complejidad de estas performances en telepresencia, que comprenden la expansión del cuerpo a la imagen y al sonido, al espacio y al tiempo, implica un flujo inestancable de transformaciones micro y macro, mediatas e inmediatas. Tal como lo expresa Ivani Santana (2006: 172) en sus conclusiones sobre la danza en la cultura digital:

\begin{abstract}
Percibir cuál metáfora está siendo utilizada en un determinado concepto permite elaborar, de forma más específica, su estructura, además de posibilitar el énfasis en los puntos de interés y el encuentro de puntos escondidos. Llegar a la mejor metáfora del objeto, por lo tanto, se transforma en una cuestión política importante de consecuencias éticas y que necesita ser ejercitada. La necesidad de la repetición de la información, de la recurrencia de la metáfora más pertinente es lo que permitirá una efectiva contaminación coherente en el sistema.
\end{abstract}

El intercambio de información entre los dispositivos, programas e interfaces, datos y formatos de recepción y transmisión más la capacidad de fluctuación del sistema, puesto a interactuar con el cuerpo, se produce contaminándose, multiplicándose, articulando sus fragmentos, generando el carácter siempre transformador de todo proceso de traducción con sus inevitables distorsiones.

En ese sentido, habría que volver a preguntarse: ¿qué es lo que propone la danza telemática? ¿Son solo "nuevos efectos, que quedan, sin embargo, ligados al viejo esquema, [y que] no hace[n] más que aumentar, como regla supletoria, la autoridad de lo ordenado"? (Adorno y Horkheimer, 1944: 45). Estas posturas aparentemente lineales y excluyentes sufrieron un incesante desplazamiento y contaminación, y se convirtieron en una característica inherente al arte tecnológico de esa era.

Una primera respuesta podría ser que la tecnología contamina y transforma el arte. Esos cuerpos que danzan telemáticamente contaminados vienen conquistando altos niveles de abstracción comunicativa que los coloca en un espectro sistémico más amplio. Son cuerpos atravesados, interpretados, trascodificados por varios medios.

Al respecto, Ivani Santana (2011: 87) sostiene que la relación de ese organismo -que es del bailarín- con ese objeto - que es la propuesta en danza conectada vía internetrepercute en ese microuniverso creado por la interconexión espacial y temporal, y por ese particular "cuerpo-mente que danza un reflejo de mundo"112.

Por su parte, Christine Greiner (2010: 133) afirma que:

\footnotetext{
112 Traducción propia: “... nesse 'corpomente' que dança um reflexo de mundo”.
} 
Cognición y comunicación no son sinónimos, ni mantienen una relación de causa y efecto [...]. El trazo común entre ellas está en el hecho de que ambas sean procesales [...]. No se trata de una serie estática de representaciones $\mathrm{y}$, en ese sentido, la comunicación no puede ser restringida a significados [...]. Esos procesos tienen lugar en el tiempo real de cambios que aún están por venir, en el ambiente, en el sistema sensorio motor y nervioso. Quien da inicio al proceso es el sentido del movimiento. Es el movimiento que hace del cuerpo un cuerpo medio ${ }^{113}$.

En la mencionada entrevista, Jacson Espirito Santo (2011: 5'12") responde a otra pregunta sobre qué relación establece el cuerpo presente con el cuerpo virtual, y explica algo que citamos como aporte a esta creciente mediatización entre los cuerpos:

\begin{abstract}
Es complicado hallar que aquella persona que está en otro continente está pudiendo trazar una poética con el performer local, y que eso esté aconteciendo de forma espontánea [...]. Esa relación es superpotencial... y una cosa que fue muy buena... cuando encontré a los compañeros de Kònic el año pasado. Ya veníamos danzando por dos años (telemáticamente) con ellos, cuando nos vimos: iiiUstedes existen!!!... y ahí abrazos.
\end{abstract}

Para cerrar este apartado, coincidimos con Adorno y Horkheimer (1944: 15) en que "las posibilidades que los dispositivos técnicos pueden brindar al arte en el futuro son imprevisibles", más aun si lo pensamos desde la opción de una narrativa de la emoción, del afecto virtual entre los cuerpos.

\title{
41. Registro y memoria corporal en los tiempos de internet
}

Susana Tambutti (2013: 2) utiliza la noción de impulso mimético "para designar la preocupación por la función imitativa que la danza debía cumplir", ya sea centrándose "en el cuerpo y su gramática corporal, es decir, en su médium expresivo; [como en] las emociones y acciones que se intentan comunicar, y construir un relato verosímil y significativo".

\footnotetext{
113 Traducción propia: "Cognição e comunicação não são sinônimos, nem mantên em uma relação de causa e efeito. [...] $\mathrm{O}$ traço comum entre elas está no fato de ambas serem processuais. [...]. Não se trata de uma série estática de representações e, nesse sentido, a comunicação não pode se restrita a significados. [...]. Esses processos têm lugar no tempo real de mudanças que ainda estão por vir, no ambiente, no sistema sensório motor e nervoso. Quem dá início ao processo é o sentido do movimento. É o movimento que faz do corpo um corpo mídia”.
} 
Actualmente, habría que reeditar esta definición de impulso mimético del cuerpo, pero no desde un enfoque puramente orgánico en el que el cuerpo es un medio de transmisión y recepción, una interfaz afectada y no tan afectiva. Tampoco desde la constitución de múltiples apariencias digitales, como avatares eyectados, exteriorizados. Sino más bien desde la "fiel o concreta representación de una persona que quiere interactuar con otras personas, y que deben estar suficientemente 'bien' identificadas corporalmente", según profesa Juan M. Prada (2011:157) sobre lo requerido en las redes sociales de la web.

Esa identificación corporal y su representación no debe discutirse en abstracto, sino en relación con prácticas específicas, tanto del espacio físico como del virtual. En ese sentido, entendemos la representación como un recurso que inventa a un otro y, mediante ese acto, controla la propia imagen a través de una autorrepresentación.

El tema de la representación está vinculado, entonces, al ejercicio de empoderamiento dentro de contextos en los que el "sujeto ya no se ubica lejos de la imagen, en el enfrentamiento dramático de la representación, sino que se sumerge, se desenfoca, se translocaliza, se expande o se condensa" (Couchot, 1998: 229).

El sujeto físico busca esta autorrepresentación para distintos fines, uno de los cuales puede ser lograr una representatividad virtual dentro de la cibersociedad. Si consideramos que la autorrepresentación virtual se relaciona con la construcción eventual de memorias corporales, entonces sugerimos interrogar hasta qué punto los sujetos tienen el control sobre las tecnologías de representación y, por lo tanto, control sobre la manera cómo sus discursos y actuaciones son leídas a través del juego de patrones de reproducción.

Juan Martín Prada puntualiza la progresiva liberación del vínculo que el espacio de la red mantiene con el concepto de "virtualidad":

... cargándose de realidad, de imágenes, de cuerpos que existen físicamente, signos de identidades concretas. Dentro del arte actual, la vía que tematiza este cambio de intereses podría ejemplificarse con todas aquellas propuestas que hacen al uso de las autorrepresentaciones de los usuarios de las redes sociales [...] cientos de videos en donde usuarios de plataformas como YouTube se han grabado bailando con las webcams de sus ordenadores (2012: 157).

Encontrar las formas de relacionar la discusión sobre la representación y la construcción de autorrepresentaciones con los demás en un "conjunto de decenas de cuerpos 'físicos' actuaría, en última instancia, como una metáfora o designación 
abstracta del singular cuerpo ¿social? De la propia multitud interconectada" (Prada, 2012: 158).

Esta interconexión entre cuerpos reales y ficticios se plantea comúnmente desde las prácticas artísticas, sociales y culturales, pero no del mismo modo desde un planteo cognoscitivo, es decir, desde el cuerpo como objeto de un saber que estas prácticas imprimen. Por lo tanto, es primordial indagar qué es lo que se aprende y cómo se incorpora a nuestras prácticas corporales, observando, asimismo, desde qué conocimientos la danza ha educado al cuerpo. $Y$ no estamos haciendo referencia únicamente a reconocer cierta gramática de movimientos regida por un pensamiento analítico, sino a indagar en la incorporación de las prácticas tecnológicas actuales que abordan e inscriben el cuerpo desde una memoria colectiva registrada y reeditable.

Este enfoque facilita otro importante modo de registro del lenguaje corporal, pues, a la par que se pone en juego una corporeidad plenamente comprometida con una lógica relacional, se ponen en juego también las tensiones físicas y simbólicas frente a un cuerpo que es cada vez más material de manipulación tecnológica. Incluso, planteado desde esta idea aplicacionista, los métodos empleados permiten una autorreconfiguración de los hábitos de captura, registro y presentación del cuerpo.

El bailarín analiza en tiempo real los movimientos y se reconoce ante ese estímulo de la imagen de otro bailarín devenido modelo. Como metodología de captación del movimiento gestual se conforma una interacción más evolucionada en la cual se pueden controlar y transformar las propias acciones sobre la experiencia de registrar y cargar en la memoria corporal la huella que deja el gesto virtual observado. Se abren, pues, otras posibilidades de relación a partir del redescubrimiento de desplazamientos atemporales que se reactualizan cada vez que precisan ser solicitados.

Acostumbramos a comprender la memoria desde la presencia de las cosas y también desde nuestra sumersión en ella para identificar su poder constitutivo y sus derivaciones performativas sobre todas nuestras prácticas sociales. Sin embargo, todavía nos queda la tarea de explicar cuáles son específicamente aquellas prácticas a las que llamamos memoria y que incluyen el cuerpo. Incluso, cuando los autores que trabajan sobre memoria distinguen la importancia social de esta acción, muchos han señalado que esta inferencia básica resulta limitada para dar cuenta de un campo de estudio en el que los conceptos son todavía aproximados y en el que falta un desarrollo teórico común entre las disciplinas y las prácticas que lo interpelan.

Para ir avanzando sobre esta disquisición si estamos entre la persistencia de un impulso mimético o el registro de memorias corporales que se actualizan en la renovación de los recursos tecnológicos, tomaremos como muestra -para analizar y entrelazar ideas- un material videográfico de YouTube: "This amazing girl mastered 
dubstep dancing by just using YouTube"114. Allí, la protagonista es una joven que comenzó a danzar dubstep con YouTube como "maestro", utilizando internet para estudiar a los mejores bailarines de ese estilo, aprovechando las ventajas técnicas del visionado, con la posibilidad de detener, rebobinar y repetir las secuencias tantas veces como sea necesario:

Empecé hace siete u ocho meses. Todo comenzó con una investigación que tenía que hacer sobre Michel Jackson y me metí a internet; entonces encontré gente bailando dubstep y empecé a practicar y seguí desde entonces. Voy a YouTube y busco cosas como "cómo bailar dubstep" o "cómo hacer pop and lock", para aprender los movimientos siempre miro el video una y otra vez. Probablemente lo hice un millón de veces hasta que me di cuenta de cómo lo hacen.

A veces, pasas de un movimiento a otro, según el ritmo, y es algo extraño porque es como si estuviera en mi mundo "Lala" (mundo ideal). Si estás realmente en internet, realmente puedes aprender y enseñarte a ti mismo. Es beneficioso porque puedes rebobinar, pausar y todo eso. Puedo verlo una y otra vez, pero en una clase no puedes hacer eso. Honestamente, he aprendido todo esto en internet. Internet está en mi generación para que podamos aprender todas estas cosas. Creo que puedo mostrarle a la gente que pueden hacer todo lo que se propongan si realmente sienten pasión por ello (Malcolm, 2016).

Este material que circula viralmente en internet -más precisamente en Facebook ${ }^{115}$ nos ha servido de disparador para pensar las prácticas de los cuerpos en las redes desde una visión crítica conjunta, tomando como referencia diversas investigaciones y reflexiones aparecidas a partir del visionado de este video. Específicamente, se trata de comprender las situaciones de interacción mediada por las tecnologías digitales y ver de qué manera se está redefiniendo nuestra concepción de cuerpo, imitación, registro y memoria colectiva.

\footnotetext{
114 "Adilyn Malcolm es una niña de doce años que ha conseguido danzar dubstep por medio de la visualización de videos en línea. Navegando por la red, vio un reportaje sobre la vida de Michael Jackson, y luego la joven había quedado maravillada por esa extraña y curiosa forma de danzar. Gracias a internet descubrió todo lo preciso sobre el dubstep, un estilo de baile de movimientos asincopados, lentos, fluidos, con paradas repentinas. Cuando empezó a practicarlo, Adilyn se sintió atrapada por aquellos pasos y supo de inmediato que deseaba ser bailarina". Véase en línea: This amazing girl mastered dubstep dancing by just using YouTube, publicado el 25 de enero de 2016. Disponible en: $<$ http://vivavideo.es/nina-de-12-anos-aprende-a-bailar-viendo-videos-en-internet-y-su-forma-de-moversees-espectacular> y <https://youtu.be/OgzdDp5qfdl>.

115 Melina Masnatta compartió el video de Fusion (6 de febrero 2016): “¿Youtube nos cambia la manera de entender la educación? [...]. Si estás en internet realmente puedes enseñar y aprender por tus propios medios [...] es una de las frases de una niña que tuvo como profesor a Michael Jackson gracias a sus videos de YouTube. Las ideas de Bandura y Vigostky remixadas en esta plataforma digital".
} 
Para ello, realizamos entrevistas en las que el visionado del video y su posterior apreciación por parte de los entrevistados dieron lugar a distintas valoraciones acerca de cuerpo e imitación; cuerpo representación; cuerpo, registro y memoria en la danza, en los tiempos de internet.

Fue entonces que se analizó la naturaleza del nuevo medio comunicativo así como los tipos de lenguajes implicados, como el lenguaje visual, que utiliza la imagen como elemento nuclear, y el lenguaje corporal, como expresión de una memoria que se registra a través de los aparatos técnicos y se sube a las redes audiovisuales -como YouTube y Vimeo- y se comparte en Facebook.

Consideramos que se trata de nuestros viejos lenguajes, presentes hoy en las nuevas tecnologías, las mismas que no están haciendo el mundo más artificial, sino al contrario, más natural. En palabras de Gerald Siegmund, "lo que ha cambiado en los escenarios de danza es estrictamente el pensamiento acerca de la identidad que, a diferencia de su histórico destino de imitación, copia o mímica en la representación corporal de modelos, actualmente ha de pensarse más bien como performance, como ejecución procesual" (2003: 56).

\footnotetext{
¿Volvemos a la imitación, volvemos a este aprendizaje observacional? Yo creo que sí y que no. Porque vos ves en la chica un estilo y una personalidad, y por eso no es técnica pura, porque ella lo puede traducir a su cuerpo $\mathrm{y}$, en sus palabras, se apropió de algo. Ella tiene una forma particular de transmitirlo: no es Michel Jackson (Masnatta, 2016: 0'50").
}

Estos nuevos modos de reproducción en la danza, desarrollados en correspondencia con los principios de la web, se constituyen sobre un lenguaje de movimiento que desafía hoy uno de los procesos más sugestivos como escenario de exploración de los modelos de formación, de creación, de reflexión para la producción/expectación. Y es justamente este escenario mediático el que nos habilita un mundo de mixturas artísticas que vincula a bailarines, performers y creadores de la danza actual con un sinnúmero de disciplinas.

Este escenario que se reactualiza constantemente posibilita la comprensión de experiencias de autoaprendizaje y de producción corporal en estado de indagación, de exploración y de estudio. Cambian las características y es así como se intenta mostrar dicha producción corporal al espectador. El diseño del movimiento resulta de los estímulos que puedan surgir tanto del material observado como de la interacción en tiempo real con otro cuerpo lejano danzando y conectado por las interfaces digitales. Se trata de otro tiempo para el cuerpo. Comentarios sobre las prácticas corporales 
actuales que nos plantean una profunda reflexión sobre los conceptos y problemáticas fundamentales, y ponen el énfasis en las cuestiones derivadas de la relación artesociedad-medios tecnológicos.

Por lo tanto, volviendo a la idea de comprobar cuánto podría sobrellevar una reactualización a esta concepción de impulso mimético, vamos a migrarlo de su contexto original de definición hacia otro contexto diferente.

Al utilizar la matriz de esta conceptualización sobre la imitación en danza, se hace indispensable señalar las vinculaciones que se establecen con otros desarrollos teóricos que están problemáticamente ligados. En general, las técnicas y las estrategias de la imitación retoman lo producido para generar una copia, una representación.

Para Ana Claudia Lima Monteiro (2010: 65), "no se trata de pensar la mímesis como copia, sino como potencia". En una entrevista virtual que realizamos a Monteiro, con relación al video que estamos examinando, ella afirma que "la repetición crea memoria en el cuerpo [...]. A cada repetición, se crea un cuerpo" (2016: 1'20").

Parafraseando a Natalia Matewecki (2006: 1), diremos que "en el arte de internet se plantean diversas cuestiones por las cuales no es posible hablar en los mismos términos acerca de la apropiación" ni acerca de la imitación o la copia. Citamos a esta autora para disgregar de sus propios argumentos nuestra reflexión al respecto:

En primer lugar, no existe el concepto de original, la copia es un elemento inherente a la tecnología informática (y específicamente a la red de internet), pues todo aquello que se observa en el ciberespacio es una copia de los archivos que envía el servidor. A pesar de carecer de este concepto de original, existen mecanismos en internet para resguardar el valor exclusivo de los contenidos a través de las leyes de copyright y de propiedad intelectual; de esta forma, es posible sancionar el libre derecho a bajar y a copiar ciertos contenidos exhibidos en la red (Matewecki, 2006).

En esta aseveración de Matewecki, lo que se pone en discusión es si realmente se trata de una forma innovadora de vincularse con el material disponible en la web o se trata de plagios y una infracción de los derechos de autor. La performance corporal, como manifestación artística en el espacio público virtual, cuestiona las prácticas autoritarias y exclusivas del propio mundo artístico, tanto en lo referido a sus instituciones como a sus estrategias estéticas.

En el texto Prácticas artísticas e internet, Juan Martín Prada -además de señalar las tendencias y poéticas más distinguidas, practicadas en lo que ha denominado el 
sistema-red- grafica una genealogía del arte pre-internet en la que se anticipan algunos de los presupuestos principales que se van a observar en el desarrollo del siglo XXI. A la vez que encuadra el concepto funcional de conectividad, advierte incisivamente la progresiva intrusión de los intereses económicos y la tendencia hacia el control mediante la constitución de plataformas centralizadas, filtros y controles.

No obstante, el supuesto matiz negativo de la dominación tecnológica hacia un "orden tecno-social caracterizado por la generación de fuertes dependencias de los nuevos sistemas y dispositivos tecnológicos" (Prada, 2012: 26) estaría destinado a la inflación de conductas y comportamientos corporales, sociales y comunicativos prediseñados. Extrañamente, el sistema-red adopta una apariencia neutral ajena a las marcas de poder, "tras lo que, sin embargo, se propone siempre como un mundo idílico de nuevas posibilidades comunicativas y afectivas" (Prada, 2012: 27).

En este sentido idílico, la apropiación -desde otro ángulo de definición- refiere al proceso a través del cual los individuos transforman su comprensión y su responsabilidad a través de su propia participación. Al implicarse con una actividad determinada hacen necesariamente contribuciones continuas ya sea a través de acciones concretas o ampliando ideas de los otros, pues estos procesos sociales e individuales se producen en forma simultánea. Desde esta perspectiva, internet ha permitido un mayor desarrollo de los discursos particulares al encontrar en la red un canal que no permanece sujeto a los controles de los medios tradicionales.

De acuerdo con la opinión de Juan Martín Prada, este optimismo se aprecia en el apogeo de los productores amateur que hacen circular sus creaciones de modo gratuito con el propósito de alcanzar así una mayor difusión. Esto último ha desatado un aspecto subversivo en la comunicación artística atribuido a esta amateurización de las prácticas.

De esta manera, el autor declara que la figura de los consumidores-usuarios se ha transformado en la de "prosumidores" (Prada, 2012: 40), fruto de este acoplamiento entre productores y consumidores. Consecuentemente, es lógico que dicho acoplamiento genere nuevos sistemas de circulación y visualización relativamente autónomos. Siendo así, las opciones de participación no profesionales contribuyen al cuestionamiento de los límites entre lo artístico y lo no artístico, entre lo profesional y lo no profesional.

Esta capacidad inclusiva de las redes sociales cambia la definición misma de subjetividad como una esencia inamovible a favor de entenderla como un "permanente intercambio de intimidades o en la espectacularización de la intimidad" (Prada, 2012: 48). Somos testigos de este progresivo abandono de lo que hemos entendido hasta hoy como las formas típicamente modernas de ser y estar en el mundo, de 
aquellos instrumentos que solían usarse para la construcción de la subjetividad de sí mismo.

En La intimidad como espectáculo, Paula Sibilia analiza las claves con las que se presenta la exhibición de la intimidad en la escena contemporánea y los diversos modos que asume el yo de quienes deciden renunciar al anonimato para apropincuarse al dominio del espacio público de las redes.

Evidentemente, estamos ante un momento cultural de transición que anuncia una certera mutación en la conformación de las subjetividades. Considerando la manera en que las nuevas tecnologías de comunicación -sobre todo, los dispositivos móviles de acceso a las redes informáticas- y, en especial, los modos de vida que ellos implican, se evidencia cómo están afectando el funcionamiento de esos modos de ser y estar en el mundo, flexibilizándolos y tornándolos múltiples. Pero no confundamos la intimidad, pues sigue siendo un valor para construir la subjetividad, solo que debe ser proyectada en el espacio público de las redes para ser "vista" por los demás.

Por tanto, conviene subrayar -retornando a la apropiación- que no solo se agudizan los recursos que han generado pautas estéticas, sino, principalmente y desde su reubicación contextual, se agudiza el lugar de protagonismo del consumidor al ser exhibido. Este desplazamiento dentro del discurso artístico dispersa sus efectos hacia nuevas indagaciones de lo real que dan otra forma a las experiencias y usos corporales.

Los canales YouTube y Vimeo, como archivos audiovisuales de la memoria colectiva, son ejemplos de transformación de la noción de espectáculo en las prácticas de recepción y consumo cultural en internet. Considerando sus varios millones de usuarios en todo el mundo, estas plataformas se han convertido en el principal servicio gratuito de distribución de videos; allí conviven videos realizados tanto por emisores corporativos y colectivos como individuales e independientes.

Las matrices individuales y colectivas abren nuevas categorías del espectáculo que, a través de los dispositivos de interacción tecnológica, posibilitan el tránsito de lo público a lo privado y viceversa y, habilitan al usuario como creador, editor, interventor y protagonista de procesos innovadores de producción, circulación, consumo y socialización.

La cultura contemporánea construye -desde el diálogo con lo audiovisual y, desde el ejercicio de una interacción mediática- la posibilidad de copiar, imitar, empoderarse del pasado trayéndolo al presente y vivificándolo en su corporalidad de forma inmediata. Todo esto parece confirmarse en lo expuesto por Susana Tambutti (2016: 0'20") al visionar el video en cuestión: 
Me interesó enfocarlo desde otro punto de vista, no exactamente el de la imitación, sino el tema del registro. Por dos cosas, una es pensar que la danza es algo que pasa y se va, por eso la idea de traerla de vuelta tiene que ver con un registro. Hoy por hoy, las cuestiones tecnológicas se incorporaron a esos registros. Eso por un lado, y por otro, dado que esta niña opera sobre un personaje importante de la cultura general y de EE. UU., es también una forma de memoria cultural.

Este desplazamiento de conceptos y poéticas claves de la creación, reproducción y aprendizaje del arte mediatizado y expuesto a una particular revisión intenta localizar las bases epistemológicas que viabilicen la comprensión y valoración crítica de estas manifestaciones artísticas asociadas al diálogo polifónico de las teóricas actuales. Las ideas, posicionamientos teóricos y acciones recreativas que operan en los cuerpos así como en la dimensión política de la memoria cultural -como indica Tambuttiestablecen sentido en la actual cultura de la imagen y en su relación con las nuevas tecnologías en el entorno colectivo.

Acorde con lo expuesto, los materiales circulantes en la web -en tanto registropueden ser o bien encontrados a través de imágenes, videos, etiquetas y textos, o bien realizados, públicos y, a la vez, privados, reales, ficticios o virtuales.

El análisis de lo expuesto por Tambutti (como registro y archivo) constituye el marco de definición de los procesos de representación del arte y sus prácticas existentes que recuperan el concepto de memoria. El correrse del automatismo que ocasiona el registro audiovisual puede constituirse en una forma de intervención social cuando provoca cuestionamientos sobre la forma de ver, de pensar y de sentir un fenómeno cultural más allá del puro virtuosismo técnico.

A partir de este reconocimiento del registro como fuente de la memoria colectiva, tanto sea en sus aspectos técnicos como epistémicos, se ponen en juego diferentes parámetros de la visualidad. La actualización de la memoria se vuelve un paroxismo deseable, que restablece el diálogo entre el pasado y el presente, y el registro se torna un acto de impresiones que temporalizan existencias virtuales de una memoria cultural.

Según Jesús Martín-Barbero (1987: 200), la memoria cultural no opera desde el consumo arbitrario de la tecnología:

A diferencia de la memoria instrumental, la memoria cultural no trabaja con "información pura" ni por linealidad acumulativa, sino que se halla articulada sobre experiencias y acontecimientos, y en lugar de acumular, filtra y carga. No es la memoria que podemos usar, sino aquella otra de la que estamos hechos. Y 
que no tiene nada que ver con la nostalgia, pues su "función" en la vida de una colectividad no es hablar del pasado, sino dar continuidad al proceso de construcción permanente, de la identidad colectiva. Pero la lógica de la memoria cultural -operante por ejemplo en la narración popular en que la calidad de la comunicación está lejos de ser proporcional a la cantidad de información- se resiste a dejarse pensar con las categorías de la informática.

Estamos ante una encrucijada de posicionamientos entre memoria instrumental y memoria cultural dado que, para el estudio de caso que estamos analizando, se accede a videos de internet con el fin de observar una y otra vez el material registrado en busca de autoposicionarse ante una técnica corporal determinada. Pero, a la par, en esa gestión instrumental se da continuidad al proceso de construcción permanente de la identidad colectiva al estudiar los movimientos corporales de "un personaje importante de la cultura general y de EE. UU.", como advertirá Tambutti (refiriéndose a Michael Jackson: cantante, compositor, bailarín, actor, productor y empresario estadounidense).

Por tanto, nos encontramos ante dos regímenes de la memoria que Abril Trigo (2007: 405) dilucidará contribuyendo a su esclarecimiento:

\begin{abstract}
Indudablemente, tanto la memoria histórica nacional como la memoria pop global son, necesariamente, producto de la cultura, como toda memoria. La diferencia consiste en que, aun cuando comparten y disputan un común campo cultural campo de lucha por la producción y reproducción simbólica de la hegemonía política en el cual se forjan y representan las identidades sociales- ambas memorias cobran materialidad en distintas territorialidades y bajo diversos regímenes de producción, circulación y consumo. Mientras la memoria histórica es reproducida por los aparatos ideológicos del Estado y guiada, en consecuencia, por una ideología primordialmente nacionalista, y la memoria pop global es producida y distribuida por los medios de comunicación mundial, las memorias culturales se urden en las experiencias vividas cotidianamente por la gente.
\end{abstract}

Encontramos en esta una respuesta clave respecto a lo planteado por Tambutti sobre la intervención o no de la imitación que ha sido revivida por el contexto de la web, a lo cual ella responde: "Para mí no, para mí lo que se trabaja acá es la memoria colectiva, es decir, de cómo los aparatos tecnológicos [señalando la cámara que la estaba registrando en la entrevista] guardan las imágenes y cómo esas imágenes vuelven a nosotros y qué nos dicen hoy" (Tambutti, 2016: 7'55"). 
$\mathrm{Y}$ aquí nos detendremos por un momento, retomando la acepción de la palabra registro ${ }^{116}$ pues es imprecisa, por tanto, puede referirse a 'almacenar algo o a dejar constancia de ello en algún tipo de documento'. Si lo planteamos desde un soporte audiovisual, digital y virtual, es un dato, una información que posibilita, entre otras cosas, el acceso a un conocimiento.

Nos encontramos ante productos que técnicamente son otra cosa que registros y copias de registros de cuerpos en movimiento, tal como sería en la danza. Entonces podríamos distinguir brevemente un tipo de producción audiovisual y un lenguaje de movimiento corporal acreditado como videodanza.

Para introducirnos en el tema, diremos que se trata de la danza mediada por la cámara y la pantalla, cuyos dispositivos componen un marco que abarca las siguientes categorías, a saber: obra coreográfica para la cámara y viceversa, documental sobre grupos, individuos, técnicas, etcétera; obra experimental (relacionada con el video arte), y obras para escenario (relacionadas con la danza multimedia que hemos desarrollado ampliamente en la Parte 1 del Capítulo 2 de esta tesis). Generalmente, se aclara que en la videodanza, el video deja de ser un "instrumento de registro y documentación" para pasar a ser elemento integrante de la propuesta.

Es interesante adentrarse en esta práctica artística desde esta perspectiva técnicoexpresiva, pues el lugar que ocupa la acción del registro planteado a través del dispositivo de la cámara y de la escena que se monta alrededor de esta puesta a registrar delimita, ideológicamente, su apreciación o su depreciación. Así, ya estaríamos situando dos cuestiones que circunscribirían el campo de reflexión: dispositivo video y disciplina danza.

Lo que se desea esbozar soslayaría esta disquisición puntualizando el interés en la dependencia entre los dispositivos (la cámara, fundamentalmente), el cuerpo en movimiento y la imagen destacando básicamente que se trata de una experiencia mediada.

El lenguaje audiovisual nos ofrece una definición del espacio y del tiempo fluido, como también un punto de vista variable. La propia naturaleza de la cámara, con su capacidad de aproximarse o separarse de un área en detalle, invita a la exploración de las permutaciones del cuerpo en movimiento. En este caso, me interesa citarla desde lo que es la cámara como medio, como cuerpo-acción al

\footnotetext{
116 La noción de registro, de todos modos, tiene múltiples usos. De hecho, el Diccionario de la Lengua Española (DEL - RAE) reconoce más de veinte acepciones. Como documentos audiovisuales, son registros visuales (con o sin banda sonora), independientemente de su soporte físico y proceso de registro o grabación (películas, microfilms, diapositivas, cintas magnéticas, laser discs, CD-Rom, etc.), realizados para difusión pública a través de la radio, la TV, internet, dispositivos telefónicos digitales, por medio de proyección en pantalla o por cualquier otro medio para ser puestos a disposición del público.
} 
servicio de la danza. La cámara es un punto de conexión que evidencia un gesto, respira, vacila, circula acopiando fragmentos. Esta relación inseparable del cuerpo-cámara propone una lectura nunca lineal, siempre inconclusa, trozos y partes que se producen tras la acción de ese cuerpo que es imposible reconstruir del todo. La cámara instaura el espacio del cuerpo y de la imagen; lo transforma, estableciéndose un diálogo espacial con un cuerpo que se mueve y que lo ocupa; no solo como un ojo que sitia, sino como otra existencia que irrumpe de igual forma (Ceriani, 2010: 56).

Lo que no es aceptado y se diferencia enfáticamente es el "mero registro escénico"117. En caso contrario, si se lo presenta como un registro documental, puede percibirse el núcleo de un amplio espectro de material e información recopilada y editada como "archivo audiovisual". Es decir, el material original se traspasa por el tamiz de una edición, de una compaginación con relación a un contenido o narración que lo prescribe y contextualiza. Invariablemente se exige una postproducción del material registrado ${ }^{118}$. Hay algo en esa impronta que el registro de cámara profiere, un tipo de memoria explícita, manifiesta, que no parece ser aceptada, por lo menos conscientemente.

Esto intensifica lo expresado en párrafos anteriores por Abril Trigo cuando establece la vinculación entre la memoria histórica, la memoria pop global y la memoria cultural, y es únicamente en esta última donde se urden en las experiencias vividas cotidianamente por la gente. Cuáles son esas experiencias del cotidiano que un cuerpo que danza pareciera no poder exponer si no es por el filtro de una edición. Entonces nos preguntamos: ¿qué formas particulares de memoria prevalecen en la danza? ¿Con qué formatos tecnológicos prefiere perpetuarse? ¿Aquellos que le sigan brindando perfección y belleza al resultado?

El registro como acontecimiento pareciera no tener cabida, en este sentido encontramos puntos en común con lo manifestado por Susana Tambutti sobre el video: "Nuestra mente no está preparada para ir de mutación en mutación, sino de permanencia en permanencia. La mente de las personas está más acostumbrada a pensar en términos de reproducción" (Tambutti, 2016: 9'48”). Y agrega, "la tecnología opera sobre la memoria comunal".

117 Véase como ejemplo "No se aceptarán registros de obras o documentales". En línea: $<$ http://videodanzabolivia.blogspot.com.ar/>.

118 Es interesante remarcar cierta tendencia que la videodanza imprime en esta idea de registro que pretendemos analizar. Examinemos sucintamente este arquetipo de convocatoria a un seminario de videodanza: "La videodanza es una forma de videoarte que conjuga el lenguaje coreográfico con el lenguaje audiovisual dando paso a una forma artística producto de la postproducción del material registrado". 
¿Qué significa rescatar los movimientos de ese cuerpo? Acá se pone en juego la idea de reproducción. Esto sería una huella de una huella de una huella que se pierde y aplaza permanentemente la idea del origen, porque ese origen no existe. La idea de no poder dejar ir, nuestra civilización tiene una idea de la presencia muy fuerte, posiblemente la danza de Michel Jackson del cuerpo de MJ desaparece con MJ. Lo importante, creo, es seguir los rastros de esa huella que, obviamente, nunca nos van a conducir a un lugar de verdad. Lo que me parece interesante de esta relación es de qué forma la tecnología nos trae a la vida un rastro, porque lo que la chica está copiando es un rastro. Por un lado y por otro lado, cómo actúa la tecnología en los casos de memoria colectiva (Tambutti, 2016: 4'30").

Adilyn Malcolm, la niña del video en cuestión, genera su experiencia a partir de buscar videos de Michel Jackson en el canal de Youtube y de operar técnicamente pudiendo "verlo una y otra vez, dado que en una clase no puedes rebobinar, pausar y todo eso". $Y$ recalca: "si estás realmente en internet, realmente puedes aprender y enseñarte a ti mismo". Y continúa ejemplificando con su declaración aquel mundo idílico de nuevas posibilidades comunicativas y afectivas que Juan M. Prada precisó. Además, Adilyn expresa: "Internet está en mi generación para que podamos aprender todas estas cosas. Creo que puedo mostrarle a la gente que pueden hacer todo lo que se propongan si realmente sienten pasión por ello" (Malcom, 2016).

De modo que nos aborda un nuevo interrogante: los canales de video como YouTube, ¿se pueden considerar espacios de archivo? o ¿se trata de redes sociales de videos? En un primer atisbo, podemos afirmar que estos canales profesan aquello que atañe a la organización y manutención, pero no podríamos decir que se trata de un archivo audiovisual, pues no están realizando tareas de gestión ni conservación y tampoco se responsabilizan abiertamente por ello. Cierto es que, a cambio, nos proporcionan la inmediatez de la información, y es prioritario confirmar las fuentes ya que su origen se torna dudoso.

Ahora bien, lo destacable es el valor del registro en sí mismo, su premura y en ello su potencial autenticidad:

Pocas horas después de acontecida la ejecución, un registro audiovisual estaba publicado en YouTube, material que fue rápidamente levantado y repetido en forma incesante por una innumerable cantidad de medios de todo el mundo. No es nuestra intención [...] analizar la crudeza de las imágenes en cuestión; pero sí focalizar la atención en la forma en que se registraron y qué fenómeno tecnológico hizo que en un lapso muy corto fueran vistas por millones de 
personas y aun estén disponibles para quien quiera verlas en cualquier momento. Si analizamos el contexto que nos muestran las imágenes más las condiciones técnicas (falta de luz, encuadre poco preciso, punto de vista bajo, movimiento de cámara, etc.) podremos rápidamente dilucidar que fue registrado a escondidas (De Cicco, 2008: 29).

Reordenando estas ideas vertidas con motivo de catalogar los soportes con relación al cuerpo disciplinar y sus múltiples operaciones estéticas y políticas de las imágenes, hemos ensamblado el video con la danza, el espacio virtual de las redes sociales con los videos en internet, atravesándolos con concepciones disciplinares y operativas de diferentes espacios y tiempos.

Internet y las tecnologías ahora digitales pero muchas de origen analógico -como el video, la fotografía- nos invitan a la impronta, a la celeridad, a la instantánea compartida, dando al registro un valor inusitado. Y no solo a los dispositivos, sus lenguajes y procedimientos, sino al propio cuerpo: "Esta nena encuentra una forma de moverse, que a ella le gusta y trata de ponérsela en el cuerpo. La otra parte interesante es la incorporación, de cómo se incorpora un elemento de la cultura. Creo que es por ahí... y que se deja ir y que se transforma" (Tambutti, 2016: 6').

Otra de las cuestiones que no podemos dejar de mencionar dentro de este análisis es aquella que más aborda una de las entrevistadas cuando expone: "Lo que te dispara para mí este video es todas esas otras grandes preguntas que están al borde de estallar en cualquier momento, cómo aprendemos y qué es aprender" (Masnatta, 2016: 0'04"), cuyas respuestas está solicitando el mundo actual.

\section{La emergencia de una dimensión cibernética de la corporalidad}

Las relaciones entre las prácticas escénicas tradicionales, la tecnología y el cuerpo emergen como uno de los temas de investigación más interesantes para situar la migración del cuerpo performático al contexto mediatizado. Sobre todo, en la evolución de los canales de comunicación en internet a partir la llamada Web 2.0. Estas tecnologías de la socialización y la información actualizadas nos sirvieron de aprendizaje de prácticas digitales que hemos incorporado de manera natural en conjunto con las redes sociales y la creación de perfiles o entidades web.

Se trata de establecer como área de interés el estudio de la danza-performance con tecnologías analógicas y digitales en un espacio escénico localizado y en el espacio ubicuo y creciente de internet. Contribuir, asimismo, a explicar las condiciones de 
operatividad con la tecnología invita a un nuevo modo de concebir, ver y hacer danza, que nos obliga a reflexionar acerca de otras subjetividades, otras corporalidades artísticas que atraviesan y reconfiguran las categorías estéticas tradicionales.

De esta manera, las nuevas tendencias en las artes del movimiento se construyen en sintonía con estos nuevos modos de experimentación con la inmaterialidad del cuerpo, y ponen en crisis el espacio y el tiempo de representación y el contenido de lo disciplinar al momento de plantearse la formación, la enseñanza y el aprendizaje. "Nuestros gestos están a punto de cambiar. Nos encontramos en una crisis. Una crisis de nuestro gesto de buscar", fue anticipado por Vilém Flusser (1994: 195), cuyo trabajo reflexivo fue pionero en cuanto a advertir la transformación de paradigmas en los códigos con los cuales nos comunicamos y nos hemos tornado compatibles con aprendizajes ya adquiridos. Si antes se valoraba lo espontáneo, hoy se valora la instantaneidad, que implica un mayor interés por trabajar sobre las condiciones de producción, sus dinámicas, significación y “valor en un momento en el que el concepto de 'información' coincide plenamente con la definición que de él planteara Barlow: 'es un verbo, no un sustantivo [...] el lanzamiento, no la pelota de béisbol, la danza, no el bailarín"' (Prada, 2012: 1).

Las transformaciones son enormemente complejas, no hay solo factores tecnológicos, sino también socioculturales, financieros, políticos, que revelan cambios, incluso, a nivel de los valores, de los modos de vida que afectan también las corporalidades. Mutaciones en las formas de existir en el mundo: "Empezamos a comprender el mundo como nuestro entorno, [...] incluida nuestra manipulación de los objetos como una pantomima de ese mismo entorno. Este desplazamiento podría dar cuenta del papel que el cuerpo y los gestos juegan en la modelización de nuevas prácticas artísticas" (Flusser, 1994: 205) que hoy podríamos ratificar como transdisciplinares.

Profundizando el carácter pedagógico de nuestro estudio de caso -el video de Adilyn Malcolm- y comprendiendo el conflicto que sitúa a las instituciones, la figura del maestro y la dimensión individual y colectiva del aprendizaje generan aún en el presente ciertas resistencias y, a la par, reflexiones:

... la discusión sobre la prescindencia de un maestro o no, si la pantalla puede ser maestro o no. Por ahí está bueno que alguien tome una clase a través de un recurso tecnológico, no tenga que ser personal. En particular soy nostálgica de ese sistema, yo prefiero lo personal en cuanto a la relación con un estudiante, me gusta hablar e intercambiar cosas, prefiero ese contacto (Tambutti, 2016: 7'). 
Como ya se ha descrito, "los diferentes espacios redefinen y transforman el conocimiento. El estrato del conocimiento es, por consiguiente, perfectamente transversal en relación con los espacios" (Lévy, 2004: 128). Si la escuela -como ámbito y espacio de conformación del conocimiento y las subjetividades- se instala en contraposición al espacio creado por las redes sociales en internet, lo entendemos desestimando en principio que "ningún espacio puede ni debe reducir, asimilar o destruir los otros" (Lévy, 2004: 130). Las instituciones públicas clásicas tuvieron asignado un rol en un mundo que se concebía real, sólido, seguro y perdurable; pero, ante el posicionamiento del contexto virtual, se vuelve intermitente, indeterminado, viral, global.

En consecuencia, ¿cómo afrontan las instituciones de formación esa metamorfosis cultural? ¿Se han vuelto -como sustentan algunos- obsoletas y gradualmente incompatibles con los cuerpos y subjetividades de la época?

Paula Sibilia, en el texto ¿Redes o paredes?..., presenta una metáfora de las instituciones y dispositivos escolares como una tecnología surgida en el marco de la era moderna que empieza a estar desactualizada porque se está tornando incompatible con los cuerpos y subjetividades de los jóvenes de hoy. Probablemente este marco político, social y cultural esté en conflicto, y ese conflicto forme parte de la escuela, que ha sido un pilar del proyecto y las desarticulaciones se hacen cada vez más evidentes.

Por eso, en este nuevo contexto, el desafío no consiste en transgredir las reglas demasiado duras y escindidas de las libertades individuales, sino sugerir otro tipo de relaciones y conexiones. Se trataría de pensar en las relaciones humanas y en la construcción y el desarrollo de las nuevas subjetividades a partir de la extensión y el potenciamiento que implica el soporte virtual en las relaciones en red. Esto problematiza de modo significativo la configuración de las relaciones interpersonales contemporáneas a partir de la utilización sostenida de las tecnologías digitales en red. En este sentido, volvemos al cuerpo, pero a un cuerpo que hoy fluctúa entre redes $y$ paredes, que en pleno conflicto con su materialidad ontológica está atravesando los efectos que aún no se pueden anticipar del todo, aunque, en las instituciones como la escolar, se viven, se sienten; y las palabras que definen, que categorizan, parecieran recelar el posicionamiento.

La emergencia de una dimensión virtual de la corporalidad, que inviste identidad a partir del recurso de las redes sociales y las distintas herramientas de las TIC, suma un desafío y construye una oportunidad, que desde el recurso de la visibilización (Hacer visible artificialmente lo que no puede ser visible a simple 
vista) puede conducir a nuevos marcos de construcción de identidades, que utilicen al cuerpo en su dimensión simbólica amplia o que lo vuelvan a restringir a una dimensión de objeto (Sánchez, 2014: 2'04").

El cuerpo se presenta así como un objeto o substancia indispensable de mediación en la construcción de nuevas subjetividades. Como bien sabemos, no es posible sustentar contenidos que expliquen críticamente las transformaciones activadas desde toda instancia social, político-culturtal o tecnológica, que no contenga -y a la par disemine- repercutiendo en lo corporal. Es preciso plantearse la distribución de los roles entre las fronteras -en línea/fuera de línea, aceptando que vamos a compatibilizar ya no el uno a uno emocional, sino, y además, con un procesamiento de datos.

Se trata de reconocer un cambio de modelo en la comunicación: "Hoy nos vemos obligados a emplear un modelo distinto por completo en el entorno. Ya no podemos echar mano de la distición entre tiempo y espacio" (Flusser, 1994: 208). Las culturas de código abierto y el dominio de la web se vuelven significativos para la creación de prácticas artisticas innovadoras, pero cuyos contenidos más caducos forman la plataforma de los nuevos.

"Internet está en mi generación”, expresa Adilyn Malcolm, para quien el uso de la red no solo está basado en la comunicación en tiempo real, sino también para la búsqueda de información sobre temas que le son necesarios -ya sea para un trabajo de la universidad o por formación general-. Es decir, se autoincentiva en su propia investigación y establece una realimentación colaborativa y en la visibilidad de los vínculos con los demás.

De ahí que las relaciones que obtenemos por medio de las redes sociales son tan reales como las relaciones que tenemos fuera de ellas. Lo virtual ya no se diferencia de lo real; y en la comunicación entre personas, el cuerpo -que está virtualizadoconlleva un componente de virtualización, de descorporificación que, aparentemente, no nos afecta. Todo depende de la capacidad del colectivo para desarrollar la eficacia entre las habilidades prácticas y los dispositivos materiales, ampliando el campo de lo practicable y disminuyendo el límite entre lo imposible y lo posible.

Entonces, y para ir concluyendo, ¿cuáles son las marcas en los cuerpos de nuestro momento?, ¿qué diferencias se podrían señalar en lo referente a otros períodos históricos? Una de esas marcas la ubicaríamos en la importancia de la imagen personal como manifestacion básica de la subjetividad. Indudablemente, el prototipo de cuerpo que se construye hoy en día, o cuya construcción se incentiva, es bastante distinto de los cuerpos de otras épocas. En respuesta a la primera pregunta, podemos 
decir que es un prototipo de cuerpo al que, por un lado, se lo empodera como apariencia; y, por otro, se lo define como si su condición fuera incorpórea, virtual, inmaterial. En consecuencia, reúne una interioridad incorpórea, pero, al mismo tiempo, orgánica. No obstante, "el pensamiento mueve la interfaz entre lo imaginable y lo imaginado. El pensamiento, este productor de imágenes, de signos, de seres mentales, agranda el campo de lo imaginado y multiplica a la vez todos los otros espacios" (Lévy, 2004: 139).

Quiere decir que existen nuevas condiciones sobre las que no habría que evaluar los impactos, sino descubrir las reversibilidades. Los fenómenos sociales asociados a la evolución tecnológica (o viceversa) son el eje de las varias investigaciones actuales y de un proceso histórico que hoy procura entender para el mañana qué tipos de cuerpos y subjetividades quisiéramos concebir, por qué y para qué.

\section{Referencias bibliográfícas}

AA. VV. (2010), Terpsícore en ceros y unos. Ensayos de Videodanza, Buenos Aires, Guadalquivir.

Adorno, Theodor y Max Horkheimer (1944), Dialéctica del Iluminismo, Buenos Aires, Sur.

Agamben, Giorgio (2006), La comunidad que viene, Valencia, Pre-textos.

Alexander, Frederick Matthias (2011), Control consciente y constructivo del individuo, Buenos Aires, Editorial Pequeña Hoja.

Alonso, Rodrigo (2010), "Prólogo", en Usos de la ciencia en el arte argentino contemporáneo, Buenos Aires, Papers Editores.

Alonso Rodrigo (2011), "Mitología y reflexión crítica. El arte tecnológico y su exhibición", en Elogio de la low-tech. Historia y estética del arte tecnológico en América Latina, Buenos Aires, Luna Editores.

Ascott, Roy (2007), "Cultivando el Hipercórtex", en Jorge La Ferla (comp.), Artes y medios audiovisuales un estado de situación. Documental / cine / video / TV / telemática, Buenos Aires, Aurelia Rivera.

Ascott, Roy (2007), "De la A a la Z de las Artes Interactivas", en Jorge La Ferla (comp.), Artes y medios audiovisuales un estado de situación. Documental / cine / video / TV / telemática, Buenos Aires, Aurelia Rivera.

Benjamin, Walter (2007), Conceptos de la filosofía de la historia, Buenos Aires, Terramar Ediciones.

Berger, John (2012), El cuaderno de Bento, Buenos Aires, Alfaguara. 
Bourriaud, Nicolás (2013), Estética relacional, Buenos Aires, Adriana Hidalgo.

Brea, José L. (2007), Mutaciones de la cultura en la era de su distribución electrónica, Barcelona, Gedisa.

Brea, José L. (2009), La era postmedia. Acción comunicativa, prácticas (post)artísticas y dispositivos neomediales, Salamanca, Editorial Centro de Arte de Salamanca.

Ceriani, Alejandra (2010), "Proyecto WEBCAMDANZA: una coreografía del gesto digital", en AA. VV., Terpsícore en ceros y unos. Ensayos de Videodanza, Buenos Aires, Guadalquivir.

Ceriani, Alejandra (2012), "El descentramiento: Cuerpo, danza, interactividad”, en Arte del Cuerpo Digital. Nuevas tecnologías y estéticas contemporáneas, La Plata, Editorial Edulp.

Couchot, Edmond (1998), La tecnología en el arte, Nimes, Jacqueline Chambon.

Debord, Guy (2008), La sociedad del espectáculo, Buenos Aires, La Marca Editora.

Del Mármol, Mariana y Mariana Lucía Sáez (2013), “Arte, cuerpo y políticas del conocimiento", en Daniel Jorge Sánchez (coord.), Epistemología de las artes, la transformación del proceso artístico en el mundo contemporáneo, La Plata, Editorial Edulp.

Echeverría, Javier (1999), Los señores del aire: telepolis y el tercer entorno, Barcelona, Destino.

Ferrer, Christian (2008), "Prólogo", en Guy Debord, La sociedad del espectáculo, Buenos Aires, La Marca Editora.

Field, Simon (2010), "De la Hipercoreografía a la Kinestedición", en AA. VV., Terpsícore en ceros y unos. Ensayos de Videodanza, Buenos Aires, Guadalquivir, pp. 98-100.

Flusser, Vilém (1994), Los gestos, fenomenología y comunicación, Barcelona, Herder.

García Canclini, Néstor (2011), La sociedad sin relato Antropología y estética de la inminencia, Argentina, Katz.

Greiner, Christine (2010), O corpo em crise: novas pistas e o curto-circuito das representações, São Paulo, Annablume.

Ihde, Don (2002), Los cuerpos en la tecnología. Nuevas tecnologías: nuevas ideas acerca de nuestro cuerpo, Barcelona, Editorial UOC.

Lévy, Pierre (2004), Inteligencia colectiva: por una antropología del ciberespacio, Washington, Editeur La Découverte.

Lima Monteiro, Ana Claudia (2010), "O Aprendizado do corpo: Repetição, Imitação e transformação", en Corporeidade e educação: tecendo sentidos..., São Paulo, Cultura Acadêmica Editora. 
Martín-Barbero, Jesús (1987), De los medios a las mediaciones Comunicación, cultura y hegemonía, Barcelona, Gustavo Gili.

Mitcham, Carl (1989), ¿Qué es la filosofía de la tecnología?, Barcelona, Anthropos Editorial.

Penny, Nicholas (1993), The Materials of Sculpture, Yale University Press.

Prada, Juan Martín (2012), Prácticas artísticas e internet en la época de las redes sociales, España, Akal.

Sagaceta, Julia E. (2013), Teatralidad expandida. El teatro performático, Buenos Aires, Nueva Generación.

Santana, Ivani (2006), Dança na cultural digital, Salvador, EDUFBA.

Santana, Ivani (2011), "A consciência de cada dança: reverberações de corporel(ação)-objeto”, en Anais do 'Poéticas Tecnológicas', III Seminário Internacional sobre Dança, Teatro e Performance 2010, Salvador, Visual Editora. Programa de Pós-Graduação em Artes Cênicas/ (PPGAC) Grupo de Pesquisas Poéticas Tecnológicas, Universidade Federal da Bahia (UFBA)

Sibilia, Paula (2008), La intimidad como espectáculo, Buenos Aires, Fondo de Cultura Económica.

Sibilia, Paula (2012), ¿Redes o paredes? La escuela en tiempos de dispersión, Buenos Aires, Tinta Fresca.

Siegmund, Gerald (2003), "El problema de la identidad en la danza contemporánea: del arte de la imitación al arte de la acción”, en José Antonio Sánchez (comp.), Cuerpos sobre blanco, España, Editorial Universidad De Castilla.

Tambutti, Susana (2008), "Itinerarios teóricos de la danza", Revista Aisthesis N. ${ }^{\circ} 43$, Santiago, Instituto de Estética, Pontificia Universidad Católica de Chile.

Tambutti, Susana (2013), "Danza en Argentina y la modernidad desbordada", en Mariana Lucía Sáez (comp.), Ni adentro ni afuera. Articulación entre teoría y práctica en la escena del arte, La Plata, Club Hem Editores.

Tatarkiewicz, Wladislaw (1987), Historia de seis ideas, Madrid, Tecnos Grupo Anaya.

Zalamea, Gustavo (2006), Arte y localidad. Modelos para desarmar, Colombia, Universidad Nacional de Bogotá.

Zizek, Slavoj (2006), Órganos sin cuerpo sobre Deleuze y consecuencias, Valencia, Pre-Textos. 


\subsection{Referencias electrónicas}

Brea, José L. (2005), "Cambio de régimen escópico: del inconsciente óptico a la eimage", Estudios Visuales [en línea]. Disponible en: <http://estudiosvisuales.net/revista/pdf/num4/JIBrea-4-completo.pdf>.

Ceriani, Alejandra y Alejandra Cosin (2005), “La Danza-Performance: Una perspectiva alternativa" [en línea]. Disponible en: $<$ http://performancelogia.blogspot.com.ar/2008/07/la-danza-performance-unaperspectiva.html>.

De Cicco, Juan (2008), "La tecnología y una nueva Biblioteca de Alejandría. YouTube: el archivo audiovisual de la memoria colectiva", C\&T, Universidad de Palermo [en línea]. Disponible en: <https://www.academia.edu/2346783/YouTube_el_archivo_audiovisual_de_la_m emoria_colectiva>.

De la Haba, Juan y Enrique Santamaría (2001), "Dilemas de la globalización: hibridación cultural, comunicación y política. Entrevista a Néstor García Canclini”, Revista Voces y Culturas, núm. 17, Barcelona, pp. 143- 165 [en línea]. Disponible en: <http://www.antropologia.cat/files/Entrevista_N\%C3\%A9stor_Garc\%C3\%ADa_C anclini_Dilemas_de_la_globaliz\%E2\%80\%A6.pdf>.

Escudero, María Carolina (2008), El cuerpo: un recorrido temático y conceptual [en línea]. Disponible en: <http://perio.unlp.edu.ar/ojs/index.php/question/article/view/619>.

García Canclini, Néstor (2008), "Geopolítica y estéticas Interculturales". Conferencia presentada en la Universidad de Miami [en línea]. Disponible en: $<$ https://es.scribd.com/document/125733268/Conferencia-Qgeopolitica-yEsteticas-Interculturalesq>.

Giannetti, Claudia (1998), "Ars Telematica. Telecomunicación, internet y ciberespacio” [en línea]. Disponible en: <http://www.artmetamedia.net/pdf/3Giannetti_ArsTelematicalntro.pdf>.

Hubert Godard (1988), "El gesto y su percepción" [en línea]. Disponible en: <http://www.raco.cat/index.php/EstudisEscenics/article/viewFile/253945/340731> López Pérez, Ricardo (s/f), Prontuario de la creatividad [en línea]. Disponible en: <https://mcomudd.files.wordpress.com/2008/01/r-lopez-prontuario->.

Matewecki, Natalia (2006), Arte y nuevas tecnologías. ¿Plagio o apropiación? [en línea]. Disponible en: <http://www.liminar.com.ar/simposio/pdf/matewecki.pdf>. 
Muntadas, Antoni (s/f), $O N T R A N S L A T I O N$ [en línea]. Disponible en: $<$ http://www.adaweb.com/influx/muntadas/>.

Penny, Simon (1995), "The Darwin Machine: Artificial Life and Interactive Art" [en línea]. Disponible en: <http://simonpenny.net/texts/darwinmachine.html>.

Prada, Juan Martín (2011), “¿Capitalismo afectivo?”, Revista EXIT Book, núm. 15 [en línea].

Disponible

en: <http://disciplinas.stoa.usp.br/pluginfile.php/121678/mod_resource/content/1/Cap italismo\%20afectivo_Juan\%20Martin\%20Prada.pdf>.

Prada, Juan Martín (2013), Otra época, otras poéticas 1. Algunas consideraciones sobre el arte actual [en línea]. Disponible en: $<$ http://www.juanmartinprada.net/textos/martin_prada_juan_otra_epoca_otras_po eticas.pdf>.

Tambutti, Susana (2005), "Danza o el imperio sobre el cuerpo". Conferencia presentada en el V Festival Internacional de Buenos Aires [en línea]. Disponible en: <http://movimientolaredsd.ning.com/profiles/blogs/2358986:BlogPost:3762>.

Tambutti, Susana (2008), "Itinerarios teóricos de la danza", Revista AISTHESIS N. ${ }^{\circ} 43$, pp. 11-26 [en línea]. Disponible en: <http://www.redalyc.org/pdf/1632/163219835001.pdf>.

Tambutti, Susana (2012), Cuerpo, danza, idea: desde una realidad cambiante hacia una realidad suprasensible [en línea]. Disponible en: <file:///C:/Users/Adm/Downloads/74-236-1-SM.pdf>.

Tambutti, Susana (s/f), "Danza y pensamiento moderno. Introducción a la Teoría General de la Danza" [en línea]. Disponible en: <http://www.academia.edu/9854390/Teor\%C3\%ADa_General_de_la_Danza_S. Tambutti>.

Tobar Abarca, Karla (2013), "La obsolescencia programada en el Net.Art" [en línea]. Disponible en: <http://www.ehu.eus/ojs/index.php/ausart/article/view/104>.

Trigo, Abril (2007), De memorias, desmemorias y antimemorias. EEUU: The Ohio State University Art [en línea]. Disponible en: $<$ http://letras.uc.cl/html/6_publicaciones/pdf_revistas/taller/tl49/letras49_memoria s_abril_trigo.pdf $>$. 


\subsection{Entrevistas en video}

Ceriani, Alejandra (2011), Entrevista a Jacson Espírito Santo [en línea]. Disponible en: <http://youtu.be/QAaaBReRibs>.

Ceriani, Alejandra (2016), Entrevista a Ana C. Lima Monteiro [en línea]. Disponible en: <https://youtu.be/M-_q2_IYoGs>.

Ceriani, Alejandra (2016), Entrevista a Melina Masnatta [en línea]. Disponible en: $<$ https://youtu.be/ZGQndQ4Kva4>.

Ceriani, Alejandra (2016), Entrevista a Susana Tambutti [en línea]. Disponible en: $<$ https://youtu.be/eve8zbAcMnw>.

\subsection{Otros materiales de consulta en línea}

Ceriani, Alejandra y Alberto Vázquez. 3WDS13 - Waterhole / Ojo de Agua, Waterwheel [en línea]. Disponible en: <http://water-wheel.net/media_items/view/3109> (Véase el minuto 7 en el que Suzon Fuks inicia sesión de devolución en el TAP).

Marker, Chris (1983), Sans Soleil [en línea]. Disponible en: <https://youtu.be/0K8j3MU9dw4>.

Sánchez, Daniel (2014), El cuerpo y la educación formal [en línea]. Disponible en: <https://youtu.be/Q4Ghyncdzcl>.

Youtube (2012), Conversations with Suzon Fuks and James Cunningham [en línea]. Disponible en: <http://youtu.be/J5I_A7wLSgs>.

Youtube (2013), Waterhole, performance interactiva, Waterwheel Symposium 2013 [en línea]. Disponible en: <http://youtu.be/oubAe4kFzUo> y <http://youtu.be/dLn582BmghY>.

Youtube (2014), Fragmento del capítulo "TechCrunch Disrupt Parod", de la serie Silicon Valley [en línea]. Disponible en: <http://youtu.be/J-GVd_HLIps>.

Youtube (2014), Speak 4.0, Liquid, Waterwheel Symposium 2014 [en línea]. Disponible en: <http://youtu.be/XEW0jRCoqJ0>.

Youtube (2016), This amazing girl mastered dubstep dancing by just using YouTube [en línea]. Disponible en: < https://youtu.be/OgzdDp5qfdl>.

Youtube. Conversations about processes in performances with technology Suzon Fuks [en línea]. Disponible en: <http://youtu.be/pggd1kxzoc8>. 


\section{CAPÍTULO 3: Diseño metodológico para el estudio de casos de Danza Performance Interactiva}

\section{Introducción}

El presente capítulo despliega los resultados de la sistematización alcanzada a través de las consideraciones metodológicas y la construcción de categorías analíticas aplicadas al vínculo cuerpo-sistema-escena interactiva.

Para ello, fue preciso definir un paradigma teórico no antropocéntrico en el campo de los estudios sobre mediatización con el fin de poder considerar que los dispositivos son productores de sentido, "de discursividad (es decir, capaces de generar operaciones de denotación no previstas por el sujeto operador)" (Carlón, 2016: 14).

Asimismo, en la progresiva conquista de la autonomía de los usuarios -en la que el intercambio dinámico entre producción y formas de mediatización se torna clave para la situación actual de la danza performance con tecnología-, se intenta producir perfiles de los casos para su aplicación en el estudio de los procesos de mutación del cuerpo orgánico al cuerpo como interfaz electrónico-digital y para el reconocimiento de formatos de producción interdisciplinares.

Ambas posibilidades de autonomía -ya sea del dispositivo o del usuario- indagan cómo las nuevas prácticas sociales están afectando a los campos de las prácticas artísticas, más aún, a los cambios que estas coyunturas generan.

\section{Análisis de un estudio de caso a partir del sistema de matrices de datos}

En este apartado, detallaremos las interfaces, los dispositivos y las programaciones utilizadas para la comprobación de nuestra práctica experimental. Estas experiencias han originado reflexiones que incumben tanto a lo particular del espacio escénico, la danza performática, el arte generativo, así como a su mixtura. Desglosaremos los aspectos técnico-expresivos a la par que vamos a describir la experiencia multimediática con el lenguaje de movimiento producido a partir de la interacción.

Nos referiremos a la performance interactiva experimental llamada COD05 ${ }^{119}$, realizada en dos etapas $\left(2013^{120}\right.$ y $\left.2015-16\right)$ por la performer interactiva Soledad Belén

\footnotetext{
119 Con el fin de ampliar la información, véase: <emmeLab-COD05-IDE> y $<$ https://vimeo.com/172159607>.

120 Etapa analizada en el Capítulo 2, Parte 3: Ciclo de Danza UNLP.
} 
y el equipo del emmeLab, Facultad de Bellas Artes, Universidad Nacional de La Plata. En esta oportunidad, analizaremos el período 2015-16: sondeo de una programación (software ${ }^{121}$ ) diseñada (humanware) para ser utilizada en escena interactiva (parámetros de interacción e inmersión) por performers. En este sentido, los algoritmos se programaron teniendo como base los movimientos corporales (cuerpo presencial y modelizado) y se vincularon a través de la captura de movimiento con dispositivos (hardware) como Kinect o Xtion.

Esta propuesta busca:

- Relacionar el campo de la danza performance con el de las nuevas tecnologías, y más específicamente, vincular la puesta e interacción entre cuerpo-interfazescena.

- Actualizar los procesos de producción en los campos de la danza performance y la programación especializada en la escena interactiva.

- Indagar en el uso de nuevas tecnologías aplicadas a las prácticas corporales, audiovisuales, compositivas y escénicas que inaugura una nueva capacidad de inferir y experimentar con lo conocido.

- Considerar los preconceptos disciplinares y los roles ejecutivos que comúnmente se anteponen a las prácticas escénicas como "la" bailarina, "la/el coreógrafa/o", "el programador técnico", "el artista programador o desarrollador", etcétera.

\section{Parámetros de observación y de experimentación}

El sistema interactivo que analizaremos funciona en tiempo real y suministra al artista performático un diseño de programación que propone intercalar movimientos "puramente expresivos con otros que [se] llevarán a cabo en desarrollo y [con] control del algoritmo"122. Con el fin de superar -según criterios de los programadores del emmeLab (Rivero en emmeLab, 2016-2017: 53")- el "encorsetamiento" o "grillete" que los sistemas "aportan como una restricción" a la libertad expresiva del performer, enuncian que este algoritmo programado genera y controla sistemas de partículas ${ }^{123}$, pero con sus cualidades y con sus comportamientos condicionados en función de los movimientos que proponga el performer interactivo.

Estos parámetros involucran las siguientes tareas:

${ }^{121}$ EmmeLab designa a Cod05 como un lenguaje de programación informático en etapa experimental y no como un software.

122 Véase: <http://emmelab.fba.unlp.edu.ar/cod05/>.

${ }^{123}$ Las partículas son elementos lógicos a los que se deben otorgar propiedades gráficas para que sean visibles. Un sistema de partículas es una función de los programas de animación, con la que se puede animar una gran cantidad de objetos, por ejemplo: condensación de gases, gotas de lluvia, etcétera. 
- Hallar otros campos de generación de movimiento. Los diseños corporales propondrán estructuras formales que controlarán y modificarán la programación algorítmica, produciendo, de ese modo, cambios en el sistema gráfico del software.

- Indagar más allá del propósito estético de consumo habitual de lo escénico.

- Programar un sistema de asociación gestual-visual mediante el monitoreo de los movimientos físicos del performer y sus coordenadas espaciales.

La puesta busca comprometer varios niveles de modalidad de atención sensorial por parte del performer y de los espectadores en ambientes visuales inmersivos, exaltando así la capacidad de ser afectado de manera imperceptible y apelando a la expansión de la detección más allá de lo visual, lo cual compromete la ejercitación de la recepción sensorial y la experimentación entre lenguajes y medios como formato de producción escénica.

\subsection{Análisis desde las unidades propuestas}

Para el desarrollo de este análisis entre lenguaje corporal y lenguaje de programación, se focalizará en dos maneras diferentes de producción de conocimiento: uno, centrado principalmente en un espacio unidimensional sobre el que se diseñan -de modo previo- medidas y cálculos de tiempos, longitudes y desplazamientos por áreas bien definidas; y otro, centrado en una idea de espacio subjetivo en donde la actualización del movimiento reinventa espacios y manifiesta ese otro espacio interior, exteriorizándolo. Por tanto, la resultante de posturas corporales respecto a los ejes de movimiento del cuerpo ${ }^{124}$ es captada por un sensor óptico como la cámara Kinect o Xtion y vincula estos movimientos posturales en bloque con la escritura de código.

Avanzaremos poniendo en juego, a medida que la trama del texto lo requiera, los elementos y los criterios seleccionados para las unidades de análisis: cuerpo presencial-modelizado, sistema hardware-software-humanware, escena interactiva parámetros de interacción-inmersión a través del análisis de entrevistas semiestructuradas y grabaciones de ensayos, ambos en soporte audiovisual.

\footnotetext{
${ }^{124}$ El movimiento se organiza a partir de planos y ejes del cuerpo y su ubicación en el espacio. Existen tres planos corporales que sirven para definir una serie de movimientos: el sagital, el frontal y el transverso. Cada plano corporal se asocia con unos movimientos determinados, pero, en la práctica, los movimientos y posiciones corporales se realizan en planos mixtos.
} 


\title{
46.2. Sobre la unidad de análisis sistema: software de creación Cod05
}

Cod05, lenguaje de programación o software, fue creado entre los años 2014 y 2016; continúa en estado de experimentación y evaluación por parte del equipo del emmelab y se basa en un sistema de partículas como algoritmo de salida y de visualización. Sus programadores ${ }^{125}$ lo sustentan en tres pautas:

a) No limitar la libertad de movimiento del performer. Asimismo, se proponen unos rangos o familias de posiciones y movimientos.

b) "Que [el programa] no se cuelgue", es decir, que continúe corriendo aun si se ingresa un dato erróneo. Esta es una particularidad heredada del live coding ${ }^{126}$.

c) Si ingresan datos ambiguos, el programa tiene que ser capaz de tomar una decisión.

Estas pautas se basan en el paradigma asociado con la actividad de programar con la funcionalidad misma del programa, es decir, escribir código en vivo. Lo que convierte al sistema y a su escritura -desde el punto de vista del humanware- en una actividad experimental. En este mismo sentido, el director del equipo del emmeLab Emiliano Causa (en Intercambios con emmeLab Cod05 2016: 5'40") propuso el siguiente desafío: “¿Podemos hacer que un performer construya código con su cuerpo?”.

\begin{abstract}
Aunque nuestra inspiración surge en parte del live coding, no consideramos que se pueda clasificar este proyecto dentro de esa disciplina, pues buscamos generar una expansión de la danza hacia la tecnología, y no del live coding hacia la danza. Nuestros criterios ya están bastante limitados por nuestra intención de no restringir al performer como para obligarnos a respetar otras limitaciones en un proyecto tan experimental.
\end{abstract}

En un espacio de intercambio realizado entre equipos de investigación (universidades de La Plata y Buenos Aires), el mismo equipo reflexionó y compartió sus experiencias respecto del cuerpo en interactuación con los elementos de Cod05. Este tiene que realizar determinadas posiciones y movimientos dentro de un rango que parte del eje central y de las extremidades, que posibilitará cambiar el aspecto de las partículas programadas ensamblándolas en tiempo real. Esta buscada combinación se presta para articular la ejecución consciente del propio performer y la autogeneración de los modificadores de visualización a partir de códigos programados.

\footnotetext{
125 Francisco Alvarez Lojo - Ezequiel Rivero - Daniel Loaiza - Hernán González Moreno - Carolina Ojcius (UNLP, FBA, SeCyT, Laboratorio emmeLab).

126 Live coding es una práctica derivada de la música electrónica por computadora y de la videoanimación, en la que se programa en vivo mientras se expone el código junto con el sonido y la imagen proyectada.
} 
En este sentido, el límite de las combinaciones posibles lo determina la propia gramática del código, puesto que hay una cantidad determinada de modificadores que se pueden seleccionar. Cod05 consta de un grupo de ellos que afecta el comportamiento de las partículas en masa y otro que afecta el vínculo de estas con el propio espacio arquitectónico, virtual, proyectado de la pantalla.

El primer grupo de modificadores de visualización de partículas lo conforman:

- Círculo (dibuja las partículas como círculos): da a las partículas el aspecto de elipses.

- Flecha: transforma las partículas en flechas que apuntan según la dirección y el sentido (en que se mueven las partículas) de los recorridos.

- Reas ${ }^{127}$ (en vez de dibujar las partículas, dibuja las interacciones entre estas, traza líneas entre las que se encuentran próximas): vuelve invisibles las partículas y traza una línea entre los centros de aquellas que se localizan próximas.

Dentro de este primer grupo continuamos con las siguientes categorías de modificadores:

- Mover: proporciona movimiento a las partículas.

- Calcular Rastro: provee a las partículas de un registro de sus posiciones anteriores, es decir que registra el rastro de su movimiento.

- Atracción al Centro: provoca que las partículas sean atraídas al centro de la pantalla.

- Aplicar Gravedad: dota de peso a las partículas y genera su caída.

- Fricción Global: genera una fricción que hace que las partículas desaceleren su marcha cuando no están sometidas a fuerzas, induce el avance y la desaceleración.

- Flocking Separación: simula otros comportamientos de bandadas, que mantienen una mínima distancia entre las partículas con tendencia a alejarse.

- Fuerza por Semejanza: las partículas se atraen o se rechazan sobre la base de la semejanza de sus colores.

En cambio, los modificadores de escena determinan el comportamiento de las partículas en relación con los bordes de la pantalla; generan que los bordes izquierdo y derecho, y superior e inferior se conecten entre sí. O, que los bordes de la escena se comporten como paredes con los que las partículas colisionan y rebotan, así como también que las partículas reboten entre sí.

127 Según Paco Álvarez Lojo, integrante del emmeLab: "Este modificador produce una imagen que es símil a una red, pero se llama Reas porque el creador del algoritmo original se llama Casey Reas". Su trabajo puede verse en: <http://reas.com/compendium_lecture/>. 


\section{MODIFICADORES}

APLICAR MOVIMIENTO

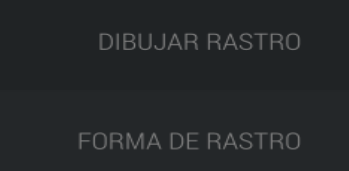

APLICAR FUERZA

VISUALIZAR PARTÍCULAS

ESCENA

FIOCKINC

TRANSPARENCIA

APLICAR COLISIONES

RESTABLECER LLUVIA

FUERZA POR SEMEJANZA

VARIOS

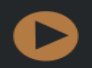

(cero

(1)

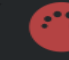

$\leftrightarrow$

(

C

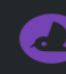

8

(

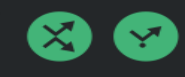

rastro normal / rastro elástico

circulos / triángulos / líneas

fricción / atracción al centro / gravedad

círculo / flechas / Reas

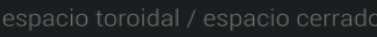

separación / atracción / Alineación

El sistema está preconfigurado en lo concerniente a la gramática, no así en cuanto a las posibilidades de combinaciones - de los modificadores de partículas de visualización y de escena-, pues estas son muy variadas. En este sentido, hay modos de agregar y de quitar modificadores a través de la activación de cambios en el sistema de partículas. Nos referimos a: Modo Quitar Modificador (elimina del programa los modificadores que hayan sido agregados), Modo Configuración (accede a otras opciones en las que el control no se ejerce a través del movimiento, sino a partir de dispositivos periféricos convencionales) y Modo Agregar Modificador (agrega modificadores de cambios). Sus iconos, de acuerdo con el orden presentado, son: 

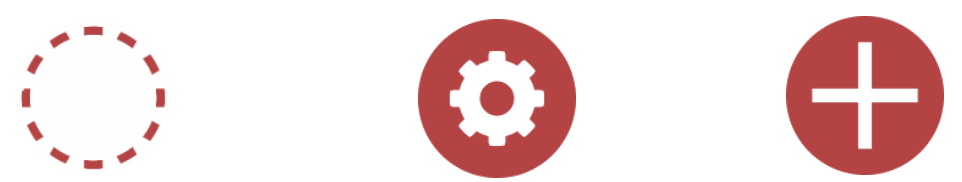

\section{Quitar Configurar Agregar}

Seguidamente, describiremos los monitores de control (en Vimeo Proyecto COD05 monitor). Estos permiten al usuario corroborar que el sistema de captura óptica lo esté tomando correctamente; e indican: Monitor de Estados (si el performer se encuentra realizando un movimiento abierto o cerrado), Monitor de Inclinación (si el centro de gravedad se desplaza a izquierda o a derecha) y Monitor de Nivel (exhibe la ubicación en tres alturas).

Los distintos niveles, junto con los estados, determinarán la aplicación o eliminación del modificador seleccionado; con estas combinaciones, el performer podrá controlar los modos. Los iconos de los monitores son:

\section{Monitor}
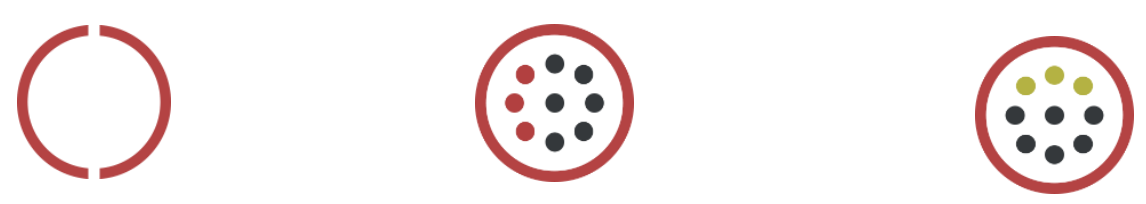

Abierto-Cerrado Izquierda-Derecha Arriba-Abajo
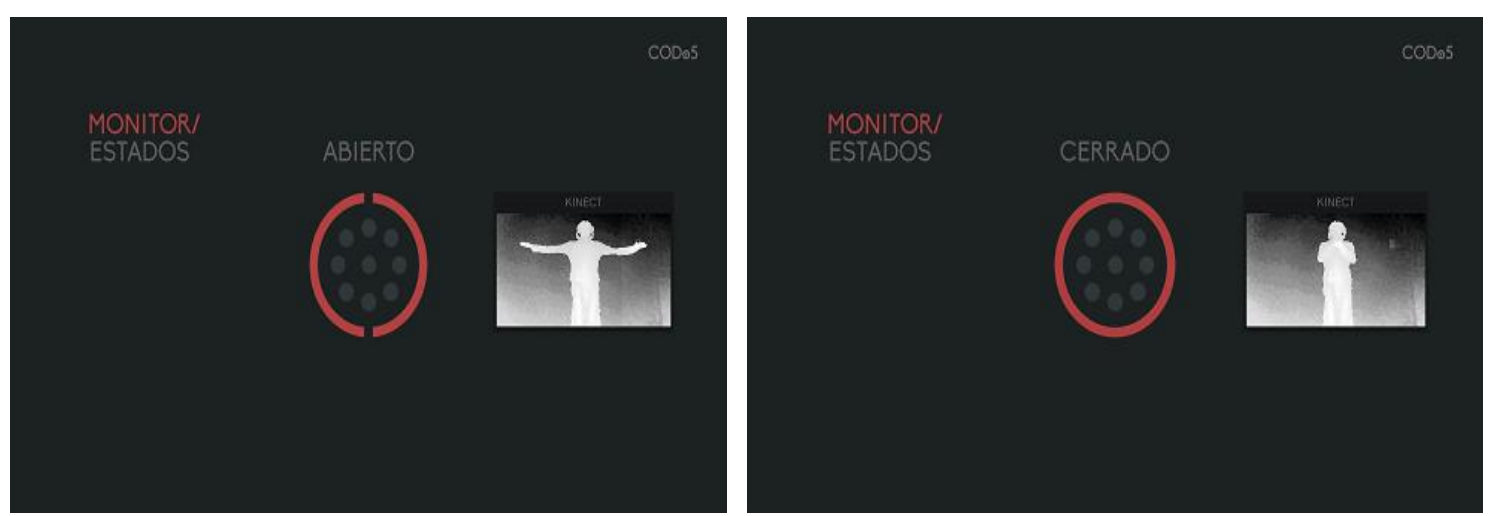

Monitor indicando un movimiento abierto y cerrado

Combinando estas características de las posturas abierto y cerrado, el sistema detecta tres niveles de altura: alto, medio y bajo; e ilumina en el monitor una línea de puntos que se corresponde con la altura que esté alcanzando el performer. 

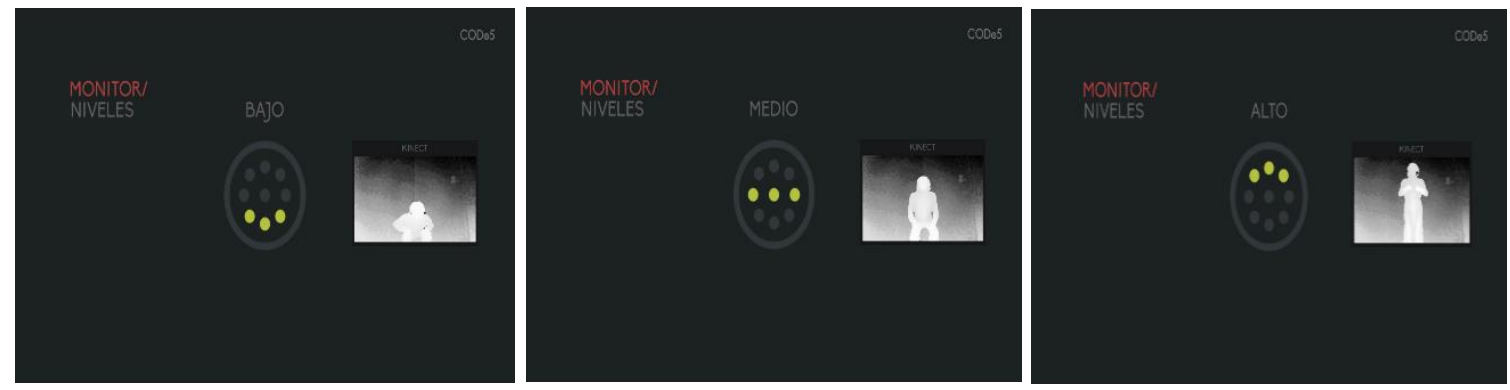

Tres niveles de alturas detectadas en líneas de puntos

Igualmente, desde la posición axial, el centro de gravedad se desplaza de la posición central hacia ambos lados y, de esa manera, el sistema se irá reciclando entre los diferentes modificadores presentes.
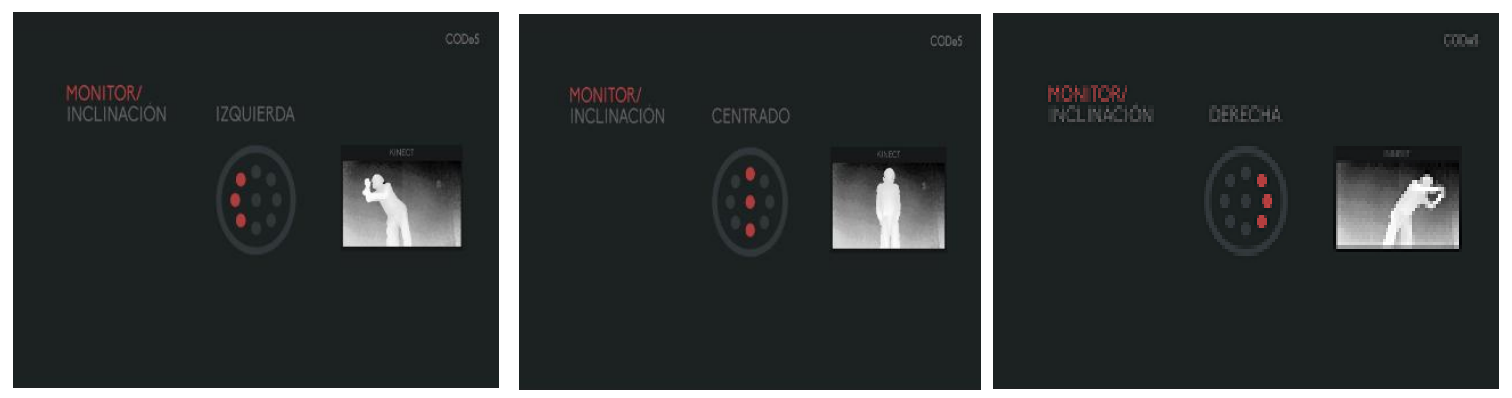

Monitor de inclinación

Se utilizan, en principio, tres aplicaciones ejecutables que cumplen diferentes funciones denominadas módulos. Cada uno de estos cumple un rol muy concreto y se articulan entre sí a través de un mismo protocolo de comunicación. Por tanto, pueden actuar en una misma computadora o en computadoras diferentes; reduciendo, significativamente, la cantidad de procesos computacionales necesarios, a la par que pueden promediarse en especial con facilidad en un entorno escenográfico audiovisual. Dichos módulos son denominados el Observador, el Carrete y el Lienzo.

El Observador es el módulo que hace la captura de movimiento a través del dispositivo óptico de la Kinect, que interpreta esos datos.

El Carrete es el monitor desde donde se visualiza la interpretación que está haciendo el observador a través de la Kinect del cuerpo. Es similar a una interfaz, pues no solo emite una representación del algoritmo del sistema de partículas que se está ejecutando, sino que también sirve para hacer las modificaciones sobre este.

El Lienzo es el resultado visual, gráfico, que genera el sistema de partículas que se está construyendo.

Así se vería un esquema del lienzo con los modificadores en actuación: 


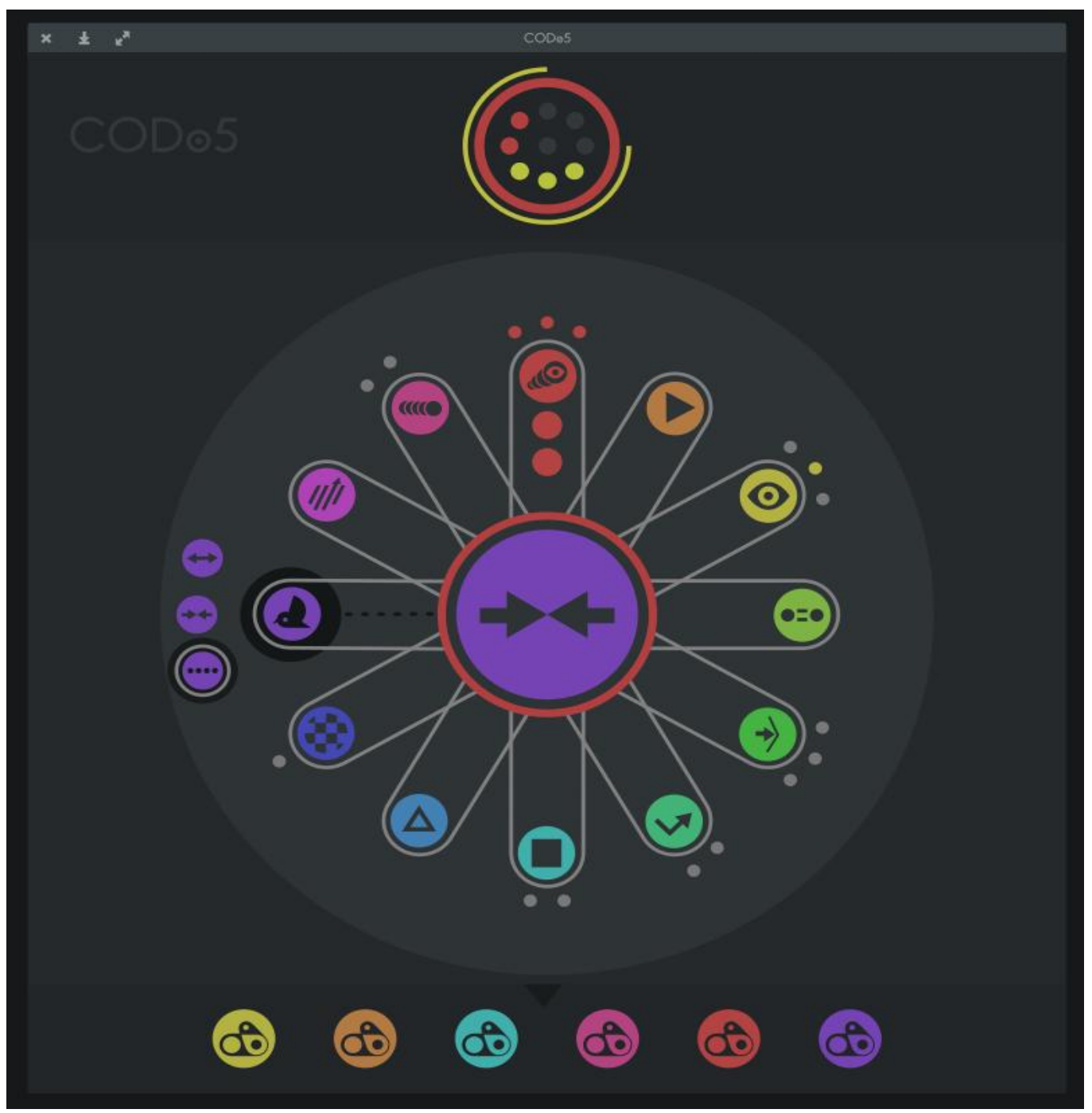

Lienzo con modificadores

En palabras de uno de sus desarrolladores, Cod05 se basa en un formato que se asocia con el movimiento que guarda coherencia con el lenguaje de la danza.

Tras algunas propuestas, elegimos una retórica inspirada en los proyectores fílmicos o grabadoras analógicas, donde una cinta que contiene información circula continuamente a través de mecanismos que hacen algo con ella [...]. El lenguaje se basa en dos elementos claves: una cinta o canal de información, y un sistema de mecanismos modificadores (emmeLab, 2016).

Entonces, por un lado, está el programador y el sistema interactivo diseñado (hardware-software-humanware), a través de los cuales se modelizan las señales de colocación del cuerpo del performer, se transforman en paradigmas computacionales y las devuelven en configuraciones gráficas. 
Por otro, está el performer en vivo, que ejecuta y procesa el sistema interactivo en tiempo real, tanto de lo generado por él mismo como a través de otros dispositivos puestos a interactuar escénicamente.

Para ello,

- se definirán, a nivel compositivo, los nuevos modos de experiencia del cuerpo propuestos por el sistema escénico interactivo, y se reflexionará sobre las posibilidades inmersivas y expresivas inauguradas por la modelización del movimiento corporal en vivo.

- se definirán, a nivel postural, los movimientos particularmente en pos del seguimiento de ciertas partes del cuerpo captadas por la cámara-sensor (izquierda-derecha, arriba-abajo), con el reconocimiento de patrones de entrada y salida a los espacios delimitados.

- se definirán, a nivel escénico, los nuevos modos de experiencia perceptiva del sonido y la imagen gráfica computacional.

A la pregunta sobre qué proponen los actuales desarrolladores en el orden emergente y en la práctica artística interactiva, como ideas o herramientas, podemos responder, a partir de lo analizado, que los programadores (humanware) se inscriben en una alternativa en la que se cuestionan el paradigma determinista de la interactividad como respuesta preestablecida.

Estas nuevas ideas de comportamiento interactivo emergente y generativo no se derivan de un conjunto de alternativas predeterminadas. Más bien, los comportamientos pueden surgir a través de una cadena de desencadenantes eventuales y no interconectados que, a partir de un comportamiento simple, produce una acción que da lugar a un comportamiento de nivel más complejo. Este es un nuevo prototipo de interactividad, radicalmente diferente de la noción de base de datos preconcebida. En este sentido, considerar un acercamiento emergente a la interactividad es una manera de aportar premisas básicas atribuidas a la complejidad del desarrollo de las herramientas de un sistema interactivo que, decididamente, se embarcan hacia una estética de la actuación corporal escénica.

Si la modelización generativa sucede a la animación por visuales, quizás los algoritmos genéticos crearán no solo criaturas, sino también argumentos. En consecuencia, creemos que el papel del programador-desarrollador se convierte en un estadio más allá de la propia voluntad de estar haciendo una base de reglas que genere la interactividad. 
Los programadores estarían construyendo un modelo de ecosistema informático ${ }^{128}$ dentro del cual puede ocurrir la transformación no ya como una representación, una mimesis, sino en la estructura de los sistemas: algoritmos de crecimiento biológico, ecosistemas simulados en comunidades, algoritmos genéticos o redes neuronales. Este proceso permite comprender que cada partícula es un conjunto de información que irá conectándose una con otra, y acorde va escalando de nivel en la variación de sus combinaciones, el sistema va respondiendo a los factores o parámetros que el cuerpo del performer va proponiendo.

Entender este diseño como un mapa genético en el que siempre se parte de datos originarios que se irán conectando unos con otros aumentando de nivel en su jerarquía estructural concretiza el movimiento propuesto por el performer en formas visuales que irán evolucionando, además de contener la información de lo transitado. Se trata de operar con la huella física del recorrido de los movimientos a través de un algoritmo que generará estos conjuntos autoorganizables de dinámicas no lineales.

Al respecto, William Forsythe ${ }^{129}$ (Nueva York, 1949) -coreógrafo clave para los estudios de danza y tecnología- fue un pionero. Aplicó las visualizaciones en forma de animaciones e imágenes gráficas en $2 \mathrm{D}$ y $3 \mathrm{D}$, para estudiar y exhibir las estructuras y los componentes de los diseños coreográficos, y destacó los patrones espaciales y temporales de los movimientos equivalentes a trazos coreográficos. Esto fundamentándose, en parte, en la concepción del espacio geometrizado planteada por el coreógrafo, profesor, filósofo y teórico de la danza Rudolf Laban (1879-1958).

Los bailarines reflejan las experiencias de su cuerpo en el espacio, las cuales se conectan a través de algoritmos (en matemáticas, computación y objetos relacionados. Un algoritmo es un método efectivo para resolver un problema usando una secuencia finita de instrucciones. Cada algoritmo es una instrucción bien definida para completar una tarea). El coreógrafo crea una importante secuencia de movimientos, entonces, el bailarín la toma. Son un set de instrucciones a realizar por el bailarín, tal como un software usa un algoritmo (Arreguín Garmendia, 2011: 49).

Del párrafo citado, individualizamos una consideración que hace el autor que nos resulta interesante distinguir. Se trata de esta idea de transmisión de esquemas

\footnotetext{
128 Según Fabricio Costa Alisedo, "Este tipo de obras ha trascendido las limitaciones del marco donde se compusieron llevando el diseño de la obra interactiva a una problemática con características similares a las de un ecosistema, un sistema complejo y vivo". Véase: <http://www.biopus.com.ar/tarcisio/pfds_papers/Fabricio\%20Costa\%20Alisedo_2014.pdf>.

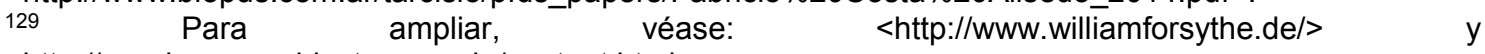
<http://synchronousobjects.osu.edu/content.html>.
} 
previos de movimientos, desde el coreógrafo al bailarín: "El coreógrafo crea una importante secuencia de movimientos, entonces el bailarín la toma"; sobre todo desde la concepción que venimos trabajando a lo largo de esta tesis y a lo largo de nuestro propio proceso como artistas investigadores ratificando, principalmente, los procesos de exploración mancomunada entre los actuantes de una propuesta de interactividad escénica.

Sin extendernos en los modos de vínculo entre coreógrafo e intérprete, entendemos la experimentación conjunta como el formato de relación que garantiza la transformación de las estructuras operatorias entre performers interactivos (aunando las figuras del coreógrafo y del bailarín) y programadores o desarrolladores de software y sistemas interactivos.

Sin desconocer la tradición que preexiste en las estructuras de producción escénicas, en las que el coreógrafo asume un rol de dirección dominante en el proceso de creación escénica, lo que acontece en la configuración de una escena interactiva es diametralmente diferente. Por tanto, operar con tecnología escénica interactiva conlleva procesos de producción conjunta tanto coreográficos como de improvisación. Hecha esta aclaración, haremos otra observación de lo expresado por Luis G. Arreguín Garmendia al referirse a la creación de secuencias de movimiento: "Son un set de instrucciones a realizar por el bailarín, tal como un software usa un algoritmo". Cod05 -como ya se ha explicado- es un lenguaje de programación diseñado para ser utilizado en escena por performers -por su parte, el tiempo real sigue preponderando$\mathrm{y}$, los algoritmos se programan a través de movimientos corporales, ingresando comandos en el mismo momento [en] que se ejecuta la danza o performance. Para estos desarrolladores, el modo de vincular los movimientos con la escritura de código se realiza a través de captura de movimiento utilizando dispositivos como Kinect o Xtion. En este sentido, el performer interactivo crea coreográficamente sus diseños algorítmicos en tiempo real. Entonces, cabría preguntarse cómo retenerlos.

\subsection{Sobre la unidad de análisis cuerpo}

En principio, consideraremos, como punto de partida, los resultados obtenidos en las conclusiones de las pruebas abiertas y las entrevistas semiestructuradas realizadas para la tesis de maestría 2010-2011. Ahora se hace evidente la necesidad de introducir cambios en los criterios que permitan "reconocer los 'sistemas autónomos' vinculados a la modalidad generativa de las prácticas artísticas" (Solaas, 2014: 13). 
Si bien la interacción física con sensores de movimiento, programaciones de imagen y de sonido y dispositivos de captura en el campo de la danza o performance con mediación tecnológica ha evolucionado, creemos que lo ha hecho con relación al interés puntual que algunos equipos desarrollaron dentro del ámbito investigativo. Es costoso y tardío implementarlo y difundirlo más ampliamente.

El estudio de lo documentado y las derivaciones obtenidas al ensayar con sistemas interactivos en el período 2010-2016 dieron lugar al cumplimiento de uno de los objetivos perseguidos: construir marcos conceptuales que posibiliten reflexionar sobre la articulación de estos lenguajes disciplinares combinados en relación con su especificidad en el arte actual. Esta serie de reflexiones problematiza los medios y los modos de creación, representación y producción.

Por eso podemos continuar afirmando que, en principio, las nuevas tecnologías no están revolucionando la danza, sino expandiéndola o, en el mejor de los casos, la danza como disciplina artística está apropiándose de las nuevas tecnologías como si se tratase de nuevos recursos escénicos.

Los diferentes elementos y procedimientos vinculados a lo escénico, al adaptar o al apropiarse de los nuevos recursos tecnológicos, dejan entrever que no todos sus componentes y experiencias dan respuesta a las nuevas formas de interacción o están disponibles. La discusión hace foco en la incumbencia de lo disciplinar: la danza o performance vinculada a la escena informática generativa. Por esto mismo, seguimos planteando cuestiones tales como:

- Cuál es la concepción desde donde se aborda la creación o la realización del movimiento ante un sistema escénico interactivo en tiempo real.

- Cuál es la concepción de las formas de producción y recepción conocida como espectáculo ante procesos de experimentación.

- Cuál es la concepción de la formación disciplinar ante la incorporación de las tecnologías aplicadas en diálogo con el cuerpo, el espacio y la mirada (Ceriani, 2011: 113).

En consecuencia, se hace inevitable la revisión de lo investigado para el reconocimiento de nuevas concepciones que conlleven un desvío del flujo de las prácticas actuales. Hemos planteado que "hay otra presencia del cuerpo, por consiguiente, otra gramática del lenguaje de la danza, percibida como danza performática y performance interactiva" (Ceriani, 2011: 113). Esta puntualización de una nueva gramática exige el análisis desde la hipótesis presentada en su momento: 
El desplazamiento antropocéntrico del performer y la priorización de otros sentidos por sobre los habituales son básicos para comprender y proyectar cualquier propuesta de esta índole. Esta noción de un desplazamiento del centro -descentramiento- se originó a partir de "la imagen del cuerpo virtual y digitalizado". Esta imagen y sus cualidades están dadas por el tipo de interfaz y sensado escogido.

A cada opción de interfaz, software, programación y capacidad de sensado, le corresponderá un tipo de movimientos con los cuales se interactuará y pondrá en diálogo el cuerpo con el sistema. Una instalación interactiva con plataformas de pisado (son sensores digitales de contacto, llamados así porque solo tienen dos estados posibles: prendido o apagado) generará una interacción diferente a la captura óptica, usando como sensor una cámara colocada de manera cenital o frontal.

Las interfaces tienen la capacidad de adaptarse a diferentes situaciones de sensado: cantidad de sujetos en el espacio, su posición en dos o tres dimensiones, color del vestuario, recorrido y velocidad de desplazamiento, etcétera. En consecuencia, podemos plantearnos la particularización de todo un universo gestual, toda una ergonomía interactiva, donde el cuerpo compone en diálogo con las interfaces, con los dispositivos, etcétera (Ceriani, 2012: 138).

Para los miembros del emmeLab, el diálogo entre cuerpo y sistema es un problema clave. Ya lo planteaba Claudia Giannetti (2004: 2) a través de un nuevo concepto de estructura de la obra:

Cuando hablamos de arte interactivo, nos referimos a un tipo de producción concebida específicamente para proporcionar el diálogo con el usuario: la obra como tal se revela a partir de la actuación y de la intervención del espectador. El público debe operar en el contexto de la obra o producción, que se transforma en un entorno experimentable física y emocionalmente.

Emiliano Causa (emmeLab, 2016) detalla y pone en duda esta idea de un diálogo entre cuerpo y sistema, puesto que, a veces, se transforma -según sus propias palabras- en una especie de lucha libre, y esto es un punto clave que hay que explorar para establecer el enfoque interdisciplinar acorde a la situación escénica. Por su parte, Ezequiel Rivero (emmeLab, 2016: 1'56") apunta respecto al sistema:

Vos vas a obtener una respuesta de él, cuando hagas solamente lo que él quiere que hagas, por lo cual eso no es un diálogo, es un monólogo donde la única opción que tenés es responder, o no participas del sistema; no hay libertad. No 
conozco ningún sistema que realmente interprete lo que vos le estás diciendo y, a partir de esa interpretación, tome una decisión cual sujeto $y$, te dé una respuesta posterior al proceso de tu mensaje; que es lo que llamamos una relación dialógica... Estamos en presencia, en tal caso, de dos monólogos.

Nuevamente citamos a Giannetti, quien deja en claro cuáles son las problemáticas del diálogo interactivo desde la reflexión teórica, para que, tiempo después, nosotros logremos apropiarnos de soluciones posibles, a partir de la investigación local con software de programación abierta, como Moldeo.org y Cod05, pensados, específicamente, para la práctica escénica:

El usuario ejerce un control sobre el proceso, sobre la navegación, pero no un verdadero diálogo con la obra. Es por eso [por lo] que gran parte de las obras de web art o arte multimedia no pueden ser caracterizadas como interactivas, sino [que] son básicamente participativas o reactivas. Las obras interactivas -para que sean consideradas como tal[es]- implican un intercambio real de información entre los sistemas, como el humano y el digital, es decir, la posibilidad de que un elemento externo a la máquina entre a formar parte del proceso mediante la introducción de información, y pueda generar nueva información no contenida en el programa (Giannetti, 2004: 3).

Si vemos esto desde el propio sistema informático, la computadora y sus dispositivos, ciertamente, no tienen conciencia alguna de su interacción con algo o alguien. Entonces, ¿cómo vamos a captar esta interactividad mediada por el hardware, software y humanware, con respecto al performer percibido desde un espectador? Con el desarrollo de la interfaz:

El límite o la posibilidad de la interfaz representan el conocimiento del contexto de la interacción por parte de los agentes interactuantes. En este contexto, se trata tanto de buscar la reducción de la distancia y del tiempo de comunicación, como de lograr la optimización del tiempo de reacción y de la flexibilidad en la interrelación. Esta optimización tiene por resultado el replanteamiento respecto a la comprensión de las posiciones asumidas por cada sistema -sujeto y máquinaque interviene en el proceso de comunicación: el sujeto deja de ser el operador que controla consciente e íntegramente la herramienta; y la máquina experimenta un incremento progresivo en el grado de "independencia" de su funcionamiento, es decir, ya no es una herramienta "inerte" en el sentido convencional. Esto significa que, para que se produzca la intercomunicación, debe haber un proceso 
de traducción de lenguaje. Así, apuntamos a tres factores esenciales para entender la interfaz: el contexto, el tiempo y la traducción (Giannetti, 2004: 4).

Sostener que las computadoras simplemente facilitan la interacción humana es parte del discurso de quienes afirman que la obra interactiva no es un "diálogo", sino una convención cultural que representa la capacidad física de hacer emerger -a partir de la gestualidad- otros espacios, imágenes, gráficos responsivos, sonidos, etcétera; es decir, una escena interactiva virtual, simulada.

Podemos ejemplificar esto con los videojuegos en línea en los que los jugadores físicos, ubicados en un espacio físico, acceden a interacciones lúdicas con jugadores ubicados en todo el mundo. Buscan emular las capacidades corporales reales restringidas con las virtuales.

Así lo prodigioso y lo ficticio del ser humano enfrentan una forma tecnológica de vida natural y generan mundos habitables paralelos. Estos cuerpos electrónicos descorporizados sin peso pero con potencia referencial se posicionan en las fantasías futuristas contemporáneas.

Los cuerpos de la realidad virtual son delgados. Jamás llegan a tener el espesor de la carne. La fantasía que se nos revela diciéndonos que podemos tener simultáneamente los poderes y las capacidades de un medio tecnológico tan incorporados a nuestros organismos que se sientan partes vivientes del mismo y sin limitaciones es la fantasía del deseo (Ihde, 2002: 36).

Consecuentemente, surge una reflexión acerca de la emulación: para funcionar, la obra debe activar con éxito asociaciones, empatías, que hagan significativa la experiencia de contacto. Pensemos que ya estamos en sintonía con un raudal de respuestas mecánicas, electrónicas: semáforos, puertas, cajeros, celulares, etcétera.

En qué medida la tecnología -o para expresarlo mejor, el diseño de la interfaz- está encorsetando el cuerpo sigue siendo un escollo, un recorte, una reducción; pues cuando el sistema te circunscribe hacia y hasta dónde podes moverte dentro de un rango de captura, ya no es un movimiento autónomo sino condicionado, subordinado. Según Emiliano Causa (emmeLab, 2016), el performer "empieza a pensar en una especie de cuerpo disociado: uno que es su cuerpo pero también el cuerpo que está siendo capturado por el sistema". Para nuestra exploración esta disociación, este doble cuerpo, es parte del aprendizaje básico que un performer interactivo intentará percibir, experimentar. En palabras de la performer Soledad Belén, la experiencia 
senso-perceptiva se ampliaría notablemente: "Me parecía estar en una burbuja en el tiempo y en el espacio" (2016: 3'36").

Con relación al concepto de encorsetamiento del cuerpo del bailarín, podemos agregar que, disciplinarmente, se conciben los "límites" como inherentes a la concepción de la danza. Rudolph Laban, por ejemplo, inscribe su teoría sobre lo que denominó "kinesfera"130 basado en estas delimitaciones: el radio de acción normal de los miembros del cuerpo estacionado y en su máxima extensión; sin perder de vista que la sensibilización es básica para la interacción de este con otros cuerpos, objetos o el espacio que lo rodea.

Sus concepciones disponen el cuerpo y el movimiento en un continuo intercambio con el entorno y lo disponen también como un ente orgánico en el que se desarrollan tanto los procesos externos como internos. La frontera entre interior y exterior del cuerpo ya no es solo un límite, sino que en ella tiene lugar una infinidad de procesos de intercambio. La piel del bailarín -para Laban- es la zona de contacto.

Me encontré con una presencia distinta del cuerpo. Me superaron los sentidos. Me ocupaban el espacio propio. Mi cuerpo se transformaba en oídos, vista, piel, el tacto que pasaba por esas zonas donde tocaba o pasaba con alguna parte de mi cuerpo y reaccionaba el sistema con algún efecto, con alguna visual. Desde la experiencia subjetiva me generaba eso, estar jugando con sonidos, con cosas que había en el espacio general, en mi propio espacio y en ese espacio real que era acotado, limitado, reducido como tiene, por ejemplo, la cámara Kinect (Belén, 2016: 1'06").

Es interesante analizar los diferentes tipos de espacios que considera la performer en su experiencia interactiva y que se conjugan con los sentidos y zonas del cuerpo. Retomando los testimonios recabados:

Yo nunca sentí el espacio de captación como reducido. Sí sabía dónde me captaba la cámara y dónde no se producía nada. En un momento me olvidé y me quedé con el registro de ese lugar acotado. Después en la experiencia sensoperceptiva se me amplió notablemente. Me parecía estar en una burbuja en el tiempo y en el espacio (Belén, 2016: 3'30").

\footnotetext{
130 Kinesfera es un espacio esférico alrededor del cuerpo que se dibuja al extender las extremidades, y es el espacio en el que el cuerpo puede moverse. Las tres dimensiones de este espacio son: vertical, horizontal y transversal, y corresponden respectivamente a la altura, a la anchura y a la profundidad de este. De la combinación de estas tres dimensiones, aparecen doce direcciones que el cuerpo puede tomar dentro del espacio.
} 
Esta "burbuja" -que menciona Belén y que bien podríamos asociar al espacio esférico alrededor del cuerpo de Laban- es parte de esta creación de un espacio próximo; pero en propuestas de sistemas interactivos para la escena interactiva, tanto los parámetros de interactividad como los de inmersión, son parte integrante y no escindente entre cuerpo y espacio. Esto sería apuntado como un aporte meritorio de los sistemas interactivos e inmersivos escénicos y sus programaciones.

\begin{abstract}
Yo sonaba y no sabía desde dónde y por dónde ni cuánto tiempo iba a durar ese sonido; tampoco creo que cada vez que pasara por ese lugar sonara de la misma manera. Entonces parecía estar en un espacio determinado con todos esos elementos dispersos en el aire. $Y$ también era muy interno. Pude salirme de la necesidad de proyectarme, extenderme, estirarme, elongarme, de llegar hasta la otra pared... aparecieron otros tipos de movimientos, quizá más pausados por momentos. Pero el juego mismo me llevaba, no fue que el sistema no funcionara. Insisto con lo de la "limitación". Porque había cosas que no funcionaban: no sonaba, no me captaba la Kinect...; pero yo lo aproveché, sentí que era parte, era la letra, era lo que estábamos produciendo con el sistema (Belén, 2016: 3'41").
\end{abstract}

En el sistema utilizado en las pruebas practicadas -en el marco del Ciclo de Danza "En2Tiempos" año 2013-, el sensor registra el cuerpo y lo traduce a un avatar que el sistema modeliza, y devuelve, asimismo, la propia acción ejecutada sobre un compuesto de partículas. Por ende, al captarnos, lo hace desde esta descomposición de un tipo de materialidad física hacia otro tipo de materialidad virtual. El propio movimiento del cuerpo es decodificado como un gráfico dinámico. Dentro de las performances generativas híbridas, el discernimiento de lo que sucede con el cuerpo en movimiento atañe a la mixtura entre el cuerpo y los algoritmos de la programación, entre el movimiento y el procesamiento de datos.

Nuestra hipótesis anterior -que conforma el fundamento conceptual de la presente- se basa en las operaciones que ejercen las imágenes mentales y sus niveles de conciencia, permitiéndonos dialogar de forma sensible con el sistema. Aquellas imágenes, acontecidas a partir del trabajo consciente con los sistemas interactivos en tiempo real, erosionan fundamentalmente las estructuras de movimiento conformadas en nuestra formación disciplinar, en la memoria corporal, y promueven la trasformación. Pero, sin perder de vista que no solo atañen al bailarín, sino también al programador: "Escoge aquellas metáforas que permitan al usuario comprender los 
detalles del modelo conceptual. Las buenas metáforas son historias que crean imágenes mentales"131 (Tognazzini, 2006).

Por consiguiente, la imagen del cuerpo modelizado es lo que determina, directa o indirectamente, la conciencia del estado interno y externo del cuerpo físico interactuando con dispositivos e interfaces en el entorno de programación y en el de proyección; y es, en esa determinación, donde cobra sentido. Opera tanto simultánea como diacrónicamente. Uno puede estar siendo consciente o no de lo que está aconteciendo a esos niveles perceptivos, y así se pone en claro la diferencia.

Por lo cual, consideramos que entre la imagen proyectada -digital y modelizada- y la imagen mental de nuestras sensaciones se fecunda un lenguaje corporal propio. Podría designarse al descentramiento como un primer resultado a nivel del trabajo consciente del cuerpo con la hibridación del espacio físico junto con el espacio virtual. El cuerpo real se fusiona, se expande, se bifurca en la imagen del cuerpo proyectado desde el software de captura y procesamiento. El entendimiento del movimiento no viene de lo indeterminado, viene de interactuar corporalmente con los dispositivos físicos y sistemas generativos. Por tanto, en la presente tesis confirmamos la siguiente hipótesis:

\begin{abstract}
Las tecnologías digitales proponen nuevas trayectorias a los procesos de producción y formación en el campo de la danza performance. La programación libre, interfaces y aplicaciones así como las plataformas de código abierto para la presentación escénica en conectividad con redes de internet permitirán establecer otros principios de organización espacio-temporales tanto de la gestualidad expresiva como de la corporalidad distribuida, lo que proporcionará el acceso a herramientas conceptuales y experimentales inéditas. En consecuencia, identificar, estudiar y sistematizar el conocimiento que bailarines, performers, coreógrafos y programadores desarrollan cuando están operando con tecnología y sus entornos nos habilitará para construir una genealogía de los desplazamientos de la mirada y la corporalidad (Ceriani, 2015: 16).
\end{abstract}

Lo que hemos estudiado desde el vínculo particular del cuerpo disciplinar con los sistemas interactivos nos permite hoy construir este otro estudio que desplaza el interés por el vínculo disciplinar -específicamente los modos de acceso al conocimiento- entre la danza y la informática, bailarines y programadores, cuerpos de unos y de otros.

\footnotetext{
131 Con el fin de ampliar la información, véase: <http://www.galinus.com/es/articulos/principios-diseno-deinteraccion.html\#objetos-humanos>.
} 


\subsection{Sobre la unidad de análisis escena interactiva}

El estudio de los aspectos escénicos refiere al entramado de los procesos dinámicos entre el sistema generativo y las visuales, articulados por el movimiento postural y la ubicación del cuerpo. Por consiguiente, la escena interactiva derivará de la retroalimentación que hay entre el movimiento individual o grupal con las partículas de salida y visualización del software Cod05; y, la puesta en escena, del conjunto de determinaciones entre unidad cuerpo y unidad sistema.

Pensamos dos dimensiones: una, que compromete los niveles de intervención según la reciprocidad y la modificación de un entorno; y otra que compromete los niveles de ambientación según la actividad sensible del entorno escénico proyectado. Pudiéndose, a la par, argumentar que la proliferación de formas de interactividad mediada ya ha dado lugar a una nueva posición del performer en relación con los modos de experiencia audio-visual y corporalidad.

En una entrevista realizada a la performer Soledad Belén apuntaba respecto a su trabajo con el equipo emmeLab:

S: Yo aproveché las dificultades. Tuve que entender un montón de cosas. Igualmente, ellos se sorprendieron de las decisiones tomadas en el momento, que fueron coreográficas, porque querían generar un clima, un cambio.

$\mathrm{E}:$ ¿Dirías que tu cuerpo baila distinto hoy?

S: Sí. El cuerpo toma otra forma, otra expansión. Es desafiante. No tenés que dejar de lado la proyección, un montón de cosas que están más hacia afuera. Es una posibilidad de entrar y salir del cuerpo de uno.

E: El cuerpo está atravesado, todo pasa por el cuerpo, nada está fuera del cuerpo.

S: A mí me gusta olvidarme [de] si hay un sistema, si hay tres tipos programando... Seguimos investigando, por ejemplo, sobre que el performer tome más decisiones sobre lo que quiere hacer, sobre parte de la programación. Hay efectos y decisiones tomadas a partir del lenguaje de la danza, pero yo soy dueña ahora de apretar la tecla como performer, por decirlo de alguna manera.

Por tanto, a la pregunta acerca de "qué sucede con el cuerpo entre una escena analógica y una escena digital", la respuesta se actualiza e invita a revisar cada nueva formulación entre sistema informático, cuerpo y escena. Sobre esta experimentación con el software Cod05 y a través de las pruebas realizadas con la performer, los participantes afirman que surgieron acontecimientos no previstos a partir de esa 
concatenación con los modificadores. Si bien el sistema es determinista, hay un punto en el cálculo matemático que es imprevisible puesto que determinadas combinaciones emergen en nuevas entidades, $y$, en este proceso generativo, hay que anexar que el sistema de partículas utilizado es complejo y aleatorio.

Entonces podemos sostener que esto se genera en el intercambio disciplinar del programador con el bailarín, en ese espacio mediador que es la escena interactiva. Esa escena donde se producen todos los cruces es un espacio en común que habilita un cuerpo en común.

Los usuarios constantemente experimentan el medio de forma multidimensional. Así, la cualidad monosensorial de estos medios fácilmente revela que las reducciones tecnológicas ocurren a la par que dramáticas amplificaciones y magnificaciones en esos mismos medios auditivos o visuales (Idhe, 2002: 30).

$\mathrm{Y}$ aquí podemos realizar diferentes consideraciones respecto al espacio multidimensional, o, al menos, aquellas que nuestros entrevistados han explicitado. $\mathrm{Y}$, llamativamente se anclan a concepciones arraigadas en el escenario tradicional del teatro o la novela televisiva, donde no se concibe al performer situado de espaldas al público, o en el piso, o sin iluminar, etcétera.

Observaciones opuestas se hacen desde el espectáculo audio-visual. Implicando la proyección de animaciones, el procesamiento de imágenes, videos y datos tridimensionales, se procuran telas elásticas, transparentadas, donde la proyección se espacialice de modo tal que originen ambientaciones sinestésicas como sería una instalación de arte con proyecciones o un video mapping ${ }^{132}$. Indudablemente podemos suponer que, para un informático o un programador, el universo de lo audio-visual está más próximo a su cotidiano que el universo de lo escénico entendido desde el cuerpo disciplinar y sus modos de producción y exhibición: teatro, danza, performance.

En este punto, hasta podríamos presuponer -dado nuestro análisis del período analógico reactivo de la danza multimedia (en Capítulo 2, Parte 1)- que las problemáticas de la articulación cuerpo-espacio-proyección y sus respectivos tamaños y proporciones se reproducen y perpetúan en el imaginario disciplinar o en la ficción epistemológica (Sarquis, 2011: 18) desde donde son abordadas.

132 El video mapping consiste en proyectar o expandir una animación o imágenes sobre superficies u objetos corpóreos. El mapping más habitual es el que vemos sobre los edificios monumentales acompañados de sonidos para efectuar un mayor espectáculo. De esta forma, se permite una interacción con el público y se crea una relación entre el arte, la tecnología y la sociedad. Actualmente, no solo es una técnica de proyección, ya que puede ser utilizado por tecnologías como pantallas de leds, video muros, etcétera. 
En la Parte 2 del Capítulo 2, hemos desarrollado los conceptos de interfaz, entorno, lenguaje de programación, software libre, open source, programador, operador y materialidad del código. Retomando el concepto de interfaz, lo asociamos con el lugar de la traducción, pues nos permite extrapolar de nuestra experiencia cultural ejemplos que llevan algunos rasgos que parecieran tener una relación análoga con lo que estamos viendo.

Pero la definición de interfaz como "cuerpo del software" es la que pone de relieve la consciencia corporal del programador informático como parte vital de este proceso de indagación conjunta; se supera así la actitud de técnico facilitador de las condiciones computacionales o de quien conoce de programación sobre la caja negra. Ser consecuente con la limitación del uso y la ergonometría de la interfaz, coloca al cuerpo y al sistema interactivo escénico en el foco del intercambio entre ambos métodos creativos. Una concepción de interfaz que empodere, a la par, tanto al programador como al performer interactivo predispone al diálogo equitativo y a la idea de un cuerpo en común, que no es lo mismo que un cuerpo expandido o desdoblado.

Ese cuerpo común hoy estaría consolidado por nuevas concepciones que los desarrolladores de software abordan para la resolución del problema de comprensión de la traducción y la modelización en la escena interactiva. Deducimos, por ende, que esta es la vía para que un algoritmo opere a partir de las actuaciones intercondicionadas por los movimientos de un bailarín. Así son el cuerpo epistémico de la danza y el cuerpo epistémico de la tecnología: porosos, emigrantes dinámicos entre sus territorios, que, a través de movimientos bilaterales, convergen generando este espacio mancomunado.

Pero, aun en medio de las transformaciones que se están gestando a partir de estas exploraciones relacionadas con prácticas interdisciplinares, emerge la ambivalencia que el vínculo tecnológico parece provocar: "El usuario quiere y no quiere la tecnología. No quiere los límites ni las transformaciones que ella inyecta en el proceso de extender su cuerpo" (Ihde, 2002: 35), y transformarse así en voyeur de su propio espectáculo que no es igual a ser el autor.

No entraremos en esta disquisición de la autoría en arte interactivo, pero sí nos resulta interesante destacar, de la siguiente cita, el vínculo con la materia y el acto creativo en su evolución:

En las modalidades tradicionales de adición y sustracción, es el artista quien decide a cada paso qué se añade o qué se quita para llegar a la forma que su espíritu, intuición, inspiración, idea o instinto le dictan. Por ende, él está presente en persona en cada trazo, pincelada, curva o acorde. Todo es huella de su paso. 
De cualquier parte de la obra puede decirse: "el artista estuvo ahí". Existe una contigüidad física entre el artista y la obra que se vuelve uno de los principios fundamentales del arte: es lo que llamamos la autoría.

El molde interno, en tanto agregado de reglas, por contraste, entraña una cierta impersonalidad. El sistema hace por sí solo, en ausencia de todo control externo o decisión humana. Alguien pone materia, o la sustrae, pero algo se desarrolla.

La semilla revolucionaria del concepto de molde interno es el colapso de la idea sobre la materia. Mientras ambas permanecían separadas, como toda la historia del pensamiento occidental daba por sentado, había necesidad de un intermediario, un demiurgo, que se dedicara laboriosamente a unir esa forma o plan abstracto con la sustancia que lo corporizara. Pero si el plan está en la materia misma, como una cualidad inseparable de ella, el topos uranus prescribe, el mundo de las ideas se vuelve innecesario y el demiurgo se queda sin trabajo (Solaas, 2014: 13).

En esta cita, hay ciertas cuestiones para destacar, que aportan al análisis de lo relevado en las entrevistas -tanto con la performer como con los desarrolladores- y que residen en esta concepción de un nuevo paradigma que proviene de las matemáticas y la física: los sistemas generativos autónomos en tecnologías digitales. Estos permiten producir, desde la materia digital, dinámicas autoorganizadas semejantes a las que se pueden observar en la naturaleza. Temas tales como caos y complejidad, evolución interactiva, agentes autónomos y vida artificial son procedimientos generativos que, aplicados a lo escénico y al cuerpo, dan plataforma al cambio en nuestras áreas de interés.

Reparemos en dos pasajes de lo expresado por la performer y por un integrante del equipo emmelab que, en un momento, propusieron correrse "totalmente de la programación”, a lo que Soledad Belén (2016: 8’58”) les respondió “que no, que no es posible, que siempre va a haber algo preprogramado" que condicionará la interacción. En consecuencia, la programación es considerada el nuevo material con el cual los artistas contemporáneos crean y producen obra.

La materia tecnológica por excelencia es el código. Por consiguiente, el código es materia prima para un programador que considera artística su labor: "Es una forma de hacer arte. Y, un artista que usa la programación es un artista” (emmeLab, 2016: 7'). Pero ¿por qué hoy es una preocupación de programadores y desarrolladores de softwares escénicos la interactuación "expresiva" del performer? Esta preocupación por inhabilitar el "grillete" o el "corsé", "que la programación y las interfaces locales no han logrado proveer, forma parte del tesón innovador del equipo de programadores de Cod05 de invertir los roles: 
Lo que nosotros creemos que es una innovación -habría que constatar si es tan innovador o no-, pero lo que le agregamos es que el programa en sí es un lenguaje de programación donde no está precodificado, no está preprogramado lo que va a suceder cuando el performer haga determinado comportamiento. El performer se está comunicando con el programa y está programando lo que el programa va a hacer en las subsiguientes acciones. El mismo movimiento corporal del performer le está diciendo al programa qué tiene que hacer con cada movimiento (emmeLab, 2016: 5'15').

Podemos establecer que el espacio escénico es siempre paramétrico, mas no siempre se desarrolla por algoritmos generativos, ya que los procesos de diseño difieren en cuanto a la conceptualización de información, pero siempre estarán en función de las condicionantes o parámetros que deberán responder para llegar a un resultado del proceso dialógico. Por lo tanto, cabe subrayar que la verdadera evolución está en la digitalización, por ende, en la definición de un algoritmo generativo como optimizador de procesos de diseño y no como una herramienta que se entienda como productora de configuraciones orgánicas mediante la abstracción aleatoria de parámetros producidos por la actividad performática.

Una dificultad, más que un problema, es que el performer tiene demasiada consciencia. Estamos trayendo al performer demasiado al plano consciente, por lo cual, le estamos quitando un poco lo expresivo que puede encontrar en el arte corporal... Yo no sé mucho de eso (Rivero en emmeLab, 2016: 6').

De lo enunciado, es necesario advertir: uno, pensar como dificultad el plano consciente del performer en desmedro de su potencial expresivo; y, dos, declarar no conocer, no saber mucho del arte corporal. Si bien no es considerado un descrédito el "no saber" de la otra disciplina, sí lo es al momento de plantearse un modelo de participación, pues libera un imaginario de reciprocidad regido por criterios que aducen a esa disciplina que se desconoce. ¿Qué imposibilita al performer bailarín ser consciente a la par que expresivo? ¿Es la consciencia una falta de expresividad? ¿O viceversa? Repensar los modelos simbólicos que se exponen ahorraría claridad a los dominios de intercambio de los cuales se parte.

Entonces, primero la práctica, que es la manera en que el pensamiento hace experiencia (Foucault, 2013), y después el cuerpo, primero la práctica y después la subjetividad. ¿Por qué? Porque las prácticas son modos de subjetivación y 
constituyen al sujeto en las relaciones que pueden darse con el saber, con los otros y consigo mismo. La educación del cuerpo, en función de suponer que el objeto de la educación son las prácticas y no las actividades, habilita a nuestro entender no solo la formación de expertos, sino la formación de cuerpos para un uso. Donde el uso del cuerpo remite a la posibilidad, que en los límites de la práctica nos habilita a tener un pensamiento crítico respecto de una organización y problematización racionalizada de la conducta, cuando esta no está sometida a interdictos explícitos o códigos de comportamiento rígidos. El uso del cuerpo supone la reflexión, en los límites de la práctica, de lo que podemos hacer con lo aprendido, con su racionalidad, con su dimensión de saber, de acción con los otros y uno mismo. El uso supone la reflexión, porque es el resultado, en la acción, de la pregunta por el hacer cuando no está especificada la forma (Escudero, 2014: 8).

Es interesante atender a cada frase de esta cita pues, desde una perspectiva crítica planteada por los propios programadores que dejan en claro el objetivo de no "encorsetar o engrillar" el cuerpo del performer-, bastaría con no someter el cuerpo a códigos de comportamiento rígidos. Igualmente, podemos ahondar más y proponer otra noción para poner en práctica siempre "lo aprendido, con su racionalidad, con su dimensión de saber, de acción con los otros y uno mismo" (Escudero, 2014: 8). Considerar que el "uso supone la reflexión, porque es el resultado, en la acción, de la pregunta por el hacer cuando no está especificada la forma" es confiar en que esa forma surgirá de la práctica y de la reflexión en una retroalimentación permanente.

Asimismo, es posible entrever el quid de la cuestión desde los parámetros del humanware que radican en la novedad de su concepción de subjetividad y emotividad: mostrar la unidad de lo subjetivo y objetivo desde la posibilidad del conocimiento de las facultades humanas en su propia esfera expresiva. Pero suponiendo que no se especula desde la pura formalidad ornamental, queda creer que es desde un desconocimiento disciplinar sobre la danza que pareciera inmiscuirse.

$Y$ sugerimos que no solamente se ejerce un desconocimiento disciplinar referido al cuerpo de la danza o la performance, sino desde la propia corporalidad. En las disciplinas informáticas, en general, no se educa el cuerpo para su uso desde "una estética de la existencia, donde el cuerpo que se constituye se tome como objeto de elaboración de la conducta a lo largo de una vida subjetiva" (Escudero, 2014: 8). Tampoco podemos ofrecer a los programadores criterios de interpretación para comprender la práctica de la danza, ya que: 
... esa interpretación tiene un efecto de constitución en términos simbólicos. No queremos decir que vamos a construir una danza nueva y nunca antes bailada, por el contrario, queremos decir que interpretando de otra manera los modos de hacer, estos se transforman, se constituyen en algo diferente, ya que al extender los límites de lo que nos hace ser, transformamos nuestra experiencia, lo que hacemos y lo que somos (Escudero, 2014: 8).

Si podemos construir conjuntamente experiencias, reflexiones y formas elaboradas de interdisciplinariedad en busca de una transdisciplinariedad artística y tecnológica, significa que pudimos comprender, en principio, cuáles son las metodologías y modos de producción e imaginarios de cada disciplina.

\begin{abstract}
En el comportamiento de los sistemas se ve una marcada evolución hacia los sistemas autoorganizativos, capaces de desarrollar comportamientos autónomos sostenidos, y de evolucionar y adaptarse sin la intervención humana. Es en esta última línea en la que se centra el presente trabajo, particularmente en los intentos por lograr una interacción humano/computadora más eficiente mediante la articulación de la comunicación emocional, la Computación Afectiva. La afectividad es una dimensión significativa del comportamiento y la comunicación humana. Lograr que las computadoras puedan comprender nuestras emociones, y a la vez que puedan "expresar" (o simular) emociones propias, sería un paso importante para establecer un cambio cualitativo en la interactividad (Causa y Sosa, 2013: 1).
\end{abstract}

Retomando el argumento sobre si están trayendo al performer demasiado al plano consciente, por lo cual le están "quitando un poco lo expresivo que puede encontrar en el arte corporal" (Rivero en emmeLab, 2016: 6'10"), advertimos que, sin una consciencia procesual, el performer puede limitarse y recurrir directamente al software sin entender lo que conlleva realizar todo el proceso de diseño que está activando con su movimiento. Por lo tanto, este nuevo estado de consciencia que vive el performer como consecuencia de la era informática provoca una modificación total en la manera en que tendrá que concebir sus procesos de diseño expresivo, propiciando un antes y después en la constitución de un proyecto escénico interactivo.

Así pues, esta innovación de procesos de diseño como algoritmos generados por medio de la modelación virtual del movimiento humano no solo es aplicada al campo de las erudiciones técnicas, sino que su inclusión gradual va de la mano de los sistemas estéticos complejos. Se trata de una red disciplinar alimentada desde la tecnología digital por el mismo punto de partida de materiales y metodologías 
operacionales lanzados al encuentro aleatorio entre elementos hasta entonces tomados como paralelos.

\section{Dos estudios de casos: observación y análisis}

Se seleccionaron y se analizaron dos casos ya presentados dentro del desarrollo de este texto y que aportan a las conclusiones de nuestra hipótesis, por una parte. Y por otra, ambos casos tienen en común los equipos de programadores y performers dispuestos a la investigación académica y el hecho de haber desarrollado un lenguaje de programación propio, pero que se diferencian en el tiempo de trabajo consumado; a saber:

1- Equipo emmeLab -laboratorio de investigación y experimentación en nuevas interfaces para el arte, dependiente de la Secretaría de Ciencia y Técnica de la Facultad de Bellas Artes, UNLP- cuyo proceso de investigación cuerposistema-escena abarcó dos períodos comprendidos entre los años 2013 y 2014-2016. (El período 2013 está especialmente desarrollado en el Capítulo 2, Parte 2, apartado Danza performance interactiva de esta tesis). Asimismo, durante el período 2014-2016, el equipo se planteó dar cuerpo a un sistema programable (Cod05) que sea controlado a través de la captura de movimiento corporal expresivo (una serie de gestos o poses que serían detectados como entradas para intervenir el código) en tiempo real.

2- Equipo Speak -laboratorio independiente, interdisciplinar e interactivo abierto al público- cuyo proceso de investigación cuerpo-sistema-escena abarca un período comprendido entre los años 2006-2016 con sus propuestas articuladas y en evolución. Se consignó, para este análisis, lo acontecido en el año 2014 "Speak 4.0 Fractal Liquido" 133 en una plataforma performática en línea conocida como Waterwheel (Especialmente desarrollado en el Capítulo 2, Parte 3, Apartado Danza Performance Telemática y en Red de esta tesis). 
Las observaciones de campo se complementaron con las entrevistas semiestructuradas de respuesta abierta-; que fueron filmadas, editadas y subidas a los canales de video Youtube y Vimeo.

Seguidamente, presentaremos la información recabada de las unidades cuerpo, sistema y escena, como síntesis reflexiva del material derivado del cuaderno de notas que se elaboró durante el visionado del material videográfico y de las entrevistas.

\subsection{Estudio de caso 1: observación y análisis por unidad}

Es necesario aclarar que, dentro de esta síntesis del conjunto de datos cualitativos y cuantitativos, siempre vamos a estar arribando a conclusiones parciales, pues estamos conscientes de que el estudio de caso seleccionado está en etapa de exploración.

\subsubsection{Cuerpo físico y presencial}

Nivel de conciencia entre la ejecución de determinados movimientos globales y particularizados para generar un sistema de partículas, y su representación visual y estética.

Del análisis de la muestra que se tomó -de la selección de contenidos de las entrevistas y ensayos en soporte audiovisual con los participantes del estudio de caso-, se arriba a la conclusión parcial de que el nivel de coincidencia entre la formulación de gestos y movimientos globales y particularizados en función de lo que se va generando con las visuales es alto, por:

- $\quad$ sostener el interés por el sistema de partículas durante el extenso desarrollo de las pruebas abiertas ejecutadas en el laboratorio del emmeLab;

- otorgar relevancia a los movimientos globales y dar cuenta de la no operatividad del micromovimiento;

- $\quad$ percibir la acción corporal como generativa del diseño de partículas.

Nivel de vinculación entre el cuerpo, como volumen en movimiento, o como fragmento de cuerpo particularizado en gestos, que interactúa físicamente con los dispositivos e interfaces de la instalación.

Del análisis de la muestra, se arriba a la conclusión parcial de que el nivel de vinculación es alto, por: 
- otorgar relevancia al movimiento en relación con la producción de partículas: si la interfaz de la cámara Kinect no capta los ejes axiales del cuerpo presencial, no hay modificación de los procesos algorítmicos;

- reconocer el campo de detección, el espacio de registro de la cámara Kinect como sensor óptico.

\subsubsection{Cuerpo parametrizado y modelizado}

Nivel de conciencia del control del sistema de partículas mediante la captura de movimiento (una serie de gestos o poses) que será detectado como acceso para intervenir el código.

Del análisis de la muestra, se arriba a la conclusión parcial de que el nivel de coincidencia es medio, por sostener en un tiempo relativamente reducido de ejecución el interés por el control del sistema.

Nivel de vinculación entre el cuerpo como avatar en interacción con los dispositivos e interfaces del sistema.

Del análisis de la muestra, se arriba a la conclusión parcial de que el nivel de vinculación del control del sistema a través del movimiento es medio, por:

- otorgar una relevancia relativa al estudio del movimiento parametrizado para generar un algoritmo;

- otorgar una relevancia relativa a la detección del movimiento a través del sensor óptico.

\subsubsection{Sistema}

Nivel de conciencia y vinculación de la dimensión hardware: aquí se analizaron el rendimiento del computador y las interfaces periféricas de entrada y de salida para la detección del movimiento, y se arribó a la conclusión parcial de que el nivel de conciencia es alto, por otorgar relevancia a la detección del movimiento utilizando el sistema accesible de la cámara Kinect.

Nivel de conciencia de la dimensión software: aquí se analizaron las capacidades de interpretación, traducción y modelización del lenguaje de programación, y se arribó a la conclusión parcial de que el nivel de conciencia es alto, por:

- otorgar relevancia a lógicas simbólicas del movimiento para generar una coherencia entre el lenguaje informático y el lenguaje de la danza; 
- otorgar relevancia al sistema de partículas cuyo comportamiento está ligado al movimiento;

- otorgar relevancia al lenguaje específicamente visual (sistema de partículas) para funcionar escenográficamente.

Nivel de vinculación de la dimensión software: aquí se analizaron las capacidades de interpretación, traducción y modelización del lenguaje de programación con el lenguaje de movimiento corporal, y se arribó a la conclusión parcial de que el nivel de vinculación es medio, por:

- otorgar relevancia a la "interpretación estética o natural"134 del movimiento corporal;

- restar relevancia a la investigación sobre diseños de movimiento parametrizados en interacción con el sistema de detección y generación de algoritmos en tiempo real.

Nivel de conciencia de la dimensión humanware: aquí se analizaron las habilidades de interpretación, traducción y modelización del programador o desarrollador, y se arribó a la conclusión parcial de que el nivel de conciencia es alto, por:

otorgar relevancia a crear paradigmas de programación reconocibles para el usuario performer;

- otorgar relevancia a generar una herramienta de uso específico para el movimiento corporal en danza;

- otorgar relevancia a un lenguaje específicamente visual (sistema de partículas) para uso escenográfico.

Nivel de vinculación de la dimensión humanware: aquí se analizaron las habilidades de interpretación, traducción y modelización del programador o desarrollador desde el conocimiento interdisciplinar, y se arribó a la conclusión parcial de que el nivel de vinculación es medio, por:

restar relevancia a una investigación sostenida sobre el lenguaje del movimiento generado a partir de la interacción con un sistema interactivo;

otorgar relevancia a un lenguaje de movimiento disciplinar precedente al proceso de interacción con el sistema interactivo.

134 Equipo emmeLab: "Tras una pequeña investigación en danza encontramos que existen ciertos parámetros 'técnicos' en la disciplina que son utilizados para describir pasos y movimientos. Tratamos de explotar estos parámetros y, al mismo tiempo, intentamos que los gestos propios del lenguaje no estorbaran la posibilidad de una interpretación estética o natural por parte del performer". 


\subsubsection{Escena interactiva}

Nivel de conciencia de la dimensión modelo de interacción: aquí se analizaron los niveles de intervención según la reciprocidad, reacción o modificación de un entorno en situación interdisciplinar, y se arribó a la conclusión parcial de que el nivel de conciencia es alto, por:

- otorgar relevancia al vínculo programador-performer para generar visualizaciones en tiempo real;

- otorgar relevancia a un sistema generativo de visuales que sea controlado a través de un acto performático escénico.

Nivel de vinculación de la dimensión modelo de interacción: analizados los niveles de intervención según la reciprocidad, reacción o modificación de un entorno, se arribó a la conclusión parcial de que el nivel de vinculación es alto, por otorgar relevancia a la detección de movimiento para generar un entorno visual a nivel escenográfico.

Nivel de conciencia de la dimensión modelo de inmersión: analizados los niveles de ambientación según la actividad sensible de un entorno, se arribó a la conclusión parcial de que el nivel de conciencia es alto, por:

- otorgar relevancia al performer para elegir concentrarse en el acto de generar un algoritmo o que ese acto sea secundario;

- otorgar relevancia a la inmersión escénica si se ingresa un dato erróneo o ambiguo al programa.

Nivel de vinculación de la dimensión modelo de interacción: analizados los niveles de intervención según la reciprocidad, reacción o modificación de un entorno, se arribó a la conclusión parcial de que el nivel de vinculación es alto, por otorgar relevancia al diseño de un lenguaje de programación que opere con instrucciones predefinidas.

\subsubsection{Representación gráfica de la información}

Creemos que la información proporcionada por la medición puede consistir en una expresión evaluable de las características cualitativas. Asignar un símbolo de tipificación a una entidad empírica o a un hecho crea una alternativa que, a través del diseño de criterios de valoración e indicadores categóricos o de graduaciones, permite obtener una 
mayor transparencia a la hora de presentar los datos analizados. Por ende, es factible llegar a las conclusiones que faculten el contenido de nuestra hipótesis.

\begin{tabular}{|c|c|c|c|c|c|c|}
\hline \multirow{2}{*}{$\begin{array}{l}\text { Indicadores } \\
\text { Valoración UA }\end{array}$} & \multicolumn{3}{|c|}{ Nivel de conciencia } & \multicolumn{3}{|c|}{ Nivel de vinculación } \\
\hline & Alto & Medio & Bajo & Alto & Medio & Bajo \\
\hline \multicolumn{7}{|l|}{ UA CUERPO } \\
\hline Físico y presencial & $x$ & & & & $\mathrm{x}$ & \\
\hline Parametrizado/modelizado & & $x$ & & & $x$ & \\
\hline \multicolumn{7}{|l|}{ UA SISTEMA } \\
\hline Hardware & $x$ & & & $x$ & & \\
\hline Software & $\mathrm{X}$ & & & & $x$ & \\
\hline Humanware & $x$ & & & & $x$ & \\
\hline \multicolumn{7}{|l|}{ UA ESCENA INTERACTIVA } \\
\hline Interacción & & $x$ & & & $x$ & \\
\hline Inmersión & $x$ & & & $x$ & & \\
\hline
\end{tabular}

\subsection{Estudio de caso 2: observación y análisis por unidad}

Este caso específico no solo vincula interdisciplinarmente a programadores y performers, sino que, a través de la interfaz que propone la plataforma Waterwheel que transmitió en vivo, permitió a los usuarios de diferentes puntos del planeta intervenir en tiempo real las visuales del software libre Moldeo.org.

Para esta instalación se utilizaron -a través del protocolo de interfaces tangiblesdispositivos conectados a la red como tablets y smartphones (TUIO: TuioDroid para sistemas Android y TuioPad para sistemas iOS). Esta versión de la performance interactiva Speak ${ }^{135}$ fue intervenida por los dispositivos touch o táctiles apuntados a una dirección de internet, para compartir, junto a la performer, la afectación -que se generaba al tocar (touch) la pantalla del celular programado- de las visuales, la imagen y del sonido.

135 Véase:

<https://ia600201.us.archive.org/28/items/EscritosSobreLaObraSpeakDeAlejandraCerianiFabricioCostaYF abin/Speak4.0Fractal-LiquidEnglish.pdf>. 


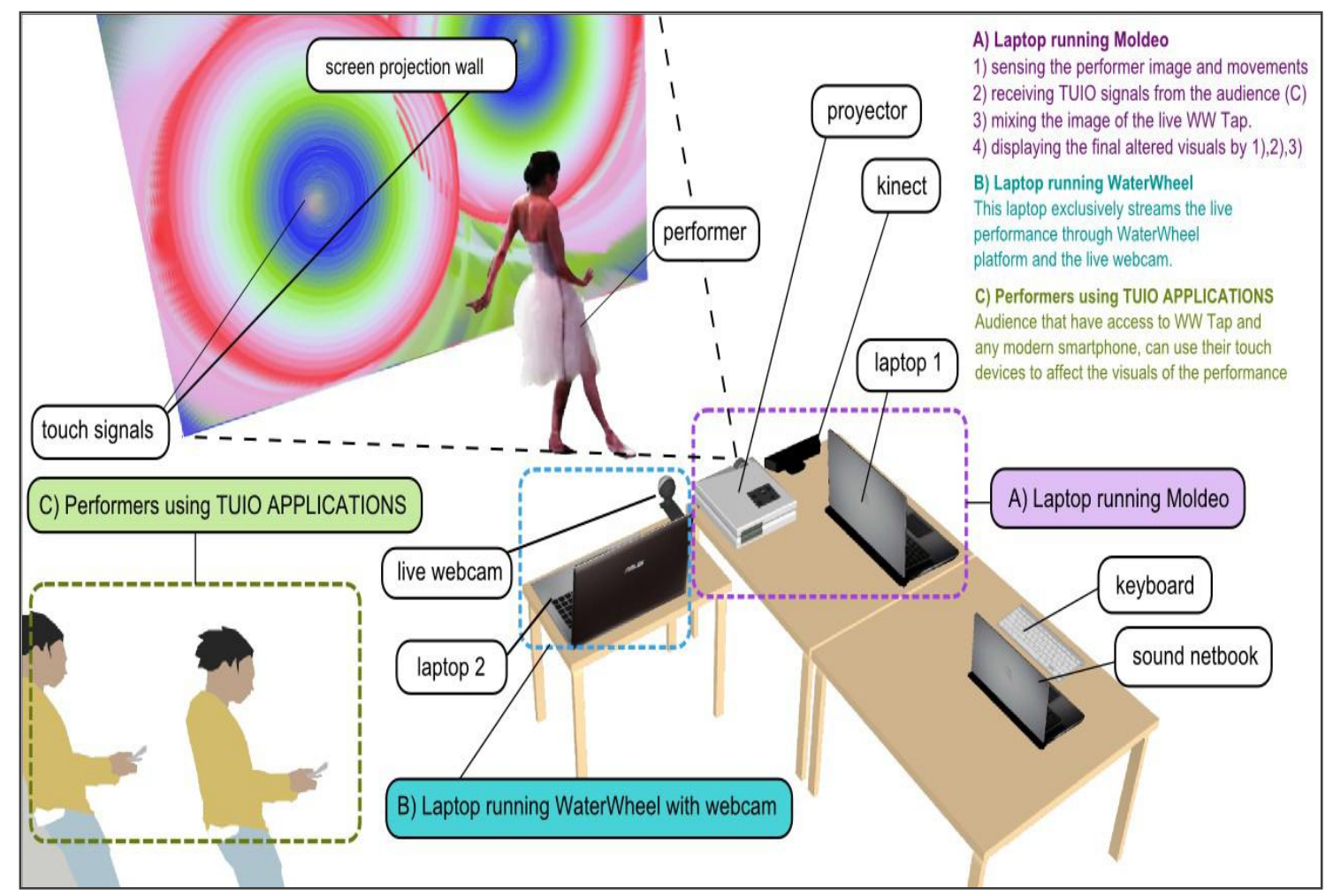

SPEAK 4.0 / LIQUID. Especificaciones técnicas
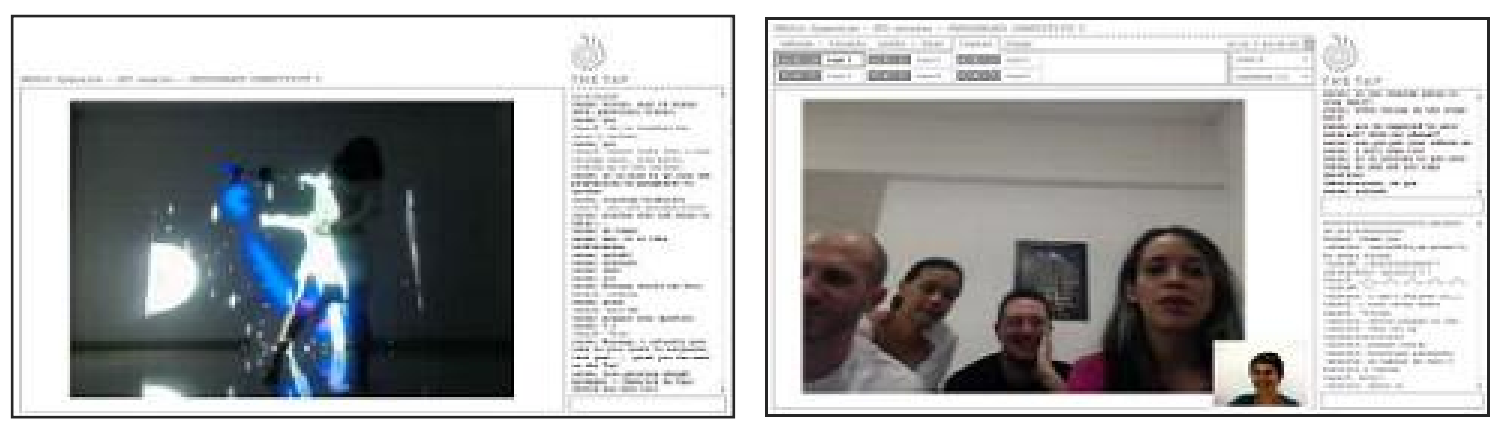

Performance en vivo e intercambios en streaming en la plataforma Waterweel

\subsubsection{Cuerpo físico y presencial}

Nivel de conciencia alto-medio-bajo entre la ejecución de determinados movimientos globales y particularizados en función de generar un sistema de partículas, su representación visual y su operatividad conectiva.

Del análisis de la muestra, se arriba a la conclusión parcial de que el nivel de coincidencia entre la formulación de gestos y movimientos globales y particularizados en función de lo que se va generando con las visuales es alto, por: 
- $\quad$ sostener el interés por el sistema de partículas durante el proceso en tiempo real en el desarrollo de la performance en conexión ubicua;

- otorgar relevancia a los movimientos globales así como a la operatividad del micro-movimiento.

Estos dos motivos permitieron percibir la acción generativa de la propia dinámica corporal por sobre el diseño de partículas.

Nivel de vinculación alto-medio-bajo, entre el cuerpo, como volumen en movimiento, o como fragmento de cuerpo particularizado en gestos, que interactúa físicamente con los dispositivos e interfaces de la instalación.

Del análisis de la muestra, se arriba a la conclusión parcial de que el nivel de vinculación es alto, por:

- otorgar relevancia al movimiento en relación con la producción de partículas. Si la interfaz de la cámara Kinect no capta los ejes axiales del cuerpo presencial, no hay modificación de los procesos algorítmicos;

- reconocer no solo el campo de detección en el espacio de registro de la cámara Kinect como sensor óptico, sino, también, en el toque (touch) de los dedos de las manos en otros dispositivos conectados a la red, como tablets y smartphones a través del protocolo de interfaces tangibles.

\subsubsection{Cuerpo parametrizado y modelizado}

Nivel de conciencia del control del sistema de partículas mediante captura de movimiento (una serie de gestos o poses) que será detectado como acceso para intervenir el código.

Del análisis de la muestra, se arriba a la conclusión parcial de que el nivel de conciencia del control del sistema a través del movimiento es alto, por sostener ese interés durante el tiempo de duración total de la performance interactiva compartida con los participantes ubicuos.

Nivel de vinculación entre el cuerpo como avatar en interacción con los dispositivos e interfaces del sistema.

Del análisis de la muestra, se arriba a la conclusión parcial de que el nivel de vinculación del control del sistema a través del movimiento es alto, por:

- otorgar relevancia al estudio del movimiento parametrizado para generar un algoritmo compartido; 
- otorgar relevancia a la detección del movimiento a través del sensor óptico y los dispositivos touch.

\subsubsection{Sistema}

Nivel de conciencia y vinculación de la dimensión hardware. Aquí se analizaron el rendimiento del computador, las interfaces periféricas de entrada y de salida, y los dispositivos táctiles para la detección del movimiento, y se arribó a la conclusión parcial de que el nivel de conciencia es alto, por:

- otorgar relevancia a la detección del movimiento utilizando el sistema accesible de la cámara Kinect;

- otorgar relevancia a la detección del movimiento utilizando el protocolo de interfaces tangibles.

Nivel de conciencia de la dimensión software. Aquí se analizaron las capacidades de interpretación, traducción y modelización del lenguaje de programación, y se arribó a la conclusión parcial de que el nivel de conciencia es alto, por:

- otorgar relevancia a lógicas de captura del movimiento para generar una coherencia entre el lenguaje informático y el lenguaje de la danza;

- otorgar relevancia al sistema de partículas, pues su comportamiento está ligado al movimiento colaborativo;

- otorgar relevancia al lenguaje específicamente visual (sistema de partículas) vinculado a la temática de la plataforma convocante para funcionar escénicamente.

Nivel de vinculación de la dimensión software. Aquí se analizaron las capacidades de interpretación, traducción y modelización del lenguaje de programación con el lenguaje de movimiento corporal, y se arribó a la conclusión parcial de que el nivel de vinculación es medio, por:

- otorgar una excesiva relevancia a las capacidades del software conectado en tiempo real a las redes de internet;

- dar relativa relevancia a la investigación sobre diseños de movimiento parametrizados en interacción global con el sistema de detección y generación de algoritmos en tiempo real. 
Nivel de conciencia de la dimensión humanware. Aquí se analizaron las habilidades de interpretación, traducción y modelización del programador o desarrollador, y se arribó a la conclusión parcial de que el nivel de conciencia es alto, por:

- otorgar relevancia a crear paradigmas de programación reconocibles para el usuario performer global;

- otorgar relevancia a generar una herramienta de uso ubicuo y en conectividad para el movimiento corporal en danza performance interactiva;

- otorgar relevancia a un lenguaje específicamente visual (sistema de partículas) para uso e interacción escenográfica en red.

Nivel de vinculación de la dimensión humanware. Aquí se analizaron las habilidades de interpretación, traducción y modelización del programador o desarrollador desde el conocimiento interdisciplinar, y se arribó a la conclusión parcial que el nivel de vinculación es medio, por:

- dar relativa relevancia a una investigación sostenida sobre el lenguaje del movimiento generado a partir de la interacción con un sistema táctil;

- otorgar relativa relevancia al estudio del movimiento global y particular en el proceso de interacción colaborativo.

\subsubsection{Escena interactiva}

Nivel de conciencia de la dimensión modelo de interacción. Se analizaron los niveles de intervención según la reciprocidad, reacción o modificación de un entorno en situación interdisciplinar, y se arribó a la conclusión parcial de que el nivel de conciencia es alto, por:

- otorgar relevancia al vínculo programador-performer-usuarios para generar visualizaciones en tiempo real;

- otorgar relevancia a un sistema generativo de visuales que sea controlado a través de un acto performático escénico y comunitario en conexión.

Nivel de vinculación de la dimensión modelo de interacción. Se analizaron los niveles de intervención según la reciprocidad, reacción o modificación de un entorno, y se arribó a la conclusión parcial de que el nivel de vinculación es alto, por otorgar relevancia a la detección de movimiento para generar un entorno visual y sonoro a nivel local y ubicuo. 
Nivel de conciencia de la dimensión modelo de inmersión. Se analizaron los niveles de ambientación según la actividad sensible de un entorno, y se arribó a la conclusión parcial de que el nivel de conciencia es alto, por:

- otorgar relevancia al performer para elegir concentrarse en el acto de generar un algoritmo individualmente o que ese acto sea compartido;

- otorgar relevancia a la inmersión escénica pensando un resultado visual y sonoro colaborativo.

Nivel de vinculación de la dimensión modelo de interacción. Se analizaron los niveles de intervención según la reciprocidad, reacción o modificación de un entorno, y se arribó a la conclusión parcial de que el nivel de vinculación es alto, por otorgar relevancia al diseño de un lenguaje de programación que opere juntamente con otros dispositivos conectados a la red

\subsubsection{Representación gráfica de la información}

Consideramos que la información proporcionada por la medición puede consistir en una expresión evaluable de las características cualitativas. Asignar un símbolo de tipificación a una entidad empírica o a un hecho crea una alternativa que, a través del diseño de criterios de valoración e indicadores categóricos o de graduaciones, permite obtener una mayor transparencia a la hora de presentar los datos analizados. Por ende, llegar a las conclusiones que faculten el contenido de nuestra hipótesis.

\begin{tabular}{|c|c|c|c|c|c|c|}
\hline \multirow{2}{*}{$\begin{array}{l}\text { Indicadores } \\
\text { Valoración UA }\end{array}$} & \multicolumn{3}{|c|}{ Nivel de conciencia } & \multicolumn{3}{|c|}{ Nivel de vinculación } \\
\hline & Alto & Medio & Bajo & Alto & Medio & Bajo \\
\hline \multicolumn{7}{|l|}{ UA CUERPO } \\
\hline Físico y presencial & $x$ & & & $x$ & & \\
\hline Parametrizado/modelizado & & $x$ & & $\mathrm{X}$ & & \\
\hline \multicolumn{7}{|l|}{ UA SISTEMA } \\
\hline Hardware & $x$ & & & $x$ & & \\
\hline Software & $\mathrm{x}$ & & & $x$ & & \\
\hline Humanware & $\mathrm{x}$ & & & $\mathrm{X}$ & & \\
\hline \multicolumn{7}{|l|}{ UA ESCENA INTERACTIVA } \\
\hline Interacción & $\mathrm{X}$ & & & $\mathrm{X}$ & & \\
\hline Inmersión & $x$ & & & $\mathrm{x}$ & & \\
\hline
\end{tabular}




\title{
48. Conclusiones generales
}

La sistematización de los datos obtenidos a través de los distintos instrumentos de recolección (entrevistas semiestructuradas y observación de campo) permitió organizar la información acerca de la interacción del cuerpo disciplinar con sistemas de programación pensados específicamente para ser controlados mediante la captura de movimiento.

\begin{abstract}
Para que las conclusiones sean válidas y se esté en condiciones de sustentar eventuales generalizaciones resulta especialmente relevante alcanzar el punto de saturación, momento en el cual la incorporación de nuevos relatos no modifica en nada sustancial la construcción progresiva de la representación del objeto sociológico que se estudia. El análisis de varios testimonios simultáneamente con una vocación comparativa refuerza la validez de las regularidades y patrones que se encuentran. El descubrimiento de mecanismos genéricos permite aproximarse a la generalización (Seid, 2013: 4).
\end{abstract}

El estudio de lo documentado dio lugar a la concreción de uno de los objetivos finales: actualizar el marco conceptual que permita reflexionar sobre la articulación de estos lenguajes disciplinares combinados en relación con su especificidad en el arte actual. Entonces podemos confirmar y generalizar la hipótesis diciendo que, en principio, los nuevos diseños de programación y desarrollo de sistemas interactivos electrónicodigitales no están revolucionando la danza performance, sino expandiéndola, o en el mejor de los casos, la danza performance -como disciplina artística escénica- está apropiándose de ellos, por una parte, como si se tratase de nuevos recursos escénicos; y, por otra, reconociéndolos como "productores de discursividad" (Carlón, 2016: 16) y portadores de nuevos sentidos.

Los diferentes elementos y procedimientos vinculados a lo escénico, al adaptar o al apropiarse de nuevos recursos y discursos, dejan entrever que no todos sus componentes y experiencias dan respuesta o están disponibles para renovar "conceptualmente" las formas y las metodologías de interacción en la creación y producción escénica. La discusión hace foco en la incumbencia de lo disciplinar: la danza performática vinculada a los sistemas generativos e hipermediados a través de la captura del movimiento y de la conexión remota. Por esto mismo, volvemos a plantearnos cuestiones que atañen tanto a performers bailarines como a performers programadores desarrolladores y usuarios de redes ubicuas: 
- Cuál es la concepción desde donde se aborda la configuración del movimiento ante un sistema escénico interactivo electrónico-digital inmersivo en tiempo real.

- Cuál es la concepción de la formación disciplinar ante la incorporación de las tecnologías aplicadas en interacción con el cuerpo y el espacio inmersivo y ubicuo.

Así, se hace inevitable la revisión de lo vigente para la aparición de nuevas concepciones que conlleven un desvío del flujo de las prácticas actuales. En consecuencia, planteamos que, respecto a la unidad de análisis sistema (hardware, software, humanware), se hace imperiosa una reformulación que, a través de la reflexión crítica del concepto de interdisciplinariedad, reconduzca los modos de relacionamiento para configurar, investigar y producir con otras artes ajenas a su idiosincrasia.

Asimismo, para la unidad de análisis escena interactiva, se requiere de nuevas maneras de habitarla a través de la vinculación espacial y los usos de las visuales descentralizadas.

Respecto a la unidad de análisis cuerpo (presencial y modelizado), indicamos que el movimiento no es el único imperativo que define la danza y allí instalamos una problemática: los sistemas de captación interactivos (cámara sensor Kinect la más utilizada en el presente) no operan -por ejemplo- con la inmovilidad corporal. Lo que significa para las disciplinas corporales una dificultad para poder desarrollar otro paradigma de investigación en este campo.

En este sentido, estaríamos puntualizando solo en aquella danza performance que en tiempo real vincula el movimiento con la escritura de código. Es decir, habrá un diseño corporal consecuente y consciente de ser capturado por una interfaz o dispositivo, traducido, parametrizado y modelizado en pos de interactuar con una programación o con otros performers que acabaran generando y controlando un sistema de partículas con sus cualidades, y comportamientos condicionados en función de estos diseños conscientes tanto sea en entornos locales como en entornos conectados para la creación y producción artística. Por lo tanto, aportaremos, de los casos analizados metodológicamente, las siguientes conclusiones diferenciadas por cada estudio de caso. De este modo, discriminaremos el uso de tecnología en contextos mediados e hipermediados, es decir, en contextos convergentes y colaborativos del espacio arquitectónico local y en contextos convergentes y colaborativos del espacio ubicuo de internet. Hacer esta diferenciación nos parece importante puesto que, como manifiesta Mario Carlón (2016: 19): 
transformación en las dimensiones principales de la cultura (o, al menos, en la forma en que esas dimensiones se articulan).

Un universo algorítmico digital irrumpe con sus resignificaciones en el devenir del espacio y del tiempo físico y virtual. Se trata de otras presencias de los cuerpos en el espacio interactivo e inmersivo local, por una parte, y que conlleva otra gramática del lenguaje de la danza performance a la que denominamos danza performática algorítmica. Es decir, aquella configuración del movimiento corporal interactivo que incluye la conciencia de estar aplicando sistemas generativos informáticos a partir de un algoritmo. Por otra parte, esta otra dimensión ubicua que propone un nuevo espacio hipermediado para la danza performance a la que proponemos designar danza performance en redes hipermediadas. Es decir, aquella configuración del movimiento corporal interactivo que incluye la conciencia de aplicar nuevas lógicas productivas del mundo digital y comprender cómo esta favorece la creación de entornos colaborativos.

Finalmente, y en ocasión de reconsiderar la estimación realizada sobre los criterios de valoración e indicadores en ambos casos de estudio presentados, indicaremos que las diferencias entre niveles altos y medios se vinculan -entre otras apreciaciones posibles- a una cuestión temporal: Speak lleva más de diez años investigando con su software de creación Moldeo.org, y emmeLab lleva aproximadamente cuatro años con su software de creación Cod05. En consecuencia, las diferencias se manifiestan así en el tiempo de estudio dedicado que mantienen ambos equipos y en las estrategias empíricas adoptadas tanto sea cuantitativa o cualitativamente en este tipo de investigación técnico-artística interdisciplinar. Hay una lógica subyacente que devela la importancia fundamental de aquellas acciones que se practican en la prosecución de una investigación. Acciones de sostener en el tiempo, de sustentar, de acompañar, de colaborar, de intercambiar con la comunidad a la cual se pertenece, de ser consecuentes y reconocer otros estudios afines.

\subsection{Estudio de caso 1: hacia una danza performática algorítmica}

La hibridación es un fenómeno multiforme y de gran complejidad con el que se vinculan algunas de las transformaciones del acceso al conocimiento en las últimas décadas. Los intentos de establecer una conceptualización de dicho fenómeno para fines del análisis cultural -y artístico, en nuestro caso específico- han sido una 
preocupación latente, sobre todo a partir del año 2000, cuando la tecnología digital impactó enormemente.

En esta tesis, nos hemos propuesto discernir de cuánta consciencia, es decir, de qué grado de aprehensión de conocimiento respectivo disponemos quienes trabajamos "interdisciplinariamente". No solo desde los procesos de producción sino, y principalmente, desde los modos de acceso a la comprensión que esa hibridación depara. Seguimos los pasos de Juan Samaja (2003: 29) cuando advierte que "debemos examinar minuciosamente no solo las semejanzas sino también las diferencias".

Esa fue nuestra búsqueda a lo largo de veinte años, la idea fue observar y analizar cómo esos modos y procesos han variado. Por ende, estamos en condiciones de afirmar que nos desenvolvemos en una mutación permanente en nuestras prácticas artísticas híbridas; pero de manera asincrónica entre el ritmo de los cambios estructurales en una sociedad y el ritmo con que nuestra consciencia investigativa ${ }^{136}$ pueda corresponder. O bien, como lo formula Nicolas Bourriaud (2013: 9):

\begin{abstract}
Es importante aprehender las transformaciones que se dan hoy en el campo social, captar lo que ya ha cambiado y lo que continúa transformándose. ¿Cómo podemos comprender los comportamientos artísticos [...] y los modos de pensar que los sostienen si no partimos de la situación misma de los artistas?
\end{abstract}

Por consiguiente, asumir esa asincronía en los procesos de producción artística plantea nuevas maneras de apropiarse de los diversos modos en que las prácticas artísticas se vienen desarrollando en el ámbito de la cultura contemporánea. La hibridación entre la danza performance interactiva y la informática se presenta cuando programadores y bailarines performers ponen en reciprocidad dichas fuerzas creacionales. Se expresa aquí una condición de mediación entre lo que se considera o representa, una dependencia que pone en tensión y conflicto estas prácticas sistemáticas, hegemónicas y supeditadas.

Al respecto, es dicha "dependencia" la que hemos vuelto evidente para poder analizarla. Trazar una visión dinámica del sentido y dirección que siguen los procesos de metamorfosis interdisciplinares -a partir del reconocimiento de las experiencias resultantes que, sin duda, pueden implicar aspectos cualitativamente nuevos- arroja, por lo general, resultados automatizados ante un creciente patrón unificador.

\footnotetext{
136 Podríamos examinar, en principio, que tal como lo describe Samaja en el método de la tenacidad o de la intuición o "corazonada" así como en el método de la metafísica -que podríamos conjugar con el hacer de los artistas- se "ven" estos fenómenos de cambio tanto como se "reflexiona" con anticipación sobre ellos, pero de cuyo trabajo particular no se registran impactos sincrónicos a gran escala sino en ciertos campos de incumbencia cultural.
} 
La expansión de las redes sociales -como síntoma de una nueva etapa- es un hecho aún más indiscutible, puesto que, han puesto definitivamente el concepto de "contacto virtual" visual, sonoro y corpóreo en el centro de la escena, originando así un giro antropocéntrico en la historia de la mediatización.

En la tesis de magíster y en su hipótesis anterior, se postuló el pasaje de una perspectiva antropocéntrica y disciplinar a otra no antropocéntrica e interdisciplinar. Además, se produjo el acercamiento a la situación actual en la que la emergencia y consolidación de un nuevo sistema de mediatización con base en internet nos insta a comprender la evolución de los procesos "materiales" hacia la hipermediatización entre cuerpo, danza performance y tecnología.

Teniendo en cuenta que la presencia de internet se ha convertido en una condición estructural sobre la cual se soportan todas las prácticas actuales que comprenden lo cultural, económico, político, etcétera, en base a un contexto digital en el que sistemáticamente todos los aspectos de la vida se han mediatizado, es lógico suponer la mutación de la vida física, virtual y mental. Por ende, el espacio que reconocemos como un hiperespacio -donde se construyen y se proyectan las principales prácticas performativas contemporánea- evidencia este paso de las mediatizaciones hacia las hipermediatizaciones.

Otra cuestión para tener en cuenta es la transformación en el campo del sentido, esto es, producir diferencia, producir lo que hasta allí no estaba en proceso y alterar, de ese modo, lo que se constituía solo como situación coreografiada, prevista. ¿Y lo imprevisto? Para responder esto, es preciso repreguntarse ¿para quién hay imprevisibilidad, es decir, transformación por funcionamiento diferente a lo esperado? ¿Para el performer o para el programador (léase: cuerpo presente y modelizado o sistema software y humanware)? Concluyentemente, la renovación de lo previsible solo puede verse como tal desde el punto de vista de lo metodológico, donde las expectativas y el reconocimiento de otras apropiaciones posibilitan la conexión que activará un proceso diferente para ambos. Pero si pretendemos distinguirlo desde el punto de vista de la resultante escénica, las innovaciones para nuestras tecnologías low-tech no han sido significativas.

Retomando la unidad de análisis cuerpo con relación a las hipótesis planteadas en ambas investigaciones (de maestría y doctoral), una reincidente concepción del cuerpo interactivo reclamado desde las propias disciplinas aboga por un cuerpo unificado, ya no desdoblado en un cuerpo físico y en un cuerpo virtual, sino en "uno": "El cuerpo y su proyección no, sino uno", como manifiesta Soledad Belén (2016: 19').

Acerca de esta idea de unidad corporal ya hemos expresado que sin una consciencia procesual el performer queda limitado a recurrir directamente al software sin 
aprehender lo que está activando con su propia dinámica corporal presencial-espacial y virtual-modelizada consciente. Por lo tanto, este nuevo estado de consciencia que vive el performer -como consecuencia de la interacción escénica con sistemas de sensado del movimiento corporal- crea una nueva condición de concebir sus procesos de diseño expresivo, propiciando así un antes y un después en la constitución de un proyecto escénico interactivo.

Las prácticas escénicas interactivas fueron observadas y analizadas desde la espacialidad creada a partir de la materialidad de sus sistemas reactivos o interactivos $\mathrm{y}$, desde la subjetividad de quienes ocupan esas espacialidades, esto es, performers y desarrolladores. Vale aclarar que hay una evolución compleja y constitutiva de las materializaciones actuantes en términos de reciprocidad individual o colectiva. Esto no quiere decir que la interdisciplinariedad sea finalmente simétrica, nada indica que una de las disciplinas tenga los mismos valores o conforme un campo idéntico al de las otras. Precisamente, la transformación emergente en cualquier proceso de mediatización escénica sería la transformación de la presencia corporal y su dinámica. La afinidad de quienes intervienen puede coincidir o diferir. Está claro que la tecnología ha impactado de manera profunda en la construcción básica de la interactividad escénica, individual o colectiva. La materialización en prácticas conscientes y continuas, en la medida en que habilita la inscripción de una presencia corporal autónoma, permite la identificación de tipos de interacción escénica.

Para cerrar, nos gustaría manifestar la restricción del campo artístico en donde los que operan con sistemas y tecnología digital interactiva -artistas, críticos y teóricos- parten de una lógica concreta que, en general, aspira a hallar las analogías y las diferencias, espaciarse para que el arte con su especificidad crítica pueda proceder interdisciplinariamente.

\footnotetext{
Siempre que hablamos de tecnología suponemos -culturalmente- que todo es posible, estamos acostumbrados a una mirada positivista: "con esto la bailarina va a poder volar". Yo ya tengo quince años trabajando con tecnología, mi camino me ha mostrado siempre lo contrario: todo lo que la tecnología no puede, todo lo que la tecnología no abarca, todo lo que la tecnología dispara que no está contemplado (Causa en emmeLab, 2016: 4'40").
}

Pero si atendemos a las semejanzas entre el arte contemporáneo y las prácticas sociales no artísticas, creemos encontrar una clave que impregna toda experiencia actual, sea esta del ámbito académico o del espectáculo. Estas prácticas -según cómo las resolvemos hoy- hubieran sido irrealizables sin la digitalización e internet; 
productos convergentes de este tiempo pero, a la vez, que conforman en tanto instauran, en gran parte, las condiciones espaciales y temporales futuras. Nos estamos apropiando de nuestros conocimientos prácticos de modo radicalmente distinto del que lo hicimos hasta ahora.

Tal como lo expresa el artista mediático, director, coreógrafo y compositor Klaus Obermaier, ante la inquietud sobre el dominio de los sistemas interactivos digitales y la división entre escenario, performer, público y obra: "Pienso que la única solución es actuar, como siempre" (Obermaier, 2015).

\subsection{Estudio de caso 2: hacia una danza performance de redes hipermediadas}

Plantearse y desarrollar una danza performática que interactúe en las redes de internet requiere, entre otros recursos, conocer cómo las expresiones técnico culturales del pasado reciente pueden ser renovadas con las ventajas de la tecnología digital de vanguardia. Siempre en el terreno de lo low-tech, las performances interactivas y distribuidas precisan -para superar el estadio de "evento técnico"- de una indagación consciente y una experimentación interdisciplinar. Esto conllevaría un punto clave que exige la modificación de la relación de los artistas con el mundo y con los modos de producción en su totalidad.

Aquellos cambios epistemológicos dieron respuesta en las nuevas estructuras de la percepción que hoy se renuevan utilizando todos los dispositivos e interfaces conocidas -la pantalla y sus dimensiones-, pero exigiendo otros comportamientos.

Como equipo de investigación artística, Speak forma parte de estas iniciativas que, en los últimos años, apuestan, desde el plano artístico, productivo y académico, por un espacio de trabajo común que sigue el modelo denominado laboratorio. Esta convergencia de arte, tecnología y ciencia genera espacios de encuentro y de experimentación colectiva principalmente desde el acceso a la Web 2.0 que ha implicado, básicamente, una nueva forma de pensar e interactuar democráticamente con la Red y en ella.

Por consiguiente, estos laboratorios tienen como función principal ofrecer plataformas que facilitan la participación de los usuarios en los procesos de experimentación y desarrollo de proyectos interactivos llegando a crear su propio software libre y colaborativo. Tal y como ocurre en la Red, los participantes que se reúnen para colaborar -bailarines, performers, programadores, técnicos, etc.- tienen diferentes perfiles, y esta mezcla de saberes permite que se diseñen proyectos ecuánimes entre 
la postulación corporal, tecnológica o científica, pero no por ello se pueden eludir la inclusión y los requerimientos técnicos para su desarrollo.

Una de las claves para que se hayan dado estas intervenciones en red es la capacidad -no solo de los programadores, sino de los miembros de la plataforma en línea- para proveerse de los protocolos y las reglas para producir y gestionar recursos en este entorno colectivo. Esta operatoria, a cuatro años de la presentación de la performance Speak 4.0 / Liquid en la plataforma en línea, ha dado un salto cualitativo absoluto; a tal punto que el propio software Moldeo.org está pudiendo ser operado desde la web, sin necesitad de instalarlo en la memoria del hardware.

Por su parte, proyectar una puesta colaborativa en el espacio híbrido de internet implica el acompañamiento de una mirada y una participación mediática e hipermediática. En este sentido, lo que se está jugando en la nueva escena no es solo la imagen de los cuerpos mediatizados, sino la mirada del espectador hipermediatizado. Nuevamente, se trata de una mirada cinematográfica, televisiva, de video; fragmentada, interactiva o hipermediada construida por cada medio. El usuarioespectador se percibe a sí mismo en el acto performático de mirar y redescubre el modo que propone cada medio.

La puesta en escena de la imagen del cuerpo en la web y las acciones que conlleva la velocidad -por ejemplo del acto de linkear- habilitan una mirada y un comportamiento cada vez más mediatizado. Normalmente, se ha utilizado el video para lograr un contacto más interactivo entre actores y público, que se hacen presentes en escena por medio de la imagen, especialmente en el campo del performance y las instalaciones.

"El tema del video contemporáneo muy pocas veces es libre", asegura Nicolas Bourriaud (2013: 96):

De la manera en que los artistas enfoquen este problema depende el futuro del arte como instrumento de emancipación, como herramienta política que busca la liberación de las subjetividades. Ninguna técnica constituye un tema para el arte.

Así, nos disponernos a la reflexión sobre la necesidad de imbricar una metodología para la escena teledistribuida que -creemos- pondrá en evidencia cómo articular las intervenciones escénicas en red y, sobre todo, cómo interpretar y concatenar una experiencia transdisciplinar situada. Esta metodología establecerá relaciones más profundas entre la tecnología, las artes escénicas, el movimiento, el sonido, etcétera, en interacción directa con los datos digitales. A la par que, nos pondrá en relación con otro, ubicuo. 
Colaborar con el objetivo común de incidir en la investigación, de coparticipar de los conocimientos en la comunidad artística; formar, crear comunidades y debatir en torno a los conceptos de escena virtual y conectiva para la danza performance es nuestro gran desafío y el modo de canalizar nuestra pasión. "De lo contrario, el arte se convertirá en un elemento de decoración high-tech, en una sociedad cada vez más inquietante" (Bourriaud, 2013: 97). Entonces, nos proponemos desnaturalizar los comportamientos de nuestro cuerpo disciplinar para desterritorializar nuestra subjetividad construida desde la mediación contemporánea. En suma, nos ocuparemos de estudiar los cambios desde la poética del cuerpo y su consciente tecnologización.

\section{Referencias bibliográficas}

Bourriaud, Nicolas (2013), Estética relacional, Buenos Aires, Adriana Hidalgo editora.

Carlón, Mario (2016), “Las nociones de la teoría de la mediatización, revisitadas en el nuevo contexto teórico y discursivo contemporáneo", en Visualidad y dispositivo(s). Arte y técnica desde una perspectiva cultural, Buenos Aires, Ediciones Universidad Nacional General Sarmiento.

Ceriani, Alejandra (2011), “Espacio digital y cuerpo expresivo”, Diego Carrera (comp.), en Configuraciones de la danza. Sonido y video del cuerpo, Montevideo, Universidad de la República.

Ceriani, Alejandra (2012), “El descentramiento: cuerpo-danza-interactividad", en Arte del cuerpo digital: nuevas tecnologías y estéticas contemporáneas, La Plata, Editorial de la Universidad Nacional de La Plata.

Inde, Don (2002), Los cuerpos en la tecnología. Nuevas tecnologías: nuevas ideas acerca de nuestro cuerpo, Barcelona, Universidad Abierta de Cataluña

Santana, Ivani (2006), Dança na cultura digital, Salvador, Editora da Universidade Federal da Bahia.

Sarquis, Jorge (2011), Itinerarios del Proyecto 1. Ficción Epistemológica, Buenos Aires, Nobuko.

Seid, Gonzalo (2016), “La pluralidad de procedimientos para alcanzar validez en las investigaciones cualitativas", Revista Latinoamericana de Metodología de la Investigación Social N. ${ }^{0}$ 12, año 6, Argentina, pp. 41-55.

Ynoub, Roxana (2015), Cuestión de método. Aportes para una metodología crítica, México, Cengage Learnng Editores. 


\subsection{Referencias electrónicas}

AA. VV. (2006), "Competencias tecnológicas de los trabajadores informáticos argentinos. Más allá de las restricciones de demanda y oferta", en La informática en la Argentina. Un desafío a los problemas de especialización y competitividad, Buenos Aires, Universidad Nacional de General Sarmiento, Prometeo [en línea]. Disponible en: <http://www.littec.ungs.edu.ar/pdfespa\%F1ol/1\%20Partetrabajadoresinform\%E1ticos.pdf>.

AA. VV. (2014), SPEAK 4.0/LIQUID [en línea]. Disponible en: <https://ia600201.us.archive.org/28/items/EscritosSobreLaObraSpeakDeAlejandr aCerianiFabricioCostaYFabin/Speak4.0Fractal-LiquidEnglish.pdf $>$ y $<$ http://waterwheel.net/media_items/view/4905>.

AA. VV. (2016), Un lenguaje de programación para el cuerpo. Abordaje retórico sobre la programación y su articulación con las artes performáticas, Laboratorio emmeLab, Facultad de de Bellas Artes, Universidad Nacional de La Plata [en línea]. Disponible en: <http://sedici.unlp.edu.ar/handle/10915/57348>.

Arreguín Garmendia, Luis Gilberto (2011), Utilización del trabajo interdisciplinario y del lenguaje multimedia en la danza contemporánea: el bosque una propuesta práctica, Departamento de Escultura y Pintura, Facultad de Bellas Artes, Universitat Politècnica de València, España [en línea]. Disponible en: $<$ https://riunet.upv.es/bitstream/handle/10251/13834/tesisUPV3696.pdf?sequenc $e=1>$.

Causa, Emiliano (2014), "Cuerpo, movimiento y algoritmo", en Emiliano Causa (comp.), Invasión generativa. Fronteras de la generatividad en las tres dimensiones, la robótica y la realidad aumentada, Buenos Aires, Invasores de la generatividad [en línea]. Disponible en: <http://www.invasiongenerativa.com.ar/descargas/INVASION_GENERATIVA_2. pdf>.

Causa, Emiliano y Andrea Sosa (2013), "La computación afectiva y el arte interactivo" [en línea]. Disponible en: $<$ http://biopus.com.ar/textos/Computacion_Afectiva_Y_Arte_InteractivoEmiliano_Causa-Andrea_Sosa.pdf>.

Ceriani, Alejandra (2015), Génesis y desarrollo de la escena tecnológica de Buenos Aires: estudio de lo digital en la danza performance (1996-2016) [en línea]. Disponible en: <http://www.alejandraceriani.com.ar/pdf/TESIS_DOC.pdf>.

Costa Alisedo, Fabricio (2014), "De la ambientación interactiva a la instalación ecosistémica", Buenos Aires, Universidad Nacional de las Artes [en línea]. 
<http://www.biopus.com.ar/tarcisio/pfds_papers/Fabricio\%20Costa\%20Alisedo_2 014.pdf>.

Escudero, María Carolina (2014), "Educación corporal: enseñanza, cuerpo y subjetividad", en VIII Jornadas de Sociología de la UNLP, 3 al 5 de diciembre de 2014, Ensenada, Argentina [en línea]. Disponible en: <http://www.memoria.fahce.unlp.edu.ar/trab_eventos/ev.4701/ev.4701.pdf>.

Giannetti, Claudia (2004), "El espectador como interactor. Mitos y perspectivas de la interacción", Conferencia pronunciada en el Centro Gallego de Arte Contemporáneo de Santiago de Compostela, [en línea]. Disponible en: <http://www.artmetamedia.net/pdf/4Giannetti_InteractorES.pdf > .

Hlebovich, Ludmila (2013), "El resto como resultado. Algunas consideraciones sobre la obra performática CuerpoMóduloCódigo", en Arte y Cultura. Anuario 2013, Prosecretaría de Arte y Cultura, Secretaría de Extensión Universitaria, Universidad Nacional de La Plata [en línea]. Disponible en: <http://www.unlp.edu.ar/uploads/docs/anuario_2013_de_arte_y_cultura.pdf>.

Martínez Pimentel, Ludmila C. (2010), La coreografía digital interactiva, Universidad Federal de Bahía, Programa de Postgrado en Danza, Grupo de Investigación en Ciberdanza, Laboratorio de Investigaciones Avanzadas del Cuerpo, Brasil [en línea]. Disponible en: <http://interaktionslabor.de/lab11/lachoreografia.pdf>.

Obermaier, Klaus (2015), Conferencia Magistral "Intersección + laboratorio: Código encarnado", en Encuentro Internacional de Artes Performática, Ciencia y Tecnología. Efusión: código y producción de sentido, Centro de las Artes San Luis Potosí Centenario (CEARTSLP), México [en línea]. Disponible en: $<$ http://efusion.bioscenica.mx/klaus-obermaier/> $<$ http://www.exile.at/ko/installations.html>.

Samaja, Juan (2003), Los caminos del conocimiento, Buenos Aires, Universidad de Buenos Aires len línea]. Disponible en: $<$ http://catedrafevre.com.ar/32rMl/Los_caminos_del_conocimiento\%20Samaja_r ed.pdf>.

Seid, Gonzalo (2013), "Más allá de subjetividades, discursos y sentidos: el método biográfico para reconstruir trayectorias de clase", en XXVIII Congreso Internacional de la Asociación Latinoamericana de Sociología Crisis y Emergencias Sociales en América Latina (en línea]. Disponible en: $<$ http://www.conicet.gov.ar/new_scp/detalle.php?keywords=\&id=40580\&congres os=yes $>$. 
Solaas, Leonardo (2014), "Generatividad y molde interno. Los sistemas de reglas en el desarrollo de la forma artística", en Emiliano Causa (comp.), Invasión generativa. Fronteras de la generatividad en las tres dimensiones, la robótica y la realidad aumentada, Buenos Aires, Invasores de la generatividad [en línea]. Disponible en:

<http://www.invasiongenerativa.com.ar/descargas/INVASION\%20GENERATIVA -1_1.pdf>.

Tognazzini, Bruce (2006), "Principios de diseño de interacción" [en línea]. Disponible en: <http://galinus.com/es/articulos/principios-diseno-de-interaccion.html>.

\subsection{Entrevistas en video}

Youtube. Intercambios con integrantes del emmeLab/Cod05: $<$ https://youtu.be/CAdv41KrZxY>.

Youtube. Entrevista a integrantes del emmeLab 2016-17: <https://youtu.be/ddnqMMeVdOg>.

Youtube. Entrevista a Soledad Belén 2016-17: <https://youtu.be/fy7pjjBF_QA>.

\subsection{Otros materiales de consulta en línea}

Speak 4.O Fractal "Liquid" En Water Wheel 2014: <https://youtu.be/XEW0jRCoqJ0>. Cuerpo Módulo Código de emmeLab: <https://vimeo.com/92772100>. emmeLab: <http://emmelab.fba.unlp.edu.ar/cod05/>. Proyecto COD05 - monitor: <https://vimeo.com/168413862>. 


\section{ANEXO}

\subsection{Introducción}

En este apartado, se presentan las transferencias que se han ido realizando en el período que corresponde a la presente investigación, pues, uno de los objetivos principales se ha centrado en que los resultados obtenidos fueran proveedores de contenidos digitales-multimedia para la educación artística. Este aporte para la danza performance, en conjunción con la tecnología, promueve y facilita el uso de software y equipos de computación portátil en la educación pública tanto para los docentes como para los estudiantes en esta nueva conformación del espacio áulico.

Por consiguiente, se exponen las actividades de extensión e investigación científica, tecnológica y artística llevadas a cabo a través del aporte teórico de los estudios y experiencias de intercambio académico con numerosos equipos de artistasinvestigadores y con laboratorios pertenecientes a universidades de nuestro país y de Latinoamérica.

Reparamos entonces en el porvenir de estas actividades de extensión que buscan contribuir al estudio de las interrelaciones entre arte, ciencia y tecnología e impulsar nuevas manifestaciones artísticas y nuevas tendencias, y a las múltiples problemáticas que plantea el arte contemporáneo, las tecnologías de la comunicación y la información (TIC) y la construcción del conocimiento de modo colaborativo.

\subsection{Transferencias en el campo artístico y educativo}

Este proceso de transferencia o aplicabilidad de los resultados obtenidos da cuenta de la posibilidad de extenderlos a otros contextos y evidencia qué tanto se ajustan las derivaciones a otros ámbitos de estudio y practica. Es de recordar que, en la investigación cualitativa el grado de transferibilidad depende de la aproximación entre los contextos en los que se efectúa un estudio; por lo tanto, el trabajo de campo se torna fundamental. Como ya se ha expuesto, nuestra investigación es entendida como descriptiva y exploratoria (Ynoub, 2014). A la par, la investigación cualitativa se define por el uso en paralelo de diversos métodos y técnicas de recolección, por lo cual el trabajo de campo implica un desafío de fuentes y materiales variados y significativos, que brindan legitimidad y profundidad a la exploración.

Es nuestro propósito compartir el estudio realizado como una construcción conjunta en la que participantes -básicamente iguales- efectúan aportes diferentes. Esos aportes 
son la derivación de distintas formas de interpretar y procesar la realidad próxima, entre las que se encuentra el propio conocimiento científico.

En pocas palabras, la transferencia del conocimiento se presenta como uno de los principales desafíos de la investigación en arte más allá de la especialización disciplinar; tanto sea para acoger su contribución como para multiplicar, renovar, transformar o adaptar a diversos entornos independientes 0 institucionales. Plantearnos esto nos convoca a preguntarnos: ¿Qué estrategias facilitan la transferencia de conocimiento? ¿Logramos establecer ciertos indicadores para evaluar un conocimiento generado fuera del ámbito disciplinar? ¿Qué metodologías preexisten para la transferencia de conocimiento interdisciplinar? Y, en definitiva, ¿se incorporan substancialmente los aportes que genera el conocimiento artístico interdisciplinar? Una respuesta factible a estos interrogantes sería proponer, a futuro, la elaboración de una sistematización para la investigación interdisciplinar; impulsando, de este modo, el tratamiento de contextos propicios para que la ciencia y la cultura puedan participar sus conocimientos, metodologías y modelos de experimentación y pensamiento crítico. Esta sistematización tendría como objetivo ofrecer herramientas para la transferencia de conocimiento y un marco teórico a instituciones, grupos de investigación, artistas, científicos y protagonistas comprometidos en contextos transdisciplinares.

En definitiva lo que esta tesis pretende ofrecer -no solo al campo disciplinar e interdisciplinar de producción artística sino también al campo educativo- constituye un acervo incipiente donde instalar el diseño metodológico ideado -para la especificidad en danza performance interactiva- así como también gestar un plan estratégico para la programación de políticas en transferencia de conocimientos inter/multi/transdiciplinarios aplicables a futuro.

Vislumbrar la poética de estas relaciones es una contribución lúcida para el avance de los lenguajes artísticos, el análisis y la reflexión en una sociedad cada vez más informatizada y global. Con estas ideas, los espacios distinguidos para el trabajo de campo se sustentan promoviendo criterios para el conocimiento y la incorporación de las nuevas tecnologías electrónico-digitales como parte de un proceso de innovación pedagógica cimentada en el propio intercambio social y participativo. A esta tarea la hemos denominado curaduría académica, entendida como un despliegue en paralelo de lo que ya es la curaduría en artes pero pensada, organizada y llevada a cabo como una práctica de transferencia o coparticipación del conocimiento derivado de la investigación en artes.

Esto tiene que ver con lo que consideramos trabajo de campo y enriquece la reflexión y la búsqueda de nuevas instancias en la vivencia del intercambio con la comunidad. A 
continuación, expondremos las actividades académicas de transferencia realizadas en el desarrollo del trabajo de campo.

Estos espacios son los siguientes: Cátedra Libre de Educación y Mediación Digital en Danza y Performance (2014 a 2016), perteneciente, en su inicio, a la Prosecretaría de Arte y Cultura de la Universidad Nacional de La Plata (UNLP), actualmente, a la Secretaria de Arte y Cultura, UNLP; Ciclo de danza "En dos tiempos" perteneciente a la Prosecretaría de Arte y Cultura, UNLP; y los Proyectos de Investigación y Desarrollo Científico, Tecnológico y Artístico (I+D) así como sus derivaciones concernientes al proceso de esta tesis.

\section{Cátedra libre de educación y mediación digital en danza y performance}

\section{Fundamentación}

Las Cátedras Libres son dependientes de la Presidencia de la Universidad Nacional de La Plata, y fueron llamadas así por difundir áreas de la cultura y del saber que no encuentran un espacio respectivo en el currículo de alguna de las carreras que esta Universidad dicta.

La Cátedra Libre Educación y Mediación Digital en Danza y Performance pertenece a la Secretaría de Arte y Cultura de esta universidad. Fue creada en el año 2014 y continúa promoviendo criterios para el conocimiento y la incorporación de las nuevas tecnologías digitales como parte de un proceso de innovación pedagógica. En el marco de las transformaciones suscitadas en el ámbito de la educación artística, la Cátedra está orientada a establecer instancias de formación continua, acompañamiento y diseño de material de apoyo con el fin de contribuir y sostener el desafío que esta tarea representa para la comunidad educativa y artística. La Cátedra se estructura sobre varias actividades abiertas al público con el fin de abordar los objetivos y la problemática del cuerpo y la imagen en la actualidad, a través de: la lectura analítica de textos, la redacción de informes crítico-analíticos de seguimiento, el visionado de trabajos en diversos formatos y la colaboración de otros docentes y artistas a través de las invitaciones a conferencias y jornadas centralizadas y descentralizadas. 


\section{Objetivos}

- Contribuir al desarrollo de la danza performance interactiva y ampliar los conceptos y las prácticas disponibles.

- Desarrollar un estado de la cuestión de las teorías y los casos de estudio que aborden la vinculación entre la danza, la performance y las nuevas tecnologías.

- Incrementar la documentación relativa a la danza performance interactiva a través de la observación y producción crítica de obras, artículos, trabajos de investigación y otras colaboraciones provenientes de las nuevas tecnologías de la información y la comunicación (TIC).

- Promover contenidos digitales multimedia para la educación artística en la disciplina Danza y performance.

- Favorecer el despliegue de experiencias, procesos y actividades vinculadas con la danza performance interactiva, la mediación tecnológica y el cuerpo y establecer contacto con los actores y centros de formación que desarrollan prácticas escénicas multimediales.

- Fomentar la necesidad de creación de espacios institucionales a partir del desarrollo de políticas culturales actualizadas que contemplen ese tipo de producciones a través de programas artísticos interdisciplinares y extracurriculares (en los casos de educación formal).

- Indagar e intercambiar sobre posibles abordajes pedagógicos en las instituciones de formación con el fin de comprender las posibilidades cognitivas y prácticas de la danza en formato digital.

- Organizar conferencias, jornadas, seminarios y talleres con el fin de intercambiar experiencias artísticas y áulicas en materia de danza y nuevas tecnologías.

\section{Destinatarios}

Artistas locales, regionales y extranjeros, docentes de instituciones educativas en sus diferentes niveles y orientaciones pedagógicas, y personas interesadas en el conocimiento y la difusión de las artes y el público en general. 


\section{Actividades}

- Organizar ciclos de seminarios, conferencias y charlas.

- Difundir los conocimientos y las experiencias a la comunidad, a través de jornadas de intercambio de investigaciones académicas 0 independientes entre instituciones, artistas e investigadores.

- Organizar muestras en instituciones educativas, en espacios de transferencia locales e internacionales a través de red en videoconferencias y en la UNLP.

- Convocar a teóricos, artistas y talleristas reconocidos por su trayectoria

- Registrar, editar y producir documentos a través de fotos y videos para su difusión en los canales en línea pertenecientes a la Cátedra Libre.

- Entregar certificados de la UNLP.

\section{Organización}

Directora: Mag. Alejandra Ceriani

Secretaria: Prof. Lucía Merlos y Prof. Paula Dreyer

\section{Contacto}

Consultas: tecnologiaydanza@gmail.com.ar

Blog: URL: <http://tecnologiaydanza.blogspot.com.ar>.

\subsection{Actividades 2014}

Título: I Encuentro sobre Educación, Danza y Mediación Digital

Jueves 29 de mayo, de 16 a 20 horas

Salón Dardo Rocha, $1 .^{\circ}$ Piso. Edificio Presidencia UNLP, Av. 7 N. ${ }^{\circ} 776$

\section{Descripción}

Este evento tuvo por objetivo promover espacios de diálogo sobre la producción y la formación en tecnologías aplicadas a la Danza. Se expusieron experiencias e investigaciones individuales y grupales. Se propuso un encuentro para la reflexión y los intercambios, que permitió comenzar nuevos lazos y posibles desafíos en el 
abordaje de producciones artísticas futuras, como también develar procesos provenientes de estas interrelaciones.

Fue organizado conjuntamente entre los coordinadores de la Cátedra Libre Educación y Mediación Digital en Danza, Universidad Nacional de La Plata; el Departamento de Artes del Movimiento, Universidad Nacional del Arte, y la Escuela de Danza de la Universidad Federal de Bahía, Brasil.

\section{Disertantes}

- Prof. Diana Montequín y Dra. Mariana Saez.

- Emmelab, Grupo FBA, UNLP: Francisco A. Lojo, Ezequiel Rivero, Emiliano Causa.

- Aula 20, Grupo de danza de la FBA, UNLP.

- Dra. Ludmila Pimentel y Mag. Natalia Ribeiro. Eléctrico, Grupo de Investigaciones en Ciberdanza, Universidad Federal de Bahia Salvador, UFBA, Brasil.

- Prof. Aníbal Zorrilla, Maximiliano Wille, Gabriela Baldoni, Analía Cannone InTAD, Equipo de Investigación en Tecnología Aplicada a la Danza, UNA, Departamento de Artes del Movimiento, CABA.

Material de consulta en línea

Reseña: Diana Montequín y Mariana Sáez.

URL: <http://www.unlp.edu.ar/uploads/docs/anuario_arte_y_cultura_2014_julio.pdf>, pág. 26.

Título: Conferencia sobre Coreografía Cuántica. Generadores de Movimientos e Interacciones Fundamentales.

Lunes 19 de mayo, 18 horas

Usina de las Artes (CABA)

Descripción

Actividad coorganizada con la compañía Gilles Jobin, el Instituto de Investigación del Departamento de Artes del Movimiento UNA, junto a la Dirección de Ciencia y Tecnología del Gobierno de la Ciudad y la Embajada de Suiza en Buenos Aires. Compartimos su búsqueda coreográfica y sus impresiones de "embedded choreographer" en el mayor laboratorio de física de partículas del mundo. Se exhibieron documentos audiovisuales sobre las intervenciones en el CERN 
(Organización Europea para la Investigación Nuclear) y la creación de Quantum y algunos extractos de sus piezas coreográficas. La conferencia contó con una demostración de los bailarines en el escenario.

Disertante

Gilles Jobin (coreógrafo, bailarín e investigador suizo).

Material de consulta en línea

Reseña: Mag. Alejandra Ceriani.

URL: <http://www.unlp.edu.ar/uploads/docs/anuario_arte_y_cultura_2014_julio.pdf>, paa. 136 .

\section{Título: Conferencia Performática}

Martes 24 de junio, 15 a 18 horas

Salón Alfredo Palacios. Edificio Presidencia UNLP, Av. 7 N. ${ }^{\circ} 776$

Descripción

Maida Withers es una referente artística mundial a la hora de pensar en términos de vinculación entre danza-cuerpo- tecnología de los últimos cuarenta años. Bailarina, coreógrafa, cineasta, directora artística de la "Maida Withers Dance Construction Company", profesora de la Universidad de George Washington. Su trabajo se caracteriza por la innovación interdisciplinaria y obras interactivas en constante evolución en sintonía con los desarrollos y avances tecnológicos.

Disertantes

- Maida Withers.

- Adrián Salinas Traductor simultáneo (miembro del colectivo artístico A.mo.ver, UNA).

Materiales de consulta en línea

Reseña: Mag. Alejandra Ceriani (FBA, UNLP).

URL: <http://www.alejandraceriani.com.ar/pdf/Resena_Danza.pdf>, pág. 3.

Título: Conferencia performática: Inevitable / Inagotable

Lunes 14 de julio, 14 a 16 horas 
Aula 7 Sede Fonseca. Facultad de Bellas Artes UNLP

\section{Descripción}

Situándonos en un espacio donde conviven las capas virtuales con la realidad, Inevitable / Inagotable es una instalación performática multimedial vinculada a la creación coreográfica y musical en vivo en la que Valeria Pagola es la protagonista. Federico Joselevich Puiggrós genera visuales en vivo: animaciones e imágenes proyectadas que se traducen a palabras, frases y recuerdos y que interactúan con la performer, el baile, la música y el espacio mismo. Danza performance sonora y programación.

\section{Disertantes}

- Valeria Pagola (Taller de Danza Contemporánea del Teatro Municipal General San Martín).

- Federico Joselevich Puiggrós (FBA/UNLP).

Materiales de consulta en línea

Reseña: María Mercedes Viola (FBA, UNLP).

URL: <http://www.alejandraceriani.com.ar/pdf/Resena_Danza.pdf>, pág. 4.

Título: I Jornadas Nacionales de Cuerpo, Danza y Performances en Clave Audiovisual

Viernes 12 de septiembre, 9 a 18 horas

Salón Alfredo Palacios, Edificio Presidencia UNLP, Av. 7 N. ${ }^{\circ} 776$

Descripción

Actividad coorganizada con la Red de Videodanza y Multimedia Argentina, integrada por docentes, realizadores e investigadores de la Facultad de Filosofía y Letras (UBA), Carrera de Artes Orientación Artes Combinadas y la Cátedra Libre Educación y Mediación Tecnológica en Danza (UNLP). El objetivo fue promover el intercambio entre académicos, realizadores e investigadores de disciplinas afines interesados en analizar el cuerpo, el movimiento y la performance desde una perspectiva audiovisual y multimedial. En esta oportunidad, se trabajó en mesas a cargo de reconocidos especialistas para continuar pensando en la articulación entre danza, educación y nuevas tecnologías. 


\section{Disertantes}

- Melina Masnatta (UBA/FLACSO).

- Gabriel Gendin (UNNE).

- Gabriela Redondo y Leandro Navall (UNVM).

- Claudia Sánchez (UBA).

- Daniela Muttis (UBA).

Mesas de trabajos coordinación

- Diana Montequín (FBA-UNLP).

- Natalia Matewecki (FBA-UNLP).

- Maximiliano Wille (UNA).

- Melina Masnatta (Flacso/UBA).

Material de consulta en línea

Reseña: Mag. Natalia Matewecki.

URL: <http://www.unlp.edu.ar/uploads/docs/anuario_arte_y_cultura_2014_julio.pdf>, pág. 42.

\section{Título: Jornadas sobre Espacios y Cuerpos de Código Abierto}

Viernes 28 de noviembre, 16 a 20 horas

Salón Alfredo Palacios, Edificio Presidencia UNLP, Av. 7 N. ${ }^{\circ} 776$

Descripción

Su eje central fue promover el intercambio entre los participantes: docentes, artistas, académicos, realizadores e investigadores de disciplinas afines interesados en analizar el cuerpo, el movimiento, la danza y la performance desde una metodología colaborativa.

Se dividieron las actividades en tres grandes bloques:

Un primer bloque orientado a ciertas reflexiones sobre la presencia-ausencia del cuerpo en la escuela como problemática contextual y la discusión sobre software libre, a cargo del Lic. Daniel Sánchez (FBA, UNLP) y la Mag. Bianca Racioppe (FPyCS, UNLP).

Un segundo bloque en el que se llevó a cabo la presentación del software Moldeo para usar en las netbooks - un programa de visuales en tiempo real destinado a la escena artística-. Se contó con la presencia del especialista Dante Sáez Mansilla. 
Un tercer bloque destinado a la realización de dos improvisaciones pautadas a cargo de las bailarinas Soledad Belén y Claudia Cárdenas Gainza, en dos secciones del programa Moldeo en carácter de clínica abierto al público.

Disertantes

- Daniel Sánchez (FBA-UNLP).

- Bianca Racioppe (FPyCS-UNLP).

- Dante Sáez Mansilla (UISEK, Santiago de Chile).

- Soledad Belén (FBA-UNLP).

- Claudia Cárdenas Gainza (EDC-DGCyE).

Material de consulta en línea

Reseña: Lic. Javiera Sáez Mansilla.

URL: <http://www.unlp.edu.ar/uploads/docs/anuario_arte_y_cultura_2014_julio.pdf>, pág. 137.

URL: <http://youtu.be/NskULiEIUVs>.

URL: <http://youtu.be/Q4Ghyncdzcl>.

URL: <http://youtu.be/NskULiEIUVs>.

URL: <http://youtu.be/WOc0NU7hl_o>.

\subsection{Actividades 2015}

En el transcurso del año 2015, como continuidad de las acciones que se venían realizando desde el 2014 por parte de Cátedra libre, se propusieron actividades de diversa índole abiertas a la comunidad, en distintos períodos, entre ellas: vinculación con la Bienal de Performance BP.15 organizada por la UNA, organización de jornadas de reflexión e invitación a especialistas, trabajos vinculados a experiencias en el aula, transferencias de contenidos del PID "Danza y nuevas tecnologías: Nuevas estrategias en el campo de la formación y la producción. Código 11B258" radicado en la Facultad de Bellas Artes, UNLP., intercambio con investigadores internacionales, entre otras. Asimismo, la cátedra articuló la vinculación con el Área Académica de la UBA y la Secretaría de Arte y Cultura de la Universidad Nacional de La Plata, en una coparticipación para la Bienal de Performance BP.15 realizada en la ciudad de La Plata, a partir de distintas instancias (seminarios, workshops, encrucijadas, 
conferencias) susceptibles de generar espacios de exposición y problematización del concepto de performance y sus derivaciones.

\subsubsection{Actividades coorganizadas con la Bienal de Performances BP15}

Título: Encrucijada sudando el discurso. Conferencia performática.

Domingo 10 de mayo, 11.30 a 13.30 horas

Planetario de la ciudad de La Plata, Facultad de Ciencias Astronómicas y Geofísicas (UNLP). Av. Iraola y calle 118

Disertante

- Mag. Aimar Pérez Galí (España).

Materiales de consulta en línea

URL: <https://youtu.be/1arkuSCsgew>.

Título: Workshop "Etnografía y prácticas en las artes performativas. El juego de los métodos de investigación y la cualidad de la etnografía"

26 y 27 de mayo, 15 a 19 horas

Sala Dardo Rocha. Edificio Presidencia UNLP, Av. 7 N. ${ }^{\circ} 776$

Disertante

- Dr. Ricardo Seiça Salgado (Portugal).

Título: Workshop "Intervenciones virtuales locativas. Resonancias del cuerpo, la imagen y el sonido"

11 y 12 de mayo, de 11 a 15 horas

Sala Dardo Rocha Edificio del Rectorado de la UNLP y Laboratorio de Acústica y Luminotecnia, Centro de la Comisión de Investigaciones Científicas de la provincia de Buenos Aires. Cno. Centenario e/ 505 y 508 M. B. Gonnet/La Plata, Buenos Aires, Argentina.

Disertantes

- Mag. Alejandra Ceriani (FBA-UNLP).

- Lic. Fabián Kesler (UNQUI). 
- Fabricio Costa Alisedo (UBA).

- Lic. Dante Sáez Mansilla (UISEK, Santiago de Chile).

Material de consulta en línea

URL: <https://youtu.be/Ho5Dyp1bpOQ>.

URL: <https://youtu.be/auy9YSuwwBc>.

URL: <https://youtu.be/yt8iEF52RHQ>.

URL: <https://youtu.be/gajzOFSsXOg>.

Título: Conferencia "Liminalidades y communitas para llorar la muerte, para imaginar la vida"

20 de mayo, 18 horas

Sala del Consejo Superior. Edificio Presidencia UNLP, Av. 7 N. ${ }^{\circ} 776$

Disertante

- Dra. lleana Diéguez (México).

Título: Conferencia “Entre-medio de la otra cosa: un 'no lugar' desde la Danza, el teatro y la performance"

20 de mayo, 16 horas

Sala del Consejo Superior. Edificio Presidencia UNLP, Av. 7 N. ${ }^{\circ} 776$

Disertante

- Mag. José Rafael Álvarez Colón (Puerto Rico).

Material de consulta en línea

URL: <https://youtu.be/gGFmGPuZ4d4>.

\subsubsection{Actividades de la Cátedra Libre}

Título: I Jornada de Danza y Performances. Escenarios Interactivos

Jueves 19 de marzo, 17 a 20 horas

Salón Alfredo Palacios. Edificio Presidencia UNLP, Av. 7 N. ${ }^{\circ} 776$ 
Descripción

En esta oportunidad contamos con la exposición de la compañía Proyecto en Bruto, de la ciudad de La Plata, a cargo de la bailarina y coreógrafa Florencia Olivieri, la artista audiovisual Cirila Luz Ferrón y la antropóloga, y bailarina Mariana Sáez, y la conferencia del licenciado en Coreografía (Escuela Nacional de Danza, Centro Nacional de las Artes, México DF) Gabriel Arteaga Portillo.

La jornada dio lugar a la presentación de obras y de experiencias de danza en relación con la tecnología, con la mirada centrada en la construcción de espacios. Dio lugar también a la reflexión sobre la praxis de la danza y el discurso académico.

\section{Disertantes}

- Gabriel Arteaga Portillo.

El propósito de la conferencia fue brindar la experiencia obtenida en doce años de trabajo con el concepto-herramienta "Escenario Interactivo", creado por Gamultimedia, de la cual es fundador y director, exponiendo sus inicios, antecedentes, contexto histórico donde surge, desarrollo tecnológico y teórico, obras que han resultado de su ejercicio, la vinculación del proyecto con instituciones culturales y su implementación académica a través de talleres, cursos y diplomados y proyectos futuros.

- Florencia Olivieri y Cirila Luz Ferrón (Proyecto en Bruto).

Proyecto en Bruto es un grupo autogestivo que nace en el año 2007, con la necesidad de conformar un espacio de exploración e investigación en el lenguaje de la danza. Está integrado por artistas que provienen de ámbitos heterogéneos (danza, música, cine, antropología, literatura) y establecen un vínculo particular con la danza en cada caso. Esta característica aporta diversidad de miradas acerca del objeto de investigación, los vínculos posibles entre los lenguajes de la danza y el video que enriquecen la propuesta estética del grupo.

Material de consulta en línea

URL: $\quad$ <http://tecnologiaydanza.blogspot.com.ar/2015/03/marzo-2015-i-jornada-dedanza-y.html>.

URL: <https://youtu.be/JVbK4w1ISvM>.

URL: <https://www.youtube.com/watch?v=WKJ5ZeORC_U>.

Título: II Jornada de Danza y Performance. Etnografías desde y en la Práctica Artística

Martes 7 de abril, 16 a 20 horas 
Sala Consejo Superior. Edificio Presidencia UNLP, Av. 7 N. ${ }^{\circ} 776$

\section{Descripción}

Organizada por la Prosecretaría de Arte y Cultura de la Universidad Nacional de La Plata junto con la Cátedra Libre Educación y Mediación Digital en Danza de la misma universidad. En esta oportunidad contamos con el Grupo Estudio sobre Cuerpo (GEC) Centro Interdisciplinario Cuerpo, Educación y Sociedad, Instituto de Investigaciones en Humanidades y Ciencias Sociales, Facultad de Humanidades y Ciencias de la Educación, UNLP.

Tuvimos, además, la presencia del Lic. Martin Seijo destacado actor, performer, dramaturgo y director con una amplia trayectoria y formación en los cruces artísticos y académicos. Esta jornada puso el acento en la reflexión sobre la praxis de la práctica artística, la performance y el discurso académico; anticipando el programa académico de la Primer Bienal de Performance 2015 con sede en la Secretaría de Arte y Cultura de la UNLP, a desarrollarse en el mes de mayo.

\section{Disertantes}

- Dra. Ana Sabrina Mora, Lic. Mariana Lucía Sáez, Lic. Gisela Magri y Lic. Mariana del Mármol.

"Modo Rec o cómo transitar prácticas estéticas desde la etnografía"

La exposición buscó presentar diferentes concepciones y aproximaciones a la etnografía, en sus diferentes sentidos (como método, disciplina, enfoque, texto, dispositivo generador de teoría, entre otras posibles) para, a partir de ellas, pensar un posible diálogo o articulación entre etnografía y prácticas artísticas. Para esto se hizo referencia a las experiencias de trabajo en investigación, producción y gestión del Grupo de Estudio sobre Cuerpo en su conjunto y a las investigaciones particulares de sus integrantes, haciendo foco especialmente en las distintas estrategias y modos de articulación entre arte y etnografía que se fueron dando en cada caso.

- Lic. Martín Seijo.

"Subastas de objetos disfuncionales: un cruce posible entre las Artes Performáticas, las Artes Escénicas y las Ciencias Sociales"

La Subasta de Objetos Disfuncionales fue un evento performático que consistió en una convocatoria abierta a artistas, diseñadores, profesionales y aficionados para realizar un objeto disfuncional (definido como aquel objeto que tiene en su diseño y fabricación algún material o concepto no convencional que produce el rechazo, la burla o la extrañeza de los consumidores), defender su utilidad en público y luego subastarlo con la ayuda de un actor que oficiaba de martillero. 
Material de consulta en línea

URL:<http://tecnologiaydanza.blogspot.com.ar/2015/03/proximamente.html>.

Etnografías desde y en la práctica artística. Parte I URL:<https://youtu.be/PXdVtrTmGy4>.

\section{Título: Jornada de Integración de las TIC en la Educación Artística-Danza}

Martes 27 de octubre, 16 a 20 horas

Salón del Consejo Superior, Edificio Presidencia UNLP, Av. 7 N. ${ }^{\circ} 776$

Descripción

En la jornada se expusieron los procesos que investigadores, docentes y colaboradores del proyecto Integración de las TIC en la Educación Artística-Danzaque han registrado a través de la experimentación, análisis y reflexión de la enseñanza con mediación tecnológica. Trayectoria que propuso, a lo largo de tres meses de trabajo, espacios formación, diálogo e implementación del uso del software libre Moldeo a equipos de docentes de diferentes niveles educativos en danza con el objetivo de experimentar con grupos de alumnos los procesos compositivos en la vinculación Danza+TIC. Se llevó al territorio educativo para construir junto con docentes y estudiantes la gestión y operatividad de recursos y contenidos digitales en el aula desde la instancia de transferencia de contenidos del PID "Danza y nuevas tecnologías: Nuevas estrategias en el campo de la formación y la producción. Código 11B258" radicado en la Facultad de Bellas Artes, UNLP.

\section{Disertantes}

- Inspectora de Artística: Silvia Lalli.

- Lic. Daniel Sánchez.

- Lic. Patricia Ciochini.

- Escuela de Estética N. ${ }^{\circ}$ 1: Ana Blatt y Ana Carlón.

- Escuela de Estética N. ${ }^{\circ}$ 2: Rocío Alarcón.

- Escuela Primaria N. ${ }^{\circ}$ 10: Martina Alonso, Victoria Trapaniy Gabriela Verlut.

- Escuela de Danza Contemporánea: Diana Rogovsky, René Zgainer y Nora Stigol.

- Escuela de Danzas Tradicionales: Jorge Caballero y Marisa Velázquez.

- Escuela de Educación Secundaria N. ${ }^{\circ}$ 2: Lucia B. Merlos y Yanina Reisvig. 
- Colaboradores Informáticos: Miguel González, Aimé Guzmán, Victoria Dallachiesa y Cirila Luz Ferrón.

Muestras en vivo con software Moldeo: 19.30 horas

Material de consulta en línea

URL: $\quad$ <http://tecnologiaydanza.blogspot.com.ar/2015/10/integracion-de-las-tic-en-laeducacion_0.html>.

\section{Título: Jornada de Artes Performáticas, Danza y Tecnología}

Martes 17 de noviembre, 15 a 18 horas

Salón del Consejo Superior. Edificio Presidencia UNLP, Av. 7 N. ${ }^{\circ} 776$

\section{Descripción}

Nuestro objetivo fue promover el intercambio entre académicos, realizadores e investigadores de disciplinas afines interesados en analizar el cuerpo, el movimiento y la perfomance desde una perspectiva multimedial. Fue nuestra intención construir tanto un espacio de intercambio académico como un ámbito de difusión más general, que permita alcanzar a un público más amplio interesado en estas temáticas.

\section{Disertantes}

- Prof. Dra. Ludmila C. Martínez Pimentel (UFBA, Brasil).

"Las tecnologías Motion Tracking y Motion Capture: Poéticas y Cibernéticas"

Entre los años de 1982 y 1990, el artista David Rokeby desarrolló Very Nervous System (VNS), un sistema por el cual, a partir de los movimientos y datos obtenidos del cuerpo a través de cámaras y sensores de movimiento, alimentaba la programación del software y producía outputs gráficos o sonoros.

- Lic. Ana Vértiz Lavaniegos (UNA, DAM, Posgrado)

"Tecnologías descarnadas. Análisis de Domestic Tension. Instalación performática de Wafaa Bilal"

Tecnologías descarnadas es una reflexión acerca del efecto político y bélico de las tecnologías actuales y las posibilidades discursivas críticas que una obra de arte performática puede desarrollar. Siendo Latinoamérica el espacio geográfico y cultural de este encuentro se consideró vital conocer la obra de artistas que abordaran problemáticas políticas afines a las nuestras. 
- Prof. Diana Inés Montequín (FBA, UNLP).

"Sobre lo performativo en la danza contemporánea"

En el marco de un arte atravesado por el cambio evidente de los paradigmas estéticos, la performance emerge como una de las manifestaciones propias de la época y pareciera ser necesaria una nueva perspectiva para mirar y analizar los fenómenos artísticos. La danza no está ajena a los cambios que pueblan las artes y, en particular, los mundos escénicos.

Material de consulta en línea

URL: $\quad$ <http://tecnologiaydanza.blogspot.com.ar/2015/11/jornada-de-artesperformaticas-danza-y.html>.

\subsection{Actividades 2016}

En el presente año esta Cátedra Libre de Educación y Mediación Digital en Danza realizó cuatro jornadas coorganizadas con diferentes equipos vinculados al quehacer artístico y académico. Profundizó en el concepto de performance vinculando al cuerpo con las nuevas tecnologías y su coparticipación en la educación artística.

Título: Integración de las TIC en la Educación Artística-Danza. Audiovisual sobre el proceso en territorio

Martes 5 de abril, 8.30 a 11.30 horas

Salón del Consejo Superior, Edificio Presidencia UNLP

Coorganización de Cátedra Libre de Educación y Mediación Digital en Danza, Comunidad Moldeo, Sede Norte de Inspectores-Artística

Disertantes

- Inspectora de artística Prof. Silvia Lalli.

- Equipo Moldeo.org: Aimé Guzmán, Victoria Dallachiesa y Fabricio Costa Alisedo

- Prof. EDC Cirila Luz Ferrón.

Descripción

En esta jornada contamos con la presencia de las inspectoras de Enseñanza Artística del distrito de La Plata, los creadores del software libre Moldeo.org y la videasta que 
documentó la experiencia llevada a cabo en 2015 por docentes y estudiantes del área Danza en los diferentes niveles educativos.

Título: ¡Cuerpo-Maquina-Acción! 1. ${ }^{\text {a }}$ Reunión de intercambios sobre las investigaciones de performances y tecnología

Sábado 2 de julio, 10 a 14 horas

Aula 7. Sede Fonseca. Facultad de Bellas Artes, UNLP

Coorganización de Cátedra Libre de Educación y Mediación Digital en Danza y el PID FBA/UNLP (B: 315)

Disertantes

- Equipo de investigadores del Departamento de Artes Dramáticas, Universidad Nacional del Arte, CABA. "Performatividad en Teatro y Artes en el Campo Artístico Latinoamericano" (Código: 34/0305): Julia E Sagaseta (UNA), Martín Seijo (UNA, DAM, Posgrado), Federico Aguilar (UNA, DAM, Posgrado), Ana Seoane (UBAUNA) y Sergio Dante Spinella (UNA- UNSAM).

- Equipo de investigadores de la Facultad de Bellas Artes (UNLP). "Prácticas Performáticas Multimediales, Redes Telemáticas y Educación" (Código: B315, FBA, UNLP): Emiliano Causa (UNLP), emmelab (Multimedia, FBA), Alejandra Ceriani (FBA, UNLP), Natalia Matewecki (FBA, UNLP), Daniel Sánchez (FAB, UNLP), María De Rueda (FBA, UNLP) y Andrea Napolitano (FBA, UNLP).

Descripción

Nos propusimos reflexionar sobre los modos en que investigamos y cómo nos planteamos el cuerpo y la performance en interacción con dispositivos, sistemas interactivos, redes de internet y sus procesos sensibles.

Material de consulta en línea

Noticias UNLP Cátedra libre educación y mediación digital en danza performance.

URL: <https://youtu.be/8C4Y_Uj04-U>.

URL: <https://youtu.be/-4aDFo_gAA>.

URL: <https://youtu.be/CAdv41KrZxY>.

Título: Jornada del Cuerpo y Dispositivos: Videodanza. Videoperformance. Fotoperformance 
Miércoles 28 de septiembre, 15.30 a 18.30 horas

Aula B200. Facultad de Humanidades y Ciencias de la Educación de la UNLP.

Coorganización de Cátedra Libre Educación y Mediación Digital en Danza Performance UNLP; GEC, CICES, IdIHCS, UNLP-CONICET y el PID FBA/UNLP B315

Disertantes

- Ximena Monroy (Directora festival Internacional de Video Danza Agite y Sirva, México).

- Ladys Gonzalez (Codirectora del Festival Internacional Corporalidad Expandida, AR).

- Gabriel Sasiambarrena (Maestría en Teatro y Artes Performáticas, UNA).

Descripción

Charlas magistrales sobre la articulación del cuerpo, los dispositivos de registro y las performances tecnológicas, interactivas, multimediales o performances ampliadas: videodanza, fotoperformance y videoperformances.

Material de consulta en línea

URL: <https://youtu.be/roLD-cwrmpA>.

URL: <https://youtu.be/RFNTD_x3YX0>.

Título: Jornadas Cuerpo, Performance y Tecnologías Emergentes. Experiencias Artísticas y Educativas.

Miércoles 9 de noviembre, 11 a 15 horas

Salón del Consejo Superior. Edificio Presidencia UNLP

Organización de Cátedra Libre Educación y Mediación Digital en Danza y Performance y PID FBA/UNLP B315

Disertantes

- Paula Doberti y Carolina Defosse (Maestría En Teatro y Artes Performáticas, UNA).

- Darío Sacco (Maestría en Tecnología y Estética de las Artes Electrónicas, UNTREF).

- Natalia Matewecki (FBA-UNLP).

- Ivan Haidar (Taller de Danzas Teatro General San Martín). 
- Diana Montequín (FBA-UNLP).

- Ayelén Barrionuevo (Escuela de Educación Estética N.ำ1).

- Andrea Napolitano (FAHCE-UNLP).

Descripción

Reuniendo estudiantes, docentes y artistas de diferentes instituciones, se dialogó sobre las experiencias y contenidos de la performance y su ampliación hacia las nuevas tecnologías y tendencias tanto en el mundo artístico como educativo contemporáneo.

\section{Ciclo de Danza "En2Tiempos"}

El ciclo de danza de la universidad, una iniciativa de la Prosecretaría de Arte y Cultura -espacio institucional dentro de la Secretaría de Extensión Universitaria de la UNLP-, comenzó en el 2011 y finalizó en el 2015 con presentaciones mensuales de producciones vinculadas a las artes del movimiento y sus cruces interdisciplinarios.

Desde este marco, se promovió: el trazado de una cartografía de la danza desde una perspectiva situada en el juego del arte contemporáneo global, regional y local; y, un espacio de encuentro, reflexión e intercambio de estos procesos artísticos con el público, en el que se incentivó la inclusión de la danza performance con mediación tecnológica.

Todo lo realizado se encuentra documentado por las publicaciones de los anuarios del organismo académico, con sus respectivos links a textos y a videos facilitando su visado y consulta.

Publicaciones del Anuario de la Universidad

- 2011. Anuario Prosecretaría de Arte y Cultura. UNLP.

- URL:

<http://www.unlp.edu.ar/uploads/docs/anuario_2011_arte_y_cultura_unlp.pdf $>$.

- 2012. Anuario Prosecretaría de Arte y Cultura. UNLP. URL: <http://www.unlp.edu.ar/uploads/docs/anuario_2012_arte_y_cultura.pdf>.

- 2013. Anuario Prosecretaría de Arte y Cultura. UNLP. URL: <http://www.unlp.edu.ar/uploads/docs/anuario_2013_de_arte_y_cultura.pdf>.

- 2014. Anuario Prosecretaría de Arte y Cultura. UNLP. URL: <http://www.unlp.edu.ar/uploads/docs/anuario_arte_y_cultura_2014.pdf > y 
<http://www.alejandraceriani.com.ar/pdf/Resena_Danza.pdf>.

Links a videos producidos dentro del Ciclo "En2tiempos"

2011

- "En2tiempos. Itinerarios de danza". URL: <https://youtu.be/ZVlaRcaj0bY>.

2012

- Videos UNLP. URL: <https://youtu.be/u5uoZUpJ9El>.

- Arte del cuerpo digital. URL: <https://youtu.be/97J919NzJBg> y <https://youtu.be/SkKVAbQ6RMI>.

- "En2tiempos". Ciclo de danza en la UNLP. URL: <https://youtu.be/u5uoZUpJ9EI>, <https://youtu.be/ny1IRqBSyEE> y <https://youtu.be/HmCOyMGNAOY>.

- II Encuentro de Fotografía y Video en danza. URL: <https://youtu.be/kElbuUD7MqU> y <https://youtu.be/SsuDKdIJ2BE>.

- Ensayo vertical. URL: <https://youtu.be/lfjv_WwSMB4>.

2013

- Videos UNLP. URL: <https://youtu.be/lv3Dzi_utmc>.

- Ensayo "Proyecto032" Ciclo de Danza "En2tiempos". URL: <https://youtu.be/x4kMRjeyPqg>.

- Performance interactiva sonora. Ensayos. URL: <https://youtu.be/gq5ThuK-aMM>.

- "Vestida de datos". Dispositivo sonoro de alimentación de un cuerpo en movimiento. $\quad$ URL: <https://youtu.be/OYHHml4mKCk> y <https://youtu.be/QyCeBy5R80c>.

- Cuerpo.Módulo.Código1. URL: <https://youtu.be/8rmf0oUNBIE>.

- Generatividad, código y cuerpo: intersección entre la danza y las nuevas tecnologías. URL: <https://youtu.be/IEzJPqXS2VA>.

- CuerpoMóduloCódigo2. URL: <https://youtu.be/P3c8MnDg-4Q>.

- Presentación de CuerpoMóduloCódigo. URL: <https://youtu.be/AqXULE067uY>.

- 3. Encuentro de Especialistas en Danza y Nuevas Mediaciones Tecnológicas. URL: <https://youtu.be/kSuQBv3G4Ml>.

- Entrevistas “En2Tiempos”, UNLP. URL: <https://youtu.be/b49tK14NQrs>.

- Speak 4.0 Universe. En vivo nuevo Planetario. URL: <https://youtu.be/_bkvz7XZzeE>.

- "En2tiempos. Itinerarios de Danza" CuerpoMóduloCódigo. URL: <https://youtu.be/pTbbRUXFUSs>. 
- "Vestida de datos". URL: <https://youtu.be/6um4Bjb7dSE>.

\section{Proyectos de investigación y desarrollo científico, tecnológico y artístico}

Los Proyectos de Investigación y Desarrollo Científico, Tecnológico y Artístico (I+D) se desarrollan en el marco del Programa de Incentivos que pertenece al Ministerio de Educación de la Nación, en áreas de interés dentro de la política científica de la UNLP y de sus Unidades Académicas. Estos son conducidos por equipos de trabajo conformados por docentes y estudiantes, con la dirección y codirección de investigadores formados, con sólidos antecedentes en la disciplina y que avalan capacidad de dirección.

Es a través de este programa que hemos consolidado dos proyectos, uno ya concluido y otro en proceso. En ambos hemos establecido un aporte teórico-práctico a los estudios sobre el vínculo cuerpo-danza-performance-tecnología; sus metodologías, herramientas de recolección, observación y análisis de datos, trabajo de campo y transferencia en diversos formatos y para diversos espacios de formación y producción, a saber:

- Proyecto de Investigación y Desarrollo PID, UNLP; "Danza y Nuevas Tecnologías: nuevas estrategias en el campo de la formación y la producción". Código 11B258 (Director Mag. Alejandra Ceriani; Codirector: Lic. Daniel Sánchez, 2012-2015 FBAUNLP).

- Proyecto de Investigación y Desarrollo PID, UNLP; "Prácticas Performáticas Multimediales, Redes Telemáticas y Educación. Código: B315 (Director: Mag. Alejandra Ceriani; Codirector: Ing. Emiliano Causa, 2016-2017 FBA/UNLP).

53.1. Danza y nuevas tecnologías: nuevas estrategias en el campo de la formación y la producción

Facultad de Bellas Artes, UNLP. Código: 11B258. Entidad que lo acredita: FBA, UNLP. Duración: 01/01/12-31/12/15. 


\subsection{Introducción}

Un aporte teórico fundamental de este PID fue definir los campos de acción, las especificidades y las vinculaciones entre los componentes y los procesos de hibridación que impulsaron la aparición de nuevos modos de operar entre los lenguajes artísticos y tecnológicos. Se propuso la construcción de categorizaciones, criterios y prácticas que contribuyeron tanto al análisis como al diseño de estas nuevas prácticas de producción y de creación.

Otro aporte estuvo fundamentado en formular un formato de interacción entre el cuerpo, los dispositivos y el ámbito o contexto educativo. La acción del cuerpo físico con imágenes y sonidos precisa de una programación y de un sistema informático apropiado a los dispositivos en uso: computadora portátil y cámara web. Para ello, se trabajó en la obtención de un software que enlace con el hardware de las notebooks, y que permita experimentar, sin condiciones de idioma y con licencia libre.

Por ende, se trabajó en la incorporación de estas nuevas lógicas, tanto en las instituciones como en lo disciplinar, como parte de un proceso de innovación pedagógica, de un cambio de paradigma en la educación. Por ello se requirió, entre otras cuestiones, de instancias de capacitación continua, acompañamiento y materiales de apoyo que posibiliten asistir y sostener el desafío que esta tarea representaba.

Nos formularnos transferir los estudios y resultados, materiales y conclusiones de esta investigación en el campo institucional, para lo cual debimos trazar marcos teóricos y metodológicos acerca de la relación entre los dispositivos y sistemas multimedia, la danza y los procesos de producción y formación interdisciplinares.

\subsection{Transferencia al campo educativo}

En los últimos años, se ha incorporado, en los documentos curriculares de la educación artística en nuestro país, un vocabulario más preciso respecto a las prácticas de producción a través de la inclusión de recursos tecnológicos. El producir contenidos digitales multimedia para disciplina Danza permite incorporar el cuerpo como lenguaje en el espacio escolar. Nos propusimos reflexionar sobre el uso pedagógico de las TIC (Tecnologías de Información y Comunicación) en el campo de la Educación Artística, a partir de concebir a las nuevas tecnologías como herramientas y medios para mejorar y enriquecer la construcción de conocimiento. 
Tomando como modelo la materia Proyectos de producción en Danza -plan curricular para el $6 .^{\circ}$ año de la Escuela Secundaria Orientada en Arte- se promueve el desarrollo de una mirada global acerca de la producción y la búsqueda de material de movimiento en función de lograr la síntesis discursiva con las TIC.

A continuación describiremos la propuesta de transferencia de contenidos y resultados de la investigación 11B258 a partir del ingreso de equipos de computación portátil en la educación pública. Las tareas en las etapas año 2014 y 2015 se concentraron en actividades de transferencia y se relacionaron con el ingreso a las instituciones educativas formales.

En primera instancia, año 2014, se realizó la selección de instituciones y docentes del lenguaje Danza para la realización de jornadas de asistencia técnica a escuelas de nivel secundario con equipamiento informático del Programa Conectar Igualdad.

- Resumen etapa 2014

a) Selección de instituciones de nivel secundario que tengan, en primera instancia, el lenguaje Danza; y, en segunda instancia, el equipamiento informático del Programa Conectar Igualdad, para la realización de pruebas abiertas con docentes y estudiantes del módulo de programación operable.

b) Selección de instituciones de formación de nivel superior en el lenguaje danza, para la realización de pruebas abiertas con docentes y estudiantes del módulo de programación operable en la notebook adquirida en este proyecto.

Una de las dificultades encontradas fueron las restricciones formales a la hora del ingreso a las instituciones. Se actuó en consecuencia:

a) Se presentó el proyecto de capacitación "El uso de las netbooks como recurso para la enseñanza de la Danza en la Escuela Secundaria" a la Dirección de Educación Artística del Ministerio de Educación de la provincia de Buenos Aires. Fue aceptado y ejecutado en el mes de octubre del 2014 en la Región 22 municipio de Bahía Blanca y Región 20 municipio de Balcarce.

b) Se realizó la experiencia de pruebas abiertas con el software Moldeo (programa de licencia libre y creación local que nuestra investigación contribuye a desarrollar) en instituciones donde ya se estaba trabajando y el proyecto tenía viso de confianza. Nos referimos a la Escuela de Educación Estética N. ${ }^{\circ} 1$, La Plata, provincia de Buenos Aires y el seminario Performance y Corporalidad, dictado por la Prof. Alejandra Ceriani, dentro del posgrado Maestría en Teatro y Artes Performáticas, Universidad del Arte (UNA), CABA. 
- Resumen etapa 2015

Abrimos la agenda educativa con unas jornadas sobre la temática, organizadas por la supervisión de la Dirección de Inspección General, Jefatura de Región 1 distrito La Plata, el día 18 de mayo de 9 a 16 horas, convocando a docentes de artística de teatro y danza. Se brindó una capacitación instrumental a equipos docentes para el seguimiento y la realización de un proyecto áulico:

a. Formación técnico-conceptual en instituciones seleccionadas de nivel primario, secundario y superior que tengan, en primera instancia, el lenguaje Danza; y, en segunda instancia, el equipamiento informático del Programa Conectar Igualdad.

b. Formación técnico-conceptual de un grupo de trabajo en cada institución que lidere esta primera instancia para luego difundirla interdisciplinariamente entre sus pares

- Organización general de la propuesta de transferencia 2015

Dados los resultados obtenidos a partir de trabajar en las asesorías técnicas desde la Dirección de Educación Artística (DEA), se propusieron las siguientes etapas:

Primer trayecto:

a. Presentar la propuesta a la Jefatura Distrital e Inspección de Educación Artística, Sede de Inspección Norte.

b. Recibir la aceptación y establecimiento de premisas y puntos clave para su realización.

c. Seleccionar instituciones de nivel primario, secundario y superior que tengan, en primera instancia, el lenguaje Danza; y, en segunda instancia, utilicen algunos de los programas o líneas de acciones nacionales o provinciales de integración de las TIC en la educación estatal.

d. Seleccionar docentes de las instituciones de nivel primario, secundario y superior. Formar equipos internos, es decir: el docente de danza va a trabajar con un par que posea formación o efectivo entendiendo en informática. Es muy importante que la dirección o autoridad competente del establecimiento tenga conocimiento y dé apoyo.

e. Realizar el contacto con los directivos y docentes de los establecimientos convocados.

f. Recibir la aceptación y establecimiento de premisas y puntos clave para su realización general y específica. (Entre ellas, que el equipo docente tenga un proyecto o esbozo de proyecto con algún grado o grupo de estudiantes a cargo 
para iniciarse en la particularidad de esta propuesta. Algunos recursos técnicos imprescindibles: computadoras, proyector, espacios adecuados. En el caso del nivel primario, el consentimiento de los padres acerca de este proyecto escolar, etc.).

g. Comprometer al capacitador técnico del software Moldeo para el dictado de una clase magistral, que será sustentada por el presupuesto de los incentivos que recibe este Proyecto de Investigación y Desarrollo PID, UNLP (Danza y Nuevas Tecnologías: nuevas estrategias en el campo de la formación y la producción, Cód. 11B258).

h. Establecer día y horario de la clase magistral.

i. Organizar el encuentro en un espacio y tiempo adecuado con las cinco (5) instituciones cuyos equipos docentes se verán comprometidos.

Segundo trayecto:

a. Combinar horarios y días en las diferentes instituciones para realizar un seguimiento de observación y acompañamiento a los docentes y estudiantes comprometidos en la experimentación de este proyecto, con la idea de ser mostrado en su estado procesual o definitivo a fin de año.

b. Primeras rondas de exposiciones de proyectos, acuerdos técnicos y preparación para la clase magistral sobre el software Moldeo.

c. Registro de la $1 .^{\circ}$ entrevista realizada a los docentes que participarán en el proyecto. URL: <https://youtu.be/1wV9Vn2W_iY>.

Tercer trayecto:

A partir de la clase magistral sobre el software Moldeo dictada por el Lic. Dante Saénz Mansilla, los equipos docentes comenzaron con la investigación-acción en sus respectivas instituciones, en el aula y con sus estudiantes.

En los meses de agosto a octubre se llevó a cabo un seguimiento de las propuestas a partir de:

a. Acuerdos de agenda con cada escuela y equipo docente para su seguimiento (registro fotográfico y fílmico, entrevistas y muestras de avances) hasta la realización del proyecto con un grupo de alumnos a fin del año lectivo 2015.

b. Se organiza en derredor de los equipos un acompañamiento por parte de los colaboradores tecnológicos ( 3 asistentes al taller de Moldeo dictado dentro de la Secretaría de Extensión de la Facultad de Bellas Artes, sábados de mayo-junio) así como de la coordinadora del proyecto. 
c. Registro de la $2 .^{\circ}$ entrevista realizada a los docentes que participarán en el proyecto. URL: <https://youtu.be/OYhxDJQ1hOE>.

d. Asistencia semanal en los horarios de clases y fuera de ellos para generar procesos de aprendizaje, pruebas y puestas del software en las netbooks.

e. Registro del acompañamiento en las clases, URL: <https://youtu.be/RZaIV_R4m0>, <https://youtu.be/ls_Cx0LEtnA>, <https://youtu.be/S6w1dwKQxew>, <https://youtu.be/F80hkYXsPQA> y <https://youtu.be/PlaTX-rrOt0>.

f. Paralelamente se organizaron jornadas desde la sede de inspectores de Artística (7 y 33) para el intercambio y puesta a punto de las experiencias, así como se creó un grupo cerrado en Facebook donde se compartieron videos, imágenes y comentarios y se fomentó el concepto práctico de comunidad.

g. Presentación en jornadas abiertas al público en el edificio de la Presidencia de la UNLP, Salón del Consejo Superior $1 .^{\circ}$ piso. Muestras a la comunidad educativa de los trabajos realizados con los estudiantes en sus respectivas instituciones.

h. Muestra del working progress del documental sobre el proceso y realización del proyecto Integración de las TIC en la Educación Artística-Danza (jueves 17 de diciembre del 2015, en la sede Fonseca de la FBA).

Cuarto trayecto:

a. Muestra del documental sobre la experiencia realizada en cada institución, entrevistas y fragmentos de los trabajos en el aula (martes 30 de marzo del 2016 en el edificio de la Presidencia UNLP, Salón del Consejo Superior $1 .^{\circ}$ piso).

Integración de las TIC en la Educación Artística-Danza. Parte 1. URL: <https://youtu.be/O_FJh7yH1aw>.

Integración de las TIC en la Educación Artística-Danza, Parte 2 URL: $<$ https://youtu.be/Ff8Qm2-tMMA>.

Jornada Integración TIC en Educación Artística-Danza. Parte 3 URL: $<$ https://youtu.be/3Bzl0U9915k>.

Esta tarea de coparticipación del conocimiento estudiado y experimentado fue acompañada por las diferentes jornadas en la universidad a través de las actividades de la cátedra libre, presentaciones a congresos, así como por los seminarios y las capacitaciones:

- La Enseñanza de la Danza: Aportes para la Vinculación con las TIC, Asistencia Técnica en materia Danza, regiones Bahía Blanca, Balcarce y Morón; Dirección de Educación Artística, provincia de Buenos Aires, año 2014 . URL: <http://www.alejandraceriani.com.ar/pdf/asistencia_tecnica_danza.pdf>. 
- Nuevas estrategias en el campo de la formación y la producción en Danza TIC, Campus de la Universidad Nacional de Villa María (UNVM), Secretaría de Investigación y Extensión del Instituto de Ciencias Humanas, Córdoba, año 2014. URL: <http://www.alejandraceriani.com.ar/pdf/SeminarioPID.pdf>.

- Prácticas y Producciones de la Danza Mediada con Tecnología para la Creación de Contenidos Educativos, en Jornadas de Educación y Danza. Facultad de Artes de la UDELAR y Dirección de Educación del MEC, Montevideo, Uruguay, y Facultad de Danza de la Universidad Veracruzana, Encuentro Internacional de Danza-Performance, México, año $2014 . \quad$ URL: <http://www.alejandraceriani.com.ar/pdf/TALLER_videodanza.pdf>.

- El uso del software Moldeo: nuevos recursos y estrategias para la enseñanza de la Danza en la Escuela Secundaria. Experiencias en la Escuela de Educación Estética N. 1, DGCyE, La Plata, Taller para jóvenes de Danza y Coreografía 2013. URL: <http://www.alejandraceriani.com.ar/pdf/moldeo/1_capacitacion_moldeo.pdf> y <https://youtu.be/4YBvl_J8nyY>.

- Moldeo: Herramienta libre para la composición de ambientaciones interactivas en tiempo real. Docentes a cargo: Alejandra Ceriani y Dante Saéz Mansilla

Destinatarios: artistas y docentes escénicos y visuales, interesados en general en la utilización de herramientas Open Source (código abierto) para la experimentación visual y la generación de ambientaciones interactivas. Realizado en la Facultad de Bellas Artes; Curso de la Secretaria de Extensión; UNLP, 2015. URL: $<$ https://youtu.be/-pQW7hf_EmU>.

- Taller Incorporación del gesto al espacio virtual moldeable. Docentes: Fabricio C. Alisedo y Alejandra Ceriani

Destinatarios: artistas interesados en la escena contemporánea, creaciones visuales y mediales con software libre. Encuentro Internacional Efusión: código y producción de sentido, Centro Nacional de las Artes, San Luis de Potosí Centenario; México; 2 al 5 de diciembre de 15 a 19 horas. URL: <http://efusion.bioscenica.mx/cuerpo-analogicocuerpo-digital-hibridaciones-y-alcances-en-el-ambito-de-las-mediaciones- 


\subsection{Evaluación del PID 11B258}

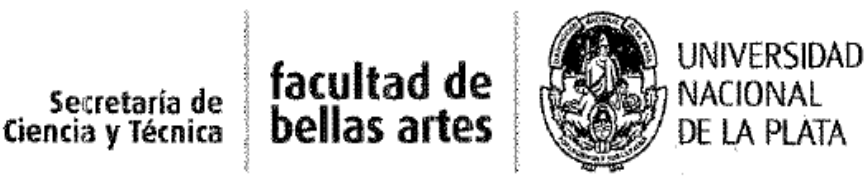

La Plata, 28 de septiembre de 2015

Sr. Directora del Proyecto 11/B258

Mg. Alejandra Cristina, Ceriani

\section{OBJETO}

Elevar a Ud. la transcripción de las observaciones realizadas por los evaluadores de los informes 2012/2013, información incluida en el Memorando $N^{0} 214 / 15$ producido por la Secretaría de Ciencia y Técnica de la UNLP, con fecha 22 de septiembre de 2015

\section{Código: B258}

Proyecto: Danza y nuevas tecnologías: nuevas estrategias en el campo de la formación y la producción.

Observaciones: "Orientado en una perspectiva contemporánea de la relación entre la danza, la tecnología, la educación y la creación, y continuando lineas previas de investigación, el proyecto ha desplegado una interesante producción cientifica, tecnológica y artística. Ha procedido a la formación de becarios y tesistas (postgrado). Se resalta la actitud superadora de dificultades con una clara orientación ético-democrática en cuanto a participar el conocimiento producido académicamente".

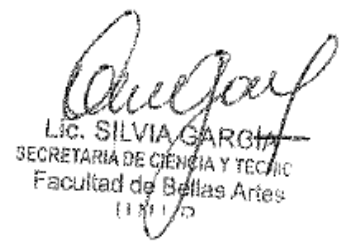

54. Proyecto de Investigación y Desarrollo PID, UNLP: Prácticas performáticas multimediales, redes telemáticas y educación (Código: B315). Director: Mag. Alejandra Ceriani y Codirector: Ing. Emiliano Causa, 01/01/16-31/12/17, FBA-UNLP 


\subsection{Introducción}

Este proyecto se propone brindar un marco teórico a los desarrollos artísticos de las prácticas performáticas multimediales en redes telemáticas y con dispositivos de comunicación móvil. Tras la producción de este marco teórico, se tratarán las posibilidades y proyecciones pedagógicas en la educación Secundaria y Superior, en cuanto al aporte de contenidos didácticos propicios de ser incluidos en el currículum de la educación artística actual.

\subsection{Transferencia al campo educativo}

Teniendo en cuenta la dimensión de las transformaciones estructurales en el arte contemporáneo y su conexión con los nuevos medios, consideramos los estudios y su transferencia una cuestión central para poder profundizar el pensamiento crítico y la proyección hacia otras poéticas. Por ende, pensamos a la educación artística y el aporte de otras instancias de enseñanza en nuevas condiciones en las que el desarrollo de la subjetividad debe comprometer cada vez más una actuación transdisciplinaria de las artes y de las ciencias. Tanto el concepto de "transdisciplinariedad" como el de "nuevas tecnologías" no solo ha impactado en los niveles de creación y producción artística, sino también en los modos en que se organiza metodológicamente la investigación.

Así es que las dificultades encontradas en este período refieren al desconocimiento generalizado sobre la práctica artística transdisciplinar que involucra a la performance arte, al cuerpo y a las nuevas tecnologías de la información y la comunicación (TIC).

Se ensayaron varias estrategias hasta lograr capitalizar lecturas, contactos y posibles intercambios. Un logro importante, surgido de esta misma dificultad, fue realizar jornadas y encuentros periódicos con otros equipos de investigación de otras universidades, artistas y gestores culturales -nacionales e internacionalesespecializados en la temática.

Otra posibilidad fue concurrir a una estancia académica de intercambio en la Unidad de Posgrado de la UNAM, México DF. - a través de un subsidio para viajes/estadías de la UNLP, 2016-2017- para indagar sobre las derivaciones que surgen de vincular arte, cuerpo y ciencia, entender sus significados y elaborar una posición sobre la trascendencia de sus aportes sociales, culturales y de conocimiento científico-artístico. Otra meta lograda para superar esta dificultad inicial fue generar instancias de colaboración y visibilidad a través de publicaciones en revistas educativas y 
presentaciones a congresos y encuentros educativos que compartan las mismas inquietudes.

A continuación dejaremos constancia de estas actividades consignando una serie de links que proporcionan publicaciones, jornadas y documentación audiovisual: con el fin de establecer un acerbo de estudio y observación para próximas investigaciones.

\subsection{Actividades de la Cátedra Libre 2017}

Título: II Jornada Cuerpo, Performance y Tecnología Emergente

Martes 25 de abril, 9 a 12 horas

Salón del Consejo Superior, Edificio Presidencia UNLP, Av. 7 N. ${ }^{\circ} 776$

Organizadores: Cátedra Libre Educación y Mediación Digital en Danza y Performance y PID FBA/UNLP (B315)

Disertantes

- Theor Román (Universidad de Murcia, España).

- Myriam Beutelspacher y Minerva Hernández (Bioscénica, México).

- Natalia Matewecki (Universidad Nacional de La Plata, Argentina).

Descripción

Esta jornada se enmarca en la investigación del PID Prácticas Performáticas Multimediales, Redes Telemáticas y Educación (Código: B315), FBA, UNLP; cuya temática atraviesa al cuerpo, la performance, la ciencia, las tecnologías emergentes y los modos posibles de interacción con sistemas híbridos. Se presenta igualmente el libro Encuentros, arte y nuevos medios en la prácticas artísticas contemporáneas, dentro de la línea de investigación "Translab: artes performáticas + tecnología", editado por la Universidad Autónoma Metropolitana - Lerma en México. Se trata de un aporte valioso para el intercambio de conocimiento entre las instituciones académicas de América Latina.

Material de consulta en línea

II Jornadas Cuerpo, Performance y Tecnologías Emergentes Parte 1. URL: <https://youtu.be/USh0Sz6h5zs>.

II Jornadas Cuerpo, Performance y Tecnologías Emergentes Parte 2. URL: <https://youtu.be/5dH76Q0MqPQ>. 
II Jornada Cuerpo, Performance y Tecnologías Emergentes. Parte 3. URL: <https://youtu.be/TYHFWF8zO4g>.

II Jornada Cuerpo, Performance y Tecnologías Emergentes. Parte 4. URL: <https://youtu.be/P1IOlckvBSw>.

Título: III Jornada Cuerpo, Performance y Tecnología Emergente

Martes 6 de junio, 10 a 13 horas

Salón del Consejo Superior, Edificio Presidencia UNLP, Av. 7 N. ${ }^{\circ} 776$

Organizadores: Cátedra Libre Educación y Mediación Digital en Danza y Performance y PID FBA/UNLP (B315)

Disertantes

- Juan Pablo Ferlat (UBA).

- Gloria Mendoza (Posgrado UNAM, México).

- Maia Pedroncini (UNA.C3).

- Agustín Parmisano (Facultad de Informática, UNLP).

- Paula Castillo (FBA-UNLP).

Descripción

Esta jornada se enmarca en la investigación del PID Prácticas Performáticas Multimediales, Redes Telemáticas y Educación (Código: B315), FBA, UNLP, cuya temática atraviesa al cuerpo, la performance, la ciencia, las tecnologías emergentes y la robótica, con los modos posibles de interacción entre sistemas híbridos. Se trata de un cruce de ideas para continuar reflexionando sobre las diversas experiencias teórico-prácticas junto a investigadores, docentes, artistas y público interesado en comprender las claves del arte actual.

\section{Título: IV Jornada Cuerpo, Performance y Tecnología Emergente}

Sábado 1 de julio, 10 a 16 horas

Centro Cultural Estación Provincial. Calle 17 esq. 71 (EDCLP, anexo)

Organizadores: Cátedra Libre Educación y Mediación Digital en Danza y Performance PID FBA/UNLP (B315), Escuela de Danzas Clásicas de La Plata

Disertantes

- Alejandra Cosin (Universidad Católica de Chile). 
- Mirella Carbone (Pontificia Universidad Católica del Perú).

- Lorna Violeta Ortiz Adoum (Pontificia Universidad Católica del Ecuador).

- Emiliano Causa y emmelab (Universidad Nacional de La Plata).

- Iván Haidar y Constanza Copello (Asociación de Coreógrafos, Intérpretes y Afines de Danza Independiente Platense).

\section{Descripción}

La propuesta para estas jornadas fue integrar instituciones de educación artística: la Secretaría de Arte y Cultura (UNLP) a través de la Cátedra Libre Educación y Mediación Digital en Danza y Performance; la Escuela de Danzas Clásicas de La Plata (DGCyE); la sede Norte de Inspección Artística (DEAR, el posgrado de Teatro y Performances del (UNA), y la Asociación de Coreógrafos, Intérpretes y Afines de Danza Independiente Platense (ACIADIP). Se trata de un cruce de ideas para continuar reflexionando sobre las diversas experiencias teórico-prácticas junto a investigadores, docentes, estudiantes, artistas y público interesado en comprender las claves del arte actual y la educación en vías de transformación.

\subsection{Colaboraciones e intercambios}

Una experiencia destacable desde el intercambio como metodología de edificación de conocimiento participativo fue una estancia colaborativa entre el doctorando Antonio Sánchez Román (Theor) perteneciente al programa de Artes y Humanidades de la Universidad de Murcia (España) y nuestro proyecto de investigación. En el proceso de intercambio e investigación participamos de unas jornadas organizadas por la Escuela Universitaria de Artes de la Universidad Nacional de Quilmes. Estas jornadas ofrecieron un lugar de discusión a exponentes referenciales del campo. El propósito fue lograr un espacio de transferencia, producción y crítica sobre las nuevas tecnologías aplicadas al arte y pensar los nuevos universos de la puesta en escena de la tecnología.

Asimismo, se presentó la experiencia de campo realizada en la Escuela de Educación Estética N ${ }^{\circ} 1$ de la Rama Artística, dependiente de la Dirección General de Cultura y Educación de la Provincia de Buenos Aires, ciudad de La Plata. Allí nos interrogamos: ¿arte performance en la escuela? Pensamos que la performance puede tener propósitos educativos, porque la entendemos, por un lado, como disparador de experiencias que comprometen al cuerpo significativamente frente a las transformaciones, en parte por los advenimientos tecnológicos, y como consecuencia 
de esto el consumo cultural globalizado que plantea la necesidad de producir un corpus de conocimientos que al presente están fuera del currículo académico y de enseñanza artística, y que podrían -eventualmente- ser incluidos en sus programas lectivos. Esta experiencia interdisciplinar, llevada a cabo como actividad de la escuela junto a sus docentes y alumnos, ha quedado documentada tanto por un registro audiovisual como por publicaciones correspondientes.

Otra de las mesas en que se intervino en el área de práctica performáticas y soportes digitales estuvo a cargo de investigadores pertenecientes a nuestro PID (Sánchez, Napolitano y Montequín) en la que se abordó el papel de la performance pública y colectiva como activación en la realidad cotidiana; una evidencia de verdad, a diferencia del modelo ficcional moderno.

Se participó, además, en la mesa de Dramaturgia y Tecnología, en la que el investigador Román acuñó el término: "partitura escénica hipermedia". Dicha expresión reúne la creación dramática contemporánea y los nuevos medios digitales, que hace especial hincapié en la aplicación de la hipermedialidad como germen para generar nuevos diálogos entre el dramaturgo y el creador escénico.

Conjuntamente, se presentó dentro de los conciertos brindados, la performance interactiva Speak 4.0 FRACTAL, del laboratorio artístico referenciado anteriormente (Capítulo 2 Parte 2 y Capítulo 3 de esta tesis). Esto nos permitió poner en práctica, por una parte, la investigación realizada entre los tres integrantes (Costa Alisedo, Kesler y Ceriani), y por otra, la colaboración como dramaturgo hipermediático de Román. Un logro fundamental para destacar fue que, los programadores, se incluyeran en la acción pero, transformando esa acción en una acción performática. Esta inclusión causo que la operación de estar programando en vivo (tema tratado en el Capítulo 2 Parte 3) fuera más orgánica en relación con el público, es decir, exponiendo que los artistas electrónicos no se encuentran solo abstraídos en su contacto con la escena tecnológica y el espectador.

Material de consulta en línea

Jornadas de Arte, Música y Tecnología 2017. URL:

<http://musica.unq.edu.ar/jamtec2017.php>.

Performance en la Escuela Primaria. URL: <https://youtu.be/oKmjrr5rC1g>.

Revista Novedades Educativas 311 - noviembre 2016. URL: $<$ http://www.noveduc.com///revista-novedades-educativas-311-noviembre2016/1717/03283534>. 
Revista Novedades Educativas 317 - mayo 2017. URL: <http://www.noveduc.com///ne317-creacion-imagen-y-palabra-asesoramiento-educacional/1803/03283534>. SPEAK F2017 en vivo en JAMTEC Jornadas de Arte Música y Tecnología Universidad de Quilmes. URL: <https://youtu.be/pU-VyDcpqkg>.

\subsection{Subsidio 2016-2017 para viajes/estadías UNLP}

La Universidad Nacional de La Plata nos ha otorgado la prestación de un subsidio para ayuda para viajes y estadías (2016-2017), lo que posibilitó la concurrencia al laboratorio de Ergonomía, del Posgrado en Diseño Industrial de la Universidad Nacional Autónoma de México, para realizar una estancia de intercambio e investigación procesual y performática en Interacción Humano-Robot.

Por su parte, la performance es una práctica artística puramente multidisciplinar, por lo que no conviene abordarla desde una sola área. En ella, entran en juego el teatro, la música, la danza, los recursos tecnológicos y multimediales, y, al presente, la ciencia. Un ejemplo de ello es Bioarte (Matewecki, 2015); una de las más recientes corrientes desarrolladas por el arte contemporáneo. Esta nueva forma interdisciplinar de producir, junto a otras muchas tendencias y lenguajes propios del arte contemporáneo, ha contribuido a ampliar y enriquecer el campo de lo transdisciplinar y ha abierto a nuevas posibilidades a través de las redes de comunicación en internet fomentando las interacciones sociales que implican nuevos dispositivos.

Nos involucramos con diversos robots, entre ellos, el robot humanoide NAO, adquirido por este centro académico. La inclusión de los sistemas robóticos e inteligentes en la vida cotidiana es un proceso que ya se inició y que próximamente será realidad en los países avanzados tecnológicamente. Por ello, es de suma importancia entrar en contacto con quienes desde Latinoamérica están iniciando estudios que confieren al arte y a la performance un espacio de intercambio.

Los adelantos tecnológicos en el campo de la informática, el software libre, el diseño, el desarrollo y la programación de robots es hoy en día una tarea que comienza a incorporarse en las aulas desde los primeros niveles de la escolarización.

En este sentido, y luego de meses de gestión con docentes de la Facultad de Informática de la UNLP, se inició el Taller "Abriendo el conocimiento con Arduino: integración de arte y robótica". Dentro de las actividades dirigidas a la comunidad que imparte la Escuela de Educación Estética N ${ }^{\circ} 1$ se propicia -en el futuro inmediato- la implementación de una actividad curricular permanente que vincule el aprendizaje básico de conceptos de electrónica con conceptos de creación y producción artística. 
Esta posibilidad de intercambiar con colegas artistas y científicos no pretende que el arte imite a la ciencia, sino que ambos colaboren para el desarrollo de expresividad capaz de superar su dimensión utilitaria. Asimismo, es una variante de la actividad artística que merece ser profundizada para entender sus significados y elaborar una posición sobre la trascendencia de sus aportes sociales, culturales y de conocimiento en su aplicación dentro del ámbito educativo de las artes.

Material de consulta en línea

Diálogos sobre Robótica Social. URL: <https://youtu.be/rlt3hy1dqKU>.

Conociendo a NAO en la UNAM. URL: <https://youtu.be/4IWgvNx9rrs>.

Observando los movimientos del Robot Humanoide NAO. URL: <https://youtu.be/xYAuoY3IxpE>.

Observando los movimientos del Robot Humanoide NAO 2. URL: $<$ https://youtu.be/alpcAIRa7og>.

Hemos presentado hasta aquí algunas de las experiencias realizadas entendidas como trabajo de campo en su más amplia acepción, incentivando actividades teóricoprácticas que enriquezcan el aprendizaje y el diálogo entre educadores, artísticas, programadores e investigares de diferentes áreas. Vislumbrar la poética de estas relaciones es una contribución lúcida para el avance de los lenguajes artísticos, el análisis y la reflexión en una sociedad cada vez más informatizada y global. Con estas ideas, continuaremos promoviendo criterios para el conocimiento y la incorporación de las nuevas tecnologías electrónico-digitales como parte de un proceso de innovación pedagógica cimentada en el intercambio social y participativo.

\section{Referencias bibliográfícas}

Ceriani, Alejandra (comp.) (2012), Arte del cuerpo digital. Nuevas tecnologías y estéticas contemporáneas, La Plata, EDULP.

Lion, Carina (2012), "Pensar en red: metáforas y escenarios", en Mariano Naradowski y Alejandra Scialabba (comps.), ¿Cómo serán? El futuro de la escuela y las nuevas tecnologías, Buenos Aires, Prometeo.

Lion, Carina (2006), Imaginar con tecnologías: relaciones entre tecnologías y conocimiento, Buenos Aires, Stella. 
Maggio, Mariana (2012), Enriquecer la enseñanza. Los ambientes con alta disposición tecnológica como oportunidad, Buenos Aires, Paidós.

Sibilia, Paula (2012), ¿Redes o Paredes? La escuela en tiempos de dispersión, Buenos Aires, Tinta Fresca.

Ynoub, Roxana (2014), Cuestión de método. Aportes para una metodología crítica. Tomo 1, México, Cengage.

\subsection{Referencias electrónicas}

AA. VV., (2007), Tecnologías de la información y la comunicación en la escuela: trazos, claves y oportunidades para su integración pedagógica, Buenos Aires, Ministerio de Educación, Ciencia y Tecnología de la Nación [en línea]. Disponible en: <http://www.me.gov.ar/curriform/publica/tic.pdf>.

Matewecki, Natalia (2015), "Estética y bioarte. Pasajes de lo moderno a lo contemporáneo en torno a las nociones de obra, artista, espectador y experiencia". Tesis de doctorado [en línea]. Disponible en URL: <http://sedici.unlp.edu.ar/handle/10915/44457>.

\subsection{Otros materiales de consulta en línea}

URL: <http://portal.educ.ar/debates/educacionytic/debate/robots-en-las-escuelas.php> URL:<http://www.unlp.edu.ar/uploads/docs/maza_y_otros_taller_de_robotica_en_la_e scuela.pdf>

URL: <http://robots.linti.unlp.edu.ar/> 